RICARDO ZAGALLO CAMARGO

\title{
RESPONSABILIDADE SOCIAL DAS EMPRESAS: FORMAÇÕES DISCURSIVAS EM CONFRONTO
}

Tese apresentada ao Programa de Pós-Graduação em Ciências da Comunicação, Área de Concentração Interfaces Sociais da Comunicação, Linha de Pesquisa Políticas e Estratégias de Comunicação, da Escola de Comunicações e Artes, da Universidade de São Paulo, como exigência para obtenção do Título de Doutor em Comunicação, sob a orientação do Prof. Dr. Ivan Santo Barbosa. 


\title{
RICARDO ZAGALLO CAMARGO
}

\section{RESPONSABILIDADE SOCIAL DAS EMPRESAS: FORMAÇÕES DISCURSIVAS EM CONFRONTO}

\begin{abstract}
Tese apresentada ao Programa de Pós-Graduação em Ciências da Comunicação, Área de Concentração Interfaces Sociais da Comunicação, Linha de Pesquisa Políticas e Estratégias de Comunicação, da Escola de Comunicações e Artes, da Universidade de São Paulo, como exigência para obtenção do Título de Doutor em Comunicação, sob a orientação do Prof. Dr. Ivan Santo Barbosa.
\end{abstract}




\section{Camargo, Ricardo Zagallo.}

Responsabilidade social das empresas: formações discursivas em confronto. / Ricardo Zagallo Camargo. - São Paulo, 2009.

$229 \mathrm{f}$.

Bibliografia.

Tese (Doutorado). - Departamento de Propaganda, Relações Públicas e Turismo/Escola de Comunicações e Artes/USP.

Orientador: Prof. Dr. Ivan Santo Barbosa.

1. Responsabilidade Social Empresarial. 2. Sustentabilidade. 3. Marketing. 4. Comunicação Mercadológica. I. Título. II. Camargo, Ricardo Zagallo. III. Barbosa, Ivan Santo. 

RICARDO ZAGALLO CAMARGO

RESPONSABILIDADE SOCIAL DAS EMPRESAS:

FORMAÇÕES DISCURSIVAS EM CONFRONTO

BANCA EXAMINADORA

\begin{tabular}{|c|c|}
\hline Orientador & \multicolumn{1}{|c|}{ Prof. Dr. Ivan Santo Barbosa } \\
\hline \multicolumn{2}{|l|}{} \\
\hline Examinador 1 & \\
\hline Examinador 2 & \\
\hline \\
\hline Examinador 3 & \\
\hline \multicolumn{2}{|}{} \\
\hline Examinador 4 & \\
\hline & \\
\end{tabular}

São Paulo, de de 2009 
Para meu pai Cezar 


\section{Agradeço}

À oportunidade de ser orientado pelo Professor Ivan, bem como as valiosas contribuições da banca de Exame de Qualificação, composta pelo Professor Paulo de Salles Oliveira e pelo saudoso Professor Cidmar Teodoro Pais.

À presteza e compreensão de toda a equipe do CRP, da pós-graduação da ECA e da Biblioteca da ESPM-SP.

À paciência do tricolor Juliano que insiste em saber se para ser jogador de futebol precisa fazer doutorado.

Aos cuidados de Tatiana que pedia planejamento no trabalho até a última hora possível.

Ao apoio da família manifestado por palavras e silêncios.

Ao Professor Piratininga, que aprendi a respeitar nos termos de Hannah Arendt.

À torcida participativa da Manolita, Gláucia, Amatucci e Ilan.

À compreensão da equipe do CAEPM nas minhas ausências.

Aos amigos fiéis de todas as horas (mesmo) Ana, Jamir, Danilo e - aos 48’ - Roberto.

Ao café de Lau para as manhãs e tardes na labuta. 
Chama-se mecânico ao todo se alguns de seus elementos estão unificados apenas no espaço e no tempo por uma relação externa e não os penetra a unidade interna do sentido. As partes desse todo, ainda que estejam lado a lado e se toquem, em si mesmas são estranhas umas às outras.

Bakhtin, Mikhail. Arte e Responsabilidade. In: Estética da criação verbal, São Paulo: Martins Fontes, 2003. 


\section{RESUMO}

CAMARGO, Ricardo Zagallo. Responsabilidade Social das Empresas: Formações Discursivas em Confronto. 2009. 229 p.

Nosso trabalho propõe-se a compreender como é formulado o discurso das empresas acerca da responsabilidade social, por meio do entendimento das formações discursivas em conflito, reconhecendo potencialidades e limitações deste discurso. Discute a heterogeneidade de vozes em diálogo, a constituição da cena enunciativa e busca delinear como são construídos os sentidos do discurso das empresas acerca da responsabilidade social. A consecução dos objetivos se deu por meio do método de análise do discurso de linha francesa (AD), a partir de três conjuntos de dados: um conjunto de textos jornalísticos, com ênfase na mídia especializada em negócios; série longitudinal de documentos (balanços sociais) de uma organização com destacada ação socioambiental; entrevistas realizadas com profissionais que atuam nas áreas de responsabilidade social de grandes organizações. Os resultados indicam que o discurso das empresas a respeito do social constitui-se a partir da oposição entre duas formações discursivas concorrentes, a gerencial e a política, sua identidade a partir da negação e construção de simulacros do marketing, da filantropia, e, sobretudo, do conflito, como forma política de lidar com as questões sociais.

Palavras-chave: Responsabilidade Social Empresarial; Sustentabilidade; Marketing; Comunicação mercadológica; Formação discursiva. 


\begin{abstract}
CAMARGO, Ricardo Zagallo. Responsabilidade Social das Empresas: Formações Discursivas em Confronto. 2009. 229 p.

Through the study of conflicting discursive formations this work aims at understanding how corporate discourse on social responsibility is constructed, taking into account its potentialities and limitations. It discusses the heterogeneity of dialogic voices and the constitution of the enunciative scene in an effort to outline how meaning is produced within such discourse. These objectives were attained by applying the methodology of Discourse Analysis (DA), particularly the French tradition in this field, to three types of data: journalistic texts, especially those from the business media; a series of documents (reports on social impact) from an organization widely known for its environmental concern; and interviews with professionals involved with social responsibility policies in large organizations. The results indicate that corporate discourse on social issues is constituted by two opposing discursive formations, one managerial and the other political. Its identity is defined by negation and construction of marketing simulacrum, by philanthropy, and above all by conflict as the political path to deal with social issues.
\end{abstract}

Key words: Corporate social responsibility; Sustainability; Marketing; Market Communication; Discursive formations 


\section{SUMÁRIO}

$\begin{array}{ll}\text { INTRODUÇÃO } & 01\end{array}$

$\begin{array}{ll}\text { Tema, objeto e objetivos justificados da pesquisa } & \mathbf{0 1}\end{array}$

$\begin{array}{ll}\text { Origens internacionais } & 05\end{array}$

Indícios de origens históricas da responsabilidade social no Brasil $\quad 06$

$\begin{array}{ll}\text { Definições de responsabilidade social empresarial } & \mathbf{0 7}\end{array}$

$\begin{array}{ll}\text { A responsabilidade social empresarial no contexto mercadológico } & \mathbf{0 8}\end{array}$

Capítulo 1 - MÚLTIPLOS ENQUADRAMENTOS 15

Critérios e procedimentos adotados $\quad \mathbf{1 5}$

Gênese e trajetória do conceito, delimitação teórica, e definição do campo $\quad \mathbf{1 9}$

Questionamentos de origem e dilemas atuais $\quad \mathbf{2 9}$

Difusão do conceito no ambiente empresarial e surgimento de nicho de $\mathbf{3 9}$ mercado

Aperfeiçoamento de práticas e mensuração de resultados $4 \mathbf{4 1}$

Relações de trabalho - arranjos produtivos

Crítica gerencial $\quad 54$

Gestão da comunicação e informação - Terceira via 57

Voluntariado $\quad \mathbf{6 0}$

Economia da Comunhão $\quad \mathbf{6 1}$

Mídia, publicidade, consumo e cidadania $\quad \mathbf{6 2}$

Crítica e propostas de resistência e "empoderamento" $\quad 66$

$\begin{array}{ll}\text { Disputa dos sentidos da enunciação sobre o social e esfera pública } & \mathbf{7 0}\end{array}$

$\begin{array}{ll}\text { Investimentos privados e espaço público } & \mathbf{7 6}\end{array}$

CAPÍTULO 2 - NOSSOS REFERENCIAIS $\quad 94$

$\begin{array}{ll}\text { Vita activa } & 95\end{array}$

A promoção do social $\quad \mathbf{9 7}$

A esfera pública: o comum e a esfera privada: a propriedade 99

$\begin{array}{ll}\text { Labor, trabalho e ação } & 101\end{array}$

$\begin{array}{ll}\text { Ação e Discurso } & 103\end{array}$

$\begin{array}{ll}\text { Democracia, participação e emancipação } & 105\end{array}$

$\begin{array}{ll}\text { Ideologia, sociedade civil e classes sociais } & \mathbf{1 0 8}\end{array}$

$\begin{array}{ll}\text { Mídia e simulacro } & \mathbf{1 1 0}\end{array}$

$\begin{array}{ll}\text { Cidadania e privilégio } & 111\end{array}$

$\begin{array}{lr}\text { Sociedade do espetáculo } & 112\end{array}$

$\begin{array}{ll}\text { Cidadania } & 114 \\ & 124\end{array}$

$\begin{array}{ll}\text { Declínio do homem público } & 124\end{array}$

$\begin{array}{lr}\text { Corrosão do caráter } & 125\end{array}$

$\begin{array}{lr}\text { A cultura do novo capitalismo } & \mathbf{1 2 8}\end{array}$ 
CAPÍTULO 3 - NOSSA PESQUISA

Referenciais teóricos para tratamento e análise dos dados

Percurso da pesquisa

Material empírico selecionado, procedimentos e justificativas

CAPÍTULO 4 - NOSSA ANÁLISE

4.1 Análise de textos jornalísticos

4.2 Análise longitudinal de documentos: Balanços Sociais 176

4. 3 Análise das entrevistas 


\section{NOTAS DE LEITURA}

\section{NÓS}

O uso do "nós" ao longo do trabalho encontrou uma justificativa primeiramente nas colocações de Mikhail Bakhtin que entende o discurso como parte de uma cadeia historicamente construída. Nossa fala dialoga e reverbera, portanto, falas de outros, que a partir da posição de sujeito selecionamos e incorporamos à nossa, conscientemente ou por meio das coerções e constantes que o interdiscurso nos impõe.

Ficamos, dessa forma, à vontade para usar o "nós”. Até então, em outros escritos, havia a permanente sensação de dúvida entre a primeira pessoa, que de alguma forma soava dura ao cortar pelo prisma pessoal uma realidade de todos; a terceira, que nos parecia falsamente modesta ao dividir sem vontade achamos que considerávamos meu; ou ainda o verbo no impessoal, que deixava o gosto insípido de uma isenção de compromisso e responsabilidade.

Escrevemos “nós” confortável e conscientemente pela clareza que a teoria de Bakhtin nos concedeu de que todo texto é sempre "nosso”.

Escrevemos também porque aprendemos, com Hannah Arendt, que a ação e discurso pelos quais os seres humanos manifestam-se como homens só se realizam numa teia de relações, que nos inter essa e interliga, fazendo com que a força, que é a qualidade natural de um indivíduo isolado, converta-se em poder entre os homens quando eles agem juntos.

Escrevemos ainda a partir das palavras de Richard Sennett que percebe o "nós” como o caminho para colocar em xeque a desconsideração pelo outro, uma vez que a política depende da existência de um “nós” comunal.

E polifonia é grande. Muitas vozes não nossas que, ao serem escolhidas passam de alguma forma a sê-lo. Como guia de leitura, informamos que a terceira pessoa será usada exclusivamente em nossos comentários ou elaborações. Os outros tempos verbais referem-se a falas dos demais autores. Em relação aos quais procuramos nos aproximar, seja pela concordância, seja pelo conflito. 


\section{INTRODUÇÃO}

\section{Tema, objeto e objetivos justificados da pesquisa}

Esta investigação situa-se na confluência das temáticas sociais e mercadológicas, por meio de uma compreensão orientada para a discussão da esfera pública e da ação política.

Na trajetória pessoal, o deslocamento profissional de publicitário redator, envolvido com a prática mercadológica, para publicitário professor, interessado em aliar aspectos criativos a reflexões sobre as implicações sociais do trabalho, marcou, num primeiro momento, a aproximação com questões que dizem respeito a nossa responsabilidade em relação aos outros.

O envolvimento sistematizado com o tema da responsabilidade social deu-se, contudo, em nossa pesquisa de Mestrado, que estudou as relações tensas entre educação, criança e consumo, por meio da análise de um projeto empresarial voltado à educação infantil para o consumo (melhor seria dizer treinamento, uma vez que a concepção de educação utilizada não nos permitiu denominar as ações como educativas). Uma tensão reverberou na defesa do trabalho, marcada pela presença e indignação de uma das pessoas entrevistadas, que percebia sua atuação colocada em xeque a partir dos questionamentos levantados. Esse episódio teve como desdobramento concreto a realização de dois eventos (Fóruns Criança \& Consumo), realizados na ECA-USP, onde alunos, professores, pesquisadores e profissionais de mercado discutiram as relações entre intenções mercadológicas e educacionais.

Após esse primeiro contato científico com a questão, nossa trajetória dirigiu-se ainda mais para a relação entre o mercado e sociedade, ao iniciarmos, em 2005, a convite do professor Luis Celso de Piratininga, a construção de um centro de pesquisa, na ESPM, escola conhecida por sua proximidade com o mercado publicitário, que sinalizava, dessa forma, a intenção de ampliar os espaços voltados para a pesquisa e a reflexão. A partir de então, o publicitário professor passou a ser publicitário administrador, responsável pelas atividades do Centro; e publicitário pesquisador, sobretudo pela realização desta pesquisa, iniciada em 2005, mas também pelo contato simultâneo com pesquisadores experimentados de diversas áreas do conhecimento, tais como sociologia, antropologia, educação, filosofia, administração e comunicação. Tal diversidade foi ampliada pelo contato com profissionais de mercado e 
empresários, que mantêm relações próximas com a ESPM. Uma situação de profissão e de vida, que nos colocou diretamente na confluência entre mercado e academia, com todas as dificuldades e potencialidades dessa posição.

Associado à nossa trajetória, o objeto escolhido por esta pesquisa para discutir a responsabilidade social é o discurso das empresas, discurso esse que chama a atenção por ter se tornado onipresente na mídia e nas ações de comunicação empresarial, como observaremos ao longo deste trabalho. Trata-se, contudo, de um discurso que não apenas faz parte do jargão “promocional” das empresas, mas possui ampla produção científica. Segundo o CEATS ${ }^{1}$, a Responsabilidade Social Empresarial pode ser definida como uma forma de gestão marcada pela relação ética e transparência da empresa com todos os públicos com que se relaciona (stakeholders), e o estabelecimento de metas empresariais compatíveis com a noção de desenvolvimento sustentável, que inclui a preservação de recursos ambientais e culturais para gerações futuras, respeito à diversidade e combate às desigualdades sociais.

O entendimento desse discurso empresarial oscila entre a percepção de que se trata de uma evolução do marketing social, até a percepção de que estaríamos diante de uma alteração efetiva nas relações sociais, pautada pela modificação do papel da empresa. Traz, também, consigo, a idéia de prestação de contas, o que tem levado organizações de grande porte a divulgar, anualmente, um relatório onde são descritas e quantificadas, na forma de um balanço, suas ações nas áreas sociais e ambientais. Essa atitude pode ser compreendida tanto como um instrumento para mostrar a transparência, quanto como peça importante na construção da imagem da empresa junto aos seus públicos, que parecem estar cada vez mais atentos aos aspectos sociais e ambientais das empresas.

Embora as ações realizadas pelas empresas tenham impactos reais é evidente que sua base de sustentação é a manutenção do lucro e não a transformação social. O presidente de uma empresa citada como exemplo de responsabilidade social, explicita essa questão:

Apesar de elas terem avançado em várias áreas de responsabilidade social e ambiental, elas certamente não destinarão uma parte significativa de seus lucros para que sejam distribuídos na sociedade, pois este não é o seu papel. [...] o velho Estado tem um papel fundamental na distribuição de riqueza por intermédio de

\footnotetext{
${ }^{1}$ O CEATS - Centro de Empreendedorismo Social e Administração em Terceiro Setor - foi criado em 1998 na FEA-USP, com suporte da Fundação Instituto de Administração, entidade sem fins lucrativos. Desde então, tem desenvolvido pesquisas e oferecido cursos com foco no empreendedorismo e cidadania empresarial.
} 
políticas públicas [...] De qualquer forma, a empresa deve ser um instrumento a favor da sociedade [...] (Diálogos Akatu, 2002, nํㅜㄹ, p. 17).

O princípio da produção de mais-valia, de lucro, fundamento do crescimento econômico, permanece. É visto inclusive como uma das responsabilidades sociais da empresa, no sentido de gerar empregos. Não se trata, portanto, de nova relação entre trabalho e capital, mas definição do quanto de obtenção de mais-valia é licito e ético.

O consumidor, por sua vez, é ponto chave nas ações de responsabilidade social. Seja como comprador influenciado pelas ações da empresa, seja como consumidor potencial a incluir no sistema de consumo. Quanto ao primeiro aspecto, pesquisa ${ }^{2}$ de 2004 sobre a percepção do consumidor brasileiro em relação à responsabilidade das empresas indicou que $70 \%$ dos consumidores consideram que elas devem estar envolvidas na resolução de problemas sociais, 57\% acham que deveria haver leis que obrigassem as empresas a ir além do básico (pagamento de impostos, respeito aos direitos trabalhistas e cuidados ambientais já regulados por lei) e 86\% acreditam que, como consumidores, podem interferir na atuação responsável das empresas. Há, contudo, pouca relação com o consumo, pois $70 \%$ não pensaram em “prestigiar” empresas responsáveis por meio da compra, assim como 76\% não pensaram em punir, deixando de comprar produtos. Em linhas gerais, pode-se dizer que, mesmo de maneira pouco efetiva no que diz respeito ao consumo, a responsabilidade social já entrou na pauta do consumidor, interferindo direta ou indiretamente em suas escolhas. Outro aspecto destacado por essa pesquisa é que, em relação aos funcionários, as ações responsáveis das empresas são fatores de motivação e lealdade.

Quanto à inclusão de novos consumidores no sistema, a questão ganha contornos mais explícitos. Na matéria 'Inclusão social é o futuro do capitalismo' ${ }^{\prime 3}$, o estudioso Stuart Hart, autor do livro Capitalism at the Crossroads, afirma que, sem a inclusão dos cerca de 4 bilhões de pessoas que vivem com até US\$ 1,5 mil por ano, a chamada"base da pirâmide", não haverá futuro para as empresas e para o próprio capitalismo. Sugere a reformulação de estratégias de negócios, para oferecer produtos à massa excluída, com base em inovação tecnológica, com prioridade para energias com menos impacto sobre os recursos naturais do planeta. Uma visão

\footnotetext{
${ }^{2}$ Pesquisa Responsabilidade Social das Empresas - Percepção do Consumidor Brasileiro, edição 2004, realizada pelo Instituto Ethos de Responsabilidade Social Empresarial, que contou com 1000 entrevistas em todo Brasil questionário estruturado - em todos os níveis sociais.

${ }^{3}$ O Estado de São Paulo, Andrea Vialli, 31 de agosto de 2005.
} 
que faz eco a Prahalad (2005), autor que ganha destaque entre o empresariado, ao salientar o potencial de lucro existente nas camadas mais pobres e a possibilidade de lucrar com a erradicação da pobreza.

Dentro dessa temática e objeto, este trabalho, com foco na comunicação e, em particular, nas suas interfaces sociais, propõe-se a discutir questões relativas às formas pelas quais o discurso da responsabilidade social das empresas articula-se com movimentos sociais mais amplos; assim como os caminhos pelos quais a proposta corporativa de cidadania corporativa participa da disputa pela enunciação do político e do social.

Por conseguinte, o processo de delimitação dos objetivos desta pesquisa baseou-se na premissa de que o discurso de responsabilidade social das empresas não é algo que possa ser isolado do contexto em que é produzido. Com isso em vista, delimitamos o objetivo geral desta pesquisa:

- Compreender como é formulado o discurso das empresas acerca da responsabilidade social, por meio do entendimento das formações discursivas em confronto.

Como desdobramento, os objetivos específicos são:

- Discutir a heterogeneidade de vozes em diálogo que caracterizam o discurso das empresas acerca da responsabilidade social;

- Explicitar como se constitui a cena enunciativa do discurso das empresas acerca da responsabilidade social;

- Delinear de que forma são construídos os sentidos do discurso das empresas acerca da responsabilidade social.

A consecução dos objetivos se dará por meio do método de análise do discurso de linha francesa $(\mathrm{AD})$, cuja caracterização será detalhada a seguir, mas que podemos definir, sinteticamente, como método de estudo que se apoia sobre os conceitos e métodos da linguística e se relaciona, como destaca Maingueneau (1997, p.13), com textos produzidos no quadro de instituições que restringem fortemente a enunciação, e nos quais se cristalizam conflitos históricos e sociais. Essas características justificam sua escolha, para abordar os textos produzidos no âmbito do discurso das empresas acerca da responsabilidade social. 


\section{Estrutura do trabalho}

O resultado final do processo de pesquisa está estruturado em quatro capítulos, sendo o primeiro dedicado ao levantamento, o mais exaustivo possível, dos trabalhos que tratavam do tema e do objeto de pesquisa na área das ciências sociais, assim como trabalhos que focavam temas e objetos que dialogam com o nosso.

O segundo e terceiro capítulos expõem, como propõe Bosi (2003, p.50), os dois grandes níveis para definir o método de um trabalho científico: a orientação geral da pesquisa, na qual apresentamos o grupo de referências que constitui a "tendência teórica" que guiou o trabalho; e procedimento, ou sua técnica particular, com os referenciais metodológicos, o percurso seguido e os procedimentos adotados por nosso trabalho. São níveis que, como ressalta a autora, se cruzam durante todo o percurso.

O quarto capítulo apresenta, por sua vez, a análise realizada a partir das orientações teóricas e procedimentos apresentados, desdobrando-se em quatro momentos, que buscam realizar os objetivos da pesquisa, a partir da abordagem de diferentes objetos empíricos:

a) Tratamento e análise de um conjunto representativo de textos jornalísticos, com ênfase na mídia especializada em negócios, com ferramental de AD;

b) Análise longitudinal de documentos (balanços sociais) de empresa com ações de responsabilidade social reconhecida pelo mercado, com ferramental de AD;

c) Análise das entrevistas realizadas com profissionais de empresas com ações de responsabilidade social reconhecida pelo mercado, com ferramental de AD;

d) Breves considerações gerais sobre as análises realizadas: a oposição de formações discursivas no âmbito da RSE

Concluímos com considerações gerais acerca do processo e resultados obtidos, e propondo, a partir da análise, uma compreensão do discurso das empresas acerca da responsabilidade social, por meio do entendimento de suas formações discursivas em conflito.

Para situar, preliminarmente, o objeto de estudo no contexto histórico e mercadológico, apresentaremos, a seguir, uma breve trajetória da noção de responsabilidade social, que será ampliada e detalhada a partir da revisão da literatura; e sua contextualização no âmbito mercadológico, em especial da comunicação mercadológica contemporânea. 


\section{Origens internacionais}

Gomes (2007, p.12-21) lembra que a idéia de colaboração das empresas na área social não é recente, citando (lembrando de) Robert Owen (1773-1858), sociólogo que virou industrial e implantou uma série de mudanças, tais como, salários maiores, jornada de trabalho menor (10h/dia), e outros benefícios como creches, hospitais e escolas, obtendo grande aumento dos lucros. Suas propostas tornaram-se referências para a legislação social, mas avançaram no sentido de uma sociedade comunista e ele acabou sendo banido dos EUA.

A primeira menção ao termo responsabilidade social ligado ao mundo dos negócios, segundo Oliveira (2002:200 apud GOMES, 2007, p.30), surge em um manifesto de 120 empresas inglesas, sobre o equilíbrio entre interesses públicos e dos acionistas. Gomes (2007, p.30-35) afirma que a idéia central de responsabilidade social das empresas surge em trabalho de Charles Eliot, em 1906, nos EUA, uma proposta que não mobilizou as empresas. Ainda no mapeamento de origens históricas, menciona, entre outros eventos, a disputa judicial entre os sócios Ford e Dodge (1919), a respeito da distribuição de lucros, que terminou com a vitória de Dodge, contra a distribuição, e resultou na formação de duas empresas separadas; e a obra de Oliver Sheldon, The Philosophy of Management (1923), que abordava a importância de ações sociais, e obteve pouca receptividade.

O autor observa, contudo, que, após a grande depressão, a partir das idéias de Keynes (1936) a respeito da necessidade de regulação estatal e, especialmente após a $2^{a}$ Guerra, uma atmosfera remodelada recebe o livro de Howard Bowen, em 1953, Responsibilities of the Businessman, com uma visão ética dos negócios. Em 1960, é a vez de The Meaning of Modern Business, de Richard Eells, focando a relação da empresa com seu meio.

O autor prossegue, destacando o primeiro artigo científico, assinado por H.Gordon Fitch (1976), que tratava a empresa como “problema-solução” no mundo capitalista; e a obra de Thomas J. Zenisek (1979), que faz um apanhado do movimento e apresenta a proposta de duas vertentes: ética dos negócios, e expectativas da sociedade. São também citados Archie B. Carroll (1979), com um modelo "três pontas" (o que deve ser contemplado, quais demandas, e filosofia organizacional); e Wartick e Cochran (1985), que identificam três estágios evolutivos: responsabilidade econômica, pública e social, sendo este último considerado o “paradigma” (entendido em administração como estado da arte). Em termos gerais, o autor observa que criar modelos e prescrições parece ser a tônica das publicações. 


\section{Indícios de origens históricas da responsabilidade social no Brasil}

Segundo Rico (2001), filantropia e assistência não fizeram, historicamente, parte da cultura empresarial brasileira. Até o início do nosso processo de industrialização, e mesmo após, as ações sociais empresariais foram heterogêneas, pontuais, dependentes e tuteladas pelo Estado. Constituíam uma forma de os ricos ascenderem aos valores aristocráticos, pela prática do "bem", através de esmolas (SPOSATI, 1988); uma postura assistencialista, de um auxílio material ou financeiro destinado a atender a problemáticas imediatas, tais como alimentação, saúde, habitação etc., e marcada por um viés clientelista, que envolve uma relação de dominação e dependência. A partir do processo de transição democrática, nos anos 70, e especialmente a partir da década de 80 , é que se pode identificar uma ação social empresarial com a expectativa de participação no desenvolvimento social do país. Para ilustrar esse momento, podemos destacar iniciativas como a criação do Pensamento Nacional das Bases Empresariais (PNBE), em 1987, movimento constituído por um grupo de empresários paulistas para exprimir "os anseios das bases da iniciativa privada no Brasil moderno que começava a se delinear”, defendendo o aprofundamento da democracia, economia de mercado, melhor distribuição da renda; negociação para a resolução dos conflitos; aceitação da diversidade; defesa do patrimônio material e humano do país. Um dos fundadores do PNBE, o empresário Oded Grajew, veio a se tornar figura emblemática do movimento de responsabilidade social. Em 1990, criou a Fundação Abrinq pelos Direitos da Criança e do Adolescente, em 1994, fundou a Cives - Associação Brasileira de Empresários pela Cidadania e, em 1998, participou da fundação do Instituto Ethos de Empresas e Responsabilidade Social, entidade empresarial mais representativa nessa temática.

Outro fato significativo ocorre em 2000, quando o Instituto Ethos conduziu o processo de engajamento das empresas brasileiras ao Pacto Global, uma iniciativa das Nações Unidas para avançar na prática da responsabilidade social corporativa, buscando uma economia global mais sustentável e inclusiva. Em Junho de 2004, realizou-se, na Sede da ONU, o evento Compact Leaders Summit, reunindo representantes de 480 empresas signatárias, líderes de organizações internacionais do trabalho, sociedade civil e agências das Nações Unidas. Do Brasil, estiveram presentes representantes da Aché Laboratórios, Aracruz Celulose, Banco do Brasil, BOVESPA, Grupo Pão de Açúcar, FGV, Natura, Petrobrás, Souza Cruz, jornal Valor Econômico, entre outras organizações. 
É, portanto, a partir dos anos 90 que se consolidam os investimentos sociais empresariais, entendidos, segundo o GIFE (2001,p.11), como uso planejado, monitorado e voluntário de recursos privados. A preocupação com benemerência e ações pontuais cede lugar a investimentos que possibilitem retorno na aplicação de recursos em programas sociais.

\section{Definições de responsabilidade social empresarial}

Gomes (2007) destaca algumas definições brasileiras de RSE:

A RSE pode ser vista como uma obrigação moral da gestão empresarial, ou como resultado da pressão da sociedade organizada por políticas e legislações que protejam os direitos humanos, promovam melhores condições de trabalho e preservem o ambiente para as presentes e futuras gerações (BORGER, 2003, p.7 apud GOMES, 2007, p.178)

A do Instituto Ethos, que possui definição abrangente e está se tornando hegemônica:

A Responsabilidade Social Empresarial está além do que a empresa deve fazer por obrigação legal. A relação e os projetos com a comunidade ou as benfeitorias para o público interno são elementos fundamentais e estratégicos para a prática da RSE. Mas não é só. Incorporar critérios de responsabilidade social na gestão estratégica dos negócio e traduzir as políticas de inclusão social e de promoção da qualidade ambiental, entre outras, em metas que possam ser computadas na sua avaliação de desempenho é o grande desafio. (INSTITUTO ETHOS, 2003, p.13 apud GOMES, 2007, p.179-180)

A definição de Patrícia Ashley (2003), muito citada na produção do Rio de Janeiro:

Responsabilidade social pode ser definida como compromisso que uma organização deve ter para com a sociedade, expresso por meio de atos e atitudes... assume obrigações de caráter moral, além das estabelecidas em lei, mesmo que não diretamente vinculadas a suas atividades...[ numa visão expandida] é toda e qualquer ação que possa contribuir para a melhoria da qualidade de vida da sociedade (ASHLEY, 2003, p. 6-7 apud GOMES, p.181)

Alessio (2004, p.142-143), em citação indireta de Gomes (2007):

(...) um modelo de gestão baseado em comportamento ético e responsável na condução dos negócios, cujas decisões e ações resgatam valores humanos e universais, preservam e respeitam interesses de todas as partes direta e indiretamente envolvidas no negócio, assim como os de toda a sociedade, numa relação na qual todos obtêm benefícios (GOMES, 2007, p.181)

E a definição de Melo Neto e Froes (2001) que o autor considera um exemplo isolado de reconhecimento da necessidade de mobilização de mais setores para viabilizar as ações:

As ações de RSC buscam aprimorar as relações das empresas com seus diversos públicos, inseri-las devidamente no âmbito social das comunidades vizinhas e, sobretudo reforçar a atuação das ONGs, associações comunitárias, entidades filantrópicas e o governo local, seus principais parceiros. (MELO NETO e FROES, 2001, p.22 apud GOMES, 2007, p.182 


\section{A responsabilidade social empresarial no contexto mercadológico}

\section{Responsabilidade social e marketing}

O surgimento de uma parcela significativa de não consumidores, caracterizados como indivíduos excluídos da sociedade de consumo, reflexo esse do aumento da desigualdade social, assim como o agravamento de problemas ambientais que colocam em risco o futuro do planeta, começou a surgir a partir da década de 60, com questionamentos sobre o crescimento econômico desvinculado do bem estar da maior parte da população. O marketing, a partir de então, passou a incorporar à ótica empresarial ações voltadas, também, para causas sociais e ambientais. Nesse contexto, surge a expressão marketing social, formulada por Kotler e Zaltman.

\footnotetext{
“Marketing social é a modalidade de ação mercadológica institucional que tem por objetivo atenuar ou eliminar problemas sociais, carências da sociedade relacionadas principalmente com questões de higiene e saúde pública, trabalho, educação, habitação, transporte e nutrição" (KOTLER \& ROBERTO, 1992: p.25).
}

No escopo do marketing social, surge, ainda, o conceito de marketing comunitário, que faz referência às ações desenvolvidas em contextos comunitários, limitados geograficamente a uma coletividade, que podem, ou não, ter o caráter de amparo social. Vaz (1995: p.299) ressalta que a grande maioria das ações de marketing comunitário têm caráter social, fazendo com que os conceitos se aproximem. Além disso, Mendonça (2002, p.158) adverte que esse tipo de marketing só funciona se, além de benefícios à comunidade, tiver como retorno benefícios para a imagem da empresa.

Por esse prisma, o termo responsabilidade social, pode ser compreendido como uma espécie de evolução do marketing social, que daria conta de uma conscientização maior da empresa do seu papel dentro da sociedade. Além disso, o termo marketing encontra-se bastante desgastado e associado, no senso comum, a ações eminentemente voltadas para o lucro. A relação entre marketing e responsabilidade social tem sido, contudo, negada pelo discurso das empresas e da mídia, como observaremos na análise a seguir, sobretudo pela aproximação com o conceito de gestão, que afirma o caráter mercadológico da iniciativa como positivo, por gerar riqueza, e afasta o caráter negativo trazido pela associação direta com o marketing.

Outro aspecto mercadológico importante são os vários públicos atingidos pela divulgação das ações sociais e ambientais das empresas, descritos na classificação de Matrat, citada por Oliveira (2002: p. 215): 
- Público de decisão - que inclui funcionários e governo, públicos cuja concordância afeta diretamente o funcionamento organizacional.

- Público de consulta - que se presta a sondagem para dar parâmetros às ações da empresa, incluindo universidades e centros de pesquisa, organizações nãogovernamentais, institutos e empresariado em geral.

- Público de comportamento - cuja atuação pode prejudicar ou favorecer a ação da organização, tais como comunidade em geral, fornecedores e associações.

- Público de opinião - que influencia a organização pela manifestação do seu ponto de vista, incluindo formadores de opinião e a imprensa.

Para dar conta desses vários públicos, a comunicação das empresas extrapola os meios de comunicação de massa (sobretudo TV, rádio e impressos), que continuam com papel importante, e desenvolvem uma "gestão de contatos" (nomeação que vem ganhando terreno em relação à mídia), utilizando-se de inúmeras ações que, anteriormente, não eram percebidas como ferramentas de comunicação. As ações de responsabilidade, com todos os cuidados que suas peculiaridades demandam para serem comunicadas, fazem parte do rol de possibilidades, uma vez que são, sob a ótica do marketing, potenciais ferramentas de comunicação e construção de marca.

\section{A comunicação mercadológica contemporânea}

A comunicação empresarial, que envolve a questão da responsabilidade social, constitui, portanto, um conjunto integrado que não envolve somente a publicidade, mas várias outras formas de comunicação mercadológica que também cumprem o papel publicitário junto a diversos públicos, tais como os balanços sociais, matérias jornalísticas, eventos, e as próprias ações sociais, transformadas em comunicações sociais.

É um composto que, integrando as organizações, passa, no mundo contemporâneo, por um processo profundo de transformação e encontra-se num contexto de diluição dos limites entre comunicação interna e externa das organizações, centralidade do marketing, exigência permanente de resultados mensuráveis, e estruturação organizacional a partir de cadeias de valor horizontais, apontados, no âmbito do marketing, por Harter (2007), entre outros.

Nesse contexto, as ações de comunicação com os diferentes públicos articulam-se em torno da construção de marca. Como detalha Perez (2004, p.48), a publicidade atua para criar o espaço 
perceptual da marca, lançando mão de inúmeros canais, para se conectar sensorial e afetivamente com os diversos públicos, por meio de imagens, símbolos, sensações e associações.

Os números de levantamentos estatísticos recentes, como a Pesquisa Anual de Produtos e Serviços do IBGE, cujo Suplemento 2004-2005 focou os Serviços Publicitários, não revelam significativas modificações no quadro econômico geral, que ainda aponta para o predomínio dos veículos de comunicação de massa (sobretudo a TV e os impressos). Um olhar mais atento torna possível, contudo, identificar indícios que sinalizam a configuração de novos cenários e de expressivas alterações no mercado da Comunicação e da Publicidade.

Crescimentos pontuais (sobretudo em percentagens) e desdobramentos significativos em algumas áreas importantes da comunicação (a exemplo do segmento formado por eventos) apontam com vigor para as novas abordagens da comunicação, com as quais muitos profissionais já trabalham ${ }^{4}$.

Indícios de mudanças de grande monta já estão presentes no discurso e nas diretrizes definidas pelos Chief Marketing Officers (CMOs), em todo o mundo. Resultados de pesquisas realizadas por consultoria especializada em estratégia e tecnologia - Booz Allen Hamilton - e pela Association of National Advertisers (ANA), envolvendo líderes de grandes empresas globais, ${ }^{5}$ identificam os desafios que merecem ser perseguidos, de forma cada vez mais contundente: explorar o potencial oferecido pelas novas mídias; estabelecer novos paradigmas de organização e de relacionamento com as agências; manter-se flexível, para poder permanecer adaptável; tornar o marketing mensurável. Apesar de não serem questões novas para aqueles que atuam profissionalmente no cotidiano desse mercado, e haja grande distância entre o que se diz e o que se faz, o discurso desses líderes aponta tendências já em curso que, mais cedo ou mais tarde, atingirão o mercado nacional.

São mudanças intensas e apontadas por diversos autores. Francisco Gracioso (2007, p.10/16) abrigou a complexidade da comunicação atual sob a nomeação de Arenas da Comunicação com o Mercado, termo que abrange mega-shows de música; patrocínio de

\footnotetext{
${ }^{4}$ Esses pontos são detalhados em Ensaio Interpretativo, elaborado por Denis da Silva Lima, Manolita Correia Lima e Ricardo Zagallo Camargo, a respeito dos dados levantados a partir da parceria da Associação Brasileira de Agências de Propaganda (ABAP) e IBGE, distribuído como anexo do documento Números oficiais da indústria da comunicação e seu impacto na economia brasileira publicado pela ABAP/IBGE, em 2008

${ }^{5}$ Os principais achados da pesquisa estão condensados na publicação CMO Thought Leaders - The rise of the strategic marketer, que conta com 15 entrevistas com executivos de grandes corporações. A obra está disponível para compra no site http://www.strategy-business.com/cmoreader. Os aspectos aqui abordados constam do capítulo introdutório, intitulado Marketing Metamorphosis.
} 
atletas ou clubes e grandes eventos esportivos; o universo da moda; grandes feiras; o mundo digital; o grande varejo; além da própria propaganda. Inspirado nas idéias desenvolvidas por Debord (1997), reconhece o espetáculo como o denominador comum da complexa configuração da comunicação contemporânea. Gracioso (2007) lembra, ainda, que novas arenas surgem a todo momento, refletindo a evolução econômica e social. Convergem, porém, para um mesmo ponto: são, simultaneamente, capazes de atrair e divertir, persuadir e vender. Esse fenômeno pressupõe a reorganização das estratégias de comunicação formuladas pelas empresas, na direção da ampliação do mix de comunicação, e de adoção de ações que extrapolam os veículos da mídia tradicional. Não é difícil resgatar exemplos de empresas que diminuíram o montante de investimento em propaganda tradicional (rádio, TV e impressos) e passaram a investir fortemente na organização de espetáculos oferecidos aos consumidores, como forma de persuasão à compra. Há algum tempo, grandes empresas, entre outras, adotaram este tipo de estratégia de comunicação.

A socióloga Egeria Di Nallo (1999), por sua vez, propõe o conceito de Meeting Points, deslocando o olhar dos perfis de consumidor para os processos de consumo. Essa Autora lembra que, na contemporaneidade, o consumidor não representa mais um território de conquista por parte da empresa, mas alguém que se encontra, assim como as empresas, no interior de "fluxos de comunicação”; possui identidades sociais, estilos de vida e hábitos de consumo mutantes, contraditórios e flexíveis. Nesse contexto, os Meeting Points são entendidos como pontos de encontro de consumidores, de produtos, e também de uma grande quantidade de fluxos comunicativos que tendem a constituir um sistema de expectativas que dá corpo e credibilidade a um determinado estilo de consumo. Por exemplo, para os Meeting Points dos quais faz parte o produto chocolate, convergem atividades agrícolas associadas, decoração de bolos, orientações dietéticas, literatura, filmes etc.

Seja nas Arenas de Gracioso, seja nos Meeting Points de Di Nallo, o entretenimento passa a ser entendido como uma linguagem que permeia praticamente todas as relações estabelecidas na sociedade atual - razão pela qual vem sendo cada vez mais explorado na comunicação mercadológica. Pesquisadores como Kellner (2006), contudo, alertam para o impacto negativo desse fenômeno, destacando o potencial esvaziamento que a ‘espetacularização’ pode provocar no conjunto das atividades culturais e políticas. Para o autor, quando entretenimento e espetáculo se conjugam como princípios organizadores da economia, política, sociedade e vida cotidiana, a exposição de conflitos sociais e políticos à 
‘forma-espetáculo’ da mídia faz com que esses conflitos sejam facilmente transformados em casos sensacionalistas de homicídios, atentados terroristas, escândalos sexuais de políticos e celebridades, e na explosiva violência do quotidiano. Diante desse esvaziamento da política, Kellner (2006) alerta para a necessidade de identificar, nessa nova expressão da cultura, formas renovadas de dominação e opressão, bem como seu potencial para processos de democratização e justiça social.

A velocidade das transformações, aceleradas pela tecnologia, tornam ainda mais difícil refletir a respeito do que está acontecendo. Como lembra Muniz Sodré (2007), as tecnologias avançadas da comunicação e a velocidade de circulação das informações produzem uma temporalidade em "tempo real”, onde os acontecimentos estão sempre a frente da possibilidade de serem interpretados. É, contudo, esse cenário de multiplicidade dos fenômenos comunicativos e "midiatização" que se apresenta diante daqueles empenhados em refletir sobre a forma como as atividades se organizam no mundo real.

Uma lente para decifrar a realidade da comunicação mercadológica é a oferecida pela noção de cadeia produtiva. Castro et all (2002) assinalam que o conceito foi desenvolvido sob a premissa de que a produção de bens pode ser representada por um sistema, onde os diversos atores estão conectados por fluxos de materiais, de capital e de informação. Surgido, originalmente, para retratar a produção agropecuária, foi usado no processo de planejamento da Embrapa, no início da década de 90, e, posteriormente, passou a ser aplicado a atividades produtivas de outra natureza, mostrando-se útil para aumentar a compreensão de complexos sistemas de produção, determinar gargalos e oportunidades não exploradas nos processos produtivos, gerenciais e tecnológicos. Os elos de uma cadeia produtiva envolvem as questões de insumos (pré-produção), produção, distribuição, comercialização e consumo.

No caso da comunicação, como destacam Pereira e Reis (2008), a questão central é a gestão de informações e fluxos de sentido. Para chegar a estratégias comunicacionais eficientes, as empresas devem administrar uma logística do sentido: da natureza e da distribuição e das formas de circulação de fluxos de sentido em determinado ambiente ou contexto. Para observar como esse conceito pode ser utilizado para decifrar os caminhos atuais da comunicação, pesquisa realizada pelo Centro de Altos Estudos da ESPM tomou grandes eventos como objetos empíricos. Entre os observados, destacamos a Fashion Rio, um evento que é articulado pela empresa patrocinadora, que não apenas empresta o nome e financia o evento, mas gerencia todo o fluxo de comunicação que impacta em dimensões 
anteriormente não percebidas como atividades de comunicação. Questões como a estruturação do espaço físico, segurança e infra-estrutura têm que ser pensadas dentro da estratégia de comunicação. Vale ressaltar que o evento já existia, mas, a partir do momento em que passa a ser utilizado como ferramenta de comunicação e construção de marca, passa a incorporar uma série de preocupações novas, dimensionando os recursos físicos e humanos em função das necessidades específicas do patrocinador.

O conceito de cadeia produtiva de comunicação pressupõe, pelo princípio sistêmico, a interligação e, por vezes, sobreposição entre cadeias diferentes, como a da moda, a mais evidente nesse caso, mas também a indústria têxtil e do turismo, entre outras. Permite, dessa forma, percebermos os novos desdobramentos da comunicação mercadológica. Requer, contudo, cuidado, para não cairmos em generalizações do tipo “tudo é comunicação”, pouco contributivas e esclarecedoras.

No que diz respeito diretamente à nossa pesquisa, observamos que a noção ampliada de comunicação mercadológica permite a reincorporação das ações de responsabilidade social, não mais entendidas como marketing social, mas como ações que integram arenas ou meeting points de contato com os consumidores. Um reenquadramento que parece deslocar a discussão da motivação (comercial) para o modo de comunicar as ações.

Outro olhar que julgamos pertinente para entender a comunicação mercadológica, e que não será desenvolvido aqui, é o das indústrias criativas, termo que, como informa Bendassoli (2007), surgiu nos anos 1980, associado originalmente ao contexto das políticas públicas de cultura e designa, hoje, os setores onde a criatividade é uma dimensão essencial. Situadas no cruzamento das artes, cultura, negócios e tecnologia incluem, hoje, o consumo cultural (espetáculos, moda, música), software, arquitetura, cinema, design, editoração, televisão e publicidade, entre outras. Representa uma articulação de atividades que dialoga diretamente com as propostas de Arenas de Comunicação e Meeting Points, abordadas anteriormente, que aqui ganham uma dimensão estratégica, não só para as empresas mas também para países e blocos comerciais.

Além disso, pensar a comunicação mercadológica requer avaliar sua inserção num mercado global, aspecto que interfere diretamente nas ações de responsabilidade social, que respondem a movimentos empresariais em grande escala e representam, para Porter (1990), entre outros, vantagens competitivas numa economia global. 


\section{CAPÍTULO 1 - MÚLTIPLOS ENQUADRAMENTOS}

\section{Critérios e procedimentos adotados}

O levantamento incluiu trabalhos que tratavam diretamente da responsabilidade social e de denominações e temas correlatos. As buscas foram realizadas da forma mais exaustiva possível em livros, bancos de dados de teses e dissertações, periódicos, programas de pósgraduação e anais de eventos, entre outras fontes.

Pela característica do objeto de estudo, que tem sido observado a partir da perspectiva de diversas áreas do conhecimento, a revisão incluiu, sobretudo, trabalhos de comunicação, foco desta pesquisa, e de administração, área que concentra a maior parte das publicações. Os trabalhos da área de administração contribuíram para a construção da evolução do conceito, sobretudo pela ótica gerencial e da cadeia produtiva, e para dar um panorama atualizado à descrição e aperfeiçoamento das práticas empresariais. Em virtude do foco e interesse desta pesquisa, foi dada especial atenção aos trabalhos que possuem um olhar crítico em relação às ações das empresas.

Além dessas duas áreas, que concentram a maioria dos textos localizados, o escopo da revisão abrangeu, tendo como referência a classificação das Áreas do Conhecimento elaborada sob a coordenação da Capes e do Cnpq, a grande área das Ciências Sociais Aplicadas, com trabalhos nas áreas de Direito, Serviço Social, Filosofia (subárea Ética), Sociologia, Antropologia, História, Geografia (Subárea Geografia Política), Psicologia (subáreas Psicologia Social, Psicologia do Trabalho e Organizacional), Educação e Ciência Política. Um leque abrangente que não permitiu o aprofundamento das questões levantadas, mas possibilitou a coleta de visões complementares e enriquecedoras sobre o tema e o objeto de estudo.

A dinâmica de busca em bancos de dados (sobretudo com a utilização da internet) era a seguinte: caso a busca com palavras mais abrangentes como "responsabilidade social” ou “cidadania” revelasse muitos achados, era refinada com a incorporação de "corporativa” e “empresarial”, que se aproximavam do tema em estudo. No caso de poucos achados, todos eram consultados. Os trabalhos considerados correlatos tinham seus resumos registrados, e os mais próximos eram lidos e fichados parcial ou integralmente.

O processo de coleta ocorreu ao longo de todo o processo de pesquisa, com destaque para três grandes momentos: levantamento inicial, para a elaboração do projeto (realizado no 
ano de 2004), (a) revisão para o exame de qualificação (realizada no segundo semestre de 2007), e o levantamento final para redação da tese (realizado no final de 2008).

Foram consultadas as seguintes fontes:

\section{Anais de reuniões acadêmicas}

- Anais do Encontro da Associação Nacional de Pós-Graduação e Pesquisa em Administração - ENANPAD (edições de 2006, 2007 e 2008);

- Anais do Encontro Nacional dos Cursos de Graduação em Administração ENANGRAD (edições de 2006 e 2007);

- Anais dos Encontros anuais da Associação Nacional dos Programas de PósGraduação em Comunicação - COMPÓS (todas as edições);

- Anais do X Colóquio Internacional de Poder Internacional (2006);

\section{Periódicos}

- Revista de Administração de Empresas - RAE (números disponíveis no acervo histórico online);

- Revista e-compós (todas as edições);

- Portal Revcom, que congrega periódicos da área de comunicação, mantido pela Sociedade Brasileira de Estudos Interdisciplinares da Comunicação - Intercom. Foram consultados 19 periódicos, por meio de busca geral com as palavraschave: Responsabilidade (Social), Cidadania, Ética, Filantropia, Voluntariado, Investimento social (privado), Sustentabilidade, Terceiro Setor, Empresas, sem limitação de data de publicação;

- Portal de periódicos da CAPES, a partir do qual foram consultados os sites dos 20 periódicos nacionais de Comunicação, avaliados com A ou B pelo programa QUALIS com as palavras-chave: Responsabilidade Social, Cidadania, Ética, Filantropia, Voluntariado, Investimento social (privado), Sustentabilidade e Terceiro Setor, sem limitação de data de publicação;

\section{Bases de dados}

- Biblioteca Digital Brasileira de Teses e Dissertações, mantida pelo IBICT Instituto Brasileiro de Informação em Ciência e Tecnologia www.ibict.br. Palavras-chave: Responsabilidade Social, Sustentabilidade e Desenvolvimento Sustentável, Cidadania, Ética, Filantropia, Voluntariado, Investimento Social, Empresas, sem limitação de data de publicação. 
- Banco de Teses e Dissertações da CAPES, consulta restrita a doutorados no período entre 2004 e 2007, com expressão exata: Responsabilidade Social Corporativa, Empresarial, das Empresas; Cidadania Empresarial, Corporativa e Empresa-cidadã; Filantropia, Voluntariado; Sustentabilidade, Desenvolvimento sustentável ( a maior parte dos trabalhos localizados referia-se a meio-ambiente e agricultura - ecoturismo, ecologia, biodiversidade, cadeia produtiva).

- Biblioteca Digital de Teses e Dissertações da USP, filtro área de Ciências Humanas e título, período 2004 a 2008. Palavras no título: Responsabilidade Social Corporativa, Empresarial, das Empresas; Cidadania Empresarial, Corporativa e Empresa-cidadã; Filantropia, Voluntariado; Sustentabilidade, Desenvolvimento sustentável.

- Sistema Nou-Rau Biblioteca Digital UNICAMP, com as palavras-chave "Responsabilidade Social”, “Cidadania Empresarial”, "Cidadania Corporativa”, “Ética nos negócios, “Ética empresarial”, "Filantropia”, “Voluntariado”, “Investimento social (privado)” e “Sustentabilidade”.

- Google Acadêmico - A busca por páginas de internet em português, com a palavra-chave "Responsabilidade Social” no título, realizada em fevereiro de 2009, obteve 3.750 páginas, entre livros, citações e artigos publicados no período entre 2006 e 2008, o que corrobora a afirmação de Gomes (2007), ou seja, que o tema é bastante popular e abrange outras áreas, como biologia e medicina, não necessariamente relacionadas às empresas. A consulta restringiu-se aos livros e artigos, descartando-se as citações e, para refinar o levantamento, foi usada a palavra-chave "Responsabilidade Social empresarial”, com a obtenção de 219 páginas, que foram reduzidas para 110, restringindo-se a busca aos anos de 2006, 2007 e 2008. De forma complementar, foram utilizadas as seguintes palavras-chave: “Responsabilidade Social corporativa” (76 páginas); "Responsabilidade Social das empresas” (98 páginas); “Responsabilidade Social dos/nos negócios” (19 páginas, consultadas superficialmente por conterem muitas repetições das buscas anteriores); “Cidadania Empresarial” (37 páginas, consultadas superficialmente por conterem muitas repetições das buscas anteriores); “Cidadania Corporativa” (31 páginas, consultadas superficialmente por conterem muitas repetições das buscas anteriores); “Ética nos negócios” (17 
páginas, consultadas superficialmente por conterem muitas repetições das buscas anteriores); “Ética empresarial” (181 páginas, consultadas superficialmente, com muitas páginas em espanhol); "Filantropia empresarial” (28 páginas, consultadas superficialmente por conterem muitas repetições das buscas anteriores); "Filantropia corporativa” (4 páginas); "Voluntariado empresarial” (10 páginas); “Investimento social privado” (15 páginas, consultadas superficialmente); “Sustentabilidade” (4.210 páginas, reduzidas para 227, utilizando-se como filtro a presença do termo no título dos artigos, e o período de 2006 a 2009, com muitos trabalhos relacionados ao meioambiente e muitas citações).

- Bases de dados internacionais -_A coleta teve como fonte o serviço de clipping da ESPM, que diariamente seleciona artigos relacionados às áreas de interesse da instituição (administração, comunicação mercadológica, design, relações internacionais, e marketing), provenientes da EBSCO, empresa que gerencia e dá acesso, através de serviços de assinaturas de periódicos impressos e eletrônicos, que conta, entre outras, com a Business Source Complete, base de dados na área de gestão e áreas relacionadas, e Communication \& Mass Media Complete, na área de comunicação; e da Emerald, base de dados de periódicos eletrônicos nas áreas de administração, negócios, marketing e economia (a lista completa das publicações do clipping ESPM encontra-se no apêndice 2 ). Trata-se, contudo, de uma coleta não exaustiva.

- Sites dos Programas de Pós-Graduação em Comunicação brasileiros - Foram consultados, por meio do portal Portcom, mantido pela Sociedade Brasileira de Estudos Interdisciplinares da Comunicação - Intercom, os sites de 23 programas, envolvendo teses, dissertações, artigos em periódicos e outras publicações, no período entre 2004 e 2009, sempre que possível. Nos casos em que a linha de pesquisa e/ou linha editorial dos periódicos localizados estava mais próxima do foco deste estudo, a busca se estendeu a 2002, ou foi feita integralmente, sem restrição de data. Constitui-se na busca mais detalhada (lista completa no apêndice 1).

Dentro do objetivo de rastrear a produção científica e fortalecer o potencial de contribuição deste trabalho, esse levantamento possibilitou, portanto, a obtenção de uma visão atualizada das diferentes maneiras pelas quais a questão da responsabilidade social das 
empresas tem sido estudada, em especial pelos pesquisadores brasileiros (uma vez que a coleta internacional não foi exaustiva). Foi dada especial atenção aos trabalhos que focam as questões da cidadania, solidariedade e democracia e suas articulações com as ações das empresas, aproximando-se, dessa forma, da análise de discurso que este trabalho se propõe a fazer._Os artigos foram agrupados de acordo com as áreas, temáticas abordadas e enfoques utilizados. Essa divisão foi a forma encontrada para sistematizar as informações e possibilitar o diálogo com o referencial teórico e os achados desta pesquisa. Tal procedimento implica, contudo, a desconsideração de nuanças e diferenças importantes entre trabalhos tratados como de um mesmo "grupo”. A seqüência proposta para os grupos parte de autores que apresentam a gênese e trajetória da noção de RSE, tentativas de delimitação do campo e dilemas enfrentados pelo conceito; passam por sua difusão no ambiente das empresas, tentativas de aperfeiçoamento e gestão; e chegam às críticas, das gerenciais até aquelas que discutem a disputa de conflitos e sentidos e aproximam-se, portanto, da proposta desta pesquisa.

\section{Gênese e trajetória do conceito, delimitação teórica, e definição do campo}

Autores clássicos da área mercadológica associaram mercado e sociedade, como Kotler, que define marketing social como “a modalidade de ação mercadológica institucional que tem por objetivo atenuar ou eliminar problemas sociais, carências da sociedade relacionadas principalmente com questões de higiene e saúde pública, trabalho, educação, habitação, transporte e nutrição” (KOTLER, 1998: p.25). Até chegar a pesquisadores que propõem a prática da responsabilidade social como "uma nova filosofia, um novo modo de conceber as relações entre os fatores de produção (trabalho e capital), dos quais surge uma nova concepção da empresa e de seu papel social.” (OLIVEIRA, 2002: p.206).

Atualmente, a responsabilidade social empresarial tem como principal referência no campo empresarial, o Instituto Ethos ${ }^{6}$. Para classificar as empresas quanto à responsabilidade social, esse instituto desenvolveu um instrumento de acompanhamento e monitoramento das práticas empresariais denominado Indicadores Ethos de Responsabilidade Social Empresarial, um conjunto de questionários utilizado como ferramenta de autoavaliação nas empresas. Por sua vez, os respondidos pelas empresas e enviados para o instituto, se prestam, entre outras coisas, à divulgação, mediante autorização, de práticas exemplares. Destaca-se, também, no processo de institucionalização da RSE no Brasil, o IBASE, organização da sociedade civil.

\footnotetext{
${ }^{6}$ O Instituto Ethos de Empresas e Responsabilidade Social é uma associação de empresas criado em 1998, com a missão de promover e disseminar práticas empresariais socialmente responsáveis, contribuindo para o desenvolvimento sustentável nos aspectos econômico, social e ambiental.
} 
Segundo o Instituto Ethos, a noção de Responsabilidade Social decorre da compreensão de que a ação empresarial deve: buscar benefícios para a sociedade, propiciar a realização profissional dos empregados, promover benefícios para os parceiros e para o meio ambiente, e trazer retorno para os investidores. É uma abordagem alinhada com a conceituação da Comissão da Comunidade Européia, segundo a qual a RSE é um conceito por meio do qual as empresas integram preocupações sociais e ambientais às operações dos seus negócios e nas interações com outras partes interessadas. Formulações semelhantes são encontradas na norma brasileira NBR 16001:2004, que cita diretamente a redução das desigualdades sociais, e na ISO (2004). As noções atuais unem, dessa forma, aspectos sociais, ambientais e econômicos, os três "Ps" que norteariam as empresas responsáveis (Profit, Planet e People) e são as bases do conceito de sustentabilidade que vem, recentemente, substituindo a nomeação RSE. Uma mudança que traz, como veremos adiante, importantes implicações.

Wanderley (2006) traça um panorama da evolução do conceito, a partir de Bowen (1953), passando por Friedman (1962), Carroll(1979) e Freeman (1984). Buchholz e Rosenthal (2001), afirmam que o tema ganha relevância no mundo dos negócios, nas décadas de 1960 e 70, em decorrência de mudanças sociais, como as lutas pelos direitos das minorias, a igualdade de direito das mulheres, a proteção ao meio ambiente, e com a segurança e saúde dos trabalhadores, além de uma ampla gama de preocupações por parte dos consumidores. Os autores afirmam que, segundo Carroll (1979), o debate em torno do tema intensifica-se a partir de 1962, quando Milton Friedman declara que a primeira e única responsabilidade social da empresa é gerar lucro para os acionistas. O progresso social, por sua vez, seria decorrência do econômico.

Bovens (1998 apud Wanderley 2006) propõe cinco formas de entendermos o conceito de responsabilidade empresarial:

1. Responsabilidade como causa: "responsável por”, no sentido de conseqüência. Empresas são responsáveis por reparar os estragos que causaram.

2. Responsabilidade como accountability: tornar-se responsável, comprometer-se com os resultados. Envolve obrigações legais e morais.

3. Responsabilidade como capacidade: no sentido de ter os meios para realizar ações responsáveis. Envolve a decisão da empresa de assumir (ou não) as responsabilidades. Uma decisão limitada pelas competências específicas da empresa. 
4. Responsabilidade como tarefa: relacionada à competência, performance e condutas relacionados ao core business da empresa.

5. Responsabilidade como virtude: envolve o compromisso ativo de boas práticas, assim como advogar julgamentos de valor positivos. Contribuição ativa e voluntária para uma sociedade melhor.

Levantamento de Cajazeira e Barbieri (2006) - O tema Responsabilidade Social Empresarial ou Corporativa (RSC) já vinha produzindo grandes polêmicas no ambiente acadêmico desde meados do século passado, como mostra Carroll (1979). Na opinião de Buchholz e Rosenthal (2001), esse tema deslancha nas décadas de 1960 e 70, em decorrência de profundas mudanças que ocorrem no âmbito da sociedade e que afetam o ambiente de negócios, dentre elas, o interesse pelos direitos das minorias, a igualdade de direito das mulheres, a proteção ao meio ambiente, a segurança e saúde dos trabalhadores e uma ampla gama de preocupações por parte dos consumidores (p. 366-7). Segundo Carroll (1979), o debate em torno desse tema tornou-se mais intenso a partir de 1962, quando Milton Friedman declara que a doutrina do RSC é fundamente subversiva. Para Friedman (1982; p. 497), uma das poucas coisas a minar as bases da sociedade livre seria a aceitação, por parte dos dirigentes das empresas, de uma responsabilidade social que não a de fazer tanto dinheiro quanto possível para os acionistas. Marrewijk (2003) denomina de abordagem do acionista (shareholder approach). Esse entendimento a respeito da RSC ainda encontra muitos defensores nos meios empresariais. A Fundação criada por Bill Gates e sua esposa Melinda, para promover a filantropia, é inteiramente financiada com recursos próprios do casal e não das suas empresas.

Para a Comissão da Comunidade Européia (2002; p. 5), RSC é um conceito por meio do qual as empresas integram preocupações sociais e ambientais às operações dos seus negócios e nas interações com outras partes interessadas.

A norma brasileira NBR 16001:2004 define responsabilidade social como a relação ética e transparente da organização com todos os públicos com os quais se relaciona, e pelo estabelecimento de metas compatíveis com o desenvolvimento sustentável da sociedade, preservando recursos ambientais e culturais para gerações futuras, respeitando a diversidade e promovendo a redução das desigualdades sociais.

Essa abordagem é a mesma do Instituto Ethos (2005), cuja noção de RS decorre da compreensão de que a ação empresarial deve, necessariamente, buscar benefícios para a sociedade, propiciar a realização profissional dos empregados, promover benefícios para os 
parceiros e para o meio ambiente, e trazer retorno para os investidores. A ISO (2004) mostra que a maioria dos entendimentos atuais sobre o tema explora a inter-relação entre responsabilidade social e os aspectos e impactos econômico, ambiental e social das atividades de uma organização, o que o associa ao tema do desenvolvimento sustentável.

Desenvolvimento sustentável é definido Pela Comissão Mundial Sobre Meio Ambiente e Desenvolvimento (1991; pg 46) como "aquele que atende às necessidades do presente sem comprometer a possibilidade das gerações futuras atenderem às próprias necessidades” (CMMAD, 1987, p. 46).

Nascimento (2006) situa o desenvolvimento sustentável, a partir de Egri e Pinfield (1998), entre três perspectivas da relação homem/natureza: o paradigma social dominante (arriscamos dizer que em processo de transição) do capitalismo ocidental, voltado para o crescimento econômico e lucro, com recursos naturais vistos como infinitamente exploráveis e os impactos ambientais como externalidades; o ambientalismo radical, guarda-chuva filosófico oposto ao paradigma social dominante, que visa o equilíbrio holístico na natureza e sociedade; e a perspectiva do ambientalismo enovado, surgido no século XIX, com valores biocêntricos e o conceito de stakeholders, visando o desenvolvimento sustentável do ambiente natural, bem como da economia para reduzir as desigualdades sociais.

Meira (2006), em pesquisa inspirada na abordagem de Maurício Tragtenberg, associa a gênese da responsabilidade social empresarial ao surgimento da noção de pessoa jurídica. Resgata 1866, quando a Suprema Corte norte-americana, no caso Condado de Santa. Clara versus Southern Pacific Railroad, outorgou à corporação o status jurídico-legal de pessoa. Desde então, os tratados de direito passaram a conceber as empresas como “entidade natural”. Uma legitimidade jurídica que não foi acompanhada, contudo, pela legitimidade social, uma vez que as práticas inescrupulosas e a concentração de poder fizeram com que grandes magnatas americanos, como Vanderbilt, Rockfeller e JP Morgan, ficassem conhecidos como robber barons. Nos anos 20, essa imagem começa a ser combatida com o despertar do management no cultivo das relações com os públicos. Meira associa esse fato ao surgimento da gerência como profissão. Os gerentes “esclarecidos” passam então a eclipsar o poder das corporações, postando-se como defensores públicos, e a se autointitularem trustees da nova instituição. Não há, contudo, abertura efetiva para controle social, pois os gerentes são completamente identificados com a corporação.

A preocupação com o social, entrelaçada à ótica gerencial, desenvolveu-se historicamente, constituindo o campo de estudos Business and Society, tradicional na área de 
administração, sobretudo nos EUA, a partir da década de 60, buscando a compreensão da relação entre empresa e sociedade como continuidade e não como antagonismo. Um marco importante desse processo é o livro Social Responsibilities of the- Businessmen de Howard R. Bowen, de 1953, apontado por Carroll (1999) como obra fundadora da era moderna da responsabilidade social. $\mathrm{O}$ autor era um economista keynesiano e a obra faz parte de conjunto de estudos patrocinados pelo Conselho Nacional das Igrejas Cristãs nos EUA, projeto iniciado em 1949, que contou com seis volumes sobre relações entre religião e economia. As propostas de Bowen ancoram-se num confronto entre perspectivas dos homens de negócios e pensadores sociais protestantes. No sentido de encontrar um equilíbrio razoável, ele propõe um sistema que combine empreendimentos privados, públicos e cooperativos, com ênfase nos primeiros. Em tal sistema, que não conta com indicações práticas de aplicação, o controle seria exercido pelo mercado, com auto-regulação e regulamentação pública. A renda seria distribuída não levando em conta apenas as alocações de produção, mas as necessidades das pessoas. O livro traz, ainda, orientações genéricas de priorizar a sociedade ao lucro, preservar o ambiente para futuras gerações, não discriminar as pessoas, oferecer condições saudáveis de trabalho etc. Resp Social como reconciliação entre sociedade e corporação. Outro autor da época, Carl Kaysen (1957), fala de uma “corporação com alma”, onde gerentes assumem responsabilidade por clientes, acionistas, empregados e não apenas pelos lucros.

Meira (2006), retomando as concepções de Maurício Tragtenberg (livro Administração, Poder e Ideologia), para quem a teoria geral da administração é uma ideologia, estabelece a relação entre o conceito de responsabilidade social e o processo de legitimação da gerência, com a consolidação de sua posição hegemônica. Recorre a Zizek (1996) para detalhar as etapas dessa operação: 1-identificação do antagonismo; 2-admissão de campo neutro compartilhado; 3- criação de um terceiro ambiente neutro, no qual os polos coexistam. Esse ambiente neutro, o “e” que se situa entre empresa e sociedade, é o espaço ocupado pela responsabilidade social. O autor lembra, contudo, que, para Tratgtenberg, não há função social possível para a propriedade privada, porque ela funda uma sociedade dividida em classes, onde os antagonismos são irreconciliáveis. Uma afirmação que, sem desconsiderar o valor social efetivo de muitas dessas iniciativas, serve de base a alguns questionamentos. Primeiro, no que diz respeito à própria conceituação do termo responsabilidade social. A responsabilidade, para ser "social”, deve ser percebida, pensada e praticada por sujeitos sociais que vivam uma vida em comum. Uma proposta que exige um deslocamento do “ajudar” para o “envolver-se com”, que coloca em xeque boa parte das 
ações. Apesar de perceber a importância da prática da boa cidadania corporativa para a sustentabilidade dos negócios e sucesso das marcas, os empresários, pela própria finalidade lucrativa das empresas, acabam não aprofundando o envolvimento com causas sociais.

Borges (2000), por sua vez, aborda os conceitos de espaço público e marketing institucional e a inter-relação com a publicidade (visibilidade). Por outro lado, Machado Filho (2004) trata da questão do capital "reputacional” das empresas, associando a responsabilidade social à criação de valor para as organizações.

Silva (2004) utiliza o aporte da Sociologia e da Antropologia, para analisar até que ponto a gestão da responsabilidade social corporativa, no Brasil, pode ser associada aos princípios da dádiva e da solidariedade. De acordo com o paradigma da dádiva, as relações sociais se compõem por quatro polos: o interesse, a obrigação, o prazer e a espontaneidade. A autora observa que os quatro polos do paradigma da dádiva estão presentes na gestão da responsabilidade social corporativa da empresa estudada, em graus variáveis, de acordo com cada projeto social. Nota, também, que a concepção de solidariedade, relacionada à interdependência, está no cerne da gestão da responsabilidade social corporativa, embora a maior parte dos atores sociais envolvidos a associem a uma prática assistencialista.

Machado (2005) insere a noção de desenvolvimento sustentável como parte de uma Formação Discursiva mais ampla - a do “desenvolvimento” - , palavra cujo sentido está incrustado na nossa maneira de ler, pensar e representar o mundo. Aborda o desenvolvimento sustentável como eixo de uma prática discursiva entendida na perspectiva construída por Foucault, e distancia-se de aportes que explicita ou implicitamente apresentam a noção de desenvolvimento sustentável como "progresso" ou como resultado de um processo de evolução crescente da consciência ambiental e do ambientalismo. A partir da análise das discussões encaminhadas no âmbito das Nações Unidas e da CEPAL, entre a preparação da Conferência de Estocolmo e a realização da Conferência do Rio de Janeiro, a autora apreende a conformação de um campo de disputas onde noções, conceitos e práticas assumem o papel de dispositivos de mediação das relações de poder travadas em torno da configuração da problemática ambiental.

Ventura (2005), focando as organizações bancárias, utiliza a noção de interesse, em Bourdieu (1996), para chegar a um modelo de análise que compreendera RSE como parte de um movimento de deslocamento do capitalismo, cuja institucionalização é justificada em termos do bem comum, legitimando-se via provas e arranjos estruturais e, ao mesmo tempo, 
atendendo a interesses inerentes ao Campo. Verifica que a RSE passa, na última década, a ser uma ação estruturada nas organizações bancárias e adquire o status de valor social.

Almeida (2007) pesquisa os fundamentos éticos da RSE, centrando o estudo no pensamento moral do gestor, enquanto agente com poder de decisão relevante na empresa. A partir da fundamentação em correntes clássicas da filosofia moral, propõe um modelo teórico de análise denominado Modelo de Atitude Individual perante a Responsabilidade Social. O estudo de campo, realizado com 252 gestores brasileiros, predominantemente das regiões metropolitanas de São Paulo e do Rio de Janeiro, revela que a atitude gerencial alinhada à RSE é favorecida por valores pessoais conservadores, ligados à estabilidade e vontade coletivas, e por um critério ético baseado na justiça distributiva.

Barbosa (2007) diferencia os vários tipos de organizações não governamentais como assistencialistas, desenvolvimentistas e cidadãs. Tendo em vista o foco de nossa pesquisa, destacamos a distinção oferecida por Sanglard (2003:1095-1096 apud BARBOSA, 2007, p.35) para quem a maior diferença entre os conceitos de caridade e filantropia esteja não na ação propriamente dita, mas nos meios de realizá-la, uma vez que caridade, como obra piedosa, pressupõe a abdicação da vaidade do autor, valorizando o anonimato como valor máximo, enquanto que a filantropia, por ser gesto de utilidade, tem na publicidade sua arma.

Gomes (2007) comenta o caráter "bipolar" do discurso das empresas, que nega o vínculo direto com os problemas sociais abordados e mantém, simultaneamente, uma postura propositiva e pragmática em relação a eles. Afirma, ainda, que as propostas são neologismos com forte apelo ideológico, levando-se em conta a aderência dos termos a definições clássicas da Sociologia. A tabulação dos dados levantados (sobretudo documentais e bibliográficos) aponta como dado mais significativo o uso de recursos na divulgação das ações de RSE. Pesquisa de campo feita pelo autor fecha a análise, demonstrando claramente o descolamento entre discurso e atos praticados. "Enfim, a RSE não passa de velhas práticas com nova roupagem”. Gomes (2007, p.36) elenca uma série de realizações que mostram o aspecto ambiental precedendo o social: 300 mil no Dia da Terra - EUA, 1970; Programa homem/biosfera - Paris, 1971; Conferência de Estocolmo, que focou casos de degradação, com representantes de 113 países - Suécia, 1972; Pesquisa sobre camada de ozônio - EUA, 2974; Criação da política Nacional do Meio Ambiente EIA e posterior RIMA Lei 6939 Brasil, 1980/81; Agências de regulamentação Sisnama, Conama e Ibama - Brasil, 1985; Relatório da ONU “Nosso Futuro Comum”, sobre a falta de recursos naturais, 1987; Conferência Eco-92, no Rio de Janeiro, como preparação da agenda 21; Adoção ISSO 14001 
gestão ambiental - 1996 ; Pacto Global, apelo aos dirigentes do mundo dos negócios sobre direitos humanos, trabalhistas e ambientais, 1999; entre outros eventos e declarações. O autor aponta, ainda, a transição dos enfoques utilizados: controle ambiental (década de 70); planejamento ambiental (80); gestão ambiental (90); Responsabilidade Socioambiental (90 e 2000). Não levanta, contudo, a movimentação na área social nesse período. Pela observação dos documentos e literatura consultada, podemos propor que as questões sociais confluem no sentido das questões ambientais, sob o guarda-chuva da sustentabilidade. O autor (2007, p.202-209), ao avaliar o julgamento do mercado sobre as ações de responsabilidade social, cita a Pesquisa Ethos/ Akatu (2003) percepção dos consumidores - parte brasileira do Corporate Social responsibility - Global Public Opinion on the Changing Role of Companies, que envolveu entrevistas domiciliares, divididas em cotas, pelos critérios PNAD IBGE, e não identificou o reflexo das ações de RSE no consumo, não havendo a correlação esperada pelos defensores da proposta. Outra pesquisa Ethos/Akatu ,de meados de 2004 RSE: um retrato da realidade brasileira - parte de pesquisa mundial com 630 empresas do GRI e observa que a maior quantidade de programas classificados como RSE são ações de aperfeiçoamento de funcionários e canais de comunicação com clientes. Numa "escala de responsabilidade”, a pesquisa constata que: 19\% das empresas não realizam nenhuma ação; 31\% realizam até 8 ações,como pós-venda, entrega de notas fiscais etc.; 18\% realizam de 9 a 13 ações, envolvendo compra de matérias-primas de procedência lícita; 19\% realizam 14 a 22 ações, como o uso racional da energia e postura ética com dados cadastrais; 13\% realizam mais de 23 ações, incluindo aperfeiçoamento dos empregados, extensão de benefícios às famílias e abertura de canais de relacionamento com sindicatos.

O levantamento do IDIS (Instituto para o Desenvolvimento do Investimento Social), com 108 empresas entre as listadas nas 500 maiores e melhores da revista Exame, constatou, em 2004, que apenas $44 \%$ das que faturam mais de novecentos milhões/ano investem mais de 1\% em trabalhos sociais na comunidade. Dessa quantia ínfima, os maiores investimentos são na área de educação (80\%, dos quais 54\% na qualidade profissional dos colaboradores e 50\% estendendo para educação infantil), seguida de meio ambiente e cultura e arte.

Welzel, Luna e Bonin (2008) desenvolvem um modelo teórico da dinâmica interdisciplinar de RSC, gerando um quadro conceitual no qual se comparam a abrangência e delimitação do conceito face ao conceito de cidadania corporativa e aos principais conceitoschave da área de 'Business and Society'. 


\begin{tabular}{|c|c|c|c|}
\hline Conceito-chave & Definição/Características & Principais Autores & $\begin{array}{c}\text { Principal } \\
\text { Abordagem }\end{array}$ \\
\hline $\begin{array}{c}\text { Responsabilidade } \\
\text { Corporativa (RC1) }\end{array}$ & $\begin{array}{l}\text { "Representa o grau de (ir)responsabilidade observada à } \\
\text { partir das estratégias e práticas de uma empresa, tais } \\
\text { como os seus impactos nos stakeholders e no meio- } \\
\text { ambiente"(WADDOCK, 2004, p.10, tradução livre) }\end{array}$ & $\begin{array}{c}\text { Donaldson e Dunfee } \\
\text { (1994) }\end{array}$ & Mista \\
\hline $\begin{array}{l}\text { Reputação Corpo- } \\
\text { rativa (RC2) }\end{array}$ & $\begin{array}{l}\text { "(...) engloba a percepção geral que os stakeholders } \\
\text { externos e internos tem sobre aspectos empresariais } \\
\text { como estratégias, práticas, produtos e comprometimen- } \\
\text { to social, que podem ser mensuradas com base em uma } \\
\text { ampla gama de medidas, tanto financeiras quanto sub- } \\
\text { jetivas. Essas envolvem critérios que tratam as relações } \\
\text { com os stakeholders e o meio-ambiente" (WAD- } \\
\text { DOCK, 2004, p.12, tradução livre) }\end{array}$ & $\begin{array}{l}\text { Fombrun e Shanley } \\
\quad(1990) ; \\
\text { Formbrun }(1998) ; \\
\text { Wartick }(1992 ; 2002)\end{array}$ & Mista \\
\hline \multirow[t]{2}{*}{$\begin{array}{l}\text { Responsabilidade } \\
\text { Social Corporativa } \\
\text { (RSC) }\end{array}$} & \multirow[t]{2}{*}{$\begin{array}{l}\text { Basicamente define os princípios, as formas e os moti- } \\
\text { vos pelos quais as empresas devem ser responsáveis } \\
\text { (RODRIGUEZ et al., 2002, p.135) }\end{array}$} & $\begin{array}{c}\text { Bowen (1953); } \\
\text { Frederick (1960); } \\
\text { Davis (1967; 1973); } \\
\text { Preston e Post (1975) } \\
\end{array}$ & Normativa \\
\hline & & $\begin{array}{l}\text { Carroll (1979); } \\
\text { Jones (1980) }\end{array}$ & Descritiva \\
\hline \multirow[t]{2}{*}{$\begin{array}{l}\text { Responsividade } \\
\text { Social Corporativa } \\
\text { (RSC2) }\end{array}$} & \multirow{2}{*}{$\begin{array}{l}\text { "(...) significa que as empresas devem tomar a iniciati- } \\
\text { va agindo antecipadamente na proposição de políticas } \\
\text { que atendam seus públicos externos" (WADDOCK, } \\
2004, \text { p.16, tradução livre) } \\
\text { "(...) propõe a resposta das empresas frente às deman- } \\
\text { das sociais" (RODRIGUEZ et al., 2002, p.135, tradu- } \\
\text { ção livre) }\end{array}$} & $\begin{array}{l}\text { Ackerman (1973; } \\
\text { 1975); Blacke (1974): } \\
\text { Ackerman e Bauer } \\
\text { (1976); Sethi (1979); } \\
\text { Strand (1983) }\end{array}$ & Desctitiva \\
\hline & & Preston e Prost (1975) & Mista \\
\hline $\begin{array}{c}\text { Retidão Social } \\
\text { Corporativa } \\
\text { (RSC3) ou Ética } \\
\text { Empresarial (EE) }\end{array}$ & $\begin{array}{l}\text { "(...) envolve um penetrante senso de retidão, de res- } \\
\text { peito e de preceitos humanitários que devem estar } \\
\text { contidos nos princípios e valores éticos fundamentais } \\
\text { da empresa, de forma a refletir suas políticas e decisões } \\
\text { centrais" (WADDOCK, 2004, p.19, tradução livre) }\end{array}$ & $\begin{array}{c}\text { Donaldson (1992; } \\
\text { 1996); Liedtka (1998) }\end{array}$ & Mista \\
\hline \multirow[t]{2}{*}{$\begin{array}{c}\text { Performance Social } \\
\text { Corporativa (PSC) }\end{array}$} & \multirow{2}{*}{$\begin{array}{l}\text { "São as formas de mensurar a responsabilidade social } \\
\text { em termos de sua eficácia, no intuito de relacionar } \\
\text { medidas sociais e financeiras" (MATTEN et. al., 2003, } \\
\text { p.110, tradução livre). "(...) incorpora as principais } \\
\text { contribuições da RSC e RSC2 e tem como foco os } \\
\text { resultados dessas no comportamento organizacional" } \\
\text { (RODRIGUEZ et al., 2002, p.135, tradução livre) }\end{array}$} & $\begin{array}{c}\text { Sethi (1979); } \\
\text { Carroll (1979); } \\
\text { Swanson (1999) }\end{array}$ & \begin{tabular}{|c|c|} 
Normativa e \\
Descritiva
\end{tabular} \\
\hline & & $\begin{array}{c}\text { Wartick e Cochran } \\
\text { (1985); Wartick (1988); } \\
\text { Wood (1991); } \\
\text { Clarkson (1995); } \\
\text { Swanson (1995) }\end{array}$ & Mista \\
\hline $\begin{array}{l}\text { Cidadania Corpora- } \\
\text { tiva (CC) ou Cor- } \\
\text { porate Citizenship/ } \\
\text { Business Citizen- } \\
\text { ship }\end{array}$ & $\begin{array}{l}\text { Envolve uma perspectiva ampla dos direitos e deveres } \\
\text { empresariais (WADDOCK, 2004, p.10, tradução livre) }\end{array}$ & $\begin{array}{c}\text { Wood e Logsdon } \\
\text { (2001); } \\
\text { Marsden (2000); Mars- } \\
\text { den e Andrioff (1998); } \\
\text { McIntosh, Leipziger, } \\
\text { Jones e Coleman } \\
\text { (1998); } \\
\text { Waddock (2002; 2004) } \\
\end{array}$ & Mista \\
\hline \multirow{4}{*}{$\begin{array}{c}\text { Teoria dos Stake- } \\
\text { holders }\end{array}$} & \multirow{4}{*}{$\begin{array}{l}\text { "É a identificação concreta com base em princípios de } \\
\text { legitimidade e priorizacão dos grupos sociais para com } \\
\text { os quais a empresa possui responsabilidades e que ao } \\
\text { mesmo tempo influenciam as decisões corporativas" } \\
\text { (DONALDSON e PRESTON, 1995, p.110-111, tradu- } \\
\text { ção livre) }\end{array}$} & Carroll (1989) & Normativa \\
\hline & & $\begin{array}{c}\text { Brenner e Cochran } \\
\text { (1991); Mitchell et. al. } \\
\text { (1997) }\end{array}$ & Descritiva \\
\hline & & $\begin{array}{l}\text { Freeman }(1984 ; 1999) ; \\
\text { Jones }(1995)\end{array}$ & Instrumental \\
\hline & & $\begin{array}{c}\text { Donaldson e Preston } \\
\text { (1995); Jones e Wicks } \\
\text { (1999); } \\
\text { Clarkson (1995) }\end{array}$ & Mista \\
\hline $\begin{array}{c}\text { Gestão Sustentável } \\
\text { (GS) }\end{array}$ & \begin{tabular}{|l|} 
Tem como premissa básica o reconhecimento de que o \\
mundo corporativo é parte integrante de um sistema \\
social e natural. Isso tem duas implicações dramáticas: \\
a aceitação da escassez dos recursos naturais e a noção \\
de que as empresas e a sociedade são co-responsáveis \\
pela utilização e desenvolvimento dos recursos (RO- \\
DRIGUEZ et al., 2002, p.137, tradução livre)
\end{tabular} & $\begin{array}{l}\text { WECD (1987) } \\
\text { Müller-Christ (2003) } \\
\text { Hülsmann (2004) }\end{array}$ & Mista \\
\hline $\begin{array}{l}\text { Governança Corpo- } \\
\text { rativa (GC) }\end{array}$ & $\begin{array}{l}\text { "Refere-se ao sistema pelo qual sociedades empresari- } \\
\text { ais são dirigidas e controladas, envolvendo o relacio- } \\
\text { namento entre acionistas, conselhos e diretoria das } \\
\text { empresas" (RABELO e VASCONCELOS, 2002, } \\
\text { p.322, tradução livre) }\end{array}$ & $\begin{array}{l}\text { Hart }(1990,1995) \\
\text { La Porta et al. }(1997 \\
1998,1999)\end{array}$ & Normativa \\
\hline
\end{tabular}

Fischer (2007) descreve a trajetória da responsabilidade social empresarial a partir de uma ótica evolutiva, tomando a filantropia como atividade periférica até chegar ao conceito de sustentabilidade integrado ao core business das empresas e associado à idéia de desenvolvimento sustentável regional. Descreve, a partir da segunda metade do século 20, as seguintes etapas (ressaltando que não se tratam de tipos "puros" e necessariamente

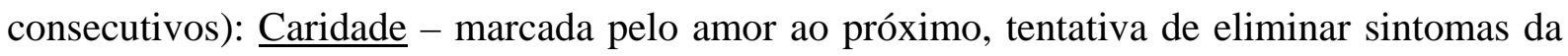
miséria, altruísmo individual, paternalismo; Filantropia Organizada - Fundações independentes, busca de emancipação, voluntariado organizado/ especializado (psicólogos, 
pedagogos), considerada pela autora ainda insuficiente e distante; Investimento Social - Foco nos resultados, filosofia empresarial (transferência de métodos para organizações sociais), mobilização de recursos de maneira ampla, sinergia com negócio e inserção na comunidade;

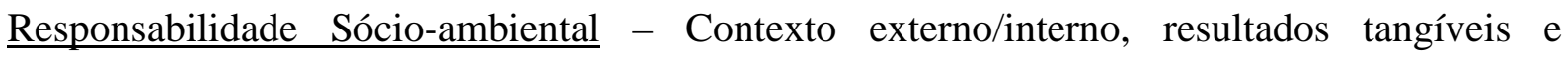
intangíveis (avaliação do processo), direcionamento estratégico, cultura de responsabilidade (internalizada e para fora da empresa), alianças intersetoriais; Sustentabilidade - Conceito de desenvolvimento sustentável (social, econômico e ambiental) patamar macroeconômico, convergindo para o desenvolvimento sustentável (da região, país, planeta). Visa perenidade e inovação, e abrange 4 capitais: biodiversidade, ativos sociais (conhecimento e experiência), humano, social.

Além de migrar para o cerne da atividade empresarial, a autora destaca (que se) tratarse de uma evolução que aposta na cidadania, calcada nas propostas de empoderamento, como ferramenta para empreender mudanças na vida pessoal e comunitária

Conclui, relacionando o conceito de sustentabilidade à disseminação da cultura da responsabilidade, geração simultânea de valor econômico e de valor social, estímulo ao empreendedorismo social, renovação/inovação de recursos e processos, colaboração intersetorial, transparência de resultados, métodos e procedimentos, direcionamento estratégico focado em relacionamento e à eliminação/redução de impactos negativos (ambientais, sociais, políticos).

Assumpção et al. (2008), em documento que apresenta dados sobre responsabilidade social corporativa (RSC) no Brasil e na Noruega (Relatório FAFO 2008), compreendem o Sistema S (Sesc, Senac, Sesi, Senai etc.) como forma de responsabilidade social corporativa pelos serviços oferecidos à população. Ressaltam, contudo, que o desconhecimento de seus métodos gerenciais e resultados dificultam o acompanhamento do público e de instituições democráticas. Os autores destacam, ainda, que a RSC não se refere a obrigações legais e, portanto, não incluem no seu escopo ações, programas e benefícios adotados pela companhia em virtude de negociações trabalhistas (acordos e convenções). Dissociam, dessa forma, a responsabilidade social de questões que envolvam disputas de poder e ações políticas. Em termos comparativos, os autores afirmam que enquanto na Noruega o Estado (com regulação “soft”) ajuda os negócios a operarem de acordo com a RSC, no Brasil a RSC “ajuda o Estado a ser socialmente mais responsável”. Apresentam o sistema S como modelo híbrido de RSC surgido em 1942, sob o Estado Novo, sustentado pela taxação compulsória dos pagamentos de INSS (montante de 2,5\% do total dos salários pagos pelas companhias aos trabalhadores, 
cerca de 13 bilhões de reais em 2006). Afirmam que o sistema constitui importante complexo de provisão de serviços à população e gerencia montante considerável de recursos públicos, mas tem operações pouco transparentes, gerenciadas por associações empresariais. Por sua natureza semipública, o sistema é controlado pela Controladoria Geral da União, mas tal controle é feito de forma não sistemática e, às vezes, os resultados levam anos para tornaremse públicos. Além disso, o sistema é altamente centralizado, com diretores executivos que são também diretores de corporações privadas, havendo reduzida participação de trabalhadores.

\section{Questionamentos de origem e dilemas atuais}

O economista Milton Friedman (1970), em artigo publicado no The New York Times Magazine, critica veementemente o discurso sobre as responsabilidades sociais das empresas, afirmando que se trata de pura pregação socialista. Considera que apenas pessoas podem ter responsabilidades, o que não se aplicaria de forma alguma aos negócios. Lembra que, no sistema de propriedade privada, o executivo é empregado do dono da empresa e sua responsabilidade é conduzir os negócios de acordo com os desejos desse dono, que usualmente consistem em obter o maior lucro possível, agindo dentro das regras legais e éticas socialmente aceitas. Friedman reconhece que o executivo pode assumir outras responsabilidades pessoais voluntariamente, com sua família, sua consciência, igreja, clube etc., mas enfatiza que tais responsabilidades sociais são eminentemente individuais. Os executivos não teriam, portanto, o direito de gastar o dinheiro dos proprietários para interesses gerais da sociedade, uma vez que, os responsáveis por esse trabalho são funcionários públicos, eleitos por um processo político.

Essa é a razão básica apontada por Friedman para considerar que a doutrina da responsabilidade social envolve a aceitação do ponto de vista socialista, no qual mecanismos políticos, e não mecanismos de mercado, consistem no modo apropriado de determinar a alocação de recursos escassos para usos alternativos. Ele destaca que o princípio político que subjaz ao mecanismo de mercado é a unanimidade. Em um mercado livre ideal apoiado na propriedade privada, nenhum indivíduo pode coagir o outro, toda cooperação é voluntária.

Para o autor, não há, portanto, responsabilidades “sociais” em nenhum sentido além do compartilhamento de valores e responsabilidades individuais. A sociedade é "uma coleção de indivíduos” e dos vários grupos que esses indivíduos formam, voluntariamente. Por outro lado, para Friedman, o princípio político que subjaz ao mecanismo político é a conformidade. O indivíduo é submetido a um interesse social geral - determinado por um ditador ou pela 
maioria. Pode ter direito a voto e a dizer o que deve ser feito, mas, se for vencido, precisa se conformar. É apropriado para alguns requerer que outros contribuam para um propósito geral, independente da vontade deles. Conclui, dizendo que, se a doutrina da "responsabilidade social” (com uso de aspas) for levada a sério, estenderá o escopo do mecanismo político a toda atividade humana, diferindo, assim, das doutrinas coletivistas mais explícitas apenas por professar a crença de que resultados coletivos podem ser obtidos sem meios coletivos. Por esses motivos, o autor afirma que em seu livro Capitalism and Freedom chamou a RS de doutrina essencialmente subversiva numa sociedade livre e que há uma e apenas uma responsabilidade social dos negócios: usar todos os recursos possíveis para aumentar seus lucros dentro das regras permitidas pelo mercado livre.

A colocação de Friedman toca num ponto crucial. Toda a referência à política e, por conseguinte, a deliberações coletivas não pode ser levada a sério, pois levaria, no limite, à instalação de conselhos populares na empresa. Os stakeholders são consultados, mas não podem determinar diretrizes. Parece ser esse o limite da empresa. As instâncias políticas devem estabelecer-se fora dela. Hoje, ao contrário do que temia Friedman, a RSE não tenta impor o mecanismo político á atividade empresarial. Levou adiante a idéia de obter resultados coletivos sem processos de deliberação coletiva, apresentando o político como um mecanismo de consulta e mantendo sua conduta atrelada ao core business. A RSE não pode ser levada a sério nos termos em que é comunicada, envolvendo cidadania, democracia, emancipação.

Carrieri (2005), a partir de pesquisa de campo qualitativa com agentes sociais envolvidos com ações de RSE, observa que a prática da responsabilidade social se situa num contexto mais significativo que o mero discurso empresarial. Tendo como referência o trabalho de Sethi (1975), o autor classifica o comportamento das corporações como obrigação social, o que caracterizaria resposta às obrigações legais; responsabilidade social, definida como a atitude cujas expectativas sociais ainda não se converteram em requisitos legais e não implicam em mudanças substanciais na forma predominante de fazer negócios; ou responsividade social, papel a ser desempenhado num contexto social dinâmico, onde a corporação antecipa prováveis mudanças no cenário social. O autor traduz, a partir dessa gradação, a ideologia da responsabilidade social como um processo onde a preocupação das empresas com a pressão social externa impulsiona a aceitação de novas normas, que, por sua vez, tornam comportamentos anteriores socialmente inaceitáveis. Afirma, ainda, que o discurso da ideologia liberal, estritamente associado ao lucro, tornou-se contraproducente na economia capitalista competitiva atual. 
Também para situar a RSE, Guimarães (1984) propõem uma estrutura semelhante, mas voltada para a relação entre objetivo econômico e objetivo social, apresentando três correntes: a "postura tradicional”, que resume a missão da empresa à geração de lucros e dividendos para os acionistas, representada, sobretudo, pelo economista Milton Friedman, e numa versão renovada pelas propostas de Robert Reich; uma corrente de polo oposto, que defende o benefício social acima do econômico, numa nova ordem social, sem propriedade privada e benefícios econômicos compartilhados; e uma corrente de "terceira via" com posição intermediária, que considera o lucro legítimo, mas exige postura social e tem arrebatado mais adeptos desde o início dos anos 80. Recorre, ainda, a Davis (1975), para expor premissas aceitas de forma generalizada por essa terceira corrente: a responsabilidade social emerge do poder social; as empresas devem estar abertas para dialogar com a sociedade; custos e benefícios sociais devem ser considerados e incorporados ao preço dos produtos (o consumidor é quem paga); e as empresas devem contribuir para sanar problemas sociais. A autora destaca, contudo, que a proposição de benefício social precedendo o econômico é estranha ao capitalismo, e que, portanto, o envolvimento com RSE não será espontâneo e será determinado pela consciência e pressão de grupos sociais organizados e sindicatos fortalecidos. Observamos, contudo, como será detalhado a seguir na análise do discurso empresarial, que o as empresas não situam sua fala no campo da disputa por direitos.

Magalhães (1984), por sua vez, trata a RSE como moda que vai longe, apesar da crise (o artigo é de meados dos 80), mas também alerta para a incompatibilidade entre a cultura de responsabilidade social e valores atuais que sustentam toda a estrutura econômica e social das organizações. Com o passar dos anos, observamos que as propostas de prevalência do social foram assimiladas pelo discurso da empresa, como elemento de sustentação. Na outra direção: discurso de direitos sociais assimila discurso da empresa.

Ventura e Vieira (2006) apontam a RSE como um deslocamento que busca a legitimidade do sistema capitalista, incorporando a crítica e engajando as pessoas com a inclusão de uma dimensão moral. Analisando o campo bancário, aponta a institucionalização da RSE, percebido, nos termos de Bourdieu, como um valor para o campo. A análise feita pelos autores da produção acadêmica reitera a percepção do balanço bibliográfico preliminar desta pesquisa ao verificar que, apesar das diferentes perspectivas e abordagens existentes, os trabalhos cumprem a função de informar aos reprodutores do discurso qual o melhor caminho a ser seguido. Muitas dimensões da RSE são deixadas de lado nas análises existentes, sendo “o movimento inquestionavelmente aceito como positivo para o bem comum, pela maioria 
das pessoas e também pelos estudiosos do assunto.” (VENTURA e VIEIRA, 2006: 9) Os autores reconhecem que o discurso da RSE reflete a conscientização dos dirigentes em relação a questões de cidadania e justiça social, mas gera um efeito de despolitização. Propõem um esquema que indica como a incorporação da crítica e mecanismos de legitimação, constituídos pela soma da credibilidade e eficiência na prestação de serviços bancários e da apropriação de reivindicações sociais, fazem com que a RSE se institucionalize e torne-se, ela própria, um ‘bom negócio’ para o capitalismo, ao favorecer o apaziguamento dos conflitos e, ao mesmo tempo, estabelecer dispositivos para aprimorá-lo.

Artigo de Misocky e Pereira (2006), derivado de pesquisa que analisou o discurso de Peter Drucker, observam, com uso da Análise Crítica do Discurso, os mecanismos de legitimação da responsabilidade social promovida pelas empresas. Mostram como a defesa da teoria neoliberal começa com o deslegitimar do espaço social da política, e o discurso da responsabilidade social é conectado ao discurso do desempenho econômico, descolando cidadania de política.

Wanderley (2006) estuda a responsabilidade social de grandes corporações por dois ângulos: as ações que as empresas têm utilizado e a percepção que os profissionais envolvidos com essas ações possuem a respeito dos problemas sociais. Para responder e avaliar em que medida as ações das empresas contribuem efetivamente, partiu do Instrumental Freedoms de Amarya Sen (1999) levando em conta os critérios de representação política, investimento direto de fundos ou recursos, promoção da educação e/ou saúde, transparência sobre as decisões da corporação, e oferecimento de redes de segurança social em crises ou privações profundas de qualquer espécie. Propõe o IDH (Índice de Desenvolvimento Humano) e os critérios de Sen como base para formulação de esquemas e prioridades dos projetos sociais das corporações. Os dados levantados apontam mudanças pontuais positivas, mas, em linhas gerais, mostram que os projetos sociais privados não foram capazes de alterar as desigualdades do país, no que diz respeito à distribuição de riqueza, poderes e oportunidades. Outro aspecto a destacar é o fato de que a maior parte das ações provém de análises feitas, pelas próprias empresas, dos problemas da comunidade.

Fontenelle (2006), ao estudar o caso McInternet, aborda o que denomina "mercado da cidadania”; discurso social como resposta aos excessos de uma economia desregulada. A autora considera que se trata, na verdade, de um paradoxo, na medida em que a proposta de uma responsabilização coletiva parte do mercado, a mesma instância que não requer freios para a sua atuação. Nesse sentido, opera-se o deslocamento da proposta de um "Estado 
Mínimo” para defesa de um Estado que “coopere com o mercado” e a sociedade, na promoção social, (como fica explícito no documento de reforma do aparelho de Estado brasileiro do governo FHC, que será abordado a seguir, nesta pesquisa). Observando que o marketing da solidariedade se tornou a nova estratégia comercial e comunicacional das empresas, a autora refere-se à “mercantilização da cidadania”, onde o social deixa de ser uma conquista e um direito, e passa a ser interpretado dentro de uma lógica privada da filantropia e como forma de "gerir o social". O mercado surge, dessa forma, como sujeito operador do poder político, como observa Francisco de Oliveira (2003a) (2004), citado pela autora, ao afirmar que, embora algumas das ações implementadas pelo empresariado possam ser consideradas inovadoras e tecnicamente competentes, elas acabam por deslocar a questão da pobreza da arena pública (envolvendo política, cidadania e direitos) para o campo indeterminado do mercado, onde passam a vigorar como “políticas de exceção”.

Nascimento (2008) questiona a sustentabilidade do tripé econômico-social-ambiental, devido ao choque entre a melhoria das condições sociais das classes com menor poder aquisitivo, que adentram ao universo do consumo, e o equilíbrio ambiental, que sofrerá fortes impactos a partir dessa nova demanda. O autor considera que, tecnicamente, existem alternativas e situa a dificuldade na mudança do comportamento do ser humano. Sugere que algum tipo de cobrança pelo consumo excessivo seria socialmente e ambientalmente correto no século XXI, e considera que as propostas de redução de consumo não irão dar as respostas esperadas diante do aquecimento da economia a partir do consumo na base da pirâmide social.

Santos (2008), com base na Teoria Institucional, principalmente nos conceitos de legitimação e isomorfismo, e também na Teoria dos Stakeholders, considera que a RSC se institucionaliza no Brasil como adaptação das empresas ao ambiente. Elas elegem temas e populações beneficiadas convergentes com suas atividades, consideradas simpáticas pela sociedade e/ou que tenham grande visibilidade na mídia, deixando de lado grupos menos “atraentes” e igualmente problemáticos como, por exemplo, a população carcerária.

Souza (2008) aborda a questão da solidariedade, entendida como relação social que demanda qualidade política. Recorre a Demo (2004) para afirmar que solidariedade implica negociação interminável e deve privilegiar a formação política, diferentemente de propostas que privilegiam a capacitação técnica para a produção, reduzindo a solidariedade a um processo imbecilizante. Ainda com Demo, o autor destaca que é na esfera da economia, e não propriamente na educação, que se encontra a raiz dos problemas sociais, e que respostas 
viáveis ao exercício solidário devem ocorrer pela via de transformações na gênese - esfera da economia - e não na adjacência - educação.

Oliveira e Vieira (2008) destacam que o discurso do desenvolvimento sustentável, pautado em mudanças nos padrões de produção e de consumo, apesar de apresentar uma aparente preocupação com o “futuro do planeta” é construído sob as mesmas estruturas que mantém em funcionamento o atual (e criticado) modelo de sociedade de consumo. Os autores consideram que a conquista social da sustentabilidade a partir do consumo representa uma tentativa ilusório-reformista de reafirmar o modelo social sob o qual vivemos.

Sampaio (2008) discute o processo de adoção de práticas de RSE por empresas siderúrgicas na Amazônia Oriental, descrevendo as estratégias de legitimação empresarial face às críticas relativas ao uso de trabalho escravo na produção de carvão vegetal, tendo como referência a perspectiva proposta por Boltanski e Chiapello (1999, p.59 apud SAMPAIO, 2008). Para estes, o capital precisa construir, a partir das críticas sociais, uma espécie de 'espírito', um quadro normativo capaz de fundamentar o engajamento das pessoas no funcionamento do sistema. $\mathrm{O}$ autor considera que o desenvolvimento de ações apresentadas como de responsabilidade social pode ser compreendido como um conjunto de respostas das empresas à atuação da crítica social, o que sugere um processo de responsabilização social, no qual as empresas são pressionadas a assumir responsabilidades (inicialmente rejeitadas), devido à atuação de ONGs, movimentos sociais e aperfeiçoamento da regulação do Estado.

Cappellin e Giffoni (2007) delineiam a difusão do lema da responsabilidade social nos EUA, Brasil e União Européia. No primeiro caso, a vasta literatura sociológica relata como diferentes atores sociais pressionaram empresas americanas ao longo dos anos 1960. No Brasil, a movimentação começa com associações empresariais, em meados dos anos 60, e se amplia com demandas sociais no fim dos anos 1990. Na União Européia, o lema da responsabilidade social é introduzido nos finais dos anos 90, associado ao combate do desemprego estrutural. As autoras organizam o quadro dos diversos conteúdos da responsabilidade social a partir da questão, fundamental nas várias sociedades, do fortalecimento do vínculo de emprego como fonte de cidadania social. Partem da premissa de que o círculo de atores e instituições ligados à RSE é como um cenário que se expande e se articula com a agenda nacional, de acordo com a capacidade de mobilização de grupos e setores organizados. Destacaremos aqui, segundo o foco de nossa pesquisa, o histórico brasileiro da RSE, que tem início por meio de duas entidades: a Associação dos 
Dirigentes Cristãos de Empresas do Brasil (ADCE), fundada em São Paulo, em 1961, e a Fundação Instituto de Desenvolvimento Empresarial e Social (Fides), fundada em 1986, que em linhas gerais se propõem a "humanizar" a empresa e promover sua relação com a sociedade. A elas se somam outras três entidades, que representam a postura proativa do empresariado no processo de redemocratização dos anos 80. A Câmara Americana de Comércio de São Paulo (Amcham), a partir de 1982, introduz o conceito de "cidadania corporativa", instituindo o Prêmio Eco para ações sociais nas áreas de cultura, educação, meio ambiente, comunidade e saúde. O grupo Pensamento Nacional das Bases Empresariais (PNBE) que, em 1987, com a proposta de priorizar os interesses nacionais, propaga os conceitos de democracia e cidadania no meio empresarial, no sentido de criar um pacto social nacional. E a rede de Grupo de Institutos, Fundações e Empresas (GIFE), que realiza sua primeira reunião em 1988, com um debate sobre filantropia, patrocinado pela filial brasileira da Alcoa e da Kellogg Foundation, em colaboração com a Amcham. O grupo propõe-se a colaborar com o Estado(,) em programas destinados a reduzir a desigualdade social e contribuir com o programa nacional da Comunidade Solidária. A partir dos anos 90, as empresas passam a associar a RS com propostas que visam ampliar a competitividade e administrar os riscos e reputação das empresas, sendo priorizado o envolvimento em áreas específicas, como pobreza, violência, a educação e meio ambiente. Muitas empresas e seus dirigentes brasileiros utilizaram-se do lema da RS para restabelecer a confiança dos trabalhadores (como amenizadora dos efeitos decorrentes da flexibilização dos mercados de trabalho e desregulamentação dos custos da mão-de-obra), e consolidar a fidelidade dos consumidores e aceitação social. A ampliação da agenda de RSE, durante a década de 90, se dá pelo circuito de doações empresariais que se dirigiram, sobretudo, para ações sociais extramuros, sendo raros os investimentos para aumentar a qualificação dos trabalhadores. Investimentos que surgem somente numa segunda onda da difusão da RSE, estendida até nossos dias, que se associa à pressão sobre o Estado para que as normas de trabalho e os direitos trabalhistas sejam excluídos da legislação nacional e transferidos para a órbita da negociação direta. Dinâmica que possibilita reduzir, com amparo legal, os empregos protegidos e enxugar o volume de trabalhadores contratados, possibilitando diminuição dos salários, graças à substituição e rotatividade da mão-de-obra. A RSE aparece, portanto, como uma "abordagem paliativa", a fim de mitigar os danos sociais. No fim dos anos 90, em uma nova conjuntura política, aumenta o leque de entendimento desse lema. Por meio da descentralização das políticas públicas, criação do Estatuto da Criança e do Adolescente, do 
Código de Defesa do Consumidor, e da lei federal de incentivo fiscal aos investimentos de apoio à cultura, entre outros movimentos governamentais, amplia-se a relação entre Estado e sociedade, estimulando o desenvolvimento do chamado Terceiro Setor. Durante as eleições presidenciais de 1994, empresários que integravam o Fórum da Média e Pequena Empresa (Fopeme) fundam a Associação Brasileira de Empresários pela Cidadania (Cives), definindo como seu principal objetivo a reforma estrutural do Estado, na qual eram incluídas a reforma fiscal e a defesa da universalização dos direitos trabalhistas. Em 1998, é criado o Instituto Ethos, organização patrocinada por mais de 400 empresas que desenvolve parcerias internacionais com grupos como o Business for Social Responsability (BSR), o Instituto Kellogg, o International Business Leaders Forum e o United Nations Global Compact; uma organização que enxerga as empresas, em virtude de seu poder econômico, como agentes “civilizadores” capazes de promover a mudança cultural, levando novos valores às comunidades. Desse conjunto tão diverso emerge uma convivência de diferentes entendimentos. As autoras enfatizam, contudo, que as diversas iniciativas e programas não incluem propostas para reverter políticas seletivas de oferta de empregos de modo a reduzir a persistente taxa de emprego informal. Destacam, também, a participação da sociedade civil organizada na construção do lema da RS, que começa timidamente, segundo as autoras, em 1999, com o lançamento do Balanço Social pelo IBASE, e o Partido dos Trabalhadores que elabora proposta de lei para tornar obrigatório esse documento. O detalhamento dessas iniciativas e também das Prefeituras é objeto de artigo de Cappellin e Giuliani (2004).

No que tange às relações de trabalho, as pesquisas realizadas pelas autoras indicam que a divulgação da responsabilidade social coincide com o movimento empresarial Custo Brasil, que sugere a diluição das garantias trabalhistas a serem incluídas agora nas negociações contratuais coletivas. A reforma constitucional, enviada ao Ministério do Trabalho e apresentada para a Comissão de Assuntos Sociais do Senado Federal, desde 1997, visa abrir negociação a uma série de encargos, tais como férias, abono de férias, $13^{\circ}$ salário, descansos remunerados etc. Por outro lado, as metas de bem-estar social propostas pelas empresas (incluindo áreas de intervenção, finalidades e definição dos públicos assistidos) não são fruto de diálogo ou negociação direta com atores sociais (trabalhadores, população local, sindicatos, agências do poder estatal). Frente a EUA e UE há no Brasil resistência das empresas ao envolvimento direto na reversão da relação assimétrica entre a acumulação de riqueza e o bem-estar geral. As autoras enfatizam que, mesmo realizando programas e serviços sociais, as empresas mantêm uma postura impermeável ao diálogo junto aos 
trabalhadores. Algo sustentado por uma crença arraigada e difusa, a crença de que a empresa é um sistema relativamente autônomo de governo. Concluem, afirmando que a responsabilidade social é um lema que se molda às interpretações sociopolíticas em vários espaços, nacionais e multilaterais, sendo que aspectos acentuados na União Européia, como o fomento ao emprego de qualidade, a salvaguarda dos direitos trabalhistas e o diálogo social de desenvolvimento local parecem pouco enfatizados no contexto brasileiro.

Cappellin e Giuliani (2006) afirmam que a economia brasileira, desde a década de 80, tem produzido, por meio da reestruturação e desregulamentação do mercado de trabalho, a piora das condições dos trabalhadores e declínio da segurança no emprego. Detalham a estratégia governamental que passou a eliminar ou substituir direitos trabalhistas por meio de decretos e editais, particularmente após 1994, destacando as seguintes medidas: Lei 8.949/1994, que admite que os trabalhadores se organizem entre si para formação de uma cooperativa de trabalho, e prestem serviços a uma empresa sem que se caracterize o vínculo trabalhista, suspendendo os direitos trabalhistas previstos na CLT; Denúncia, em 1996, através de um decreto do Poder Executivo, da Convenção 158 da OIT que estabelece normas que limitam o poder absoluto do empregador de efetuar demissões, provocando a retirada dessa norma pública internacional do direito interno brasileiro, sob a justificativa de que estaria tumultuando as relações de trabalho por meio de decisões judiciais com entendimentos distintos, e sua incompatibilidade com o novo contexto econômico de globalização; Introdução, pela lei 9601, de 1998, do contrato de trabalho temporário de 24 meses, que reduz os direitos dos empregados e diminui a contribuição dos empregadores à previdência social; Programa de Participação nos Lucros e Resultados (PLR), que introduz uma política salarial com compensações não incluídas em contrato de trabalho e calculadas a partir de informações (lucros operacionais) controladas unilateralmente pela empresa; Medida provisória 1053, de 1994, que elimina a política de reajuste salarial através do Estado; proíbe as cláusulas de reajuste automático de salários; e procura induzir a “livre negociação”, mas com controle para não haver reajuste real nem nas negociações e nem no Judiciário; Lei 9.061/1998, cria o "Banco de horas, que, entre outras modificações, elimina o pagamento de horas extras", permitindo organizar a jornada conforme as flutuações da produção ou serviço; e Decreto 1970, de 1994, que introduz o Programa de Desligamento Voluntário (PDV), para facilitar a redução da força de trabalho, ao oferecer incentivos para pedidos de demissão.

Kallio (2006) aborda aspectos sistematicamente não abordados pelo discurso da RSC, constituindo-se em tabus, entendidos na perspectiva do desenvolvimento social como 
“âncoras culturais” que obliteram mudanças efetivas. Para o autor, são três os grandes tabus que levantam questões fundamentais, silenciados no discurso da RSC: o tabu da amoralidade dos negócios, noção associada ao economista Milton Friedman; o tabu do crescimento econômico contínuo, considerado impossível, que implica o silêncio sobre o fato de que é impossível que todas as pessoas do mundo atinjam níveis de consumo dos países desenvolvidos; e o tabu da natureza política da RSC (o termo "natureza política” designa atividades que visam a promoção de interesses das próprias empresas na busca da sua legitimação social), que faz com que a maioria dos pesquisadores não questione o tom prónegócios da ideologia do campo. O autor finaliza, colocando que o mantra do crescimento contínuo não é questionado, porque o desenvolvimento é sagrado para as corporações e o liberalismo; a natureza amoral não é debatida seriamente, porque a legitimação moral é essencial para as empresas parecerem responsáveis aos olhos da sociedade; e a natureza política não é debatida, por colocar em risco a integridade da disciplina (que, ao discutir uma postura ideológica pró-empresa, sairia do lugar de uma pretensa neutralidade científica); concluindo que a permanência dos tabus esvazia o potencial crítico do discurso. A nosso ver, esses tabus parecem ser constituintes do discurso, cujo lugar de origem não permite abordar essas questões diretamente.

Moretti e Campanário (2008) avaliam o estado-da-arte na área de responsabilidade social empresarial (RSE) em administração, por meio de uma pesquisa bibliométrica, considerando as publicações acadêmicas no EnANPAD, entre 1997-2007. Os autores observam que predomina a reprodução das mesmas idéias, o que dá força à tese de uma zona de “conforto intelectual”, apontando que no discurso da RSE tem um componente “reprodutor”, com referências gerais, para facilitar o trânsito entre diversos modelos conceituais. Foram detectados 329 artigos, reduzidos para 216 (com a exclusão do Terceiro Setor, uma vez que o foco dos autores é a responsabilidade social praticada pelas empresas), classificados em quatro grupos: a) Fundamentos: razões da adoção das práticas de RSE, ética e cidadania; b) Marketing: ações de comunicação, Balanço Social, reações dos consumidores; c) Gestão Social: atividades praticadas pelas empresas, relatos de casos práticos, gestão interna; d) Gestão Ambiental: atividades das empresas e o ambiente construído e natural, casos práticos das atividades das empresas. Em relação aos autores, observam a grande participação de "outras áreas”, abrindo a possibilidade de futuros estudos investigarem a interdisciplinaridade que se forma na RSE. Quanto à distribuição da origem das citações, os autores observam que a alta 
incidência de livros (43\% das menções) em relação a artigos e material de congressos (46\%) indica uma estratégica adesão à zona de conforto ao invés da análise das novas propostas.

\section{Difusão do conceito no ambiente empresarial e surgimento de nicho de mercado}

Fischer e Falconer (1999) fazem um apanhado das estratégias de ação social e voluntariado das empresas brasileiras, indicando que, na época, já 56\% das organizações investiam em ações desse tipo. Outro trabalho de Falconer (1999) aborda o surgimento do $3^{\circ}$ setor, na década de 90, como promessa de renovação do espaço público, resgate da solidariedade e da cidadania, levanta dúvidas acerca da validade e paradigma tri-setorial, e procura contribuir para uma delimitação mais precisa do campo, buscando o aperfeiçoamento da gestão em bases mais realistas dos papéis que o setor pode assumir.

Koerich (2003) faz a análise do modelo de Balanço Social aplicado a entidades públicas, enfatizando a necessidade da aplicação da responsabilidade social para tornar a organização mais eficaz, em um ambiente altamente competitivo. Enfatiza o Balanço Social como instrumento capaz de evidenciar a materialização da responsabilidade. Tanaka (2003) estuda a responsabilidade social das instituições de ensino superior e propõe a elaboração de estratégias de ação para a incorporação de preceitos éticos nos relacionamentos.

Fischer e Falconer (1999) fazem um apanhado das estratégias de ação social e voluntariado das empresas brasileiras, indicando que, na época, 56\% das organizações já investiam em ações desse tipo. Outro trabalho de Falconer (1999) aborda o surgimento do $3^{\circ}$ setor, na década de 90, como promessa de renovação do espaço público, resgate da solidariedade e da cidadania, levantando dúvidas acerca da validade e paradigma tri-setorial; procura contribuir para uma delimitação mais precisa do campo, buscando o aperfeiçoamento da gestão em bases mais realistas dos papéis que o setor pode assumir. Borges (2000), por sua vez, aborda os conceitos de espaço público e marketing institucional e a inter-relação com a publicidade (visibilidade), enquanto Machado Filho (2004) trata da questão do capital “reputacional”, associando a responsabilidade social à criação de valor para as organizações.

Passador, Ferraz e Canopf (2007) apresentam um resgate teórico do tema da responsabilidade social, a partir do estudo dos artigos apresentados nos anais do EnANPAD (Encontro da Associação Nacional de Pós-Graduação e Pesquisa em Administração), bem como das bibliografias mais utilizadas até o ano de 2006, dois anos após a área de gestão social ter sido criada, ampliando o alcance da temática. O resgate teórico classifica o tema em: 
Responsabilidade Social como Modismo; Os Liberais, Neoliberais e Afins; Legitimação Social; Uma Questão Ética; e, por último, Responsabilidade Social Corporativa.

Pereira, Souza e Vieira (2006) consideram a RSE como uma dupla estratégia, com promoção de mudanças internas, aliada ao fortalecimento de marcas por meio de inovações tecnológicas e da boa imagem comunicada à sociedade. Trata-se, para os autores, de uma “nova postura” que deve melhorar com o tempo. Uma melhora pautada, contudo, pela ótica gerencial. Apresentam panorama atualizado (2006) das principais normas, certificações e premiações, evidenciando a formação de um novo nicho de mercado. A saber: AccountAbility 1000 (AA 1000), melhores práticas de prestação de contas contábeis e de ações de responsabilidade social e ética, lançada em 1999 pelo instituto AccountAbility, não certifica, apenas apresenta normas; Social Accountability 8000 (SA 8000), de 1998, voltada para o bem-estar e condições de trabalho, desenvolvida pela Social Accountability International EUA; Occupational Health and Safety Assessment Series (Oshas 18001), de 1999, sistemas de gestão da segurança e saúde no trabalho, desenvolvida por organismos da Irlanda, Austrália, África do Sul e Inglaterra; British Standard 8800 (BS 8800), de 1996, focada na minimização de riscos para trabalhadores; International Organization for Standardization 1400 (ISO 14000), de 1993, com normas para gestão ambiental e social; ISO 26000, lançada em 2008, com padrão internacional para sistema de gestão e certificação de empresas ; Eco management and Audit Scheme (EMAS), de 1993, voltada para o comportamento ambiental; Humane Cosmetic Standard (HCS), de 1998, coalizão internacional de protetores de animais; Forest Stewardship Council (FSC), de 1993, associação ligada a ONGs dos EUA e Europa que emite certificados e selo para produtos ambientalmente corretos; Marine Stewardship Council (FSC), fundado em 1997, central em Londres, preservação de recursos pesqueiros, pesca marítima sustentável; Global Reporting Initiative (GRI), ONG internacional com sede em Boston EUA, dissemina Diretrizes GRI para preparar relatórios sobre desempenho econômico, ambiental e social; ABNT/NBR 16001, norma voluntária e auditável, criada em 2004, para a gestão da RS, compatível com ISO 9001 e ISSO 14001; Prêmio Selo Empresa Cidadã, desde 1998, Câmara Municipal de SP; Prêmio Top Social ADVB (promovido pela Associação dos Dirigentes de Vendas e Marketing do Brasil), desde 1999; Marketing Best Responsabilidade Social (promovido pela editora Referência), desde 2002; Prêmio ECOAMCHAM (Câmara Americana de Comércio), desde 1982; Selo do Programa Empresa Amiga da Criança - 1995 Fundação Abrinq (Associação Brasileira dos Fabricantes de Brinquedos); Prêmio Ethos de Jornalismo, desde 2000 (promovido pelo Instituto Ethos); 
Prêmio Balanço Social, desde 2001, promoção conjunta de ABERJE (Associação Brasileira de Comunicação Empresarial), APIMEC (Associação dos Analistas e Profissionais de Investimento do Mercado de Capitais, FIDES ( Fundação Instituto de Desenvolvimento Social e Empresarial), IBASE (Instituto Brasileiro de Análises Sociais e Econômicas), SEBRAE (Serviço Brasileiro de Apoio às Pequenas e Microempresas) e Petrobrás; Prêmio Valor Social, desde 2001, promovido pelo jornal Valor Econômico e pelos Institutos Ethos e Akatu; Prêmio Ethos-Valor , desde 2000, concurso para trabalhos de graduação e pós.

Lopes (2005) detecta, entre as empresas com estratégia de atuação social mais "madura”, diversos pontos de interface e sinergia entre ações socioambientais e o negócio, evidenciando o caráter estratégico da responsabilidade social corporativa.

Gomes et al. (2006) estudam a sustentabilidade de empresas de base florestal, com foco no papel dos projetos sociais voltados para as comunidades locais. As empresas estudadas que atuam numa mesma região compartilham a visão de que as ações de responsabilidade social são fontes de agregação de valor. Os autores identificam, diante disso, a oportunidade para potencializar em escala os efeitos relacionados à competitividade e ao desenvolvimento sustentável, por meio da ação conjunta entre as empresas, envolvendo fornecedores e alianças locais. Como vantagens dessa ação conjunta são destacadas, entre outras, a economia de recursos humanos e materiais e o aumento da capacidade de intervenção.

Dinato (2006) estudo o caso da Natura, maior fabricante brasileira de cosméticos, empresa que se destaca mercadologicamente por suas ações de responsabilidade socioambiental, considerando, de forma especial, a linha Ekos, com produtos que utilizam “ativos” da biodiversidade brasileira. O trabalho toma o caso da empresa como atuação de excelência e busca conhecer os aspectos que explicam tal atuação, assim como a influência que ela exerce em sua cadeia. A abordagem teórica utilizada foi a da produção e consumo sustentáveis que, segundo a autora, desloca a atenção, tradicionalmente dada aos aspectos ligados à produção, para questões associadas à demanda, salientando aspectos do consumo. A autora conclui, de forma laudatória, que a teoria se adapta à pratica de uma "grande e lucrativa empresa”, que influencia as empresas fornecedoras, assumindo o papel de "líder e articuladora”, e dissemina entre seus clientes “valores sociais e ambientalmente mais adequados”.

\section{Aperfeiçoamento de práticas e mensuração de resultados}

Impacto no consumo e competitividade 
Ferreira e Mayer (2008) comparam o efeito de três fontes de informação sobre RSC um amigo, um jornal de grande circulação, e uma propaganda da empresa - no nível de preço que o consumidor estaria disposto a pagar por um produto de uma empresa socialmente responsável. A metodologia experimental, com quatro cenários de pesquisa (incluindo um de controle) e análise estatística, indicou que os consumidores estão dispostos a pagar mais, quando recebem a informação de amigos ou jornal de grande circulação, mas não quando a fonte é uma propaganda da própria empresa.

Bruni, Silva, Paixão e Carvalho Júnior (2008) realizam experimento com 424 consumidores, cujos resultados indicam que a prática de RSC impacta positivamente na intenção de compra e percepção de justiça de preço. A ausência de RSC, por sua vez, produziu um impacto negativo ainda maior. Os autores observam que os efeitos são potencializados em produto "hedonista" e concluem que a adoção de práticas socialmente responsáveis pode representar vantagem competitiva.

Kitahara (2007) realiza estudo empírico, utilizando o balanço social padrão IBASE (no período entre 2000 e 2004), e não rejeita a hipótese de relação entre desempenho financeiro e investimento em ações de RS. Trata-se, contudo, de um indício, uma vez que os resultados são particulares ao grupo da amostra (composta por 298 empresas) e não podem ser generalizados.

Cruz e Boehe (2008), diante da inserção da RSC nas agendas de gestores de empresas globais, e do aumento das fatias de mercado ocupadas por produtos responsáveis nos aspectos sociais e ambientais, buscam identificar as condições para a criação de cadeias de valor globais sustentáveis como fator de competitividade internacional. Como contribuições, apresentam o conceito de Cadeias de Valor Globais Sustentáveis e seis proposições com condições-chave para que a cadeia sustentável torne-se competitiva.

Arantes (2006) apresenta dados sobre a relação entre o investimento em responsabilidade social e o desempenho econômico das empresas. Compara a evolução do valor de ações negociadas nas bolsas de valores de Nova Iorque e São Paulo, de empresas que investem e empresas que não investem em responsabilidade social. Apesar da limitação do estudo (que não envolve outras variáveis possivelmente relevantes), a autora conclui que empresas que demonstram desenvolver ações socialmente responsáveis apresentam maior valorização de suas ações, oferecendo mais um indício empírico nesse sentido.

Macedo, Sousa e Sousa (2007) analisam o desempenho de empresas socialmente responsáveis, através de indicadores contábil-financeiros de Liquidez, Endividamento e Lucratividade, referentes ao ano de 2005. A partir da seleção de empresas que constavam do 
Índice de Sustentabilidade Empresarial (ISE) da BOVESPA, e da lista Melhores e Maiores da Revista Exame (2006), procederam à comparação do comportamento de empresas socialmente responsáveis com outras pertencentes aos seus respectivos setores. Os autores concluem que, de forma geral, com base nos indicadores utilizados para amostra analisada, não foi possível captar vantagens significativas para a responsabilidade social. Informam, ainda, que os resultados estão em consonância com os achados da pesquisa de Rezende e Santos (2006), porém estão em desacordo com os resultados gerais de Bertagnolli et al (2006).

Souza, Dreher e Amal (2007) observam que é crescente o número de organizações que, no sentido de não perder competitividade, procuram conformidades e normalizações relativas à responsabilidade socioambiental (RSA) reconhecidas em escala global. Realizam o estudo de caso sobre a RSA no processo de internacionalização de organização catarinense atuante no Mercado Internacional do Aço. A pesquisa exploratória qualitativa, por meio de uma entrevista com executivo da empresa, aponta para a percepção de que a estratégia de RSA contribui para a inserção competitiva internacional e ocorre, principalmente, por meio de instrumentos de padronização global.

Bragato et al. (2008) analisam, em estudo exploratório, a responsabilidade social corporativa (RSC) no ambiente organizacional das usinas de cana-de-açúcar paulistas, que integram o agronegócio brasileiro de açúcar e álcool. Os autores identificam, entre outros aspectos, que as principais ações sociais das empresas vêm contribuindo para a melhoria da imagem do setor sucroalcooleiro como agente do desenvolvimento sustentável, e que o foco das ações está concentrado nas áreas educacional e ambiental, com cultura, esporte e saúde num plano secundário.

Santana et al. (2006) discutem o impacto dos investimentos em responsabilidade sócio-ambiental para o desempenho financeiro de empresas do setor de energia elétrica. Observam, preliminarmente, a forte correlação entre esses investimentos e o faturamento das empresas. Resultado obtido por meio da aplicação da ferramenta DEA (envoltória de dados) que aponta os investimentos em responsabilidade sócio-ambiental como um dos fatores explicativos do faturamento das empresas.

Roque e Cortez (2006), analisando empresas portuguesas no mercado de cotações oficiais da Euronext Lisboa, no período entre 2000 e 2004, obtêm resultados empíricos que sugerem que as empresas que não divulgam informação ambiental tem uma performance financeira superior as que o fazem. Em particular, as empresas que apresentam um melhor relato ambiental são as que apresentam pior performance financeira. Os autores informam, contudo, que tais resultados não são estatisticamente significativos. 
Silva (2006) aborda o impacto da ética e sustentabilidade na volatilidade de ações de bancos latino-americanos. O autor observa que a qualidade dos padrões corporativos é captada pelo mercado acionário, impactando no potencial da lucratividade dos negócios e do valor para acionistas.

Peixoto (2003) apresenta resultados empíricos, evidenciando que alguns consumidores estão dispostos a pagar mais em atributos do produto para contribuir com programas sociais. Diante disso, afirma que as empresas possuem a oportunidade de focar nesse público, atingindo seus objetivos e contribuindo para a sociedade.

Serpa (2006) também investiga a influencia da RSC sobre o benefício e o valor percebidos pelo consumidor, constatando, entre os consumidores pesquisados, a percepção de um benefício e valor maiores e a disposição para pagar 10\% a mais pelo produto de uma empresa socialmente responsável. Outro aspecto observado é a influência maior de ação social geradora de um impacto direto na vida do consumidor, em relação à ação social geradora de um impacto indireto.

Pontes (2007) visa verificar se há alteração no desempenho da empresa, resultante das ações sociais por ela promovidas, por meio de um modelo com base no pensamento sistêmico, utilizando os princípios da causa e efeito. O autor identifica, dessa forma, o grau de influência dos indicadores de responsabilidade social sobre os indicadores de desempenho da empresa. Com a aplicação do modelo em uma empresa, constatou a importância das ações sociais em relação aos indicadores de desempenho e o impacto existente entre eles.

Araújo (2006) estuda a concessionária de eletricidade do estado do Pará, observando que o fato de a empresa realizar ações socialmente responsáveis ainda não é claramente percebido pelo seu consumidor, e influencia pouco na satisfação com a empresa, que teve seus atributos avaliados com conceito razoável pelo consumidor.

Bhattacharya, Sen e Korschun (2008) estudam como os empregados reagem a RSC. Por meio de entrevistas em profundidade, grupos focais, surveys on-line com empregados e survey global buscam obter subsídios para uso estratégico da RSC na captação de talentos, por meio da manutenção emocional do funcionário, além da recompensa financeira. Os autores constatam que a percepção das ações varia de acordo com a área e nível do funcionário, e que as principais barreiras são: a defasagem de conhecimento sobre ações, não levar em consideração a diversidade de funcionários atingidos, o não entendimento das reações psicológicas, e formulações de cima para baixo na hierarquia da empresa. Propõem incrementar a proximidade da RSC com os funcionários, identificando as necessidades e 
reforçando a identificação com o espírito da empresa, por meio de atividades de cocriação do valor de RSC, gerando atração, motivação e retenção de funcionários.

Kleinrichert (2008) observa que relações mais significativas entre empresas e comunidades devem ocorrer e isto implica em mais poder para os envolvidos nesse esforço. Afirma que relações com "outros” fortes podem gerar uma RSC baseada em reciprocidade e troca sustentável, substituindo uma noção de responsabilidade paternalista. Focando o caso da Starbucks Coffe Company, apresenta o desenvolvimento de aliados (Ally-bulding) como modelo efetivo de envolvimento com a comunidade baseado em relações recíprocas. Sugere engajamento individual nos esforços corporativos de desenvolver vínculos com a comunidade, como efetiva fonte de poder e uma prática ética para profissionais de negócios.

Barnett e Salomon (2006) combinam teorias de portfolio modernas e de stakeholders, para propor a hipótese de que as perdas financeiras em fundos de investimentos socialmente responsáveis devidas à pouca diversificação são compensadas quando se intensifica a heterogeneidade de empresas “sociais”, porque firmas melhor administradas e mais estáveis são selecionadas no portfólio. A partir de teste empírico em painel de 61 fundos SRI, de 1972 a 2000, os resultados mostram que, com a ampliação do número de setores/focos sociais, o retorno financeiro diminui a princípio, mas volta a subir, quando o número chega ao máximo. Trata-se de uma relação curvilínea, que mostra que os pontos de vista podem ser complementares e sugere que a performance financeira varia de acordo com os tipos de recortes/enfoques sociais usados. Há indícios de que as relações com a comunidade melhoram, enquanto meio-ambiente e relações trabalhistas diminuem o desempenho financeiro. Afirmam, ainda, que pesquisas teóricas e empíricas sobre a relação positiva ou negativa entre desempenho financeiro e social dão suporte às duas posições contrárias.

Strike, Gao e Bansal (2006), avaliando a diversificação internacional da RSC, observam que as empresas podem ser, simultaneamente, socialmente responsáveis e irresponsáveis. Analisaram dados de 222 firmas dos EUA, entre 1993 a 2003, evidenciando que multinacionais exploram os padrões frouxos de regulamentação social e ambiental nos países estrangeiros, ao mesmo tempo em que transferem boas práticas. Os autores argumentam, contudo, que as empresas podem ser socialmente responsáveis em algumas atividades e irresponsáveis em outras, e propõem a decomposição da RSC em elementos positivo (CSR) e negativo (CSiR).

Yadong (2006) propõe que as multinacionais (MNE) têm propensão a colaborar com o governo dos países onde se instalam, em relações positivas de contribuição filantrópica, e que 
sua assertividade com os governos locais é positivamente associada com sua ênfase em ética e credibilidade organizacional. O autor observa que, quando aumenta a corrupção percebida no segmento de negócio, MNE com mais foco em ética têm uma grande propensão para usar sua força de barganha para fazer acordos com o governo, ao passo que as com menos foco em ética têm uma grande propensão para usar conexões sociais para fazer esses acordos. Amostras de MNE na China dão suporte a essas proposições.

Waldman et al (2006) examinam variáveis culturais e de liderança, associadas a RSC, com dados de 561 empresas localizadas em 15 países (incluindo o Brasil), em 5 continentes, para ilustrar como as dimensões culturais de coletivismo institucional e distância do poder (valores relativos à extensão da crença que o poder pode ser desigualmente distribuído numa cultura) predizem valores de RS nas equipes de gestores de alto escalão. A pesquisa mostrou que fatores demográficos, econômicos, culturais e de liderança são determinantes críticos para a formação dos valores de RSC.

Tombi, Salm e Menegasso (2006) estudam o caso da empresa Gerdau, com aporte da Teoria da Delimitação dos Sistemas Sociais (Ramos, 1989) que considera o mercado como enclave social legítimo, mas limitado e regulado, e propõem um paradigma paraeconômico dividido em categorias como economia (contexto organizacional e ordenado) e isonomia (contexto com todos os membros iguais/ nível comunitário). Baseados em Porte e Kramer (2002), apontam a existência de um possível círculo virtuoso: fortalecimento da qualidade do mercado local, capacitação profissional, infraestrutura da região, aumento da qualidade dos processos administrativos locais, melhor utilização de recursos naturais etc.

Ribeiro Filho et al (2006) realizam investigação com amostra de 200 alunos de instituição de ensino superior federal (100 do curso de Ciências Contábeis e 100 de Serviço Social), abordando a decisão de investimento em empresas não lucrativas com fortes ações de cunho social. Por meio de teste não paramétrico U de Mann-Whitney, observam que não existem diferenças significativas entre os dois grupos, e que a maioria decidiu por não comprar ações de empresas não lucrativas responsáveis socialmente. Artigo discute o estigma do lucro, a partir de experimento, e revela que, em decisões de investimento pessoal, o lucro da empresa é fator determinante, afirmando que ações sociais são bem recebidas, desde que não interfiram no lucro, principal função da empresa.

Nan e Heo (2007), por meio de estudo experimental, observam que mensagem comercial com inclusão de marketing relacionado a causas (CRM), comparada a similar sem CRM, favorece uma atitude positiva do consumidor em relação ao anunciante. Além disso, 
constatam que a adequação entre marca e causa costuma ser negligenciada, interferindo positivamente apenas em consumidores com alta percepção de marca.

Ashley e Macedo-Soares (2001) desenvolvem um modelo para incorporação da responsabilidade social à governança das relações entre empresa e sociedade, denominado Modelo Relacional Multidimensional para a Responsabilidade Social nos Negócios (RMRSN). Afirmam que a RS não é um conceito absoluto, mas contextualizado à ideologia dominante na governança das relações negócios-sociedade, relacionada a aspectos fundamentais na constituição das empresas, o que faz com que a estratégia de RS tenha que incorporar o nível core business para efetiva transformação. A partir dessa premissa, utilizam a teoria de governança de transações (Heide, 1994), que indica as normais sociais como fundamentais para trocas relacionais, necessárias a um ambiente turbulento, para propor a incorporação da filosofia de RS a toda a rede de stakeholders, permitindo que o próprio conceito de RS nos negócios seja sustentável, no sentido de sua reprodução ampliada.O modelo conceitual, para dar conta de toda a rede de relações, é obtido a partir de pesquisa bibliográfica e documental, e conta com quatro dimensões: Dimensão de Relações de Produção e Distribuição “Internas” (capital e finanças; trabalho contratado; agentes de direção); Dimensão de Relações Econômicas (objeto e meio do negócio ou relações core business); Dimensão de Relações Político-Sociais (legitimação da empresa junto a instituições do Estado e Sociedade); Dimensão Tempo \& Espaço (contextualização e historicização). A essas dimensões as autoras acrescentam o Vetor Comunicação \& Conhecimento, visando aprendizagem e redução da assimetria de informação na rede, para estabelecer confiança entre as partes. Em termos empíricos, o modelo é aplicado ao setor supermercadista brasileiro, considerado ponto nodal da rede de negócio e abastecimento alimentar em áreas urbanas e, portanto, ponto-chave para disseminar práticas (algo que ocorre hoje com a movimentação da rede Wal-Mart em torno de ações “verdes”) que pode atuar como "procurador” dos consumidores, ignorantes tecnicamente sobre a produção dos alimentos.

Grau e Folse (2007) observam que o grande número de campanhas relacionadas a causas (cause-related marketing), competindo por um limitado número de consumidores socialmente conscientes, associado ao surgimento de novas gerações menos engajadas, leva empresas e parceiros a considerar outros públicos. Eles realizam dois experimentos, sobre o papel da proximidade da doação e sobre o tom da comunicação nas atitudes e intenção de participação de consumidores menos envolvidos. Observam que doações locais e mensagem de caráter “positivo” servem como guias para produzir retornos favoráveis. 


\section{Avaliação de resultados sociais e ambientais}

Oliveira e Reis (2008) aplicam a metodologia desenvolvida pelo UNEP/UNESCO (1987), originalmente destinada à avaliação de bacias hidrográficas para verificar o nível de equilíbrio das ações econômicas, sociais e ambientais da Empresa Natura Cosméticos, calculando um índice de sustentabilidade. A adaptação do modelo leva em conta os indicadores de desempenho propostos pelo Global Reporting Initiative (GRI), que desenvolve diretrizes para relatórios de sustentabilidade. A análise do Relatório Anual da Empresa, referente ao ano de 2006, obteve um índice de sustentabilidade calculado de 0,538, considerado aceitável, porém em estágio ainda incipiente de equilíbrio sustentável, devido ao baixo desempenho na perspectiva ambiental. Além desse achado, que evidencia a dificuldade em levar adiante o que é divulgado na comunicação institucional das empresas (lembrando que a Natura é considerada, mercadologicamente, exemplo de conduta social e ambiental), o artigo interessou a esta pesquisa, por detalhar os critérios do GRI, utilizados para a análise dos balanços sociais, realizada adiante.

Bronzo (2008), a partir da concepção de vulnerabilidade e riscos, examina alguns programas de transferência condicionada de renda desenvolvidos no Brasil (Bolsa Família), México (Oportunidades),e Chile (Puente). De forma exploratória, a partir de survey da literatura disponível sobre o tema, observa que os programas de transferência de renda produzem efeitos positivos em relação ao isolamento social, acesso à informação, identidade, pertencimento e autoestima, mas ressalta que tais alterações, sem mudanças substanciais nas formas de organização social e econômica, são insuficientes para provocar alterações significativas na situação de milhões de famílias em situação de pobreza e indigência

Campos et al (2008) utilizam método redutor de pontuação para a análise da escala Likert e categorização dos dados para a abordagem qualitativa, buscando apresentar alternativas para avaliação das ações sociais, no sentido do seu aperfeiçoamento de metodologias e sistemáticas de gestão de projetos sociais.

Rodrigues (2006) propõe uma abordagem para avaliar as ações sociais distinta da orientada por resultados (“marco lógico” BID). Busca “isolar efeitos” de um programa social, tentando captar efeitos líquidos não “contaminados” por outros processos e eventos. Realiza um estudo que compara grupos de participantes e não participantes do projeto Ação social Xerox na Mangueira, adaptando a lógica experimental utilizada pelo setor público, para a avaliação de programas sociais no setor privado. Trabalha com grupos de pessoas da 
Mangueira e funcionários da Xerox, avaliando a percepção, com base na memória dos entrevistados, das condições antes/depois da implantação do projeto. No âmbito do que nomeia como eficácia pública, detecta como possíveis efeitos positivos os seguintes: 1 capacitação para mercado de trabalho; 2 auto-estima; 3 inserção no mercado de trabalho; 4 sociabilidade; 5 saúde; e 6 lazer. No âmbito escolar, o projeto não apresentou os efeitos desejados , pois, na percepção dos entrevistados, influenciou em quem já ia bem, uma vez que os alunos com dificuldades não participavam dos projetos. Conclui, nesse âmbito, que os projetos vêm beneficiando a comunidade, e sugere aumentar o foco nas demandas da população, ouvir os moradores e inclú́-los no processo de planejamento. Chama-nos a atenção, contudo, que a inclusão sugerida pela autora vise aumentar a "retenção" nos projetos. Além disso, ela propõe maior atenção para o grupo de excluídos em situação de risco social, uma vez que o alvo do projeto é no campo da prevenção e da criminalidade. No âmbito da eficácia privada, detectou pouco conhecimento da ação por parte dos funcionários, que conheciam o projeto pela mídia (sobretudo o projeto Olímpico da Mangueira, que teve grande repercussão) e uma sensação difusa de orgulho, desvinculada da produtividade. A autora conclui, destacando a oportunidade de desenvolvimento que está sendo “dada” às crianças e adolescentes de baixa renda, mas observa que apenas crianças com características individuais e familiares mais sólidas conseguem aproveitar a oportunidade.

Essa tentativa de mensuração científica de resultados aponta, a nosso ver involuntariamente, a impossibilidade de isolar as ações das empresas e seus efeitos dos contextos e sistemáticas sociais, econômicas e culturais. Diante dessa impossibilidade (negada pela pesquisadora), e sob a premissa, avaliada cientificamente, de que a ação melhora a situação social das crianças e adolescentes, os esforços direcionam-se para a "retenção" dos jovens. Chama também a atenção que os resultados mais expressivos, se "isolados”, referemse ao mercado de trabalho e "auto-estima”.

Garcia et al (2007) consideram a falta de modelos de avaliação um gargalo ao desenvolvimento e evolução da RSE. Diante disso, propõem um sistema para a avaliação de projetos por meio de um modelo matemático, construído a partir da lógica fuzzy (fuzzy logic), ou lógica difusa, que permite integrar diferentes dimensões do desenvolvimento sustentável e gera subsídios para gestão, mesmo contando com dados incertos e de naturezas distintas, característicos da complexidade do campo social. A lógica fuzzy trabalha com a noção de grau de pertinência; não representa uma medida ou valor probabilístico, medindo a compatibilidade do objeto analisado com o conceito representado pelo conjunto fuzzy $\mathrm{O}$ 
objetivo do sistema é fornecer uma nota para os projetos de RSE, a partir das avaliações das dimensões social, ambiental e econômica, além do fator proveniente da identificação da percepção dos stakeholders. O modelo também permite incorporar, no processo de avaliação, o conhecimento de especialistas da área social, ambiental e da área de economia, além dos stakeholders. Ressaltam que a participação de um número maior de especialistas gera respostas mais confiáveis. O modelo matemático, percebido como cientificamente neutro, ganha uma característica peculiar ao incorporar a opinião de especialistas, para avaliar os resultados de projetos sociais, uma vez que o perfil desses especialistas faz com que o sistema, assim como a palavra “vazia” proposta por Bakthin, gere resultados muito diferenciados.

Frey (2007), por sua vez, propõe um sistema de Gerenciamento da Responsabilidade Social Empresarial - SIGRESE, modelo criado a partir da metodologia do Balanced Scorecard (BSC), sistema de gerenciamento estratégico baseado na mensuração, por meio de métodos que alinham a estratégia às atividades empresariais, monitorando o desempenho de metas por período. Para tanto, o autor enquadra os indicadores de responsabilidade social empresarial nas perspectivas do BSC (financeira, cliente, processos internos, e aprendizado e crescimento).

Siqueira (2007) aborda a Demonstração do Valor Adicionado (DVA) como instrumento de avaliação da RSE. A DVA visa demonstrar a geração de valor pela empresa e sua distribuição entre os elementos que contribuíram para sua geração. O autor destaca, contudo, que a DVA apresenta limitações preocupantes, sobretudo no âmbito estrutural. Tais limitações estruturais residem na ambigüidade informativa existente nos números oferecidos pela demonstração, ambigüidade que se inicia na apresentação da construção do valor, uma vez que a afirmação de que a alta criação de valor torna uma empresa socialmente desejável não se sustenta, pois este pode ser conseguido através de práticas monopolistas, em economias sem salvaguardas ambientais, ou com fornecedores com práticas questionáveis. E permanece na distribuição do valor criado, uma vez que os altos valores pagos em salários podem representar a canalização de resultados para uma elite gerencial ou familiar. Por outro lado, elevados valores em impostos devidos à progressividade, em função de uma essencialidade declinante, são encontrados na indústria de tabaco e álcool, que não constituem exemplos de responsabilidade social. O autor conclui, afirmando que essas limitações devem ser discutidas, para oferecer aos usuários demonstrações com capacidade informativa ampliada, com a inclusão de informações complementares.

Chicharro e Carrillo (2006), com base no marco conceitual da Responsabilidade Social Corporativa, analisam a segurança e saúde no trabalho. Por meio da identificação e 
classificação dos grupos de interesse, e suas demandas, definidoras das metas a serem alcançadas, propõem, como ferramenta de acompanhamento e de resultados, um quadro de indicadores que integra variáveis financeiras e não-financeiras (quantitativas e qualitativas), visando oferecer uma imagem detalhada das ações da empresa em matéria preventiva.

Gomes (2006) aborda a “educação” para consumo ético e responsável, referindo-se à necessidade de mudança de um paradigma antropocêntrico para uma visão de mundo biocêntrica, comprometida com a vida na Terra. Sugere a revisão dos padrões de consumo, impostos pelo sistema capitalista, e aponta a educação para o consumo como fundamental na conscientização da população em relação à sua responsabilidade social na manutenção do planeta.

Souza e Sampaio (2006) realizam estudo exploratório de projetos de turismo sustentável e de responsabilidade social empresarial, no qual analisam processos de tomada de decisão organizacional que tentam superar uma racionalidade utilitarista econômica e incorporar outros modos de racionalidade, voltados para o eco-desenvolvimento. Os autores consideram que as experiências analisadas possuem elementos que incorporam os conceitos de turismo sustentável e de responsabilidade social empresarial, evitando análises mais criteriosas que, segundo eles, poderiam inibir o surgimento de novos conceitos ainda em construção.

Coutinho, Macedo-Soares e Silva (2006), a partir de revisão da literatura e das recomendações de Kerlinger (1973) para operacionalização de conceitos, definiram construtos, desmembrados em dimensões, às quais foram atribuídos indicadores, chegando a um arcabouço conceitual que pode ser utilizado na condução de pesquisas empíricas sobre projetos sociais desenvolvidos por empresas e obtenção, por parte dos gestores, de maior efetividade e sustentabilidade dos resultados. Destacamos, no artigo, a discussão sobre os conceitos de eficácia, eficiência e efetividade. Os autores afirmam que há divergências sobre critérios de avaliação, sendo o mais utilizado e relativamente consensual o critério de eficácia, definido por Mokate (2002), entre outros, como grau em que se atingem os objetivos, em período de tempo com qualidade esperada, independente de seus custos. Já o conceito de eficiência envolve a relação entre duas dimensões: os resultados do projeto e os recursos utilizados, referindo-se à maneira como objetivos são alcançados. O conceito de efetividade, por sua vez, é objeto de diferentes interpretações, de sinônimo de eficácia ou impacto à capacidade organizacional para ser eficiente e eficaz ao longo do tempo, alcançando níveis de impacto elevados e sustentados. Os autores consideram efetividade como medida geral de desempenho, desmembrada em eficiência e eficácia. 


\section{Relações de trabalho - arranjos produtivos}

Molica, Carvalho Neto e Gonçalves (2008) buscam verificar como a negociação coletiva entre trabalhadores e empregadores têm refletido o discurso da RSE. A investigação, de abordagem qualitativa, abrangeu três negociações coletivas, TRE e sindicatos de trabalhadores, duas empresas e um sindicato de empregadores, dentre os mais atuantes das regiões metropolitanas do sudeste brasileiro. Foram tomadas como variáveis de análise os indicadores propostos pelo Instituto Ethos, como parâmetros da relação entre empresa e trabalhadores. Os resultados indicam que nem empresas, nem sindicatos relacionaram os temas reivindicados e ou acordados com tais indicadores, sendo que muitas cláusulas que se constituíam como indicadores de RSE não foram entendidas dessa forma pelos dois lados. Os autores consideram que os sindicatos perderam a oportunidade de usar o discurso da RSE a seu favor, e as empresas perderam a oportunidade de melhorar imagem e reputação; e que um complicador é o predomínio de intervenções na comunidade e não para ações consistentes voltadas para o público interno. Afirmam que, se praticada para dentro, resultaria em ganho de imagem interno e motivação, e poderiam transbordar para ambiente externo de negócios. Acreditamos que tal desconexão está diretamente ligada à forma como o discurso é construído.

Abramovay e Magalhães (2007) abordam o Programa Nacional de Produção e Uso de Biodiesel (PNPB) que se volta à integração de agricultores familiares, empresas e sindicatos por meio de modalidades produtivas que evitem a monocultura e permitam o uso de áreas até então pouco atrativas. Os autores afirmam que já existem bases científicas suficientemente sólidas para a concepção de sistemas integrados de produção de energia e alimentos, e que a proposta oferece inúmeras vantagens pelo sistema de cultivos conjugados.

A defesa do arranjo proposto fundamenta-se em uma idéia central da chamada nova sociologia econômica: a percepção de que mercados não são pontos de encontro neutros e impessoais entre oferta e procura, mas estruturas sociais, formas recorrentes e estáveis de interação, submetidas a sanções (Swedberg, 2005). A partir dessa concepção, os autores lembram que a motivação das empresas em relação ao PNPB reside na determinação de que uma porcentagem crescente (começando com 2\%, em 2008, e passando a 5\%, em 2013) de matérias-primas de origem não fóssil entre na composição do óleo diesel. Dessa forma, observam que a abordagem do selo social do biodiesel coloca a responsabilidade social no centro estratégico da gestão da empresa. A relação com os agricultores significa, para as empresas, estabilização das fontes de abastecimento de matéria prima, menor custo de produção, e uma marca social com maiores oportunidades de acesso e menores riscos de 
contestação no mercado internacional. Os autores elencam, também, vantagens para os agricultores, como o apoio técnico para a introdução de inovações, pauta produtiva da agricultura familiar (com participação da EMBRAPA); ampliação dos laços e controle recíproco entre ação sindical, governo e empresas (ressaltam, nesse sentido, que parte do MST propõem unidades cooperativas geridas pelos próprios trabalhadores, sem vínculo com as empresas); as áreas cultivadas voltadas à bioenergia são pequenas e não ameaçam a diversidade da agricultura familiar.

Consideramos que a proposta de incorporação dos pequenos como parte da cadeia produtiva apresenta efetivamente ganhos importantes para as empresas. O lado dos agricultores tem, a nosso ver, seus benefícios condicionados ao papel dos sindicatos, elementos importantes para unir a parte mais fraca do acordo. Contudo, sua estrutura "oficial” e "empoderada” pelas empresas podem conduzi-lo mais a tiranete do que a parceiro dos agricultores. Seria esclarecedor, nesse sentido, ter acesso detalhado aos questionamentos do MST. Parece interessante a empresa se revelando como tal, com seus interesses declarados em termos de cadeia produtiva, mas a relação ainda é desequilibrada e o aspecto político, desaparecido, carece de reinvenção; uma reinvenção que não deve vir da empresa.

Oliveira (2007) discute as demandas sociais presentes na silvicultura brasileira, desenvolvida em moldes concentradores de terra. Focando a retirada irregular de madeira, busca equacionar a situação de conflito e elaborar propostas de superação. A partir de perspectiva da nova sociologia econômica, que leva em conta laços, obrigações e compromissos morais nas relações de troca, o autor aposta na possibilidade de sustentabilidade entre as empresas florestais e as comunidades rurais do entorno, em razão da demanda por emprego e renda e dos riscos criados pela situação de conflito na retirada irregular de madeira.

Mendonça (2007) analisa duas experiências de alianças estratégicas entre empresas e comunidades na Amazônia, no início do século XXI, concluindo que o aprendizado obtido com as práticas de alianças pode contribuir para o desenvolvimento socioambiental dessa região. Percebe grande potencial, se as alianças intersetoriais forem estimuladas e passarem a fazer parte de fóruns de discussão mais amplos, superando preconceitos e com regras do jogo mais claras. Os dois estudos de caso (Grupo Orsa e Natura) revelaram, entre outros aspectos, que os princípios de preço justo e repartição de benefícios, presentes no discurso, são ambíguos e cheios de contradições na prática, dificuldades atribuídas parcialmente pela autora à falta de conhecimento de gestão e finanças das comunidades, e à postura das empresas que 
não sabem lidar com modos de vida locais. Acrescenta que as empresas levam em conta apenas aspectos econômicos, para calcular o valor a ser pago pelos produtos, ganhando forte ascendência sobre parceiros ao não incluir, na remuneração, valores de conservação ambiental, cultura local e de imagem incorporada.

Dowbor (2007) avalia, calcado em inúmeros dados de órgãos internacionais, que uma visão sistêmica e de longo prazo se impõe, o que implica mecanismos de decisão e de gestão que vão além do interesse microeconômico imediato. No âmbito da desigualdade social, critica a percepção dos pobres como oportunidade de negócio, em contraponto com a “sabedoria e eficiência” do Grameen Bank, do indiano Yunus. Denomina o sistema atual de economia do desperdício, apontando, entre outras formas de desperdício social: o não aproveitamento de gigantescas reservas de mão-de-obra; desperdício de poupanças desviadas para atividades especulativas; a criação de um sistema de pedágios sobre o conhecimento tecnológico. Contrapõe o que chama de "bobagens simplificadoras”, que reduziram a inovação social a um Estado mínimo, a um "sistema racional de tomada de decisão”, que seria exigido pelo desenvolvimento sustentável, afirmando que "Dos ricos, o que se está exigindo cada vez mais, não é bondade, é inteligência”. A partir dessa proposta de melhorar o sistema sem mexer com os ricos “inteligentes”, propõe a democratização do governo que, depois do Estado gerencial, deve “evoluir” para o responsive governance, no qual as chefias escutam melhor o cidadão, promovendo uma eficiência democrática pela base; e a democratização das corporações, numa proposta onde o essencial é desenvolver o 'core business' de maneira responsável, o que significa, para o autor, “evoluir” para a avaliação da produtividade sistêmica do território (não conseguimos perceber o aspecto “democrático” dessa proposta). O texto utiliza muitas vezes a idéia de "evolução", com a desigualdade social e os problemas ambientais apresentados como fenômenos decorrentes de desajustes do sistema, passíveis de serem reequilibrados a partir de uma conduta mais inteligente e racional, sobretudo das elites.

Souza e Sampaio (2006) focam processos de tomada de decisão organizacional, que visam superação da racionalidade econômica utilitarista, a partir da proposta de ecodesenvolvimento (Ignacy Sachs), que envolve satisfação das necessidades básicas das populações (hierarquizadas em materiais e psicossociais), autonomia sem isolamento das comunidades, e relação simbiótica homem-natureza. Analisam o PNMT - Programa Nacional de Municipalização do Turismo -- e outras metodologias, que visam o turismo sustentável.

\section{Crítica gerencial}


Para Robert Reich, em entrevista publicada na revista Época (2007), as ações de RSE criam a falsa impressão de que as empresas são pessoas, com preocupação moral. São práticas de boa gestão se ajudarem empresas a aumentar lucro, uma vez que os seus executivos não têm o direito de decidir sobre o que é público, pois, para isso, há leis e normas, sendo esse o propósito do processo democrático. Reich afirma que o supercapitalismo toma forma nos 70, por meio da tecnologia, melhoria de transportes e comunicação, e multiplicação do poder dos consumidores e investidores. Por outro lado, as instituições que conduziam as negociações formais ou informais para distribuir riqueza perderam importância. Capitalismo triunfou, mas democracia se enfraqueceu, e a idéia do bem comum desapareceu. Muitos se beneficiam, mas há consequências perversas. Os acontecimentos recentes mostram que o capitalismo pode ser uma condição necessária para democracia, mas a democracia pode não ser essencial para o capitalismo. Cita China, Cingapura e Rússia, que parecem, mas não são consideradas democracias pelo autor. Reich não acha que os consumidores e os investidores devam ser responsáveis pela definição dos rumos da sociedade.

Porter e Kramer (2006) consideram que a RSE, ligada à estratégia da empresa, é capaz de gerar grandes oportunidades para a empresa e para a sociedade. Afirmam que o debate sobre RSE já chegou aos conselhos de administração das empresas, mas as soluções ainda são “cosméticas” e há uma “cacofonia de vigilantes autoproclamados”. Elenca problemas sobre os dados apresentados em balanços sociais e documentos congêneres, lembrando, por exemplo, que o respeitado índice Dow Jones de Sustentabilidade usa o tamanho do conselho da empresa como indicador de seu envolvimento na comunidade, e que, em geral, as classificações tem pouco significado e permitem que quase todas atinjam uma medida de RS. Examinam as quatro grandes justificativas/ escolas de pensamento (dever moral, sustentabilidade, licença para operar e reputação), apontando suas limitações. A idéia do dever moral esbarra no fato de que obrigações morais absolutas (bem e mal) não são compatíveis com equilíbrio de custos, interesses e valores conflitantes, deixando sem resposta a questão: Como distribuir moralmente a receita entre ações sociais e acionistas? A sustentabilidade apela para o que os autores chamam de um sadio interesse próprio, mas fica esvaziada, quando não coincide com interesses da empresa; a licença para operar é mais pragmática, mas a proposta de diálogo construtivo com as partes interessadas apresenta o risco de ceder controle primário da pauta de RSE a terceiros. Os autores expõem aqui a impossibilidade de levar adiante uma proposta de deliberação efetivamente democrática, pois consideram que dividir a pauta de deliberação não é estratégico, afirmando que "Embora sua 
opinião pese, esses grupos jamais terão uma plena compreensão dos recursos da empresa, de seu posicionamento competitivo ou das concessões que precisa fazer” (2006, p.56), e que veemência de um grupo não indica a relevância da questão para a empresa ou para o “mundo”. Para concluir, lembram que a justificativa da reputação costuma gerar confusão entre relações públicas e resultados sociais e empresariais, e que os estudos sobre a relação entre RSE, consumidor e bolsa de valores são inconclusivos. Partem, então, sob a premissa de interdependência sociedade-empresa (noção de que a competitividade empresarial é o motor da sociedade), para defesa da proposta de que a empresa deve integrar a perspectiva social aos modelos já usados, para entender a concorrência e nortear a estratégia. Identificaria pontos de intersecção em quatro áreas do contexto competitivo: quantidade e qualidade de subsídios; regras e incentivos; porte e sofisticação da demanda local; disponibilidade de indústrias de apoio (elementos da teoria do “diamante”, de Porter, muito difundida no meio acadêmico da administração). Afirmam que as causas/questões sociais precisam ser categorizadas e classificadas, para a criação de uma pauta social empresarial explícita e afirmativa, visando "escolher muito bem um punhado de iniciativas sociais que gerem o maior valor compartilhado” (2006, p.59), pois a RSE estratégica deve promover número pequeno de iniciativas, cujos benefícios sociais e empresariais são amplos e distintivos. São citados, como exemplos: Toyota e o carro elétrico híbrido Prius; a incorporadora mexicana Urbi, voltada para moradias de baixa renda; o banco Crédit Agricole França, que foca produtos financeiros e certificações orgânicas; e o Working Connections, parceria entre a Microsoft e a American Association of Comunity Colleges AACC, que investe em tecnologia e voluntário para gerar mão-de-obra em falta no mercado. Inversamente, podemos deduzir que, se houvesse excesso de mão-de-obra, a empresa não investiria na formação desses alunos. Ressaltam, ainda, que práticas plenamente integradas tornam difícil distinguir RSE das atividades rotineiras da empresa, citando, como exemplo, a Nestlé e desenvolvimento de distrito leiteiro na Índia. Em linhas gerais, o artigo argumenta que a postura fragmentada e defensiva deve dar lugar a uma estratégia integrada e afirmativa. Para os autores, a proposta de stakeholders, ao medir satisfação das partes, inverte as prioridades, pois o que deve ser medido é o impacto de iniciativas sociais focadas, proativas e integradas com o cerne das estratégias empresariais, capazes de gerar diferenciação competitiva, uma vez que o melhor que a empresa pode fazer é contribuir para economia próspera. A redução à estratégia empresarial dá o exato tamanho e a limitação das iniciativas. Só uma instância fora da empresa pode articular e definir investimentos sociais. A empresa, por definição, faz investimentos empresariais com eficiência. 


\section{Gestão da comunicação e informação - Terceira via}

Freitas e Gomes (2008), por meio de um estudo empírico qualitativo sobre o posicionamento das organizações em relação à prática social e suas estratégias discursivas na construção de uma identidade positiva de “empresa-cidadã”, concluem que há dificuldade para manter coerência entre o discurso e a prática, no âmbito de um mercado competitivo. Tomando a responsabilidade social como um instrumento de gestão e de ampliação da competitividade empresarial, as autoras identificam a necessidade de uma postura mais cuidadosa por parte das organizações, incorporando a responsabilidade social à missão e aos valores das empresas, e comunicando seus propósitos de forma transparente.

Porém (2005), em dissertação de Mestrado, foca a gestão da comunicação e da informação nas empresas contemporâneas, sob a ótica da responsabilidade social. O trabalho, finalizado com recomendações práticas, observa que a promoção da RSE como mote da gestão da empresa depende da implantação prévia de uma política de comunicação e informação, constituída a partir do estudo de sua cultura organizacional e disseminada entre os stakeholders.

Zacarias (2004), em pesquisa de Doutorado, observa o envolvimento da propaganda brasileira com a questão da cidadania, a partir da lente do terceiro setor. Para tanto faz a análise de conteúdo de anúncios nos anuários do Clube da Criação de São Paulo, no período entre 1996 a 2002, tendo como eixo a questão da solidariedade. Assume tom prescritivo, ao discutir a capacitação dos alunos dos cursos de Publicidade e Propaganda para realização de campanha em que visa "lucro social” agregado à imagem.

Lucien et alli (2007), levando em conta a relevância da internet, em especial, os websites corporativos, como ferramenta comunicacional, realizaram pesquisa estatística com amostra de 120 empresas de países emergentes, participantes do G-20. Os resultados indicaram a existência de relação entre a comunicação da responsabilidade social empresarial pelos websites e o país de origem da empresa, destacando a importância de fatores socioeconômicos, legislação e cultura do país, na comunicação da RSE pela internet.

Murad (2005) avalia que há convergência entre as demandas sociais e as mudanças de paradigmas, que o capitalismo vem enfrentando. As corporações, ao se posicionarem como atores políticos e sociais, possibilitam a elaboração de estratégias competitivas vantajosas para a comunidade, a própria empresa e todo o público interessado. O trabalho segue a linha da "humanização" do modelo econômico do capitalismo, sem perder competitividade e lucratividade, propondo uma saída intermediária entre as posições utilitaristas e de convicção 
(moral) assumidas pelas empresas. Ao sugerir uma "adaptação" dos movimentos sociais, adequando soluções propostas pelos atores externos (especialistas) aos modelos e estruturas culturais do território, o autor não enfrenta, contudo, as tensões e conflitos envolvidos nessa disputa. Também não problematiza a possível incompatibilidade entre plena cidadania (conjunto de direitos universalizados pelo Estado) e uma administração privada lucrativa e calcada na manutenção dos fluxos de produção e consumo.

Tese de Martins (2005), tese que desenvolve a proposta de uma terceira linguagem para as organizações em geral e para o estudante de comunicação em particular, situada entre o que designa linguagem de marketing (primeira linguagem) e linguagem de relações públicas (segunda linguagem), capaz de expandir a abrangência das duas anteriores e integrar o trato das atividades empresariais à responsabilidade social. O destaque é a elevação da pessoa humana do mero conceito de consumidor à condição de participante de um relacionamento, uma atitude de mestiçagem por parte do profissional com integração de princípios éticos, culturais e de responsabilidade social, em paralelo aos conceitos mercadológicos.

Farache, Wanderley, Perks e Sousa Filho (2007) comparam as estratégias de divulgação, adotadas pelas maiores empresas francesas no Brasil e na França, e observam que os websites franceses apresentam mais informações e maior detalhamento dessas informações sobre Responsabilidade Social Empresarial do que os de suas filiais brasileiras.

Wanderley et al. (2008), ampliando a comparação entre a divulgação das ações de responsabilidade social nos websites de empresas francesas no Brasil e na França, realizam estudo comparativo de websites de 127 corporações de países “emergentes”, como Brasil, Chile, China, India, Indonésia, México, Tailândia e África do Sul. Os resultados apontam para uma significativa influência do país de origem na divulgação das informações a respeito da RSC, seguida pela influência do setor ao qual a empresa pertence.

Roberto (2006) parte da afirmação de que a atuação social das empresas constitui um novo pacto social, como uma forma de proteção social paralela à oferecida pelo Estado. Destaca, contudo, que as questões ligadas à responsabilidade social das empresas privadas são controversas, sobretudo quanto a seu real potencial de atuação frente aos problemas sociais. A partir da observação das informações disponibilizadas, Balanços e Relatórios Sociais, a autora analisa a postura socialmente responsável dos principais bancos privados que atuam no Brasil, e constata que a publicação dos balanços e relatórios, nesse sentido, tem se orientado mais na direção de oferecer uma "satisfação" ao público que acompanha a questão da RSE do que de 
estabelecer uma diferenciação estratégica frente à concorrência. Isso sugere, à autora, ausência de uma substantiva postura socialmente responsável.

Petrini (2006) apresenta um modelo teórico para a concepção de sistemas de Inteligência de Negócio, integrando o conceito de responsabilidade social corporativa, o qual passa a compor o conjunto de informações relevantes a serem gerenciadas.

Brugmann e Prahalad (2007) defendem que a aproximação entre empresas e entidades sociais tem gerado empresas mais “sociais” e ONGs mais “empreendedoras”, uma vez que a atenção à base da pirâmide aproxima gerentes das realidades locais e possibilita troca de expertises. Ex: Danone e Grameen Bank. Os autores afirmam que a convergência de interesses e recursos pode gerar negócios inovadores e novos nichos de mercado, reduzindo a oposição entre os agentes à divergência "quanto à natureza e velocidade da desregulamentação”, e enfatizando um deslocamento dos conflitos para a aprendizagem mútua (por meio da montagem de negócios) e relações comerciais de criação conjunta. ONGs assumem papel de reguladoras da atividade empresarial, ocupando o “vácuo do Estado”, uma vez que podem ferir reputação das empresas, levando a alterações nas práticas e códigos de conduta. Também ajudam na aproximação com o mercado de baixa renda, a partir da visão do pobre como um empreendedor sem capital, reconhecimento e apoio. Os autores afirmam que modelos de negócios bem calibrados podem liberar forças para o bem comum, erradicando a pobreza com lucro, citando o microcrédito, redes informais convertidas em cooperativas e seguros de viuvez, patrimônio, chuva, colheita, para a baixa renda. Mas são explícitos no caráter da relação, em que devem pautar-se por modelos de negócios para criar mercados, com foco em tarefas específicas (criar produtos para os pobres ou produtos de nicho - feitos pelos pobres - para os ricos), e não por “discussões de caráter ideológico ou programático” (2007, p.56) citando, como exemplo, uma cooperativa de camelôs, na África, que cedeu espaços para patrocínio nas barracas, no lançamento de refrigerante popular. Isso nos deixa a sensação da criação de um tipo de "segunda categoria” de relações comerciais e humanas, no qual os mais “aptos” poderiam ascender ao primeiro time. Enfatizam, ainda, que um “Diálogo discreto, longe do debate público, já gerou princípios fundamentais para estruturas de governança futuras” (2007, p.59), e permite a todos, na cadeia, ganhar dinheiro, numa cultura de franqueza e resolução conjunta de problemas, criando um ecossistema comercial. Citam, como exemplos, o desenvolvimento de fogão ecológico pela Índia BP (antiga British Petroleum), institutos de pesquisa e ONGs, e parcerias como Acción e ABN AMRO (América Latina); Danone e Grameen Bank; Microsoft e Pratham (Índia), entre outras. 
Kunsch (2004) aborda a importância da comunicação nos dias atuais, tomando a comunicação organizacional como setor estratégico. Faz, também, um apanhado sobre a questão da cidadania, citando, entre outros, Marshall (1967), com a divisão de direitos civis, políticos e sociais; e Liszt Vieira (1997, p.22-27 apud KUNSCH, 2004), que aponta direitos de $1^{\text {a }}$ geração, direitos civis individuais e políticos (séc. XVIII e XIX) ; de $2^{\text {a }}$ geração, direitos sociais (séc. XX); de $3^{\mathrm{a}}$ geração, que tem grupos como titular (segunda metade século XX); e de $4^{\mathrm{a}}$ geração, relativos a bioética, com foco na vida. A partir de Giddens (1999, p.79-108 apud KUNSCH, 2004), entre outros, a autora observa o surgimento de formas emergentes de cidadania, não restritas à “visão tradicional”, centrada nos movimentos de lutas sociais e confrontos com o poder econômico e político, chegando à cidadania empresarial, afirmando que as questões sócio-ambientais entraram na agenda corporativa e, como "microsociedades”, as empresas têm compromisso social global, além do negócio e do lucro. Idéia que a autora reforça com a citação de Anitta Roddick, da empresa The Body Shop, para quem a empresa, como organização mais poderosa da sociedade atual, deve assumir sua "liderança moral”. Nesse contexto, a autora afirma que as Relações Públicas devem cumprir, no contexto empresarial, uma função social, ao lado das funções estratégicas.

\section{Voluntariado}

Fagundes (2006) estuda a ação voluntária e solidária, identificando, em termos gerais, um comportamento que está radicado na tradição filantrópica da benemerência, originando um trabalho de doação que é próprio da cultura cristã. Considera as ações voluntárias e solidárias paradoxais por conciliarem uma "solidariedade utilitária”, na forma de mercadoria valorizada pelo mercado, e a possibilidade de sensibilidade dos sujeitos em relação ao outro.

Ortiz (2007) investiga a prática do voluntariado hospitalar, como foco na produção da subjetividade no discurso dos voluntários. A partir da realização de entrevistas, analisadas com o método de discursos elaborado por Marlene Guirado, ele constata que o voluntariado tem como objeto institucional não a cura, mas o bem-estar, sendo que a produção de subjetividades se dá pelas diversas formas de construir as relações de proximidade entre voluntários e pacientes

Garay (2008), por sua vez, foca os programas de voluntariado corporativo, uma das opções de ações em responsabilidade social valorizadas pelas empresas e presente em instrumentos de avaliação, como o proposto pelo Instituto Ethos, ou em modelos de balanço social (Ibase). A autora buscou identificar esse tipo de trabalho que é percebido pelo voluntário, envolvido num cenário organizacional com uma série de novas demandas. Entre 
os significados encontrados, destaca-se voluntariado como história de vida e forma de ser reconhecido pela empresa, entre outros, sendo observados ganhos individuais de ordem afetiva e também profissional. Por outro lado, percebeu-se também a influência de formas de controle mais sutis sobre os funcionários, a reprodução de relações de poder tradicionais no exercício da ação voluntária, bem como um nível de sofrimento nessa prática.

\section{Economia da Comunhão}

Leitão e Spinelli (2008), em artigo que avalia a produção acadêmica em administração pública e de empresas no Brasil, definem, a respeito do tema, a economia de comunhão (EdC) como um projeto empresarial e econômico, surgido de um movimento cristão (focolares) vinculado à Igreja Católica, que se disseminou mundialmente pela fundação de pequenas comunidades chamadas "mariápolis", e contava, em 2006, com mais de 8,5 milhões de pessoas em 820 empresas situadas nos cinco continentes. A Itália é o país com mais empresas registradas no projeto e com maior produção acadêmica sobre ele, seguida do Brasil, que possui, em Vargem Grande Paulista, a empresa Espri S.A., com cerca de 4 mil acionistas. Os autores lembram que grande diferencial estaria na qualidade dos relacionamentos interpessoais e interorganizacionais, sendo também possível destacar as redes de contato comercial que elas formam, criando uma zona de amortecimento de choques, para suportar pressões do mercado.

A tese de Carvalho (2007), por sua vez, realiza o estudo de caso de uma proposta de EdC, entendida como um tipo particular de Responsabilidade Social. Os resultados identificaram a associação de representações de origem religiosa a outras já sedimentadas no discurso capitalista (como meritocracia, lucro como direito legítimo, sociedade como soma de indivíduos), indicando que a EdC não se configura como uma proposta contra-hegemônica, à medida que complementa o modelo capitalista. O rompimento com a lógica capitalista não se concretiza plenamente, uma vez que a concepção de comunhão dos lucros considera como dádiva o que é direito, mantendo relações assimétricas e de dominação.

Apostando na transformação a partir do indivíduo, Melo (2008) afirma que, na EdC, a solidariedade tem lugar sobre o individualismo e o homem tem primazia sobre o capital. Em diálogo com o trabalho de Dalabrida (2005), observa que no sistema empresarial há uma incorporação, mesmo que tímida, de outros modos de agir vinculados a princípios éticos, o que permitiria pensar na hipótese da adoção de Responsabilidade Social Empresarial e da EdC 
como experiências concretas na direção de tornar o modelo de racionalidade e utilitarista econômico mais equilibrado.

\section{Mídia, publicidade, consumo e cidadania}

Lisenberg (2006) foca a inserção da imprensa no discurso do terceiro setor, por meio da análise de duas colunas dirigidas às questões sociais e cidadania de jornais da grande imprensa. O trabalho utiliza método da Análise de Discurso de linha Francesa e identifica as seguintes instâncias constitutivas do campo discursivo: agentes mobilizadores,(:) fundadores ou gestores da causa, iniciativa ou instituição; instâncias de apoio,(:) onde se inserem aqueles que contribuem para a efetivação do trabalho, tais como,(:) patrocinadores, leis que fundamentam e normatizam o segmento, voluntários e colaboradores eventuais; destinatários,(:) população beneficiada pelas ações; e instituição midiática,(:) lugar ocupado pelo jornal ou grupo ao qual pertence, bem como pelos jornalistas que nele trabalham.

Tendo como referências Baierle (2000), Manzini-Covre (2001) e Dagnino (1994), observa que, nos lugares discursivos analisados, prevalece uma noção organicista, em que a cidadania e os direitos são vinculados ao acesso ao mercado formal de trabalho; o cidadão é identificado como o consumidor ou contribuinte; e a idéia de cidadão é associada àquele que contribui para o "resgate” de não-cidadãos. Há(Com) a concomitante destituição da idéia de cidadania vinculada a direitos e pressão para transformações sociais. Tais achados dialogam com a primeira parte da análise realizada neste trabalho, que focou matérias jornalísticas publicadas acerca da responsabilidade social empresarial.

Barros (2007), por sua vez, analisou a cobertura dada à vigilância sanitária em quatro jornais de circulação nacional. Tendo em vista que a área, sob competência de uma agência reguladora, oferece espaços para a participação social, como consultas públicas, ouvidorias e câmaras setoriais divididas, o autor observou que o cidadão é vinculado ao papel de consumidor, pela imprensa, e está em desvantagem em relação a atores econômicos, representantes do Estado e profissionais de saúde. Nos textos jornalísticos, o cidadão é identificado com figura de vítima de um sistema de saúde falho, algo que tende a "mutilar direitos do cidadão”, evidenciando aspectos individuais e financeiros.

Reginatto (2007) realiza uma análise sobre a institucionalização do merchandising social na telenovela das oito. Destaca que o departamento responsável pela inserção de causas sociais nas novelas surgiu no final dos anos 90, momento coincidente à consolidação da idéia de um Estado gerencial. Cria-as, nas palavras da autora, uma cidadania de mercado, que visa 
lucratividade e ganho de imagem, e converte direitos assegurados na Constituição de 1988 em moeda de troca. A rede de televisão coloca-se, dessa forma, numa posição ambígua que ao mesmo tempo rechaça a responsabilidade, pelo caráter voluntário e ocasional das ações, e as realiza, sob a premissa de ter poder para "pautar questões de relevância social” (REGINATTO, 2007, p.120).

Ferreira (2006), tendo como objetos empíricos, palestras, publicações e pesquisas sobre ação social e perfil do consumidor no Brasil, enquadra o papel social da comunicação empresarial no rol das ferramentas estratégicas da moderna administração, cuja finalidade é persuadir o consumidor-cidadão de que ela atua de forma socialmente responsável, criando uma nova utopia.

Martineli e Machado (2007) analisam três campanhas publicitárias ligadas a questões de cidadania e direcionadas ao público jovem. Observam que, ao revestir os objetos que produzem ou serviços que fornecem com conotações políticas e sociais, as empresas passam a ser representadas como ativas organizadoras da vida cotidiana e fazem do consumo uma instância de construção de liberdade, expressão e autonomia. A idéia de cidadania vinculada a uma comunidade desloca-se, dessa forma, para uma cidadania de feições individualizadas. As autoras destacam que diversos trabalhos apontam para uma aproximação entre "consumidor" e “cidadão”, lembrando que é imprescindível introduzir a questão política nesse debate.

Santa Cruz e Martineli (2007) analisam a comunicação dos bancos brasileiros como caso emblemático de humanização das marcas e das ações de responsabilidade social, entendidas como estratégia de comunicação e gestão empresarial. Na análise, observam que a instituição pública (Banco do Brasil) segue na tentativa de estimular a cidadania e a mobilização social, enquanto instituições privadas oscilam entre o papel de defensores da sustentabilidade (Bradesco e Itaú), e criadores de produtos cujo uso realize essa função (Real ABN-AMRO e HSBC). No geral, os discursos publicitários sobre responsabilidade social empresarial ganham uma aura de mobilização coletiva, endossando, reciprocamente, marcas e causas defendidas. Articula-se, dessa forma, um discurso político (negado pelas empresas), com pretensão de agir sobre o que é público e social e organizar a vida dos cidadãos.

Baldissera e Araújo (2007), tendo como marco teórico o Paradigma da Complexidade (Morin), discutem as apropriações e atualizações da idéia de diversidade e respeito à diversidade nas campanhas publicitárias Dove - Real Beleza e Verão Sem Vergonha. Para os autores, as campanhas, mais do que traduzirem responsabilidade social, constituem-se em estratégias de comunicação de marketing. Os autores observam que a idéia de 
responsabilidade social assume, com o reforço da mídia, um valor positivo. Fato que o artigo reforça, ao propor uma distância entre as estratégias de comunicação e marketing e a noção de responsabilidade social, reivindicada por empresas que agirem de maneira "comprometida com o ambiente ecossistêmico”. Na campanha em lente a empresa assume o papel de arauto da diversidade. Trata-se, contudo, da utilização de um valor caro à sociedade para devolver discurso e imagem que se assemelham ao discurso social. Os autores afirmam, porém, que, em algum nível, a campanha contribui para a difusão da questão da diversidade, aumentando o nível de informação. O artigo ressalta, portanto, a prática publicitária de dialogar com questões sociais no sentido de envolver seus públicos. A questão é, contudo, tratada de forma esquemática, colocando marketing e sociedade em campos distintos.

Ezequiel (2005) analisa a campanha publicitária “Produto do Bem”, de uma rede de drogarias, que utiliza como estratégia o apelo "social”. Observa que, ao vincular uma causa à venda de produtos, as campanhas repassam a responsabilidade pela "ajuda" social ao consumidor. Dessa forma, há uma negação implícita do papel do Estado na realização de políticas sociais associada à idéia de que as soluções serão gestadas na sociedade, a partir dos indivíduos e com a “ajuda” das empresas privadas. Esvazia-se, dessa forma, a noção política da cidadania.

Cazeloto (2007) estuda a significação histórica e cultural dos Programas Sociais de Inclusão Digital (PSID), no contexto vigente de reestruturação do capitalismo, detectando que o caráter potencialmente emancipatório de apropriação de técnicas digitais não se realiza, sendo os resultados dessas políticas restringidos ou anulados pela própria lógica de reprodução do capitalismo, que necessita do processo de informatização social para produzir valor.

Santa Cruz (2006), em pesquisa de doutorado, caracteriza a epresentação midiática do discurso da RSE como "palavra de ordem” no sentido proposto por Gilles Deleuze e Félix Guattari . Faz um levantamento de como as atividades em prol do "social” ganharam, paulatinamente, desde meados da década de 90, suplementos, programas de rádio e cadernos exclusivos, obtendo grande visibilidade na mídia. Para a autora, a RSE é palavra de ordem que trabalha no interior de um discurso econômico, que se dissemina para todas as camadas da vida. Observa que, nos dois jornais analisados, o discurso econômico ganha tom apriorístico, ocupando o espaço do discurso político.

Um aspecto interessante desse trabalho é a identificação de um “jornalismo do bem”, onde questões críticas como pobreza, fome, desemprego são vistas por uma ótica positiva, com ênfase na eficiência, agilidade e resultados contabilizáveis das ações empresariais. O 
discurso jornalístico sobre responsabilidade social empresarial usa e abusa do termo cidadania, como uma noção autoexplicativa, quase uma licença para as ações reportadas. Processo que transcende a informação e ganha ares de projeto (classificação da CBN para seu boletim diário), incluindo, além da coleta de notícias, doação de parte dos salários dos jornalistas e parte da receita publicitária para causas noticiadas. Há uma quase mitificação de "sobreviventes”, que desbravaram a fronteira da exclusão, e a construção das notícias deixa a sensação de relação direta entre a entrada da empresa/projeto e obtenção instantânea de qualidade de vida. Na visão neoliberal, o cidadão se torna cada vez mais um consumidor, afastado de preocupações com a política e com os problemas coletivos

Trata-se, para a autora, de um enunciado que opera, nos termos de Deleuze e Guattari (1995:12), como palavra de ordem onde “a informação é apenas o mínimo estritamente necessário para a emissão, transmissão e observação das ordens consideradas como comandos”. A autora vislumbra, contudo, inseridas no agenciamento coletivo de enunciação que é o movimento de Responsabilidade Social Empresarial, possíveis linhas de fuga, mesmo que não aparentes, capazes de fazer vibrar o que aparentemente está cristalizado ou em processo de cristalização. A percepção do movimento de Responsabilidade Social Empresarial, como um “agenciamento coletivo de enunciação” (SANTA CRUZ, 2006: 221), encontra ecos em vários trabalhos.

Peruzzo (2001) realiza breve análise de conceitos de comunidade, público comunitário e responsabilidade social, observando que a empresa tem uma série de obrigações a cumprir com a sociedade (como pagar os impostos, cumprir contratos, oferecer produtos/ serviços de qualidade e adequados, respeitar leis, voltar-se para o desenvolvimento e reinvestir na produção, preservar o meio ambiente e o ecossistema, e pagar salários dignos e justos). Além dessas obrigações, a empresa entraria no âmbito da filantropia e da contribuição para melhoria das condições de vida, compromissada com a autopromoção humana, o desenvolvimento da cidadania e a vida no planeta Terra. Ressalta que, embora tais ações sejam "no fundo" estratégias mercadológicas e também de classe, para garantir as condições necessárias à reprodução do modo de produção capitalista, devem ser reconhecidas como válidas ações que beneficiem a pessoa e demais formas de vida no planeta.

Livingstone, Lunt e Miller (2007) analisam o uso dos termos “cidadão”, “consumidor”e “cidadão-consumidor”, na articulação dos interesses dos cidadãos na regulação da mídia e da comunicação na Inglaterra. Observam que o Ato Parlamentar de 2003, que regula o setor de comunicações, apresenta uma grande variedade de formas de 
definir “consumidor” e “cidadão”, indo da oposição à estrita sobreposição de sentidos. O que mais chama a atenção é a ausência continua de uma definição clara dos interesses dos cidadãos, em relação à mídia e à comunicação. Enquanto o termo “consumidor” é visto como relativamente não problemático, a inclusão do “cidadão”, nos deveres estatutários da nova agência regulatória das comunicações, tem sido alterada por meio de estratégias discursivas que questionam sua definição, sua coerência e sua aplicabilidade à prática regulatória._Uma maneira de minimizar essa questão seria oferecer uma definição clara e operacionalizável dos interesses dos cidadãos. Mas isto, segundo os autores, tem se mostrado difícil, uma vez que a própria estratégia da agência reguladora tem se convertido às práticas de pesquisa de mercado (coerente com a ênfase no mercado e na regulação econômica), coletando dados sobre exclusão social que justificam sua concepção de consumidor. O resultado é uma concepção de cidadão como minoria vulnerável, deixando que a maioria expresse seus interesses de cidadão primeiramente, por meio de seu papel ativo como consumidores no mercado.

Peruzzo (2007), a partir de estudo baseado em pesquisa bibliográfica, destaca que uma proposta efetiva de democratização da mídia pressupõe um direito à comunicação, que não diz respeito apenas ao acesso à informação mas também o acesso aos canais de difusão de conteúdos.

Oliveira (2007), em sua dissertação, destaca o papel da comunicação e suas tecnologias na articulação e formação de parcerias entre o Primeiro, o Segundo e o Terceiro Setores, na busca de soluções para os problemas brasileiros. Dá ênfase a internet, apresentando a proposta tecnológica denominada e-social como mecanismo capaz de promover comunicação, articulação e a formação de parcerias intersetoriais.

\section{Crítica e propostas de resistência e "empoderamento"}

Hoff e Santos (2008) abordam o conceito de cidadania e a possibilidade de um “empoderamento” discursivo associado à comunicação processual, presente nas práticas cotidianas. Fazem um contraponto com o tratamento dado à questão da cidadania na mídia, apostando no potencial do que se situa "fora da mídia” como o melhor lugar para a construção da cidadania. Os exemplos utilizados para balizar a discussão são as campanhas de solidariedade, promovidas pela Rede Globo de televisão, em particular a campanha Criança Esperança, e o trabalho da ASA - Articulação do Semi-Árido. O artigo discute as condições de legitimação do poder pelo uso abusivo e "inadequado" do conceito de cidadania, como a possibilidade política de um discurso de ruptura, tendo como referenciais as formulações de Michel Foucault e Hannah Arendt. A partir do conceito de dom, de Marcel Mauss, 
retrabalhado por Maurice Godelier, as autoras lembram que o ato de dar estabelece uma relação desigual e mantenedora do status quo. Por outro lado, associam a cidadania à reunião de condições para a resistência.

Enfatizam a necessidade de ir além da caridade e estimular a emancipação social de grupos, denunciando a atmosfera de espetacularização que cerca o uso da palavra cidadania, especialmente do uso da expressão “empresa cidadã”:

Para que uma empresa fosse cidadã, ela precisaria prescindir de seus valores usualmente etnocêntricos, que tomam o ritmo e as perspectivas do outro como simbolicamente inferiores e abdicáveis. Teria, também, que conferir voz e condição de ação aos agentes sociais com que interage, em vez de buscar, muitas vezes, convencê-los de projetos que não são seus ou, pior, fazê-los crerem seus quando na verdade nunca foram. A comunicação, neste ponto, desempenha papel importante no jogo da dominação, já que muitas vezes sugere escuta onde há apenas efeito de interlocução. (HOFF e SANTOS, 2008, p.8)

A crítica severa às estratégias de dominação, sustentada pelo referencial teórico calcado em Foucault, é contraposta ao entendimento da comunicação processual, realizada no nível micro das relações sociais, como capaz de gerar fraturas nas relações de poder e saber. Como destacou a relatora do artigo, ao propor uma oposição esquemática entre uma comunicação midiática hegemônica e a comunicação reduz a complexidade das ações e relações estabelecidas. Por outro lado, o conceito de cidadania é também simplificado ao ser associado à implantação de cisternas no semi-árido. Esse texto, assim como outros da área de comunicação, ao desenharem um sistema poderosíssimo de dominação, contraposto a propostas de resistência associadas a termos como fissuras e fraturas, oferece um caminho que parece tornar mais distante a transformação contra-hegemônica proposta.

Santos e Hoff (2007) analisam a possibilidade política de um discurso de ruptura, entendendo resistência como construção de novos sentidos nas entrelinhas do modelo de produção capitalista, utilizando a noção foucaultiana de linhas de fuga. Analisam o Projeto Carbono Social, desenvolvido por uma ONG, que é uma experiência bem sucedida de empoderamento sócio-econômico de trabalhadores rurais. As autoras abordam a noção de “direitos de primeira e segunda geração”, ou seja, os direitos civis, políticos e sociais que implicam sempre algum nível de atuação do Estado, e o surgimento dos chamados "direitos de terceira geração” (VIEIRA, 2005), que têm como titular grupos humanos como o povo, a nação, coletividades étnicas ou a própria humanidade. (VIEIRA, 2005, p.2 apud SANTOS e HOFF, 2007, p.6). A partir dessa perspectiva afirmam, que só é possível falar em cidadania se 
há aumento do espaço discursivo que permita aos indivíduos e grupos participarem da constituição dessa trama simbólica social. As autoras apresentam, contudo, um relato que deixa dúvidas quanto à “ruptura” construída pelo trabalho analisado, ao afirmar, por exemplo, que as ONGs transformam comunidades tradicionais em "agentes protetores da biodiversidade”, atuam “gerenciando conflitos” ou, ainda, realizam “trabalho educativo”.

Santos (2005), tomando o consumo como produção simbólica e também como potencial ato político capaz de "gerar fissuras na lógica de mercado", faz uma crítica ao que chama de “capitalismo leve”, cuja comunicação oculta o consumo de água, energia e combustíveis fósseis, entre outros. A autora propõe o conceito de desenvolvimento sustentável como ruptura no discurso marcado pelas aparências, por demandar uma mudança na linguagem publicitária e no conjunto de códigos com os quais ela lida, obrigando as narrativas do consumo a deslocarem-se do apelo ao efêmero. Nesse processo, o enquadramento dado pela mídia teria papel decisivo, ao pautar as novas preocupações de consumo.

Zammouri (2009) descreve a ação da Brigada Anti-Publicidade, na cidade de Paris, a partir de pesquisa realizada nos anos de 2006 e 2007. O autor nomeia o movimento como ativismo pós-moderno, em diálogo com o novo espírito do capitalismo de Luc Boltansky e Eve Chiapello. É um enfoque de antropologia urbana; o consumo, nesse caso, a comunicação para o consumo, como caminho para uma possível ação política.

Rossy (2006), em dissertação de Mestrado, faz a análise das rotinas de agendamento na mídia, promovidas por três organizações do Terceiro Setor que atuam na área de políticas públicas de segurança, na cidade do Rio de Janeiro. A hipótese principal da pesquisa é a de que a divulgação de notícias voltadas ao interesse público, assim como experiências bem sucedidas, normalmente não encontram receptividade nos meios de comunicação, o que levaria as organizações a artifícios de espetacularização e ações performáticas. Com base na Teoria do Agenda-Setting, de McCombs e Shaw (1972), segundo a qual os meios de comunicação têm capacidade de inserir temas para discussão na agenda pública, observa a existência de um “contra-agendamento”, no sentido da sociedade (representada pelas ONGs) para os meios de comunicação; uma vez que as organizações estudadas têm domínio das técnicas e rotinas jornalísticas e realizam um trabalho sistemático para "instrumentalizar” e “educar” os jornalistas. As ONGs transformam-se, dessa forma, em fontes permanentes para as matérias jornalísticas, mas, apesar do clima amigável, convivem com a necessidade de criar “pseudo-acontecimentos” e “eventos programados”, para inserção na agenda midiática, procedimento chamado pela autora de “co-participação”. 
Pesquisa de Doutorado de Barbosa (2007) analisa os programas públicos nacionais de combate à fome e à miséria, como o Programa Comunidade Solidária e os programas de transferência de renda, dos governos do presidente Fernando Henrique Cardoso. A autora conclui, com referencial teórico e metodologia marxiano, que esses programas não eliminaram e nem mesmo reduziram, de forma significativa, a fome e a miséria. Ao adotar o princípio da focalização, para atingir os mais "pobres" e transferir a responsabilidade com o social para o chamado "terceiro setor", revelaram-se assistencialistas e atuaram contra a universalização dos direitos. Dessa forma, apenas controlaram e administraram a miséria, sem perspectiva de superá-la

Viana (2007), por sua vez, em tese de Doutorado, busca compreender as implicações da assistência social plural ou mista, porém, não pública, em substituição às políticas do Estado do Bem-estar, observando que essa orientação mudou substancialmente o significado e conteúdo da assistência social, destituindo-a de sua dimensão pública e do seu status de cidadania. Questiona ações como voluntariado, redes de proteção e programas de renda mínima de inserção (RMI na Europa), e/ou de transferência de renda (Bolsa Família, no Brasil), por apresentarem uma perspectiva focalizada e residual, e não tratarem a pobreza e a desigualdade social como fenômenos estruturais e de classe que resultam de uma brutal concentração de renda e de riqueza. Tendo como unidade de análise empírica o Sul da Europa e o Brasil, compreende que a assistência social vem sendo usada de "forma deturpada", como mera reparação de danos sociais, deixando de lado princípios universais e redistributivos.

Tese desenvolvida por Affonso (2007) estuda as contradições da inserção de dirigentes sindicais da CUT (Central Única dos Trabalhadores) em instâncias do Estado ampliado, ao longo dos anos 1990 e 2000 . A partir de opção teórica e metodológica marxistas, detecta uma ressignificação do discurso e da prática sindical, forjada pela mudança do padrão produtivo na contemporaneidade e pela adesão da CUT às formulações clássicas da social democracia, sobre a possibilidade de ampliação da democracia através da gestão de políticas públicas universais, custeadas pelo fundo público, num momento de avanço da reforma do Estado no sentido de uma conduta gerencial/empresarial.

Brittos e Bolaño (2006) propõem-se a esclarecer o caráter de instrumento de manipulação e controle social das indústrias culturais, a partir da análise do merchandising social desenvolvido pela Rede Globo de Televisão, tendo como referências teóricas os trabalhos de Gramsci, Marx e Habermas. Observam que, no merchandising social, grandes temas nacionais ou universais são apresentados, num simulacro de debate que tem a duração 
da telenovela, promovendo mobilizações provisórias e auxiliares da "pedagogia capitalista para o consumo”. Constatam que se trata de "uma colossal estratégia reticular de apropriação publicitária da idéia mesma de transformação social” e de energias sociais que poderiam, em outras condições, promover mudanças sociais e democráticas efetivas. E acrescentam que “ $O$ espaço público é o espaço para o homem aliar-se ao outro, no debate lúcido e honesto de idéias. Mas o que se tem hoje é uma panacéia, um arremedo, pois isso não se concretiza, diante do predomínio da lógica mercadológico-midiática” (BRITTOS e BOLÃNO, 2006, p.10) É uma crítica devastadora que apresenta, como movimento “oculto” de dominação, estratégias de mercado amplamente conhecidas, ao mesmo tempo em que subestima a capacidade do público de reelaborar as mensagens recebidas.

\section{Disputa dos sentidos da enunciação sobre o social e esfera pública}

Boff (2004) analisa o discurso de workshop, promovido pela Fundação Novartis para o Desenvolvimento Sustentável (FNDS), com vistas a reestruturar administrativamente o Serviço de Educação e Organização Popular (SEOP), seu parceiro no Brasil. Apresenta um apanhado da trajetória das ONGs, de sua origem como movimentos sociais à alteração do seu papel, com a derrubada dos regimes militares, nos anos 80, e o avanço das políticas neoliberais, quando muitas passaram a ser financiadas por grandes empresas e organismos multinacionais, gerando um conflito entre os princípios empresariais - de eficiência, produtividade e qualificação - e o ideário inicial que pautava suas atividades. O caso estudado focou a disputa de sentido do "desenvolvimento sustentável”; uma disputa em que o SEOP constitui um lugar de fala alternativo (e mais frágil) em relação ao regime de significação preponderante, associado à FNDS. De forma sintética o autor aponta o tratamento dado às estruturas de poder como diferença crucial entre as entidades, uma vez que o SEOP colocaria essas estruturas em xeque e a FNDS, não. Observa, diante disso, que não existe um transplante fácil de técnicas de gerenciamento e produção, à medida em que questões éticas e políticas estão em jogo, sobretudo porque a proposta de "inclusão" é feita sob a ameaça velada de escolher outros parceiros com "potencial para desenvolvimento" mais alto, caso não haja adequação aos padrões exigidos. Aponta o enlace emocional e a ação comunicativa com os outros, como caminhos possíveis para a construção de um novo princípio legitimador desse tipo de conflito.

Rego (2008) define o status social de cidadão como um complexo de condições políticas, sociais, econômicas e culturais garantidas aos membros de uma nação, apontando 
seu enraizamento na vida coletiva, como medida fundamental do grau de democratização de uma sociedade. Faz um apanhado histórico da trajetória européia da cidadania, e lembra que o status de cidadão refere-se à esfera pública, entendida como espaço fundador de processos de legitimação de identidades e suas demandas.

A autora destaca que há três grandes classes de direitos: os civis, os políticos e os sociais, desdobrados em culturais, ambientais e muitos outros, e que esses direitos sempre foram motivo e objeto de conflito permanente, onde a dimensão regulatória da política como o "fazer de todos" permanece como a única garantia para impedir a redução da cidadania aos ditames do mercado.

Lembra, ainda, que, sob a justificativa da rapidez e da eficiência, processos de decisão democráticos são substituídos por políticas estatais seletivas, formuladas por agentes de poderes privados ou por experts que as elaboram em benefício direto de grandes corporações privadas. É um caminho que ganhou força no Brasil a partir das privatizações das empresas públicas, realizadas nos decênios dos anos de 1980 e 1990, associadas à desconstrução sistemática dos direitos sociais, e foi realizado em vários países, com maior ou menor sucesso, em virtude das resistências de sujeitos políticos. Como forma de produzir identidade política, cultural e de gênero, a autora propõe a necessidade de uma temporalidade tridimensional, que inclui o tempo da memória, o tempo do projeto e o tempo do desejo e do futuro, lembrando que somente a política pode unir estas três temporalidades e tornar possível uma esfera pública como espaço legítimo e legitimador de encontro de identidades e do conflito.

A partir desses marcos teóricos e de trabalho de campo realizado no alto sertão do estado de Alagoas, a autora conclui que o Programa Bolsa Família, embora tenha características de compensação assistencialista, pode ser pensado como potencial programa de cidadania, por oferecer potencialidades emancipatórias, ao garantir a dotação financeira, chão concreto de qualquer outra consideração; e por colocar a titularidade do benefício nas mãos das mulheres, historicamente discriminadas. A partir dessas considerações, propõe o início do debate sobre sua ampliação e transformação em renda básica universal e permanente, como direito fundamental dos cidadãos brasileiros.

Pereira e Carvalho (2008), em artigo, apresentam o pensamento de Boaventura Souza Santos (2000), autor que sustenta que estamos vivendo em um momento de transição paradigmática, no qual o paradigma da modernidade se encontra em declínio, em função do colapso do pilar da emancipação no pilar da regulação, fruto da convergência do paradigma da modernidade e do capitalismo. Diante disso, Souza Santos propõe a transformação do 
conhecimento científico (totalizante e antidemocrático) em um novo senso comum, definido como "conhecimento prudente para uma vida decente" (SANTOS, 2000, p.107), que possui cinco dimensões: a solidariedade, a participação, o prazer, a autoria e a artefactualidade discursiva. Dentre elas, os autores focam a dimensão da participação, que, diante do reconhecimento da limitação imposta por uma definição restrita do espaço da política, propõe tentativas de ampliar os espaços da ação política para além do Estado e da esfera pública. Mencionam o projeto Democratizar a democracia - os caminhos da democracia participativa, que resultou em obra organizada por Souza Santos (2003), com estudos de caso em diferentes países do Sul e cujas experiências analisadas evidenciam a democracia como conceito em aberto, em constante desenvolvimento e em conflito com o modelo hegemônico, que procura desqualificá-las ou não reconhecê-las. Os autores abordam, então, a formulação teórica de Dagnino (2002) e Dagnino, Olvera e Panfichi (2006), especialmente relevante para esta pesquisa, Nessa proposta teórica, a discussão sobre a construção democrática é problematizada a partir de três instrumentos analíticos: o reconhecimento da heterogeneidade da sociedade civil e do Estado; o conceito de projetos políticos, que se refere ao conjunto de crenças, interesses, concepções de mundo, representações do que deve ser a vida em sociedade; e as trajetórias sociedade civil e sociedade política.

Reforça-se, dessa forma, a percepção do conflito como componente inerente das relações políticas e sociais, e a ênfase é fundamental para perceber as relações existentes dentro da própria sociedade civil, entre a sociedade civil e o Estado, e dentro do próprio Estado (também perpassado por diferentes interesses e percepções). Coloca, ainda, em xeque o consenso liberal (Santos, 2002), que se desdobra em: consenso econômico (liberalização dos mercados, diminuição da intervenção estatal na economia e a sua submissão aos organismos internacionais de regulação econômica); consenso do Estado fraco (que sustenta a proposta de Estado gerencial); consenso democrático liberal em torno de uma concepção minimalista da democracia, que restringe a participação ao seu mínimo e busca transformar conflitos em questões tecnocráticas e gerenciais (Dagnino, Olvera e Panfichi, 2006); e consenso do primado do direito e dos tribunais, que cria condições para o desenvolvimento, sem entraves, da economia de mercado.

Os autores concluem, afirmando que um projeto político-participativo procura ampliar a noção da política, ao reconhecer uma heterogeneidade de atores, práticas e temas.

Araújo (2007) descreve e analisa o projeto governamental Fome Zero como um conjunto heterogêneo e polissêmico de ações e proposições, envolvendo normas, discursos, 
instituições, agentes e fundamentações técnicas, éticas e morais, entre outros elementos. Propõe, dessa forma, seu entendimento como um produto político, elaborado no interior da disputa pela definição legitimada da pobreza e da fome no Brasil. A análise do autor mostra como a conjunção entre filantropia e direitos sociais desemboca numa série de conflitos, tensões e ambigüidades no âmago do próprio Fome Zero; um olhar que nos parece apropriado para entender a dinâmica das ações empresariais voltadas para o social.

Almeida (2006) lembra que, nas últimas três décadas, o conceito de sociedade civil foi amplamente utilizado, indicando um amplo leque de significados nem sempre conciliáveis, atendendo aos mais diversos interesses políticos e projetos societários em disputa. Alçada à condição de protagonista do processo de redemocratização dos anos 70, por intelectuais e políticos vinculados à "nova esquerda", a sociedade civil é concebida como uma esfera autônoma com relação ao Estado (entendido pela autora como sociedade política) e às relações econômicas, como espaço das virtudes cívicas e do associativismo voluntário; assim como espaço da fragmentação e da diferença, numa forte oposição à identidade de classe e aos projetos e sujeitos coletivos. Utiliza o conceito de sociedade civil de Gramsci, para fazer uma leitura dos conflitos de classe presentes na sociedade civil, negados por uma grande parte das interpretações contemporâneas.

Guivant e Tomiello (2008) identificam as ambivalências na comunicação das estratégias de sustentabilidade da empresa Wal-Mart, em particular no que diz respeito à comercialização dos produtos orgânicos, entendendo que a produção, divulgação e comercialização de um determinado alimento podem interferir sobre o ethos organizacional. Sintetizam a ambivalência do Wal-Mart a partir da simultaneidade de valores irreconciliáveis: discurso sobre a importância dos colaboradores e condenação em milhões de dólares de indenização a seus trabalhadores por abusos; facilitação do acesso dos consumidores a produtos de qualidade e comercialização de produtos fabricados sem as condições mínimas estipuladas pela Organização Internacional do Trabalho (OIT); premiação pelos programas de desenvolvimento dos fornecedores regionais e imposição unilateral de métodos, condições e preços ao adquirir as mercadorias; entre outros aspectos.

Dagnino (2004) analisa a confluência de dois projetos políticos discrepantes. De um lado, o processo democratizante e participativo que emerge da luta contra o regime militar, envolvendo movimentos sociais e tendo com marcos a Constituição de 1988, a democracia formal e eleição do presidente Lula. Aposta na ação conjunta, sociedade civil e Estado, para aprofundamento democrático, por meio de Conselhos Gestores de Políticas Públicas e 
Orçamentos Participativos, por exemplo. De outro, o projeto de Estado mínimo, adequado ao modelo neoliberal, que se isenta de responsabilidades e as transfere para a sociedade civil. A autora afirma, que na última década (90), ocorre confluência perversa entre os dois projetos, semelhantes pelo fato de requerem uma sociedade ativa e propositiva. Há uma identidade de propósitos aparente, construída por referências comuns, uma série de “coincidências” no nível do discurso, que envolvem disputa de significados e deslizamentos semânticos; algo que implica dilemas para quem trabalha nesse campo, uma vez que as mesmas forças podem servir a projetos antagônicos.

Para contribuir com o deciframento dessa situação, a autora trabalha com o conceito de Projetos políticos, oriundo de Gramsci e entendido como um conjunto de crenças, concepções, representações do que deve ser a vida em sociedade, que orienta ações políticas dos sujeitos e que expressa, veicula e produz significados de matrizes culturais mais amplas. Procura superar a visão homogeneizadora de sociedade civil como "polo de virtudes" e Estado como "mal encarnado". Lembra que a redefinição da sociedade civil passa pelo crescimento das ONGs, emergência $3^{\circ}$ Setor, e uma filantropia redefinida (FERNANDES, 1994; LANDIM, 1993; ALVAREZ, 1999; PAOLI, 2002; SALAMON, 1997 apud DAGNINO, 2004), e destaca o papel das agências internacionais na raiz dessa transformação. Observa que as ONGs, desvinculadas dos movimentos sociais, passam a ser responsáveis perante financiadores e o Estado que as contrata, mas não perante a sociedade civil, setores atendidos, ou qualquer instância de caráter propriamente público. Vivem um dilema: recusar esse papel significa abrir mão da possibilidade concreta de produzir resultados positivos, ainda que fragmentados e limitados, na diminuição da desigualdade e melhoria das condições de vida. A questão da representatividade desloca-se, dessa forma, do número de participantes e mobilização, para o tipo de competência que possuem junto a determinados setores, assim como para a visibilidade. A autora lembra que para compor o Conselho da Comunidade Solidária, centro de políticas sociais no governo FHC, foram convidados indivíduos com “visibilidade”, entendida esta como espaço ocupado na mídia, e que se retiraram depois do período inicial do programa. Ocorre, dessa forma, uma despolitização da participação, pois as novas definições dispensam espaços públicos de debate, reduzindo a participação à gestão.

A autora aborda, ainda, a noção de cidadania que, segundo ela, sofreu o deslocamento de significado mais dramático. Lembra que a nova cidadania, final de 70 e anos 80, articulou movimentos sociais em torno de demandas de acesso a equipamentos urbanos e questões identitárias, propondo sujeitos e direitos de novo tipo, ampliação do espaço da política, por 
meio do laço constitutivo entre cultura e política. É uma cidadania “desde baixo”, que requer mudança cultural para aprender a viver com cidadãos emergentes que se recusam a permanecer nos seus "lugares", e orientou as mudanças institucionais incluídas na Constituição de 1988, considerada a "Constituição Cidadã”.

As redefinições neoliberais reduzem, contudo, o significado da cidadania a um entendimento individualista, estabelecendo sedutora conexão cidadania-mercado. Ser cidadão passa a ser integrar-se ao mercado como produtor e consumidor, assim como ajudar os outros a "adquirir cidadania”. Lida com a pobreza, não como igualdade de direitos (como fazia o CONSEA Conselho de segurança alimentar), mas como gestão, com apelo à solidariedade restrito à responsabilidade moral. Isso leva a autora a afirmar que a cidadania fica reduzida à solidariedade para com os pobres (hobby da classe média), em doações e caridade. Consideramos, nesse aspecto, que o discurso e as ações são bem mais sofisticados, com o uso da noção de "empoderamento" e franca oposição à caridade do discurso de setores mais “engajados”. Ressalte-se, ainda, que a distribuição de serviços e benefícios ocupa o lugar dos direitos e cidadania, ao mesmo tempo em que obsta a própria enunciação da questão política, completando a idéia da pobreza como denegação de direitos. Trata-se, portanto, de um Estado mínimo, complementado por concepção minimalista de política e democracia, restringindo espaço, participantes, processos, agenda e campo de ação da arena política. Para finalizar, cita como exemplo discursivo dessa concepção a menção do então presidente FHC para desqualificar MST “É um movimento político” (caso dos tanques na greve dos petroleiros), e "Democracia se faz é no Congresso", concluindo com a constatação de que existem, de fato, dois projetos distintos, não havendo confluência nem perversidade.

Gomes (2007), a partir da crítica à noção de esfera pública proposta por Habermas, que soa para o autor como "excessivamente cooperativa”, afirma que no contexto midiático atual tal esfera poderia ser definida como o domínio social das coisas e temas com alta visibilidade social, lembrando que o enfoque deliberacionista da teoria democrática contemporânea deixou de lado a visibilidade. Levanta, então, a seguinte questão: a deliberação pode ser separada de uma extensa visibilidade e, ainda assim, ser democraticamente importante? Parte então para considerações a respeito da formação da opinião pública no contexto atual, que são especialmente relevantes para nossa pesquisa.

O autor afirma que opinião coletiva, resultante da discussão pública, assume, hoje, outros sentidos, sendo o principal a opinião pública como opinião publicada. Conserva a “publicidade” no sentido de "acessibilidade” ou “disponibilidade”, mas descarta a discussão 
realizada em público, assim como a sustentação coletiva da opinião. Trata-se de uma opinião seminal, que não é pública, porque produzida por muitos, mas, porque publicadores de opinião (autodenominados formadores de opinião), produzem opiniões que, devido à sua extrema visibilidade, outros vão assumir e replicar. A opinião pública seria produzida, portanto, de suas formas; a partir das falas daqueles que o autor chama de "príncipes da mídia”, e por meio de sondagens políticas e/ou mercadológicas, que oferecem medições da disposição do público em face de um pequeno conjunto de opções pré-estabelecidas.

Conclui, observando que a predileção pela discutibilidade, em detrimento da visibilidade, enfraquece empiricamente a noção de esfera pública, embora a escolha se justifique do ponto de vista ideal. Ressalta que o fato das opiniões publicadas serem mais eficazes do ponto de vista da influência política resulta de, na prática, a visibilidade ser mais influente do que a discutibilidade, e que a visibilidade e os sistemas especializados na sua produção e gestão têm papel central para o entendimento da democracia contemporânea.

\section{Investimentos privados e espaço público}

Tese de Almeida (2006) investiga o que denomina marco discursivo da participação solidária, um conjunto articulado de termos que podem ser apreendidos, pelos significados e efeitos políticos que produzem, como componentes articulados de um projeto de intervenção social. No estudo, foram enfatizados os termos "capital social”, “terceiro setor", “solidariedade”, “responsabilidade social empresarial” e "investimentos privados com fins públicos”, e utilizados, como referentes empíricos, a Comunidade Solidária e o Fome Zero. A autora mostra que na esteira das lutas pela democracia (anos 70 e 80) e das reformas orientadas para o mercado, deu-se o embate entre dois conjuntos de forças. De um lado, as forças comprometidas prioritariamente com o mercado e, de outro, as forças engajadas nas formas de participação e afirmação de direitos. Embate marcado por disputas e convergências, mas onde predomina o primeiro conjunto de forças, articulado pelo marco discursivo da participação solidária em torno do projeto Comunidade Solidária e seus desdobramentos. È uma proposta que substitui a luta por um sujeito portador de direitos, pela formação de empreendedores e cujo discurso naturalizado, calcado em consensos superficiais e aparentes, não ataca o objetivo dos antagonistas (primado da justiça social frente ao mercado), mas os qualifica como "atrasados" e incapazes de fornecer respostas apropriadas. O sujeito portador de direitos é, por sua vez, associado ao sujeito acomodado pelas políticas de bem estar, e a cidadania já não expressa medida de igualdade politicamente construída e fundamentada em 
direitos, mas uma igualdade fundada no potencial empreendedor, que carece de condições favoráveis para se desenvolver. Trata-se de um conjunto que aponta para uma definição de interesse público que não resulta de negociações políticas, mas pressupõe ausência delas, uma vez que as instituições para formulação de políticas públicas, voltadas para a garantia de direitos, dão lugar a parcerias pontuais e provisórias, que ficam à mercê da boa vontade de empresas privadas. A trilha apontada por Almeida (2006), associada às questões levantadas pelos demais autores, reforça a pertinência de um trabalho na área de comunicação, que se proponha a explicitar os mecanismos de produção do discurso acerca da RSE, apontando, sob os consensos aparentes, a heterogeneidade de sujeitos e vozes, assim como trabalhar com um novo jogo de referências teóricas, capaz de dar conta dos deslizamentos semânticos ocorridos no âmbito das questões e ações sociais.

Calegare (2005) analisa a transformação social no discurso de uma organização do Terceiro Setor. Pela confrontação dos diferentes discursos abordados na dissertação, notou-se que o debate sobre a transformação social segue os imperativos de um projeto político dominante, demonstrando que um dos mecanismos dessa uniformização é a substituição ideológica das significações das palavras. O autor focou, em suas análises, mudanças no plano subjetivo, mas a leitura do trabalho contribuiu para esta pesquisa, sobretudo, pela discussão a respeito do conceito de cidadania e pelas considerações a respeito do termo "terceiro setor", e de sua transmutação de uma questão social para uma questão organizacional. Para discutir cidadania, o autor cita a tipologia de direitos tripartite, proposta por Thomas Humphrey Marshall (1967): direitos civis (direitos necessários à liberdade individual de dispor sobre o próprio corpo); direitos políticos (direito de participar no exercício do poder político); e direitos sociais (atendimento das necessidades humanas básicas e ao bem-estar econômico, e segurança ao direito de participar), que inclui o cumprimento de deveres, com a disposição de dons e talentos para construção de uma vida coletiva melhor. Avança, ainda, com autores como Liszt Vieira e Manzini Covre. Viera (2001, p. 37 et. seq.) descreve a trajetória da cidadania, desde o liberalismo, passando pela crítica comunitarista (críticas marxistas ao modelo capitalista liberal e suas propostas); crítica social-democrata (direitos sociais Marshall - e Welfare State); crítica nacionalista (em que se critica o indivíduo reconhecido apenas pelos seus direitos, mas também pela sua identidade); crítica multiculturalista (com o processo de globalização, na qual se deve pensar a cidadania vinculada a pessoa universal); e crítica feminista. Manzini Covre (2003, p. 21 et. seq.), por sua vez, coloca que uma das formas de compreender a cidadania, atualmente, é ver como ela se desenvolveu juntamente 
com o capitalismo. Em relação ao Terceiro Setor, o autor destaca que, tal qual sustentado por Falconer (1999, p.27), deve ser pensado, enquanto uma tipologia organizacional, um campo específico das ciências da gestão que merece atenção especial: a administração das organizações sem fins lucrativos, o que justifica o nome de “organizações”. Uma estratégia que objetiva o desvencilhar-se das expectativas depositadas nessa nova forma de intervenção social, e das pretensões sociológicas e políticas de justificativa de sua existência. Esse fato é explicitado pelo autor pela exposição da impossibilidade de "conceituar” o Terceiro Setor, e da passagem de sua "inconsistência teórica” para "materialização prática”, enquanto novo padrão de intervenção social, tornando claras as ligações dessa operação com a ordem econômica dominante. É um processo que inclui o uso de léxicos como cidadania, exclusão, sociedade civil, de forma indiscriminada, sem suas devidas contextualizações.

Berghin (2005) percebe as ações de responsabilidade social como estratégias de intervenção, ajustadas à ideologia neoliberal, que operam sem se contrapor à lógica do mercado, retirando da arena política e pública os conflitos distributivos e a demanda coletiva por cidadania e igualdade. Segundo a autora, as ações empresariais implicam, em certa medida, na regulação da pobreza, por meio de uma sociabilização que substitua a solidariedade coletiva. Desenvolve-se um sentimento social fundado em deveres mútuos, sendo que o dever substitui a noção de direito, na base da reciprocidade social. Uma vez que a filantropia não consegue fazer frente à magnitude e complexidade do fenômeno da pobreza, surge uma "neofilantropia”, que busca gerir a pobreza a partir do entendimento de que a massa de excluídos constitui-se num grande entrave ao desenvolvimento da sociedade de consumo. Para Berghin (2005), as formas de intervenção das empresas, ao apropriar-se de valores circulantes na sociedade, tais como cidadania, solidariedade, cooperação e participação, contribuem para dissolver os espaços de deliberação pública e consolidar a idéia de inutilidade do público. A questão que surge é: como pensar e propor direitos de cidadania num contexto que desarticula e dissolve os valores que construíram esses direitos?

Segundo Gohn (2005), alguns indícios de resposta podem ser encontrados nas ambivalências e contradições da fragmentação da sociedade. Percebe-se, aqui e acolá, um incipiente “controle social” de alguns movimentos sociais. Surgem de esferas públicas, onde os cidadãos se fazem ver como sujeitos, em propostas como a Economia Solidária, colocada em prática, ainda em pequena escala, por Paul Singer, com a circulação de bens e serviços a partir de motivações baseadas na reciprocidade. Gohn (2005: p.29-30), ao tratar do assunto, afirma que a análise histórica revela, em resumo, atributos de ordem jurídica (leis relativas à 
ordem socioeconômica, política e cultural), de ordem normativa (comportamento do "bom cidadão”), e atributos construídos pelas ciências sociais, que ampliam a noção de direitos e deveres, discutindo igualdade/desigualdade, universal/particular, público/privado etc. Para Gohn (2005: p.30), a cidadania pode ser definida como um "processo onde se encontram redes de relações, conjuntos de práticas (...), tramas de articulações que explicam e ao mesmo tempo sempre estão abertas para que se definam as relações dos indivíduos e grupos com o Estado”. Essa noção de processo altera também o conceito de sociedade civil, que. segundo a autora, deixa de ser percebida como "simples guarda-chuva que abriga o que não está no âmbito estatal”.(GOHN, 2005: p.68), A sociedade civil pode ser concebida como um tipo de “comunidade civil”, esfera solidária na qual um certo tipo de comunidade universal desenvolve-se com códigos e narrativas próprios, expressos em idiomas democráticos, modelada por um conjunto de instituições particulares e de práticas interativas de cidadania. Nesse contexto, as forças sociais têm que descobrir estratégias para dialogar com as corporações, uma vez que a discussão sobre cidadania, que, como já dissemos, varia através do tempo e espaço e está calcada nas relações, deve incluir, hoje, inevitavelmente, o ativismo social das chamadas “empresas-cidadãs”.

Wacquant (2008), em artigo sobre prisões e administração da pobreza, nos Estados Unidos, apresenta dados que mostram a sociedade americana como 5 vezes mais punitiva que em 1975, com um aumento de 380 mil para 2 milhões de presos entre 1975 e 2000, além de 6,5 milhões sob supervisão da justiça. Descreve a reformulação do perímetro e funções do Estado, por meio de um dowsizing do welfare e upsizing de setores policiais, correcionais e jurídicos, apontando a ascensão do estado penal nos EUA como revelação e manifestação do reverso do projeto neoliberal de desregulamentação e degradação do setor público. Lembra, nesse contexto, que os três maiores empregadores nos EUA são hoje a Manpower Inc. (empresa de terceirização de mão-de-obra), o Wal-Mart, e o sistema prisional. Estabelece uma sombria semelhança entre a dinâmica atual e o encarceramento de pobres e imigrantes em meados do século XIX, para controlar populações divergentes e dependentes. Aborda, ainda, os serviços sociais “reformados”, levando-nos a uma percepção da RSE como uma possível face amigável da administração da pobreza.

Pereira (2007) desenvolve tese fundamentada nas propostas do professor Milton Santos, partindo da premissa de que a globalização só se realiza em lugares, espaços de globalização - que se definem pela presença conjunta de tecnosfera (mundo dos objetos) e psicosfera (mundo da ação), funcionando de modo unitário. As psicosferas são entendidas 
como "reinos das idéias, crenças, paixões e lugar da produção de sentido" (SANTOS, 1996 apud PEREIRA, 2007, p.204), reconhecíveis através do discurso das empresas, que evoca valores, símbolos, preceitos e relações que preenchem de significado seu agir no território, em relação ao qual as ações das empresas incidem como verticalidades disciplinadoras e/ou como produtoras de horizontalidades. Propõe, diante disso, uma cidadania híbrida, baseada na posse de direitos e pertencimento ao local como distinta da cidadania empresarial, que trata o espaço apenas pelo filtro econômico. Pereira (2007, p.158) trabalha com a noção de espaço banal, do professor Milton Santos, espaço rugoso, onde se vive o mundo e o lugar como condição para cidadania híbrida, marcada pela coexistência de agentes, independente de poder e posição. O “espaço cotidiano de todos, inclui contradições e conflitos e também vontade ou realidade da cooperação e do acordo” (SANTOS, 2000, p.20 apud PEREIRA, 2007, P.158). O trabalho, além de trazer uma contribuição original, partindo da leitura da responsabilidade social empresarial a partir do território, destaca-se pela construção de uma matriz com eventos marcantes para a evolução da questão da RS, ao longo do período 1930 - 2006, no Brasil, foco principal (e outros países), coleta sites, artigos, matérias jornalísticas e envolve premiações, certificações, balanço social, instituições criadas, políticas de instituições e declarações coletivas e “demais eventos”. (PEREIRA, 2007, p.182-188). Dessa matriz, destacamos, a seguir, pontos que consideramos especialmente relevantes para nossa pesquisa.

A autora observa que, até a década de 30, a filantropia empresarial caracterizava-se como "favor", com ações personalizadas, de cunho paternalista e refratárias à regulação estatal. Destacam-se, nesse momento, as vilas operárias, verdadeiras cidades construídas em torno das fábricas, marcadas por moralização, vigilância e pensamento higienista, com resistências, no plano das horizontalidades, da vida cotidiana. Com o crescimento urbano e expansão do capitalismo, houve processo de transição, que incluiu implantação de mentalidade técnico-científica, onde a elevação da produção e despertar do consumo passam a ser tônica empresarial. Essa nova racionalidade foi gradualmente implantada e consolidou-se, no período entre os anos 30 a 80, caracterizando-se pela regulação do Estado, direitos trabalhistas, pressão sindical e orientações da igreja. As atividades ligadas à empresa passam a alcançar toda população, e o empresário assume papel político, como representante da livre iniciativa contra o socialismo. A psicosfera passa a ser constituída pela tríade: ciência "neutra” - racionalismo; religião; e luta contra o comunismo. Sendo que, nesse contexto, o discurso das Igrejas católicas e protestantes forneceu os fundamentos teóricos e morais da RSE. A autora lembra a FIESP (Federação das Indústrias do Estado de São Paulo), que recebe 
apoio sistemático das instituições católicas desde a década de 30. Destacamos, também, a “Carta da Paz Social”, redigida por empresários na Conferência das Classes Produtoras, em 1946, que entendia o capital como meio de expansão econômica e bem estar coletivo, reconhecendo que "uma sólida paz social, fundada na ordem econômica há de resultar precipuamente de uma obra educativa, através da qual se consiga fraternizar os homens, fortalecendo neles os sentimentos de solidariedade e confiança”.(SESC, p.24 apud PEREIRA, 2007, P.23). Nesse período (entre 30 e 80), os recursos passam a ser alocados de forma “científica e despolitizada”, favorecendo as regiões com mais indústrias. É criado o "sistema S”, com serviços sociais gerenciados pelos empresários, visando a reorganização social como um todo, tendo o SENAC e SENAI como formadores de trabalhadores ideais, e o SESI e SESC, focados na contenção da ameaça comunista, uma vez que baixo nível de vida e educação eram considerados riscos para infiltração política, e esses serviços sociais também serviam como forma de amenizar o conflito com o movimento operário crescente. O papel do sistema S reconfigura-se pós o golpe de 1964, perdendo a função de controle (exercido diretamente pelo Estado) e atuando na disseminação de uma psicosfera que promove a nova fase da industrialização, baseada no capital externo, no lugar da substituição de importações. Destaca-se, aqui, um efeito colateral inesperado, o fato de que trabalhadores formados pelo SESI deram origem ao movimento sindical. A partir dos anos 80, a regulação começa a se deslocar do Estado para as empresas, com a multiplicação de fundações e institutos empresariais, que, sob a ótica da competitividade, coordenam o que deve ou não ser considerado interesse social. Um movimento que atualmente caminha no sentido de integrar ações ao negócio, como observamos na coleta de dados para esta pesquisa, com movimentos de terceirização e adaptação das ONGs à ótica da cadeia produtiva. Surge, nesse contexto, uma oposição entre assistencialismo, percebido de forma pejorativa, e as novas práticas RSE. A autora destaca que os eventos fundamentais para "alinhar" o pensamento e elaborar discurso empresarial surgiram em SP, elencando: o prêmio ECO da AMCHAM (Câmara de Comércio EUA-Brasil), PNBE - Pensamento Nacional das Bases Empresariais, GIFE Grupo de Institutos e Fundações Empresariais, FIDES - Fundação Instituto de Desenvolvimento Empresarial e Social, Fundação Abrinq e Instituto Ethos. Há uma multiplicação e difusão de normas, por meio de mídia e publicidade, trabalhos acadêmicos (sobretudo na área de gestão), políticas internacionais, prêmios e certificações, com indicação das práticas “de excelência”, como exemplo a ser seguido. As ações transitam, dessa forma, de um modelo ético de "contrato social” entre empresas e sociedade, nos anos 60, para um 
modelo político, com a criação de universidades privadas, estímulo à filantropia e recursos para ganhar legitimidade como centro de poder. A mídia articula e reverbera o discurso, que é legitimado pela academia, de onde parte também a crítica (na área de ciências sociais, sobretudo), que surge também nos sindicatos.

Diante desse discurso vertical, a autora foca a importância da horizontalidade, a partir da relação empresa-lugar. Apresenta o caso da ACESITA e a "construção" da cidade de Timóteo, do controle total da empresa, passando pela entrega da cidade à Prefeitura, até a privatização, detalhando as relações da comunidade com os diferentes momentos da indústria; entre vários outros casos empresariais. Conclui o estudo com a já citada proposta de cidadania híbrida, percebendo a lógica cotidiana como contraponto à lógica e temporalidade da empresa, imposta, verticalmente, no sentido de mobilizar a produção e o consumo.

Martins (2007) apresenta as estratégias de educação política e inseridas no programa neoliberal da Terceira Via, que foi sistematizado nos anos de 1990. Considera que tais esforços políticos visam uma nova hegemonia, que tem na ideologia da "responsabilidade social” sua principal referência, redefinindo noções históricas como participação, cidadania e solidariedade. Aponta a unificação de forças políticas em torno do programa neoliberal da Terceira Via, ultrapassando seu campo de origem (social-democracia) e estendendo-se aos liberais e aos ex-militantes socialistas e comunistas. No foco específico do estudo pelo autor, a partir da noção de intelectual orgânico de Gramsci, é destacada a participação dos intelectuais da ABRINQ (Associação nacional de produtores de brinquedos) no processo que gerou o Estatuto da Criança e do Adolescente, promulgado em 1990, e como essa experiência foi decisiva para a criação da Fundação Abrinq pelos Direitos da Criança e do Adolescente, no mesmo ano. Essa Fundação passou a fortalecer os esforços para a criação do Conselho Nacional de Defesa dos Direitos das Crianças e Adolescentes e de Conselhos estaduais e municipais, e para o funcionamento dos Conselhos Tutelares, tornando-se um sujeito político coletivo influente na mobilização social e na definição de políticas públicas para a população infanto-juvenil e desempenhando um papel decisivo na luta de classes no país. O autor ressalta, ainda, que os principais dirigentes dessas organizações (ABRINQ e Fundação Abrinq), Oded Grajew e Emerson Kapaz, compreendidos como intelectuais orgânicos, foram os mesmos que lideraram a criação e as articulações políticas do movimento de renovação das estratégias burguesas, dirigido pelo PNBE entre os anos de 1989 a 1995. Destaca, também, a configuração do Grupo de Institutos, Fundações e Empresas (GIFE), em 1995, e do Instituto Ethos, em 1998, como aparelhos formuladores da ideologia da RSE. Constitui-se, dessa 
forma, uma resposta positiva aos preceitos da Terceira Via, tendo o modelo empresarial de gestão como referência para o campo social, sob a perspectiva de uma cidadania reflexiva. $E$ ́ considerado cidadão reflexivo aquele dotado de espírito empreendedor, capacidade de iniciativa individual e um elevado senso de responsabilidade social, comprometido com a busca de soluções para a promoção do bem-comum. Nesse sentido, a sociedade civil seria um espaço de coesão e de ação social, em que prevaleceria o colaboracionismo e a responsabilidade social. O autor considera, portanto, que muito mais do que enunciar um tipo de ação, ou nomear uma determinada prática, a "responsabilidade social” se constituiu numa ideologia que reúne idéias, experiências e propostas, dentro de uma única concepção que visa organizar e impulsionar a classe burguesa para a ação coletiva.

Simionatto e Pfeifer (2006) apontam as mudanças que vêm ocorrendo nas relações entre Estado e sociedade civil (especialmente nas propostas articuladas em torno da responsabilidade social das empresas) como práticas que vêm contribuindo para a formação de consensos que fortalecem a hegemonia do capital na atualidade, mediante a redução do papel do Estado e o fortalecimento da esfera privada como setor de regulação social. Identificam que os serviços sociais oferecidos dessa forma fortalecem o campo do voluntariado, da solidariedade e das instituições do terceiro setor, mas precarizam o trabalho do Assistente Social, ao impactar a esfera da cidadania e outros valores e princípios que sustentam o projeto ético-político da profissão.

Lemos Junior (2007) analisa, na área do Direito, a mudança na concepção do direito de propriedade que, de início, era individual e, gradativamente, adquiriu um caráter social, tornando-se um direito-dever, com o surgimento do princípio da função social da propriedade, que se projeta, de forma dinamizada, na empresa. Delineia o caráter social e seus aspectos de sustentabilidade, institucionalidade e interdisciplinariedade, que devem revestir a empresa para integrá-la em uma cultura empresarial moderna, segundo os valores jurídicos e sociais previstos na Constituição Federal.

Lima (2008) aborda as dificuldades enfrentadas pelas comunidades carentes, ao atuarem dentro de uma lógica empresarial, obedecendo às pressões de mercado e dos seus stakeholders, e trabalhando com conceitos como clientes e relação custo/benefício, incompatíveis com o empowerment (que este é lento e segue seu ritmo próprio), evocado pelo seu discurso e pelo discurso das empresas. Considera, portanto, que, dentro desse contexto, os movimentos e organizações do Terceiro Setor desenvolveriam uma prática “não-política”, mas harmônica, integradora. Ressalta, ainda, que questões que dificilmente fariam parte do 
dia-a-dia das comunidades, como gestão estratégica, captação de recursos e marketing, unemse, muitas vezes, em um grau maior de importância, aos problemas relacionados à saúde, emprego, educação, violência, moradia e saneamento básico. Com referência a Montaño (2002 apud LIMA, 2008, p.210), destaca que a atividade de captação de recursos, que deveria ser funcional, passa a ser fundamento da "missão" das ONGs, para possibilitar a disputa por recursos externos, dos quais são dependentes.

Costa (2004) constata, no que tange às relações das entidades com a esfera da responsabilidade social corporativa, um maior distanciamento na interação e destinação de recursos empresariais a um número restrito de organizações, detentoras de maior capital político nas instituições representativas do terceiro setor. Fato que produz significativa desigualdade na prestação dos serviços, que tende a reforçar o papel hegemônico assumido por essas entidades, na definição das agendas políticas do setor.

Branco (2002) analisa a parceria entre a Natura Cosméticos e a Escola Estadual Matilde Maria Cremm, tomada como um caso representativo das relações de cidadania empresarial na década de 90. Para tanto, reflete sobre o papel do Estado, a partir do Plano Nacional de Educação e o Programa Escola em Parceria, da Secretaria de Educação do Estado de São Paulo; traça o percurso do Programa Natura/Escola, entre 1994 e 1998, do contato inicial até o final da parceria, e a criação do Programa Crer para Ver, em 1998, com uma nova proposta “sustentável”. Do relato observa-se a migração da relação rica, porém trabalhosa e conflituosa, com uma escola (que serviu como uma espécie de projeto piloto), para a formatação das ações de acordo com a prática empresarial, onde os recursos são gerados a partir da venda de produtos desenvolvidos por voluntários; os recursos e apoio técnico são destinados a projetos selecionados, culminando num fórum anual, com visibilidade e peças de comunicação impressas e eletrônicas, para disseminar as boas práticas. A autora reflete sobre tensões e situações conflituosas e desconfortáveis entre os representantes da empresa e professores, permeadas de tensão, com destaque para uma reunião, a portas fechadas, com diretor de alto escalão da empresa que, irritado com os constantes questionamentos, declarou, segundo trecho da ata, que para vender seus produtos comprava trinta segundos no horário nobre da televisão e não precisava do programa (Natura/Escola) para promover a empresa. Diante das tensões, a autora propõe transparência do que se ganha e do que se perde na relação, e deixa no ar a questão: para que negar o que todos sabem? Como lembra Bucci (2001), o marketing social ganha força se for “descoberto” pela mídia, colocação também destacada em entrevista com representante de empresa, na nossa pesquisa de Mestrado, ao 
afirmar que o marketing (infantil naquele caso) tem que ser sutil. A pesquisa de Branco (2002) mostra um quadro com pouco espaço para a negociação, no qual a empresa oferece pacote pronto que visa e considerando a autonomia como a finalidade do processo. O rompimento se dá por iniciativa da empresa, com uma série de cuidados para não passar uma imagem negativa de abandono. No caso, a empresa optou por desarticular programas desinteressantes politica e/ou economicamente e reduzir recursos, legitimando o rompimento por meio de uma avaliação técnica do percurso, e da publicação de material de comunicação bem cuidado graficamente, indicando para o parceiro (a escola) aspectos a serem considerados para continuar ações de forma autônoma, tirando proveito do período de “amparo”. Conclui, reforçando a necessidade de uma relação sem ingenuidades, e afirmando o risco de pautar as ações de parceria pelos interesses do setor produtivo.

Souza (2008) aborda o projeto "Amigos da Escola", implementado pela Rede Globo de Televisão, que é o maior projeto de RSE em educação, no Brasil, e incentiva o desenvolvimento de trabalho voluntário em escolas públicas. A análise associa tal ação a um conjunto de ações paliativas, para atenuar a crise provocada pelo desemprego estrutural, conjugado com a redução dos direitos sociais, que são repassados para a responsabilidade individual. Lembra, ainda, que tais atividades melhoram a imagem da empresa e de seus produtos, traduzindo-se em aumento de lucros. Conclui que o trabalho voluntário, ligado às ações de RSE, torna-se involuntário, forçado, ao ser associado à perspectiva de empregabilidade. Afirma, também, ainda que educação é a área majoritariamente escolhida para o desenvolvimento das ações de RSE, por propiciar o distanciamento da perspectiva assistencialista e se aproximar da sustentabilidade social. A pesquisa de campo, qualitativa, na forma de estudo de caso e de inspiração etnográfica, realizada em duas escolas públicas estaduais, revelou que a maior parte do trabalho voluntário é descontínuo e não contribui para o desenvolvimento das atividades na escola, havendo rejeição unânime em relação ao projeto dentre os entrevistados, que não percebem qualquer melhoria ou mudança na escola após ter sido cadastrada.

Gonçalves Júnior (2008) apresenta os principais resultados de um estudo de caso sobre o Programa Moto Perpétuo, da Fiat Automóveis S. A., que, durante cinco anos (1997-2001), voltou-se à doação de kits de materiais paradidáticos para milhares de escolas de diferentes regiões do Brasil. Apesar do amplo alcance do Programa, promovido como a maior parceria da iniciativa privada com o governo federal, dentro do programa “Acorda Brasil! Está na hora da Escola” do MEC, o autor destaca que não há, até o momento, nenhum estudo que 
demonstrasse os efeitos práticos dessa ação na melhoria da Educação. Mediante informações obtidas com a realização de entrevistas, e pelo levantamento e exame de diversos documentos, verificou que as correntes expectativas da eficiência de gestão e transferência de recursos em quantidade e qualidade suficientes não se concretizaram. Por outro lado, a iniciativa logrou êxito na construção de uma imagem positiva, em diversos setores da opinião pública. Apresenta, também, indícios de que a implementação do programa Moto Perpétuo esteve condicionada pelas relações público (Governo Federal) - privado (Fiat). O autor descreve o programa, que se originou na Itália, na primeira metade da década de 1990, patrocinado pela Fiat Automóveis S. A. e gerenciado pela empresa italiana de comunicação e marketing La Fabbrica. Na versão brasileira, contou com kits de materiais paradidáticos para Ensino Fundamental, sobre os temas da segurança e educação no trânsito, história dos transportes, cidades e meio ambiente. Para o Ensino Médio, foram adaptados, de versões italianas kits específicos para as áreas de Física, Biologia e Psicologia. Nos dois casos, as abordagens conduziam ao tema principal da mobilidade, com especial enfoque para o automóvel, sobretudo na versão destinada ao Ensino Médio. O autor chama a atenção para a chancela do MEC, dada a um material de baixa qualidade, para a relação reduzida com os professores e, especialmente, para a coincidência do mapa da indústria automobilística com as áreas de implantação do projeto. O programa atingiu, somados Ensino Fundamental e Médio, 6.398 escolas privadas e 10.918 escolas públicas, privilegiando os estados mais desenvolvidos do país. O processo foi marcado por atrasos na entrega dos kits, e por uma relação distante (telemarketing), deixando o uso do material a critério das escolas (algumas não chegaram a usar). Foram investidos aproximadamente R 10 milhões durante os cinco anos de existência do Moto Perpétuo, valores menores do que a publicidade “espontânea” obtida (medida a partir do tempo e espaço de exposição na mídia).

Valero e Camacho Reyes (2006) abordam o caso da floricultura colombiana, em grande parte localizada na savana de Bogotá, que mantém, há décadas, importante presença em mercados internacionais. Destacam que nexo com o processo de globalização tem feito avançar a aplicação das práticas de Responsabilidade Social Corporativa, como os códigos de conduta e selos de qualidade, mas, no que diz respeito à situação trabalhista, os avanços percebidos são limitados. Predomina um enfoque defensivo e do manejo de imagem, em um contexto com acentuada orientação à flexibilidade de custos, sem reconhecimento ao trabalhador, nem diálogo social. 
Alves (2007) estuda o Instituto Pró-Criança, percebido como uma reação dos empresários da indústria calçadista brasileira às denúncias de utilização de trabalho infantil na cadeia produtiva. Por meio da análise de conteúdo de entrevistas, e levantamento das declarações históricas registradas pela mídia, a autora detecta a força preponderante do interesse econômico associado ao mercado internacional e a fragilidade nacional na aplicação do dispositivo legal, relativo à utilização de trabalho infantil.

Carvalho (2006) aborda como idéia de sustentabilidade legítima a posição privilegiada ocupada pelo agronegócio da celulose, domínio que se desdobra em vantagens obtidas junto a instituições estatais, financeiras e de certificação. Observa-se, assim, uma redução dos espaços sociais da pequena produção, com a desestruturação e enfraquecimento de alternativas e saberes locais tradicionais, e o aumento do poder dos setores modernos da agroindústria em detrimento de outros projetos sócio-territoriais para a região.

Metzner (2004), ao avaliar trabalhadores de indústrias têxteis que se encontram em diferentes estágios de responsabilidade social empresarial, não encontra diferenças estatisticamente significativas entre os resultados das auto-avaliações de fadiga, e do índice de capacidade para o trabalho, entre os trabalhadores dos diferentes grupos estudados. Concluiu, portanto, que o fato de uma empresa ter diversos projetos na área de RSE, não implica, necessariamente, que as condições de trabalho sejam melhores ou que os seus trabalhadores tenham percepção de fadiga menor, ou maior capacidade para o trabalho, se comparada a outras empresas que não têm projetos desse tipo. Recomenda a inclusão do público interno nas ações de RSE, sobretudo, que os trabalhadores participem do estabelecimento desses programas. Sugere, ainda, que sejam feitos novos estudos sobre eventuais impactos na saúde e segurança dos trabalhadores.

Santana (2006) investiga as motivações empresariais para desenvolvimento de políticas de Responsabilidade Social. A partir de pesquisa realizada junto às empresas indicadas na publicação da Revista Exame, edição especial, Guia de Boa Cidadania Corporativa de 2003, como “modelo” de Responsabilidade Social, detectou que a motivação relaciona-se à preferência dos consumidores e fornecedores ao fato de tornar empregados mais orgulhosos da empresa e dedicados, à admiração da sociedade, ao aumento da chances de sustentabilidade e continuidade no tempo, e à possibilidade de maior competitividade e de maiores resultados financeiros. Razões que identificam as ações de RSE com o componente estratégico de planejamento em longo prazo. 
Araújo (2006) afirma que, a partir dos anos 90, sob o rótulo de "responsabilidade social”, foi incluído um conjunto de normas e práticas que se tornou condição para garantir lucratividade e sustentabilidade aos negócios. A hipótese que norteou essa pesquisa é de que tais mudanças não decorrem da pressão do consumidor ou do mercado, mas da interpretação que os gestores fazem do cenário e do que entendem ser a melhor conduta para seus negócios. A pesquisa envolveu análise dos documentos das principais Organizações Não Governamentais (ONGs) que atuam na área de responsabilidade social, entrevistas abertas com os gestores das áreas de responsabilidade social de empresas do comércio e setor bancário, e questionário a uma amostra selecionada, a partir do ranking da Revista Exame (2005). Entre outros achados, a autora constatou, nas entrevistas, que, a partir da história profissional e política dos gestores, eles são tendentes a se identificar com o conteúdo de responsabilidade social, ou seja, são comprometidos com a causa. Na análise dos questionários, observou que empresas aumentam investimentos em valores brutos na área social, quanto mais crescem receita líquida, resultado operacional, número de empregados e participação em ONGs, e quanto menor a exposição ao consumidor.

Domingos (2007) toma a responsabilidade social das organizações como ações concretas, expostas publicamente para anunciar uma nova postura dos dirigentes dos sistemas de produção, frente às contradições e às tensões provocadas pelo capitalismo. Com suporte da teoria dos interesses, de Habermas (1983), que envolve interesses técnicos, comunicativos e emancipatórios, destaca a importância de reconhecer as coações presentes na existência da humanidade e, por extensão, em qualquer sistema de produção por ela criado, inclusive aquele denominado, atualmente, responsabilidade social corporativa.

Fontenelle (2006), ao estudar o caso McInternet, aborda o que denomina "mercado da cidadania”, com um discurso do “Estado Mínimo” sendo paulatinamente substituído, nos discursos das agências multilaterais, pela defesa de um Estado que "coopere com o mercado" e a sociedade na promoção social. Para a autora, a "mercantilização da cidadania” ocorre na medida em que o social deixa de ser uma conquista e um direito para ser interpretado, dentro de uma lógica privada da filantropia, como forma de "gerir o social". Assim, mesmo que algumas das ações possam ser analisadas como propostas inovadoras e tecnicamente competentes, elas acabam por deslocar a questão da pobreza da arena pública para o campo indeterminado do mercado, onde passam a vigorar como "políticas de exceção", na formulação de Oliveira (2003a) e (2004). 
Oliveira (2006) estudou o universo de organizações economicamente solidárias, tendo como princípios norteadores da investigação a igualdade (justiça e equidade da distribuiçãodas grandezas obtidas) e a democracia (distribuição equânime de direitos e responsabilidades). Como um dos achados da pesquisa, observa que cooperar é um exercício que implica partilha de benefícios, e depende fundamentalmente da participação do outro enquanto sujeito atuante na construção desses benefícios, ponto-chave para pensarmos as ações de responsabilidade social das empresas. O autor alerta, também, para outro aspecto importante: cultura e economia solidária são fragmentos no interior de uma formação social adversa que carregam a ambigüidade de ser uma experiência cooperativa que depende de um mercado competitivo.

Goldstein (2007: 26-28) destaca que a questão ideológica é a que mais suscita polêmicas. Cita o trabalho de Garcia (2002), premiado pelo Instituto Ethos, que aponta uma disputa entre um projeto participativo e democrático e um projeto "neoliberal de redução do Estado”, com predomínio deste último nas ações empresariais. Semelhante a Almeida (2006). Alude também ao economista Gilberto Dupas, que considera louváveis as açõs filantrópicas, mas não capazes de tocar em questões estruturais geradoras da redução de empregos e concentração de renda. E, enfim, numa gradação para o “mais radical”, na qualificação usada pela autora, cita o autor uruguaio Carlos Montaño que destaca a despolitização da questão social promovida pelo terceiro setor e pelas ações empresariais que, ao calcarem-se na benemerência voluntária, eliminam a referência a direitos que toda população deveria ter por princípio. No fecho do tópico dedicado às controvérsias a respeito do tema, a autora afirma que ainda é cedo para tirar conclusões. Deixa a dúvida a respeito do fato do movimento constituir um paliativo pontual, que exclui mudanças efetivas, mas declara indiretamente sua posição, ao afirmar, logo após, “Ou pode ser que, sem ele, o mundo ficasse ainda pior”. Esse é o discurso do outro, trazido para dentro do texto e neutralizado, sob o rótulo da controvérsia e de possíveis radicalismos.

Paoli (2005), em estudo que integra projeto internacional, coordenado por Boaventura de Sousa Santos, faz uma análise do potencial democratizante e de ampliação da cidadania das ações empresariais. Para tanto, aborda as noções de cidadania e direitos, recorrendo a Hannah Arendt (1989), para quem essas noções possibilitam esclarecer a indissociabilidade entre bem público e bem comum, que implica a existência de um lugar de todos, além de decisões particularistas. 
Assim considerada, a noção de cidadania faz distinção entre o espaço de origem da ação (mundo empresarial) e o espaço da política e sociabilidade que ela cria, ou seja, a ampliação (ou anulação) da consciência e prática de direitos de cidadania para uma sociedade (PAOLI, 3002, p.376)

A autora ressalta que, no caso brasileiro, desde a década de 80 o conceito de cidadania ocupa um dos centros do pensamento social e político, sendo o parâmetro crítico de uma dupla transformação que envolveu a ampliação do exercício democrático e a desregulamentação público-estatal da economia de mercado. Nesse contexto, a circulação da palavra cidadania como linguagem conotativa de civilidade e integração social gerou, na opinião pública, uma demanda por responsabilidade, capturada através do apelo ao ativismo social voluntário. A palavra "solidariedade”, por sua vez, tornou-se, senso comum, a disposição altruísta de um indivíduo ou organização, um quase sinônimo de cidadania. Surge uma "sociedade civil" que, a princípio, por meio de movimentos sociais autônomos e politizados, e depois, de ONGs profissionalizadas, “deslocou o ativismo político pela cidadania e justiça social para o ativismo civil, voltado para a solidariedade social” (PAOLI, 2005, p.378), organizando a demanda por bens públicos, por meio de negociações pragmáticas e tecnicamente formuladas com os governos, dispensando base ampliada de participação popular.

Passa, então, a analisar a mobilização responsável empresarial, percebendo, de um lado, seu possível potencial inovador para combater a pobreza e melhorar condições de vida; e, de outro, "que esta mobilização oculta das políticas que aprofundam a exclusão social e desorientam politicamente a sociedade, além de ocupar vantajosamente, em termos de seus interesses particulares, o próprio espaço que abre como ação civil para um público” (PAOLI, 2005, p.379), sob a hipótese de que se trata de um contra-exemplo de ação democrática participativa. Primeiramente, a autora conecta as ações empresariais às propostas de Antony Giddens, recriadas no Brasil por Bresser Pereira (1999), de um público não estatal, que propõe um Estado gerencial, de investimento no capital humano, como forma de prevenção e não de benefícios compensatórios, deslocando a referência aos direitos fundamentados na solidariedade coletiva para solidária privada, responsável pela “execução de serviços sociais” por meio de critérios seletivos. Descreve, então, como a proposta de responsabilidade nos negócios, nesse contexto do encolhimento das garantias e direitos legais, implica a redefinição de sentido e modo de operar da filantropia, que se distancia do assistencialismo no sentido da noção de cidadania, com foco na reinserção social futura: infância, família e educação. Visa colaborar para sanar questões sociais e criar uma “consciência de cidadania” para o setor empresarial (materializada, sobretudo, no trabalho do Instituto Ethos, como veremos adiante). É um movimento proativo, que contrasta 
com o silêncio sobre fontes de produção da miséria e política econômica, e no qual ecoa o discurso neoliberal que preconiza a eficiência da iniciativa individual e privada contra a ineficiência burocrática do Estado e a politização dos conflitos sociais; argumentos de peso diante da burocratização de políticas e negligência de qualidade no investimento público. A autora aponta a Fundação Abrinq como inauguradora, em 1990, dessa nova filantropia “cidadã”, modelo que se associou ao crescimento do $3^{\circ}$ Setor, ocorrido sobretudo após a conferência Eco 1992 e corresponde, hoje, a um "nicho" de mercado, ocupado por consultorias.

Destacamos, a seguir, algumas das tensões, contradições e ambiguidades das práticas responsáveis das empresas levantadas por Paoli (2005). Lembra, primeiramente, que, além de beneficiarem a imagem da empresa e atraírem consumidores e empregados (o que nos parece previsível na ótica de um “capitalismo civilizado”), as ações sociais empresariais deslocam parcelas e territórios sociais para o campo dos seus interesses, transformando essas ações em “produtos”, cujo público é formado por acionistas e consumidores. Ainda na ótica financeira, observa que a maior parte das empresas não doa do bolso, pois são captadoras ou usam modelos de aliança com outras empresas e organismos, assim como trabalham com a participação ativista ampla de um voluntariado não remunerado. Tal colocação é corroborada por Gomes (2007, p.7), que ressalta que a doação é fração mínima dos custos que deveriam ser incorporados, além da isenção tributária (dedução de IR de até 2\% do lucro operacional para OSCIPs lei 9.970 23/mar/1999). Por outro lado, há poucas informações sobre as mudanças operadas nas realidades sociais, que geralmente se referem a números da população assistida, e incrementos na cadeia de produção e consumo, numa noção de impacto mais ligada a retorno (mercantil) dos recursos e percepção dos públicos de interesse (consumidores, empregados e acionistas). A autora exemplifica essa questão, citando a pesquisa de Falconer (2000), que constatou a baixa capacidade transformadora do selo "Empresa amiga da criança" na indústria calçadista da cidade de Franca-SP, iniciativa que se mostrou mais efetiva para as empresas, que reconquistaram a credibilidade e possibilidade de comercialização.

Paoli (2005, p. 404-405) aborda brevemente a trajetória das práticas participativas, ligadas aos “novos movimentos sociais” das décadas de 70 e 80, que abriram espaço para a forte inclusão das palavras “cidadania” e “direitos”, na nova Constituição e nos fóruns públicos de debate. Movimentação essa que, por vias indiretas (associadas pela autora à desmobilização social e política, gerada pelos efeitos do modelo neoliberal), viu a aspiração de autonomia pública dirigida ao Estado tomar a forma de organizações públicas não estatais, com a diluição de 
linguagem do conflito. Crescimento e especialização das ONGs, como mediadoras ao poder público, articularam-se com a queda da disposição do Estado de manter sua capacidade de regulação social e compromissos públicos, em meados dos 90, fazendo com que as organizações empresariais de investimento social se institucionalizassem como $3^{\circ}$ Setor. Dessa forma, a "filantropia empresarial cidadã” liga-se à "substituição da idéia de deliberação participativa ampliada sobre os bens públicos pela noção de gestão eficaz de recursos sociais, cuja distribuição é decidida aleatória e privadamente” (PAOLI, 2005, p.404), associada ao silêncio sobre motivações mercantis (algo que muda de figura nos dias atuais, com a proposta de trazer a responsabilidade social para o cerne dos negócios da empresa).

A questão do descompasso entre o que se diz e o que se faz, por sua vez, não é considerado pela autora o problema principal, uma vez que uma auditoria de avaliação de resultados poderia resolver tecnicamente essa questão. Acrescentamos, aqui, que o descompasso entre o dito e o realizado faz parte da autocrítica empresarial. Em sintonia com a colocação de Paoli (2005), nos parece que a contradição não ocorre entre o que as empresas divulgam e o que elas fazem, mas entre as ações empresariais (regidas pela ótica de mercado) e ações ampliadas de participação social. Soma-se a isso o fato de as ações serem apresentadas como prova da ineficiência e arcaísmo das políticas públicas estatais, o que obscurece a renovação continuada de parte de um serviço público comprometido, que tenta agora, ser alternativa política ao desmantelamento do setor público, por sua retomada eficiente e renovada.

Para colocar em xeque essa pretensa superioridade, Paoli (2005, p.410-411) levanta experiências dos trabalhadores, como contraponto nas formas de lidar com a questão do desemprego no capitalismo flexível, citando o Centro de Solidariedade do Trabalhador da Força Sindical, e a Central de Emprego e Renda da CUT, em operação conjunta com a Prefeitura da cidade de Santo André-SP, que caminha no sentido de um "sistema público de emprego", centrado no direito dos trabalhadores; assim como com cooperativas, incubadoras, microcrédito e bancos do povo. Para concluir, a autora pondera que ação social e welfares privados nas empresas podem ser consideradas experiências sociais e humanitárias relevantes, diante das carências brasileiras, e que seriam recebidas sem restrições em uma sociedade apoiada em garantias reais de direitos universalizados. Ressalta, contudo, que para se tornar politicamente relevante, como experiência de formação de atores investidos de responsabilidade social, o movimento das empresas precisaria reconhecer, na sua própria constituição, “a projeção da sombra da disputa pelo poder de enunciar o espaço público e a cidadania sob o cenário da desregulamentação estatal” (PAOLI, 2005, p.414). Esse 
reconhecimento parece constituir-se numa impossibilidade, uma vez que a negação dessa disputa é constituinte do discurso empresarial, como analisaremos a seguir. Para Paoli (2005), sob o prisma da participação, a “regeneração da classe dominante” é uma proposta conservadora, pois, embora sensível às desigualdades, preserva hierarquias desiguais que reproduzem a desigualdade, criando cidadãos de segunda e terceira classes, dependentes da caridade da ação externa privada. Observamos, nas análises, que o discurso das empresas (e também de pesquisadores) incorpora essa crítica, ao propor o “empoderamento” de indivíduos e comunidades. A busca de autonomia esbarra, contudo, na não alteração das condições coletivas que permitiriam exercê-la. Gostaríamos, também, de destacar que, pela abrangência e pertinência das questões levantadas, a leitura do artigo de Paoli (2005) fez com que nosso trabalho começasse, de fato, a ganhar forma. A idéia de uma cidadania “enredada” pelas empresas nos levou a avançar no entendimento das propostas empresariais que absorvem e reelaboram as críticas, de forma similar ao que ocorreu com a incorporação mercadológica de elementos da contracultura dos anos 60, descrita no livro The conquest of the cool de Thomas Frank (1997). Como lembra esse autor, os homens de terno cinza não eram monolíticos, como pensavam os opositores da época, mas sensíveis aos questionamentos, embora submetidos a uma lógica que convertia esses questionamentos em objetos de consumo. Acreditamos poder dizer o mesmo de muitos dos envolvidos com as ações de responsabilidade social. 


\section{CAPÍTULO 2 - NOSSOS REFERENCIAIS}

Levando em conta a proposta de Bosi (2003, p.50) segundo a qual os dois grandes níveis para definir o método de um trabalho científico são a orientação geral da pesquisa e o procedimento, ou sua técnica particular, neste capítulo nos propomos a oferecer o grupo de referências que constitui a “tendência teórica” que guiou o trabalho, desde a aproximação inicial com o objeto, até a interpretação final dos dados.

Nosso objeto de estudo, o espaço discursivo da responsabilidade social empresarial, é marcado pela convergência de diferentes referenciais teóricos, dos quais destacamos os três aspectos, que surgem entrelaçados, e que consideramos especialmente relevantes para discutilo, buscando, em cada um deles, autores cujas proposições e teorias nos oferecessem elementos capazes de ampliar o entendimento do objeto e do tema estudados.

O primeiro aspecto, uma vez que se trata de um discurso sobre o social, refere-se à sociedade e às esferas pública e privada, com foco nas questões relativas à cidadania e à democracia. Para tratar dessas questões, trabalhamos com textos de Hannah Arendt, trazendo a discussão para o contemporâneo e a realidade brasileira com textos de Florestan Fernandes, Milton Santos, Boaventura de Sousa Santos, Evelina Dagnino, entre outros.

O segundo refere-se à mídia, ao marketing e publicidade e ao consumo, tanto do ponto de vista da comunicação com o mercado, quanto da crítica ao consumo e ao simulacro da sociedade atual. Essas questões serão discutidas a partir dos textos de Guy Debord, Marilena Chauí e Nestor Garcia Canclini.

O terceiro refere-se ao mundo do trabalho e, num sentido mais amplo, ao momento atual do capitalismo, no qual foram trabalhados, sobretudo, textos de Richard Sennett.

Como lembra Bosi (2003, p.50), a escolha desses referenciais delimita um caminho, uma visão preliminar do objeto a ser estudado, uma vez que várias outras referências possíveis foram deixadas de lado. Nesse sentido, tendo em vista a escolha de um enfoque dialético, deixamos de lado, a partir da orientação da banca de qualificação, trabalho de Michel Foucault. Não passamos, contudo, imunes à leitura de seus textos, cujas teorias parecem ressoar na análise do espaço discursivo das empresas (como referência metodológica, que será apresentada adiante, o autor retorna como um dos referenciais da análise de discurso de linha francesa). Não pareceu prudente, mantê-lo como referência fundamental num trabalho que pretendia privilegiar autores que trabalham numa perspectiva dialética e não apenas a determinação, como Foucault faz de maneira irretocável, mas também 
movimentos que negam essa determinação. Como lembrou o professor Paulo de Salles Oliveira, na banca de qualificação, o real sempre produz determinações, mas, ao mesmo tempo, recusas e contradições, elementos fundantes em qualquer interpretação dialética.

\section{Vita activa}

Hannah Arendt (2004, p.15-20) utiliza a expressão vita activa para compreender três atividades humanas fundamentais: o labor, atividade relacionada ao processo biológico de sobrevivência do indivíduo e da espécie, e cuja condição humana é a própria vida; o trabalho, que corresponde à produção de um mundo “artificial”, cuja condição humana é a mundanidade e o produto, o artefato humano, e empresta certa permanência e durabilidade à vida mortal e ao caráter efêmero do tempo; e a ação, única atividade exercida (que se exerce) diretamente entre os homens, sem mediação das coisas ou matéria, cuja condição humana é a pluralidade e, na medida em que se empenha em fundar e preservar corpos políticos, cria condição para a lembrança e para a história. A ação relaciona-se à condição humana de natalidade, como capacidade de criar algo novo, de agir. A condição humana e a objetividade do mundo complementam-se reciprocamente. A autora ressalta, contudo, a distinção entre condição humana e natureza humana, o que somos, pois as condições da existência humana a própria vida, a natalidade e a mortalidade, mundanidade, pluralidade e o planeta Terra - não dão conta de explicar o que somos, jamais nos condicionam de modo absoluto.

Arendt (2004, 20-26) utiliza o termo numa acepção distinta da visão tradicional, que desde os gregos percebe a ação como subordinada à contemplação (theoria), colocando em xeque a hierarquia proposta, sob a premissa de que a ênfase na contemplação obscureceu as características da vita activa e que esta não é superior nem inferior à vita contemplativa.

Para ilustrar os dois princípios, de ação e de pensamento, Arendt (2004, 26-30) usa a diferença entre imortalidade e eternidade. A luta pela imortalidade, que é o modo de vida do cidadão (bios politikos), relaciona-se à sua capacidade de produzir obras, feitos e palavras que possam pertencer à eternidade. A experiência do eterno, por sua vez, não corresponde a qualquer tipo de atividade, nem mesmo o pensamento (bios theoretikos). A queda do Império romano e a promoção do evangelho cristão decretaram a vitória da idéia de eternidade, tornando vita activa e bios politikos servos da contemplação; situação que, segundo a autora, não foi alterada na era moderna.

A autora (2004, p.31-37) prossegue dizendo que as três atividades componentes da vita activa são condicionadas pelo fato dos homens viverem juntos, mas a ação é a única que 
não pode ser imaginada fora da sociedade dos homens, uma relação que justifica a tradução do zoon politikon como animal socialis, que aparece em Sêneca e até Tomás de Aquino e foi aceita como consagrada. Ressalta, contudo, que são conceitos distintos, pois a palavra “social” é de origem romana e não tem equivalente em grego, cujo termo societas significa aliança para fins específicos. Só com o conceito romano de societas generis humani “sociedade da espécie humana” é que o termo social começa a adquirir o sentido geral de condição humana fundamental. Para os gregos, essa era uma condição próxima dos animais, imposta pelas necessidades da vida biológica, centrada na casa (oikia) e família, e oposta à organização política. Para Aristóteles, só duas atividades constituíam o bios politikos: a ação (práxis) e o discurso (lexis), das quais surge a esfera dos negócios humanos, que exclui tudo que seja apenas necessário ou útil. As ações políticas incluem o ato de encontrar as palavras no momento certo, independente da informação ou comunicação que transmitem e, na experiência da polis, a ênfase passou da ação para o discurso. Ser político, viver na polis, significava tudo decidir por palavras e persuasão.

Arendt (2004, p.37-47) lembra, ainda, que a ascensão da esfera social é um fenômeno que coincidiu com o surgimento da era moderna e encontrou sua forma política no estado nacional. Por não ser pública nem privada, e de certa forma sobrepor-se a elas, borrou a divisão entre essas esferas, dificultando a distinção entre atividades pertinentes a um mundo comum e atividades pertinentes à manutenção da vida. Para Arendt, a linha divisória é difusa, por percebermos os corpos de povos e comunidades políticas como "uma família cujos negócios diários devem ser atendidos por uma administração doméstica geral e gigantesca”. (p37) Nesse sentido, o termo “economia política” seria, para os antigos, uma contradição, pois o que fosse "econômico", relacionado com a vida individual e sobrevivência da espécie, não era assunto político, mas doméstico por definição. A autora ressalta não negar que o estado nacional e sua sociedade tenham surgido no feudalismo, onde família e casa tinham muito mais importância do que entre os antigos, mas destaca que a casa real e os senhores feudais organizavam-se como pares e não como uma família. Historicamente, portanto, é provável que o surgimento da cidade-estado e esfera pública tenha ocorrido em detrimento da esfera privada da família. Mas a antiga santidade do lar, maior na Grécia clássica do que na Roma antiga jamais foi inteiramente esquecida. O respeito pelos limites da casa não se relacionava, no entanto, à propriedade como a entendemos, mas pelo fato de que ser dono de uma casa significava ter um lugar no mundo e, portanto, poder participar dos negócios mundanos. Chama a atenção, nesse aspecto, o fato de que cidadãos eram obrigados por lei a dividir a 
colheita, mas tinham propriedade absoluta de seu pedaço de terra, pois como destaca a autora, eram dois tipos de propriedade completamente diferentes.

A esfera familiar era movida por necessidades e carências, e unida pela própria vida, cuja manutenção era obtida individualmente pelo labor do homem no suprimento de alimentos e, pelo labor da mulher, no parto. A esfera da polis, por sua vez, era a esfera da liberdade, sendo que a superação das necessidades na vida em família era condição para alcançar a liberdade da polis. A força e violência, atos pré-políticos, eram justificadas na esfera privada, do lar, por serem os únicos meios de vencer a necessidade e alcançar a liberdade. Um homem livre e pobre preferia a insegurança de um mercado de trabalho, a trabalho regular garantido (considerado servidão), que restringia a liberdade de fazer o que quisesse a cada dia. Trabalho árduo e penoso era preferível à vida tranqüila de alguns escravos domésticos.

A autora afirma que a família era o centro da mais severa desigualdade, enquanto a polis só reconhecia iguais, que não obedeciam nem mandavam. Essa igualdade da esfera política tem, contudo, pouco a ver com o conceito contemporâneo de igualdade, pois significava estar entre pares e supunha desiguais (em maior número) para sustentá-la, não se relacionando com a justiça como nos tempos modernos. Era a própria essência da liberdade, que significava estar isento da desigualdade presente no ato de comandar, e mover-se numa esfera sem governo nem governados.

No mundo moderno, a política é apenas uma função da sociedade, sendo ação, discurso e pensamento superestruturas assentadas no interesse social.

\section{A promoção do social}

De acordo com Arendt (2004, p.47-59) para os antigos a esfera privada referia-se a se privar de alguma coisa, até mesmo das mais altas capacidades do homem. O enriquecimento dessa esfera, com o moderno individualismo, transfigurou essa visão, fazendo com que ela passasse a ser percebida não como o oposto da esfera política, mas da social - com a qual tem laços autênticos e mais estreitos. A autora lembra que o primeiro explorador e teorista da intimidade foi Rousseau que, com os românticos, promoveu uma rebelião do íntimo contra o social, não pelo princípio de igualdade, mas pelo fato de a sociedade exigir comportamento similar ao de uma grande família. Na sociedade, a força do interesse comum replicado acaba dispensando o homem que o representa, resultando no fenômeno do conformismo, característico da última fase dessa evolução moderna. 
A sociedade passa a excluir a possibilidade de ação - algo antes exclusivo do lar doméstico - em todos os níveis, inicialmente pela imposição de regras de comportamento, até chegar, após séculos de desenvolvimento, à sociedade de massas, na qual a esfera do social atingiu o ponto que abrange e controla, igualmente e com igual força, todos os membros de determinada comunidade (ARENDT, 2004, p.50).

A igualdade moderna é, portanto, baseada no conformismo, com a ação sendo substituída pelo comportamento como principal forma de relação humana. O conformismo, suposição de que homens se comportam ao invés de agir em relação uns aos outros, está na base da moderna ciência da economia, que nasceu com a sociedade e tornou-se a ciência social por excelência, junto com seu principal instrumento, a estatística. Arendt (2004) lembra que, por trabalhar com grandes números e flutuações, a estatística descarta feitos e eventos, de forma que quanto maior a população tem-se maior validade e menos “desvios”, aumentando a probabilidade de que o social ocupe o lugar do político na constituição da esfera pública.

A autora ressalta que o moderno tratamento matemático da realidade, com grandes números justificando o conformismo, o behaviorismo e o automatismo nos negócios humanos carrega a "triste verdade” (referindo-se especialmente às "leis” behavioristas) de que quanto mais pessoas existem, maior é a possibilidade de que se comportem e menor de que tolerem o não-comportamento. Com o declínio da flutuação, feitos não conseguem conter a maré do comportamento e eventos perdem importância. Arendt (2004, p.53) afirma, portanto, que a uniformidade estatística, portanto, o ideal político, não mais secreto, de uma sociedade que, submersa na rotina do cotidiano, aceita pacificamente a concepção científica relativa à sua própria existência.

A substituição da ação pelo comportamento, evidenciada pelas "ciências do comportamento”, vai além dos padrões econômicos e pretende reduzir o homem ao nível de um animal de comportamento condicionado. Indicam o estágio final da vitória da sociedade com a “conduta social”, promovida a modelo de todas as áreas da vida. O processo vital passa a ser tratado em escala mundial na esfera pública, fato evidenciado pela conversão de todas as comunidades do mundo em assalariados e operários voltados para o labor. Mesmo que não sejam operários de fato, consideram o que fazem primordialmente como modo de garantir a própria subsistência e a vida de suas famílias. Contra esse crescimento da esfera social, que devora as demais, a intimidade, por um lado, e a política, por outro, se mostram impotentes.

O antes obscuro labor (ligado entre outras coisas às dores do parto) adquiriu uma excelência anônima, mas a capacidade de discurso e ação perdeu muito de sua antiga qualidade, desde 
que a esfera social ascendente os baniu para a esfera do íntimo e do privado. A crítica a esse fato repousa, contudo, numa possível mudança psicológica do ser humano - padrões de comportamento - e não numa mudança do mundo que habitamos. Essa é uma interpretação psicológica, que parece duvidosa para a autora, uma vez que nenhuma atividade pode se tornar excelente, se o mundo não proporciona espaço para que seja desenvolvida. "Nem a educação, nem a engenhosidade, nem o talento podem substituir os elementos constitutivos da esfera pública, que fazem dela o local adequado para a excelência humana”. (ARENDT, 2004: 59)

\section{A esfera pública: o comum e a esfera privada: a propriedade}

Termo "público" indica dois fenômenos correlatos, mas não idênticos. Primeiramente, significa que tudo que vem a público pode ser visto e ouvido por todos e tem a maior divulgação possível. A percepção da realidade depende da aparência, e, portanto, da existência de uma esfera pública na qual as coisas possam emergir da treva da existência resguardada, da vida privada e íntima, cuja meia-luz deriva da luz da esfera pública. A autora ressalta, contudo, que há coisas que não podem suportar essa luz. O amor, por exemplo, falsifica-se, quando deslocado do espaço privado aparecendo, por exemplo, no discurso de um político, traduzido como transformação ou salvação do mundo. O amante da bondade, por sua vez, é um homem isolado, pois convive com os outros, mas deve ocultar-se deles e nem permitir a si mesmo ver o que está fazendo, pois a bondade que sai do esconderijo e assume papel público torna-se corrupta. Algo que remete ao significado elementar de que há coisas que devem ser ocultadas e outras que necessitam ser expostas em público, para adquirir alguma forma de existência.

O segundo significado é o próprio mundo, enquanto artefato humano; o mundo feito pelo homem é público, na medida em que é comum a todos nós e diferente do lugar que nos cabe dentro dele. Em contraste com a “objetividade”, cuja base única é o dinheiro como denominador comum para satisfação de todas as necessidades, a autora lembra que

\footnotetext{
Somente quando as coisas podem ser vistas por muitas pessoas, numa variedade de aspectos, sem mudar de identidade, de sorte que os que estão à sua volta sabem que veem o mesmo na mais completa diversidade, pode a realidade do mundo manifestar-se de maneira real e fidedigna. (ARENDT, 2004: 67)
}

Nas condições de um mundo comum, a realidade não é resultante da natureza comum dos homens, mas do interesse num mesmo objeto. Por outro lado, quando não se pode discernir a natureza do objeto, o mundo comum é destruído, e os homens tornam-se prisioneiros da subjetividade das próprias existências singulares, que continuam singulares 
mesmo multiplicadas inúmeras vezes, num mundo comum visto por um único aspecto e uma única perspectiva.

Desenvolvimento do lar e da família, deve-se ao senso político do povo romano, que jamais sacrificou o privado em benefício do público, por compreender que eles só subsistem em coexistência. A esfera privada oferecia espaço protegido, por exemplo, para os escravos, que encontravam espaço para acumulação de riqueza e devoção às artes e ciências. Havia, contudo, a clara consciência de que a vida restrita do lar era privada de algo essencial, consciência que perdeu força e quase se extinguiu com o cristianismo, uma vez que a moralidade cristã sempre pregou que cada um cuidasse de seus afazeres, e que a atividade política constituia-se em um ônus aceito em prol do bem-estar dos demais.

Para a autora, isso parece indicar que o estágio final do desaparecimento da esfera pública seja acompanhado pela ameaça de igual liquidação da privada. Nesse sentido, lembra que, na discussão sobre a propriedade privada ser desejável ou não, a palavra privada, em conexão com propriedade, perde caráter privativo e grande parte de sua oposição à esfera pública.

Arendt apresenta, então, outra distinção entre propriedade e riqueza, importante para discutirmos as ações de responsabilidade social empresarial. Lembra que a propriedade privada tinha caráter sagrado para todas as civilizações, antes da era moderna e, por outro lado, a riqueza do indivíduo ou publicamente distribuída não era sagrada. Propriedade significava seu lugar em determinada parte do mundo e poder pertencer ao corpo político. A riqueza não substituía essa propriedade, e a pobreza não fazia com que o chefe da família perdesse seu lugar no mundo. A esfera privada era o complemento da esfera pública. Ser político significava atingir a mais alta existência, mas não possuir lugar próprio e privado significava deixar de ser humano. Origem diferente e mais recente tem a riqueza privada como condição para entrar na esfera pública, não pelo empenho em acumulá-la, mas por representar liberdade em relação à subsistência. A moderna evolução das riquezas por si, independente da ocupação dos proprietários, as converteu em qualificação para a cidadania, mas cidadania como privilégio, desvinculado de atividades políticas específicas.

Arendt conclui, dessa forma, que a defesa moderna da propriedade privada como riqueza particular não pode vinculá-la à tradição de defesa da esfera pública, uma vez que o enorme acúmulo atual teve sua origem na expropriação (esbulho das classes camponesas, efeito quase acidental da expropriação de bens monásticos e da Igreja, após a Reforma) e jamais demonstrou grande consideração com a propriedade privada. O dito_de Proudhon - $a$ propriedade é um roubo - tem sólida base de verdade nas origens do moderno capitalismo. 
Aponta, ainda, que, a longo prazo, a apropriação individual de riqueza não deve tratar com maior respeito a propriedade privada, que pode apenas estorvar a "produtividade” social geradora de acumulação de riqueza. Observamos que a lógica do "acesso"7, com a tendência desenhada atualmente de uma desmaterialização da economia, pode ser entendida como mais um estágio da expropriação. A abolição dos bens materiais seria uma forma de desobstruir de vez o livre fluxo de capitais, que não preza a propriedade privada, mas sim a acumulação de riquezas. Tratar-se-ia, portanto, do esvaziamento das formas de propriedade - individual ou coletiva - capazes de garantir lugar no mundo. Nesse sentido, o esvaziamento das profissões também tira esse lugar no mundo. Os únicos que se sentem bem nessas condições são os muito ricos, que podem - embora escravos do financeiro - comprar moradas provisórias, ou os muito jovens, que podem exercer diversas capacitações e obter posições profissionais sempre provisórias, como indicam as considerações de Richard Sennett, que abordaremos adiante.

Arendt não vê, portanto, onde se baseia o otimismo dos economistas liberais que afirmam que a apropriação individual de riqueza será suficiente para proteger as liberdades individuais, lembrando que, numa sociedade de detentores de empregos (que também se corroeram), essas liberdades só estão seguras, se garantidas pelo Estado. A riqueza pode durar por gerações, mas é algo destinado ao uso e consumo e não pode, portanto, tornar-se comum. O que se tornou comum, com o tempo, foi o governo, nomeado para proteger os proprietários privados uns dos outros na competição por mais riqueza. Nesse sentido, a autora afirma que a mais revolucionária contribuição moderna ao conceito de propriedade foi situá-la não no mundo, mas no próprio homem, na posse de um corpo e na indiscutível propriedade da sua força, chamada por Marx de "força de trabalho". A autora ainda atenta para o fato de que a intimidade não é substituto seguro para a propriedade privada no sentido de lugar tangível, possuído na terra por uma pessoa. A eliminação da necessidade, correlata à vida, não estabelece automaticamente a liberdade, mas dificulta a percepção da diferença entre ser livre e ser forçado pela necessidade

\section{Labor, trabalho e ação}

Arendt (2004, p.89-148) aborda as distinções entre os componentes da victa ativa, delineando os percursos atuais e tendências possíveis para o mundo construído pelos homens. Ao apostar na ação como origem potencial de desdobramentos improváveis a autora oferece

\footnotetext{
7 Jeremy Rifkin, autor do livro a Era do acesso (2004), entre outros, aponta para a substituição dos produtos materiais a serviços e produtos intangíveis por meio do acesso a bancos de dados e redes de relacionamento.
} 
referencial teórico que permite olhar para nosso objeto de estudo com uma perspectiva dialética, que trabalha a determinação, mas não se esgota nela, admitindo movimentos de recusa e contradição.

Retomando a distinção entre trabalho e labor, a autora_destaca que o labor possui uma “produtividade” própria, que não reside em seus produtos, mas na "força” humana, que pode ser utilizada para a reprodução de mais de um processo vital, mas nunca "produz” outra coisa senão “vida” e, mediante violência pode ser canalizada, de forma que o labor de alguns é bastante para a vida de todos. Isso nos possibilita distinguir bens de consumo (ligados ao labor), objetos de uso (ligados ao trabalho, que precisa de instrumentos) e "produtos” da ação e do discurso (ligados à ação).

Outra distinção importante é efetuada entre apropriação e propriedade, lembrando que, numa sociedade de proprietários, é o mundo que está no centro das preocupações, o que não ocorre quando o interesse passa a ser o crescimento da riqueza e o processo de acumulação em si. A autora observa que, na trajetória contemporânea, os ideais do homo faber (ligado ao trabalho), tais como permanência, durabilidade, estabilidade, foram sacrificados em benefício da abundância, que é o ideal do animal laborans (ligado ao labor). Tal abundância requer uma sociedade de consumidores para ser escoada, uma vez que, assim como aponta Debord, a autora percebe labor e consumo como estágios de um mesmo processo imposto ao homem pelas necessidades da vida. Dizer sociedade de operários equivale, portanto, a dizer sociedade de consumidores, uma vez que as horas vagas do animal laborans são gastas no consumo. Toda economia torna-se, dessa forma, economia do desperdício, onde as coisas devem ser devoradas e abandonadas rapidamente, para que o processo não chegue a um fim repentino e catastrófico. Porque, como anuncia uma marca de cartão de crédito, a vida é agora.

Arendt (2004, p.149-187) volta também o olhar para as transformações no processo de produção, dialogando com as colocações de Richard Sennett, que abordaremos a seguir. Lembra que pelo fato de o homo faber (de facere, fazer) trabalhar sobre os materiais, um elemento de violação e violência está sempre presente em todo processo de fabricação. O homo faber, criador do artifício humano, sempre foi, portanto, um destruidor da natureza. Além disso, o modelo, que é a idéia do produto, permanece após a fabricação, que tem começo e fim bem definidos. Já no processo vital de labor permanente não cabem perguntas de meios e fins. O que preside o labor é o movimento do processo e o ritmo que impõe aos operários. O caráter natural de que se alimenta faz com que o processo de avanço tecnológico se converta numa evolução biológica da humanidade, na qual as características inatas do 
organismo são transplantadas, de maneira crescente, para o ambiente do homem. Podemos dizer, nesse sentido, que a idéia de cadeia produtiva, com seu ciclo de sustentabilidade aproxima-se, portanto, do labor.

Outro aspecto levantado pela autora é o fato de que a esfera pública do homo faber é o mercado de trocas, onde pode exibir seus produtos e receber a estima que merece. Trata-se, contudo, de uma relação mediada pelas coisas (produtos) e regida por sua utilidade. O artesão, este precisa de isolamento para estar a sós com a idéia para produzir e, embora existam as figuras dos mestres e aprendizes, estes são etapas provisórias, uma vez que nada pode ser mais alheio e destrutivo ao artesanato do que o trabalho em equipe.

Essas considerações ensejam a observação da autora de que o valor, termo muito presente nos dados levantados em nossa pesquisa, é a idéia da proporção entre a posse de uma coisa e a posse de outra no conceito do homem. Sendo que as coisas, idéias ou ideais morais só se tornam valores em sua relação social. A entrada do dinheiro como denominador comum, no lugar de regras, medidas e padrões “absolutos”, diluiu a percepção do valor, uma vez que o dinheiro não possui existência independente e objetiva, que possa transcender o uso e sobreviver à manipulação como os instrumentos de medida em relação às coisas e homens que as manuseiam. Arendt afirma, nesse âmbito, que a medida das coisas não precisa ser nem a compulsiva necessidade/ consumo da vida biológica e do labor, nem o "instrumentalismo" utilitário da fabricação e do uso.

\section{Ação e Discurso}

Interessam-nos, também, as considerações da autora (2004, p.188-259) sobre ação e discurso, entendidos por ela como os modos como os seres humanos se manifestam uns com os outros enquanto homens; modos intrinsecamente ligados, uma vez que, sem o discurso, a ação deixaria de ser ação, pois não haveria ator e o ator; agente do ato, só é possível se for, ao mesmo tempo, o autor das palavras.

A ação ocorre, por sua vez, numa teia de relações construída pelos interesses humanos, percebidos como algo que inter-essa, que está entre as pessoas e que, portanto, as relaciona e interliga. É em virtude dessa teia, com inúmeras vontades e intenções conflitantes, que a ação quase sempre não atinge seu objetivo, mas é também graças a esse meio, onde somente a ação é real, que ela "produz” histórias, intencionalmente ou não, assim como a fabricação produz coisas tangíveis. A ação é, portanto, a única atividade que constitui o lado público do mundo, que nem sempre existe, mas sem o qual nenhum homem pode viver permanentemente. 
O poder, por sua vez, só é efetivado, quando palavra e ato não se divorciam, e é sempre potencial. A força, que é a qualidade natural de um indivíduo isolado, converte-se em poder entre os homens, quando eles agem juntos. Por isso Arendt afirma que, enquanto o trabalho é apolítico, mas liga-se, por meio dos produtos e do desempenho, ao mundo da aparência, o labor é anti-político, pois nele o homem está só com seu corpo e a necessidade de manter-se vivo. A igualdade política (igualdade de desiguais) é, portanto, o oposto da igualdade de todos perante a morte (biológica). $\mathrm{O}$ que os textos analisados parecem indicar é que o tipo de igualdade proposta pelas ações das empresas aproxima-se do segundo caso, ao vincular a igualdade à inserção no fluxo produtivo e a um "potencial” radicado no indivíduo isolado. Potencial esse, que, como nos indica Arendt, não se converte em poder com potencial transformador, mas em força, cuja única função é manter o indivíduo ativo na produção e no consumo.

Destacamos, ainda, a definição de respeito (outro termo muito presente nos textos de RSE), que equivaleria, na esfera mais ampla dos negócios, ao amor.

\section{(...) respeito é uma espécie de “amizade” sem intimidade ou proximidade; é uma consideração pela pessoa, nutrida à distância que o espaço do mundo coloca entre nós, consideração que independe de qualidades que possamos admirar ou realizações que possamos ter em alta conta. Assim a perda do respeito nos tempos modernos, ou melhor, a convicção de que só se deve respeito ao que se admira ou preza, constitui claro sintoma da crescente despersonalização da vida pública e social. (ARENDT, 2007, p.254-255)}

Arendt conclui (2004, p.260-338), a partir das considerações sobre trabalho, labor e ação, que o processo do acúmulo de riqueza, estimulado e por sua vez estimulando a vida humana, é possível somente se o mundo e a mundanidade do homem forem destruídos, alertando para o fato de que o que os homens têm agora em comum é uma mesma capacidade de raciocínio, “de prever as conseqüências”.

Essa situação se iniciou na noção de fabricação, com o deslocamento dos modelos e produto para o processo, fazendo com que a contemplação perdesse sua posição na vita activa, e prosseguiu com uma segunda inversão hierárquica, mais gradual, que substituiu o princípio da utilidade pelo princípio “da maior felicidade do maior número”, no qual os interesses do indivíduo e da humanidade são equacionados com a vida individual ou da espécie, como se fosse lógico e natural considerar a vida como o mais alto bem. Arendt chama esse fenômeno de vitória do animal laborans, entendida como afirmação da espécie causada pelo surgimento da sociedade, em detrimento da experiência humana; na qual a contemplação perdeu o significado e o próprio pensamento reduziu-se à “previsão de 
conseqüências”, passando a ser função do cérebro e substituível por instrumentos eletrônicos, que exercem essa função muito melhor do que o homem.

O último estágio de uma sociedade de operários, que é a sociedade de detentores de empregos, requer, portanto, que seus membros funcionem automaticamente, como se a vida individual tivesse sido afogada no processo vital da espécie e a única decisão ativa exigida fosse deixar-se levar de forma entorpecida e "tranquilizada". Arendt conclui, ressalvando que o ato de pensar, que ficou de fora das considerações feitas por ela sobre a vita activa, ainda é possível onde os homens vivem em condição de liberdade política.

\section{Democracia, participação e emancipação}

SANTOS e AVRITZER (2005), na introdução do livro Democratizar a Democracia, que integra coleção que aborda as possibilidades de uma globalização alternativa, destacam que o debate democrático predominante encerra uma solução minimalista para o problema da participação, pela via da discussão das escalas e complexidade (conforme autores como Bobbio, 1986 e Dahl, 1991). Fazem um recuou histórico, para compreender como a burocracia, e sua indispensabilidade, foi trazida para o centro da teoria de democracia. Lembram do alerta de Weber, em relação à perda do controle do processo de decisão econômica e política pelos cidadãos, e controle crescente por formas de organização burocrática, ligadas ao surgimento do Estado Moderno (WEBER, 1978, II:1394 apud SANTOS e AVRITZER, 2005, p.46-47). Configura-se uma situação em que o protagonista é o especialista e não o cidadão comum, que abre mão do controle sobre atividades políticas e econômicas, exercidas por burocracias privadas e públicas. Avançando no tempo, os autores lembram que burocracias centralizadas não possuem condições de lidar com o conjunto das informações necessárias para a execução de políticas complexas nas áreas social, ambiental ou cultural, o que enseja a re-inserção, no debate democrático, dos “arranjos participativos” (SABEL et al., 1999 apud SANTOS e AVRITZER, 2005, p.48). A concepção hegemônica da democracia reduz, contudo, a representação à questão das escalas. Dessa forma, das três dimensões da representação (autorização, identidade e prestação de contas), as duas últimas são dificultadas.

$\mathrm{Na}$ segunda metade do século XX, surgem concepções não-hegemônicas de democracia (LEFORT, 1986; CATORIADIS, 1986; HABERMAS, 1984 E 1995; LECHNER, 1988; BÓRON, 1994; NUN, 2000 apud SANTOS E AVRITZER, 2005, p.50-53) que a entendem, em linhas gerais, não como engenharia institucional, mas como "nova gramática histórica”, que implica romper tradições e tentar instituir novas determinações, normas e leis. 
Defendem um princípio de deliberação amplo, pelo qual, para ser plural, a política tem de contar com assentimento dos atores sociais em processos racionais de discussão e deliberação, e não se reduzir a um método de autorização de governos.

No processo de redemocratização, no Sul, os autores destacam a grande participação dos movimentos sociais, e o surgimento de uma disputa pelo significado da democracia e constituição de nova gramática social (ESCOBAR e ALVAREZ, 1992; ALVAREZ, DAGNINO e ESCOBAR, 1998; DOIMO, 1995; JELIN e HERSCHBERG, 1996; AVRITZER, 2002 apud SANTOS E AVRITZER, 2005, p.54-55), acrescentando que, no Brasil, no processo de democratização dos anos 80 e 90, vários atores que implantaram as experiências de democracia participativa colocaram em questão uma identidade que lhes fora atribuída externamente, por um Estado colonial ou por um Estado autoritário e discriminador.

De forma geral, Santos e Avritzer (2005, p.59) afirmam que a concepção hegemônica de democracia liberal (minimalista e elitizada) busca estabilizar a tensão entre democracia e capitalismo, pela prioridade à acumulação de capital (em relação à redistribuição social) e pela limitação da participação cidadã (individual e coletiva), para não "sobrecarregar” o regime democrático com demandas sociais “excessivas”. Mas destacam que a coexistência e complementaridade das democracias participativa e representativa (predominantes, respectivamente, no Norte e no Sul) podem gerar caminhos diversos e inovadores.

Comentam, ainda, o estudo que abordaremos a seguir, desenvolvido por Maria Célia Paoli, que, segundo os autores, ao analisar o ativismo social dos empresários contra a exclusão social, oferece um exemplo de cooptação do ideal da participação da sociedade civil, para realizar uma operação de “marketing social”, reduzindo o público às categorias de consumidores e empregados da empresa. Embora não consideremos que a operação seja somente de cooptação, a redução dos públicos a categorias da cadeia produtiva é um aspecto que detectamos em nossa pesquisa, conforme será exposto na análise e considerações finais.

Em texto construído a partir de um conjunto de palestras (SANTOS, BRANDÃO, VIANNA, 2001), Boaventura Souza Santos discorda da afirmação de que vivemos um período de auto-reflexividade, sustentada por autores como Ulrich Beck, Scott Lash e Anthony Giddens, que propõem um indivíduo auto-reflexivo, que não se mobiliza sem razões, cuja própria vida é um objeto de meditação, auto-análise e reversão de percursos. Considera que se vive um processo de transição, de grande criação e destruição, não a destruição criativa, proposta por Schumpeter, mas processos concomitantes sobre os quais não se consegue estabelecer relações coerentes, num quadro onde, em termos gerais, se observa a 
presença de dois grupos sem condições propícias para pensar. Por um lado, os que comandam esse processo não têm tempo para pensar, como os stockbrokers das bolsas de valores, cujo automatismo da ação não exige e não permite pensamento. Por outro lado, a maioria da população mundial, que sofre as conseqüências do processo, por meio da exclusão e a desigualdade, também pouco pode pensar, pois sua prioridade é sobreviver. O autor avalia, dessa forma, que a auto-reflexividade não encontra condições sociais para acontecer. Faz, contudo, uma ressalva, ao considerar a idéia da auto-reflexividade parcialmente aplicável no âmbito dos movimentos coletivos, nos quais atualmente as pessoas têm que ter razões próprias para se mobilizarem para as lutas sociais. É algo que demanda a formação de constelações de sentido, onde as tarefas intelectuais, políticas e morais convirjam.

O autor coloca em xeque a ruptura entre a busca da verdade e a busca do bem, que marca a ciência moderna, por considerar que, nessa fase de transição, é muito perigoso dividir a busca da verdade da busca do bem. Ao que acrescentamos que julgamos também perigosa a postura dos que se arvoram como “do bem”.

Lembra que a separação entre bem e verdade teve, historicamente, a vantagem de permitir que os intelectuais, sendo "neutros", fossem tolerados. Mas afirma que essa tolerância deve ser reivindicada por outra via, articulando ciência, moral e política. Destaca, para que isso seja realizado, a necessidade de sermos objetivos sem sermos neutros, ao utilizar as técnicas e os métodos que estão à nossa disposição, sem sectarismos nem dogmatismos, sempre preparados para nos deixarmos surpreender pela realidade. Para o autor, o cientista social deve ser um “tradutor”, capaz de contribuir, permitir, aumentar a inteligibilidade entre as diferenças, por meio do pensamento crítico marcado pela negatividade. Negatividade essa que permita desarmar a lógica afirmativa da sociedade de consumo, que, depois de sujeitar os gostos ao cardápio de escolhas que oferece, parece ter ofertas para todos os gostos.

Coloca, também, em xeque a compatibilidade, apresentada como conquista da globalização, entre a democracia e o capitalismo, afirmando que a democracia sempre criou tensões com o capitalismo através das tentativas de redistribuição por meio de sucessivas ampliações dos direitos de cidadania, e, se, hoje, as tensões parecem ter desaparecido, é porque a democracia deixa de ser redistributiva.

Questiona, ainda, que os baixos níveis de contestação social sejam decorrentes do consenso a respeito das transformações; e ressalta uma distinção especialmente importante para a análise que nos propomos a fazer nesta pesquisa, entre consenso e resignação. Para Santos (2001), o 
consenso é a afirmação do conflito resolvido, enquanto a resignação é a negação do conflito, sustentando, dessa forma, duas estratégias de dominação muito diferentes.

\section{Ideologia, sociedade civil e classes sociais}

Chauí (1994) retoma Hegel, para quem a história é movida pela contradição, conceito que se distingue da oposição. Enquanto esta pressupõe dois termos com características e existência próprias que se opõem quando se encontram, a contradição pressupõe relação e opera com a negação interna, que nega a própria realidade de um dos termos. Na contradição, os termos que se negam só existem nessa relação, que define uma realidade em si mesma dividida em dois polos. Somente quando o senhor afirma que o escravo não é homem, mas instrumento de trabalho, e somente quando o escravo afirma sua não humanidade, dizendo que só o senhor é homem, temos contradição. Afirma, ainda, que a produção e superação das contradições é o motor da história, que se realiza por meio de uma luta mortal entre polos contrários, que termina quando os dois termos se negam inteiramente e engendram uma síntese, que já nasce fraturada e reabre a luta dos contraditórios. Em certa medida, nossa análise, desenvolvida na sequencia deste trabalho, aponta para a percepção de que o discurso da RSE nega o conflito humano, traduzindo-o como coisa natural.

Outro conceito de Hegel apresentado por Chauí (1994, p.42) e importante para nosso estudo é o de sociedade civil, entendido como negação da família, que não depende mais só dela própria, mas existe em relação com a sociedade civil. Para Hegel, pela mediação das classes sociais a sociedade civil nega o indivíduo isolado (pessoa e sujeito) e o indivíduo como membro da família, fazendo-o aparecer como membro de uma sociedade e pertencente a uma classe social. Os cidadãos (classes sociais) passam, dessa forma, a ser a unidade síntese do proprietário, do sujeito e do membro da família, entre os quais existem conflitos e se reabre a contradição, cuja resolução é feita pelo Estado, que constitui unidade final, e busca harmonizar interesses da pessoa (proprietário), do sujeito (moral) e do cidadão (sociedade e política). Marx, por sua vez, revê o conceito, percebendo sociedade civil como:

(...) sistema de relações sociais que se organizam na produção econômica, nas instituições sociais e políticas e que são representadas ou interpretadas por um conjunto sistemático de idéias jurídicas, religiosas, políticas, morais, pedagógicas, científicas, artísticas, filosóficas” (CHAUÍ, 1994, p.73-74)

A sociedade civil se realiza como luta de classes, presente nos procedimentos de que a classe dominada lança mão para organizar o processo do trabalho, mantendo a dominação pela separação dos trabalhadores uns dos outros. Para Marx, a sociedade civil não é, portanto, 
“a sociedade”, grande sujeito coletivo da história. Esta são os indivíduos fazendo-se uns aos outros (práxis social) e pertencendo a classes sociais, o verdadeiro sujeito da história. Mantém, portanto, a idéia hegeliana de dialética como movimento interno de produção da realidade, cujo motor é a contradição. Mas a contradição, para Marx, se estabelece entre homens reais em condições históricas e sociais, e se chama luta de classes.

Pelo método histórico-dialético, propõe começar pelo aparecer social, e chegar, por mediações reais, ao ser social. Chaú (1994, p.48-49) lembra que se transita assim, da mercadoria à percepção de que há mais mercadorias, uma vez que o trabalhador que vende força-de-trabalho também é mercadoria. A compreensão da gênese da mercadoria é dada pelas noções de valor de uso e valor de troca, sendo que o valor de troca comanda o valor de uso; ou seja, o valor da mercadoria não é determinado pelo mercado, mas pela quantidade de tempo de trabalho necessário para produzi-la. Para Marx, a mercadoria é entendida, portanto, como "trabalho social concentrado" e não pago, a mais-valia, que consiste na diferença entre a quantidade de tempo necessária para produzir a mercadoria e o tempo remunerado do trabalhador. É essa diferença, ocultada pela mercadoria, que torna a mercadoria um valor capitalista. Lembramos, aqui, que a idéia da "geração de valor” compartilhado, recorrente no discurso de RSE, nega ou omite isso, percebendo-a como algo coletivo/natural.

Chauí (1953, p.52) acrescenta que a dialética de Marx é materialista, ao considerar como matéria os homens produzindo em condições determinadas, seu modo de se reproduzir e de organizar suas vidas. Uma concepção que coloca como sujeito da história as classes sociais, que "são o fazer-se classe dos indivíduos em suas atividades econômicas, políticas e culturais.” A autora (1994, p.54-57) apresenta, ainda, outro conceito válido para nossa pesquisa, o conceito de alienação, pelo qual o produto surge como poder separado do produtor (trabalhador), dominando-o e o ameaçando. (que o domina e ameaça.) Algo que denomina fetichismo da mercadoria e se dá em dois momentos: a mercadoria é fetiche (coisa que existe em si e por si); assim como o fetiche religioso (deuses, objetos, gestos, símbolos) tem poder sobre seus adoradores, a mercadoria também domina, transformando o mundo numa imensa fantasmagoria. Homens transformados em coisas e coisas, em gente. A humanização das coisas passa a impressão de que a cadeia produtiva e suas atividades econômicas operam sozinhas, por si mesmas, independente dos homens que as realizam. Cabe a estes gerir um fluxo que tem vida própria. Consideramos que essa concepção dá base a ótica gerencial. A alienação não é apenas algo subjetivo a ser superado pela “conscientização”, mas processo social como um todo, resultado da ação social dos homens. Nesse sentido, a condição atual 
de liberdade de escolha e expressão deve levar em conta quais coisas são dadas para que os homens escolham e quem dá condições para a escolha. A autora lembra (1994, p.105) que a idéia de contrato entre partes “iguais e livres” e de igualdade do direito à propriedade (do capital, da terra e sua renda, do salário) oculta que o salário não é propriedade do trabalhador, mas é trabalho não pago pelo capitalista; que a renda não vem da terra, mas de sua transformação em capital pelo trabalho não pago dos trabalhadores; o que torna propriedade efetiva apenas o capital.

São definições sustentadas pela ideologia dominante, sendo ideologia entendida pela autora como:

(...) um corpo explicativo (representações) e prático (normas, regras, preceitos) de caráter prescritivo, normativo, regulador, cuja função é dar aos membros de uma sociedade dividida em classes uma explicação racional para as diferenças sociais, políticas e culturais, sem jamais atribuir tais diferenças à divisão da sociedade em classes, a partir das divisões na esfera da produção. Pelo contrário, a função da ideologia é a de apagar as diferenças como de classes e de fornecer aos membros da sociedade o sentimento da identidade social, encontrando certos referenciais identificadores de todos e para todos, como, por exemplo, a Humanidade, a Liberdade, a Igualdade, a Nação, ou o Estado (CHAUÍ, 1994, p.113-114)

Uma classe é hegemônica não só por deter a propriedade dos meios de produção e o poder do Estado, mas é hegemônica, sobretudo, porque suas idéias e valores são dominantes, e mantidos pelos dominados até mesmo quando lutam contra a dominação. A dificuldade de manter controle econômico e político não é crise de hegemonia no sentido gramsciano. (CHAUÍ, 1994, p.97).

\section{Mídia e simulacro}

Chauí (2006, p.5-12) aborda a destruição da esfera da opinião pública, com a intimidade sendo tomada como objeto central do espetáculo televisivo. Sentimentos, impressões e opiniões sobrepõem-se ao que as pessoas pensam ou julgam, obedecendo a padrões de mercado de endosso a produtos e marcas, por meio de especialistas críveis e confiáveis. Dessa forma, as relações interpessoais e grupais ocultam ou dissimulam as sociais e políticas. O direito de todos opinarem passa para os "formadores de opinião" (intelectuais, artistas e jornalistas), sob os efeitos das tecnologias e formação de oligopólios midiáticos globalizados. A partir de Debord, Chauí (2006, p.14-21) observa que, nos dias atuais, o espetáculo deixa de se referir ao acontecimento, mas à encenação do acontecimento, ao seu simulacro $^{8}$. A autora (2006, p.32-50) recorre, também, a David Harvey, que entende o que

\footnotetext{
8 Chauí (2006, p.82) lembra que simulacrum - vem de similis semelhante. Que tanto pode significar representação ou cópia, como fingimento ou simulação. Simulacro é a imagem de uma imagem percebida, ou seja, passamos da percepção da imagem de uma coisa à sua representação ou reprodução em uma outra imagem,
} 
chama de condição pós-moderna como uma compressão espaço-temporal (aqui e agora), que reúne a fragmentação num espaço indiferenciado e plano de imagens fugazes, onde o cidadão dá lugar a um “infatigável olhador de imagens”. Os meios de comunicação, por meio da propaganda que desloca de produtos para imagens e signos, têm papel importante num processo de invenção de novos desejos, para dar conta da fugacidade do mercado. O jornalismo, por sua vez, reforça a desinformação, pela ausência de referências espaçotemporal (atopia e acronia), com uma enxurrada de notícias que vem do "nada”. Exemplo atual: mortes e doença nos cruzeiros de navio. Compõe um quadro de ausência de condições materiais, econômicas, sociais, políticas e históricas do mundo editado que aparece na TV; num procedimento deliberado de controle social, político e cultural.

Nesse contexto, a autora avalia que o poder econômico e ideológico dos meios de comunicação de massa é questão central, uma vez que, segundo Costa (2005, p.1 apud CHAUÍ, 2006, p.73), sete grandes corporações globais (Disney, Time Warner, Sony, News Corporation, Viacom, Vivendi-Universal e Bertelsmann) e seis grandes corporações/ grupos familiares nacionais, Abravanel, Civita, Frias, Marinho, Saad e Sirotsky, instituem e comandam o espaço e o tempo públicos. Lembrando que, segundo 75Lefort (1982 apud CHAUÍ, 2006, p.74), a ideologia contemporânea é discurso anônimo e impessoal, que parece brotar da sociedade como se fosse o discurso do social, e que o poder da comunicação de massa não opera por inculcação, mas por intimidação social e cultural, ao dizer o que devemos pensar, sentir, fazer e ao afirmar que nada sabemos. A autora (CHAUÍ, 2006, p.78) ressalta que o que torna essa intimidação possível é, por um lado, a difusão da idéia de competência como forma que dá sentido racional às divisões e desigualdades sociais; e, por outro, sua manifestação reiterada e perfeita na estrutura dos meios de comunicação, através do aparato tecnológico, gerando a competência suprema de criar realidade por meio da produção de simulacros.

\section{Cidadania e privilégio}

Chauí (2006, p.104-110) aborda o que nomeia como divisão social do medo, tendo, acima, o medo de perder privilégios, que dizem respeito a interesses; e, abaixo, o medo de queda de humanização, que diz respeito a direitos e seu pressuposto, justiça. A sociedade brasileira, enquanto autoritária (tendo como base a escravidão), concebeu, historicamente, a cidadania como privilégio de classe, com uma esfera pública que nunca chega a se constituir

como na pintura. O espelho nos dá um duplo, o simulacro. Como é evidente para quem vê alguém olhando para o espelho. 
como pública, sendo definida sempre e imediatamente pelas exigências do espaço privado. Seu autoritarismo não se encerra, contudo, no governante ou governo, mas na estrutura da sociedade, uma vez que a sociedade civil, como espelho do Estado, também é estruturada por relações de favor, tutela e de dependência.

A autora (2006, p.140-142) ressalta que, na sociedade brasileira, o privilégio é sempre particular e não pode generalizar-se sem deixar de sê-lo, e a carência, por sua vez, é sempre específica e singular, e não ultrapassa a esfera da demanda, incapaz de generalizar-se como interesse e universalizar-se como direito. Como o campo democrático é constituído pela criação e reconhecimento de direitos, e a cidadania se define a igual distância do privilégio e da carência, a estrutura autoritária bloqueia a instituição do campo democrático e da cidadania e reforça a violência que atravessa, de várias formas, o social e o político. Uma vez que onde não há direitos, não há sujeitos, estes são tratados como coisas. Trata-se, contudo, de uma sociedade tirânica e não tiranizada, sustentada pela servidão voluntária de La Boétie (2001), onde poderes tirânicos atuam numa cadeia, onde cada um tiraniza os inferiores.

\section{Sociedade do espetáculo}

Debord (1997, p.11), ao comentar, em 1992, suas teses redigidas em 1967, afirma que a burocracia totalitária pode ser considerada uma "forma subdesenvolvida de classe dominante” (referente ao capitalismo militar descrito por Weber) que sabia que precisava evoluir. Seu axioma 58 afirmava que a raiz do espetáculo surge na economia abundante, cujos frutos tendem a dominar o mercado espetacular. Cita como prova do progresso da técnica espetacular a instantânea conversão da Rússia, em 1989, à ideologia da democracia, ou "liberdade ditatorial do Mercado, temperada pelo reconhecimento dos Direitos do homem espectador”, registrada apenas pela aparência de uma espécie de “abalo geológico”, “a-quedado-muro-de-Berlim”, apresentada de forma indiscutível, assim como outros sinais democráticos. (grifo do autor). Esse é o fenômeno que se revelou com mais nitidez, em 1991, com a completa dissolução da Rússia, como resultado desastroso da evolução geral da economia, fazendo ressoar a pergunta apavorante: “como fazer os pobres trabalharem, quando a ilusão é desenganada e a força se desagrega?”.

Consideramos que essa colocação, assim como vários pontos levantados por Debord (1997) em suas teses ou axiomas são capazes de colaborar para o entendimento das questões levantadas por nossa pesquisa. Selecionamos, a seguir, alguns pontos, começando pela tese 3: 
O espetáculo apresenta-se ao mesmo tempo como a própria sociedade, como uma parte da sociedade e como instrumento de unificação. Como parte da sociedade, ele é expressamente o setor que concentra todo olhar e toda consciência. Pelo fato de esse setor estar separado, ele é o lugar do olhar iludido e da falsa consciência; a unificação que realiza é tão-somente a linguagem oficial da separação generalizada. (DEBORD, 1997, p.14)

O autor prossegue, ressaltando que “o espetáculo não é conjunto de imagens, mas relação entre pessoas mediada por imagens” (DEBORD, 1997, p.13), e que o espetáculo afirma, em seus próprios termos, a aparência e toda vida social como aparência. Lembrando que, após uma primeira fase de dominação da economia, que levou do ser ao ter, desliza-se, com a vida social tomada pela economia, do ter para o parecer. De forma que a toda realidade individual, moldada pela força social, só é permitido aparecer naquilo que ela não é. (grifo do autor). Afirma que, enquanto o espetáculo sagrado, de acordo com o interesse dos senhores, embelezou o que a sociedade não podia fazer, o espetáculo moderno expressa o que a sociedade pode fazer. Nessa expressão, contudo, o permitido se opõe de todo ao possível. _(grifos do autor)

Debord (1997, p.31) levanta também uma questão importante, para entender a preocupação atual com a qualidade de vida dos trabalhadores, ao afirmar que, na fase primitiva da acumulação capitalista, o proletário recebia o mínimo para conservar sua força de trabalho, ao passo que a abundância das mercadorias exige uma colaboração maior. Do absoluto desprezo com que é tratado no controle da produção, começa a surgir a preocupação com sua existência fora dela, numa espécie de "humanismo da mercadoria” (grifo do autor), que passa a se encarregar dos "lazeres e da humanidade”, por meio do consumo, uma vez que a economia política também deve dominar essas esferas. Destaca, contudo, que a sobrevivência consumível deve aumentar sempre, uma vez que contém em si a privação. O autor lembra, ainda, que (2007, p.128-129) aqueles que denunciam os perigos da incitação ao desperdício, na sociedade da abundância econômica, não entendem a função do desperdício, dos “bons vigias irracionais”, sem os quais a racionalidade econômica despencaria.

Dentre os comentários acrescidos, em 1988, às teses principais, destacamos os seguintes aspectos, relevantes para a análise do discurso das empresas, em especial no âmbito de sua articulação com a imprensa. Debord (1997, p.179-196) afirma que existe uma espécie de solidariedade de profissão e alma entre os especialistas da mídia, pois “Só gente de mídia pode responder a todas as asneiras que são apresentadas espetacularmente”. Além disso, a autoridade espetacular não está sujeita a nenhuma réplica, nem em seu terreno, nem em qualquer outro, uma vez que o discurso apresentado no espetáculo não deixa espaço para a resposta, e a lógica só pode ser formada socialmente por meio do diálogo. O autor afirma, ainda, que marcados pelo pensamento espetacular empobrecido, os indivíduos podem até 
tentar combater a ordem estabelecida, mas obedecem a linguagem do espetáculo. Além disso, o uso, numa mesma narrativa, de informações com escalas e medidas diferentes, impede qualquer juízo de valor ou grandeza.

Por outro lado, Debord (1997, p.227-230) lembra que uma falsa crítica contrajornalística se une à prática do boato, aplicando, na prática, teorias formuladas na década de 50/60 pela sociologia americana da publicidade; a tática dos "homens locomotiva”, o que hoje conhecemos como “formadores de opinião", entendidas pelo autor como personalidades criadas artificialmente, para atuar como difusoras de estilos determinados pelo mercado.

\section{Cidadania}

Arriscando-se em analogias entre momentos históricos diferentes, consideramos importante levantar alguns aspectos considerados relevantes para entender a complexa questão da cidadania no Brasil, e oferecer elementos para a análise do discurso das empresas a esse respeito. O conceito de cidadania será tratado neste trabalho como um tema transversal, que, assim como o consumo, perpassa o discurso das empresas, muitas vezes associado às idéias de consumo e empreendedorismo.

\section{Tipos e percursos da cidadania}

Carvalho (1996), ao traçar os tipos e percursos da cidadania, cita Richard Morse (1982), que salienta o contraste entre as tradições ibérica e anglo-saxônica, e acrescenta que vários outros estudos chamam a atenção para tradições distintas dentro da própria Europa, exemplificadas, sobretudo nos casos inglês, francês e alemão. Utiliza os eixos propostos por Turner (1990), que classifica os tipos de cidadania a partir da origem (propostos de "cima para baixo", com expansão dos direitos da elite, ou de "baixo para cima”, a partir de demandas e revoluções populares) e do escopo (cidadanias que se construíram no âmbito público ou no âmbito privado), para apresentar quatro tipos “clássicos” de cidadania: o francês (público e de baixo para cima), o inglês (público e de cima para baixo), o alemão (privado e de cima para baixo) e o americano (privado e de baixo para cima). Recorre, também, a Almond e Verba (1965:cap.1 apud CARVALHO, 1996), que identificam três tipos de cultura política: a paroquial, ou localista (completa alienação em relação ao sistema político, reduzida ao mundo privado da família ou da tribo); a súdita (relacionamento com o sistema político limita-se a uma percepção dos produtos de decisões político-administrativas); a participativa (acrescentaria uma percepção do processo decisório em si, e uma visão do 
indivíduo como membro ativo do sistema); e um quarto tipo, a cultura cívica, que seria a combinação dos três anteriores, sendo que pode haver várias combinações desses três tipos, na medida em que diferentes setores da população se relacionam de maneira distinta com o sistema político

Ao analisar o caso do Brasil, no século XIX, o autor tem, contudo, dificuldade para enquadrar o caso brasileiro. Ocorreu no espaço público, mas se afasta do modelo francês, uma vez que, na França, a revolução possibilitou aos cidadãos apoderarem-se do Estado e definirem a cidadania de maneira universal; enquanto que, no caso brasileiro, a centralidade do Estado coopta seletivamente os cidadãos e os cidadãos também buscam o Estado para o atendimento de interesses privados. O tipo alemão, por sua vez, a princípio parece compatível, mas subsistem diferenças importantes, uma vez que tradição de obediência rígida às leis, segundo alguns de origem luterana, estão ausentes de nossa cultura, muito mais fragmentada e quase cínica em relação ao poder. O privatismo brasileiro, no século XIX, estaria, então, mais próximo do paroquialismo do que o privatismo alemão, podendo este último enquadrar-se numa cultura súdita. Diante dessas dificuldades, o autor opta por reter para a análise apenas a idéia de Turner sobre cidadania construída de cima para baixo, e a de Almond e Verba, sobre culturas políticas que se movem entre o paroquialismo e o caráter súdito (inativo), com incursões no ativismo político, propondo que o cidadão ativo das constituições do século XIX, no Brasil, é o cidadão participante de Almond e Verba, fruto de cidadania conquistada de baixo para cima, na terminologia de Turner.

Partindo dessa hipótese que propõe um perfil participativo e não súdito, elenca vários aspectos das Constituições brasileiras oitocentistas que indicam participação cidadã, destacando que, além da capacidade política de votar e ser votado, os principais pontos de contato entre o cidadão e o Estado, no Brasil do século XIX, foram a Guarda Nacional, o serviço militar, o serviço do júri, o recenseamento e o registro civil.

Quanto ao voto, destaca que a Constituição de 1824 era liberal para a época em relação a outros países e, apesar de contar com exigência de idade e renda, não tinha restrições quanto à escolaridade e permitia o voto de analfabetos, o que fez com que o país tivesse cerca de um milhão de eleitores, em1872. Essa situação promissora sofreu grande golpe em 1881, com analfabetos excluídos e aumento da exigência de renda, o que reduziu o eleitorado para pouco mais de 100 mil eleitores. Embora o comportamento dos votantes fosse muitas vezes dirigido pelos coronéis locais, Carvalho (1996) afirma que o problema principal, em 1881, não foi o comportamento dos votantes, mas a incompreensão dos que os afastaram 
da prática eleitoral, interrompendo seu aprendizado político; uma incompreensão que não foi corrigida na República.

Um pouco menos abrangente foi a participação no Poder Judiciário, que incluía, além do direito de ser jurado, a participação direta no poder judicial, possibilitada pelo exercício da função eletiva de juiz de paz. A Constituição de 1824 previa a existência de um juiz de paz, eleito pelo voto direto, em cada distrito do território nacional. Uma função que, embora alvo de muitas críticas, é entendida pelo autor como potencial instrumento de educação cívica e de desenvolvimento do espírito público.

A Guarda Nacional, por sua vez, teve como modelo a Garde Nationale francesa, criada em 1789, às vésperas da tomada da Bastilha, para colocar a defesa do país nas mãos dos proprietários, dos cidadãos ativos, como definidos logo depois pela Constituição de 1791. No Brasil, de início, os fins eram semelhantes. Criada em 1831, em meio a grandes agitações políticas, a Guarda deveria servir de proteção contra a anarquia que tomava conta do Exército, e contra as revoltas populares que pipocavam em várias capitais. Tinha, porém, uma característica que lhe aumentava o caráter democrático: os oficiais eram eleitos pelos guardas. Era um mecanismo que colocava constantemente em xeque as relações de poder, e foi suspenso, a partir de 1850, quando todos os postos de oficiais passaram a ser de nomeação do governo que, com isso, adquiriu moeda forte para negociar a lealdade dos senhores de terra. Daí em diante, a hierarquia da Guarda refletiu fielmente a hierarquia social.

No exército, por sua vez, nunca se deu a ligação entre cidadania e serviço militar. O recrutamento era feito entre desempregados, vadios, criminosos. Os ricos podiam pagar ou oferecer substituto para não se alistarem. Castigos físicos eram sistemáticos; bebedeiras, roubos e deserções, frequentes. Os soldados eram cidadãos inativos, com direitos civis básicos negados. O autor considera, contudo, a Guerra do Paraguai (1865 a 1870) como experiência atípica. Estima-se algo em torno de 135 mil combatentes, sendo quase 60 mil da Guarda Nacional, 55 mil voluntários, cerca de 8 mil recrutados e libertos e 12 mil exército de linha. Configurou-se um momento importante para formação de uma identidade nacional tendo, como contraponto um inimigo comum. Apesar de se pedir a não-cidadãos (sentido político e civil) que fossem lutar pela pátria que os escravizava, o autor considera que a guerra, como experiência de luta lado a lado com outros brasileiros, foi um evento que trouxe uma sensação de pertencimento, um sentimento cívico à boa parte da população.

Carvalho (1996) destaca, ainda, as reações contrárias, sendo que três iniciativas em especial (contra o alistamento militar, registro civil e introdução do sistema métrico) revelam uma cidadania 
em negativo, constituindo-se em reações que não são só recusa, mas recusa à interferência sem consulta no cotidiano e desrespeito a tradições; uma espécie de afirmação de direitos pelo "não”.

Levantando esses aspectos, o autor procurou caracterizar uma tradição política diferente, e não desqualificá-la por divergir do modelo anglo-saxônico. O entendimento da cidadania aqui forjada (ou não forjada, como afirma Milton Santos, cujas colocações abordaremos a seguir) é importante para a tentativa de compreensão das ações de responsabilidade social. Sobretudo porque as queixas da elite política e da burocracia da época quanto ao baixo nível de educação e civilização, influência dos potentados locais e ausência de opinião pública, parecem ecoar nos discursos atuais; elites ilustradas, agentes da modernização de cima para baixo, que, segundo o autor, na época se mostraram muito mais eficientes em cooptar setores dominantes, do que em atrair a população para dentro do sistema.

As leis reformadoras e os novos deveres cívicos introduziam na vida cotidiana mudanças cujo sentido não era compreendido, e a maior parte da população era forçada a tomar conhecimento do Estado e das decisões políticas, sem lealdade em relação às instituições, que maltratavam ou desrespeitavam as vontades e tradições da maioria.

\section{A revolução burguesa e o privilégio}

Florestan Fernandes (2006) defende a existência de uma revolução burguesa no Brasil, mas esclarece que o entendimento da noção de burguês utilizada deve levar em conta padrão de civilização implantado no Brasil. O autor afirma que o "burguês” surge no Brasil como entidade especializada, seja como agente artesanal, inserido na rede de comercialização, seja como negociante. O burguês não era figura autônoma e emergiu, de forma não organizada e esclarecida, no fermento de um espírito revolucionário que se afirmava em objetivos egoísticos e difusos. Negociantes, funcionários públicos, banqueiros, empresários das indústrias nascentes de bens de consumo, artesãos e uma massa amorfa de pessoas em busca de emprego e oportunidade "para enriquecer” eram os tipos de homens que encarnaram o “espírito burguês”. Todos mantiveram permanentes laços de interesse com a aristocracia, buscando a inclusão entre o grupo dos "privilegiados" pelo sistema, sendo que, em nenhum momento, esse grupo mobilizou-se para exigir a defesa implacável dos direitos do cidadão. Voltavam-se contra o "arcaico" e “colonial”, mas o antigo regime aparecia como noção histórica vaga e confusa, uma vez que, apesar da Independência, era pelos componentes do mundo colonial que subsistiam, indefinidamente, com renovada vitalidade. O autor observa que a ideologia liberal é inoperante no âmbito da dominação patrimonialista, mas encontra na 
“sociedade civil”, nascida da Independência, uma esfera na qual se afirma e preenche a função típica de transcender e negar a ordem. Contudo, devido à concentração de poder político no nível senhorial, essa "sociedade civil” confunde-se com “elementos sociais dominantes”, sendo que o grosso da população ficou de fora.

No panorama traçado por Florestan Fernandes, sobre a emersão do liberalismo e da revolução burguesa no Brasil, chama a atenção como as palavras "privilégio", “privilegiamento” ou, ainda, “privilegiamento dos privilegiados” permeiam a obra, caracterizando uma maneira de ser, pensar e atuar na sociedade brasileira. No dicionário Houaiss, encontramos, para a palavra privilégio, que vem do latim privilegium, - lei excepcional concernente a um particular ou a poucas pessoas - os significados de vantagem, prerrogativa, direitos válidos apenas para um indivíduo ou um grupo. Era um tipo muito especial de direito, portanto, que passou a ocupar, em decorrência da evolução social brasileira, o lugar dos direitos do cidadão; um deslocamento que inclui, ainda, apenas o acesso aos abstratos “direitos do homem” para a maior parte da população. Considerados inerentes ao homem como ser social, independente de raça, sexo, idade e religião, esses direitos lançam os fundamentos teóricos das modernas democracias liberais e social-democratas. Dão-se, contudo, num contexto de esvaziamento e deformação das noções liberais, onde se evidencia que a mudança da situação vigente não vai ocorrer pelo caminho dos “direitos humanos”, que se aproximam, na áspera comparação de Hanna Arendt, a de uma espécie de sociedade protetora dos animais, ou, ainda, de um “espaço público” congelado de nascença, como lembra Florestan Fernandes, que dá o direito à fala, mas não possibilita qualquer interferência na pauta das discussões, assemelhando-se a um código de boas maneiras.

\section{A construção do não-cidadão no Brasil}

Para a discussão da cidadania, Milton Santos (2007) traz importante contribuição, ao destacar que o progresso material no Brasil foi obtido por meio da "aceitação extrema de uma racionalidade econômica exercida pelas firmas mais poderosas, estrangeiras ou nacionais, e o uso extremo da força e do poder do Estado” (SANTOS, 2007, p.15), para criar condições favoráveis ao modelo adotado. O autor enfatiza que, na contemporaneidade, a economia aparece como “técnica das técnicas” e defende a inversão desse processo, por meio da construção de um modelo cívico que parta do cidadão e não da economia.

Define cidadania como "uma lei da sociedade que, sem distinção, atinge a todos e investe cada qual com a força de se ver respeitado contra a força, em qualquer circunstância.” 
(SANTOS, 2007, p.19), que necessita de limites definidos social, jurídica e politicamente, e descreve a dramática elaboração brasileira do não-cidadão, que envolveu processos contemporâneos e concomitantes de: desruralização, migrações brutais, urbanização concentradora, crescimento econômico delirante, mídia concentrada, degradação das escolas, instalação de regime repressivo, e triunfo de filosofia de vida que privilegia bens materiais para ascensão social. Tudo em menos de 30 anos (1960-1990), gerando, como resultado cidadãos de primeira (beneficiados pelo crescimento distorcido), de segunda e terceira classes (sem realização cultural). São personagens que compõe um quadro de cidadania mutilada, expressão que o autor justifica por meio da apresentação de uma extensa tipologia de formas de vida não-cidadãs, que incluem: elevadores separados para funcionários; praias com limitação de acesso (por meio de constrangedores portais e seguranças ou barreiras financeiras); menores salários e oportunidades para nordestinos, mulheres e negros; impostos cobrados de forma truculenta, tratando contribuintes como faltosos efetivos ou em potencial; bancos que discriminam clientes por faixa de renda, ou criam “direitos” reservados só para os mais ricos; entre inúmeros exemplos.

O autor acrescenta a esse quadro a utilização da profissionalização, como forma de enquadramento, para permitir acesso a direitos que deveriam ser indiscriminadamente assegurados. Recorre a Wanderley Guilherme dos Santos, que cunhou o conceito de cidadania regulada, marcada pelo crivo corporativo, que tem como parâmetros a regulamentação das profissões, carteira profissional e sindicato público.

\footnotetext{
Por cidadania regulada entendo o conceito de cidadania cujas raízes não estão em um código de valores políticos, mas em sistema de estratificação ocupacional (...) definido por norma legal. Em outras palavras são cidadãos todos aqueles membros da comunidade que se encontram localizados em qualquer uma das ocupações reconhecidas e definidas em lei (SANTOS, 1987, p.68)
}

Os direitos do cidadão ficam, dessa forma, restritos ao lugar que este ocupa no processo produtivo, tal como reconhecido em lei, gerando a figura de "pré-cidadãos”, cuja ocupação a lei desconhece. Guilherme dos Santos (1987) avança, afirmando que a associação entre cidadania e ocupação proporcionará condições para inflar os conceitos de marginalidade e mercado informal de trabalho, e disseminar permanente pressão pela regulamentação por parte de variados setores da sociedade (na área de comunicação são bem conhecidos os casos do jornalismo e das relações públicas).

O autor ressalta que esse “achado” de engenharia institucional, surgido na prática revolucionária pós-30, permitiu criação de um espaço ideológico, no qual a ativa interferência 
do Estado na vida econômica não conflita com a intenção de promover uma ordem fundamentalmente capitalista. Esse aspecto nos parece de grande relevância para a associação de uma cidadania vinculada à cadeia produtiva, tal qual apresentada no discurso da responsabilidade social das empresas, como detalharemos a seguir.

Olhando para a outra ponta da cadeia produtiva, retornamos a Milton Santos que destaca que a força ideológica do "milagre” econômico (década de 70) pela sensação de bemestar rapidamente obtido pelas novas classes médias, gerando a esperança de amanhã promissor, facilita suportar a pobreza. Segue afirmando que a ênfase no consumo acabou por gerar um_consumidor mais-que-perfeito, com a presença de associações de defesa e informação, que apenas aperfeiçoam o consumo e são indiferentes à estrutura do capitalismo. O autor aceita a idéia de que, contra o consumo, pode erguer-se a força do consumidor, mas desde que este seja um dos papéis de um cidadão multidimensional; que possa exercer a liberdade essencial, que é a liberdade de dizer não, mostrar-se plenamente vivo e portador de existência ativa. No caso, dizer não à falsa liberdade de escolher ( optar) por opções de consumo, num cardápio bastante restrito.

O autor alerta para o condicionamento exercido pelas empresas na vida cotidiana, e afirma que, embora o_econômico possa parecer independente em seu movimento, as entidades sociais, como ideologia, cultura, religião, instituições, organizações formais e informais e território são forças ativas que modificam as intenções do planejamento econômico, o que torna a sociedade mais do que a empresa e/ou a ótica empresarial. Uma ótica que dissemina a indistinção entre cidadão e consumidor, fazendo com que a educação, moradia, saúde, lazer apareçam ou como conquistas pessoais ou como benesses e não direitos sociais.

\section{Cidadania e consumo}

Canclini (2005) é integrado ao grupo de referências desta pesquisa, por focar diretamente a relação entre consumo e cidadania, questão chave para a discussão proposta. Lembra que, nas últimas décadas, sob a influência dos EUA, ganha força um modelo de sociedade onde muitas funções do Estado desaparecem ou são assumidas por corporações privadas, e o exercício da cidadania organizada dá lugar a práticas organizadas por meio do consumo. Sendo que, na América Latina, democracias instáveis e a suspensão de meios de representação da cidadania pelas ditaduras das décadas de 70 e 80 contribuíram para a redução das sociedades civis a conjuntos de consumidores. Para o autor, trata-se, contudo, de uma concepção insuficiente para explicar as articulações entre cidadania e consumo, 
propondo uma noção de consumo como um espaço para pensar, uma vez que, ao selecionar e comprar bens, definimos o que consideramos publicamente valioso. Acredita, portanto, que é possível mudar as visões de consumo e cidadania a partir do seu estudo conjunto. Ressalta, nesse sentido, que a cidadania sempre esteve associada à capacidade de consumo, mas acreditava-se que diferenças seriam compensadas por direitos abstratos igualitários. Hoje, no entanto, o consumo de bens e serviços parece responder por questões típicas do cidadão (a que lugar pertenço, que direitos isso me dá, como posso me informar, quem me representa), sendo que a adesão entre consumo e cidadania é reforçada, nas eleições, pela fusão entre planos de marketing e propostas políticas. Além disso, a burocratização técnica das questões econômicas, que parecem ser decididas em esferas inalcançáveis, deixa às pessoas apenas a prerrogativa de optar entre os bens e as mensagens oferecidas pela comunicação midiática.

Para compreender essas questões no âmbito da América Latina, o autor considera que, após a confirmação identitária no papel de colonizados e oprimidos, não é mais suficiente “dar voz” aos excluídos, mas “entender e nomear os lugares em que suas questões ou sua vida cotidiana entram em conflito com os outros” (CANCLINI, 2005 p.28). Para tanto, propõe as categorias de contradição e conflito como centrais, para compreender a estrutura atual e possível dinâmica. Tais categorias são especialmente caras a esta pesquisa, por contribuírem para o entendimento do que o discurso da empresa sobre o social deve silenciar, para se garantir sua identidade.

Canclini (2005) destaca que o olhar político foi desacreditado pelo mercado, não apenas pelo confronto (diríamos que, sobretudo, negando o confronto), mas exibindo-se como mais eficaz para organizar a sociedade, cobrando o preço da submissão às regras do comércio e da publicidade, do espetáculo e da corrupção. Diante disso, propõe repensar cidadania em conexão com o consumo e como estratégia política, afirmando que a insatisfação com o sentido jurídico-político de cidadania canalizou essas participações para o mercado e para os meios de comunicação de massa. Nesse aspecto consideramos importante não tomar o consumo como único canal de ação política, assim como levar em conta que a dinâmica de mercado é fator constituinte da insatisfação com os canais políticos de representação.

Aponta, ainda, a passagem do cidadão como representante de uma "opinião pública” (ligada originalmente ao âmbito público) ao cidadão interessado em “qualidade de vida”, com formas argumentativas, dando lugar à fruição de espetáculos nos meios eletrônicos. A esse respeito, as considerações de Hannah Arendt sobre uma ênfase biológica na condução dos indivíduos, que serão apresentadas adiante, são especialmente relevantes. Além disso, consideramos que a opinião 
pública também foi incorporada na forma de espetáculo, sendo a reflexão "satisfeita” pelo acompanhamento da opinião pública filtrada pelos meios de comunicação, mecanismo que enfatiza a visibilidade no lugar da discutibilidade como aponta Gomes (2007).

Canclini (2005) também aponta uma crise do popular, revelada, entre outros aspectos, pela diminuição das manifestações e dispersão em múltiplos partidos, movimentos femininos, indigenistas, jovens, gays etc. A dificuldade de falar em nome do popular, levou a um questionamento do discurso e a políticas de representação e substituição do termo "popular” por sociedade civil, uma entidade amorfa, entendida por cada um à sua maneira.

[...] uma senhora que entende as coisas muito bem, sabe o que quer e o que tem de fazer, é boazinha, e, sem dúvida, a única adversária possível da perversão estatal. É tão virtuosa e tão segura de si mesma, que dá medo. (LOAEZA, 1994, p. 5-6, apud CANCLINI, 2005, p.44)

Além da compreensão pela racionalidade econômica, que percebe o consumo como parte de cadeia com produção e opções de consumo pré-determinadas, o autor destaca a manifestação de uma racionalidade sociopolítica interativa, afirmando que consumir é participar de cenário de disputas pelo que a sociedade produz e pelos modos de usá-lo. Cita a demanda pelo aumento do consumo e salário indireto dos sindicatos e reflexão crítica das associações como evidências de que o consumo é pensado pelos setores populares, assumindo, a nosso ver, uma posição que parece superestimar o potencial cidadão da escolha de produtos oferecidos pelo mercado, por meio de um cardápio de opções pré-determinadas. Lapida, contudo, a proposta, ao elencar condições para que o consumo possa ser articulado ao exercício refletido da cidadania, tais como oferta vasta e diversificada de bens e mensagens acessíveis para as maiorias; informação multidirecional confiável a respeito da qualidade dos produtos; participação democrática dos principais setores da sociedade civil nas decisões de ordem material, simbólica, jurídica e política em que se organizam os consumos.

Canclini propõe, então, a reconquista criativa dos espaços públicos, por meio de ombudsman, comissões de diretos humanos, instituições e periódicos independentes, instâncias não governamentais e apartidárias, que permitiriam desembaraçar a necessidade de fazer valer o público em face da decadência das burocracias estatais, permitindo que o consumo seja lugar de valor cognitivo útil para renovar a sociedade. Segue, afirmando que a constituição das identidades vai além do confronto bipolar entre classes, cuja relação não é apenas de oposição e combate, havendo, mesmo de forma desequilibrada, espaços de negociação. Essas afirmações são calçadas em pesquisas realizadas pelo autor na região de fronteira (México-EUA), onde percebeu que, a partir de uma visão menos idealizada do 
(norte) americano, foi possível o desenvolvimento de negociações constantes, incorporações de informações e entendimento de hábitos distintos.

O espaço de fronteira nos parece realmente muito rico para interações positivas, mas consideramos importante não abandonar as categorias de contradição e conflito, anteriormente levantadas pelo autor, para entender as relações estabelecidas nesses espaços de "negociação desequilibrada”. Canclini (2005, p.209-210) parece ter isso em mente ao afirmar que na etapa “pós-política”, se age como se não houvesse luta e que Negociar é lembrar que há luta, que há dissenso e visões opostas em disputa; deixa a sugestão de que o confronto não se dá apenas entre classes ou grupos, mas entre duas tendências culturais: a negociação "racional” e crítica x o simulacro de um consenso, induzido pela devoção aos simulacros, ressalvando que isso não ocorre de forma absoluta, uma vez que simulacros fazem parte de todas as culturas.

Colocar consumo como cidadania, sem o pressuposto da participação democrática nos circuitos de organização, é mais uma forma de cidadania mutilada. É algo semelhante à redução da participação política na escolha eleitoral de candidatos. As cobranças, o controle e até o impeachment têm características similares à pós-venda.

\section{Cidadania negada}

Antunes (2002) observa a acentuação da lógica destrutiva do capitalismo, a partir de tendências que o autor entende como respostas à crise estrutural do capital, tais como, a substituição do padrão produtivo taylorista e fordista por formas flexíveis e desregulamentadas; e o solapamento do modelo de regulação social-democrático (bem-estar) pela (des) regulação neoliberal. Trata-se de um quadro que tem como uma de suas manifestações mais graves a precarização do trabalho, com superexploração, especialmente de mulheres e crianças. O autor ressalta que, sem o perigo socialista, os direitos são rebaixados, por intermédio de reestruturação produtiva, privatização, enxugamento do Estado e políticas fiscais e monetárias sintonizadas com organismos de hegemonia do capital, como o FMI.

No contexto onde predomina o Toyotismo, com produção sob demanda, trabalho em equipe e multifuncional, estoques mínimos e horizontalização das atividades, as consequências para o mundo do trabalho são as seguintes: redução crescente do operariado fabril estável, com o crescimento de um novo proletariado- terceirizados, subcontratados, part-time etc., em todo o mundo; aumento do trabalho feminino, absorvido, sobretudo, como trabalho precarizado e desregulamentado; incremento de assalariados médios e de serviços; exclusão de jovens e idosos, nos países centrais; inclusão precoce e criminosa de crianças, na 
Ásia, África e América Latina; expansão do trabalho social combinado (MARX,1978 apud ANTUNES, 20002, p.43), com trabalhadores de diversas partes do mundo participando do processo de produção e serviços. O autor conclui, constatando que, dessa forma a classe trabalhadora fragmentou-se, heterogeneizou-se e complexificou-se, com o surgimento de uma minoria composta por trabalhadores "polivalentes e multifuncionais", e uma massa de trabalhadores precarizados.

\section{Declínio do homem público}

O sociólogo Richard Sennett (1998) aborda a questão do domínio público, estabelecendo uma semelhança entre o declínio do Império Romano (fim da época de Augusto) e a atualidade, pelo esvaziamento do espaço público. Tendo a Res publica apenas como formalidade, o homem romano voltava-se para um compromisso privado místico, religioso, com o Cristianismo deixando de ser praticado em segredo e passando a ser um novo princípio de ordem pública. Hoje, o homem contemporâneo tem a vida pública como obrigação formal, numa espécie de concordância resignada. O autor estabelece, contudo, uma diferença a partir do significado da privacidade, pois, para os romanos, o princípio que se contrapunha era o da transcendência religiosa e, hoje, buscamos saber o que é autêntico em nossos sentimentos, tornando o estar a sós e com a família um fim em si mesmo e não como meio de se conhecer o mundo.

A sociedade, por sua vez, só faz sentido se convertida num "grande sistema psíquico" (SENNETT, 1998, p.17), com obsessão pelos aspectos pessoais, onde o líder político tem “credibilidade” pelo que é e não por suas ações, e a comunidade é percebida como ato de autodesvendamento mútuo. O autor avalia essa preocupação, apenas com suas próprias histórias de vida e emoções particulares, mais como uma armadilha do que como uma libertação; configurando uma imaginação psicológica da vida, chamada por Sennett de "intimidade”, conceito relacionado a aconchego, calor, coisas que a vida pública não pode dar, que torna o mundo exterior impessoal, fonte constante de decepção. Algo que estaria levando as sociedades de um estado voltado para o outro, para um tipo voltado para a interioridade, com o agravante de não se poder dizer o que há dentro. Isso gerou uma confusão entre público e íntimo, fazendo com que assuntos públicos, que deveriam ser tratados de forma impessoal, fossem tratados em termos de sentimentos pessoais.

Sennett (1998) aborda a relação entre capitalismo e domínio público, por meio de apanhado histórico, observando que a tentativa de controlar a ordem pública (que escapava do 
controle), do século XIX, gerou um trauma que deu lugar à proteção contra ela. Novas condições sociais geraram a busca romântica da personalidade e da auto-realização, atuando no sentido de erodir a vida pública, enquanto investimento balanceado de si mesmo, e também na deformação das relações íntimas. O autor (2004, p.21) observa que o narcisismo, entendido como obsessão com o que pessoas e acontecimentos significam para si, obscurece pelo filtro do "eu” a percepção das coisas (ou desenvolve apenas uma percepção das coisas), fazendo com que objetivos atingidos sejam sempre insatisfatórios. Trata-se, nas palavras dele, de uma "voraz introjeção nas necessidades do eu e bloqueio da satisfação". Soma-se a isso um processo de inversão, onde o indivíduo acusa-se por não sentir o bastante diante de um mundo exterior que o decepciona.

Aliam-se nesse processo uma "busca infrutífera de identidade composta de materiais vindos de dentro" (SENNETT, 1998, p.23), e o tratamento como "pessoa” entendido como troca mercantil de revelações íntimas. A possibilidade de se “relacionar” com acontecimentos e pessoas se iguala a um código para medir o outro em termos de espelho, e saber se as pessoas estão “abertas” umas para as outras; constitui-se, dessa forma, num disfarce para medir interação social em termos de permuta de confissões. Aqui consideramos plausível afirmar que, ao se afastar da construção coletiva de propostas comuns a RSE seria, em certos aspectos, uma manifestação de narcisismo empresarial.

As mudanças apontadas por Sennett (1998) começaram, sobretudo do XVIII para o XIX, por meio de uma dupla relação do capitalismo com a cultura pública, marcada, por um lado, pela pressão de privatização da sociedade burguesa e mistificação da vida material; e, por outro, pela mudança da crença quanto à vida terrena, com o código imanente substituindo o transcendente. As sensações e fatos imediatos passam a ser alvo das atenções, e qualquer circunstância ou sinal pode ser importante, o que gera dúvida sobre si mesmo e sobre o aparato cognitivo.

O autor (1998, p.44) afirma que essas duas forças teriam levado o sistema ao desastre, algo que não ocorreu pela prevalência da intimidade e negação do problema público. Uma resolução pela negação da existência, mecanismo que nos parece válido para entender o discurso da RSE.

\section{Corrosão do caráter}

Sennett (2007), na obra A Corrosão do Caráter, defende a tese de que, ao atacar a rotina e as burocracias rígidas, o novo formato flexível do capitalismo trouxe inúmeras vantagens, 
possibilitando aos trabalhadores organizar seu tempo e espaço de trabalho de forma personalizada, com mais autonomia para tomar decisões cotidianas, prestando contas de tarefas e participando de projetos em equipe. O autor observa, contudo, que esse saltar entre tarefas e equipes não tem contribuído para reforçar laços de solidariedade, deixando os trabalhadores cada vez mais sozinhos e sem perspectiva clara de sua carreira (cita Walter Lipmann e a origem inglesa da palavra, como trilha, caminho bem definido, estrada para carruagens).

Evitando um olhar nostálgico, aponta para os males da nova situação, que, segundo ele, não trouxe mais liberdade, mas sim um aumento da ansiedade, distinta do medo pelo fato de se referir a algo não definido com clareza. Em outras palavras, se antes o trabalhador tinha medo das punições ou da possível perda do emprego, em decorrência das suas realizações e do perfil da chefia, hoje há uma ansiedade difusa e permanente, uma vez que a manutenção do emprego não tem relação direta com o desempenho e os resultados; o trabalhador vive na iminência de mudanças bruscas, originadas em instâncias distantes e sobre as quais nem ele nem a chefia têm controle, pois estão situadas no âmbito dos movimentos de grandes corporações transnacionais, que controlam direta ou indiretamente a sobrevivência das empresas. Nesse contexto, não há autoridade visível. As chefias se ausentam e se isentam das responsabilidades, sendo consideradas facilitadoras das tarefas. Um mundo flexível e mutante que é atraente e desafiador para os patrões, mas que se mostra capaz de desnortear os funcionários, chamados de colaboradores. Para Sennett (2007), as experiências com tempo, lugar e trabalho do novo capitalismo "flexível” criam conflito entre caráter e experiência. O sucesso obtido com um comportamento flexível cobra como preço um enfraquecimento do caráter, ao divorciar vontade de comportamento, e afrouxar laços de confiança e compromisso. O autor observa, também, que há uma aparente paradoxal concentração de poder sem centralização, algo que se refere ao fato de que a descentralização não reduziu o controle sobre os empregados. Como manifestação concreta, Sennett lembra que boa parte das empresas americanas dá tarefas que podem ser cumpridas em horários flexíveis ou permitem um dia livre. O controle por meio da tela do computador, ligações e controle de e-mails, mostra que a estrutura institucional continua rígida.

Sennett afirma, ainda, que "Sem um sistema burocrático que canalize os ganhos de riqueza através de hierarquia, as recompensas gravitam para os mais poderosos” (2007, p.05) constatando que a flexibilidade acentua a desigualdade no mercado, que funciona na base do "vencedor leva tudo”, corroendo a confiança, internamente. Além disso, a ética do trabalho em equipe, que se presta à economia flexível, não tolera o conflito, com técnicas de 
administração que buscam fugir do aspecto "autoritário", mas fazem com que os administradores escapem da responsabilidade por seus atos. Esse quadro tem gerado um sentimento de fracasso mais profundo entre os trabalhadores, relacionado à sensação de um futuro não coerente, de não realizarção de algo valioso em si.

O autor conclui, abordando o que chama de "pronome perigoso", e afirmando que um lugar se torna comunidade, quando as pessoas usam o pronome "nós”, uma vez que a política depende da existência de um "nós” comunal. Como conseqüência não pretendida, o capitalismo moderno fortaleceu o valor do lugar e despertou o anseio da comunidade. Incertezas da flexibilidade, ausência de confiança e compromisso, superficialidade do trabalho de equipe e, sobretudo, o espectro de não fazer nada de suas vidas levam as pessoas a buscar outra cena de ligação e profundidade. Alerta, contudo, para o fato de que, muitas vezes, o "nós", no novo regime de tempo, tornou-se um desejo de comunidade defensivo (por exemplo, a rejeição a imigrantes e outros considerados marginais).

Sennett recorre a Lewis Coser ( autor de The functions of Social Conflict), para oferecer uma visão que considera mais realista de como as comunidades se mantém juntas. Lembra que, para esse autor, as pessoas são mais ligadas pelo conflito do que pela concordância verbal; um envolvimento que se deve, sobretudo, ao esforço conjunto, como ocorre, por exemplo, em negociações trabalhistas e diplomáticas. Percebe-se, dessa forma, a do conflito como comunidade, no sentido de que as pessoas aprendem a ouvir e responder umas às outras, mesmo quando as diferenças são sentidas de forma mais aguda. è uma visão que nos permite avançar no entendimento do discurso da RSE, que, pelo que observamos na análise do material empírico e revisão da literatura, enfatiza uma cooperação aparentemente superficial. Segundo Coser (1976, apud Sennett, 2007, p.171), a visão do “nós” comunal depende do reconhecimento das diferenças dentro da comunidade. O trabalho em equipe, contudo, não reconhece diferenças em privilégio ou poder, gerando uma forma fraca de comunidade, que supõe partilha de motivação comum, uma suposição que enfraquece a verdadeira comunicação. O autor lembra que a disputa e confronto verbal constante são a base mais realista para ligação entre pessoas de poder desigual ou com interesses diferentes. Portanto, mesmo que superiores tentem se esquivar, os subordinados devem buscar o confronto. Sennett evoca, ainda, a formulação desenvolvida por Paul Ricoeur “como alguém conta comigo, eu sou responsável por minha ação perante o outro” (1992, p.165-168 apud SENNETT, 2007, p.174), lembrando que, para sermos dignos de confiança, devemos ser necessários e, para tanto, o Outro tem de estar em necessidade. Afirma que os Senhores de 
Davos temem o confronto organizado, pois um regime que não oferece aos seres humanos motivos para ligarem uns para os outros não pode preservar sua legitimidade por muito tempo. Lembra ainda, que, se ocorre mudança, ela se dá no chão, entre pessoas que falam por necessidade interior, mais do que por levantes de massa.

\section{A cultura do novo capitalismo}

Sennett (2006) é crítico em relação ao novo mundo do trabalho e acredita que as mudanças organizacionais não libertaram, de fato, as pessoas. Ajuda-nos a refletir sobre a situação atual, ao estudar a fundo a nova arquitetura institucional, presente, sobretudo, nas indústrias de ponta (mas com grande impacto na cultura de negócios em geral).

Trata-se do que ele chama, referindo-se aos aparelhos pessoais de tocar música, de “empresas MP3”: Organizações flexíveis que podem selecionar e desempenhar, a qualquer momento, apenas algumas de suas possíveis funções e onde os elos da cadeia não são fixos. Assim como podemos ouvir músicas em qualquer sequência, esse tipo de organização se move por tarefas específicas e não por funções predeterminadas. São características marcantes desse tipo de empresa: sequenciamento não linear - o desenvolvimento linear é substituído por predisposição mental, capaz de permitir livre circulação; dessedimentação institucional funções passam a terceiros, há menos camadas na organização, que incha e se contrai, atraindo e descartando empregados, ao transitar entre tarefas; casualização - os vínculos internos têm curta duração, prolifera o trabalho temporário e contratos de curto prazo (o autor informa que, nos EUA, cerca de 1/5 da força de trabalho encontra-se nessa situação).

Esses três pilares institucionais encurtam o tempo operacional da organização, que se dedica a tarefas imediatas e de pequeno porte, e trazem conseqüências importantes para a vida do trabalhador._Assim como o laser do MP3, há, nessas organizações, uma unidade central de processamento, que estabelece tarefas, avalia resultados, promove expansão e encolhimento. Vários grupos atuam em paralelo, com recompensas “tudo-ou-nada”, carregando alto nível de estresse e ansiedade e tornando pouco clara a delimitação entre concorrentes e colegas.

Do ponto de vista psicológico, o indivíduo passa do medo (algo que se dá em relação a algo claramente definido) para a ansiedade (típica de situações ambíguas), uma vez que as reestruturações são movidas pelo mercado financeiro e não pelo funcionamento interno. No caso de uma fusão, por exemplo, os funcionários não têm a menor idéia do que irá acontecer, pois as decisões não estão relacionadas com a qualidade do seu desempenho na organização. 
O modelo fluido evoca mais possibilidade do que progresso. O indivíduo não possui posição e esta não tem conteúdo fixo. É ponto nodal (destituído de conteúdo), numa rede em permanente mudança e, como tal, precisa estar potencialmente apto a desempenhar inúmeras tarefas.

Sennett (2006, p.123-127) reflete também sobre a nova política do consumo, que estaria sendo gerada pela nova economia. Sugere que o cidadão, ao invés de ser percebido como eleitor indignado, poderia ser encarado como consumidor de política, pressionado a comprar, usando como referência o varejo, como cerne na nova economia. Cita o grupo WalMart, cuja receita corresponde a 2\% do PIB norte-americano, considerado por empresas de consultoria como um paradigma empresarial, com produtividade derivada de "permanente inovação gerencial”, ao concentrar todo poder no centro, tratar a massa de funcionários como temporários e provisórios, e atrair consumidores por oferecer tudo num só lugar.

A constatação de que, assim como na publicidade, o político tem procurado facilitar sua própria compra é uma resposta questionada pelo autor, para quem a nova economia torna complexos o marketing e a economia. Nesse sentido, podemos observar, pela análise dos textos das empresas, que se manifestam, ao menos na superfície discursiva, modificações recíprocas, que vão além de nova roupagem ou apropriação de linguagem entre os dois campos de atuação. Sennett lembra que o Wal-Mart oprime os empregados, mas satisfaz a necessidade real dos consumidores, que obtêm produtos de qualidade mais baratos. Por sua vez, a versão política da megaloja (que vivemos hoje) reprime a democracia local, mas, tal como a publicidade, faculta a fantasia individual, estimulando a imaginação para a mudança. O desafio é manter a mente aberta a respeito da comercialização dos políticos (algo considerado difícil pelo autor, para quem a perda da política mediadora parece fatal), pois, uma vez que a economia avança para modelos de ponta, os ideais políticos não podem ficar presos ao passado, para não se tornarem queixas impotentes.

Sennett (2006, p.127-137) lembra, ainda, que para certas versões do marxismo, a imaginação política era solapada pelas condições econômicas às quais os trabalhadores eram submetidos, afirmando que, hoje, esse postulado negativo vincula-se à vida cotidiana, em virtude do significado da palavra consumo. O fenômeno da paixão autoconsumptiva, onde o desejo ardente se esvai após o consumo, faz com que a imaginação intensifique-se na expectativa e debilite-se com o uso. Algo que a economia de hoje reforça no shopping e na política. As explicações do século XX para esse fenômeno seguiam duas trilhas: a demonização do marketing (cita Vance Packard, autor do livro The Hidden Persuaders e a 
eterna insatisfação gerada pelo “motor da moda”); e a responsabilização da obsolescência planejada (o mal situado na produção). O autor acredita que as duas têm méritos, mas pressupõem um consumidor passivo, ao passo que as mudanças no mundo do trabalho e busca do talento mostram que o envolvimento poderia ser bem mais ativo.

Como o trabalho é ponto nodal na rede, a questão é mais do que não estar satisfeito com o que tem, uma vez que as identidades do trabalho desgastam-se diante da constante reinvenção. Na busca do talento, as organizações valorizam capacitações portáteis, a capacidade de separar ação do contexto. O consumo de bens, por sua vez, complementa e legitima essas experiências, por meio do marketing da paixão autoconsumptiva, que é feito de duas maneiras: direta (pelas marcas) e sutil (pelo investimento de potência e potencial nas coisas).

A ênfase nas marcas tenta fazer com que produtos básicos pareçam únicos, com maneiras mais complicadas que o motor da moda de Packard. Em escala planetária de construção em plataforma, a tecnologia de produção permite mudanças rápidas, com aplicação de diferenças superficiais, chamadas pelos fabricantes de "laminagem a ouro". Soma-se a isso o fato de que o consumidor tem participação ativa no processo de amplificação das diferenças, assemelhando-se, com turista viajando por cidades clonadas, pois, para ele o estímulo está no processo do movimento. Vê, contudo, essa movimentação com uma ponta de otimismo

Olhando para frente, não seria melhor que os cidadãos pudessem votar pelo que poderia ser, votar numa imaginação compartilhada, em vez de votar para defender seus interesses particulares, para proteger o que já possuem? (SENNETT, 2006, p.139).

A potência é, por sua vez, consumida em equipamentos eletrônicos que nunca vamos utilizar integralmente. Algo que Sennett considera corporificado no iPod, máquina "conteúdo neutro”, que pode arquivar e reproduzir milhares de canções, sendo esse justamente seu atrativo: dispor de mais do que o consumidor jamais poderia usar. Apelo liga potência com aptidão potencial dos indivíduos. O autor afirma, que ao mobilizar o desejo de forma divorciada da prática, a celebração da potência oferece riscos para empresas e indivíduos, mas, por outro lado, iPods e outros produtos exercem atração positiva sobre a imaginação.

Sennett (2006, p.144-155) aborda, também, a relação entre cidadania e consumo, especialmente relevante para nossa pesquisa. A partir de comparações entre as iniciativas do Xerox Park e do Media Lab, o autor observa que o princípio de utilitarismo gangrena o espírito de inovação, e as jovens organizações tecnológicas, que preferem jogar com vagas possibilidades científicas a aderir a modelos mecanicistas de pesquisa, parecem, para Sennett, democráticas, uma 
vez que, no foro autenticamente democrático, todo cidadão deveria ter o direito de pensar em voz alta e debater com os demais, não importando sua condição de especialista ou não.

Em entrevistas com jovens líderes empresariais, que fizeram fortuna com tecnologia e semeiam dinheiro em causas ambientais e sociais, constatou que eles consideram o novo ideal de individualidade nos negócios como um modelo para o cidadão efetivamente dotado de poderes, o que não acontecia com o cidadão imaginado no capitalismo social. Contudo, para Sennett, esse sonho não tem fundamento. Usando como referência o teatro (compartilhado por consumo e política), o autor afirma que as novas instituições não gerarão políticas progressistas. Desenvolve sua argumentação, lembrando que o reino do consumo é teatral, uma vez que o vendedor como dramaturgo precisa contar com a crença no faz-de-conta, aspecto ao qual também se refere Baudrillard, para que o consumidor compre. A política não é menos teatral, mas o autor enfatiza que sua comercialização tem contornos negativos, mencionando o papel apassivador dessa ilusão de potência, e elencando cinco maneiras pelas quais o consumidor-espectador-cidadão é afastado para um estado mais passivo: 1) Convite a aprovação de plataformas de partidos, semelhantes às de produtos, num contexto de política consensual, onde conservadores e progressistas são movidos por interesses econômicos na direção de um terreno comum; 2) Diferenças laminadas a ouro, com plataformas políticas usando os expedientes da inflação simbólica de detalhes, e obsessão com traços individuais do político (gostos, valores, crenças), uma ênfase que, mais uma vez, divorcia poder da responsabilidade; 3) Esquecimento da "retorcida madeira humana”, uma vez que a impaciência com a realidade, que deveria ser progressista, transfere-se à impaciência com o outro; 4) Crédito dado a políticas de mais fácil utilização, uma vez que o cidadão-comoconsumidor pode distanciar-se, quando as questões políticas tornam-se mais difíceis ou resistentes, e, podemos acrescentar, levando em conta o que descreve a literatura a respeito do envolvimento com causas sociais, porque esse envolvimento dá trabalho, mexe na rotina, causa desconforto etc. Sennett afirma que a questão da comercialização da política é mais do que a queixa de que os superficiais saem melhor na telinha, mas abrange a forma pela qual é organizado o prestar atenção. A facilidade de uso, que faz sentido no mundo dos produtos físicos, é danosa à democracia, pois para esta é necessário esforço para descobrir como funciona o mundo ao seu redor. Quando a democracia é modelada pelo consumo, essa vontade desaparece; 5) Tendência a uma geração constante de novos produtos políticos em oferta, que indica falta de compromisso com orientação específica e solapa a confiança, algo que, para o governo, pode parecer aprendizado, o que não fica claro para o público. 
Sennett (2006, p.161) lê os problemas enfrentados em termos de consumo, observando que os dirigentes e eleitores comportam-se como consumidores de políticas. Empresas e governo agem no curto prazo, com súbitas guinadas, e geram ansiedade flutuante, desconfianças e mal-estar, que são transferidos para a esfera política, especialmente quando políticos progressistas se comportam como consumidores.

Observa, dessa forma, que a defasagem entre poder e autoridade, associada à cultura da vida institucional e à paixão autoconsumptiva, assim como conceito meritocrático de talento e individualidade idealizada são formas culturais que cultivam mudança pessoal, mas não progresso coletivo, o que decorre da maneira como essa cultura lida com o tempo (acontecimentos singulares, transações únicas x relação continuada e experiência acumulada). A partir dessa relação com o tempo, o autor propõe formas de lidar com essas situações.

Em entrevistas com trabalhadores, Sennett (2006, p.168) observou que as pessoas buscam uma âncora mental e emocional para lidar com essas mudanças no trabalho. Propõe, então, três valores que considera críticos nessa empreitada e nos parecem interessantes para discutir as ações de responsabilidade social das empresas.

O primeiro valor é a Narrativa. Em contextos culturais curtos e incertos, onde a experiência não se acumula, surgem tentativas de recuperar a conexão narrativa, de dar sentido à trajetória profissional e pessoal. O autor (2006) cita os exemplos, na Inglaterra e nos EUA, de instituições "paralelas", empenhadas em proporcionar continuidade e sustentabilidade inexistentes nas organizações flexíveis, que nos levam a repensar a natureza dos sindicatos. Enquanto os sindicatos conservadores concentram-se em determinada indústria ou especialidade, focam salário e condições materiais de trabalho, e não estão equipados para mudanças constantes de tipo de trabalho, a associação das Secretárias de Boston foca as necessidades comunitárias de mulheres e pais solteiros. Na Grã-Bretanha, os trabalhadores do setor de comunicações têm no sindicato uma espécie de agência de empregos, que paga pensões e assistência médica. São iniciativas que oferecem o senso de comunidade que falta no trabalho. Outra proposta, de que holandeses são pioneiros, é a partilha de empregos. A Holanda, assim como outros países europeus, sofre com o outsorcing (migração de atividades para países em desenvolvimento, em busca de menores custos). Foram criadas, então, redes de empregos, um sistema que divide trabalho disponível em metades ou terços; uma ferramenta útil na economia volátil, que gera um tipo especial de contexto narrativo. O fato de estar sempre trabalhando, reduz a ansiedade e sensação de inutilidade, e permite equacionar as relações família-trabalho com mais tranquilidade. Ainda 
no que diz respeito à narrativa, uma iniciativa que nos parece fundamental para qualquer tipo de transformação futura é a idéia de renda básica. Uma concepção que remete a Claus Offe e Van Pariij e propõe que todo habitante de um país contribui, direta ou indiretamente, na geração de sua riqueza, tendo, portanto, direito a uma renda mínima para fazer o que quiser. Dessa forma, todos poderiam comprar educação, cuidados de saúde e pensões no mercado aberto. Os impostos seriam utilizados para manter todos num padrão mínimo. Essa idéia tem sido aceita e implementada de diferentes maneiras, em diversos países. Na Inglaterra, por exemplo, uma criança, ao nascer, recebe uma quantidade de libras em uma conta aberta pelo governo, e pode utilizar o dinheiro ao completar 18 anos. No Brasil, o maior defensor desse sistema é o senador Eduardo Suplicy. Para deixar evidente que o problema não é de fácil solução, Sennett lembra que essas tentativas de recuperar o fio narrativo e dar às pessoas uma visão de longo prazo esbarram numa realidade dura: insegurança não é consequência indesejada, é ativada pelo novo modelo institucional.

O segundo valor abordado por Sennett é a Utilidade. Para o autor, sentir-se útil é contribuir com algo de importância para os outros; uma concepção que tem sido explorada pelas empresas com as ações de voluntariado. Nesse sentido, embora considere o voluntariado elogiável, Sennett acredita que essa vertente de entendimento pode reduzir utilidade a um hobby. Valores mais consequentes em matéria de utilidade foram encontrados em entrevistas com trabalhadores públicos e pessoas que realizam serviços domésticos não remunerados, na Inglaterra. Os funcionários públicos, embora criticados pela ineficiência das instituições, incompetência e possível incapacidade de competir no mercado privado, permanecem nos empregos, entre outros motivos, por uma questão de status. Uma palavra escorregadia para sociólogos, por vezes usada como sinônimo de esnobismo, mas cujo sentido mais profundo associa-se a legitimidade, a ser útil - fazer o bem e ser reconhecido publicamente. Uma vez que as instituições dos setores de ponta tentam se eximir das questões de autoridade e legitimidade, Sennett (2006, p.175) acredita que autêntica política progressista tentaria fortalecer o Estado como empregador, ao invés de lotear o serviço público entre privadas. Além disso, se pensarmos no Estado como fonte de atividade útil e legítima, é plausível propor que pessoas que desempenham tarefas úteis nas famílias, deveriam ser pagas pelo governo. E uma idéia que se associa à concepção de renda mínima, uma vez que o atendimento pessoal de todos os tipos, cuidados de idosos e jovens, por exemplo, constitui uma gigantesca fatia de tempo e esforço da economia doméstica, fundamental para a geração de riqueza do país, mas não remunerada. Sennett concluiu com a defesa da utilidade como 
valor a ser perseguido, afirmando que o culto da meritocracia não aliviará ansiedade e medo da inutilidade, uma vez que somos todos potencialmente inúteis.

O terceiro valor que vai de encontro à nova cultura do capitalismo é Perícia, considerado, pelo Autor, como o desafio mais radical e mais difícil de imaginar em políticas públicas. Genericamente, perícia pode ser definida como o desejo de fazer uma coisa bemfeita por si mesma, de acreditar no que se faz. Como observamos, a nova ordem no trabalho não satisfaz esse desejo. O mundo do trabalho é móvel demais para que o desejo de fazer bem feito possa se enraizar na experiência das pessoas. O sistema educacional, por sua vez, ao treinar para trabalho móvel, favorece facilidade a custa do aprofundamento. A perícia desafia a individualidade propensa à mudança, uma individualidade cheia de potencialidades, mas que, para Sennett (2006, p.178), carece de uma virtude cardeal: o compromisso. Como lealdade institucional, o compromisso é escasso nas novas organizações, uma vez que seria irracional comprometer-se com um ente que não se compromete com o trabalhador. É também difícil em matéria de talento. O desenvolvimento de uma aptidão, centrada em técnicas de solução de problemas, faz com que a pessoa se desligue de compromissos que estão além do seu controle. Fazemos aqui uma pergunta: o que está ao nosso alcance? Quais os limites de interferência e responsabilidade que poderiam ser trabalhados? Compromisso significa, também, abrir mão de possibilidades e oportunidades, algo difícil, diante da pressão da cultura que emerge para não perder oportunidades. Acompanhamos, diariamente, a rotatividade de jovens profissionais, especialmente em áreas de ponta, como tecnologia da informação. Em pleno desenvolvimento de um novo site para a Escola, um profissional desligou-se do processo, diante de uma proposta “irrecusável”. Não havia argumentos para convencê-lo a ficar. É claro que a questão financeira tem peso inegável, mas parece que o fenômeno a extrapola. Arriscamos, nesse caso, a partir das colocações de Sennett e da observação direta do ocorrido, uma explicação complementar. Pela lógica que move o mundo do trabalho, hoje, a obra realizada (o site, no caso) é muito menos importante do que o potencial demonstrado pelo profissional. É esse potencial, percebido pelas empresas, que possibilita saltar de um emprego a outro (a palavra tarefa seria mais adequada, visto que os vínculos empregatícios são tênues), obtendo melhores remunerações. Ao levantar o valor da perícia, Sennett explora o paradoxo do modo de vida cada vez mais superficial, uma cultura emergente que repudia o esforço e o compromisso, e do fato de que as pessoas só podem sentir-se bem ancoradas na vida, tentando fazer algo bem-feito. Convida-nos, diante disso, a duvidar do triunfo da superficialidade. 
As condições focadas por Sennett indicam que a versão de trabalho, talento e consumo da nova cultura do capitalismo não libertou as pessoas. As mudanças dizem respeito aos setores mais avançados da economia (boa parte das pessoas não trabalha em "empresas MP3”), mas exercem uma influência cultural acima dos valores numéricos. As capacitações pessoais que privilegiam a mobilidade de situação para situação, de problema para problema, equipe para equipe requerem um talento específico: a capacidade de pensar de maneira prospectiva sobre o que poderia ser feito, mediante o rompimento do contexto e das referências. Trata-se de um trabalho de imaginação com grandes perspectivas, quando bem feito; mas que, nas condições atuais, reduz a referência à experiência e às cadeias de circunstâncias, evita as impressões dos sentidos, separa a análise da crença e penaliza o esforço de aprofundamento. O cenário que Sennett constrói a respeito do mundo do trabalho será importante nesta pesquisa, sobretudo para o entendimento de como se constitui o lugar da fala, a comunidade discursiva da RSE. 


\section{CAPÍTULO 3 - NOSSA PESQUISA}

Tendo em vista que este estudo se propõe a explicitar os mecanismos de produção do discurso acerca da responsabilidade social e apresentar, sob os consensos aparentes, a heterogeneidade de sujeitos e vozes, optamos pela escolha de uma abordagem qualitativa, tendo como método a análise do discurso de linha francesa (AD).

O enfoque qualitativo favorece a consecução dos objetivos da pesquisa a partir do reconhecimento da realidade como multifacetada, bem como o objeto ou problema de pesquisa, enfatizando as inter-relações e a complexidade dos contextos.

Como descreve Godoy (1995, p.58-63), a pesquisa qualitativa parte de questões e focos de interesses amplos, que vão sendo refinados com o desenvolvimento do estudo; envolve dados descritivos sobre pessoas, lugares e processos, obtidos pelo contato direto do pesquisador com a situação estudada; e procura compreender os fenômenos, de acordo com a perspectiva dos sujeitos participantes, características que marcaram, com mais ou menos intensidade o desenvolvimento de nossa investigação.

Outra característica levantada pela autora que caracteriza nossa pesquisa como qualitativa é a utilização do enfoque indutivo, uma vez que não partimos de hipóteses estabelecidas à priori, mas de questões de interesse amplo, que se tornaram mais específicas no transcorrer da investigação.

Godoy (2005, p.81-84) levanta, também, pontos fundamentais a serem observados enquanto critérios de qualidade de pesquisas qualitativas, tais como: explicitação cuidadosa da metodologia, congruência entre diferentes etapas do estudo e possibilidade de transferência de resultados, e qualidade do registro dos dados. Recorre, ainda, à proposta de Lincoln e Guba (1985), que sugerem estratégias que garantam a credibilidade da pesquisa qualitativa, gerando resultados que sejam considerados dignos de confiança pelos próprios construtores da realidade social que está sendo observada, tais como: permanência no campo, uso de técnicas de triangulação, questionamento dos pares, checagem pelos participantes, entre outros.

Nesse sentido, embora os referenciais teóricos apontem para questionamentos profundos em relação à prática das empresas, este trabalho procurou entender o objeto de estudo, a partir das lógicas que o estruturam, para levantar as contradições e limitações existentes que sejam pertinentes para os sujeitos que constroem esse espaço discursivo, entre os quais os profissionais entrevistados. Foi realizada, também, como será descrito a seguir, uma tentativa de triangulação que, segundo Denzin (1977 apud GODOY, 2005, p.84), pode ser definida, de 
forma ampla, como a aplicação e combinação de várias metodologias de pesquisa no estudo do mesmo fenômeno, envolvendo quatro tipos básicos: múltiplas e variadas fontes de dados, pesquisadores, teorias e métodos.

Apresentamos, a seguir, os referenciais metodológicos, o percurso seguido e os procedimentos adotados por nosso trabalho, retomando os dois níveis propostos por Bosi (2003, p.50) para o trabalho científico, apresentados no tópico referente ao referencial teórico, a saber: orientação geral da pesquisa, "tendência teórica” que guia a investigação até a interpretação final dos dados; e técnica particular da pesquisa, o procedimento. Como ressalta a autora, os dois níveis (orientação geral e técnica particular) se cruzam durante todo o percurso, uma vez que "a tarefa do reconhecimento não se cumpre sem a escolha do campo de significação e sem a inserção das informações obtidas nesse campo” (BOSI, E. 2003:50) O encaminhar de uma questão revela a filosofia que subjaz ao trabalho.

\section{Referenciais teóricos para tratamento e análise dos dados \\ Dialética, dialogismo e enunciado}

Dentro da abordagem qualitativa, o método de análise desta pesquisa orienta-se, assim como os demais referenciais teóricos selecionados, por uma perspectiva dialética, referenciada pelas proposições de Mikhail Bakhtin.

Bakhtin (2003, p.395-410) entende o ser expressivo e falante, inesgotável em seu sentido e significado, como objeto das ciências humanas e, partindo do texto (refere-se especialmente ao texto verbal, oral ou escrito), propõe um movimento dialógico de interpretação, que se move para frente e para trás, resgatando as vozes do passado e tentando antecipar o contexto futuro. A dialética, para Bakhtin, nasce, portanto, do diálogo para retornar a ele em um nível superior, uma vez que “o texto só tem vida contatando com outro texto (contexto)” (BAKHTIN, 2003, p.401) e é esse contato que ilumina retrospectiva e prospectivamente, iniciando o texto no diálogo.

Por um processo de esquecimento paulatino dos autores, denominado monologização, permite a formação de textos únicos, mas não existe a primeira nem a última palavra, e não há limites para o contexto dialógico, que se estende ao passado e ao futuro, pois mesmo os sentidos do passado não se estabilizam e sempre mudam, ao serem retomados nos diálogos futuros. O autor lembra que existem, dessa forma, massas imensas e ilimitadas de sentidos esquecidos, que podem, serão relembrados e reviverão em forma renovada. 
Bakhtin (2004, p.44-47) afirma que existe ligação entre a ideologia e a realidade material do signo, associado a um sistema de comunicação social organizada, sistema que, por sua vez, está ligado às formas de sua base material (infraestrutura). Dessa forma, a partir dos signos podemos depreender as condições sociais às quais estão articulados. $\mathrm{O}$ autor lembra, ainda, que o signo (ideológico) reflete e refrata os seres, constituindo-se numa arena de confronto de interesses sociais, onde se confrontam índices de valor contraditórios. A classe dominante tende a conferir ao signo ideológico um caráter naturalizado, monovalente. Mas todo signo possui duas faces, que constituem sua dialética interna.

Nesta pesquisa, partiremos da proposição de Bakhtin (2003, p. 261) de que o emprego da língua efetua-se em forma de enunciados (orais e escritos) concretos e únicos, proferidos por integrantes de diferentes campos da atividade humana, sendo o enunciado o núcleo problemático essencial, meio pelo qual a língua integra a vida e a vida entra na língua. Para o autor, os enunciados refletem (acrescentamos que são constituídos por elas) as condições e finalidades de cada campo pelo conteúdo (temático), estilo de linguagem (seleção de recursos lexicais, fraseológicos e gramaticais) e, acima de tudo, por sua construção composicional.

Cada campo de utilização da língua elabora tipos relativamente estáveis de enunciados, denominados gêneros do discurso, que possuem grande heterogeneidade de tipos, mas podem ser agrupados em gêneros discursivos primários (simples), e secundários (complexos), que surgem nas condições de convívio cultural mais complexo. Para Bakhtin, os enunciados e gêneros discursivos são “correias de transmissão entre a história da sociedade e a história da linguagem” (BAKHTIN, 2003, p.268). Maingueneau (1997, p.35-38) lembra, ainda, que os gêneros encaixam-se uns nos outros, e os textos podem situar-se na intersecção de múltiplos gêneros, os quais variam segundo lugar e época.

Tomando o enunciado como a unidade real da comunicação discursiva, pois o discurso só pode existir de fato na forma de enunciações concretas de determinados falantes, Bakhtin (2003, p.272) ressalta sua natureza ativamente responsiva. Todo enunciado implica uma resposta, que pode não ocorrer imediatamente, mas ocorre cedo ou tarde (o autor destaca que os gêneros da complexa comunicação cultural foram concebidos para esse efeito retardado), nos discursos subseqüentes ou por meio do comportamento. Isso vale para o discurso escrito e lido, e torna todo falante um respondente em maior ou menor grau.

O autor (2003, p.275- 285) aponta três peculiaridades constitutivas do enunciado:

- A alternância de sujeitos do discurso, que define os limites de cada enunciado concreto, que, como réplica do diálogo, está disposto para a resposta do outro; 
- A conclusibilidade específica do enunciado, cuja inteireza é determinada por três fatores organicamente ligados: a exauribilidade plena ou relativa do objeto e do sentido; o projeto ou vontade de discurso do falante; as formas típicas composicionais escolhidas, que manifestam a vontade discursiva do falante pela escolha de gêneros de discurso, pois aprendemos a moldar nosso discurso em formas estáveis de gênero, e a comunicação discursiva seria impossível se estes tivessem que ser criados a todo o momento. O autor destaca que, embora flexíveis, os gêneros têm sentido normativo e, portanto, um enunciado singular, embora individual e criativo, não pode ser considerado uma combinação absolutamente livre de formas da língua;

- A relação do enunciado com o próprio falante (autor do enunciado) e com outros participantes da comunicação discursiva, sendo que a escolha dos meios lingüísticos e dos gêneros discursivos é determinada pelo elemento semântico-objetal, ligado ao objeto e ao sentido, e pelo elemento expressivo, que se refere à relação subjetiva emocionalmente valorativa do falante com o conteúdo do objeto e do sentido do seu enunciado. Enunciado neutro é impossível.

Para Bakhtin, as palavras e orações são neutras. “As palavras não são de ninguém, em si mesmas nada valorizam, mas podem abastecer qualquer falante e os juízos de valor mais diversos e diametralmente opostos dos falantes” (BAKHTIN, 2003, p.290), uma vez que não escolhemos palavras de forma lexicográfica, mas costumamos tirá-las de outros enunciados, sobretudo congêneres, e as colecionamos segundo sua especificação de gênero, do qual elas trazem ecos. O autor (2003, p.294-300) lembra, ainda, que para o falante as palavras existem em três aspectos: neutra, na língua; palavra alheia dos outros, cheias de ecos de outros enunciados; e minha palavra, em situação e intenção determinadas. Toda experiência discursiva individual ocorre em interação constante e contínua entre enunciados individuais, pelo processo de assimilação das palavras do outro (e não as da língua). Os enunciados, como elos da cadeia de comunicação discursiva, não se bastam em si mesmos. Bakhtin afirma que a expressão do enunciado é, por vezes, mais determinada pelo enunciado do outro sobre o mesmo objeto do que pelo conteúdo semântico-objetal. O enunciado é pleno de tonalidades dialógicas, sendo que as idéias se formam no processo de interação e luta com os pensamentos dos outros, por relações análogas às réplicas do diálogo.

O enunciado é um elo na cadeia da comunicação discursiva e não pode ser separado dos elos precedentes que o determinam tanto de fora quanto de dentro, gerando nele atitudes responsivas diretas e ressonâncias dialógicas (BAKHTIN, 2003, p.300) 
Outro traço constitutivo do enunciado é o seu direcionamento (ou endereçamento) a alguém. Todo enunciado tem autor e destinatário e cada gênero discursivo tem sua concepção típica de destinatário, que o determina como gênero. Nesse sentido, estilos neutro-objetivos pressupõem uma espécie de triunfo do destinatário sobre o falante, uma unidade de pontos de vista. Bakhtin (2003, p.331) destaca, contudo, que as relações dialógicas são amplas, diversificadas e complexas, e não podem ser reduzidas à contradição, discussão e desacordo; lembrando que a concordância, rica em variedades e matizes, é uma das formas mais importantes de relações dialógicas.

\title{
Análise do Discurso de linha francesa
}

Dialogando com a teoria de Bakhtin, utilizaremos como referencial para os procedimentos de análise o ferramental desenvolvido pela análise do discurso de linha francesa (AD).

\begin{abstract}
Julgamos preferível especificar a análise do discurso como disciplina que, em vez de proceder a uma análise lingüística do texto em si ou a uma análise sociológica ou psicológica de seu “contexto”, visa articular sua enunciação sobre um certo lugar social. Ela está, portanto, em relação com os gêneros do discurso trabalhados nos setores do espaço social (um café, uma escola, uma loja...) ou nos campos discursivos (político, científico ...) (MAINGUENEAU,1997, p.13-14).
\end{abstract}

Orlandi (2002, p17) ressalta que a $\mathrm{AD}$ considera a linguagem não transparente e procura entender o texto na sua opacidade, sendo que a questão da análise de discurso é: como este texto significa? O texto não é percebido como ilustração de algo, mas concebido em sua discursividade.

Maingueneau (1997, p.13) pontua que análise de discurso de linha francesa-AD relaciona-se com textos produzidos no quadro de instituições que restringem fortemente a enunciação; nos quais se cristalizam conflitos históricos, sociais etc.; que delimitam um espaço próprio no exterior de um interdiscurso limitado, o que se coaduna com as características de nosso objeto de estudo.

A AD também auxilia na compreensão do nosso objeto de estudo, por enxergar o contexto não apenas como um pano de fundo, que tem reflexos na elaboração dos discursos, mas sim como parte integrante deles. A AD formula as instâncias de enunciação em termos de "lugares”, enfatizando a preeminência e preexistência de uma topografia social, na qual os falantes se inscrevem. Segundo esse princípio, “cada um alcança sua identidade a partir e no interior de um sistema de lugares que o ultrapassa” (MAINGUENEAU, 1997 p.33).

Dentre os conceitos elaborados pela AD para o tratamento e interpretação de textos, destacamos, a seguir, aqueles que nos auxiliarão nesta pesquisa. 
Universo, campo, formação e espaço discursivo

A noção de formação discursiva, fundamental para nossa pesquisa, é utilizada na AD e foi introduzida por Foucault (1969, p.53 apud MAINGUENEAU, 1998, P.67) para designar conjuntos de enunciados relacionados dentro de um mesmo sistema de regras, historicamente determinadas. Tendo essa unidade em vista, abordamos as noções relacionadas de universo, campo e espaço discursivo.

Maingueneau (1997, p.116) define o universo discursivo como um conjunto finito, mas irrepresentável, e jamais concebido em sua totalidade pela AD. Trata-se de uma noção utilizada para recortar os chamados campos discursivos, constituídos por formações discursivas em relação de concorrência, que se delimitam por uma posição enunciativa em uma dada região. Ressalta, contudo, que o recorte é feito pelo analista a partir de hipóteses explícitas, não se tratando de partições espontâneas do universo discursivo. O autor (1997, p.117) define, ainda, um subconjunto do campo discursivo, que denomina espaço discursivo que liga pelo menos duas formações discursivas relacionadas e cruciais para a compreensão dos discursos considerados. Esse espaço é definido por decisão do analista, a partir de seus objetivos, e caracteriza-se pela forma (única) como as formações discursivas se opõem. Lembra, também, ainda que há oposições fundamentais para a constituição e preservação da formação considerada.

\section{Cenografia, dêixis e memória discursiva}

Na língua, "deixis" define coordenadas espaço-temporais implicadas em ato de enunciação, um conjunto de referências articulado pelo eu-tu/ aqui-agora. Na AD, a deixis discursiva, segundo Maingueneau (1997, p.41-42), refere-se ao universo de sentido que uma formação discursiva constrói através de sua enunciação, instaurando locutor e destinatário discursivos, cronografia e topografia. O autor menciona, ainda, a deixis fundadora, composta por situações de enunciação anteriores, que a deixis atual utiliza para repetição, retirando delas boa parte de sua legitimidade.

Orlandi (2002, p.128-129) lembra, ainda, que um acontecimento pode se inscrever em um tempo curto (representado pelo jornalista) de informações tomadas no cotidiano, dissolvendo a memória na atualidade, ou associar-se ao tempo longo (representado pelo historiador). Para AD, noção de memória discursiva diz respeito à existência histórica do enunciado, no interior de práticas discursivas reguladas por aparelhos ideológicos: como certos enunciados estão na origem de novos. No caso da repetição diacrônica de termos ou 
palavras, a autora ressalta que, mesmo que os enunciados sejam retomados literalmente, há deslizamento do Mesmo para Outro. Cita Deleuze (1988 apud ORLANDI, 2002, p.129), para afirmar que o Mesmo, que por voltar em outro lugar e tempo, é Outro.

\section{Ethos}

Para Maingueneau (1997, p.45-47), o discurso é inseparável de um ethos, que poderia ser entendido como uma "voz" (ethé na retórica antiga - o que os oradores revelavam pelo modo de expressão), associada a um caráter (conjunto de traços “psicológicos” atribuídos ao enunciador pelo leitor-ouvinte, por um processo de estereotipia "positiva”, no caso, que valoriza o enunciador) e a uma corporalidade (que remete a uma representação de corpo - não presença plena, oferecida ao olhar, mas uma espécie de fantasma induzido pelo destinatário). Acrescenta que ao ethos corresponde um anti-ethos. Além disso, o coenunciador não é apenas alguém a quem se propõem idéias, mas que tem acesso ao dito através de uma “maneira de dizer”, enraizada em uma “maneira de ser”. Essa noção será especialmente importante para a análise do mecanismo de construção de uma “voz” empresarial modelar, difundida pelo DRSE.

\section{Prática e comunidade discursiva}

Maingueneau (1997, p.50-55) chama a atenção para a comunidade que a enunciação de uma formação discursiva pressupõe. A relação do discurso com a topografia social não é, contudo, direta. O grupo associado ao discurso não é intermediário transparente, mas constitui um campo, nos termos de Bourdieu, com regras e mecanismos próprios. Maingueneau propõe, então, a noção de processo Discursivo, que integra a formação discursiva e a comunidade discursiva, grupo ou a organização de grupos no interior dos quais os textos são gerados. Destaca, porém, que se trata de grupos que existem unicamente por e na enunciação, e não de grupos que encontram sua razão de ser em outro lugar.

\section{Heterogeneidade e polifonia}

O discurso é heterogêneo e composto de várias vozes em diálogo, como vimos, a partir de Bakhtin. Destacamos, aqui, a heterogeneidade mostrada no texto, mais especificamente, a polifonia, que existe para Ducrot (1987 apud MAINGUENEAU, 1997, p.76-77), quando é possível distinguir em uma enunciação dois tipos de personagens: os enunciadores e os locutores. Locutor é o ser apresentado como responsável pelo enunciado, uma ficção discursiva que não coincide necessariamente com o produtor físico. O Locutor pode se desdobrar, distinguindo-se, para Ducrot, em “o locutor propriamente dito”, definido como responsável pela enunciação e considerado apenas em função dessa propriedade; e “o locutor 
enquanto pessoa do mundo”, que pode possuir outras propriedades além dessa. O enunciador, por sua vez, representa para o locutor, de certa forma, o papel que o personagem representa para o autor de ficção. Os “enunciadores” são seres cujas vozes efetivamente não falam, mas a enunciação permite expressar seu ponto de vista. Já o "locutor” pode pôr em cena posições diversas da sua, em seu próprio enunciado.

\section{A relação polêmica}

Maingueneau (1997, p.125) afirma que, para definir sua identidade, a formação discursiva só pode traduzir como “negativas” as unidades de sentido construídas por seu Outro. Além disso, para preservar sua identidade, o discurso só pode relacionar-se com o Outro através do simulacro que dele constroi. Instauram-se, dessa forma, um Discurso agente ("tradutor" e construtor do simulacro) e um Discurso paciente (que é traduzido), sendo que em uma polêmica os papéis se alternam constantemente. A polêmica pode ser dar por confronto ou indiferença. $\mathrm{O}$ autor lembra que, se um $\mathrm{D}$ parece indiferente à presença de outros, é porque, semanticamente, lhe é crucial denegar o campo do qual depende e não poderia desenvolver-se fora dele. O exercício da polêmica presume partilha de um mesmo campo discursivo e leis associadas.

\section{Paráfrase e polissemia}

Orlandi (2002, p.36-45) lembra que os sujeitos “esquecem” o que já foi dito para, ao se identificarem com o que dizem, se constituírem como tal. O funcionamento da linguagem se assenta na tensão entre processos parafrásticos e polissêmicos (o mesmo e o diferente), entre o que se mantém (paráfrase), e o deslocamento, ruptura de processos de significação (polissemia). Incompletude é condição da linguagem: nem sujeitos, nem sentidos, logo, nem o discurso estão prontos e acabados. A autora coloca que a paráfrase é a matriz do sentido, pois não há sentido sem repetição; enquanto a polissemia é fonte da linguagem e condição de existência dos discursos, pois, se os sentidos e sujeitos não fossem múltiplos não haveria necessidade de dizer.

Nós

Referindo-se à instância do locutor e desdobramentos, Brandão recorre a Benveniste (1966 apud BRANDÃO, 1998, p.51), para abordar o marcador dêitico de pessoa “nós”, que denuncia sua complexidade embutida. Para Benveniste, “nós” não é apenas pluralização, mas 
implica junção entre eu e não-eu, permitindo uma flutuação semântica entre um nós-inclusivo, ,que se refere ao eu + você (correlação de subjetividade); e um nós-exclusivo, que se refere ao eu+ele (formas que se opõem como pessoal ou não pessoal), obtendo um efeito de objetividade e distância em relação ao você.

\section{Articulação discurso e sociedade.}

Maingueneau (1997, p.188) ressalta que o sentido e a linguagem são uma dimensão constitutiva das relações econômicas e sociais. Orlandi (2002, p.47-49), por sua vez, propõe uma noção de ideologia, não como ocultação, mas como função da relação necessária entre linguagem e mundo, afirmando que a língua, como sistema sintático (passível de equívoco e sujeita a falhas), deve inscrever-se na história para construir os sentidos, fenômeno que constitui a discursividade. Nesse sentido, o sujeito discursivo é uma posição entre outras. Não constitui uma forma de subjetividade, mas um "lugar" que ocupa para ser sujeito que diz (Foucault, 1969 apud ORLANDI, 2002, p.49).

A partir das referências explicitadas e outras que surgirem ao procedermos a análise do material coletado, visamos, em linhas gerais, levantar no DRSE aspectos relativos a: heterogeneidade de vozes que nele dialogam; a constituição dos lugares instaurados e a configuração da prática discursiva; e as tensões e reconfigurações interdiscursivas, uma vez que formação discursiva constitui-se em relação com outras formações com as quais dialoga e que atravessam o seu campo. O objeto da análise é a zona de contato, que delimita e constitui a formação discursiva, sob o primado do interdiscurso. (BRANDÃO, 1998:126 e 127)

\section{Percurso da pesquisa}

O projeto original do Doutorado previa a análise do discurso das empresas, focando a forma pela qual a linguagem publicitária empresarial aborda os conceitos envolvidos e como são caracterizados os sujeitos das ações de responsabilidade social empresarial. Como primeiro passo na construção da pesquisa, cursamos três disciplinas (em 2005 e primeiro semestre de 2006), que resultaram em textos que constituem a base de capítulos da tese. Após a primeira disciplina, que apresentou referencial teórico e ferramental de análise de comunicação, a trajetória descolou-se desse campo, para buscar aportes em outras áreas do conhecimento, com disciplinas cursadas na Filosofia-USP e na FAU-USP, o que possibilitou leituras de autores marcantes como Florestan Fernandes, Michel Foucault e Hannah Arendt, entre outros. Diálogos ricos mostraram a complexidade da luta por um espaço público 
deliberativo igualitário, com a incorporação generalizada de uma ótica gerencial que, a partir de consensos superficiais, parece esvaziar o político e enfatizar o técnico, sobretudo levandose em conta uma trajetória histórica marcada pela escravidão, e relações de privilégio e exploração. A motivação de resgatar grandes narrativas e esperanças de transformação levou a leituras que resgatam experiências massacradas de mudar essa histórica relação de forças, como os quilombos e a experiência de Canudos; ou, ainda, a busca de raízes solidárias nos Parceiros do Rio Bonito, de Antonio Candido, que detalha as bases de uma cultura solidária caipira. A essas leituras associam-se tentativas mais recentes de demonstrar as possibilidades de cooperação e humanização no contexto capitalista atual, como a Cultura solidária de Paulo de Salles Oliveira, a economia solidária de Paul Singer, as visões processuais de cultura de Bosi, cotidianas, táticas de De Certeau. Ainda entre outras, como proposta de Renda Mínima do senador Eduardo Suplicy; e leituras somadas ao entendimento da cultura do novo capitalismo, proposto por Richard Sennet.

\section{A proposta de guinada e o ajuste do orientador}

Fermentada durante o $2^{\circ}$ semestre de 2006 pelas reflexões detalhadas anteriormente, elaboramos uma vontade de tomar partido, de “mudar de lado"; uma guinada do projeto original do Doutorado. Passamos da análise do discurso das empresas para a análise da forma como o discurso das empresas interfere na percepção que os beneficiários dos projetos sociais empresariais têm de conceitos fundamentais como cidadania e direitos, uma vez que esses termos permeiam a comunicação de RSE das empresas. Algo que nos parecia muito mais rico para o entendimento do tema e muito mais motivador.

Levamos a proposta ao orientador e recebemos o questionamento pertinente. Não seria exigir demais do discurso das empresas a forja de conceitos? Não estariam esses conceitos sendo (re) elaborados por um conjunto de interações, envolvendo as comunidades, a mídia e vários outros fatores sócio-culturais. E mais. A resposta associava-se à percepção, ditada pelo tempo e pelas nossas limitações, de que este trabalho não daria conta, onipotente, de tanta coisa.

Por outro lado, destacou-se a riqueza do material documental já coletado, e o fato de que a ancoragem histórica e o novo jogo de referenciais teóricos, esboçados nos trabalhos das disciplinas, já seriam, além de pilares úteis para o doutorado, contribuições em si para o entendimento do assunto tratado. Chegamos, então, a uma proposta que visava conjugar as limitações e vontades do trabalho e que pudesse contribuir, com consistência e originalidade, para a análise da RSE: associar a análise do discurso emitido pelas empresas a um trabalho de 
campo, junto a um grupo de beneficiários, e perceber as reverberações do discurso das empresas, assim como as possibilidades da construção de um novo discurso, com novos significados para cidadania e direitos.

Ajustes da Banca de Qualificação

O estudo previa duas etapas, sendo que a primeira focaria o discurso das empresas, e a segunda, em diálogo com a primeira ofereceria reverberações desses discursos junto a pessoas que se encontram entre os públicos atendidos por uma das empresas. Diante das orientações da Banca, realizada em outubro de 2008, que enfatizaram a dificuldade em cumprir a tarefa proposta, optou-se, enfim, por restringir a pretensão do trabalho ao primeiro objetivo, com o acréscimo da realização de entrevistas com profissionais envolvidos com a RSE, que não estavam originalmente previstas.

\section{Material empírico originalmente selecionado}

- Anúncios publicitários: 47 anúncios, veiculados na Revista Carta Capital. Levantamento realizado em todas as 50 edições publicadas no ano de 2006 da edição 375 (11/jan2006) até a edição 425 (27/dez/2006).

- Matérias jornalísticas: Clipping de matérias a respeito de RSE, veiculadas na mídia impressa. A partir do serviço de Clipping da Biblioteca da ESPM, que abrange os veículos: Folha de São Paulo, O Estado de São Paulo, Veja, Época, Época Negócios, Exame, Meio \& Mensagem, Revista Marketing. Foram selecionadas, a princípio, 44 matérias jornalísticas que abordaram a RSE, durante o ano 2006.

- Publicações de entidades empresariais: Textos das entidades mais representativas, definidas a partir da revisão da literatura a respeito do tema: Publicações brasileiras; Publicações do Instituto Ethos; Coleção Investimento Social do IDIS - Instituto para o Desenvolvimento do Investimento Social; Publicações do GIFE - Grupo de Institutos Fundações e Empresas; Publicações internacionais; Business in the Community BITC (Inglaterra); Relatório The Business Case for Corporate Social Responsability; Business for Social Responsibility BSR (EUA); Rede Corporate Social Responsibility Europe

- Material descritivo de projetos: Documentos enviados pelas 23 empresas concorrentes ao $4^{\circ}$ Prêmio Marketing Best, edição de 2005. Os documentos 
oferecem a descrição dos projetos, seus objetivos e referências norteadoras, bem como resultados alcançados.

A partir das orientações da banca, esse conjunto foi revisto, com a inserção de entrevistas com profissionais de empresas e seleção de objetos empíricos, que tornassem a pesquisa factível, uma vez que a amplitude do material coletado, associada à pretensão original de fazer um “mapa” do discurso das empresas, mostrou-se não operacional.

\section{Ajustes finais e material empírico trabalhado}

Após um contato mais detalhado com o material coletado, optou-se por suprimir a análise de anúncios e ampliar a coleta de matérias jornalísticas, de modo a cobrir, de forma mais exaustiva, o período de 2006 a 2007, constituindo o que chamamos preliminarmente de "précorpus”. A idéia era dar a esse conjunto de textos um tratamento qualitativo mais simples, de modo a estabelecer uma configuração semântica do campo e levantar os primeiros elementos de uma configuração discursiva da RSE, que serviria de "lastro" para a análise de discurso propriamente dita; esta seria feita a partir dos balanços sociais das empresas, e entrevistas realizadas com executivos envolvidos com as ações de responsabilidade social nas empresas. O entendimento mais aprofundado das características do discurso, em especial as questões levantadas por Maingueneau (1997, p.112-118) quanto à definição das formações discursivas, a partir do interdiscurso, como um "processo de reconfiguração incessante”, (o que) torna pouco frutífera a tentativa de fazer um mapa ou configuração estanque, que sirva de lastro a análises específicas posteriores. Tal entendimento nos levou a reelaborar a proposta, utilizando as diferentes fontes de dados de forma complementar.

Antes de passar ao material analisado e aos procedimentos efetuados, consideramos válido registrar, aqui, um resumo da trajetória seguida, que, a partir da abrangência das áreas do conhecimento envolvidas na questão da responsabilidade social das empresas, associada à pretensão de dar conta de tudo, foi gradativamente rumando para objetivos mais factíveis e menos difusos. Acreditamos que partir de algo mais fechado, em termos de intenção de pesquisa, seria certamente menos penoso. Contudo, se foco inicialmente mais abrangente acentuou, por um lado, as limitações do trabalho, revelou-se, por outro, um caminho compatível com o objeto de estudo, e rico para nosso crescimento acadêmico 


\section{Material empírico selecionado, procedimentos e justificativas}

Do material originalmente coletado, selecionamos três grupos de dados a serem trabalhados, com as justificativas aqui sintetizadas. Dentro do objetivo de compreender a dinâmica discursiva dos discursos empresariais, optamos por uma tentativa de triangulação feita no "interior" do método (AD), que, conforme Lincoln e Guba (1985 apud GODOY, 2005, p.84), envolve a replicação do estudo, com o objetivo de verificar sua confiabilidade, complementando dados de entrevistas com técnicas de observação ou exame de documentos.

Dessa forma, optamos por analisar os seguintes grupos de dados: um conjunto amplo de matérias jornalísticas, cobrindo os anos de 2006 e 2007; os balanços sociais de uma empresa com papel destacado no âmbito da RSE, de forma longitudinal (entre 2002 e 2007); e 5 entrevistas semi-estruturadas, com profissionais de grandes empresas com destacada atuação em RSE.

Cada grupo de dados foi tratado e analisado com o ferramental de $\mathrm{AD}$, que se mostrou pertinente a partir do contato com o material coletado. Não houve, portanto, uma prédeterminação dos procedimentos específicos (que serão detalhados no capítulo dedicado às análises), mas a escolha, dentro dos limites da $\mathrm{AD}$, de ferramentas que permitissem um contato mais produtivo com o material. Após a obtenção das conclusões parciais, a partir dos três conjuntos de dados, fazemos algumas breves considerações gerais, a partir da noção de formações e espaço discursivos.

\section{Matérias jornalísticas que abordam a responsabilidade social empresarial}

A partir da coleta inicial, feita diariamente entre 2005 e 2008, fizemos um recorte, definindo o período escolhido (anos de 2006 e 2007), a princípio, por conveniência, uma vez que o volume geral do material e a inserção dos textos relativos a 2008 inviabilizariam a realização da pesquisa em tempo hábil. A escolha, contudo, mostrou-se adequada para a análise, por focar o período em que o termo sustentabilidade ganhou força na pauta midiática do termo sustentabilidade, conforme informado por um dos entrevistados, e indicado pela troca do nome de uma das publicações de referência no meio empresarial, o Guia Exame de Boa Cidadania Corporativa, que passou a se chamar Guia Exame de Sustentabilidade a partir de 2007. No final de 2008, a coleta foi checada e complementada, com a colaboração da equipe do serviço de clipping da ESPM, totalizando 126 textos do ano de 2006 e 105 de 2007, que foram reduzidos, após refinamento em função do tema de estudo, para cerca 170 textos, em dois anos. 
Foram coletados todos os artigos com referências à responsabilidade social (ou termo correlato) no título, a partir de consulta diária, realizada pela equipe da Biblioteca da ESPM, e enviada na forma de clipping a todos os professores e funcionários, para uso acadêmico.

Os veículos consultados compõem um panorama representativo da mídia impressa (e respectivas versões on-line) no eixo Rio- São Paulo, a saber: O Estado de S. Paulo, Folha de S. Paulo, DCI, Gazeta Mercantil, Valor Econômico, Jornal do Brasil, O Globo, entre outros, cuja consulta não é diária; incluindo os jornais estrangeiros: The New Tork Times, International Herald Tribune, Financial Times, Le Monde, Le Figaro, El Pais, Clarin, Expansión, La Nación , El Mundo. Além dessas publicações a busca inclui títulos com foco em marketing e comunicação mercadológica.

A escolha das matérias jornalísticas justifica-se, sobretudo pelo papel central que os meios de comunicação têm na construção de representações amplamente aceitas na sociedade, como apontam Chauí (2006) e Debord (1997), entre outros autores, ao abordar a construção de simulacros midiáticos. Na consulta a literatura, esse papel foi reiterado pelos trabalhos de Lisenberg (2006), que foca a inserção da imprensa no discurso do terceiro setor; Barros (2007), que analisou a cobertura dada à vigilância sanitária, em quatro jornais de circulação nacional; e Santa Cruz (2006), que caracteriza a epresentação midiática do discurso da RSE como “palavra de ordem”, no sentido proposto por Gilles Deleuze e Félix Guattari.

Rossy (2006), em dissertação de Mestrado, faz a análise das rotinas de agendamento na mídia, promovidas por três organizações do Terceiro Setor Teoria do Agenda-Setting de McCombs e Shaw (1972). As ONGs transformam-se, dessa forma, em fontes permanentes para as matérias jornalísticas, mas, apesar do clima amigável, convivem com a necessidade de criar “pseudo-acontecimentos” e “eventos programados”, para inserção na agenda midiática. Procedimento chamado pela autora de “co-participação”.

\section{Balanços sociais}

A partir do conjunto de documentos originários de empresas e associações empresariais coletados, optamos por selecionar uma seqüência longitudinal de balanços sociais de uma grande organização, como um dos objetos empíricos de análise. O critério preliminar de seleção levou em conta o destaque mercadológico da empresa, selecionada entre as mais premiadas no Guia Exame de Cidadania Corporativa (atualmente, de Guia de Sustentabilidade). A opção pela análise de uma seqüência histórica de documentos de uma mesma empresa partiu de sugestão de profissional que presta consultoria na área de 
responsabilidade social, e foi realizada por possibilitar a observação de deslizamentos semânticos, já evidenciados nos títulos dos documentos (de Relatório Social, em 2002, para Relatório de Sustentabilidade, em 2007), e também pelo fato da empresa disponibilizar todos os documentos do período na internet. Somou-se a isso a realização de entrevista com representante da empresa, o que possibilitaria inter-relações com os dados coletados.

A escolha justifica-se, também, pelo fato dos balanços (ou relatórios) sociais se configurarem, a partir da literatura, das matérias jornalísticas e das entrevistas, como uma ferramenta de comunicação que vem ganhando relevância entre as empresas que praticam ações de RSE, e, ainda, pela característica de concentrarem, num só documento, uma visão abrangente dos conceitos e ações das empresas a respeito do tema. Matéria da revista Carta Capital (edição de novembro de 2006) indicava que mais de 5 mil empresas no mundo elaboravam o documento e que, segundo pesquisa de José Antonio Puppim de Oliveira (FGV/RJ), que avaliou balanços sociais das 500 maiores não financeiras listadas pela FGV, no biênio 2003/04, 58 entre 100 apresentaram relatórios sociais. Outro dado que mostra a relevância do documento é a existência, desde 2001, do Prêmio Balanço Social, promoção conjunta de ABERJE (Associação Brasileira de Comunicação Empresarial), APIMEC (Associação dos Analistas e Profissionais de Investimento do Mercado de Capitais, FIDES (Fundação Instituto de Desenvolvimento Social e Empresarial), IBASE (Instituto Brasileiro de Análises Sociais e Econômicas), SEBRAE (Serviço Brasileiro de Apoio às Pequenas e Micro-empresas) e Petrobras. Na literatura consultada, Koerich (2003) enfatiza o Balanço Social como instrumento capaz de evidenciar a materialização da responsabilidade. Souza, Dreher e Amal (2007), por sua vez, observam que é crescente o número de organizações que, no sentido de não perder competitividade, procuram conformidades e normalizações relativas à responsabilidade socioambiental (RSA), reconhecidas em escala global. Esse aspecto corrobora a pertinência de optar pela análise dos documentos de uma única organização ao longo do tempo, uma vez que os relatórios de diferentes empresas tendem a ficar semelhantes, em virtude do alinhamento com padrões internacionais de apresentação dos dados.

\section{Entrevistas}

Sugeridas na banca de qualificação, as entrevistas constituíram-se no último conjunto de dados a ser coletado, em parte pela dificuldade de agendarmos horários com os profissionais das empresas, em parte por nossa resistência inicial em realizá-las. Uma resistência devida, sobretudo, à premissa de que os profissionais das empresas repetiriam os 
discursos institucionais registrados nos documentos, nas matérias jornalísticas e em outros textos de organizações e associações de empresas. Tal premissa revelou-se, contudo, equivocada, uma vez que o conjunto de entrevistas constituiu-se em material importante, sobretudo para entender como o discurso é construído dentro da empresa e quais as coerções que o ambiente e as relações de trabalho impõem ao seu desenvolvimento.

O critério para a seleção das empresas foi o reconhecimento das ações sociais da empresa no âmbito mercadológico, sendo, inicialmente selecionadas as 13 empresas mais premiadas no Guia Exame de Cidadania Corporativa (atualmente de Guia de Sustentabilidade) e, posteriormente, incluídas mais 4 (também premiadas e com trabalho reconhecido na mídia). A solução se deu, a partir do contato com uma profissional que presta consultoria na área de responsabilidade social. Ressaltamos que esse contato foi decisivo para a efetivação das entrevistas, uma vez que as cinco entrevistas realizadas foram com pessoas indicadas por essa profissional, que nos ofereceu e-mails e números telefônicos para contato direto com os profissionais e, em alguns casos, indicação pessoal.

Aos possíveis entrevistados foram enviados, por e-mail, um Termo de Consentimento e questionário preliminar (apêndice). Foram contatados (por e-mail e ligação telefônica) 17 profissionais de empresas que desenvolvem ações de RSE. Além da dificuldade generalizada para o agendamento das entrevistas, chamou a atenção o procedimento de uma empresa, ranqueada como uma das mais responsáveis em termos socioambientais. Após várias tentativas, a pessoa responsável pelos contatos com a academia estranhou o fato de que seria mantido sigilo a respeito da identidade da empresa. Informou que isso dificultaria o "apoio” à pesquisa, que costumava ser concedido a pesquisas que identificam a empresa e são previamente avaliadas pelo departamento de comunicação, antes que a publicação seja autorizada, após o que desistimos de insistir na realização da entrevista. Acreditamos que tal estranhamento tenha relação com o fato de que os trabalhos mais comuns envolvem a descrição de cases empresariais, normalmente identificados e aprovados pela empresa, antes de sua publicação. Contudo, chama a atenção a estrutura montada, a percepção da entrevista como “apoio", e o controle da comunicação, que caracterizam a percepção do público acadêmico e de suas publicações como uma potencial ferramenta de comunicação mercadológica.

Foram, após um processo que durou cerca de quarenta e cinco dias, agendadas 5 entrevistas com profissionais de grandes empresas, reconhecidas pelo mercado como 
exemplos de conduta em termos de responsabilidade social e ambiental. As entrevistas foram gravadas, transcritas e interpretadas com o ferramental de análise do discurso.

Descritos os objetos empíricos selecionados, o trabalho de análise, cujos resultados serão apresentados no próximo capítulo, pode ser assim resumido, numa trajetória que procura avançar, como propõe Orlandi (2002, p.77), da análise da superfície textual para a estrutura mais profunda, passando pelo discurso:

- Tratamento e análise de um conjunto representativo de textos jornalísticos, com ênfase na mídia especializada em negócios, com ferramental de AD.

- Análise longitudinal de documentos (balanços sociais) de empresa com ações de responsabilidade social reconhecida pelo mercado, com ferramental de AD.

- Análise das entrevistas realizadas com 5 profissionais de empresas com ações de responsabilidade social reconhecida pelo mercado, com ferramental de AD.

- Considerações gerais sobre as estruturas de poder dos universos de discurso e semântica profunda.

- Breves considerações gerais sobre a análise realizadas: a oposição de formações discursivas no âmbito da RSE. 


\section{CAPÍTULO 4 - NOSSA ANÁLISE}

\subsection{Análise de textos jornalísticos}

Destacamos, inicialmente, que, para proceder à análise, separamos do material coletado pelo serviço de clipping que colaborou com a pesquisa apenas as matérias jornalísticas (oriundas de meios impressos e eletrônicos), sendo excluídos os artigos científicos (tratados como literatura) e publicações empresariais. Os trechos selecionados dos textos são aqui apresentados por números, que permitem localizar fontes e fragmentos, ampliados no apêndice.

Quanto às justificativas em relação à escolha do material como representativo para o entendimento do DRSE, acrescentamos, aos motivos levantados no capítulo anterior, dados obtidos em uma das matérias jornalísticas coletadas (Rev. Negócio da Comunicação, SP, ano 4, n. 23 - p. 12-20, 2006), que descreve a responsabilidade social como um dos segmentos de conteúdos na mídia com maior potencial de crescimento, elencando uma série de cadernos e suplementos que tem obtido bons resultados comerciais e de público, tais como: Empresa\&Comunidade, do jornal Valor Econômico (desde sua fundação, em 1999); Prêmio Valor Social (com Instituto Ethos); Guia de Boa Cidadania Corporativa - Exame Abril, desde 2000; Razão Social, encarte do jornal O Globo, desde 2003; programa Balanço Social, da TV Cultura, desde 2000; e Revista mensal do Centro de Estudos em Sustentabilidade da FGV, desde 2005. Assim como a movimentação entre as agências de publicidade, com a criação de departamentos especializados em responsabilidade social, pelas do Grupo Ypy Africa, DM9DDB, MPM, Loducca, Eugênio e Tudo; e a unidade especial do Grupo Full Jazz, denominada The Key, desde 1999

A análise do conjunto de textos jornalísticos parte de algumas considerações sobre o gênero de discurso em que se inserem, pois, como lembra Bakhtin (2003), os enunciados, embora singulares, não podem ser considerados como combinações absolutamente livres de formas da língua. Tal colocação é complementada por Maingueneau (1977, p.38), para quem o fato de enunciados recorrerem a um determinado gênero e não a outros é tão constitutivo da forma discursiva, quanto o “conteúdo”. Os textos coletados estão submetidos, portanto, a coerções e regras próprias do gênero jornalístico.

Estrutura discurso jornalístico.

O discurso da RS no âmbito jornalístico submete-se à lógica própria desse gênero, que, em linhas gerais se relaciona ao quadro descrito por Chauí (2006, p.5-12), ao abordar, a 
partir de Debord, o aspecto espetacular da mídia, que deixa de se referir ao acontecimento, mas à encenação do acontecimento, ao seu simulacro; assim como as colocações que a autora faz, recorrendo a David Harvey, para quem a condição pós-moderna é marcada por uma compressão espaço-temporal (aqui e agora), que coloca o cidadão no lugar de um "infatigável olhador de imagens”. No âmbito específico das ações sociais, podemos dizer que o discurso da responsabilidade social é, de certa forma, traduzido para o gênero jornalístico, como podemos observar nos trabalhos de Reginatto sobre o poder da mídia para "pautar questões de relevância social” (REGINATTO, 2007, p.120); Santa Cruz (2006), que identifica o fenômeno de um “jornalismo do bem”; e Rossy (2006), que descreve como as ONGs transformam-se em fontes permanentes para as matérias jornalísticas, mas convivem com a necessidade de criar "pseudoacontecimentos” e “eventos programados”, para inserção na agenda midiática.

Há, contudo, uma importante sintonia entre o discurso jornalístico e o discurso das empresas (percebido pelo seu viés mercadológico). Como destaca Pais (1995), os dois têm a mesma estrutura de poder, que pode ser representada pela seguinte sobremodalização:

poder-fazer-saber $=>$ poder-fazer-querer

Ambos possuem, como objetivo, a criação da vontade (política, no caso do jornalismo, e de consumo, no caso da publicidade), por meio da persuasão. Tal fato acaba por aproximálos ainda mais, uma vez que, como observamos a partir das colocações de Sennett, Canclini, Debord e Chaúí, entre outros, à criação da vontade política tem se utilizado do mesmo apelo ao consumo que caracteriza o discurso publicitário.

Outro aspecto que deve ser levado em conta, é que, embora de natureza responsiva como todo enunciado, apontado por Bakhtin (2003, p.272), os gêneros da complexa comunicação cultural foram concebidos para um efeito retardado, manifestado, sobretudo, por meio de formas de comportamento.

\section{Comunidade discursiva}

Mais um aspecto relevante é a percepção de que a comunidade discursiva, como alerta Maingueneau (1997, p.54-61) não é um simples “meio de transmissão”, uma vez que o grupo associado ao discurso possui condicionamentos associados a uma classe particular de condições de existência, geradas por e na enunciação, na gestão desses textos. No caso da RSE, pelo que observamos nos textos jornalísticos analisados, estes envolvem um conjunto de enunciadores e co-enunciadores que, de certa forma, se sobrepõem, formado, em linhas gerais, por componentes da cadeia produtiva: executivos, gestores, outras empresas, investidores, consumidores; do meio acadêmico: estudantes, professores e pesquisadores; e do 
meio midiático, profissionais de comunicação; sendo que há indivíduos que transitam constantemente entre esses grupos.

Heterogeneidade e polifonia

Nos termos da heterogeneidade mostrada no texto, conforme Ducrot (1987 apud MAINGUENEAU, 1997, p.76-77), e, mais especificamente, a polifonia ao nível da enunciação, observamos sinteticamente o seguinte jogo de vozes, que alternam discursos “competentes”, (CHAUÍ, 2006, p.78) resultando num discurso de tom prescritivo, dirigido, sobretudo, aos empresários, mas também aos consumidores:

Enunciadores do DRSE no âmbito jornalístico

Enunciadores: jornalistas/ jornalistas especialistas

Co-enunciadores legitimadores:

empresários/ executivos (práticos)

cientistas (teóricos)

consultores (híbridos)

pesquisas (de mercado/ acadêmicas) discurso citado

autoridades/especialistas

\section{Seleção de fragmentos textuais}

Para efetuar os primeiros recortes no conjunto de textos selecionados, contamos com a colaboração do assistente de pesquisa Danilo Meirelles de Souza, que realizou a seleção, a partir das seguintes duplas de palavras-chave: cidadania / empreendedorismo; direitos / oportunidades ou privilégios; cultura solidária / cultura de negócios; política social / gestão social. Além dessas categorias prévias, que de certa forma dirigiram os resultados, surgiu, como categoria nova, o conceito de consumo e seus termos derivados que, como poderemos observar, é marcante no DRSE. Para minimizar o risco de enviesar a pesquisa, devido a esse estabelecimento prévio “do que achar”, optamos por retornar, a partir dos fragmentos, aos textos integrais, situando-os nos contextos. Acreditamos, dessa forma, ter reduzido o procedimento a um método auxiliar de uso, conforme recomenda Maingueneau (1997, p.134). Análise: dicotomias e resposta única

Utilizamos como chave analítica para esta parte do trabalho a noção de Procedimentos de controle e delimitação do discurso, proposta por Foucault (apud BRANDÃO, p.132-133 e 153), que operam de duas formas (externa e interna), e, quando exercidos do exterior, dividem-se em interdição, rejeição e divisão. A interdição refere-se aos interditos de cada 
época e grupo; a separação/ rejeição constituem divisões arbitrárias, constituídas historicamente; e a divisão estabelece uma oposição entre verdadeiro e falso - separação historicamente constituída, apoia-se sobre suporte institucional, reforçada e reconduzida por conjunto compacto de práticas, com circulação de saber. Brandão (1998, p.153) observa que essa dicotomização - “falar mal” e "falar bem” - não permite uma terceira posição, mantendo o sentido do discurso num único eixo.

A partir do material coletado, observamos, também, a recorrência da retificação, um dos três tipos de refutação propostos por Moeschler (apud MAINGUENEAU, 1997,p.82), que identifica a: refutação posicional, considerada mais comum, que incide sobre o conjunto do conteúdo; a refutação pressuposicional, que incide sobre o pressuposto; e a retificação, que corresponde a negações indicadas por um encadeamento que se dá sobre a enunciação negativa, com base em um "par antonímico”, que seleciona o elemento refutado. No nosso caso, o encadeamento recorrente consistia em “não P mas Q”, um mecanismo que permite fazer deslizar o sentido, sem refutar o discurso da responsabilidade social como um todo.

Outro aspecto observado foi a recorrência do operador argumentativo ainda, que, conforme lembra Souza Santos (2001), não tem uma energia superior à sua matéria por não estar ainda realizado, indicando a percepção de evolução no discurso e nas práticas empresarias por parte dos enunciadores.

Apresentamos, a seguir, as dicotomias observadas, sendo que em cada grupo, distinguimos, em ordem cronológica, os textos de 2006 e 2007, permitindo observar as transformações por que passaram ao longo do tempo.

Marketing e publicidade (imagem) x Gestão (ações concretas)

Trata-se da retificação com maior incidência no material coletado, efetuada entre o termo marketing, negado ao ser associado a "mera” imagem ou a um foco exclusivamente comercial, e a noção de gestão, associada à realização efetiva das ações sociais por parte da empresa. Efetua-se, dessa forma, o afastamento da noção de RSE do âmbito do marketing, identificado de forma negativa na maior parte dos textos, e a aproximação com a noção mais neutra de gestão. Como observa Bucci (2001: p.14), uma característica marcante da responsabilidade social é sua relação com a visibilidade. Ao propor a dicotomia entre empresas que têm seu maior objetivo na visibilidade e as que focam a efetividade da ação social, o discurso trata o marketing e a comunicação (publicidade), vistos com conotação negativa de "promoção da imagem”, e ação social como coisas separadas. Uma vez feito o deslocamento, contudo, a divulgação das ações empresariais é vista como legítima. 


\section{TEXTOS DE 2006}

2 (...) Nada pior do que a empresa se valer do discurso sempre muito bonito de responsabilidade social para vender, por meio da comunicação, uma imagem cidadã ao consumidor.

5 representa a procura de soluções a um modelo cujos problemas, do ponto de vista social e ambiental, são bastante sérios. Mas também que trazem ganhos importantes às organizações que a adotam, em vários aspectos”. (consultor de sustentabilidade)

3 Para alguns especialistas, são uma ferramenta de gestão dos públicos de interesse, os stakeholders, (...)

Mas muitas vezes não passam de "marketing verde". (...) "Perde-se a credibilidade, quando o balanço vira instrumento de propaganda".

7 Falar em responsabilidade social está na moda.

(...) Mostrar para a sociedade o quanto a instituição tem apostado na responsabilidade social dando exemplos reais é o que faz a diferença na hora de ser considerada engajada ou não a esta idéia.

10 (...) Apesar de utilizar verbas publicitárias para divulger ações da N na área social, RG defende a idéia de evitar a "dispersão de recursos que podem ser usados para alavancar ainda mais as ações sociais". (...) "Nos Estados Unidos para cada dólar investido em um projeto de responsabilidade social, outro dólar vai para a mídia” diz RG, diretor de assuntos corporativos e relações governamentais da N. Implícito que isso é correto. Efeito interessante se substituirmos Estados Unidos por Venezuela, por exemplo.

13 Escolas assumem papel de difundir ações de responsabilidade social sem fazer assistencialismo, e os resultados são ganhos institucionais e até mesmo didáticos.

Longe de serem apenas estratégia de marketing, as ações de responsabilidade social (RS) passaram por uma ampliação recente em vários setores, inclusive o acadêmico.

(...) [diretora acadêmica de IES privada] Ela acha possível a utilização desse tema inclusive em campanhas publicitárias. Mas frisa que a informação deve ser coerente com a profundidade do projeto.

(...) Ela admite que a RS pode ser uma ferramenta de marketing, mas analisa que é preciso discernimento para se escolher o tom da divulgação.

(...) "Esse tema ainda precisa ser tratado com mais profundidade. Acho que os benefícios do marketing são buscados em muitos casos” fustiga Silva.

(...) "O que a empresa deveria buscar não é a imagem, mas a reputação, que é algo mais profundo" 15 (...) Eu vejo que quando a empresa quer ter apenas uma imagem de boazinha, sem conteúdo real, aí realmente a coisa fica complicada. São campanhas marquetosas, associadas ao logotipo da empresa, mas onde não se consegue enxergar nenhum fio de continuidade.

17 Responsabilidade Social: Moda ou consciência?

subtítulo: IES usam extensão universitária para projetos sociais, mas, para especialistas, as instituições ainda não incorporam seu verdadeiro compromisso perante a sociedade.

25 [referindo-se à pesquisa] Entretanto, a maioria (90\%) disse recorrer a estas práticas para proteger e fortalecer sua reputação, ou, como traduziu o palestrante, apenas para sair bem na foto. Mas $75 \%$ também esperam obter vantagens competitivas, o que é muito sensato. 
34 Responsabilidade Social: A nova palavra de ordem [...] ao contrário da responsabilidade social, o marketing social costuma restringir-se a projetos temporários, voltados, sim, à valorização da cultura, do esporte, da saúde e da educação, mas destinados, antes de tudo, a aumentar as vendas da empresa, ou melhorar a imagem da marca no mercado.

36 A Responsabilidade Social tornou-se mais que uma estratégia de marketing. (...) “Não podemos confundir estratégia de marketing com RS. “O que acontece na prática é que os consumidores estão mais atentos a participação das organizações nas causas sociais, o que acaba gerando um maior número de adeptos a um determinado produto que tenha sua marca associada a projetos desse cunho. isto agrega força positiva e valoriza a marca, mas não pode ser visto como um instrumento visionário de lucro", avalia.

(...) Porém, os diretores [de empresa que pratica RSE] afirmaram que não se pronunciariam porque estas ações estão no DNA da empresa e não se caracterizam como estratégias de marketing.

46 Ser uma empresa cidadã não é mais uma mera questão de marketing. É uma necessidade que se torna filosofia de negócios a partir da pressão da sociedade em favor de empresas que cumpram o seu papel social.

65 (...) Segundo FE, diretor da empresa [de pesquisa], na opinião de mais de $80 \%$ dos entrevistados, as corporações tentam ser socialmente responsáveis apenas para melhorar sua imagem, não porque querem dar uma contribuição positiva para a sociedade.

68 (...) "Ainda há muito ceticismo quanto aos balanços sociais. Muitos analistas pensam que se trata de mais uma ação de marketing da empresa”

\section{Ação Social ou puro Marketing?}

80 O negócio da Solidariedade (...) “As empresas não estão preocupadas em resolver problemas sociais e ambientais. As ações de responsabilidade social ainda estão muito ligadas às questões de imagem no Brasil” diz [presidente de Grupo e Fundação empresarial]

78 Fazer o que? Contar Como? (...) na dúvida, contrate um especialista e analise com muito cuidado a questão, sob todos os aspectos. Pois atuar junto às áreas mais sensíveis da população exige cuidado ainda maior, uma preocupação ainda mais acentuada - pois estamos falando de vidas, $\underline{\text { de }}$ sustentabilidade, de futuro, e não só de negócios.

84 América Latina: Cresce o interesse das empresas pela responsabilidade social empresarial (...); atenção pra com as demandas da comunidade, dos investidores, às vezes até por mera questão de moda ou desejo de maior exposição à mídia.

TEXTOS DE 2007

102 "Nunca tentamos usar o envolvimento do [empresa] com assuntos ligados a sustentabilidade para promover nossa imagem e nem vamos fazer isso de maneira ostensiva." (VP MKT)

110 (...) Podemos concluir que o grande objetivo de uma empresa não é garantir o lucro aos seus acionistas, mas, sim, existir e persistir.

112 Código de Ética e Responsabilidade Social (Lúcia Rebouças jorn)

Dados da I Pesquisa sobre Códigos de Ética no Brasil 
(...) questionamento sobre o que é verdade e o que é mero marketing entre as práticas alardeadas na mídia pelas empresas. Uma visão unicamente “marketeira” nessa seara precisa ser revista ou vai acabar saindo caro.

113 Futuro Responsável

Dados do levantamento [realizado por instituto privado] sobre Sustentabilidade em julho 2007 com homens e mulheres (+16) ABC e entrevistas com 537 executivos de 381 grandes empresas nacionais. 79\% dos executivos e 55\% dos cidadãos já ouviram falar de sustentabilidade empresarial.

(...) que investir em ações socialmente responsáveis é mais do que simplesmente uma boa ação. Pode gerar negócios para a empresa.

11610 mandamentos \& 7 pecados capitais da comunicação corporativa

Matéria elaborada a partir da consulta a “dez maiores nomes da área”. ( executivos e consultores da área de comunicação corporativa, citados ao longo do texto)

(...) A responsabilidade social é tida não como uma ferramenta de marketing, mas como uma necessidade. As empresas que querem se manter onde estão têm de oferecer à sociedade mais que seus produtos. No entanto não dá para ficar só no discurso. Gastar mais com publicidade que na ação social é em si inadmissível.

122 (...) “Sustentabilidade não é apenas um mote para comunicação. Mais do que falar, queremos fazer. Expressamos o que de fato é imagem com correspondente na identidade” pontua FM [diretor de estratégia de marca]

130 (...) Cidadania e conservação de meio ambiente não é só uma questão de moda. É um esforço duro, focado nos consumidores e nos produtores de bens e serviços que orienta o consumo, que reconhece o ciclo completo dos produtos que fornecem oportunidades de crescimento sustentável 132 Inserir ou não a responsabilidade social na propaganda de marca? Eis a questão. matéria com depoimento de publicitários/ e executivos de empresas Os entrevistados de [nome da publicação] foram unânimes no repúdio à idéia de se apropriar dos valores da responsabilidade social empresarial como mero suporte ao discurso de marketing da empresa.

133 Menos Marketing mais ações [ estudioso norte-americano ] (...) É importante ressaltar que isso [movimento de RSE] não pode se confundir com marketing, mas com o papel do empresário como transformador social e da empresa como seu instrumento.

145 (...)“A percepção [da empresa] melhorou muito, pudemos demonstrar que responsabilidade social é uma postura estratégica do banco e não apenas um modismo” [diretor de empresa]

153 [Entrevista com profissional de comunicação] Existem dois níveis em que o assunto Sustentabilidade tem sido tratado: um em que a verbalização é intensa, mas a consciência é precária. Outro em que se fala menos e se faz mais.

162 Brasil pode ter selo de boas práticas (...) A moda pegou e veio para ficar. Cada vez mais produtores têm buscado certificações para vender seus produtos, sobretudo aquelas voltadas à exportação.

163 Brasileiro vê ação social como uma ferramenta de marketing [dados de pesquisa de instituto privado com público $A B C$ e empresários] Os brasileiros estão vendo com ressalvas os investimentos em 
sustentabilidade anunciados pelas empresas e acreditam que ações não passam de estratégias de marketing. Para mudar essa imagem, grandes corporações tentam ampliar suas ações nesse sentido (...)

\section{Filantropia (arcaica) x Gestão (moderna)}

O deslocamento no sentido da gestão ocorre também por meio de outra dicotomia, entrelaçada à anterior, que nega a noção de filantropia, associada ao assistencialismo e considerada arcaica, e a proposição de uma ação pautada pela gestão do social. O trabalho de Paoli (2005), entre outros, mostra como essa negação é feita também no âmbito dos movimentos sociais, que estariam num campo oposto ao das empresas, com base numa idéia comum de autonomia dos sujeitos e comunidades. Ao estabelecer a dicotomia entre o arcaico e o moderno, o discurso deixa fora a discussão sobre a redução dos direitos e da participação democrática, como apontam Souza Santos (2001) e Dagnino (2004), entre outros.

\section{TEXTOS DE 2006}

9 Declarou Warren Buffet (...) usar meu dinheiro de uma maneira produtiva.

20 (...) "Responsabilidade Social não é filantropia. É uma forma de gestão. (...)

21 Responsabilidade Social é outra coisa (M\&M) (...) O foco são as ações que a empresa estabelece com seus diferentes consumidores. (...) No fundo, sua análise tenta desconstruir uma idéia ainda muito presente de que a RS é simplesmente apoiar um projeto social.

Felizmente isso já vem mudando. (...) Por uma questão de democracia - e não apenas pelo dinheiro precisamos ser co-responsáveis pelo desenvolvimento. Então é interessante que as companhias participem das ações no campo social. É óbvio que não estou falando de assistencialismo e dessas bobagens que não raras vezes as empresas fazem com muito capricho. A menção à democracia é tão fora de contexto que sua substituição por piedade, benevolência etc. não alteraria o sentido da fala. Experimento pode ser feito em outras menções, sobretudo à cidadania?

(...) Nesse contexto a RS não está se transformando em mero discurso de apoio ao marketing? (...) As pessoas anseiam por outros atributos, e aí é necessário inserir no universo da marca a questão do respeito, cuidado com o meio ambiente, a valorização da diversidade. Para isso, não dá para escolher o tema somente como um diferencial competitivo, mas sim um diferencial significativo, que represente algo a mais para a sociedade.

23 (...) Todo este processo vem levando donos de empresas internacionais a evitar a criação de uma entidade social para fins de filantropia e começado a investir fortemente para que causas e investimentos sociais façam parte da agenda executiva da própria empresa.

25 [ coordenador do Centro de Estudos em Sustentabilidade] (...)não é apenas mais uma palavra da moda, já que feito para ficar. Porém, como ressaltou,quando se fala em sustentabilidade é preciso qualificá-la. (...)a sustentabilidade nas empresas deve fazer sentido econômico, caso contrário será filantropia. 
45 Países Vêem de forma diferente a atuação social das empresas

[pesquisa realizada no Brasil e na Argentina ]Em ambos os países, no entanto, as empresas têm superado a mera filantropia e adotam programas mais consistentes de investimento social.

57 Empresas conhecem a teoria da atuação social. Falta a prática

(...) “Em linhas gerais, podemos dizer que a questão ambiental preocupa as empresas, mas a atuação social ainda carrega ranço paternalista.

61 A doação do investidor Warren Buffett à fundação de Bill Gates é o maior exemplo de como o capitalismo americano consegue não só gerar riquezas astronômicas como também devolvê-las de

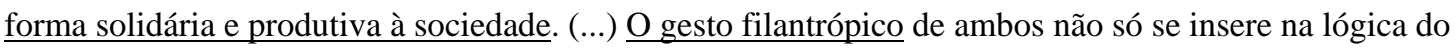
capitalismo moderno, como também coloca o regime num patamar moral superior.

TEXTOS DE 2007

99 Empresas ficam só no discurso da Sustentabilidade (...) Na prática, as empresas não estão conseguindo adequar seus modelos de negócios aos desafios do mundo contemporâneo (...) por isso, muitos programas de responsabilidade social continuam resvalando no assistencialismo e não aproveitam as novas oportunidades de negócios geradas pela crise.

[jornalista com base em dados de pesquisa]

100 Filantropicapitalismo, a nova ordem mundial (...) uma das principais especialistas mundiais em investimento social privado: “Antes, no modelo tradicional, a intervenção social ocorria por meio de um testamento (...). Hoje não. Temos um filantropo, um investidor social jovem, que quer fazer em vida, engajando-se na atividade e colocando todo o seu conhecimento de negócio na intervenção social 110 (...) Antes de tudo, responsabilidade socioempresarial se refere a uma postura, uma forma de conduzir as atividades empresariais. É, portanto, muito mais do que simplesmente realizar ações sociais pontuais ou de cunho assistencial.

142 (...) Mas, atualmente, filantropia não é sinônimo de responsabilidade social. [...] o investimento social aprovado consiste no repasse sistemático de recursos privados para fins públicos por meio de projetos culturais, socais e ambientais.

151 Voluntariado se moderniza e vira estratégia empresarial

154 Muitas são as interpretações dos termos responsabilidade social empresaria e cidadania corporativa; porém, seria um grande equívoco pensá-las como filantropia ou programas assistencialistas.

157 Apesar de ser um tema muito explorado pela mídia em geral, responsabilidade social corporativa ainda é muito confundida com filantropia, que é apenas um dos elos - ou stakeholders - que compõem uma grande corrente.

\section{Estado (ineficiente) x Empresa (eficiente)}

A questão do descompasso entre o que se diz e o que se faz, enfatizada pelas dicotomias anteriores (sobretudo aquela que opõe a divulgação exagerada à realização de ações efetivas), integra, de certa forma, a autocrítica empresarial. Em sintonia com a colocação de Paoli (2005), nos parece que a contradição não ocorre entre o que as empresas divulgam e o que elas fazem, mas entre as ações empresariais (regidas pela ótica de mercado) 
e ações ampliadas de participação social. Soma-se a isso o fato de as ações serem apresentadas como prova da ineficiência e arcaísmo das políticas públicas estatais, o que obscurece a renovação de parte de um serviço público comprometido, que tenta ser alternativa política ao desmantelamento do setor público. Nos textos apresentados, a empresa é continuamente apresentada como um exemplo a ser seguido. Desvincula-se do papel do Estado, por uma questão de escala (não pode dar conta da amplitude das questões sociais), mas se apresenta como gestão eficaz que, se replicada, resolveria essas questões. Observamos, aqui, que essa percepção da ótica gerencial como solução genérica traz consigo ecos discursivos de um movimento em escala mundial, que foi marcado, no Brasil, pela reforma do aparelho do Estado, cujo plano começou a ser implementado no ano de 1995.

\section{TEXTOS DE 2006}

2 (...) Muitas vezes, por conta das incompetências do Estado Brasileiro, surge um vazio no âmbito público, que pode ser, eventualmente, ocupado por uma empresa, que se apressará em fincar ali seu logotipo. Mas não se pode, sob nenhum pretexto, desqualificar o papel do estado nem permitir que ele intervenha nas atividades de natureza privada, além dos limites aceitáveis e legais.

26 (...) Há, portanto, uma compreensão, no mundo empresarial, de que a atuação privada não deve substituir o poder público, tendo um caráter muito maior de complementaridade da ação estatal. Pesquisa realizada pelo IPEA

40 Lucro com o Social "Apesar de muitas empresas falarem de responsabilidade social, é difícil encontrar quem queira se associar a prostituição”. GL presidente da DaVida ONG

13 E destaca: "Se o projeto dá certo, isso estimula outras empresas a fazerem o mesmo."

56 BID vai treinar 120 empresas em responsabilidade Social (...) Programa será realizado por grandes companhias em sua cadeia de fornecedores e clientes. "Queremos provocar uma mudança no comportamento de gestão". [ diretor Instituto empresarial de RSE]

59 (...) Criada pela [nome de agência de propaganda], a ação tem a assinatura "[nome de associação empresarial] 10 anos, ações sociais de resultado". "Nos últimos 10 anos, o terceiro setor verificou uma rápida expansão no Brasil, mas ainda falta ampliar a conscientização sobre a diferença entre assistencialismo e modelos planejados de transformação social”, diz FR, secretário-geral do [nome da associação empresarial]

64 Presidente do [nome de instituto que desenvolve ações sociais] faz diagnóstico assustador da educação e mostra como enfrentar o problema. (...) $\underline{\text { soluções a serem aplicadas em larga escala. É como }}$ se tivéssemos transformado o instituto em laboratório que desenvolve "vacinas" para diversos "males sociais”.(...) É a implantação de uma cultura gerencial? Exatamente. A escola agora trabalha com metas. É possível colocar quantidade e qualidade na mesma equação e construir um país para todos. 76 Empresa-modelo (identificação presente nos vários cases da mesma publicação) 
(...) O desenvolvimento sustentável deixou de ser um assunto reservado aos ambientalistas e chegou às empresas. FB - presidente do BR

82 A educação por todos e todos pela educação (...) Papel de empresas é criar modelos eficazes e replicáveis (...) [Economista]: (...) Diante de sistemas educacionais pobres, mal geridos e pouco inspirados, os programas de RS das empresas sopram como uma brisa fresca. (...) Mas infelizmente, nem tudo vai à direção certa. Há muito patrocínio para atividades que desviam a atenção da escola. (...) Já passamos a fase heróica e pioneira, quando a mera disposição de empresas para ajudar escolas era fato a ser automaticamente festejado. (...) podemos ser um pouco mais críticos, notando que nem

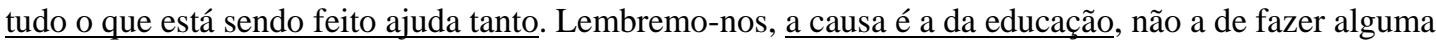
coisa na escola ou com os alunos.

$85 \mathrm{O}$ [nome de associação empresarial] tem como objetivo disseminar ações bem-sucedidas de empresas lucrativas que beneficiam a sociedade.

$70 \mathrm{Na}$ entrevista a pesquisadora do IPEA faz alguns apontamentos sobre investimentos sociais em projetos, valores e motivos que levam as empresas a doarem ou investirem em projetos e como isso foi se modificando no Brasil. Cria uma relação com o quadro nacional e o internacional. (...) A grande concordância é que todas acham que é obrigação do Estado cuidar do social. Concordam com isso 81\%, mas a maioria acha que é papel delas também fazer alguma coisa pelo social.

71 (...) Para EKR, professor da [fundação de universidade pública], o cidadão comum está mais atento à atuação social das empresas porque percebeu que o governo não dá conta do recado.

73 Negócios e Sociedade (...) Segundo a mais recente pesquisa global do McKinsey Quarterly, (...) o papel das corporações na sociedade vai muito além de simplesmente cumprir suas obrigações para com os acionistas. Contudo, esses executivos também afirmam que, para maior parte das empresas, as questões sócio-políticas (...) apresentam riscos reais. Na verdade, eles afirmam que encontrar formas de controlar tais questões é tão importante que uma administração sociopolítica eficaz deve começar pelo CEO.

80 “À medida que o Estado deixa de cumprir suas funções de manutenção do bem-estar, as empresas começam a assumir esse papel” diz MAA, [estudioso do terceiro setor ]

TEXTOS DE 2007

87 Hora da Civilização no Poder [ autoridade da área de RSC] "Existe um longo caminho a percorrer, mas agora o desafio para os negócios é estarem muito mais comprometidos em resolver os problemas da sociedade. E em fazer isso de um modo que os permita modelar as boas e sustentáveis práticas que o mundo precisa."

92 [presidente de instituto voltado para ações sociais] "Para chegar até aqui, adotei um gerenciamento que é o mesmo utilizado nas empresas: atuação em grande escala com foco em resultados.” 100 Referindo-se a países como Brasil e Índia “(...) Toda esta experiência reforça o seguinte quadro: as pessoas não têm a ilusão de que as empresas irão suprir o papel do Estado, mas ao mesmo tempo o $\underline{\text { Estado não atinge as expectativas da demanda social. Fica uma lacuna que nem a empresas e nem o }}$ Estado consegue suprir.” acrescenta Olga. 
114 Ação Social é só relações Públicas (entrevista com especialista Robert Reich - credenciado pelo mercado e pela academia) A responsabilidade Social é uma questão de relações públicas. As empresas não foram criadas para ser instituições de caridade (...). Cria a falsa impressão de que as empresas são pessoas, com uma preocupação moral. As empresas não são pessoas. Nem instituições morais da

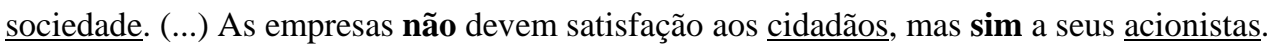

118 Ao mesmo tempo em que os grupos beneficiados melhoram a qualidade de vida da sua família, eles influenciam todo entorno. Impactam positivamente também para a unidade [rede de supermercados], com redução no índice de criminalidade e aumento da segurança para seus clientes. 123 (...) o movimento predominantemente no campo da sustentabilidade, isto é, o mainstrean, mostra um vigoroso fascínio pela idéia de que o mercado - portanto os mecanismos econômicos- podem contribuir com maior rapidez, escala e eficiência para que as sociedades de um modo geral, e brasileira dentro deste conjunto, possam dar as respostas que exigem os atuais desafios de ordem global, Estamos falando da pobreza e estamos falando dos problemas ambientais.

129 [...] a [nome da empresa], como empresa socialmente responsável, confirma suas expectativas em relação a essa nova estrutura de investimento social, que certamente, tornar-se-á uma prática adotada por outras empresas.

131 Lucro! Que mal há nisso? a vantagem do lucro “empresarial” é revertida na contribuição para que outras pessoas possam ter acesso ao "lucro individual”, caracterizado pelo emprego ou benefícios sociais.

155 Para que a atuação social gere frutos institucionais e negociais, é necessário seguir critérios estratégicos similares aos empreendimentos no trato do core business da empresa.

166 (...) Na divulgação do Informe Anual de Responsabilidade Corporativa, no início de julho, o presidente do [nome do grupo empresarial], ACV, afirmou que a intenção da companhia com a publicação - feita este ano pela terceira vez no Brasil - “é estimular outras empresas a copiar a idéia”.

\section{Responsabilidade Social $x$ Causas trabalhistas}

Um dos aspectos ligados à dicotomia anterior (empresa x Estado) e à posterior, que aborda a visão de um cidadão reflexivo, que devidamente motivado, conseguirá negociar sua posição na sociedade, é o afastamento da RSE das questões trabalhistas. Pesquisa desenvolvida por Assumpção et al. (2008), integrando documento que apresenta dados sobre responsabilidade social corporativa (RSC) no Brasil e na Noruega (Relatório FAFO 2008), enfatiza que benefícios obtidos por meio de negociações trabalhistas não podem ser considerados ações de responsabilidade social. Nos textos selecionados, destaca-se a colocação de que essas ações estão além dos direitos, aparecendo sutilmente a menção da substituição de benefícios trabalhistas por ações de RSE.O fato que chama atenção, contudo, e é amplamente relatado nos trabalhos de Cappellin e Giuliani (2006) e Cappellin e Giffoni (2007), é o paralelismo entre as ações de RSE e o movimento empresarial Custo Brasil, que 
sugere a diluição das garantias trabalhistas, a serem incluídas, agora, nas negociações contratuais coletivas. Destacamos, neste grupo, um texto de 2007, associado a outro de 2008, que não fazia parte do corpus original, para ilustrar, no discurso, essa contradição.

Trecho de artigo assinado por presidente de empresa:

95 Nós, lideranças empresariais, sindicais, acadêmicas e políticas, precisamos nos mobilizar e priorizar os investimentos na educação. (...) Isso significaria também consentir em uma situação inaceitável condenar o Brasil ao baixo crescimento e ao aumento da desigualdade social nas próximas décadas, $\underline{\mathrm{o}}$ que atinge a todos.

O mesmo executivo em Painel de encontro fechado com público empresarial:

O problema empresarial de geração e manutenção de emprego está na legislação trabalhista brasileira tremendamente inflexível. As lideranças sindicais têm um discurso uniforme: precisamos evoluir, mas não se mexe nos direitos adquiridos.

Tenho uma visão extremamente radical desse processo: ter o mínimo de obrigações estabelecidas e ter o máximo de flexibilidade de negociação.

A visão corporativa que existe na área trabalhista é proteger o coitado do operário, mas a capacidade política de organização do setor leva a estabelecer o máximo de flexibilidade em horários, em regime de trabalho em casa, fora de casa etc.

(...) Sem flexibilidade não se constrói. Num pacto precisa-se de flexibilidade e remuneração variável em função da produtividade.

\section{TEXTOS DE 2006}

5 O Desafio é ser responsável (...) Além do cuidado com o meio ambiente, a [nome da empresa] preocupa-se também com o pagamento das obrigações sociais (...) A empresa ficou fora do ISE por estar num setor polêmico e ter um produto condenado por alguns segmentos da sociedade. Provar que, mesmo nesse contexto, é possível ter uma atuação responsável 6 Responsabilidade Social corporativa (RSC): a prática para o bem de todos

(...) As empresas começam a desenvolver programas (...) também com seus funcionárioscolaboradores. A prática do bem-comum começa, portanto, “em casa”.

12 Cabe também à entidade [Fundação de RSE] administrar todo o portfólio de benefícios dos colaboradores, como plano de saúde e a complementação salarial por auxílio-doença. Outro benefício é a creche para filhos de funcionários, que atende crianças de até cinco anos.

14 A [nome da empresa] solidificou a sua atuação comunitária quando se apresentou não apenas como uma geradora de empregos e de recursos públicos pelo recolhimento de impostos, mas também por ser uma estimuladora de atitudes de cidadania nas regiões onde está presente.

15 A responsabilidade social é uma atitude mais ampla, que implica em governança, que implica em relações trabalhistas justas. Investir no exercício de responsabilidade social não é só investir em projetos sociais. 
38 Trabalho e qualidade de vida (...) os profissionais que atuam com RS e qualidade de vida devem, além do conhecimento das ferramentas de gestão, ter o que Dalai Lama chama de “valores humanos essenciais”, ou seja, serem pessoas que se relacionem cordialmente.

TEXTOS DE 2007

147 [...] a Fundação [de empresa] destaca-se por contemplar a modernização das relações de trabalho e a atuação social como um todo, atendendo as empresas nos serviços de recursos humanos e desenvolvimento, recrutamento e seleção administração de pessoal, remuneração — e também comunicação interna e responsabilidade social.

160 A [nome da empresa] procura, através de seus projetos, promover a qualidade de vida e a consciência de se prevenir danos ao meio ambiente, proporcionar a emoção artística não apenas na construção efetiva de seus empreendimentos imobiliários, mas também, em ações em que seus operários possam exercer seus talentos artísticos”.(...) “Cria-se, por meio de tais ações, a integração cada vez maior dos operários com a empresa, isto é, apesar do cotidiano duro das atividades braçais da construção civil, a momentos em que os funcionários sentem que eles criam algo para eles mesmos e não apenas belas edificações de luxo para outras pessoas”.

\section{Respostas únicas para além das dicotomias}

\section{Sustentabilidade}

Além das dicotomias, observamos no discurso, de forma crescente ao longo do período analisado, a construção de uma resposta única, a partir da transição entre a filantropia, passando pela responsabilidade social, e chegando à sustentabilidade, como descrevem Fischer (2007), entre outros: é um movimento natural. Podemos dizer que a idéia de sustentabilidade, associada à noção de uma cadeia produtiva cíclica e à preservação da vida da espécie, remete às colocações de Hannah Arendt a respeito do labor; este possui uma “produtividade” própria, que não reside em seus produtos, mas na "força” humana, que pode ser utilizada para a reprodução de mais de um processo vital, mas nunca "produz" outra coisa senão “vida” e, mediante violência, pode ser canalizada, de forma que o labor de alguns é bastante para a vida de todos.

O discurso apresenta, dessa forma, uma única alternativa (a sustentabilidade) para garantir a sobrevivência da espécie, com um tom taxativo e ameaçador para aqueles que não seguirem esse caminho.

\section{TEXTOS DE 2006}

8 deve-se apresentar o bem-comum aos líderes de negócios como uma estratégia. consumidor.

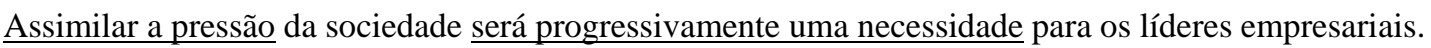


(...)A cultura de um país impacta profundamente no comportamento dos empresários. Mudar as práticas empresariais é algo muito complexo. Mas urgente e necessário.

18 (...) No mundo de hoje, argumentam, graves problemas como mudanças climáticas, crise e desperdício energéticos, pobreza absoluta, preconceitos raciais e sociais, exploração do trabalho infantil, corrupção têm de ser incorporados aos planos das organizações. Se não forem (...) é sua própria sobrevivência, (...) que estará posta em risco por essas ameaças modernas.

25 Sustentabilidade: a nova fronteira da gestão corporativa (...) “As empresas que tomarem a iniciativa de serem sustentáveis e responsáveis — antes de serem obrigadas a isto — serão recompensadas por seus acionistas, satakeholders, agências reguladoras e, não menos importante no seu botton line. Por outro lado, as que falharem nesta tarefa, ignorando a governança corporativa e seus impactos no meio ambiente e na sociedade, semearão desastrosas conseqüências financeiras”, [coordenador do Centro de Estudos em Sustentabilidade]

27 Compromisso com o Planeta (...) Ao entrar no mundo da responsabilidade social, a empresa ganha um novo status de maior visibilidade, ao mesmo tempo em que fica sob a mira de instituições e consumidores que, de alguma maneira, fiscalizam e cobram os compromissos assumidos. Não basta às empresas realizar algumas açõezinhas de responsabilidade social. Elas precisam fazê-las direito e comunicá-las adequadamente, senão... Senão não adianta nada, é dinheiro jogado fora. Além "do risco de ver seus produtos e serviços vetados num futuro próximo", como fica claro na pesquisa RS das E - Percepção do Consumidor Brasileiro realizada pelo Instituto Akatu pelo Consumo Consciente e pelo I. Ethos de Empresas e Responsabilidade Social, divulgada em julho.

(...) Responsabilidade Social, boas práticas, índices de sustentabilidade empresarial são, na verdade, algumas de muitas iniciativas que fazem parte de um grande movimento global pela vida. É o que em economia se poderia chamar de ganha/ganha, em que todos saem ganhando: consumidores, empresários, funcionários, governo. Até o planeta, que ganha a chance de ter um futuro.

29 (...) "Este espaço tem objetivo de promover a educação ambiental e conscientizar todas as pessoas, sem exceção, quanto à preservação da natureza. Principalmente através das crianças, fazendo da ação um ciclo natural, vicioso e virtuoso coletivamente”

31 (...) No novo ambiente de negócios, somente terão lugar no mercado — e, por assim dizer, no futuro - as empresas que conseguirem integrar adequadamente os fatores econômicos, sociais e ambientais, atingindo os patamares para serem consideradas sustentáveis.

35 (...) Nesse cenário, será questão de tempo o mercado exigir do profissional essa preocupação com a RS. Fatalmente, ele terá de apresentar, além da sensibilidade e do interesse por questões sociais e ambientais, a capacidade de avaliar qual a estratégia de gestão mais adequada para se atingir os melhores resultados para a empresa, a sociedade e para a comunidade que a cerca, não importando qual seja seu porte.

49 Efeito Irradiado (...) Costa [coord.da área de gestão e relacionamento com fornecedores de empresa] diz que o papel [da empresa] não é obrigar as empresas a adotar esses critérios, nem excluir parceiros que não os pratiquem. "Queremos participar da inclusão de fornecedores convencidos de que não haverá futuro para eles fora da responsabilidade social”. 
62 Consumo, logo existo (...) Consumir pode ser um passo para a construção da cidadania.(...) O que nos reserva o futuro? Por hora, consumo e consumismo crescem com vigor. Os ativistas da causa estão a avançar na batalha publicitária, porém a guerra pelos corações e mentes dos consumidores está longe de ser vencida. Transformar consumismo em cidadania não é tarefa trivial. No entanto, o preço por não fazê-lo, para a biosfera e para a sociedade, é alto.

\section{TEXTOS DE 2007}

93 (...) aquele que restringe o impacto de seu negócio aos resultados financeiros de cada fim de mês está fadado ao desaparecimento. Pelo menos é o que sentenciam os analistas. (jornalista/ seguido de citações diretas de consultores).

94 Se não por convicção, mas por puro pragmatismo e senso de sobrevivência. (...) “A falta de monitoramento do impacto das companhias no meio ambiente é vista como uma bomba em potencial para seus negócios [jornalista]

97 Com o aquecimento do planeta as preocupações neste sentido tornaram-se mais urgentes que nunca, sendo até um despropósito deixar de lado essa abordagem.[jornalista especializado]

107 Pressões Sócio Ambientais “Coitados de vocês” [consultor de sustentabilidade dirigindo-se a] CEOs que ainda não acordaram para os desafios da sustentabilidade no século 21.

119 (...) afinal, constitui, em si, ato de responsabilidade social empresarial investir em um país no qual o desemprego impõe-se como grave problema social e um entrave ao bem-estar e desenvolvimento. Mas

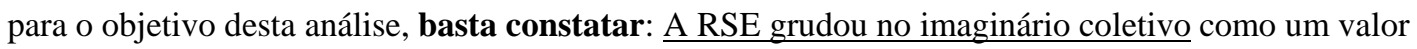
importante associado à melhoria da qualidade de vida das pessoas, do país e do planeta.

120 A mãe de todas as responsabilidades (autor não explícito / coluna site)

A empresa que tem a intenção de se perpetuar no mundo de hoje, com vistas para o futuro, deve inescapavelmente legitimar suas atitudes, ações, posturas e, especialmente, ter consciência de dar conhecimentos dos impactos de suas atividades no passado, no presente e no futuro em diferentes níveis, do comercial ao social. (...) Em risco de, peremptoriamente, sumir do mapa.

122 (...) A responsabilidade socioambiental deixou de ser uma boa ação de grandes companhias ou atitudes de empresários esclarecidos, passou por cima dos modismos e estabeleceu-se como práticas de negócios nos últimos anos. Hoje é questão básica de sobrevivência no mundo corporativo e se mostra fundamental para a continuidade do homem na Terra, diante de previsões cada vez mais terríveis sobre mudanças climáticas e degradação ambiental.

123 (...) Evidentemente, não estamos falando que todas as empresas limparam sua produção ou aderiram a tecnologias mais brandas. Mas no mundo dos negócios, sabe-se que essa é uma tendência inexorável, e quem não proceder, estará morto em poucos anos.

133 A linha mestra das ações sociais deve nascer de uma visão profunda da relação de interdependência "governo-empresa-homem-natureza". Pode-se entender essa ligação como um ciclo natural, uma cadeia de ligação: este é, sim, o princípio verde que deve ser cultivado.

137 O Futuro é Verde [Entrevista presidente de país reconhecido como exemplo ambiental]

Não temos opção. O desenvolvimento futuro será verde ou não se realizará. Precisamos cuidar de nosso principal tesouro, que é a natureza para continuar habitando este planeta. 
138 O lucro é verde [Entrevista com presidente de empresa]

(...) O senhor não teme que a sustentabilidade se transforme num modismo vazio ao qual empresas aderem mais por conveniência do que por convicção? Por convicção ou por conveniência, o fato é que as melhores empresas e alguns países estão repensando sua maneira de fazer negócios. Por crença ou pressão da sociedade, não importa. $\mathrm{O}$ assunto sustentabilidade está na pauta de todos os executivos. 138 (...) O assunto passou a fazer parte da estratégia de negócios de qualquer companhia. Isso é bom e veio para ficar. Virou negócio. (...) Obviamente há um certo exagero de algumas ONGs, mas isso é normal. Um dia chegaremos a um equilíbrio.

140 A gestão de negócio de forma socialmente responsável é uma tendência?

Sim, além de uma tendência também é uma necessidade. De um lado, as empresas vêm sendo pressionadas pela sociedade civil há pelo menos 40 anos para agir de maneira diferente [...] . De outro lado, há os impactos das mudanças climáticas (...)

Em entrevistas o senhor já afirmou que "a globalização é um modelo de desenvolvimento econômico insustentável, que vem acelerando a destruição ambiental, a exclusão social e a concentração de renda”. Que alternativas existem a esse processo?

A alternativa é o desenvolvimento sustentável, que concilia crescimento econômico com inclusão social e preservação ambiental.(...) [presidente de instituto empresarial]

\section{Consumo e cadeia produtiva}

Santos e Avritzer (2005, p.59) e Santos (2007), entre outros, aponta para a ótica predominante que dissemina a indistinção entre cidadão e consumidor, fazendo com que educação, moradia, saúde, lazer apareçam ou como conquistas pessoais, ou como benesses, e não direitos sociais. Uma visão que ganhou corpo, a partir da já citada Reforma do Estado, e que Livingstone, Lunt e Miller (2007) abordam, ao analisar o uso dos termos “cidadão”, “consumidor” e “cidadão-consumidor” na articulação dos interesses dos cidadãos, na regulação da mídia na Inglaterra. A questão do consumo, originalmente fora das palavraschave previstas para este momento da análise, apresentou-se, nos textos, como caminho para pressionar as empresas no sentido de práticas mais responsáveis.

A literatura consultada não é conclusiva a respeito da relação entre ações sociais das empresas e consumo, mas vale destacar a percepção do consumo como um possível caminho para a cidadania, levantado por Canclini (2005), entre outros. Nesse sentido, embora consideremos o argumento válido, salientamos, com autores como Paoli (2005), o risco da redução do exercício da cidadania aos caminhos oferecidos pelo consumo.

TEXTOS 2006

11 A mais querida (Revista da Indústria) Mas talvez o grande diferencial da [empresa] esteja no modo como a empresa se relaciona com seus consumidores. 
20 Capital em Prol do Social: Responsabilidade social é mais que ações filantrópicas, e são os consumidores que começam a notar a diferença entre uma e outra.

(...) A forma de consumo ainda está atrelada a concentração e crescimento da renda, além da mentalidade do consumidor. "As coisas crescem muito lentamente. Se o consumidor demandar responsabilidade social, as empresas terão que mudar. O consumidor é o estopim. "Ainda" repetidas vezes. A "evolução é uma questão de tempo. Associação com fenômeno natural, biológico 22 (...) "No entanto, responsabilidade não significa doação ou terceirização de investimento social.

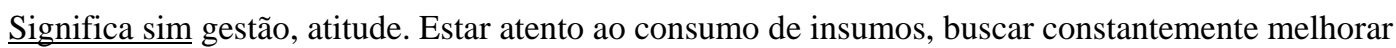
seus processos e seus produtos e adequá-los á realidade ambiental,

24 (...) “Famílias que possuem uma pequena produção, mas que ás vezes não é suficiente para transformá-la em renda vão ter uma boa oportunidade agora. Nós estamos elaborando um convênio com o governo do Estado [Minas Gerais] que visa exatamente a promoção da agricultura familiar rentável. Além disso, vamos selecionar esposas desses agricultores que produzem artesanatos para que possam vender seus produtos nos supermercados. Ou seja, vamos aproximar o supermercadista da comunidade. É uma tarefa realmente desafiadora porque teremos que criar talvez uma cooperativa”, [ presidente da AMIS]

33 Tendo por cenário um escola seu bairro e os varejistas próximos desta comunidade consumidora, propõe-se uma transferência de renda aliada a freqüência escolar e ao consumo direcionado a produtos previamente selecionados.

37 Ainda que não sejam empresas de negócios, as organizações sem fins lucrativos têm "clientes” aos quais destinam seus serviços e devem financiar suas próprias atividades, fatos que as obrigam a pensar em gestão assim como o fazem as empresas que visam lucro. Um sistema de mensuração de desempenho na criação de valor que se baseie em indicadores de qualidade deve ser considerado, portanto, obrigatório para as ONG's.

43 Solidariedade Digital Os dois endereços na rede talvez sejam os principais representantes de um novo modelo de assistencialismo social, ambiental e econômico. Em uma analogia simples, são “mercados” virtuais de projetos que reúnem iniciativas do gênero em diversas regiões do planeta. Em vez de entregarem dinheiro a grandes organizações, que decidem onde, como e quando alocar recursos, cidadãos e instituições doadoras têm a opção de escolher projetos que consideram relevantes dentro de uma ampla gama de opções.

48 A Ética no Consumo Quem são os brasileiros que transformam em militância política pela ética a tendência de consumir produtos que protejam a natureza. (...) Para estes militantes, consumir qualquer produto é um ato político.

50 Melhorar a compreensão do consumidor brasileiro sobre o papel das empresas é o primeiro passo para ampliar a RSE no Brasil (...) De um certo modo, o dado confirma a persistência de uma falsa idéia de que a empresa socialmente responsável é a que coloca recursos em projetos sociais (...) subproduto de um raciocínio simplificador e paternalista contra o qual se deve lutar, na medida em que ele reforça, na percepção do consumidor, que a atitude de RS seria um ato de generosidade e de boa vontade dos 
empresários. E não um compromisso ético mais amplo da empresa contemporânea, que como consumidores, podemos e devemos influenciar.

52 Desafio é incluir os mais pobres (...) “A verdadeira Responsabilidade Social será incluir as pessoas de baixa renda no mercado", (...) as estratégias de inclusão da população de baixa renda e as políticas de responsabilidade social empresarial podem andar juntas desde que não tenham um viés assistencialista.

Mas há quem discorde. [professor de escola de administração] entende que inclusão da população de baixa renda e políticas de responsabilidade social são coisas distintas. Para ele as empresas ainda engatinham quando o assunto é direcionar suas estratégias para essa parcela da população. “소 empresas têm que se adaptar de modo a atingir a população mais pobre, especialmente nas áreas rurais e nas periferias de grandes cidades”. Foi o que o ABN Amro Real decidiu fazer, ao criar a Real Microcrédito, braço do banco destinado a emprestar dinheiro, a taxas de juros reduzidas, para microempresários nas periferias de São Paulo e Rio de Janeiro. [ piloto na favela de Heliópolis em 2002] Aqui observamos uma discordância que é concordante.

54 Poder e Responsabilidade (...) A sociedade é influenciada pelas empresas. De certa maneira, aquilo que as empresas fazem, definem o mundo em que a gente vive. Se as empresas contratam mão-de-obra infantil, a gente vai viver num mundo que tem mão-de-obra infantil. Se a empresa disser não, lugar de criança é na escola, apoiar o desenvolvimento da educação, as crianças ficariam na escola e melhoraria a educação. E assim por diante. Isso é apenas para dar um único exemplo do poder levado a seu aspecto relacional, levado ás relações que as empresas têm.

67 A máquina Verde (...) ao abraçar um ambicioso plano para adotar práticas de negócios que sejam melhores para o meio ambiente, disse ele, o [grande grupo supermercadista] ensinará ao mundo que "não precisa haver conflito entre o meio ambiente e a economia".

(...) Os grupos ambientalistas estão em paz com o [grande grupo supermercadista]. Todavia, a empresa permanece como um grande alvo para líderes sindicalistas e ativistas liberais.

(...) Até bem pouco tempo atrás seria improvável ver em um mesmo evento executivos do [grande grupo supermercadista] e representantes das ONGs (...) Os interesses não convergem. Ou melhor, não convergiam. Na semana passada os “inimigos” se confraternizaram em São Paulo num seminário que durou dois dias e teve como palco o auditório do hotel Clarion, em Alphaville. O assunto era sustentabilidade ou, dito de outra forma, discutir como o [grande grupo supermercadista] do Brasil poderia se inserir na meta mundial do grupo de se tornar uma potência verde, preocupada com a saúde do planeta.

(...) Além das mudanças estruturais, a rede está repetindo no Brasil a filosofia de [nome do presidente do grupo] na negociação com fornecedores: quem abraçar a causa verde terá a "simpatia" do [grande grupo supermercadista]. E a simpatia do Wal-Mart em qualquer transação comercial vale ouro.

77 Uma nova mentalidade (...) Ainda há um longo caminho até que as ações sociais e ambientais da [nome da empresa] estejam completamente integradas ao negócio. Mas o processo está evoluindo rapidamente.

TEXTOS DE 2007 
88 Atitude Responsável Influencia Estratégia de Comunicação

"Se as ações de responsabilidade social se tornaram parte efetiva da rotina das corporações (...) "O motivo é claro: o outro lado, o consumidor mudou."

91 A era marquetique Segundo o especialista francês, uma empresa não pode mais apenas vender produtos. Precisa criar uma relação profunda com o público reforçando sua marca com base em valores cultuados pela sociedade.

93 “Os consumidores vêem as corporações como agentes sociais e não apenas agentes de produção, [presidente de instituto empresarial]

105 Os mais conscientes (...) Conceitos como sustentabilidade e inclusão social já passam a integrar o vocabulário diário dos executivos nas grandes corporações. Os consumidores, por sua vez, começam a identificar essas iniciativas socialmente responsáveis.

111 O social como estratégia (...) Para viabilizar o crescimento da empresa, também precisamos garantir nossa presença nos lares das classes D, E”. (Gerente de RS)

121 Avançar ou perder a dianteira (...) Crescimento + Sustentabilidade é uma equação que nem [nome da empresa] nem nenhuma outra empresa consegue hoje elucidar. "Quando a meta é crescer e crescer, em algum momento a expansão provoca um impacto ambiental maior" (consultor de sustentabilidade) (...) No passado [nome da empresa] estudou a criação de um projeto de logística reversa (...). Desistiu do sistema porque seria caro demais. Agora decidiu tentar novamente. (parceria com ONG)

124 Consciência Ambiental ganha espaço nas corporações

Muitas delas já perceberam que além, de ser responsáveis com o ambiente em que estão inseridas, diante da percepção de que podem economizar gastos e garantir a existência dessas fontes de recursos minerais no futuro, precisam também conscientizar seus empregados e envolvê-los nessas ações para que a iniciativa gere frutos. As ações contribuem, inclusive, para tornar a empresa mais atraente aos olhos dos seus colaboradores.

134 (...) “A mídia tem um papel crucial não só na transparência no que ocorre em relação às empresas e ao governo, mas também pelo conteúdo e pela mensagem que veicula, ajudando a educar ou a

deseducar os consumidores” (...) Conseguir que os consumidores percebam as ações de responsabilidade socioambiental que são feitas é um grande desafio para as empresas brasileiras. [o gerente de instituto empresarial]

142 Transformar e sobreviver (...) depoimentos de executivos do setor supermercadista e da indústria e especialistas legitimados por instituições/ organizações

(...) “A primeira regra é simples: trate o seu funcionário como gostaria que ele tratasse o seu melhor cliente. Caso contrário, qualquer ação parecerá uma jogada de marketing e, mais cedo ou mais tarde, $\underline{o}$ mercado vai perceber que todo o discurso sobre a responsabilidade social não é sincero”. (coord. de programa de RS em IES)

144 A era do consumidor politicamente correto e ecologicamente engajado (...) O estudo [elaborado pelo Pacto Global] define o marketing verde como alternativa economicamente viável — em particular para empresas que não dispõem de grandes somas para publicidade — porque as ações social e 
ambientalmente responsáveis são cada vez mais discutidas na sociedade, o que agrega valor ao produto e à empresa.

161 Dados de empresas que comercializam produtos com selo "Fairtrade" no varejo

Um executivo do setor disse” "Um comerciante esperto está a meio passo à frente do Consumidor. Dez passos à frente e você está fora do negócio”.

\section{O cidadão reflexivo}

Retomamos, aqui, a discordância de Souza Santos (2001), em relação à afirmação sustentada por autores como Ulrich Beck, Scott Lash e Anthony Giddens de que vivemos um período de auto-reflexividade, com indivíduos que não se mobilizam sem razões e cuja própria vida é um objeto de meditação, auto-análise e reversão de percursos, uma vez que a sociedade atual é marcada pela presença de dois grupos sem condições propícias para pensar. Por um lado, os que comandam esse processo não têm tempo para pensar como indivíduos, como os operadores das bolsas de valores, cujo automatismo da ação não permite pensamento e, por outro lado, a maioria da população mundial, que sofre as consequências do processo, por meio da exclusão e a desigualdade, também pouco pode pensar, pois sua prioridade é sobreviver. Dagnino (2004) e Paoli (2005), por sua vez, observam a confluência de dois projetos políticos discrepantes, tendo, de um lado, o processo democratizante e participativo, que emerge da luta contra o regime militar, e, de outro, o projeto de Estado gerencial, com a desativação de direitos universais. Coerente com a ótica empresarial é o cidadão reflexivo que surge nos textos selecionados, com apelo para a “conscientização” e a transformação operada a partir do indivíduo.

\section{TEXTOS 2006}

12 A idéia a atuar na formação ética de jovens envolvidos, despertando-os para questões como espírito de equipe, solidariedade e cidadania.

13 “Existem alunos que, além de toda a formação acadêmica, serão empreendedores sociais”.

14 (...) O segredo do sucesso talvez esteja na procura dos potenciais das pessoas, dos lugares, das situações e na possibilidade de dedicar tempo a cultivá-los.

32 (...) A responsabilidade social parte do indivíduo. Se o sujeito sozinho tem atitude cidadã correta, ele pratica responsabilidade social.

80 “O ideal seria um sistema em que a ação filantrópica partisse do indivíduo”, diz ele. TEXTOS 2007

89 Escola Fundamental agora ensino empreendedorismo

“Crianças a partir de seis anos já começam a aprender, em sala de aula, como avaliar oportunidade, ter pró-atividade e elaborar um plano de negócios.” (jornalista MA) 
109 Sustentabilidade no Brasil Artigo relaciona as questão ao negócio, obedecendo a critérios e princípios, dentro da cadeia "estratégica". No mapa de desafios da sustentabilidade, aparece, no tópico "Cidadania" (último de 31), o desafio do "baixo engajamento das pessoas na garantia do cumprimento dos seus direitos e deveres como cidadãos".

123 (...) Mas o capitalismo ético é mais do que boa política ou boa prática de "comando e controle", ele é auto-consciência, ele é transformação de relações sociais, ele é possibilidade de novas configurações econômicas, de uma nova economia.

(...) Há um otimismo no ar, só atenuado pela preocupação alarmista, mas real, de que o aquecimento global, talvez nos exija mais do que respostas capitalistas. Mas essa é uma outra história.

141 Entrevista com executiva (...) Aqui o desafio é maior por uma questão cultural. Em países da Europa e Estados Unidos as pessoas aprendem desde cedo que têm um papel social a desempenhar. (...) Já no Brasil há lacunas educacionais muito grandes e vai se construindo uma cultura de pessoas que não conhecem seus direitos e deveres. Aqui há uma oportunidade imensa de interferir no processo de transformação social e acho que devemos encarar isso como oportunidade e não como obrigação. 149 (...) E o que se espera das empresas é um comprometimento com o presente e o futuro do país. Se isso pode ser aliado à projeção da marca, ao aumento dos lucros ótimo. Mas que esses dois motivos não se sobreponham ao cumprimento de um dever ético e cidadão de descruzar os braços e dar a sua contribuição à construção de um país mais digno e justo para todos.[presidente de instituto voltado para causas sociais]

154 Cidadania corporativa é, antes de tudo o mais, um estado de espírito, um estado de consciência, são princípios e valores que começam e são praticados individualmente, estendem-se à família e desta se irradiam por toda a sociedade

Uma noção que também é aplicada à figura do líder empresarial, cujo exemplo pode servir de inspiração pois como lembra Paoli (2005), um dos objetivos do DRSE é criar no empresariado uma "consciência de cidadania”.

12 (...) referindo-se ao fundador da empresa

“[nome do fundador] foi de uma visão fantástica porque naquela época ele imaginou uma instituição voltada para a responsabilidade social que começa dentro de casa. Isso foi fantástico na época” comenta a gerente da fundação, JZ.

(...) referindo-se a visitas anuais de assistentes sociais

15 (...) Qual o tipo de empresário que age desta forma? É aquele empresário mal informado, que continua achando que responsabilidade social é um penduricalho e não uma atitude estratégica. 24 "Hoje existe uma consciência maior sobre a importância desses projetos de responsabilidade social. Cada empresa pode ajudar preocupando-se com o que está no seu entorno. Precisamos dar exemplos” frisa [ presidente da AMIS]

23 Cidadania Corporativa Estratégica: O início de uma nova Era [referindo-se a visão “tradicional”] É interessante ainda observar que este ainda é o pensamento de muitos empresários brasileiros, que começaram a entrar também no mundo corporativo internacional, recentemente. 
27 O I Ethos tem detectado uma tendência da maior importância: pequenas e médias empresas começam a despertar para consciência da RS. Se é de se esperar que grandes companhias com ações na Bolsa sejam indutoras de boas práticas, a adesão de pequenas e médias á causa deverá criar uma ampla rede de sustentabilidade (...)

39 Maior Rigor para Balanço Social "O Setor sucroalcooleiro ainda é introspectivo em responsabilidade social, mas vamos avançar na proliferação desse comportamento” afirma JPQB, presidente de grupo usineiro.

2007

92 Vejo que em muitas empresas, a chamada responsabilidade social corporativa está cada vez mais saindo do marketing, da área de recursos humanos ou do campo de relações institucionais para ocupar um lugar mais digno: o coração e a mente dos líderes empresariais.” Relação com Ethos 103 Especialista de Harvard diz que é o líder que dá o tom das ações sociais das empresas.

(...) Um bom critério é o quanto o projeto está relacionado com as políticas públicas que tangenciam o problema. (...) Outro critério é a capacidade de gerar solidariedade voluntária.

106 Responsabilidade Social Ganha papel central a estratégia da empresa - Para presidente do [instituto empresarial], porém, isso não significa que os grupos já sejam socialmente responsáveis.

Observamos, portanto, em linhas gerais, que os textos analisados apontam para o estabelecimento de uma negação do marketing e da publicidade, assim como das práticas filantrópicas, deslocando a RSE para o campo da gestão e do desenvolvimento empresarial.

As dicotomias estabelecidas apontam, por sua vez, para uma resposta única, oferecida pelo conceito de sustentabilidade e por uma proposta de cidadania reflexiva, com inserção pelo consumo.

O tom geral dos textos é prescritivo, respaldado por figuras de autoridade (especialistas, pesquisas de mercado, provas científicas e exemplos práticos), dando um efeito geral de evidência (de um fenômeno natural e inevitável que alguns ainda não enxergam).

Ressalvamos que o DRSE certamente não pode ser resumido a essas questões, mas consideramos que o levantamento, embora lacunar, é capaz de oferecer uma configuração de elementos plausíveis, a partir da superfície dos textos analisados. 


\subsection{Análise longitudinal de documentos: Balanços Sociais}

Considerações preliminares sobre a escolha do material empírico

A escolha desse segundo conjunto empírico, além das justificativas elencadas na apresentação do percurso metodológico, foi corroborada, em termos de representatividade, por dados obtidos nas matérias jornalísticas coletadas para a primeira parte das análises. Matéria do jornal O Estado de S. Paulo (23 ago. 2006, Economia, p. B16) traz dados de estudo internacional, realizado pela consultoria KPMG com 1.600 grandes empresas, e mostra que $74 \%$ delas publicam relatórios de sustentabilidade (ou balanços sociais, como são mais conhecidos no Brasil), com objetivos econômicos, ou seja, tentam garantir com as informações socioambientais um diferencial para suas ações no mercado. Na mesma matéria, um assessor de sustentabilidade afirma que "Falta transformar a responsabilidade social em números e mostrar seus impactos na produtividade, nos custos e nos riscos da operação da empresa”, tendência reiterada pela transformação dos documentos analisados, e que se encaixa no que Hannah Arendt (2004, p.50) denomina moderno tratamento matemático da realidade, que, por meio da estatística, trabalha com grandes números e flutuações, descartando feitos e eventos. Dessa forma, quanto maior a população, tem-se maior validade e menos “desvios”, aumentando a probabilidade de que o social ocupe o lugar do político na esfera pública.

Outra matéria, esta da revista Carta Capital (Seção especial, de novembro de 2006.), detecta a convergência das empresas para modelos que garantam a comparabilidade internacional, sobretudo pela adoção do modelo GRI - Global Reporting Initiative, ONG criada na Holanda, em 1997, por uma coalizão de organizações dispostas a desenvolver diretrizes "para equiparar relatórios de sustentabilidade aos balanços financeiros”. Esse deslocamento no sentido dos dados financeiros para comparabilidade é colocado como uma espécie de evolução, ao permitir o tratamento em escala dos fenômenos. Nessa matéria, uma diretora da ONG GRI destaca os principais leitores dos balanços sociais: formadores de opinião da própria empresa, como diretores e profissionais de comunicação; investidores com interesse no desempenho da empresa; e agências governamentais e jornalistas que começam a crescer como público. Aborda, ainda, a tendência de adaptação da linguagem para diferentes públicos, assim como a publicação de relatórios de sustentabilidade por ONGs e órgãos públicos, “em nome da transparência” e visando “harmonização de padrões”. 
A matéria da Revista Foco (ano 3, n. 34, p. 26-28, de 31 jan. 2006), por sua vez, informa que os relatórios anuais das empresas de capital aberto acompanham a globalização dos mercados, estão mais completos e amplos e têm, como tema central, a sustentabilidade, o que seria, segundo executivos, uma tendência mundial. Cita, ainda, empresa que converteu o relatório para a forma de uma revista e passou a ser denominado Relatório de Sustentabilidade, termo considerado mais amplo; e outra grande empresa que optou por documento conciso, mas acompanhado pelo DVD, desenvolvido por alunos de uma instituição de ensino privada.

Acrescentamos que o setor escolhido é considerado, por artigos localizados na revisão da literatura, como caso emblemático de humanização das marcas e das ações de responsabilidade social, entendidas como estratégia de comunicação e gestão empresarial, possuindo grau avançado de institucionalização das ações, percebida, nos termos de Bourdieu, como um valor para o campo. Essa constatação encontra eco, na matéria publicada pela revista Exame (ano 41, n.8, p. 84-86, 9 de maio de 2007) selecionada para análise, que considera o setor escolhido um dos mais organizados em relação à discussão sobre a sustentabilidade nos negócios, contando com critérios disseminados, que se tornaram uma espécie de nova esfera da competição das empresas do setor, em todo o mundo. Outra matéria destaca que a organização, ao lado de outra do mesmo setor, é pioneira em assumir boas práticas, e foram consideradas as mais sustentáveis e éticas da América Latina em pesquisa de empresa de consultoria em gestão.

A relevância mercadológica é enfatizada com premiações e outras informações fornecidas pela organização, nos documentos analisados, incluindo premiações internacionais, certificações e participação em índice de sustentabilidade nas bolsas de valores de São Paulo e de Nova Iorque. Conceitos norteadores e procedimentos da análise

Foram localizadas, no site da empresa, as versões eletrônicas (PDFs) dos relatórios de responsabilidade, no período entre 2002 e 2007, que, como gênero discursivo, tem uma estrutura relativamente estável de enunciado e de aspecto normativo e, como observa Bakhtin (2003, p. 285), são flexíveis, mas têm sentido normativo. Dessa forma, os relatórios de empresas, embora sejam enunciados singulares, não constituem combinações livres de formas da língua e obedecem a coerções próprias desse gênero. Além disso, ressaltamos que a escolha de gêneros utilizados DRSE não é aleatória, uma vez que esse discurso se constitui de certos tipos de texto que correspondam à sua formação discursiva predominante. Nesse 
sentido, a escolha do nome balanço social, por si só, já indica o predomínio de uma voz gerencial e administrativa.

Tendo em vista os relatórios (ou balanços sociais) como um gênero de discurso, para realizar este momento da análise partiremos das suas limitações definidoras que, conforme Maingueneau (1998, p.74), são: o status respectivo dos enunciadores e dos co-enunciadores; as circunstâncias temporais e locais da enunciação; temas que podem ser introduzidos; a extensão e o modo de organização; o suporte e modos de difusão.

No que diz respeito ao suporte, que não será foco de nossa análise, mas é fundamental para a emergência e estabilização dos gêneros, observamos que a internet têm impactado no formato e quantidade dos relatórios de responsabilidade social das empresas, como observado nos trabalhos de Lucien e outros (2007), e Wanderley e outros (2008), que realizam estudos comparativos sobre a divulgação das ações de responsabilidade social nos websites de corporações, em diversos países.

\section{Análise dos balanços sociais}

Circunstâncias da enunciação e status dos enunciadores

O DRSE instaura uma comunidade discursiva, que, no caso dos balanços sociais, se centraliza num grupo composto por formadores de opinião da própria empresa, como diretores e profissionais de comunicação; investidores com interesse no desempenho da empresa; agências governamentais e jornalistas. Como afirmamos, anteriormente, é, de certa forma, um grupo simultâneo de enunciadores e enunciatários, uma vez que a comunicação tem uma característica de comunicação conspícua (termo emprestado de Veblen, que cunhou a noção de consumo conspícuo), procurando mostrar à comunidade que a empresa fala como seus diferentes públicos, evidenciando sua responsabilidade perante eles, e demarcando, ao mesmo tempo, a posição da empresa em relação aos concorrentes.

Essa comunidade insere-se, por sua vez, numa circunstância maior de enunciação, na qual, como afirma Hannah Arendt, prevalece uma visão biológica da vida, com a conformação da atividade humana ao ciclo renovável da natureza. Chauí (2001, p.10) aborda essa questão ao se referir a um discurso competente, que emana da racionalidade do mundo organizado e tende a reduzir os sujeitos à condição de objetos sócio-econômicos e submetêlos à linguagem dos especialistas.

No âmbito do processo discursivo, a cena de enunciação condiciona a organização da língua, onde o sujeito é entendido como o "lugar” que ocupa para ser sujeito que diz (Foucault, 1969 apud ORLANDI, 2002, p.73). Contudo, nessa análise centraremos contudo o 
olhar para o Autor, função específica do sujeito, que, segundo Vignaux (1979 ORLANDI, 2002, p.75-76), é o lugar em que se constrói a unidade do sujeito, e estabelecida ao lado das outras funções (enunciativas): o locutor, que se apresenta como "eu” no discurso; e o enunciador, a perspectiva que esse “eu” constrói. A função-autor é a mais afetada pelo contato com o social, pois é do autor que são exigidas coerência, respeito às normas, clareza, unidade e não contradição; exigências cuja finalidade é tornar o sujeito visível, controlável e identificável. O sujeito reconhece a exterioridade à qual deve se referir e, simultaneamente, remete à sua interioridade, constituindo sua identidade como autor, processo denominado por Orlandi (1988 apud ORLANDI, 2002, p.76) como assunção da autoria, que implica representar um papel social na relação com a linguagem, diante das instâncias institucionais.

Nos balanços sociais, esse movimento de especialização e legitimação de autores foi observado de duas formas: a partir das modificações no Expediente dos documentos, onde a autoria foi sendo gradualmente deslocada do departamento de marketing, no sentido de uma aproximação com o núcleo dos negócios da empresa, e a entrada de empresas de consultoria na área de responsabilidade social e sustentabilidade; e por meio da ampliação de certificações e declarações de terceiros especialistas, que legitimam as publicações.

\section{Modificações no Expediente}

Podemos observar a seguinte transição na autoria dos documentos:

\begin{tabular}{|c|}
\hline 2002 \\
\hline Concepção, Coordenação, Supervisão e Edição: Departamento de Marketing \\
\hline Criação, Projeto e Produção: [nome de agência] Publicidade Ltda. \\
\hline 2003 \\
\hline Editada pelo Departamento de Marketing \\
\hline Projeto Gráfico e Direção de Arte: [nome] Comunicação e Design \\
\hline 2004 \\
\hline Concepção Básica, Coordenação e Edição: Departamento de Marketing \\
\hline Criação, Projeto e Produção: [nome] Comunicação e Design \\
\hline 2005 \\
\hline Concepção Básica, Coordenação e Edição: [nome da organização] - Departamento de \\
\hline Marketing, Assessoria de Imprensa \\
\hline Produção: [nome] Comunicação e Design \\
\hline As informações e os dados deste Relatório foram disponibilizados pelas seguintes Empresas \\
\hline Ligadas, Departamentos e Áreas do [nome da organização]: [nomes de empresas e setores \\
\hline 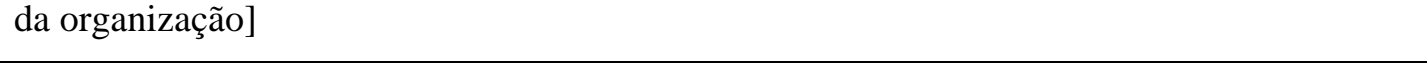 \\
\hline
\end{tabular}


2006

Coordenação Geral: Departamento de Relações com o Mercado - Área de

Responsabilidade Socioambiental

Consultoria: [nome de consultor]

Consultoria GRI e Textos: [nome de empresa de consultoria]

Apuração e Consolidação dos Indicadores: [nome de empresa de consultoria]

As informações e os dados contidos neste relatório foram disponibilizados pelas seguintes

empresas ligadas: [nomes de empresas e setores da organização.

2007

Coordenação Geral: Departamento de Relações com o Mercado - Área de

Responsabilidade Socioambiental

Consultoria: [nome de consultor]

Consultoria GRI e Textos: [nome de empresa de consultoria]

Apuração e Consolidação dos Indicadores: [nome de empresa de consultoria]

Auditoria: [nome de empresa de auditoria]

As informações e os dados contidos neste relatório foram disponibilizados pelas seguintes

empresas ligadas: [nomes de empresas e setores da organização]

Observamos, dessa forma, assim como ocorreu no âmbito das matérias jornalísticas,um gradual afastamento da RSE do setor de marketing, e a associação ao setor denominado "Relações com o mercado", dentro da perspectiva de diálogo com as partes interessadas, ou stakeholders. Um movimento que legitima o discurso, ao afastá-lo da conotação negativa de “promoção da imagem”, associada ao marketing, e é complementado pela inclusão de coautores contábeis e especialistas no campo da RS e sustentabilidade. Ampliam-se, também, os coautores, ao explicitarem-se os departamentos que forneceram dados para o relatório e os responsáveis por revisões específicas (empresas de consultoria em sustentabilidade), numa trajetória que aumenta a legitimidade do documento, por fazer referência a saberes aceitos e certificados. Também nesse sentido aumentam as certificações recebidas pela organização (de 185 em 2006, para 196 em 2007).

No âmbito da auditoria, que aparece no documento apenas em 2006, transita-se de uma declaração mais ampla para uma declaração de asseguração limitada, mais cuidadosa e menos abrangente, com a inclusão de uma “declaração de garantia”, emitida por uma empresa de consultoria internacional, especializada em sustentabilidade. 
Relatório dos Auditores Independentes sobre a revisão das informações suplementares inclusas no Relatório de Sustentabilidade do [nome da organização] 2007

Relatório de Asseguração Limitada dos Auditores Independentes sobre o Relatório de Sustentabilidade de 2007 do [nome da organização]

+ Declaração de Garantia (emitida por empresa de consultoria internacional)

Uma vez que o objetivo de uma auditoria é opinar sobre demonstrações financeiras (e outros tipos de demonstrações operacionais), a asseguração limitada representa um tipo de ressalva às informações do demonstrativo analisado, expressa no seguinte trecho do relatório “As opiniões, informações históricas, informações descritivas e sujeitas a avaliações subjetivas não estão no escopo dos trabalhos desenvolvidos”, preservando a idoneidade da empresa de auditoria (que precisa permanecer legítima para operar no mercado) e possíveis implicações jurídicas para a organização. Uma vez que tal declaração enfraquece a proposta de transparência do discurso da organização, é adicionada ao documento uma “declaração de garantia”, emitida por consultoria especializada, para restaurar a legitimação.

Temas, extensão e o modo de organização

Tendo em vista o enfoque das demais análises complementares de nosso trabalho, que se detêm na comunidade discursiva e encadeamentos, controles e delimitações, optamos por realizar uma análise voltada para a estrutura dos documentos, por permitir o tratamento de um conjunto de dados abrangente, e também por oferecer a possibilidade de detectar substituições, apagamentos, acréscimos de palavras e expressões, que determinam a partir das estruturas. Orlandi propõe, nesse sentido, a observação do efeito metafórico, que põe em relação discurso e língua e permite objetivar o modo de articulação entre estrutura e acontecimento. Recorre a Pêcheux (1969 apud ORLANDI, 2002, p.77), para quem efeito metafórico é fenômeno semântico produzido por uma substituição contextual, um deslizamento de sentido; um trabalho produzido pelo deslize, onde o ponto de partida e chegada são inteiramente diferentes, mas a diferença sustentada em um mesmo ponto que desliza de próximo em próximo.

Para observar esses deslizamentos, descrevemos as estruturas de todos os seis relatórios selecionados, trabalho que resultou no quadro comparativo em apêndice. 
A comparação geral dos relatórios permitiu detectar um movimento geral do social para o ambiental, percebido, a princípio, pela metamorfose nos títulos, fato que nos motivou a optar por uma seqüência histórica dessa organização (que é considerada exemplar no âmbito de ações RSC). Trata-se de uma movimentação que se intensifica nos detalhes dos relatórios de 2006 e 2007, que, embora mais parecidos, estruturalmente (pela adequação a critérios internacionais de comparabilidade), apresentam modificações estruturais significativas. Sinteticamente, observamos nos relatórios de 2002 a 2007:

- Ascensão do termo sustentabilidade, de uma posição subalterna, nos primeiros, até ocupar o título do documento dos dois últimos relatórios.

- Uso da palavra democracia, associado a crédito e consumo, que remete a uma concepção “minimalista” de democracia, naturalizada como a democracia possível, como destacam Paoli (2005) e Dagnino (2004).

- Transição do termo $R H$ (Recursos humanos) para Público Interno, sendo que, no diagrama de relações estratégicas, desaparece o vínculo com o $R H$ e surgem os termos Qualidade de Vida/ Clima; e desaparecimento dos Sindicatos nos públicos estratégicos; dois movimentos que vão ao encontro dos questionamentos levantados por Cappellin e Giuliani (2006), e Cappellin e Giffoni (2007), ao observar o paralelismo entre o movimento empresarial pela desregulamentação trabalhista e o crescimento das ações de responsabilidade social. Cabe aqui destacar, contudo, que a organização analisada oferece liberdade de:

- Releitura da história da organização com rótulos atuais;

- Mudança, já mencionada, da autoria do departamento de Marketing para Relações com o Mercado;

- Surgimento (em 2004) e desaparecimento do quadro de divisão do capital social.

Ressaltamos, antes de prosseguir no detalhamento da análise, que essas mudanças de rótulos correspondem a mudanças de fazer e comunicar os negócios e as ações sociais da empresa. Como indicam Hannah Arendt e Richard Sennett, tais mudanças na superfície dos textos dialogam com mudanças na esfera pública e no mundo do trabalho, no sentido da naturalização do processo econômico (ao associá-lo ao ambiente) e diluição de potenciais conflitos. Lembramos, também, que as imagens não serão objeto de análise, embora dialoguem com o texto e tragam elementos que constroem novos enunciados.

As mudanças observadas, de forma geral entre 2002 e 2007, foram objeto de descrição e comparação mais detidas nos relatórios de 2006 e 2007. A partir do cotejamento dos 
documentos desses dois anos, cuja estabilidade de formato deve-se ao alinhamento a critérios internacionais de avaliação e classificação, observamos que há, contudo, mudanças expressivas que reforçam alguns deslizamentos semânticos e delineiam a hierarquia que os termos (e, por conseguinte as prioridades, investimentos e ações) devem assumir.

Em linhas gerais, consideramos que dois aspectos merecem destaque por mostrarem, na superfície textual, o movimento declarado na mídia e, posteriormente, reiterado nas entrevistas de afastamento do marketing e da filantropia, e associação das atividades ao core business (negócio principal, ou núcleo de negócios) da organização, sob a ótica da sustentabilidade, que propõe o arranjo entre aspectos sociais, ambientais e negociais:

- Alterações na estrutura do relatório (que podem ser observadas no quadro comparativo entre os índices, apresentado a seguir):

o Deslocamento dos itens "Responsabilidade social” e "Finanças Sustentáveis” (antes independentes) para o guarda-chuva da "Visão sustentável”, sob o qual também foi inserido um tópico com o slogan comercial da empresa, onde são elencados os compromissos da organização.

o Inclusão do item “Desenvolvimento econômico”.

o Supressão do item relativo às ONGs, que deixam de ter tópico próprio, ficando sob o guarda-chuva da comunidade.

o Ajustes em relação aos públicos de interesse ou stakeholders:

- Apagamento da “freqüência” no relatório de 2007, em relação aos critérios elencados originalmente em 2006 - interesse, influência e freqüência para a definição de 7 grupos estratégicos de relacionamento (Acionistas e Investidores, Clientes, Fornecedores, Público Interno, Comunidades, Governo e Sociedade, ONGs).

- Mudanças no peso entre os grupos: ONGs perdem peso; Comunidades ganham; Público Interno mantém-se estável (com a troca da expressão "Recursos Humanos" por “Qualidade de Vida/ Clima”); Acionistas e Investidores sem alterações; Clientes, sem alterações; Fornecedores ganham peso; Governo e Sociedade (ganham peso, com a inclusão de arranjos produtivos, inclusão digital, projetos educacionais e esportivos junto a escolas públicas, num movimento geral no sentido da cadeia produtiva, associado à valorização de projetos próprios - exemplos a serem aplicados em escala por outras empresas e governos).

Essas mudanças podem ser visualizadas no quadro comparativo em apêndice. 
Complementando as observações a respeito das modificações gerais, procedemos, tendo por base o relatório mais atual de que dispúnhamos (2007), uma interpretação a partir da noção de valor.

Tal escolha deve-se à presença constante do termo no DRSE, que remete, como observa Arendt (2004, p.149-187), a idéia da proporção entre a posse de uma coisa e a posse de outra, no conceito dos homens, ressaltando que as coisas, ideias ou ideais morais só se tornam valores em sua relação social. Com a entrada do dinheiro como denominador comum no lugar de regras, medidas e padrões “absolutos”, a percepção do valor foi diluída, uma vez que o dinheiro não possui existência independente e objetiva, que possa transcender o uso e sobreviver à manipulação, como os instrumentos de medida em relação às coisas e homens que as manuseiam. Diante disso, Arendt afirma nesse âmbito que a medida das coisas não precisa ser nem a compulsiva necessidade/ consumo da vida biológica e do labor, nem o “instrumentalismo” da fabricação e do uso.

A seguir, fazemos um levantamento de como a noção de valor é associada a cada um dos grupos de interesse, percebendo que os diferentes pesos e medidas utilizados tornam difícil estabelecer alguma proporcionalidade entre os ganhos efetivos de cada parte envolvida. A essa dificuldade somam-se as limitações de Siqueira (2007) que destaca que a DVA apresenta limitações preocupantes, sobretudo no âmbito estrutural, ao abordar a Demonstração do Valor Adicionado (DVA) como instrumento de avaliação da RSE que visa demonstrar a geração de valor pela empresa e sua distribuição entre os elementos que contribuíram para isso. Limitações estruturais residem na ambigüidade informativa existente nos números oferecidos pela demonstração, que se inicia na apresentação da construção do valor, uma vez que a afirmação de que a alta criação de valor torna uma empresa socialmente desejável não se sustenta, pois esse pode ser conseguido através de práticas monopolistas, em economias sem salvaguardas ambientais ou com fornecedores com práticas questionáveis. Permanece, ainda, na distribuição do valor criado, uma vez que os altos valores pagos em salários podem representar a canalização de resultados para uma elite gerencial ou familiar. Por outro lado, elevados valores em impostos devidos à progressividade, em função de uma essencialidade declinante, são encontrados na indústria de tabaco e álcool, que não constituem exemplos de responsabilidade social.

Observamos, a seguir, como o termo "geração de valor” assume diferentes feições, ao longo do relatório (2007) da organização. 


\section{$\underline{\text { Acionistas }}$}

“A decisão de remunerar seus acionistas acima do percentual previsto pela legislação é uma tradição no [nome da organização] (...) o [nome da organização] assegura, a título de dividendo mínimo obrigatório, o pagamento de 30\% do lucro líquido ajustado, acima, portanto, dos 25\% exigidos pela Lei das S.A. No caso das ações preferenciais (PN), distribuem-se dividendos 10\% maiores que os conferidos às ações ordinárias (ON). Em 2007, a divisão de juros sobre capital próprio e dividendos alcançou a cifra de R\$ 2,823 bilhões, soma equivalente a 39,2\% do lucro líquido ajustado e mais de R \$ 660 milhões acima do valor pago em 2006.” [trecho transcrito do relatório de sustentabilidade]

\section{Clientes}

São citadas: as unidades comerciais de atendimento ao público (número de unidades); valor repassado a aposentados e pensionistas do INSS (valor em reais), os municípios que possuem a organização como único prestador de serviço no setor (número de municípios); produtos em circulação no mercado (quantidade e valores em reais); remessas financeiras (valores em reais); e investimentos em infra-estrutura, informática e telecomunicações (valores em reais).

\section{Colaboradores}

São elencados: o número de colaboradores; o total de proventos e encargos sociais (valor em reais); a participação nos lucros e resultados (que é isenta de impostos, com valor em reais); provisão para processos trabalhistas (valor em reais); treinamento (valor em reais); saúde (valor em reais); alimentação (valor em reais); previdência privada (valor em reais); creche/auxílio creche (valor em reais); outros (valor em reais).

\section{Fornecedores}

São informados o número de contratos e o volume financeiro (valor em reais).

\section{Comunidade}

Não há menção, no texto 2007, a “geração de valor”, mas de “investimento”. São descritos: “Ações de cidadania” - projetos apoiados pela organização nas áreas de educação, meio ambiente, esportes, inclusão digital, cultura e eventos comunitários, sendo informado o valor global investido (em reais), distinguindo as doações enquadradas em leis de incentivo (valor em reais); Investimentos socioambientais ( áreas de educação, meio ambiente, inclusão digital, cultura e esporte) - com o valor global investido (em reais), distinguindo recursos aplicados pela fundação da organização e pelas doações enquadradas em leis de incentivo; e 
“Investimento popular”, com a quantidade de eventos comunitários, eventos de negócios, eventos culturais, e eventos esportivos.

\section{Governo e sociedade}

O "Valor gerado para a sociedade" é descrito em termos de impostos e contribuições próprios, pagos e provisionados ou arrecadados (em reais), e repasse indireto de recursos.

Observamos, por essa descrição, que o volume de informações gera um efeito de evidência de que todos os públicos são beneficiados. A comparação dos benefícios fica, contudo, impossibilitada, pelo uso de unidades e proporções distintas. Retomando Arendt, os valores tornam-se incomparáveis, pelo não estabelecimento dos tipos de relações sociais que os sustentam. 


\section{3 Análise das entrevistas}

\section{Considerações preliminares}

Nesta última parte das análises, levantaremos alguns pontos que nos chamaram a atenção nas entrevistas realizadas com cinco profissionais de grandes organizações. Como já mencionado no tópico dedicado à metodologia, foram entrevistas semi-estruturadas, realizadas com o auxílio de um roteiro, para nortear os depoimentos.

Os procedimentos, após o processo de agendamento já descrito, iniciavam-se com um esclarecimento sobre as intenções da pesquisa, seguido da assinatura de um termo de consentimento (apêndice), no qual nos comprometemos a preservar o sigilo da identidade do entrevistado e da empresa. Dessa forma, os entrevistados serão aqui identificados como A,B, C, D e E, e os nomes das empresas e outros índices de identificação, suprimidos.

Exceto em um caso (devido a um conflito na reserva da sala, ocasião em que circulamos pela empresa e ficamos num local de uso comum), as entrevistas ocorreram em salas de reunião bastante similares, inclusive em relação ao nome (duas delas eram denominadas "sala planeta” e, uma, “sala sustentabilidade”), junto ao local de funcionamento do departamento, ou próximas, uso comum. O ambiente, com baias baixas, segue o padrão encontrado na maior parte das grandes empresas. Os entrevistados ocupavam cargos de gerência ou direção de áreas, ou setores ligados à RSE, e eram jovens (entre 30 e 50), com o tempo de trabalho na área oscilando entre 2 e 4 anos.

Em termos discursivos, podemos dizer que, de certa maneira, havia o encontro de um representante do saber científico, legitimado pela realização de pesquisa de doutorado, em uma instituição renomada, e um representante do saber "prático" ou executivo, fato que instaura um estatuto entre os protagonistas do discurso, conforme destaca Charadeau (1983, p.59 apud BRANDÃO, 1998, p.58), com uma imagem projetada do locutor sobre si mesmo (que autoriza a fala), e uma imagem que projeta do destinatário, assim como o tipo de relação que se pretende estabelecer. De nossa parte, havia a vontade de "provocar", por meio do roteiro, uma fala que trouxesse elementos além do discurso institucional das empresas, ou, ainda, que abordasse pontos que considerávamos cruciais a serem explorados. A essa vontade era contraposta outra, uma tentativa de respeitar a fala do entrevistado, deixá-lo falar, apenas levantando tópicos para que seguisse adiante. Oscilando entre os dois polos, acreditamos que a segunda tendência prevaleceu na maior parte das vezes (com a incidência de interrupções desnecessárias, como pode ser observado na transcrição completa que se encontra no apêndice). Outro aspecto que chamou a atenção foi o de que, diante do clima de cordialidade 
instalado em todos os casos, houve uma tentativa de não aparentar falsa simpatia a respeito de questões com as quais não concordávamos na tentativa de, novamente, “estimular” a fala. Acreditamos, contudo, que tenhamos, devido ao clima cordial, sido pouco incisivos ao abordar possíveis contradições.

\section{Observações sumárias sobre as situações de entrevista}

\section{Empresa e entrevistado A}

Primeira entrevista realizada. Recepção “clean”. Entrevistado da área de relações públicas, postura tranqüila. Fala clara e consciência de papel e limitações. Oscilação, na fala, da ênfase de aspectos humanos para a cadeia produtiva. Percepção das ações como evolução e não revolução. Não mudam o status quo.

\section{Empresa e entrevistado B}

Segunda entrevista. Aproximação inicial, por ter realizado a graduação na mesma instituição de ensino. Empresa comprada por controlador estrangeiro, tom de confidência, adaptações na cultura da empresa. Mudança de sala, no início da entrevista, que foi realizada, em sua maior parte, numa biblioteca, com falas sussurradas.

\section{Empresa e entrevistado C}

Terceira entrevista. Estávamos, apesar da formalidade do local, mais à vontade. Perguntas e respostas mais claras. Tranqüilidade de ambos, com falas pausadas e estruturadas. Mudanças recentes na composição do departamento.

\section{Empresa e entrevistado D}

Quarta entrevista. A mais longa de todas. Amplo detalhamento das ações, sobretudo comunitárias, assim como da gênese do setor. Empresa e setor passam por mudanças, devido à mudança de controlador.

\section{Empresa e entrevistado E}

Quinta entrevista. Setor passa por grandes mudanças no âmbito global e local. Função de direção assumida pelo entrevistado, recentemente.

\section{Comunidade e memória discursiva}

Conforme afirma Maingueneau (1997, p.53-56), a noção de condições de produção do discurso não deve ser percebida apenas como “contexto” ou “conjuntura”, uma vez que a 
situação extraverbal não age do exterior como força mecânica, mas entra no enunciado como constituinte necessário à sua estrutura semântica.

O autor propõe, ainda, como já expusemos, a noção de uma comunidade discursiva, assim como chama a atenção para o fato de que essas coletividades supostas pelas formações discursivas partilham de um "tesouro de enunciados fundadores" (MAINGUENEUAU, 1997, p.101), sem os quais a coletividade não seria o que ela é. Como discurso que emerge no ambiente empresarial, mais especialmente nos setores de marketing e gestão, o DRSE traz consigo, embora haja um esforço na tentativa de um afastamento das questões comerciais, marcas características do discurso marcado pela ótica do management (ou gestão) que ilustramos a seguir, com trecho de artigo de Tom Volmann, professor de Administração Industrial da Escola de Negócios IMD (publicado na coleção Mastering Management do jornal a Gazeta Mercantil, em 1997), com o título “Transformar ou morrer”, um tipo de discurso cujos ecos se fazem sentir nas entrevistas realizadas.

\footnotetext{
As quatro características da transformação estratégica

"Integração: O plano da empresa é um plano integrado? Há uma ligação clara entre aquilo que o mercado dita em relação a uma intenção estratégica global e as ações específicas e os processos necessários que precisam ser novamente planejados?

Coerência. As várias ações conduzem todos ao mesmo fim e complementam-se mutuamente? A equipe de administração tem uma idéia clara de como as coisas funcionam no seu conjunto? Todo o pessoal da empresa vê a mesma imagem do quebra-cabeça?

Viabilidade. O plano de transformação permite a concretização no prazo previsto? As metas_que ajudam as pessoas a evoluir são ótimas, mas os objetivos, impossíveis de atingir, conduzem seguramente à desilusão e ao cinismo. Ao mesmo tempo, é necessário que exista uma percepção do sentido de urgência. A transformação exige uma mudança fundamental no “status quo”.

Vontade. O esforço global de transformação é desejado tanto do ponto de vista da empresa quanto dos trabalhadores? A empresa, unidade estratégica e os trabalhadores têm que acreditar na necessidade de acelerar a mudança e estar preparados para a necessidade de aceitar uma situação de “crise controlada”.
}

\section{Interpretação das entrevistas}

Em termos gerais, de forma condizente com a finalidade das empresas, as falas referiam-se à questão da lucratividade, e mostraram que, mesmo ao fazer referência ao social, o discurso possui elementos constitutivos que o associam à cadeia de produção e consumo. As condições de produção, envolvendo a memória discursiva, fazem com que, apesar de individualizado (e nisso reside sua potencialidade) o discurso que nasce na empresa traga 
consigo algumas coerções, que se manifestam na superfície dos fragmentos das falas dos entrevistados.

\section{Marcas do Capitalismo flexível}

Das cinco empresas onde foram realizadas as entrevistas, quatro haviam passado, recentemente, por mudanças, sendo duas na composição acionária e duas no âmbito departamental, o que implicava coerções e mudanças de tom no discurso. Soma-se a essa sensação de permanente mudança o pouco tempo do setor de todos os entrevistados, assim como as constantes mudanças de nomeação das áreas. Algo que remete às colocações de Sennett sobre a tendência do capitalismo contemporâneo a uma (?) empresarial, onde o indivíduo não possui posição e esta não tem conteúdo fixo. O caso mais agudo manifestou-se no depoimento do entrevistado E:

Você está no meio de uma mudança estrutural poderosíssima. Que não é só lá [país sede] que tá acontecendo, mas aqui no Brasil também.

Então esse é um panorama que está agora, pode ser que janeiro mude. Pode ser que janeiro apareça algum diretor, algum gerente (...) antes era muito claro, era um departamento, a diretora, o presidente, que agora a gente foi jogado pra cá, pra lá,

\section{Evolução natural do conceito}

Ao ganhar ênfase ambiental e associar-se à noção cíclica de vida natural, o DRSE ressalta a noção de evolução biológica da humanidade, caracterizada pelo animal laborans, de Hannah Arendt. Embora a noção de "evolução natural” seja constante, surgiu, em uma entrevista, o eco do homo faber, na percepção de que não há fabricação humana sem impacto ambiental.

(...) não tenho nada a esconder, é um fato, eles não têm um histórico de publicação, relatório de responsabilidade corporativa, tanto é que o relatório anual deles é separado, (...) isto é sinal de estarem em um nível menos evoluído. [B] (...) Acho que foi uma evolução natural de construção de conhecimento e entendimento sobre a proposta (...) [D] [referindo-se ao processo de implantação] ele é orgânico, aí o que é que tem. Quando a gente tem a inserção de sustentabilidade nas áreas, todas as áreas elas são estimuladas e apoiadas [D]

(...) sustentabilidade não é uma revolução, mas é uma evolução dos processos, é minha concepção, você não está quebrando o status quo, (...) você avalia sua relação 
com sociedade, comunidade, público interno, governos e autoridades, até a maneira como você produz, mas você nunca vai ter o impacto zero no meio ambiente [A]

\section{Respostas a demandas do mercado}

(...) Tanto é que a gente na estrutura da empresa, hoje a gente tem uma área chamada desenvolvimento sustentável, super-recente este nome, uma atualização segundo os padrões. Nós estamos tentando acompanhar o mercado [B]

[referindo-se a um projeto de RSE] ele nasceu mesmo à nossa necessidade de responder aos índices, e ao CDP - que é aquela iniciativa de investidores londrinos, de você fazer um report, [C]

Eu diria assim, que hoje as iniciativas do [empresa], em relação a este tema [ações na comunidade] nascem, ou porque está sendo demandado pelo mercado. [D] (...) o [nome de empresa] está fortemente cobrando seus fornecedores sobre sustentabilidade, no caso você está estudando bastante, então, eles são muito bacanas e eles estão forçando todos fornecedores. [E]

Tem uma febre muito grande de saber o que a gente está fazendo, a febre dos investidores em saber o que as empresas estão fazendo quanto à questão ambiental, que é mais latente, talvez seja a bola da vez [C]

\section{Controle da empresa sobre as ações}

Porter e Kramer (2006) levantam, do ponto de vista gerencial, o risco de ceder controle primário da pauta de RSE a terceiros, ao ampliar o diálogo com as partes interessadas, por considerar que dividir a pauta de deliberação não é um procedimento estratégico. Nesse sentido, as entrevistas deixam clara, a percepção e os cuidados em relação a esse risco, e mostram que as ações partem sempre dos interesses da empresa.

Aqui na sede como a gente tem várias organizações E sempre se escolhe uma que seja grande o suficiente que consiga receber 500 a 600 pessoas, que tenha obviamente a necessidade, é claro (...) [referindo-se a ações de voluntariado] [B] É assim, nós temos um posicionamento, nós temos um foco, quais são as causas que [a empresa] quer trabalhar (...) o Brasil tem muitas necessidades, então se você não define, um posicionamento e uma estratégia, você fica muito vulnerável a tudo que vem [D] 
(...) todos os nossos projetos, eles estão muito alinhados com os dois temas de sustentabilidade(...) [E]

(...) a gente decidiu este ano que não teria na festa de final de ano com bebida alcoólica (...) a gente mudou o foco da festa (...) a gente colocou um conceito de responsabilidade social, que passar o dia inteiro com família, é um educandário, como se fosse um orfanato, uma espécie de fazenda... ações, dia do voluntariado, pintar, reformar, lavar cortina, fachada [A]

Depois se percebeu que pode ser investido na África, não se tem operações na África, mas a gente tem operações em muitos países emergentes, que têm indicadores muito ruins, tão baixo, como os da África. (...) São países chaves para [organização] o Brasil destes países emergentes é o que tem entregue melhores resultados (...) (...) montaram uma caravana, doadores pessoa física, uma mulher de um milionário americano (...) no interior da Bahia, na periferia do RJ, para conhecer estes projetos como poderia ajudar (...) $[\mathrm{A}]$

entender quais são os temas chaves para eles e trabalhar no sentido de ouvir e dialogar para poder construir uma comunicação para eles, tudo isso dentro de uma série de requisitos, (...) apurar um pouco daquela comunicação, lá de 2005, 2006, que era uma visão muito nossa, muito mais nossa do que do público, para uma visão mais próxima daquilo que a gente espera ou o que eles esperam ouvir, além daquilo que a gente espera passar. [C]

(...) Estes pontos são levados na discussão, mas é claro que estrategicamente pode não ser o momento de, por exemplo, de investir em tecnologia limpa, (...) É lógico, o que eu tenho que fazer no mínimo é um feedback, aliás, é previsto se dar um feedback para este tipo de interlocutor, mas não obrigatoriamente e acho que esta é uma premissa do [empresa], de escolher os temas que são estratégicos e importantes para a gente avançar, em termos de gestão e termos de report, (...) a matriz ela também vai levar em consideração aquilo que agente acha importante falar, [C]

Estes inputs podem ser transportados para nossa realidade. É ai que a gente ganha. Não necessariamente eu preciso atender a demanda pura, como ela foi concebida, mas ela pode sim, servir de inspiração digamos assim, ou direcionamento para algumas expectativas, ou até mesmo para algumas oportunidades, ou riscos. [C]

(...) a gente definiu lá trás qual era o foco. A gente definiu que seria a educação, depois a gente foi encaminhado, definiu que era a educação na relação com a escola pública, 
que era onde o grupo queria investir, depois a gente investe em educação, sim, a maior parte de nosso investimento, mas a gente investe em projetos sociais também com temas de meio ambiente, geração de renda e diversidade que são temas que a gente trabalha na perspectiva de sustentabilidade. [D]

(...) A gente tem que ter uma estratégia como pessoa jurídica, eu não posso me dar ao luxo de ficar pulverizando nosso investimento, eu tenho que ter um investimento para de fato ter resultado. [D]

\section{Institucionalização / Gestão em escala}

Conforme afirma Maingueneau, podemos observar que a dinâmica organizacional, envolvendo uma cultura competitiva, divisões departamentais, assim como o já mencionado paradigma da mudança constante, integra necessariamente, o discurso e as ações das empresas. A atuação em escala, replicação de "boas práticas”, e montagem de grupos e estruturas de trabalho moldam o discurso, num escopo de condutas possíveis.

O regimento do nosso trabalho, (...) está muito ligado a um comitê de responsabilidade socioambiental, este comitê ele tem quatro vice presidentes do banco, são nove, quatro fazem parte deste comitê, cinco diretores gerentes, são diretores executivos, e outros 11 diretores departamentais de vários departamentos, [C] (...) a gente está em plena construção do relatório [2009], (...) são 39 departamentos, são no mínimo 30 interlocutores, então, não é nada fácil. [C]

(...) a gente sentiu necessidade de você formar e centralizar os controles internos sobre todas estas fontes emissoras, (...) A gente formou grupo de trabalho, por exemplo, eu tenho cento e cinqüenta pessoas em todo [nome da organização] (...) são 11 grupos, com 150 pessoas no total, são aproximadamente nove a doze pessoas por grupo, [C] [nome de executiva] faz a proposta da estrutura então ela cria, como ela teve a entrevista com os diretores, como ela percebeu que aí os diretores que não participavam deste grupo pequeno, começavam, já estavam começando a se sentir incomodados de não fazer parte, porque o tema já estava encaminhando, a [nome de executiva] propõe para o [nome do presidente da empresa] que abram três comitês, um focado em negócio, um focado em mercado, e um focado em ação social, para poder aprofundar a discussão e ter todos os diretores participando, então, ele aceita a proposta e cada diretor então escolhe de qual comitê ele quer fazer parte, para poder acolher os interesses [D] 
(...) a gente falava que era voluntário estimulado, aquilo não era minha função, mas eu recebia, assim como eu, outras pessoas receberam esta demanda, em outros temas, mas a gente fala assim, que era fora da função, aí eu brinco quando eu faço apresentação sobre isso, que de forma alguma eu podia dizer não [D]

A gente fala assim, a gente vive a melhor situação que hoje a gente perdeu o controle de como as coisas nascem e como que elas acontecem, e que esta é a melhor situação. Mas a gente subsidia e faz muita parceria, às vezes até nós mesmos criamos algumas comunicações internas e eles são meio que consultores pra gente, às vezes até o contrário, às vezes a gente cria conteúdo dá para eles, eles acabam [E] então nós somos meio que consultores internos, a cada dia mais a gente está virando consultor interno [E]

Com esta trajetória algumas áreas vão sendo criadas, (...) nossa área já nasce com a proposta de desaparecer ao longo do tempo. (Isso que eu ia falar) semelhante a Qualidade, área de qualidade (...) seria uma área “biodegradável”, (...) então agente passou a ter um entendimento diferente, não é que a área desaparece, a área provavelmente ela muda o patamar e o foco dela, Em termos de estrutura acho que eu te dei um panorama bem geral, porque você vê que as áreas vão criando estruturas.[D]

\section{Disseminação e processo de convencimento}

A substituição da ação pelo comportamento, com a vitória da sociedade e a "conduta social” promovida a modelo de todas as áreas da vida, levantada por Hannah Arendt, pode ser sentida, na medida em que a empresa precisa uniformizar as condutas para atingir os objetivos estratégicos esperados. Uma proposta de convencimento coerente com as metas empresariais, mas que desliza para a vida cotidiana.

(...) essa nossa experiência neste período já mostra que nos estamos falando de mudança de cultura, e a melhor ferramenta para suportar uma mudança de cultura, é tudo o que agente faz em termos de educação, treinamento, (...) fazer com que o tema fosse sendo inserido em todas as ações educativas do [empresa] [D] um modelo educativo, (...) o indivíduo como pessoa não só como profissional, então tem um modelo conceitual que foi desenvolvido para suportar toda construção das iniciativas (...) que vai além da sala de aula [D]

(...) o tempo todo precisa de um suporte de comunicação e educação, porque é uma mudança de hábito. [D] 
não precisa escrever sustentabilidade, igual o CEO mundial veio aqui, e ele falou que não precisa escrever no pilar de nada, não precisa colocar no Brand de nada, porque para ele já está, tem que estar enraizado nas ações do dia-a-dia de cada pessoa.[E] (...) processo muito forte de divulgação deste treinamento, por meio das comunicações internas, e-mail marketing. (...) a gente forçou bastante o interesse pelo curso [C] (...) é o cara (...) que esta lá na linha de frente, entender que ele tem que inserir no diaa-dia dele, (...) a sustentabilidade, inserir isto no core business, como se isso, e aliás, tem que ser assim, como se isto nunca estivesse separado, a sustentabilidade ali, e meu trabalho aqui. A intenção é justamente esta, chegar nesta evolução, e não dá para fazer isto do dia, isto não se faz por decreto.[C]

A política aqui, é a última coisa que vai acontecer, depois de tudo debatido, o processo educativo feito, todo mundo já ter incorporado e aí vem uma política. O caminho é mais longo, mas este é o jeito que a organização escolheu para fazer. [D]

(...) responsabilidade social corporativa, como guarda-chuva macro de ações internas e externas. Interno a gente chama de qualidade de vida. E investimento social externo estaria dentro deste mesmo guarda-chuva de cidadania empresarial. [A]

(...) ele tem que conhecer o tema, não para utilizar só dentro de seu ambiente de trabalho, pelo contrário, assim como ética, assim como... e o curso também envolve isso, ele tem que utilizar para a vida dele. (...) A maior parte das cartilhas, por exemplo, aliás, todas as cartilhas, elas trazem muito mais informação para o dia-a-dia da pessoa do que para o seu trabalho em si. (...) [C]

\section{Políticas públicas}

Paoli (2005) conecta as ações empresariais às propostas de Antony Giddens, recriadas no Brasil por Bresser Pereira (1999), de um público não estatal, que propõe um Estado gerencial, deslocando a referência aos direitos fundamentados na solidariedade coletiva para solidária privada, responsável pela "execução de serviços sociais”, por meio de critérios seletivos. Essa proposta aparece nas falas dos entrevistados, trazendo ecos do Plano de Reforma do Aparelho de Estado, de 1995, assim como da proposta governamental de combate à pobreza “Comunidade Solidária”, de 1999, dos quais transcrevemos alguns trechos, a seguir:

A administração pública gerencial vê o cidadão como contribuinte de impostos e como cliente dos seus serviços. Os resultados da ação do Estado são considerados bons não porque os processos 
administrativos estão sob controle e são seguros, como quer a administração pública burocrática, mas porque as necessidades do cidadão-cliente estão sendo atendidas.

(...)

O paradigma gerencial contemporâneo, fundamentado nos princípios da confiança e da descentralização da decisão, exige formas flexíveis de gestão, horizontalização de estruturas, descentralização de funções, incentivos à criatividade.

\section{Nova Estratégia de Combate à Miséria: O Comunidade Solidária}

Essa estratégia teve os seguintes pontos de partida: de um lado, a seleção dos programas do Governo Federal com maior capacidade de melhorar as condições de vida das populações de baixa renda nas áreas de educação, saúde, nutrição, saneamento, habitação, capacitação profissional e geração de renda e empregos, conformando assim um elenco de ações, a Agenda Básica do Programa Comunidade Solidária, que, em seu conjunto, alcança a multiplicidade de causas constitutivas de situações de exclusão social aguda. De outro lado, a definição do âmbito prioritário de atuação do Programa, qual seja, os Municípios de maior concentração de pobreza do País, assim identificados com base em critérios objetivos referentes à renda e às taxas de mortalidade infantil, entre outros indicadores, o que desde logo determinou foco definido para as ações contempladas na Agenda Básica, evitando a dispersão de recursos, e deixou claro que o esforço de combate à miséria não se prestaria à instrumentalização de interesses político-partidários.

(...) o principal projeto hoje na relação com as escolas é o projeto [nome[, que é o voluntariado corporativo, (...), então a escola é representante do sistema (...) eu não necessariamente eu interajo com a secretaria, eu entendo que a escola é o interlocutor também para cima no sistema deles.[D]

(...) Existe uma metodologia para averiguar qual a carência que a família tem para poder realmente privilegiar aqueles que têm a maior carência, pelo estudo. [C] Como é que é esta relação no [empresa] com Políticas Públicas, se ele tem, diálogo, se isto está na pauta? Isto está muito mais distante, as políticas públicas em si, elas estão bem mais distantes. Não está na pauta agora, vigente.[C] (...). Acho também que quanto mais as empresas se inserem nos diálogos, em ações efetivas, acho que aí a máquina começa a funcionar melhor [C] Aqui tem pouca, pouco contato, principalmente com órgãos governamentais, e tem pouca demanda deles, bem pouca. Eu tenho pouquíssima experiência para te dizer o teor deste relacionamento. (...) a gente é muito procurado, principalmente pelas prefeituras, mas são ações muito pouco complicadas, alguns patrocínios específicos, ou doações, pouco complicadas, em geral não é algo complexo ou muito duradouro, em grandes projetos que o [empresa] se envolva em si, [C] 
Então, cada projeto tem um jeito, um desenho, no caso da relação com a escola, a gente não define prazo, a hora que a..., a gente orienta o voluntário e a escola, (...) de fortalecer a escola, de forma que ela não crie uma relação de dependência, (...) a gente fez um mapa do Brasil com base em dois indicadores sociais, índice de desenvolvimento infantil, e índice de exclusão social (...) [D] (...) manda o dinheiro, no ano seguinte que é o ano que ele vai executar o projeto ele tem três encontros agendados ao longo do ano, no início, no meio e final do ano, (...), a gente capacita discutindo o próprio projeto, (...) a gente tem uma posição que a gente fala, a gente não manda só o dinheiro, a gente manda o dinheiro, mas a gente quer participar, [D]

(Como é que vocês escolhem estas escolas?) Sempre em parceria com a Secretaria Municipal de Educação, seja municipal ou estadual. Por exemplo, no [nome do projeto], a gente falou com o assessor do secretário e ele falou, vamos abrir para todas as escolas, a gente readaptou o projeto ano que vem, no estado de [nome do estado]. Por exemplo, em [nome do município] o projeto [nome do projeto], já esta lá desde 2001, eles gostaram tanto da metodologia que virou política pública. [E] (...) agora a gente está num dilema, que é perceber que assim, a gente não tem como gerir escolas (...) eu não tenho como acompanhar isso no dia-a-dia, eu posso ter problema com estas comunidades, que não sabem como, se a premiação não chega no dia eu posso ter problema, se der qualquer coisa errado com o projeto eles passam a criar uma dependência. A gente está em estudo outro modelo agora de desenvolver e instrumentalizar a delegacias de ensino fomentar os multiplicadores (...) [A] (...) melhorar expertise da delegacia de ensino da secretaria de ensino, não eu reinventar a roda, mudar processo, contratar consultoria para desenvolver um projeto em uma ou duas escolas, em outras escolas geram uma demanda infinita, acaba nos tornando uma anti-propaganda (...) [A]

\section{De stakeholder para shareholder}

O economista Milton Friedman (1970), em artigo publicado no The New York Times Magazine, critica veementemente o discurso sobre as responsabilidades sociais das empresas, afirmando que se trata de pura pregação socialista. A colocação de Friedman toca num ponto crucial. Toda a referência à política e, por conseguinte, a deliberações coletivas, levaria, no 
limite, à instalação de conselhos populares na empresa. Os stakeholders são consultados, mas não podem determinar diretrizes. Parece ser esse o limite da empresa.

Deixamos para o final desta parte da análise, dentre os depoimentos colhidos, aquele que informa como a fundação responsável pelas ações sociais, sem romper com a lógica de mercado, rompe esse limite ao se deslocar para um lugar de fala e ação diferente: o lugar, o shareholder ou acionista da empresa.

Fundação ela é separada, ela tem uma gestão, (..). Ela é hoje, fora o que está no mercado, é a maior acionista do [empresa] (...), ser acionista é um outro patamar. (...) É bem diferente, outro chapeuzinho o stakeholder, que você coloca. [C] 


\section{4 Breves considerações gerais sobre a análise realizadas: a oposição de formações discursivas no âmbito da RSE}

Maingueneau (1997, p.116-117) denomina universo discursivo o conjunto de formações discursivas que interagem em uma conjuntura. Trata-se de um conjunto finito, mas irrepresentável, que não pode ser concebido em sua totalidade, mas é utilizado em AD para recortar campos discursivos. Estes, por sua vez, são entendidos como um conjunto de formações discursivas em relação de concorrência, em sentido amplo, não reduzida à competição ou rivalidade, mas como fatores que confluem num mesmo lugar e são, dessa forma, capazes de gerar enunciados e textos que trazem suas marcas, num jogo de equilíbrios instáveis.

A partir desses conceitos, o autor propõe a noção de espaço discursivo, como um subconjunto, definido por decisão do analista, que liga pelo menos duas formações discursivas relacionadas e cruciais para a compreensão dos discursos considerados.

Com elementos levantados nas três etapas das análises, e levando em conta as colocações de Hannah Arendt sobre a promoção do social (2004, p.47-59) que, ao se sobrepor à esfera pública, diluiu a divisão entre o privado e o político, consideramos que, sob o rótulo de "social”, o discurso das empresas apresenta duas formações discursivas concorrentes, descritas, aqui, esquematicamente:

Formação Discursiva Gerencial

Cultura de mercado (negócios)

Visibilidade

Empresa/ Empreendedorismo

Oportunidades ou privilégios

Gestão social

Força individual
Formação Discursiva Política

Cultura política

Discutibilidade

Cidadania/ Cidadão

Direitos

Política social

Poder coletivo

O discurso da responsabilidade social das empresas constituiria dessa forma um espaço discursivo onde, sob o primado do interdiscurso, enunciados e termos pertencentes às duas formações trabalham num processo de delimitação recíproca e "tradução" generalizada de discursos e termos que transitam de uma a outra. 


\section{CONSIDERAÇÕES FINAIS}

Ao encarar o discurso da responsabilidade social empresarial nos deparamos com um emaranhado de sentidos ou, ainda, com a sensação de enredamento, expressão utilizada por Paoli (2005), para descrever o efeito da ação social das empresas em relação à cidadania. Cidadania que, juntamente com as noções de democracia e espaço públicos, foi, ao longo do percurso de pesquisa, uma espécie de apoio para nossas observações e questionamentos no sentido de cumprir o objetivo de compreender como é formulado o discurso das empresas acerca da responsabilidade social, reconhecendo as potencialidades e limitações deste discurso.

No momento em que transitamos pela teoria dialógica de Bakhtin e pelos autores da $\mathrm{AD}$, para levar adiante o cumprimento do objetivo, por meio do entendimento das formações discursivas em conflito, fomos obrigados a perceber, contudo, o quanto seria infrutífero tentar uma crítica tendo em mente algum sentido “original” ou “clássico” de cidadania. Por mais que as definições por nós escolhidas fossem válidas, sua aplicação, para entender um discurso que não parte dos mesmos princípios, resultaria em uma denúncia que vem de “fora”.

Diante disso, optamos por aproximações em relação a vários objetos empíricos, para tentar desemaranhar o discurso, observando por que caminho se constrói o nó.

Ao longo do trajeto, nos deparamos com a existência de uma comunidade discursiva que, como aponta Maingueneau (1997, p.54-61), não é um simples “meio de transmissão” e se constitui na e para a enunciação do discurso. Essa comunidade, no caso do DRSE, se desdobra nos âmbitos da mídia e das organizações, falando, de certa forma, consigo mesma, numa espécie de comunicação conspícua, na qual mostrar que se está comunicando é tão ou mais importante do que comunicar. É algo que, por sinal, não deve ser apenas criticado, mas entendido, como aponta Gomes (2007), ao ressaltar a importância da visibilidade na esfera pública.

Tal visibilidade nos levou à primeira dicotomia proposta pelo DRSE, que procura, de todas as formas, se desvencilhar do marketing e da publicidade, ao distinguir aqueles que, efetivamente, fazem alguma coisa no âmbito social e ambiental, daqueles que apenas exploram o aspecto promocional da ação. Levou-nos, também, à segunda, que opõe o arcaísmo e ineficácia da caridade e da filantropia aos resultados da moderna gestão do social, 
deixando pelo caminho os direitos do cidadão, que autônomo e “empoderado" pode prescindir deles.

A gestão, por sua vez, associa-se à terceira dicotomia encontrada, que se estabelece entre o engessamento e ineficiência do Estado e a eficiência e dinamismo empresarial, cujas boas práticas e modelos são apresentados como passíveis de serem aplicados em todos os âmbitos, e permitem a substituição de direitos oferecidos pelo Estado por serviços competentemente prestados, que podem ser adquiridos por “clientes privilegiados”, como propõe o Plano de Reforma do Estado, de 1995.

Essa prestação de serviços sociais, que deve ser serviço do Estado, a partir da replicação de modelos desenvolvidos pelas empresas, liga-se, por sua vez, à primeira negação presente no discurso das empresas. Trata-se da negação das relações trabalhistas que, embora citadas, não se misturam com as ações de responsabilidade social que estão "além” delas ou, em um menor número de casos, no lugar delas. Soma-se a isso o fato de que os direitos dos trabalhadores, embora citados como algo a ser respeitado, têm sua pertinência simultaneamente colocada em xeque por movimentos empresariais, como o Custo Brasil, segundo descrevem Cappellin e Giuliani (2006), e Cappellin e Giffoni (2007).

Depois de observarmos, portanto, como o discurso social das empresas passa ao largo das questões trabalhistas, encontramos, nos textos analisados, respostas únicas para as questões e dicotomias apresentadas.

A primeira delas é a noção de sustentabilidade que, associada à noção de uma cadeia produtiva cíclica e à preservação da vida da espécie, remete às colocações de Hannah Arendt a respeito do labor, que possui uma "produtividade” própria, que não reside em seus produtos, mas na "força" humana, dirigida no sentido da produção e do consumo contínuos. Esse caminho nos leva à segunda resposta única: a conquista da cidadania pela cadeia produtiva. É o que apontam Santos e Avritzer (2005, p.59) e Santos (2007), entre outros, ao observar que a ótica predominante dissemina a indistinção entre cidadão e consumidor, fazendo com que a educação, moradia, saúde, lazer apareçam ou como conquistas pessoais, ou como benesses e não direitos sociais.

São respostas que estão, por sua vez, embasadas na idéia de um cidadão reflexivo, sustentada por autores como Anthony Giddens, que surge nos textos selecionados com apelo para a "conscientização” e a transformação operada a partir do indivíduo, embora Santos 
(2001) enfatize que, entretidos no ciclo de produção (de riquezas) e consumo, nos reste pouco tempo para refletir e reverter percursos.

As empresas, contudo, embora apostem na capacidade reflexiva dos indivíduos, continuam, por meio da atuação em escala e replicação de “boas práticas”, tentando uniformizar as condutas, para atingir os objetivos estratégicos esperados. Tarefa que, para ser levada a cabo, não pode ceder o controle primário da pauta de RSE a terceiros, como alertam Porter e Kramer (2006), uma vez que dividir a pauta de deliberação não é um procedimento estratégico.

O impasse nos levou às colocações do economista Milton Friedman que, em artigo publicado no The New York Times Magazine, em 1970, critica veementemente o discurso sobre as responsabilidades sociais das empresas e toca num ponto crucial: toda a referência à política e, por conseguinte, a deliberações coletivas, levaria, no limite, à instalação de conselhos populares na empresa, algo incompatível com o sistema de livre mercado. Na época, Friedman dizia que as doutrinas de RSE falseavam uma intenção socialista, ou simplesmente não podiam ser levadas a sério, ao professarem a crença de que resultados coletivos poderiam ser obtidos sem meios coletivos.

As empresas, porém, seguiram, sem derivar para o socialismo, exatamente por esse caminho. Por meio do "diálogo discreto" e "longe do debate público", como sugerem Brugmann e Prahalad (2007 p.59), avançaram em propostas de ganhos comuns, construídos em separado. Situação onde a comparação entre a geração de valores gerados para as diferentes partes interessadas com as quais se relaciona a empresa é inviabilizada. Pela falta de referências comuns, construídas a partir da clareza quanto às posições de poder ocupadas. $\mathrm{O}$ que resulta em ganhos tremendamente desproporcionais para as partes envolvidas. Uma discrepância que salta aos olhos, quando observamos uma fundação empresarial que, ao invés de ocupar o papel de stakeholder, merecedora de atenção e ajuda, surge como shareholder, ou acionista, exigindo satisfações e dividendos.

A inconsistência de levar a cabo a idéia de transformar o social, por meio da aplicação em escala de soluções pré-fabricadas, aparece, por sua vez, nos relatos de Alves (2007), Souza (2008) e Gonçalves Júnior (2008), e Branco (2008), entre outros, ao abordarem as limitações e resultados das iniciativas empresariais, no sentido de conter o trabalho infantil e de melhorar as condições de ensino. Essas pesquisas mostram como é difícil e permeada de 
tensões a tentativa de concretizar o inter-esse proposto por Arendt, de estar entre diferentes, que querem coisas diferentes.

Sair da postura do "para” e envolver-se “com” é muito trabalhoso e fora do foco das empresas, o que resulta, na maior parte das vezes, em pouco espaço para a negociação por parte da empresa, que oferece pacote pronto e trabalha considerando a autonomia como a principal finalidade do processo, como aponta Branco (2008), autora que, diante da recusa de um executivo de empresa em assumir que o projeto realizado na escola constituía-se numa ação mercadológica, deixou no ar a pergunta: por que negar o que todos sabem?

Kallio (2006), por sua vez, ao abordar aspectos não abordados pelo discurso da RSE, elege, juntamente com a amoralidade dos negócios e o mantra do desenvolvimento contínuo, o tabu que nos parece mais relevante: a natureza política da RSE.

A partir da percepção, obtida por meio da seqüência de dicotomias e negações encontradas, de que discurso da responsabilidade social das empresas constitui um espaço onde atuam formações discursivas concorrentes, gerencial e política, podemos propor uma forma de compreender essa questão.

Para tanto, partimos da proposição de Maingueneau (1997, p.119-122), para quem os elementos do espaço discursivo são criados na interdiscursividade, sendo que a identidade dos discursos é constituída por um processo de delimitação recíproca. A identidade do discurso é construída na relação com o Outro, num processo de "tradução" generalizada, ligada a uma “interincompreensão" que, ao mesmo tempo, proíbe a circulação do mesmo sentido de um sujeito para outro e permite que os sujeitos partilhem o mesmo discurso, "falem da mesma coisa”.

A partir desse processo de dupla tradução, é possível detalhar o mecanismo polêmico, no qual cada formação discursiva constroi sua identidade, a partir da negação das unidades de sentido construídas por seu Outro. A formação discursiva opõe, dessa forma, dois conjuntos de categorias semânticas: as reivindicadas (“positivas”), projetadas sobre categorias de seu próprio sistema; e as recusadas (“negativas’), uma vez que, para preservar sua identidade, o discurso só pode relacionar-se com o Outro, através do simulacro que dele constroi. O autor chama de discurso agente aquele que atua como "tradutor", construtor do simulacro, e de discurso paciente aquele que é traduzido, afirmando que em uma polêmica os papéis de agente e paciente se alternam constantemente. 
No nosso caso, a partir da análise realizada, podemos dizer que o discurso da responsabilidade social se constitui a partir da recusa de determinadas categorias semânticas, a partir de uma relação polêmica, em que traduz, na forma de simulacros, essas categorias.

Isso nos permite oferecer uma resposta para a pergunta de Branco (2006) - por que negar o que todos sabem? - em relação à recusa do executivo de empresa em admitir o aspecto mercadológico de suas ações. Essa recusa precisa ocorrer, porque a negação do marketing, assim como da filantropia são elementos constitutivos do discurso da responsabilidade social empresarial, sem os quais esse discurso não consegue definir sua identidade.

Além dessa negação evidente, percebemos, contudo, uma negação mais profunda, que pode se manifestar pelo confronto ou pela indiferença e é fundamental para constituir a identidade do discurso das empresas acerca do social.

Trata-se da negação de sua natureza política, algo que nos oferece uma chave para compreender a manutenção do tabu detectado por Kallio (2006), uma vez que essa negação constitui a identidade do discurso.

Esse discurso se aproxima do labor, proposto por Arendt, que assume uma característica antipolítica, ao deixar o homem só com seu corpo e a necessidade de se manter vivo. Faz também deslizar o sentido do pronome perigoso, de Sennet, ao negar o "nós” comunal e inclusivo, e apresentar um "nós” que exclui, como lembra Benveniste, separando os especialistas dos demais, cujo comportamento deve ser regulado.

Podemos dizer, portanto, que o discurso da responsabilidade social precisa negar, para existir, aquilo que Sennett nos lembra, ao resgatar Lewis Coser: o conflito.

Conflito que é capaz de aproximar as pessoas pelo reconhecimento das diferenças de privilégio ou poder, indo além das formas fracas de comunidade, calcadas na suposição de uma motivação comum partilhada. Conflito que nos oferece a possibilidade de ouvir e responder uns aos outros, mesmo quando as diferenças são sentidas da forma mais aguda. 


\section{REFERÊNCIAS}

ABRAMOVAY, R.; MAGALHÃES, R. O acesso dos agricultores familiares aos mercados de Biodiesel parcerias entre grandes empresas e movimentos sociais, São Paulo, junho de 2007. Textos para Discussão FIPE $n^{0}$ 6, Fundação Instituto de Pesquisas Econômicas. http://www.fipe.org.br/web/publicacoes/discussao/textos/texto_06_2007.pdf

AFFONSO. C. R. A. Relações (des)educativas entre o sindicalismo propositivo e o Estado no Brasil (1990-2000): contradições de uma experiência, 2007. 1v. 259p. Doutorado. Universidade federal fluminense - educação.

http://servicos.capes.gov.br/capesdw/resumo.html?idtese=20073131003010001P0

Acesso em 9 de fev. de 2009

AGAMBEN, G. Homo sacer. O poder soberano e a vida nua. BH: Editora UFMG, $2003 a$.

G. A zona morta da lei. Folha de SP, Caderno Mais! 16/mar/2003b.

ALMEIDA, C.C.R. O marco discursivo da participação solidaria e a redefinição da questão social : construção democratica e lutas politicas no Brasil pós 90, Tese de Doutorado. Unicamp, Campinas, 2006

ALMEIDA, E.T.V. A sociedade civil e seus múltiplos significados na sociedade contemporanea: uma leitura gramsciana, 2006. 1v. 280p. Doutorado. Universidade Federal do Rio de Janeiro - serviço social.

http://servicos.capes.gov.br/capesdw/resumo.html?idtese=200628031001017066P9 ACESSO 9/FEV/2009

ALMEIDA, F. J. R. Responsabilidade social das empresas e valores humanos: um estudo sobre a atitude dos gestores brasileiros, 2007. 1v. 156p. Doutorado. Fundação Getúlio Vargas/RJ - Administração, Linha Políticas e Estratégias.

http://servicos.capes.gov.br/capesdw/resumo.html?idtese=20071731011012004P5

ALMEIDA, M.F.L. Sustentabilidade corporativa, inovação tecnológica e planejamento adaptativo: dos princípios à ação. Rio de Janeiro: PUCRJ, Departamento de Engenharia Industrial, 2006. Tese de Doutorado - Pontifícia Universidade Católica do Rio de Janeiro, Departamento de Engenharia Industrial.

http://www.maxwell.lambda.ele.pucrio.br/cgibin/PRG_0599.EXE/9230_1.PDF?NrOcoSis=28387\&CdLinPrg=pt

ALVES, E. A. Ambiente institucional e a responsabilidade social empresarial na indústria calçadista de franca: o caso do instituto pró-criança, 2007. 2v. 296p. Tese de Doutorado. Universidade federal de São Carlos - engenharia de produção

http://servicos.capes.gov.br/capesdw/resumo.html?idtese=20072033001014013P8

Universidade Federal de São Carlos 2007-06-20

http://bdtd2.ibict.br/index.php?option=com_wrapper\&Itemid=39

Acesso em 2 de fev. de 2009

ANTUNES, R. Trabalho e precarização numa ordem neoliberal. In GENTILI, P., FRIGOTTO, G. (orgs.) A cidadania negada: políticas de exclusão na educação e no trabalho. $3^{\text {a }}$ ed. São Paulo: Cortez; [Buenos Aires, Argentina]: CLACSO,2002. 
ARANTES, E. Investimento Em Responsabilidade Social e Sua Relação Com o Desempenho Econômico das Empresas. Conhecimento Interativo, São José dos Pinhais, PR, v. 2, n. 1, p. 03-09, jan./jun. 2006.

http://66.102.1.104/scholar?hl=pt-

BR\&lr=lang_pt\&safe=active\&scoring=r\&q=cache:0VbMTrW4upoJ:revistacientifica.famec.c om.br/include/getdoc.php\%3Fid\%3D150\%26article\%3D35\%26mode\%3Dpdf+tudonot\%C3\% ADtulo:++\%22Responsabilidade+Social+Empresarial\%22

ARAÚJO, C. G. Por que as empresas investem em responsabilidade social? 2006. 1v. 200p. Doutorado. Universidade de Brasília - Sociologia.

http://servicos.capes.gov.br/capesdw/resumo.html?idtese=2006153001010009P0

Acesso em 9 de fev. de 2009.

ARAÚJO, M.R.M. Responsabilidade Social E Satisfação Do Consumidor: Um Estudo De Caso, 2006a. 1v. 182p. Doutorado. Universidade Federal Do Pará - Psicologia (Teoria E Pesquisa Do Comportamento.

http://servicos.capes.gov.br/capesdw/resumo.html?idtese=2006315001016009P0

Acesso em 9 de fev. de 2009.

M.R.M. Exclusão social e responsabilidade social empresarial. Psicologia estudos. 2006b, vol. 11, no. 2, pp. 417-426.

Disponível em: $\quad$ http://www.scielo.br/scielo.php?script=sci_arttext\&pid=S1413$\underline{3722006000200021 \& \operatorname{lng}=p t \& n r m=\text { iso }}$. ISSN 1413-7372. doi: 10.1590/S141373722006000200021.

ARAÚJO, M.S.S. Fome de pão e de beleza: filantropia e direitos sociais no Fome Zero, 2007. 1v. 215p. Doutorado. UNIVERSIDADE FEDERAL DO MARANHÃO - POLÍTICAS PÚBLICAS

http://servicos.capes.gov.br/capesdw/resumo.html?idtese=20071920001010003P6

Acesso em 9 de fev. de 2009

ARENDT, H. A crise na educação. In: Entre o passado e o futuro. São Paulo: Perspectiva, 1972.

H. O declínio do Estado-Nação e o fim dos direitos humanos. In: Origens do totalitarismo. São Paulo: Cia. Das Letras, 1998.

Universitária, 2004a.

H. A condição humana. Tradução de Roberto Raposo. 10 ed. Rio de Janeiro: Forense

H. Tiro pela culatra. In: Responsabilidade e julgamento. São Paulo: Cia. Das Letras, 2004b, p.327 a 345.

ASHLEY, P. (coord.). Ética e responsabilidade social nos negócios. 2a ed. São Paulo: Saraiva, 2005.

ASHLEY, P.A, e outros. Um modelo para incorporação da responsabilidade social à governança das relações negócio-sociedade. Enanpad 2001 - Área Teoria das Organizações. CD Anais. 
ASSUMPÇÃO, M., at alii CSR in two countries - Brasil and Norway

http://www.fafo.no/pub/rapp/20052/20052.pdf

Relatório FAFO 2008

BAKHTIN, M. Estética da Criação Verbal; introdução e tradução do russo Paulo Bezerra; prefácio à edição francesa Tzvetan Todorov. 4 $4^{\mathrm{a}}$ ed. São Paulo: Martins Fontes, 2003

Marxismo e filosofia da linguagem; tradução de Michel Lahud, Yara F.

Vieira, Lúcia T. Wisnik e Carlos H.D.Chagas Cruz. 11ª ed. São Paulo: Hucitec, 2004

BALDISSERA, R.; ARAUJO, D. C. de 1969. Responsabilidade social, diversidade e marketing: o discurso real beleza Dove. Revista Fronteiras: Estudos Midiaticos São Leopoldo, RS, v.9, n.1, p.34-44, jan-abr. 2007.

http://www.unisinos.br/publicacoes_cientificas/images/stories/pdfs_fronteiras/vol9n1/art04_a raujo-baldisserarev.pdf acesso 7/a/2009 Acesso em janeiro de 2009

BARBOSA, M. G. O processo de gestão pública da miséria, 2007. 1v. 206p. Doutorado. Universidade est. paulista Júlio de mesquita filho/araraquara - sociologia.

http://servicos.capes.gov.br/capesdw/resumo.html?idtese=20071633004030017P7

Acesso de 9 de fev. de 2009

BARNETT, M.L.; SALOMON, R.M.. Beyond dichotomy: the curvilinear relationship between SR and financial performance. Strategic Management Journal 27: 1101-1122 (2006).

BAUDRILLARD, J. O sistema dos objetos. São Paulo: Pesrpectiva, 1973.

BENDASSOLLI, P. F. Indústrias criativas: o caso do Estado de São Paulo. Relatório de Pesquisa apresentado ao Núcleo de Pesquisa e Publicação ESPM. São Paulo, 2007. 103p. mimeo.

BERTAGNOLLI, D. D. O.; OTT, E.; DAMACENA, C. Estudo sobre a Influência dos Investimentos Sociais e Ambientais no Desempenho Econômico das Empresas. In: Congresso USP de Controladoria e Contabilidade, 6, 2006, São Paulo. Anais do VI Congresso USP de Controladoria BARROS, A. P. F. L. Saúde, Sociedade e Imprensa: a visibilidade do cidadão na cobertura da Vigilância Sanitária - Dissertação de Mestrado em Comunicação - UNB Programa de pós-graduação em Comunicação e Sociedade da Faculdade de Comunicação da UNB Linha de Pesquisa: Jornalismo e Sociedade, 2007. http://bdtd.bce.unb.br/tedesimplificado/tde_busca/arquivo.php?codArquivo=1353 ACESSO EM 2/FEV/2009

BHATTACHARYA, C.B. et al Using Corporate Social Responsibility to Win the War for Talent MIT Sloan Management Review, 49 (2), 37-44, 2008.

BOFF, E. O. - Comunicação do Terceiro Setor num ambiente globalizado: o caso da Fundação Novartis para o Desenvolvimento Sustentável (FNDS) e do Serviço de educação e organização popular (SEOP). Dissertação de Mestrado em Comunicação e Cultura da Escola de Comunicação da Universidade Federal do Rio de Janeiro. Rio de Janeiro, 2004.

http://www.pos.eco.ufrj.br/ Publicações /Dissert Apresentações 2004 
Acesso em 4 de fev. de 2009

BOLTANSKI, L.; CHIAPELLO, È. El nuevo espíritu del capitalismo. Madrid: Akal,2002.

BORGES, L.A.L. Projeto viva o seu bairro - a vez e a voz das comunidades. 2000. 132p. Dissertação (Mestrado em Ciências da Comunicação) - Escola de Comunicação e Artes da Universidade de São Paulo, São Paulo.

BOSI, A. A cultura como tradição. In: Novaes, A. Cultura brasileira: tradição e contradição. Rio de Janeiro: Jorge Zahar, 1987, p. 31-58

BRANCO, M. G. F. Parceria empresa/escola : alternativa para a melhoria da qualidade de ensino? Universidade Estadual de Campinas . Faculdade de Educação Dissertação de Mestrado, UNICAMP: Programa de Pós-Grauação em Educação, 2002.

BRANDÃO, H.H.N. Subjetividade, argumentação, polifonia. A propaganda da Petrobrás. São Paulo: Fundação Editora da Unesp: Imprensa Oficial do Esatdo, 1998.

BRAGATO, I. R. et alii Produção de açúcar e álcool vs. responsabilidade social corporativa: as ações desenvolvidas pelas usinas de cana-de-açúcar frente às externalidades negativas. Gest. Prod., São Carlos, v. 15, n. 1, Apr. 2008.

Disponível em: <http://www.scielo.br/scielo.php?script=sci_arttext\&pid=S0104 530X2008000100009\&lng=en\&nrm=iso $>$.

Acesso em 30 de Jan. de 2009.

BRONZO, C. Vulnerabilidade, Empoderamento e Proteção Social. Reflexões a Partir de Experiências Latinoamericanas. XXXII ENANPAD - Rio de Janeiro, 6 a 10 de setembro de 2008. CD de anais

BRUGMANN, J. e PRAHALAD, C.K., Novo pacto social: uma criação conjunta. Harvard Business Review/ Fevereiro 2007 / 50-60.

BRUNI, A. L.; SILVA, S. C. M. et alii; Verde Que Te Quero Ver? Um Estudo Sobre Responsabilidade Social e Relações de Consumo. XXXII ENANPAD - Rio de Janeiro, 6 a 10 de setembro de 2008.

BOURDIEU, P. A demissão do Estado. In: BOURDIEU, P. (Coord.) A miséria do mundo. Petrópolis: Vozes, 1997. p. 215-224

BUCCI, E. Voluntariado para ajudar quem ajuda. In: Sonhando Juntos - coletânea de textos, São Paulo: Instituto Brasil Voluntário, 2001

CAJAZEIRA, J.E.R. BARBIERI, J.C. Responsabilidade Social e Excelência Empresarial: Um estudo com empresas ganhadoras do Prêmio Nacional da Qualidade. In: $30^{\circ}$ Encontro da Associação Nacional de Pós-Graduação em Administração, Salvador, ANPAD, 2006.

CALEGARE, M.G.A. A transformação social no discurso de uma organização do Terceiro Setor. 2005. 193 f. Dissertação (Mestrado) - Instituto de Psicologia, Universidade de São Paulo, São Paulo, 2005. 
CALLIGARIS, C. Crônicas do individualismo cotidiano. São Paulo, Ática, 1996.

CAMARGO, R.Z. Nuances do diálogo entre educação, criança e consumo: estudo do caso Pão de Açúcar Kids. Dissertação de Mestrado. Departamento de Relações Públicas, Propaganda e Turismo. ECA-USP, São Paulo, 2003, 236 p.

CAMPOS, L.M.S.; ASSUMPÇÃO, J.J. et alii Avaliação de Projeto Social: da Ação a uma Meta-Avaliação XXXII ENANPAD - Rio de Janeiro, 6 a 10 de setembro de 2008. CD de anais

CANCLINI, N. G. Consumidores e cidadãos: conflitos multiculturais da globalização. Tradução Maurício Santana Dias. 5ª edição. Rio de Janeiro: Editora UFRJ, 2005.

CAPPELLIN, P; GIFFONI, R. As empresas em sociedades contemporâneas: a responsabilidade social no Norte e no Sul. Cad. CRH, Salvador, v. 20, n. 51, Dec. 2007.

Disponível em: <http://www.scielo.br/scielo.php?script=sci_arttext\&pid=S0103$49792007000300004 \& \operatorname{lng}=\mathrm{en} \& \mathrm{nrm}=\mathrm{iso}>$.

Acesso em 30 de Jan. de 2009

; GIULIANI, G.M. A economia política da responsabilidade social e ambiental nas empresas no Brasil. Programme on Technology, Business and Society, Paper n.14. Geneva: UNRISD/UFRJ, 2006 (versão em português).

Disponível em: www.unrisd.org. Acesso pelo nome dos autores The Political Economy of Corporate Responsibility in Brazil Social and Environmental Dimensions Paola Cappellin; Gian Mario Giuliani.

http://www.unrisd.org/80256B3C005BCCF9/httpNetITFramePDF?ReadForm\&parentunid=4 00751A2D48E8DDDC1256F80003DA9CE\&parentdoctype=paper\&netitpath=80256B3C005 BCCF9/(httpAuxPages)/400751A2D48E8DDDC1256F80003DA9CE/\$file/cappelli.pdf Acesso em 30 de jan. 2009

CASTRO, M. G. et all. Cadeia produtiva: marco conceitual para apoiar a prospeç̧ão tecnológica. In: XXII Simpósio de Gestão da Inovação Tecnológica. Salvador, Bahia. 6 a 8 de novembro de 2002.

CARNEIRO, MS. Crítica social e responsabilização empresarial: análise das estratégias para a legitimação da produção siderúrgica na Amazonia Oriental. Cad. CRH, Salvador, v. 21, n. 53, Aug. 2008 .

Disponível em: <http://www.scielo.br/scielo.php?script=sci_arttext\&pid=S010349792008000200009\&lng=en\&nrm=iso>.

Acesso em 30 de Jan. de 2009.

CARRIERI, E. B. A. Responsabilidade social: ideologia, poder e discurso na lógica empresarial, UFMG, CRAE・VOL. 45• EDIÇÃO ESPECIAL MINAS GERAIS 2005.

CARVALHO, J.M., Tipos e percursos de cidadanias, Estudos Históricos, Rio de Janeiro, n. 18, 1996. Revista Estudos Históricos CPDOC - FGV

http://www.cpdoc.fgv.br/revista/arq/199.pdf 
CARVALHO. M.L. Economia de Comunhão: Representações Sociais e Ideologia de uma Nova proposta de Responsabilidade Social, 2007. v.1 p.131: Tese de Doutorado. PUCRGS - Pontifícia Universidade Católica do Rio Grande do Sul - Psicologia.

http://servicos.capes.gov.br/capesdw/resumo.html?idtese=20071642005019006P2

Acesso em 8 de fev. de 2009

CAZELOTO, E. A inclusão digital e a reprodução do capitalismo contemporâneo. PUCSP, Tese de Doutorado em Comunicação em Semiótica, 2007.

http://www.sapientia.pucsp.br/tde_busca/resultado-tdes-

prog.php?ver=1\&programa=1\&ano_inicio=2007\&mes_inicio=01-01\&mes_fim=12-

31\&ano_fim=2007\&grau=Doutor (Acesso em 25 de abril de 2006)

CHAUÍ, M. O que é ideologia. Coleção primeiros passos. São Paulo: Editora Brasiliense, $37^{a}$ edição,1994.

M. Simulacro e poder. São Paulo: Editora Fundação Perseu Abramo, 2006.

CHICHARRO, M.N.; CARRILLO, I.A. Propuesta de indicadores de responsabilidad social preventiva. Revista Universo Contábil, ISSN 1809-3337, Blumenau, v. 2, n. 1, p. 90-102, jan./abr. 2006.

COELHO, P.R.P.; MCCLURE, J. E. Ethics Education in Marketing: are stakeholders's interests over-shadowing shareholders? Journal for Advancement of Marketing Education - Volume 9, Winter 2006, 18-25 18 Mkt Educated Review (Fall 2004).

COHEN, JL \& ARATO, A Civil society and political theory. Cambridge: MIT, 1995.

COSTA, B.M. Capital social e ações voluntárias da sociedade civil, Porto Alegre. 2004. 1v. 245p. Doutorado. Universidade Federal do Rio Grande do Sul - Sociologia

http://servicos.capes.gov.br/capesdw/resumo.html?idtese=200415242001013012P7 Acesso em 9 de fev. de 2009

COSTA, M.A.C.N. Mudanças empresariais no Brasil contemporâneo: o investimento social privado é uma nova forma de solidariedade. 2006. 1v. 261p. Doutorado. Universidade Federal do Rio De Janeiro - Planejamento Urbano E Regional, Biblioteca Depositaria: IPPUR/UFRJ.

http://servicos.capes.gov.br/capesdw/resumo.html?idtese=200624531001017065P2

Acesso em 9 de fev. de 2009.

COSTA, P.R.N. Como os empresários pensam a política e a democracia: Brasil, anos 1990. Opin. Publica, Campinas, v. 11, n. 2, out. 2005.

Disponível em: http://www.scielo.br/scielo.php?script=sci_arttext\&pid=S0104$62762005000200006 \& \operatorname{lng}=$ pt\&nrm=iso

Acesso em 01 de fev. de 2009.

COUTINHO, R. B. G. Projetos Sociais de Empresas no Brasil: diferentes lentes para compreender os modelos de gestão e suas implicações. 01/09/2005 1v. 1p. Doutorado. Pontifícia Universidade Católica do Rio De Janeiro - Administração de Empresas.

http://servicos.capes.gov.br/capesdw/resumo.html?idtese=20053431005012019P6 
Acesso em 9 de fev. de 2009.

. et alii. Projetos sociais de empresas no Brasil: arcabouço conceitual para pesquisas empíricas e análises gerenciais. Rev. Adm. Pública, Rio de Janeiro, v. 40, n. 5, Oct. 2006.

Disponível em: <http://www.scielo.br/scielo.php?script=sci_arttext\&pid=S003476122006000500002\&lng=en\&nrm=iso $>$. Acesso em: 30 Jan. 2009 Versão impressa - RAP Rio de janeiro 40 (5): 763-87, set/out 2006

DAGNINO, E. Sociedade civil, participação e cidadania: de que estamos falando? In Daniel Mato (coord.) Políticas de ciudadanía y sociedad civil en tiempos de globalización. Caracas: FACES, Universidad Central de Venezuela, 2004, p. 95-110

DALLABRIDA, I S. Responsabilidade Social Empresarial (RSE) e Economia de Comunhão (EdC): Racionalidade Empresarial na Construção do Desenvolvimento Sustentável, ETHOS, 2005.

DAVIS, K. Five Propositions for Social Responsibility. Business Horizons, 18 (3): 19-24, June 1975.

DEBORD, G. A sociedade do espetáculo. Tradução Estela dos Santos Abreu. Rio de Janeiro: Contraponto, 1997

DE CERTEAU, M. Teoria e Método no Estudo das Práticas Cotidianas. In Szmrecsanyi, M.I. (org) Anais do Encontro Cotidiano, Cultura Popular e Planejamento Urbano, p.3-19.

DEMO, P. Solidariedade como efeito de poder. São Paulo: Cortez, Instituto Paulo Freire, 2002 (Coleção Prospectiva).

DE FREITAS, A.G.G.; GOMES, M. C. A. . Comunicação nas organizações: uma análise da prática social em mídia impressa. Lumina, v. 2, p. 6, 2008. Meio de divulgação: Digital; ISSN/ISBN: 1516785.

DI NALLO, E. Meeting Points - Soluções de marketing para uma sociedade complexa. São Paulo: Marcos Cobra Editora, 1999.

DINATO, M.R. Produção e Consumo Sustentáveis: o caso da Natura Cosméticos S.A., 2006. 1v. 138p. Doutorado. Universidade Federal Do Rio Grande Do Sul. http://servicos.capes.gov.br/capesdw/resumo.html?idtese=20065642001013025P1

Acesso em 9 de Fev. de 2009

DINIZ, J.H.A.S.; MATTOS, P. L. C. L. Organizações não governamentais e gestão estratégica: desfiguração de seu caráter institucional-original? IntegrAção: a revista eletrônica do Terceiro Setor. 2002. Administrando.

Disponível em: http://integracao.fgvsp.br/ano6/06/administrando.htm

Acessado em: 07 Set de 2005.

DOMINGOS, M.L.C. Responsabilidade Social Organizacional, Confiança e Capital: a exploração de um campo obscuro. 2007. 1v. 306p. Doutorado. Universidade do Estado do Rio de Janeiro - Psicologia Social. 
http://servicos.capes.gov.br/capesdw/resumo.html?idtese=20071931004016013P1

Acesso em 9 de fev. de 2009

Responsabilidade social nas organizações de trabalho: benevolência ou culpa?. Psicol. cienc. prof. [online]. mar. 2007, vol.27, no.1 [citado 30 Janeiro 2009], p.80-93.

Disponível em: <http://pepsic.bvs-psi.org.br/scielo.php?script=sci_arttext\&pid=S141498932007000100007\&lng=pt\&nrm=iso $>$.

EZEQUIEL, V C. A MERCANTILIZAÇÃO DAS “QUESTÕES SOCIAIS” E O ESPETÁCULO DA “AJUDA” Uma análise da campanha publicitária "Produto do Bem” da rede de drogarias Farmais. Mestre no curso de Pós-Graduação (Stricto Sensu), da Faculdade Cásper Líbero, 2005.

http://www.facasper.com.br/pos/pdf/vanderlei_de_castro.pdf Acesso em 29 de abril de 2007.

FAGUNDES, H. S. Voluntariado e Solidariedade: da caridade ao direito. 2006. 3v. 179p. Doutorado. Pontifícia Universidade Católica do Rio Grande do Sul - Serviço Social http://servicos.capes.gov.br/capesdw/resumo.html?idtese=2006242005019008P5 ACESSO 9/FEV/2009

FALCONER, A.P. A promessa do terceiro setor: um estudo sobre a construção do papel das organizações sem fins lucrativos e do seu campo de gestão. 1999. 152p. Dissertação (Mestrado em Administração) - Faculdade de Economia, Administração e Contabilidade da Universidade de São Paulo, São Paulo.

FARACHE, F.; WANDERLEY, L.S.O. et alii Responsabilidade Social das Empresas na Web: Estratégias de Divulgação Adotadas Pelas Maiores Empresas Francesas no Brasil e na França. Número 15 - GESTÃO.Org, v.5, n.3 - SET / DEZ 2007

http://www.gestaoorg.dca.ufpe.br/edicoes/N3_V5/resumo_08.htm

FEDATO, M.C.L. Responsabilidade social corporativa: benefício social ou vantagem competitiva? um estudo das estratégias de atuação social empresarial e sua avaliação de resultados. Faculdade de Economia, Administração e Contabilidade (FEA) Dissertação de Mestrado em Administração, 2005.

FERNANDES, F. A revolução burguesa no Brasil: ensaio de interpretação sociológica. Prefácio de José de Souza Martins. $5^{a}$ edição. São Paulo: Globo, 2006.

FERREIRA, D.A.F. Informações sobre Responsabilidade Social Corporativa: Quem Está Falando? XXXII ENANPAD - Rio de Janeiro, 6 a 10 de setembro de 2008. CD de anais

FERREIRA; V.C.R. Comunicação, poder e cultura na era da visibilidade mediática: crítica das práticas de assessoria de comunicação e de responsabilidade social. PUCSP, Dissertação de Mestrado em Comunicação em Semiótica, 2006.

http://www.sapientia.pucsp.br/tde busca/processaPesquisa.php?pesqExecutada=1\&id=2220

ACESSO 7/2/2009

FISCHER, R.M. e FALCONER, A.P. Estratégias de empresas no Brasil: atuação social e voluntariado. São Paulo: Revista de Administração São Paulo. v. 36, jul/set 2001, p. 15-27. 
FONTENELLE, I.A. O nome da marca - Mc'Donald's, fetichismo e cultura descartável. São Paulo: Boitempo, 2002.

I.A. Responsabilidade Social e Mercado da Cidadania no Brasil: o Caso da McInternet. APS-C 421

FOUCAULT, M. Em defesa da sociedade. Aula de 17/03/1976, Do poder de soberania ao poder sobre a vida. São Paulo: Martins Fontes, 2000

M. A vontade de saber. História da sexualidade 1. Capítulo V: Direito de morte e poder sobre a vida. São Paulo: Editora Graal, 2003.

M. A governamentalidade. Ditos e Escritos IV. RJ: Forense Universitária, 2003.

FRANCO, G. Palestra em evento $1^{\circ}$ Fórum Ibope Brasil 2010 Tendências e Perspectivas 18/agosto/2005.

http://www.ibope.com.br

FRANK, T. C. The Conquest of the Cool: Business Culture, Counterculture, and the Rise of Hip Consumerism. Chicago: University of Chicago Press, 1997.

FREIRE FILHO, J. (Org.); VAZ, P. (Org.). Construções do tempo e do outro: representações e discursos midiáticos sobre a alteridade. Rio de Janeiro: Mauad X, 2006. 223 p.

http://books.google.com/books?hl=ptBR\&lr=\&id=NyQOUl5v7G8C\&oi=fnd\&pg=PA7\&dq= \%22Responsabilidade+Social+Empresarial\%22\&ots=WHZ6Uq_rXl\&sig=Hv_oGvhq5bI75_ 6eOl43ppi8HSA\#PPA207,M1 (Acesso em 02 de setembro de 2007)

FREY, I.A. Sistema de gerenciamento da responsabilidade social empresarial por meio de indicadores, REDES, Santa Cruz do Sul SC, v. 12, n. 2, p. 145-162, mai./ago. 2007 http://online.unisc.br/seer/index.php/redes/article/viewFile/274/217

FRIEDMAN, M. The Social Responsibility of Business is to Increase its Profits, The New York Times Magazine, September 13, 1970. Copyright @ 1970 by The New York Times Company.

GARAY, A. B. S. Prazer e sofrimento no trabalho do voluntário empresarial. Revista de Ciências da Administração, V. 10, n. 20, jan./abr. de 2008.

http://www.periodicos.ufsc.br/index.php/adm/article/viewArticle/4751

GARCIA, KC et alii. Concepção de um modelo matemático de avaliação de projetos de responsabilidade social empresarial (RSE). Gestão Produção. São Carlos, v. 14, n. 3, Dec. 2007.

Disponível em: $\quad<$ http://www.scielo.br/scielo.php?script=sci_arttext\&pid=S0104530X2007000300009\&lng=en\&nrm=iso

Acesso em 30 de Jan. de 2009.

GUIMARÃES, HW Responsabilidade Social da empresa: uma visão histórica de sua problemática, UFMG, RAE, RJ 24(4): 211-219 - out/dez 1984. 
GOLDSTEIN, I. Responsabilidade social: das grandes corporações ao terceiro setor. São Paulo: Ática, 2007 (p.26-28).

GOMES, A. A Responsabilidade e o social: uma discussão sobre o papel das empresas / Adriano Gomes, Sérgio Moretti - São Paulo: 2007

GOMES, D.V. Educação para o consumo ético e sustentável, Mestrado em Direito Ambiental da Universidade de Caxias do Sul (UCS), Revista Eletrônica, Mestrado Educação Ambiental ISSN 1517-1256, v.16, janeiro junho de 2006.

http://www.remea.furg.br/edicoes/vol16/art02v16.pdf

Acesso em 1 de fev. de 2009

GONCALVES, O. Iniciativa privada na Educação pública: a Fiat e o Programa Moto Perpétuo. Educação e Pesquisa, 2008, v. 34, n. 1, pp. 47-62.

http://www.scielo.br/scielo.php?script=sci_arttext\&pid=S151797022008000100004\&lng=en

$\underline{\text { \&nrm=iso }}$ Acessado em 30 de jan. de 2009

GRACIOSO, F. Espetáculo e Comunicação: um casamento pós-moderno. Revista da ESPM - v. 14, ano 13, edição 4, Julho/Agosto/2007, p. 10/16.

GODOY, A.S. Introdução à pesquisa qualitativa e suas possibilidades. Revista de Administração de Empresas. São Paulo, v.35, n.2, p.57-63, Mar./Abr. 1995

. Refletindo sobre critérios de qualidade da pesquisa qualitativa. Gestão.Org, v.3, n.2, mai./ago. 2005 www.gestaoorg.dca.ufpe.br acesso em junho de 2006

GOMES, A.N.et alii. Sustentabilidade de empresas de base florestal: o papel dos projetos sociais na inclusão das comunidades locais. Rev. Árvore, Viçosa, v. 30, n. 6, Dec. 2006. Disponível em: $\quad<$ http://www.scielo.br/scielo.php?script=sci_arttext\&pid=S010067622006000600010\&lng=en\&nrm=iso>.

Acesso em 30 de Jan. de 2009

GOMES, W. Publicidade, visibilidade, discutibilidade 1, Para uma revisão do conceito de esfera pública política. Trabalho apresentado ao Grupo de Trabalho "Comunicação e Política”, do XVI Encontro da Compós, na UTP, em Curitiba, PR, em junho de 2007. Cd Anais.

Guia de Boa Cidadania Coorporativa. Exame. Edição Especial. Dez. 2002. Editora Abril.

HALL, Peter Dobkin. Historical perspectives on Nonprofit Organization. In: HERMAN, R. D. (and Associates). The Jossey-Bass Handbook of nonprofit leadrship and management. San Francisco: Jossey- Bass Publisher, 1994.

HARTER, G. et all. Marketing Metamorphosis. In: PRECOURT, Geoffrey (editor) CMO Thought Leaders - The rise of the strategic marketer. Strategy + business Reader. 2007, 300 páginas. Disponível em http://www.strategy-business.com/cmoreader

HAUG, W.F. A crítica da estética da mercadoria. São Paulo: Universidade Estadual de São Paulo, 1988. 
HOUlfeldT, A. at AL. Teorias da Comunicação: conceitos, escolas e tendências. Petrópolis: Vozes, 2001

IBGE. Pesquisa anual de serviços - Suplemento de produtos e serviços, 2004 / 2005. Rio de Janeiro: IBGE, 2007, p.1-109.

KALLIO, TJ. Taboos in Corporate Social Responsibility Discourse. Journal of Business Ethics (2007) 74:165-175. DOI 10.1007/s10551-006-9227-x / Springer 2006.

KELLNER, Douglas. Media culture and the triumph of the spetacle. http://www.gseis.ucla.edu/faculty/kellner/papers/medculturespectacle.html; última modificação em 10/07/2006. Acesso em 25 de outubro de 2007.

KITAHARA, J.R. Responsabilidade social e desempenho financeiro das empresas: um estudo empírico utilizando o balanço social padrão IBASE. Faculdade de Economia, Administração e Contabilidade, 2007.

Dissertação - Administração http://www.teses.usp.br/

Acesso em 15 de fev. de2009

KILKSBERG, B. Falácias e Mitos do Desenvolvimento Social. São Paulo, Cortez, 2001.

KIRSCHNER, G; CAPPELLIN, P (org.) et alii. As organizações empresariais brasileiras e a responsabilidade social. In. Empresa, empresários e globalização. Rio de Janeiro: Relume Dumará - FAPERJ, 2002.

KLEINRICHERT, D. Ethics, Power and Communities: CSR Revisited, Journal of Business Ethics (2008) 78: 475-485.

KREITLON, M.P.. A ética nas relações entre empresas e sociedade: fundamentos teóricos da responsabilidade social empresarial. XXVIII Encontro Nacional da ANPAD, 2004. Curitiba. 28., 2004, Curitiba. Anais... Curitiba: Anpad, 2004.

KOERICH, S.O. Balanço social - uma análise do modelo aplicado a entidades públicas de administração direta municipal: um estudo de caso na Prefeitura Municipal de Florianópolis. 2003. 156p. Dissertação de Mestrado em Administração, Programa de Pós Graduação: Faculdade de Economia, Administração e Contabilidade da Universidade de São Paulo, São Paulo.

KOTLER, P. Administração de marketing. Tradução de A. B. Brandão. São Paulo: Atlas, 1998.

KOTLER, P. \& ROBERTO, E. L. Marketing social: estratégias para alterar o comportamento público; tradução de José Ricardo Azevedo e Elizabeth Maria Braga. - Rio de Janeiro: Campus, 1992

KUNSCH, M.M.K., Organizações, cidadania, comunicação e os limites entre as estratégias e a ética. In: Moreira, Sonia V. e Bragança, A. (orgs). Mídia, ética e sociedade. Belo Horizonte: PUC Minas/ Intercom, 2004 (coleção Intercom de comunicação; v.18) 95111. Evelina Dagnino (2004) Sociedade civil, participação e cidadania: de que estamos falando? In Daniel Mato (coord.) Políticas de ciudadanía y sociedad civil en tiempos de globalización. Caracas: FACES, Universidad Central de Venezuela PP 95-110. 
KUNTZ, R. República, direitos e ordem global. Lua Nova. São Paulo, n. 60, 2003. Disponível em: $\quad<$ http://www.scielo.br/scielo.php?script=sci_arttext\&pid=S010264452003000300003\&lng=pt\&nrm=iso>. Acesso em: 23 Out 2006. doi: 10.1590/S010264452003000300003.

LEHFELD, A.S. Controles das Agências Reguladoras: A Participação - Cidadã como Limite à sua Autonomia. 2006. 1v. 404p. Doutorado. Pontifícia Universidade Católica de São Paulo - Direito.

http://servicos.capes.gov.br/capesdw/resumo.html?idtese=200614833005010019P5 ACESSO 9/FEV/2009

LEITAO, S.P.; SPINELLI, R.A. Economia de comunhão no Brasil: a produção acadêmica em administração de 1991 a 2006. Rev. Adm. Pública, Rio de Janeiro, v. 42, n. 3, Jun. 2008.

Disponível em: $\quad<$ http://www.scielo.br/scielo.php?script=sci_arttext\&pid=S0034$76122008000300002 \& \operatorname{lng}=$ en\&nrm=iso $>$.

Acesso em: 30 Jan. 2009

LEMOS, E.P.J. Tendências à publicização da empresa: uma abordagem interdisciplinar, 2007. 1v. 297p. Doutorado. Universidade Federal De Minas Gerais - Direito http://servicos.capes.gov.br/capesdw/resumo.html?idtese=20074532001010027P6

Acesso 9 de fev. de 009

LEVITT, T. The Dangers of social responsibility. Harvard Business Review, p. 41-50, set/out. 1958.

LIESENBERG, C. A inserção da imprensa no discurso do terceiro setor. Análise do Projeto Cidadão 2001 - Correio Popular e da Coluna Social - Folha de S.Paulo. Dissertação de mestrado. ECA/USP, 2004.

http://www.facasper.com.br/pos/libero/libero12/Em\%20nome\%20do\%20terceiro\%20setor\%2 086-95.pdf . Acesso em 7 de fevereiro de 2009.

LIMA, R.S. Os desafios da responsabilidade social empresarial na relação com o empowerment comunitario : um estudo de caso da favela do Jardim Colombo, na cidade de São Paulo., 2008 Campinas, SP. Universidade Estadual de Campinas . Faculdade de Educação Dissertação de Mestrado - UNICAMP: Programa de Pós-Graduação em Educação.

LIVINGSTONE, S.; LUNT, P.r; MILLER, L. Citizens, consumers and the citizenconsumer: articulating the citizen interest in media and communications regulation, DISCOURSE \& COMMUNICATION 2007; 1; 63. DOI: 10.1177/1750481307071985 http://dcm.sagepub.com/cgi/content/abstract/1/1/63

Downloaded from http://dcm.sagepub.com by on December 13, 2007

LUCAS, L; HOFF, T. Resistência E Emancipação Social: 1, A cidadania como condição participante na construção da produção simbólica. Trabalho apresentado ao Grupo de Trabalho "Economia Política e Políticas da Comunicação", do XVI Encontro da Compós, na UTP, em Curitiba, PR, em junho de 2007. 
LUO, Y., Political behavior, social responsibility, and perceived corruption: a structuration perspective. Journal of International Business Studies JIBS (2006) 37, 747766 www.jibs.net

MACEDO, M.A.S.; SOUZA, A.C.; SOUZA, A.C.C. Desempenho de empresas socialmente responsáveis: uma análise por índices contábil-financeiros. Revista Produção Online, Vol. 7, No 4 (2007)

http://www.periodicos.ufsc.br/index.php/producaoonline/article/view/4868/4212

MACHADO, A.C.M.; MELO, M.A.C. Economia de Comunhão: elementos para uma teoria organizacional. Rio de Janeiro, 2006. 266p. Tese de Doutorado - Departamento de Engenharia Industrial, Pontifícia Universidade Católica do Rio de Janeiro.

MACHADO FILHO, C.A.P. Capital reputacional e responsabilidade social: considerações teóricas. São Paulo: Cadernos de Pesquisas em Administração São Paulo, 2(11):87-89, abr/jun, 2004a.

C.A.P. A empresa socialmente responsável: o debate e as implicações. São Paulo: Revista de Administração São Paulo, 3(39): 242-254, jul/set, 2004b.

C.A.P. Responsabilidade social coorporativa e a criação de valor para as organizações. Trabalho de evento: International Conference on Agri-Food Chain/Networks Economics end Managmente. (março de 2003, Ribeirão Preto)

MAGALHÃES, C.S. responsabilidade social em empresas de confecção: um estudo multicaso no pólo de moda íntima em nova Friburgo/RJ, 2007. 1v. 99p. Doutorado. Universidade federal do Rio de Janeiro - engenharia de produção

Biblioteca Depositaria: Biblioteca Central do CT

http://servicos.capes.gov.br/capesdw/resumo.html?idtese=20072231001017035P6

MAGALHÃES, ILM, Responsabilidade Social Dos Indivíduos, CMA/Face/UFMG. RAE, RJ 24(4): 220-225 - out/dez 1984.

MACHADO, VF. A produção do discurso do desenvolvimento sustentável: de Estocolmo À RIO-92. 01/08/2005 1v. 328p. Doutorado. Unb

http://servicos.capes.gov.br/capesdw/resumo.html?idtese=200523453001010044P0 ACESSO 9/FEV/2009

MAINGUENAU, D. Novas tendências em análise do discurso. Campinas, SP: Pontes, 1997.

MANZINI COVRE, M.L. O que é a cidadania. São Paulo: Brasiliense, 2003. $3^{\mathrm{a}}$ ed.

MARSHALL, T.H.. Cidadania, Classe Social e Status. Rio de Janeiro: Zahar, 1967.

MARTINELI, F ; MACHADO, M . Política como mercadoria: consumo, cidadania e cultura jovem nos discursos publicitários. In: II Encontro ESPM de Comunicação e Marketing, 2007, São Paulo. Anais do II Encontro ESPM de Comunicação e Marketing. São Paulo : ESPM, 2007. v. 1. 
MARTINS, A.S. Burguesia e a nova sociabilidade: estratégias para educar o consenso no Brasil contemporâneo, 2007. 284 f. Tese de Doutorado, Universidade Federal Fluminense, Faculdade de Educação, 2007.

http://www.uff.br/pos_educacao/joomla/images/stories/Teses/burguesia.pdf

MARTINS, P.E.M., Canudos: Organização, Poder e o Processo de Institucionalização de um Modelo de Governança Comunitária. IN: XXX ENANPAD, 23-27 Setembro, Salvador, Bahia, 2006.

MARTINS, R. R. Terceira linguagem e mediação: da certeza à crise nos relacionamentos de uma instituição. Tese de Doutorado - PUCSP, Programa de Estudos Pós-graduados em Comunicação e Semiótica, 2005.

http://www.sapientia.pucsp.br/tde_busca/resultado-tdes

prog.php?ver=1\&programa=1\&ano_inicio=2006\&mes_inicio=01-01\&mes_fim=12-

31\&ano_fim $=2006 \& g r a u=$ Doutor

Acesso em 7 de fev. de 2009

MELO, M.O.B.C. et alii Gestão de empresas na economia de comunhão: estudo de caso no nordeste do Brasil - Revista gestão industrial. Universidade Tecnológica Federal do Paraná - UTFPR. Campus Ponta Grossa - Paraná - Brasil. v. 04, n. 04: p. 76-91, 2008.

http://www.pg.utfpr.edu.br/depog/periodicos/index.php/revistagi/article/viewFile/191/185

Acesso em 30 de jan. de 2009

MENDONÇA, L.R. Desenvolvimento e sustentabilidade: um estudo de alianças estratégicas intersetoriais no empreendedorismo social, 2007. 1v. 166p. Doutorado. Universidade de São Paulo - Administração, Faculdade de Economia, Administração e Contabilidade (FEA).

http://bdtd2.ibict.br/index.php?option=com_wrapper\&Itemid=39

Acesso em 01 de set. de 2007

http://servicos.capes.gov.br/capesdw/resumo.html?idtese=20075533002010085P5

Acesso em 9 de fev. de2009

MENDONÇA, P.M. O marketing e sua relação com o social: dimensões conceituais e estratégicas. In: Responsabilidade social das empresas - a contribuição das universidades. São Paulo: Peirópolis, 2002 p.147-169

Mensagem do Presidente ao Congresso Nacional 1999 na Abertura da $1^{\text {a }}$ Sessão Legislativa $\begin{array}{lllll}\text { Ordinária } & \text { da } & 51^{\mathrm{a}} & \text { Legislatura. } & \text { Disponível }\end{array}$ http://www.planalto.gov.br/publi_04/COLECAO/99MENS1A.HTM acesso em março de 2009

METZNER, R. J. Fadiga e capacidade para o trabalho em trabalhadores de indústrias têxteis e responsabilidade social empresarial, 2004. 1v. 245p. Doutorado. Universidade de São Paulo - Saúde Pública.

http://servicos.capes.gov.br/capesdw/resumo.html?idtese=2004124633002010067P7 Acesso em 9 de fev. de 2009

MOLICA, DG e outros. RSE: oportunidades perdidas para trabalhadores e empregadores RBGN Revista Brasileira de Gestão de Negócios, vol.10 n.8, p.215-233 jul/set 2008. http://200.169.97.103/seer/index.php/RBGN/article/viewFile/205/399 
acesso em 9/jan/2009

MORETTI, S. L. do A., CAMPANÁRIO, M. de A. Para sair da zona de conforto: análise bibliométrica dos artigos sobre responsabilidade social empresarial - RSE na EnANPAD. XXXII ENANPAD - Rio de Janeiro, 6 a 10 de setembro de 2008. CD Anais.

MURAD, E.G. Comunicação e cultura na responsabilidade social corporativa - Rio de Janeiro, 2005.189 f. : 2 cm. Dissertação (Mestrado)- Universidade Federal do Rio de Janeiro, Escola de Comunicação, 2005.

http://www.pos.eco.ufrj.br/Publicações/Dissert Apresentações 2005

Acesso em 4 de fev. de 2009

NAN, X and HEO, K, Consumer Responses To Corporate Social Responsibility (Csr) Initiatives. Examining the Role of Brand-Cause Fit in Cause-Related Marketing - Journal of Advertising, vol. 36, no. 2 (Summer 2007), pp. 63-74. (C) 2007 American Academy of Advertising. All rights reserved.

NASCIMENTO, L.P. Empresa Psicopata X Empresa Cidadã. APS-C 2655

NASCIMENTO, LP, O Insustentável Sustentável, XXXII ENANPAD - Rio de Janeiro, 6 a 10 de setembro de 2008. CD Anais.

OLIVEIRA, F.R.M. Relações públicas e a comunicação cidadã. In: Responsabilidade Social das empresas - A contribuição das universidades. São Paulo: Peirópolis, 2002. p.195-228.

OLIVEIRA, A.. C. C. ECA 2007 e-SOCIAL: comunicação e formação de parcerias entre Estado, Mercado e Terceiro Setor, na Internet, visando o desenvolvimento social. Fonte: São Paulo, 277p. Dissertação de Mestrado apresentada a(o) ECA/USP. CJE. Mestrado, 2007. http://poseca.incubadora.fapesp.br/portal/comunicacao/outrosccom/dados/2007/titulo/frontpage

OLIVEIRA, J. S. e VIEIRA, F. G. D. Produção simbólica e sustentabilidade: discutindo a lógica da salvação da sociedade pela mudança nos modos de consumo. CADERNO DE ADMINISTRAÇÃO. v. 16, n.2, p. 35-43, jul/dez. 2008.

http://www.periodicos.uem.br/ojs/index.php/CadAdm/article/viewFile/6043/3734

OLIVEIRA, P.de S. Cultura Solidária em Cooperativas: Princípios coletivos de mudança de vida. São Paulo: Edusp, 2006.

OLIVEIRA, P.H.D.; REIS, S.G. Sustentabilidade Empresarial: Avaliação do Equilíbrio Socioeconômico e Ambiental da Empresa Natura Cosméticos S.A. XXXII ENANPAD Rio de Janeiro, 6 a 10 de setembro de 2008

OLIVEIRA, PRS, D. Sc., Universidade Federal de Viçosa, julho de 2007. Relação entre empresas florestais e comunidades do entorno: proposta para superação de conflitos. Tese de Doutorado) - Universidade Federal de Viçosa - Viçosa, MG, 2007. x, 110 f.

http://www.ipef.br/servicos/teses/arquivos/oliveira,prs-d.pdf 
OLIVEIRA, S.E.; GUIMARÃES, E.R.J. Cidadania: historia e política de uma palavra. Universidade Estadual de Campinas . Instituto de Estudos da Linguagem Nível: Tese de Doutorado - UNICAMP: Programa de Pós-Graduação em Linguística http://libdigi.unicamp.br/document/?code=vtls000341384

ORTIZ, M. C. M. Voluntariado em hospitais: uma análise institucional da subjetividade, 2007. 1v. 222p. Doutorado. Universidade de São Paulo - Psicologia Escolar e do desenvolvimento humano.

http://servicos.capes.gov.br/capesdw/resumo.html?idtese=2007933002010038P7

Acesso em 9 de fev. de 2009

ORLANDI, E.P. Análise de discurso: princípios e procedimentos. Campinas, SP: Pontes, $4^{\mathrm{a}}$ ed, 2002.

OTTMANN, G. CIDADANIA MEDIADA - Processos de democratização da política municipal no Brasil - Novos Estudos 74- MARÇO 2006 - 155-175.

PAIS, C.T. Aspectos de uma tipologia dos universos de discurso. Revista Brasileira de Lingüística. São Paulo: Global Editora, 1(7):43-65, 1984.

PAOLI, M. C., Empresas e responsabilidade social: os enredamentos da cidadania no Brasil. cap.8. In: SANTOS, B. (org.). Democratizar a democracia: os caminhos da democracia participativa. $3^{\text {a }}$ Edição, Rio de Janeiro: Civilização Brasileira, 2005.

PASSADOR, C.S.; FERRAZ, M.G.L.; ALCANCE, L.C. A responsabilidade social no ENANPAD. UNIVALI - Vol. 14 - n.3 p. 469 - 492 - Set / Dez 2007.

http://siaiweb06.univali.br/seer/index.php/ra/article/viewFile/99/78

PAVAN, M.C; JÚDICE, J. Empreendedorismo, ética e responsabilidade social para micro e pequenas empresas: crescer com foco social. Revista de Ciências Gerenciais, Vol. 12, n. 16, 2008.

http://sare.unianhanguera.edu.br/index.php/rcger/article/viewArticle/381

PEIXOTO, M.C. Responsabilidade social e impacto no comportamento do consumidor [recurso eletrônico] : um caso da indústria de refrigerantes. Dissertação de Mestrado Pontíficia Universidade Católica do Rio de Janeiro, Departamento de Administração, Rio de Janeiro, 2003

http://www2.dbd.pucrio.br/pergamum/biblioteca/php/mostrateses.php?open=1\&arqtese=0116 536_03_Indice.html

Acesso em 7 de fev. de 2009

PEREIRA, C. A. M e REIS, P. Comunicação, cultura e sustentabilidade. Rio de Janeiro, 2008 (mimeo). p.105.

PEREIRA, E. A. A. A empresa e o lugar na globalização: a 'responsabilidade social empresarial' no território brasileiro, Faculdade de Filosofia, Letras e Ciências Humanas, FFLCH, 2007.

http://www.teses.usp.br/

Acesso em 9 de fev. de 2009 
PEREIRA, I; M., MISOCZKY, M.C. Peter Drucker e a legitimação do capitalismo tardio: uma análise crítica de discurso. EOR 2164

PEREIRA, M.A.; CARVALHO, E. Boaventura de Sousa Santos: por uma nova gramática do político e do social. Lua Nova, São Paulo, n. 73, 2008.

Disponível em: <http://www.scielo.br/scielo.php?script=sci_arttext\&pid=S010264452008000100002\&lng=pt\&nrm=iso $>$. Acesso em: 06 jan. 2009. doi: 10.1590/S010264452008000100002 .

PEREIRA, R.; SOUZA, M.; VIEIRA, S. L. Responsabilidade social: uma dupla estratégia corporativa? (UNINOVE) - Revista Gerenciais, São Paulo, v.5, n. especial, p. 51-62, jan./jul. 2006.

PEREZ, C. Os signos da marca - expressividade e sensorialidade. São Paulo: Thomson Pioneira, 2004

PERUZZO, C M. K. Direito à comunicação comunitária, participação popular e cidadania. In: OLIVEIRA, Maria José da costa. Comunicação pública. Campinas, São Paulo: Editora Alínea, 2004.

FAMECOS $\bullet$ Porto Alegre $\bullet \mathrm{n}^{0} 14 \cdot$ abril 2001

Comunicação uma agenda para o século XXI. Revista

PETRINI, M.C. Incorporando A Gestão da Sustentabilidade aos Sistemas de Inteligência de Negócio, 2006. 1v. 157p. Doutorado. Fundação Getúlio Vargas/Sp - Administração de Empresas.

http://servicos.capes.gov.br/capesdw/resumo.html?idtese=20064733014019001P0

Acesso 9 de Fev. de 2009

PLANO DIRETOR DA REFORMA DO APARELHO DO ESTADO de 1995. Disponível em http://www.planalto.gov.br/publi_04/COLECAO/PLANDI.HTM acesso em março de 2009

PONTES, J. Proposta Para Avaliação do Impacto das Ações Sociais Praticadas por Uma Empresa e sua Relação Com os Indicadores de Desempenho, 2007. 1v. 120p. Doutorado. Universidade Federal de Santa Catarina - Engenharia de Produção

http://servicos.capes.gov.br/capesdw/resumo.html?idtese=20072741001010051P3

Acesso em 9 de fev. de 2009

PORÉM, M. E. A GESTÃO DA COMUNICAÇÃO E DA INFORMAÇÃO NAS EMPRESAS CONTEMPORÂNEAS SOB A ÓTICA DA RESPONSABILIDADE SOCIAL. UNESP-Bauru - Mestrado em Comunicação/ defesa 2005

http://www.faac.unesp.br/posgraduacao/comunicacao/disserta.php\#maria_eugenia Acesso em 12 de maio de 2007

PORTER, M. The Competitive Advantage of Nations. Harvard Business Review. MarchApril, 1990.

PORTER, ME e KRAMER, M.R. O elo entre vantagem competitiva e responsabilidade social empresarial. , Harvard Business Review / Dezembro 2006 /52-66 
QUESSADA, D. O Poder da Publicidade na Sociedade Consumida Pelas Marcas: como a globalização impõe produtos, sonhos e ilusões. São Paulo: Futura, 2003.

REGINATO, G.R.A. Mercado Social na TV Globo: O outro espetáculo no horário nobre - Uma análise sobre a institucionalização do merchandising social na telenovela das oito. Mestrado curso de Pós-Graduação, da Faculdade Cásper Líbero, 2007.

http://www.facasper.com.br/pos/pdf/giuliana_regina.pdf Acesso em 7 de fev. de 2009

REGO, W. L. Aspectos teóricos das políticas de cidadania: uma aproximação ao Bolsa Família. Lua Nova, São Paulo, n. 73, 2008.

Disponível em: $\quad<$ http://www.scielo.br/scielo.php?script=sci_arttext\&pid=S010264452008000100007\&lng=pt\&nrm=iso $>$. Acesso em: 06 jan. 2009. doi: 10.1590/S010264452008000100007.

REZENDE, I. A. C.; SANTOS, L. S. R. Análise da Rentabilidade e Performance dos Investimentos Socialmente Responsáveis: um estudo empírico no mercado brasileiro. In: Encontro da Associação Nacional de Pós-Graduação e Pesquisa em Administração, 30, 2006, Salvador. Anais do XXX EnANPAD. Salvador: ANPAD, 2006. 1 CD.

RIBEIRO FILHO, J.F. et alii Decisões de investimento baseadas em métricas contábeis um experimento considerando variáveis de responsabilidade social. RPA, v2, n5, Mar/Abr 2006, 63-72

RIBEIRO, M.S. Balanço social. Disponível em: <http://www.balancosocial.org.br>. Acesso em abr. de 2000.

ROBERTO, A.A. Responsabilidade social empresarial : um estudo sobre as maiores instituições financeiras privadas no Brasil - Aline Aparecida Roberto / Data de Publicação: 2006 Local de Publicação: Campinas, SP. Universidade Estadual de Campinas, Instituto de Economia, Dissertação de Mestrado, Unicamp.

http://libdigi.unicamp.br/document/?code=vtls000378383

ROCHA, M.E.M. A nova retórica do grande capital: a publicidade brasileira em tempos neoliberais. 2003. 275p. Tese (Doutorado em Sociologia) - Faculdade de Filosofia, Letras e Ciências Humanas da Universidade de São Paulo, São Paulo.

RODRIGUES, M.C.P. Ação social das empresas privadas: uma metodologia para avaliação de resultados. 2004.1v. 327p. Doutorado. Fundação Getúlio Vargas/Rj Administração.

Ação social das empresas: como mensurar resultados? Novas idéias em administração FGV. Organizadores: Paulo Roberto Motta, Roberto Pimenta, Elaine Tavares, Rio de Janeiro: Editora FGV, 2006.

http://books.google.com/books?hl=ptBR\&lr=lang_pt\&id=f2lPKg5xY8kC\&oi=fnd\&pg=RA1 PA153\&dq=tudonot\%C3\%ADtulo:++\%22Responsabilidade+Social+Empresarial\%22\&ots= X9ZdEqP4eM\&sig=NrX3L9Lvr_i4mJLsqLCmsfN5zfo

ROQUE, V e CORTEZ, MC. A divulgação de informação ambiental e a performance financeira das empresas cotadas em Portugal. Tékhne, jun. 2006, no.5-6, p.119-143. ISSN 1654-9911. 
http://www.scielo.oces.mctes.pt/pdf/tek/n5-6/3n5-6a07.pdf

ROSSY, E. J. B.: Mídia e Terceiro Setor: Como as ONGs promovem a Cultura de Paz; 1; 222; Português; SILVA, L. M. (Docente);Comunicação e Sociedade; Jornalismo e Sociedade; Jornalismo Institucional:

, E. J. B. Mídia e Terceiro Setor: como as ONGs promovem a cultura de paz. Dissertação de Mestrado. Programa de Pós-graduação em Comunicação e Sociedade da Faculdade de Comunicação da UNB - Linha de Pesquisa: Jornalismo e Sociedade http://bdtd.bce.unb.br/tedesimplificado/tde_busca/arquivo.php?codArquivo=685

ACESSO 2/FEV/2009

SALAMON, L. A emergência do terceiro setor: uma revolução associativa global. Revista de Administração, São Paulo, v. 33, n. 1/2, p. 5-11, jan./mar. 1998, p.06.

SANTANA, C. O. As empresas que desenvolvem políticas de responsabilidade social. PUCSP, Pontifícia Universidade Católica de São Paulo, 2006. http://bdtd2.ibict.br/index.php?option=com_wrapper\&Itemid=39 Acesso em 2 de fev. de 2009

SANTANA, G. J.. A Economia Solidária Face à Dinâmica da Acumulação Capitalista: da subordinação a um novo modo de regulação social? 2007. 1v. 320p. Doutorado. Universidade Federal da Bahia - Administração.

http://servicos.capes.gov.br/capesdw/resumo.html?idtese=20072228001010020P3

Acesso Em 9 de fev. de 2009

SANTANA, N.B. et alii Investimento em responsabilidade sócio-ambiental de empresas distribuidoras de energia elétrica: uma análise por envoltória de dados. Revista Gestão Industrial v. 02, n. 04: p.124-139, 2006.

http://200.134.81.21/ppgep/revista/revista2006/pdf/vol2nr4/vol2nr4art11.pdf

SANTOS, B.S.; BRANDÃO, G.M.; VIANNA, L.J.W. Por que pensar?. Lua Nova, São Paulo, n. 54, 2001.

Disponível em: <http://www.scielo.br/scielo.php?script=sci_arttext\&pid=S010264452001000100003\&lng=pt\&nrm=iso $>$.

Acesso em 06 de jan. de 2009.

; e AVRITZER, L. Introdução: para ampliar o cânone democrático In: Democratizar a democracia: os caminhos da democracia participativa/ Boaventura de Sousa Santos, organizador - $3^{\mathrm{a}}$ ed. - Rio de Janeiro: Civilização Brasileira, 2005

SANTOS, G. J.Cidadania Corporativa ou Ferramenta de Legitimação? - Uma Análise da Institucionalização das Práticas de Responsabilidade Social, XXXII ENANPAD - Rio de Janeiro, 6 a 10 de setembro de 2008. CD Anais.

SANTOS, J. C. Sustentabilidade socioeconômica e ambiental de sistemas de uso da terra da Agricultura Familiar no Estado do Acre. Universidade Federal de Viçosa, 2008.

http://bdtd2.ibict.br/index.php?option=com_wrapper\&Itemid=39 
SANTOS, L.L dos; HOFF, T. A face oculta da caridade: linhas de força e de fratura no discurso midiático do bem. In: Compós 2008, 2008, São Paulo. Anais da XVII Compós, 2008.

Comunicação e Consumo Sustentável: das entrelinhas do capitalismo leve ao enquadramento da sustentabilidade na mídia. Fronteiras (Florianópolis), Unisinos, São Leopoldo, v. VII, n. 3, p. 223-233, 2005.

http://www.unisinos.br/publicacoes_cientificas/images/stories/Publicacoes/fronteirasv9n3/10_ art08_llucas.pdf (Acesso em 10 de julho de 2008)

SANTOS, M. O Espaço do Cidadão. $4^{\mathrm{a}}$ ed. São Paulo: Nobel,1998, $7^{\mathrm{a}}$ ed. - São Paulo: Editora da Universidade de São Paulo, 2007.

SANTOS, W.G. Cidadania e justiça. Campus, Rio de Janeiro, 1979.

Cidadania e justiça: a política social na ordem brasileira. $2^{\mathrm{a}}$ edição. Rio de Janeiro: Campus, 1987 (p.68)

SANTA CRUZ, L. Palavras de ordem no jornalismo contemporâneo: a representação midiática da responsabilidade social empresarial. In: João Freire Filho; Paulo Vz. (Org.). Construções do tempo e do outro - representações e discursos midiáticos sobre a alteridade. 1 ed. Rio de Janeiro: Mauad X, 2006.

, L; MARTINELI, F . O engajamento social como estratégia de comunicação: consumo e responsabilidade no discurso empresarial. In: II Encontro ESPM de Comunicação e Marketing, 2007, São Paulo. Anais do II Encontro ESPM de Comunicação e Marketing. São Paulo : ESPM, 2007. v. 1.

L. Responsabilidade social: visão e intermediação da mídia na redefinição do público e do privado. Eco-Pós (UFRJ), v. 2004, n. 1, 2004.

http://www.pos.eco.ufrj.br/ Publicações /Dissert Apresentações 2006

Acesso em 4 de fev. de 2009

SENNETT, R. O declínio do homem público: as tiranias da intimidade/ Richard Sennett; tradução Lygia Araujo Watanabe. São Paulo: Companhia das Letras, 1998.

R. A corrosão do caráter: as conseqüências pessoais do trabalho no novo capitalismo. Tradução Marcos Santarrita - 12º ed. Rio de Janeiro: Record, 2007.

Record, 2006.

R. A cultura do novo capitalismo. Tradução Clóvis Marques. Rio de Janeiro:

SERPA, D.A.F. Efeitos e Responsabilidade Social Corporativa na Percepção do Consumidor sobre o Preço e Valor: Um Estudo Experimental, 2006. 1v. 191p. Doutorado. Universidade federal do Rio de Janeiro - Administração Biblioteca Depositaria: COPPEAD. http://servicos.capes.gov.br/capesdw/resumo.html?idtese=200645231001017062P3 Acesso em 9 de Fev. de 2009

SETHI, P. S. Dimensions of corporate social performance: an analytical framework. California Management Review, v. 13, n. 3, p. 58-64, 1975. 
SILVA, L.P; Responsabilidade social corporativa, solidariedade e dádiva : o caso da Petrobras S. A. Pontifícia Universidade Católica do Rio de Janeiro . Departamento de Administração, Dissertação de Mestrado - Pontifícia Universidade Católica do Rio de Janeiro, Departamento de Administração, Rio de Janeiro, 2004.

http://www2.dbd.puc-

rio.br/pergamum/biblioteca/php/mostrateses.php?open=1\&arqtese=0116831_04_Indice.html

SILVA, M. L. O impacto dos padrões corporativos de ética, governança corporativa, responsabilidade social, sustentabilidade e transparência na volatilidade das ações de bancos latino americanos, Dissertação - Ciências Contábeis Prog. Multiinst e Inter-Regional de PG em CContabeis - UnB,UFPB,UFPE,UFRN Brasília, 2006.

http://bdtd.bce.unb.br/tedesimplificado/tde_arquivos/38/TDE-2006-11-24T151130Z-

466/Publico/Dissertacao_MLS.pdf

SIMIONATTO, I.; PFEIFER, M. Responsabilidade Social das empresas: a contraface da sociedade civil e da cidadania. Revista Virtual Textos \& Contextos, $\mathrm{n}^{0}$ 5, nov. 2006 http://revistaseletronicas.pucrs.br/ojs/index.php/fass/article/viewFile/1016/796

SIQUEIRA, J.R.M. DVA: Vantagens e Limitações de seu Uso como Instrumento de Avaliação da Estratégia Social Corporativa - Revista del Instituto International de Costos, ISSN 1646-6896, nº 1, jan./jun. 2007, p.p. 116-140.

http://www.siebraga.com/riic/Revista1\%5Cartigo5.pdf

SODRÉ, M.. Antroplógica do Espelho: Uma Teoria da Comunicação Linear e em Rede. Petrópolis: Ed. Vozes, 2002.

Sobre a episteme comunicacional. Matrizes/ Revista do Programa de PósGraduação em Ciências da Comunicação da USP, Ano 1, n.1 (jul-dez 2007) - São Paulo: ECA/USP: 2007, p. 15/26

SOUSA FILHO, J. M. ; LUCIAN, R. et alli Comunicação da Responsabilidade Social na Internet: Um Estudo Utilizando Modelagem de Equações Estruturais. Anais do II Encontro ESPM de Comunicação e Marketing, São Paulo: ESPM, nov. 2007

SPOSATI A, Falcão MC \& Fleury SMT 1995. Os direitos (dos desassistidos) sociais. $2^{\mathrm{a}}$ ed. Cortez, São Paulo.

SOUZA, S. A. Educação, trabalho voluntário e responsabilidade social da empresa: "amigos da escola" e outras formas de participação - Faculdade de Educação, FE, 2008. http://www.teses.usp.br/

Acesso em 9 de fev. de 2009

SOUZA, V.S.F.; DREHER, M.T.; AMAD, M. A influência da responsabilidade sócioambiental no processo de internacionalização: o caso da electro aço altona. Revista de Ciências da Administração • v. 9, n. 19, p. 103-126, set./dez. 2007.

http://www.cad.ufsc.br/revista/19/06.pdf

SOUZA, V. S. F.; SAMPAIO, CA. C. Em busca de uma racionalidade convergente ao ecodesenvolvimento: um estudo exploratório de projetos de turismo sustentável e de responsabilidade social empresarial, RPA Rio de janeiro 40 (3): 411-25, mai/jun 2006. 
SOUZA, W.J.O Mundo Que Nós Perdemos: da Solidariedade Pré-Industrial à Economia Solidária, XXXII ENANPAD - Rio de Janeiro, 6 a 10 de setembro de 2008. CD Anais.

STAFOCHER, V.S. Norma Internacional SA 8000 Gestão da Responsabilidade Social, 2006. 1v. 216p. Doutorado. Pontifícia Universidade Católica de São Paulo - Ciências Sociais.

http://servicos.capes.gov.br/capesdw/resumo.html?idtese=20066233005010006P0

Acesso em 9 de fev. de 2009

STRIKE, V. M.; GAO, J; BANSAL, P. Being good while being bad: social responsibility and the international diversification of US firms. Journal of International Business Studies JIBS (2006) 37, 850-862 www.jibs.net.

SUCUPIRA, J. A responsabilidade social das empresas.

Disponível em: http://www.ibase.org.br/paginas/bssucupira.html

Acesso em jun. de 1999.

TANAKA, E. A responsabilidade social das instituições de ensino superior privadas. 2003. 116p. Dissertação (Mestrado em Administração) - Faculdade de Economia, Administração e Contabilidade da Universidade de São Paulo, São Paulo.

TEREPINS, F. M. Responsabilidade Social Empresarial do Varejo no Brasil: Um Estudo Multi Casos em Empresas de Grande Porte. 2005. 1v. 247p. Doutorado. Fundação Getúlio Vargas/Sp - Administração de Empresas.

http://servicos.capes.gov.br/capesdw/resumo.html?idtese=2005117733014019001P0

Acesso em 9 de fev. de 2009

TERRA, S.P. Trabalho sem futuro: a informalização na atividade dos chapas em São Paulo, 2007. 1v. 233p. Tese de Doutorado. Pontifícia Universidade Católica de São Paulo Ciências Sociais

http://servicos.capes.gov.br/capesdw/resumo.html?idtese=20075233005010006P0

Acesso de 9 de fev. de 2009

TOMBI. W. C.; SALM, J. F.; Menegasso, Maria E. Responsabilidade Social, Voluntariado e Comunidade: Estratégias convergentes para um ambiente de coprodução do bem público, O\&S, v13, n37, abril/junho, 2006.

URAS, F. P. A Responsabilidade social é um bom negócio? Disponível em: http://www.fiesp.org.br/foco/social/artigo2.htm

Acesso em ago. 1999.

VALERO, E.A. and CAMACHO R, K. The darkside of the Colombian floriculture sector's corporate social responsability practices. Innovar. [online]. Jan./Jun. 2006, vol.16, no.27 [cited 15 February 2009], p.73-90. Available from World Wide Web: $<$ http://www.scielo.org.co/scielo.php?script=sci_arttext\&pid=S0121-

$50512006000100005 \& \operatorname{lng}=$ en\&nrm=iso $>$. ISSN 0121-5051.

VASCONCELOS, A. G. Pressupostos filosóficos e político - Constitucionais para a aplicação do princípio da democracia integral e da ética de responsabilidade na 
organização do trabalho na administração da justiça: o Sistema Núcleos Intersindicais de Conciliação Trabalhista. Estudo de Caso - a questão trabalhista regional e os resultados da instituição matricial de Patrocínio - MG (1994-2006). 2007.

2v. 907p. Doutorado. UNIVERSIDADE FEDERAL DE MINAS GERAIS - DIREITO / http://servicos.capes.gov.br/capesdw/resumo.html?idtese=20072032001010027P6

VAZ, G.N. Marketing institucional: o mercado de idéias e imagens. São Paulo: Pioneira, 1995.

VENTURA, E C.F.; VIEIRA, M M.F. Responsabilidade Social como Deslocamento do Capitalismo: Evidências de um Estudo nos Bancos no Brasil. Anais ENAMPAD 2006.

VENTURA, E.C.F. Dinâmica de Institucionalização de Práticas Sociais: Estudo da Responsabilidade Social no Campo das Organizações Bancárias. 2005. 1v. 351p. Doutorado. Fundação Getúlio Vargas/RJ - Administração

http://servicos.capes.gov.br/capesdw/resumo.html?idtese=200539631011012004P5

Acesso em 9 de Fev. de 2009

VIANA, M.J.F. Assistência social no contexto do pluralismo de bem-estar: prevalência da proteção social plural ou mista, porém não pública, 2007. 1v. 357p. Doutorado. UNIVERSIDADE DE BRASÍLIA - POLÍTICA SOCIAL

http://servicos.capes.gov.br/capesdw/resumo.html?idtese=2007853001010035P1 acesso 9/fev/2009

VIEIRA, L. Notas sobre o conceito de cidadania. BIB. São Paulo, $n^{\circ} 51,1^{\circ}$ semestre 2001 , p. 35-47.

ZACARIAS, R. B. PRODUTO SOLIDÁRIO: O TERCEIRO SETOR NA PROPAGANDA BRASILEIRA, 2004. 1(212): Tese de Doutorado. Univerisdade Metodista de São Paulo - Comunicação Social.

http://servicos.capes.gov.br/capesdw/resumo.html?idtese=200439833017018004P9

Acesso em 9 de fev. de 2009.

ZIZEK, S. Como Marx inventou o sintoma. In: ZIZEK, S. (Org.) Um mapa da ideologia. Rio de Janeiro: Contraponto, 1996. p.297-331

ZAMMOURI; H. Sociographie de la brigada anti pub LOGOS 29 Tecnologias e Socialidades. Ano 16, $2^{\circ}$ semestre 2008.

http://www.logos.uerj.br/PDFS/29/12HEDIZAMMOURI.pdf

Acesso em 7 de Fev. de 2009

WACQUANT, L. O lugar da prisao na nova administração da pobreza. Tradução: Paula Miraglia e Hélio de Mello Filho. ESTUDOS CEBRAP, 2008.

WALDMAN, D. A. at al, Cultural and leadership predictors of corporate social responsibility values of top management: a GLOBE study of 15 countries Journal of International Business Studies JIBS (2006) 37, 823-837 www.jibs.net

WALTER, L.F.C. Angola: O Papel e Contributo do Sector dos Petróleos de Angola no Desenvolvimento Sócio-Económico do País. Desafios e Expectativas (1975 - 2005). Lisboa: ISCTE, 2008. Dissertação de Mestrado. 
http://loki.iscte.pt:8080/dspace/handle/10071/656

WANDERLEY, L. (2005) Corporate Social Responsibility in Brazil: Actions and Perceptions in Large Corporations. Tese de Doutorado, Universidade de Cambridge, 2005

WANDERLEY, L.S.O. et ali. CSR Information Disclosure on the Web: A Context-Based Approach Analysing the Influence of Country of Origin and Industry Sector, Lilian Soares Outtes Wanderley, Rafael Lucian , Francisca Farache and José Milton de Sousa Filho, Journal of Business Ethics - Volume 82, Number 2 / October, 2008.

http://www.springerlink.com/content/ag18460r71224771/

WELZEL, E.; LUNA, M.M.M.; BONIN. M.A.S. Modelo da Dinâmica Interdisciplinar de Responsabilidade Social Corporativa: Contribuições Conceituais e Delimitação Teórica, XXXII ENANPAD - Rio de Janeiro, 6 a 10 de setembro de 2008. CD de anais

WOLF, M. Teorias da Comunicação. Lisboa: Editorial Presença, 2001 


\title{
APÊNDICE
}

\section{RESPONSABILIDADE SOCIAL DAS EMPRESAS: FORMAÇÕES DISCURSIVAS EM CONFRONTO}

\begin{abstract}
Tese apresentada ao Programa de Pós-Graduação em Ciências da Comunicação, Área de Concentração Interfaces Sociais da Comunicação, Linha de Pesquisa Políticas e Estratégias de Comunicação, da Escola de Comunicações e Artes, da Universidade de São Paulo, como exigência para obtenção do Título de Doutor em Comunicação, sob a orientação do Prof. Dr. Ivan Santo Barbosa.
\end{abstract}

São Paulo

Abril de 2009 


\section{REVISÃO DA LITERATURA}

\section{BUSCA PROGRAMAS DE PÓS-GRADUAÇÃO EM COMUNICAÇÃO}

Programas que tiveram seus sites consultados, com busca em teses, dissertações, periódicos e outras publicações:

1. UFBA (teses e dissertações 2004-2009)

2. UNB (teses e dissertações 2004-2009)

3. UFG

4. UFJF - início em 2007 / Revista Lumina (2002-2008)

5. PUCMG

6. UFPE - Revista Lâmina

7. UTP - Revista Interim desde 2002

8. UFRJ - dissertações e teses, publicações Livros 2004-2008

9. UFF - 2000-2008

10. UERJ - Revista Contemporânea (2006-2008); Revista Logos (2000-2008)

11. PUCRJ - busca geral

12. UFSM - Revista Animus (2005-2007)/ Cadernos de Comunicação (sem acesso)/ Teses e Dissert. não

13. UNISINOS - Teses e dissertações 2005-2007 / Revista Fronteiras 2004-2008/ Revista Verso e Reverso

14. UFRGS - Banco geral de teses (todas)

15. UNISO

16. ANHEMBI MORUMBI

17. ESPM

18. METODISTA / Revista Comunicação e Sociedade (números disponíveis online)/ Teses e dissertações (2008-2004)

19. PUCSP - Teses e dissertações 2006-2008

20. UNESP Bauru - Dissertações / Revista Comunicação Midiática (sem acesso conteúdo)

21. CASPER LÍBERO - Dissertações / Revista Líbero (2001-2008)

22. UNIP - Dissertações 2002-2008

23. UNICAMP - Multimeios

24. ECA-USP - Teses e dissertações 1989-2008 
PERIÓDICOS consultados por meio do Portcom - Portal de livre acesso à produção em ciências da comunicação da Sociedade Brasileira de Estudos Interdisciplinares da Comunicação (Intercom) - http://revcom.portcom.intercom.org.br

1. Acervo On-line de Mídia Regional - Núcleo de Pesquisa e Estudos em Comunicação da Universidade de Taubaté (NUPEC).

2. Comunicação \& Educação - Curso de Gestão da Comunicação, Escola de Comunicações e Artes (ECA-USP).

3. Comunicação \& Sociedade - Programa de Pós-Graduação em Comunicação Social da Universidade Metodista de São Paulo (Umesp).

4. Comunicação Mídia e Consumo - Programa de Pós-Graduação em Comunicação e Práticas do Consumo da Escola Superior de Propaganda e Marketing (ESPM).

5. Comunicação e Sociedade - Inst. de C. Sociais da Universidade do Minho, Portugal.

6. Contemporanea - Journal of Communication and Culture - Programa de PósGraduação em Comunicação e Cultura da Universidade Federal da Bahia (UFBA).

7. Contracampo - Programa de Pós-Graduação em Comunicação da Universidade Federal Fluminense (UFF).

8. Em Questão - Faculdade de Biblioteconomia e Comunicação da Universidade Federal do Rio Grande do Sul (UFRGS).

9. Famecos: Mídia, Cultura e Tecnologia - Programa de Pós-Graduação em Comunicação Social da Faculdade de Comunicação Social da Pontifícia Universidade Católica do Rio Grande do Sul (PUC-RS).

10. Fronteiras, Estudos Midiáticos - Programa de Pós-Graduação em Ciências da Comunicação da Universidade do Vale do Rio dos Sinos (Unisinos).

11. Iniciacom - Revista Brasileira de Iniciação Científica em Comunicação - (Intercom).

12. Inovcom - Revista Brasileira de Inovação Científica em Comunicação - (Intercom).

13. Intercom - Revista Brasileira de Ciências da Comunicação - (Intercom).

14. Líbero - Revista do Programa de Pós-Graduação da Faculdade Cásper Líbero (Facasper).

15. MATRIZes - Revista do Programa de Pós-Graduação em Ciências da Comunicação da Universidade de São Paulo (USP).

16. Media \& Jornalismo - Centro de Investigação Media e Jornalismo (CIMJ), Portugal.

17. Revista NAU - Rev. do Núcleo de Pesquisa em Comunicação Audiovisual (Intercom).

18. Observatorio (OBS*) - Observatório da Comunicação (OberCom).

19. Rebej - Revista Brasileira de Ensino de Jornalismo - Fórum Nacional de Professores de Jornalismo (FNPJ) 


\begin{tabular}{|c|c|}
\hline PERIÓDICOS CIENTÍFICOS (online - Bases de dados ESPM) & FORMATO \\
\hline Academic Journals & Bases \\
\hline Academy of Management Executive & Bases \\
\hline Academy of Management Journal & Bases \\
\hline Academy of Management Learning \& Education & Bases \\
\hline Academy of Management Perspectives & Bases \\
\hline Academy of Management Proceedings & Bases \\
\hline Academy of Management Review, The & Bases \\
\hline Accountancy & Bases \\
\hline Advertising Age & Bases \\
\hline Advertising Age's Business Marketing & Bases \\
\hline B to $\mathrm{B}$ & Bases \\
\hline Bank Management & Bases \\
\hline Bank Marketing & Bases \\
\hline BC Business & Bases \\
\hline Behavior Matters: Communication Research on a Human Connections & Bases \\
\hline Brand Packaging & Bases \\
\hline Brand Strategy & Bases \\
\hline Cognitive linguistics & Bases \\
\hline Commercial Services e Supplies Industry Profile... & Bases \\
\hline Communication Arts & Bases \\
\hline Communication Booknotes Quarterly online & Bases \\
\hline Communication Reports & Bases \\
\hline Communication Research & Bases \\
\hline Communication Review & Bases \\
\hline Communication World online & Bases \\
\hline Communications News & Bases \\
\hline Consumer Reports (with a 3 Month delay) & Bases \\
\hline Country Reports & Bases \\
\hline Design Management Review & Bases \\
\hline Design News & Bases \\
\hline Design Week & Bases \\
\hline Economic Issues online & Bases \\
\hline Industry Profiles & Bases \\
\hline International Journal of Management online & Bases \\
\hline International Journal of Market Research online & Bases \\
\hline Journal for Global Business Education & Bases \\
\hline Journal of Advertising & Bases \\
\hline Journal of Advertising Research & Bases \\
\hline Journal of Applied Economics & Bases \\
\hline Journal of Brand Management (with a 4 Month delay) & Bases \\
\hline Journal of Business \& Economic Studies & Bases \\
\hline Journal of Business Communication & Bases \\
\hline Journal of Business Economics \& Management & Bases \\
\hline Journal of Business Ethics & Bases \\
\hline
\end{tabular}




\begin{tabular}{|c|c|}
\hline Journal of Business Logistics & Bases \\
\hline Journal of Business Research (citação) & Bases \\
\hline Journal of Business Strategies & Bases \\
\hline Journal of Business-to-Business Marketing (citação) & Bases \\
\hline Journal of Communication & Bases \\
\hline Journal of Communication Management & Bases \\
\hline Journal of Consumer Behaviour (citação) & Bases \\
\hline Journal of Consumer Marketing (citação) & Bases \\
\hline Journal of Consumer Policy & Bases \\
\hline Journal of Consumer Studies \& Home Economics & Bases \\
\hline Journal of Database Marketing & Bases \\
\hline Journal of Database Marketing \& Customer Strategy & Bases \\
\hline Journal of Economic Issues & Bases \\
\hline Journal of Intercultural Communication Research online & Bases \\
\hline Journal of International Business Studies & Bases \\
\hline Journal of Management Studies & Bases \\
\hline Journal for Quality \& Participation & Bases \\
\hline Journal of Research for Consumers & Bases \\
\hline Journal for Advancement of Marketing Education & Bases \\
\hline Journal for Global Business Education & Bases \\
\hline Magazines & Bases \\
\hline Management (with a 4 month delay) & Bases \\
\hline Market Research Reports & Bases \\
\hline Marketing & Bases \\
\hline Marketing Education Review & Bases \\
\hline Marketing Management & Bases \\
\hline Marketing Management Journal & Bases \\
\hline Marketing Research & Bases \\
\hline Marketing Theory & Bases \\
\hline Marketing Week (01419285) & Bases \\
\hline Newspapers & Bases \\
\hline Product Reviews & Bases \\
\hline Public Opinion Quartely & Bases \\
\hline Publishers Weekly & Bases \\
\hline Recherche et Aplications en Marketing online & Bases \\
\hline Retail Merchandiser & Bases \\
\hline Retailing Today & Bases \\
\hline Trade Publications & Bases \\
\hline
\end{tabular}

\section{Coleta de matérias (Clipping ESPM)}

Veículos de consulta diária Nacionais: O Estado de S. Paulo; Folha de S. Paulo; DCI; Jornal do Commercio; Gazeta Mercantil; Valor Econômico; Jornal do Brasil; O Globo / Estrangeiros: The New Tork Times; International Herald Tribune; Financial Times; Le Monde; Le Figaro; El Pais; Clarin; Expansión; La Nación; El Mundo

Publicações semanais e quinzenais Carta Capital, Business Week, Época; IstoÉ; IstoÉ Dinheiro; Meio \& Mensagem; Veja; Exame; entre outras.

Publicações mensais About, Administrador Profissional, Consumidor Moderno, Época Negócios; Harvard Business Review; Marketing; Propaganda; Razão Social; Você S.A. entre outras 
BALANÇOS SOCIAIS 2006 / 2007

\section{BALANÇOS SOCIAIS - ESTRUTURAS COMPARADAS}

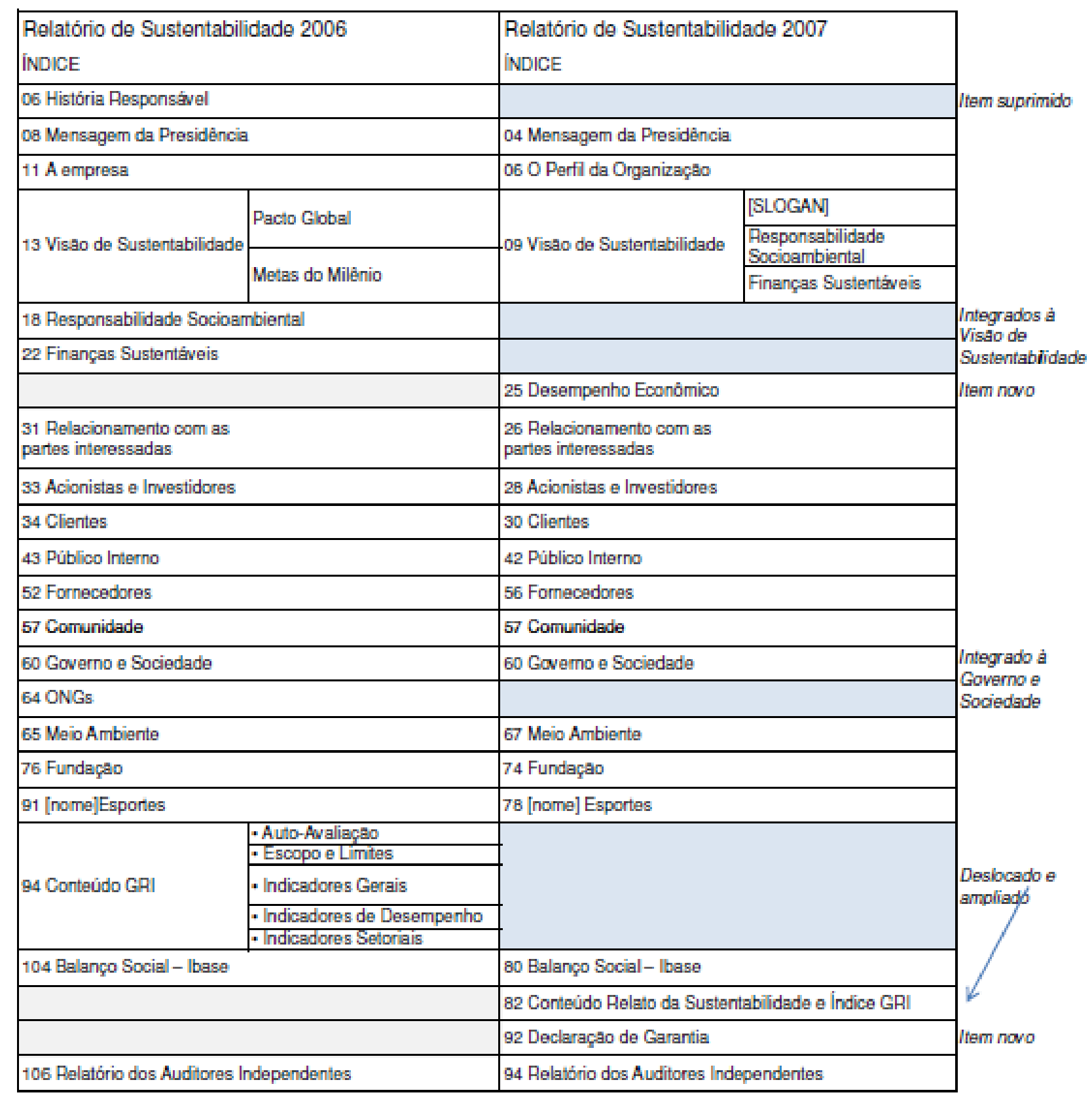




\section{APÊNDICE 4 \\ ENTREVISTAS}

MENSAGEM E QUESTIONÁRIO PRELIMINAR (e-mail)

\section{Prezado (a)}

Tomo a liberdade de contatá-lo a partir de indicação da professora

Realizo pesquisa de Doutorado em Comunicação na ECA-USP sobre o discurso da responsabilidade social empresarial. A metodologia de coleta de dados envolve levantamento bibliográfico e documental, aplicação de questionário e entrevistas com profissionais ligados a projetos de responsabilidade social.

Gostaria de consultá-lo(a) sobre a possibilidade de realizar uma entrevista, com duração aproximada de uma hora, em data, horário e local de sua conveniência,.

Seguem, preliminarmente, um breve questionário (abaixo) para o delineamento da trajetória acadêmica e profissional e um Termo de Consentimento (anexo) com informações sobre a pesquisa e sobre os cuidados que serão tomados.

Agradeço a atenção e fico no aguardo sobre a possível realização da entrevista. Em caso positivo, peço a gentileza do envio do questionário preenchido e de opções de data/horário e local mais convenientes. O termo será assinado na data da realização da entrevista.

Grato pela atenção,

Ricardo Zagallo Camargo

Questionário preliminar

\begin{tabular}{|l|l|l|l|}
\hline Nome & \multicolumn{3}{|l|}{} \\
\hline Sexo & $($ ) $\mathrm{F} \quad(\quad) \mathrm{M}$ & Idade & \\
\hline
\end{tabular}

\begin{tabular}{|l|c|c|}
\hline \multicolumn{3}{|c|}{ Formação Profissional - Graduação } \\
\hline Curso & Instituição de Ensino & Ano de \\
& & conclusão \\
\hline
\end{tabular}




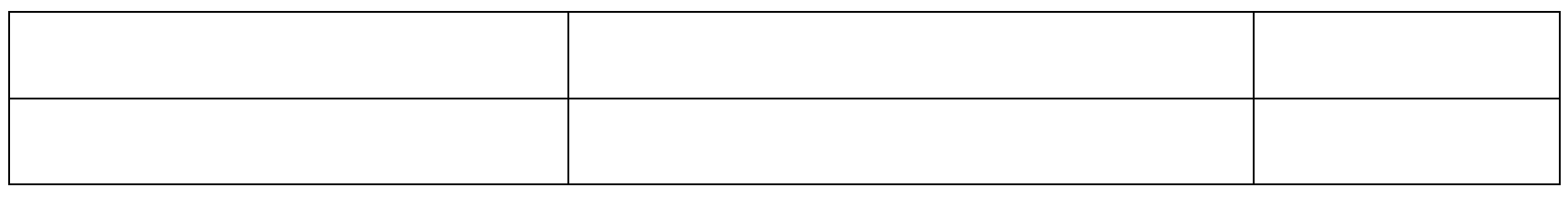

\begin{tabular}{|l|c|c|}
\hline \multicolumn{3}{|c|}{ Formação Profissional - Pós-Graduação } \\
\hline Curso & Instituição de Ensino & Ano de \\
& & conclusão \\
\hline & & \\
\hline & & \\
\hline
\end{tabular}

\begin{tabular}{|c|c|c|c|c|c|}
\hline \multicolumn{6}{|c|}{ Trajetória Profissional } \\
\hline \multicolumn{2}{|c|}{ Período } & \multirow[t]{2}{*}{ Empresa } & \multirow[t]{2}{*}{ Função } & \multicolumn{2}{|c|}{$\begin{array}{l}\text { Envolvimento } \\
\text { com } \\
\text { responsabilidade } \\
\text { social }\end{array}$} \\
\hline 串 & 具 & & & $\sum_{\omega}$ & $\stackrel{0}{Z}$ \\
\hline & & & & & \\
\hline & & & & & \\
\hline & & & & & \\
\hline & & & & & \\
\hline & & & & & \\
\hline
\end{tabular}

Outras informações preliminares que julgar necessárias e importantes 


\section{Termo de Consentimento Livre e Esclarecido}

Esta pesquisa de Doutorado em Ciências da Comunicação, em realização na Área de Concentração Interfaces sociais da comunicação do Programa de Pós-Graduação da ECA-USP, tem como título Responsabilidade Social das Empresas: configuração do campo discursivo, tensões e reverberações.

Seu objetivo é caracterizar e compreender o conjunto dos discursos acerca da responsabilidade social empresarial, contextualizando as questões levantadas no campo da comunicação.

A metodologia de coleta de dados envolve levantamento bibliográfico e documental, aplicação de questionário e entrevista.

$\mathrm{Na}$ pesquisa de campo os colaboradores serão profissionais com envolvimento na elaboração e execução de projetos de responsabilidade social no âmbito das empresas.

Inicialmente será encaminhado um breve questionário, via internet, para o delineamento da trajetória acadêmica e profissional. No segundo momento serão realizadas entrevistas com base em um roteiro previamente definido.

Será garantido o direito ao anonimato, ou seja, a não identificação dos entrevistados e das empresas nas quais atuam ou atuaram; assim como o sigilo de determinadas informações quando solicitado pelo colaborador. Destaca-se que o estudo não se presta a fazer comparações entre projetos empresarias, mas avançar na compreensão do discurso acerca da responsabilidade social.

O acesso às informações da pesquisa para esclarecimento ou revisão de informações, seja ao longo de seu processo ou no momento final, é um direito do colaborador. Há qualquer momento da pesquisa o colaborador pode desistir de sua participação sem seja necessário apresentar qualquer justificativa.

Trata-se de uma pesquisa que não oferece nenhum risco de vida ao participante da pesquisa.

Após estes esclarecimentos posso afirmar que estou ciente de quais as condições de participação na pesquisa, assim concordo voluntariamente em participar da mesma.

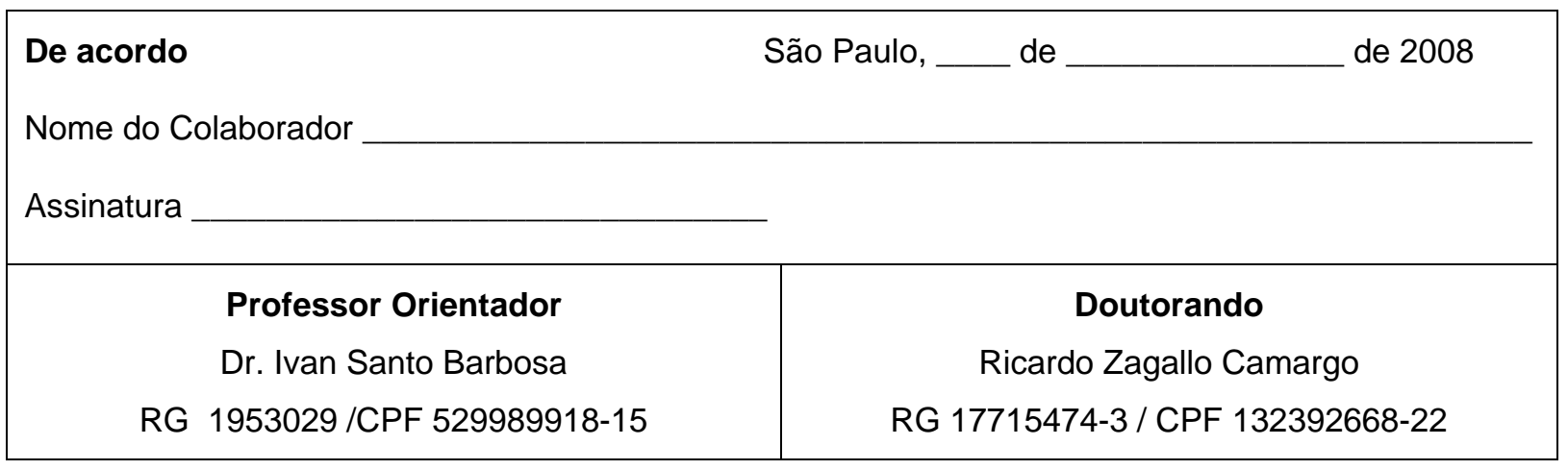




\section{ROTEIRO PARA ENTREVISTA (semi-estruturada)}

Apresentação da pesquisa: discurso das empresas.

Não é uma avaliação das ações da empresa nem do engajamento social do entrevistado.

Não haverá identificação da empresa e do entrevistado.

Objetivo: apontar limites da ação da empresa. O que podemos e não podemos esperar.

Conceito

- O que a empresa/você compreende por responsabilidade social empresarial?

Qual o papel da empresa no que tange a responsabilidade social

- O que significam/para que servem as ações de RSC para a empresa?

- Responsabilidade social, sócio-ambiental e Sustentabilidade: como você vê esses conceitos?

- Como a noção de RSC chega até o âmbito dos funcionários?

\section{Estrutura}

- De que forma entraram na pauta da empresa?

- Como a empresa tem se estruturado para cuidar da RS?

- Como a responsabilidade social faz parte da empresa (origem, posição no organograma, pessoas envolvidas, ações transversais)? Há departamento próprio? A qual setor está ligada?

- O setor (de RSC) tem quanto tempo? O que mudou? Como é hoje, como era antes?

Ações

- Quais ações você destacaria, por quê?

- Ações internas (voltadas para os funcionários) Aplica-se a terceirização?/ externas?

- Ações externas - quais? Descrição das ações propostas

- Como se dá a definição ou seleção/escolha de temas/projetos para realização das ações? Como são pensadas?

- Quais os critérios para decidir como a verba será investida?

- Como são realizadas? Citar casos concretos Como as ações são desenvolvidas (concepção, estruturação, etapas, objetivos, controles) - o entrevistado pode focar um projeto específico ou as destacar ações da empresa que julgar mais relevantes

- Que momentos/situações/depoimentos chamaram a atenção nas ações desenvolvidas.

- Quais resultados gostaria de destacar?

- Quais as perspectivas/projetos para o futuro na sua opinião?

Comunicação

- Como são comunicadas para diferentes públicos?

- Balanço social e relatório anual. Juntos ou separados? Desde quando? Outras considerações 
CLIPPING

MATÉRIAS JORNALÍSTICAS

\author{
$2006 / 2007$
}




\section{FRAGMENTOS ARTIGOS 2006}

10 Lado Social das Empresas (site clientes SA)

Pesquisa IRES (Instituto ADVB de RS) - VIII Pesquisa Nacional sobre RS - dados 2006 / 3.110 empresas (prova/ legitimação) aumento do valor investido (ínfimo em termos gerais / 62\% de novos programas; $42 \%$ aumentar recursos para o já feito)

Não "evoluiram" na propagação. 71\% não publicam balanço social.

Segundo Livio Giosa, diretor do Insituto ADVB de RS (IRES) "com os resultados desta pesquisa percebemos que, afinal, as empresas estão, de forma construtiva, passo a passo, fazendo a sua parte. Que estas atitudes

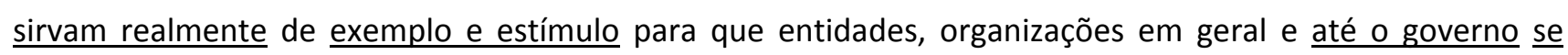
$\underline{\text { apercebam }}$ de uma vez por todas, que somente depende de cada um dar o passo certo e rápido para o resgate social do nosso país.

(texto síntese?)

20 Balanço Social é Pop (Paulo Nassar / ABERJE/ ver negócios da comunicação)

É necessário que a alta direção esteja disposta a praticar o que fala. Afinal, nada mais patético do que um presidente de empresa a pregar verdades aos quatro ventos, que os jornais, incautos, publicam, a na prática, no dia-a-dia, fazer tudo diferente. Nada pior do que a empresa se valer do discurso sempre muito bonito de responsabilidade social para vender, por meio da comunicação, uma imagem cidadã ao consumidor.

(...)

Nada mais descabido do que investir um monte de dinheiro para ajudar as criancinhas do orfanato e nada fazer para seus próprios empregados. Ou adotar o discurso fácil do socialmente responsável e não cumprir obrigações comerciais com consumidores e fornecedores, fiscais com o Estado, e trabalhistas com os empregados.

(...)

Muitas vezes, por conta das incompetências do Estado Brasileiro, surge um vazio no âmbito público, que pode ser, eventualmente, ocupado por uma empresa, que se apressará em fincar ali seu logotipo. Mas não se pode, sob nenhum pretexto, desqualificar o papel do estado nem permitir que ele intervenha nas atividades de natureza privada, além dos limites aceitáveis e legais.

(...)

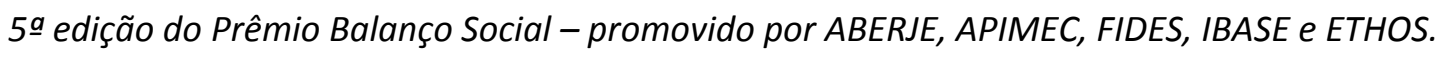

(...) 
Nessa perspectiva, a publicação do balanço social, concebido dentro de parâmetros preestabelecidos, é um avanço da organização rumo a um relacionamento mais transparente com seus públicos de interesse particular, e com o Brasil em geral.

3 Novos rumos para relatórios corporativos (Carta Capital)

Mais de 5 mil empresas no mundo já elaboram. Não há único modelo

José Antonio Puppim de Oliveira FGV/RJ - avaliou balanços sociais das 500 maiores não financeiras listadas pela FGV em dois biênios 2001-2002 / 2003-2004.

2003/04 - 58 entre as 100 apresentaram o documento / 14,5\% nas derradeiras

Primeiro no mundo, segundo Ethos, Singer em 1972

Para alguns especialistas, são uma ferramenta de gestão dos públicos de interesse, os stakeholders, que servem tanto para aprofundar a responsabilidade social corporativa como para consolidar o desenvolvimento sustentável, aquele que prega ganhos econômicos com cuidados ambientais e justiça social. Mas muitas vezes não passam de "marketing verde".

(...)

Na comparação temporal, Puppim diz que o avanço mais evidente está na divulgação pela internet, hoje quase unanimidade. Mas continua a tendência de priorizar o que é favorável. "Se a empresa deu prejuízo, isso aparece no balanço financeiro. No social, raramente ressaltam-se problemas ou críticas dos stakeholders"

Entre as distorções, ele cita que alguns relatórios descrevem projetos governamentais como benefícios da empresa para a comunidade. Foi o que fizeram várias companhias de energia, ao mencionarem o Programa Luz no Campo, diz. "Perde-se a credibilidade, quando o balanço vira instrumento de propaganda". (como se pudesse não ser)

(...)

(...) quando o balanço social começa a incluir elementos quantitativos, é auditado e traz objetivos a médio prazo, torna-se ferramenta de comunicação com mercado indicador de perenidade da empresa.

(...) "Muitas vezes, as companhias dizem que respeitam o fornecedor, sem uma política de apoio aos pequenos; falam da comunidade, mas não tem um diálogo estabelecido", critica. (Alberto Perazzo presidente FIDES)

(...)

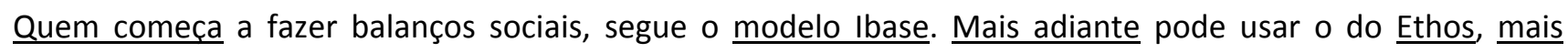
complexo. Mas, se quiser comparabilidade internacional, adotará o padrão GRI, do Global Reporting 
Initiative, ONG criada na Holanda em 1997 por uma coalizão de organizações dispostas a desenvolver diretrizes para equiparar relatórios de sustentabilidade aos balanços financeiros, reconhece Glaucia Terreo, coordenadora de programa no Ethos.

Deslocamento no sentido dos dados financeiros para comparabilidade é colocado como aumento da complexidade e/ou evolução. Dados comparáveis são mais valiosos para o mercado (e para a academia).

Nelmara Arbex - diretora de serviços de aprendizagem do GRI

Quem lê os balanços sociais:

1- Formadores de opinião da própria empresa, como diretores e profissionais de comunicação

2- Investidores com interesse na performance da empresa a longo prazo

3- Agências governamentais e jornalistas começam a crescer como público

Para $G$ do Ethos, um dos desafios é preparar organizações da sociedade civil para que leiam esses documentos. "Como adaptar o balanço para que uma comunidade tradicional, fornecedora de insumos da Natura, entenda a linguagem" exemplifica. Mais que isso, ela e $\mathrm{N}$ defendem que, em nome da transparência, ONGs e órgãos públicos tenham seus próprios relatórios de sustentabilidade.

Em nome da revelação da opacidade e parcialidade de todos os relatórios.

$\mathrm{Na}$ "harmonização de padrões"

"Há um desequilíbrio, pois indústrias e consultores têm mais força do que ONGs e sociedade civil" rebate Lisa Gunn, do Idec.

4 Ética, ao menos para obter a lealdade do cliente (Guilherme Bova, designer) artigo de opinião

Portanto, é certo que as empresas privadas devem tomar iniciativa e estabelecer códigos de ética entre seus funcionários e clientes, pois este é o primeiro passo (se não o mais fundamental) para uma empresa dizer-se responsável socialmente. Porém, antes disso é preciso repensar como os profissionais são educados até o momento em que ocupam seus cargos nas empresas.

(cita a seguir, Paulo Freire)

50 Desafio é ser responsável

Beatriz Marques Dias / entrevista com executivos da Ambev/ dados da empresa

Depoimento de coordenador de projetos especiais do Ministério dos Transportes

Há no final uma "ficha de avaliação da EXAME

Fracasso em tentativa de colocar a Ambev na lista do ISE/Bovespa em 2005

A empresa ficou fora do ISE por estar num setor polêmico e ter um produto condenado por alguns segmentos da sociedade. Provar que, mesmo nesse contexto, é possível ter uma atuação responsável tem sido um desafio e tanto para a Ambev.

$(\ldots)$ 
Além do cuidado com o meio ambiente, a Ambev preocupa-se também com o pagamento das obrigações

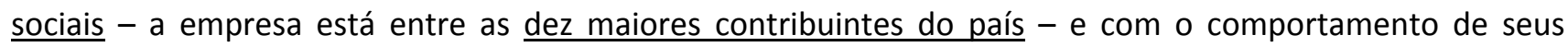
consumidores.

"Reconhecemos que o consumo inapropriado de bebidas alcoólicas gera problemas e, por isso mesmo, temos nos empenhado em fazer a nossa parte". diz MS, diretor de relações corporativas da Ambev.

6 Responsabilidade Social corporativa (RSC): a prática para o bem de todos

(Maricy de A. Queiroz Banas)

\section{$(\ldots)$}

As empresas começam a desenvolver programas e gestões de responsabilidade social corporativa que visam uma atuação mais ativa na comunidade com a qual se relacionam e também com seus funcionárioscolaboradores. A prática do bem-comum começa, portanto, "em casa".

(...)

“(...) um processo onde, idealmente, todos os envolvidos ganham: empresas, investidores, público interno, fornecedores, clientes, comunidades e sociedade em geral. A sua importância, se pudermos sintetizar, é o fato de que representa a procura de soluções a um modelo cujos problemas, do ponto de vista social e ambiental, são bastante sérios. Mas também que trazem ganhos importantes às organizações que a adotam, em vários aspectos". (consultor de sustentabilidade)

(...)

Sintetizando, podemos dizer que a abrangência da atuação das empresas mudou e a RSC se tornou estratégica para elas. Além de contribuir para o desenvolvimento social e econômico da população menos favorecida e a preservação dos recursos naturais, a RSC estabelece com os diversos públicos da empresa uma comunicação e relacionamento diferenciado desta forma a alterar a percepção de consumidores, fornecedores e demais atores, e agregando novos valores às corporações e suas marcas. (consultor de sustentabilidade)

7 Especialistas defendem conceito como missão de IES. Saiba porquê.

Lilian Burgardt (Universia - RS - Gestão)/ fala de consultor voltado para IES/ caso Ibmec e Sumaré (com cliques para saber mais sobre "história de sucesso")

Falar em responsabilidade social está na moda.

(...)

Mostrar para a sociedade o quanto a instituição tem apostado na responsabilidade social dando exemplos reais é o que faz a diferença na hora de ser considerada engajada ou não a esta idéia. E mais: é o que demonstra o quão à frente ela está da concorrência. "Sem dúvida, a responsabilidade social é um diferencial competitivo" afirma o gerente de Marketing da CM News consultoria, RFB. 
8 Ética e responsabilidade Social (Marina Terra - Idéia Social)

Retranca "Réplicas"

Entrevista com Henri-Claude de Bettignies, professor de Liderança de Responsabilidade Global na China Europe International Business School

Leia, a seguir, as suas principais idéias.

Pássaros também são stakeholders

A primeira reação dos empresários é achar que o bem-comum é responsabilidade dos Governos e das Ongs.

E não das empresas. Para substituir esse pensamento, deve-se apresentar o bem-comum aos líderes de negócios como uma estratégia. Gradativamente a sociedade tem exigido uma mudança de comportamento das empresas. Aquelas que destroem o meio ambiente, pagam propina, exploram crianças ou o trabalho escravo e que não dizem a verdade em sua propaganda, serão eliminadas da preferência do consumidor.

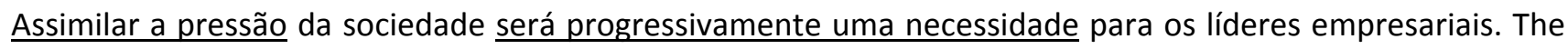
conquest of the cool

\section{(...)}

Lucros agora versus benefícios ambientais amanhã

(...) Comportar-se eticamente é muito mais custoso. Alguns pensam que não serão pegos. Outros confiam que, se não se safarem, ainda poderão subornar um fiscal. Muitos culparão a competitividade. E dirão que ela exige trilhar caminhos mais curtos, pois se produz mais dinheiro e também porque, afinal de contas, todos fazem isso. (...) A cultura de um país impacta profundamente no comportamento dos empresários. Mudar as práticas empresariais é algo muito complexo. Mas urgente e necessário.

Desafios da RSE entre as empresas na China

O modo como a RSE é tratada difere conforme o tipo de companhia. As empresas administradas pelo Estado tem um longo caminho a trilhar no que se refere à implementação de políticas ligadas ao campo social, porque se moldaram num sistema não compatível com as dimensões RSE. No entanto, elas sabem que precisam se tornar socialmente responsáveis.

Evidência - esforço para realizar o que já sabem que devem fazer

90 avanço da filantropia alavancado pela Dupla Gates - Buffett (Revista Qualimetria)

Retranca "Filantropia" (sem assinatura?)

Diz Steve Ballmer: (...) ele soube lucrar com o produto [software], tenho plena convicção que o mundo vai ganhar o maior filantropo de todos os tempos.

(...)

Declarou Warren Buffet: "Sei o que quero fazer e faz todo sentido prosseguir. Acabei percebendo que existe uma Fundação fantástica - a de Melinda e Bill Gates - que poderia usar meu dinheiro de uma maneira 
produtiva. Eles já se comprometeram com algumas questões extraordinariamente importantes para o mundo e, se Ihes estavam faltando recursos, estou colocando à disposição. Agora Melinda e Bill Gates podem obter mais sucesso ainda na luta no mundo pela redução da pobreza, do acesso à tecnologia em países pobres, no financiamento de projetos na área de saúde e na melhoria da educação nos EUA.

10 Muito Além da Boa Vontade

Luiz Mora - Revista Negócios da Comunicação / Depoimentos Ethos/ jornalistas/ profissionais de comunicação

\section{(...)}

A mídia deveria refletir esse fenômeno da vida real, mas está falhando, segundo a reclamação dos próprios envolvidos na propagação dessas novas práticas entre as empresas.

Na maioria das abordagens, falta ainda o entendimento de que responsabilidade social é muito mais que benemerência e investimentos no terceiro setor, dizem os críticos.

Cita pesquisa Ethos, que detecta falta de "domínio do conceito da RSE" e "visão crítica sobre a real efetividade de ações divulgadas".

\section{(...)}

"No mundo dos negócios, o termo acabou deturpado e desgastado. Mas acredito que a confusão tende a se dissipar", diz ela. (CV, Diretora de redação de E, que publica Guia de Boa Cidadania)

Uma atividade que valoriza as empresas (Box)

(...) Diante da grande mobilização da sociedade civil contra os efeitos desta nova realidade [globalização e liberalização da economia], com grupos organizados, como as organizações não governamentais (ONGs), as corporações viram-se obrigadas a adotar políticas voltadas para o controle do impacto ambiental e contra as desigualdades sociais.

FD política/social "enquadrada" como pressão/fiscal do caminho que a "nova realidade" obriga as empresas a seguir.

\section{(...)}

O comportamento perante a sociedade tornou-se tão importante no mundo empresarial que o mercado de ações já adota índices que atestam aos acionistas a capacidade das empresas de incorporar elementos ambientais e sociais a sua gestão.

\section{(...)}

Ele diz que a mera divulgação desses dados já constitui uma ação de responsabilidade social, pois é dever das empresas expor-se publicamente, da forma mais transparente possível. (responsável pela comunicação da Odebrecht!!!!!!!!!!)

A questão posta é divulgar (ou não) dados "reais". 
(...)

A responsabilidade social é um dos novos segmentos de conteúdos na mídia com maior potencial de crescimento.

Cadernos e suplementos sobre o assunto com bons resultados comerciais e de público.

Empresa\&Comunidade - Valor Econômico (desde sua fundação em 1999?)

Prêmio Valor Social (com Ethos)

Guia de Boa Cidadania Corporativa - Exame Abril desde 2000

Razão Social - O Globo desde 2003

TV Cultura - Balanço Social - desde 2005

Revista mensal do Centro de Estudos em Sustentabilidade da FGV, desde 2005

(apoio Odebrecht e Banco Real)

(...)

“Nos Estados Unidos para cada dólar investido em um projeto de responsabilidade social, outro dólar vai para a mídia" diz RG, diretor de assuntos corporativos e relações governamentais da N.

Implícito que isso é correto. Efeito interessante se substituirmos Estados Unidos por Venezuela, por exemplo. (...)

Apesar de utilizar verbas publicitárias para divulger ações da N na área social, RG defende a idéia de evitar a "dispersão de recursos que podem ser usados para alavancar ainda mais as ações sociais". Nesse sentido, ele prefere dar ênfase à comunicação de responsabilidade social por meio da área de relações públicas para atingir a mídia especializada, entidades de classe e governo.

Outra empresa que aposta na mídia espontânea como meio de divulgar seus feitos na área social é o BI.

Por que negar? (pergunta de tese sobre Natura e educação) Porque a negação é constitutiva desse discurso.

Tratamento de pesquisadores/ Entrevista não ocorreu.

Movimento entre agências

Grupo Ypy - Africa, DM9DDB, MPM, Loducca, Eugênio e Tudo criou diretoria de RS

Grupo Full Jazz - unidade The Key - desde 1999

11 A mais querida (Revista da Indústria)

Premiada em 1ㅇ lugar. A mais admirada - Carta Capital; Melhor para a mulher trabalhar (Exame); destaque Prêmio B. Social; prêmio FIESP de Mérito Ambiental

(...)

"Além de lançar bons produtos, queremos participar da construção do País e da cidadania", diz RG, diretor de assuntos corporativos da N.

(...) 
Mas talvez o grande diferencial da $\mathrm{N}$ esteja no modo como a empresa se relaciona com seus consumidores. Além de bem variados e sempre renovados, seus produtos são, em grande parte, vendidos diretamente por consultoras especializadas (hoje elas são mais de 500 mil em todo o País).

Consumo, produtos, distribuição (cadeia produtiva) - calcanhares: direitos das comunidades locais e cadeia reversa.

\section{Lição começa em casa}

(Christye Cantero - revista Consumidor Moderno)

Subtítulo: A fundação Ponto Frio nasceu para oferecer melhor qualidade de vida aos colaboradores.

(...) referindo-se ao fundador da empresa

“ Monteverde foi de uma visão fantástica porque naquela época ele imaginou uma instituição voltada para a responsabilidade social que começa dentro de casa. Isso foi fantástico na época" comenta a gerente da fundação, JZ.

(...) referindo-se a visitas anuais de assistentes sociais

O objetivo é estabelecer um vínculo com os colaboradores da loja, fazendo com que eles se integrem com as atividades desenvolvidas pela fundação. Cabe também à entidade administrar todo o portfólio de benefícios dos colaboradores, como plano de saúde e a complementação salarial por auxílio-doença. Outro benefício é a creche para filhos de funcionários, que atende crianças de até cinco anos.

Direitos/ disputas trabalhistas deslocadas para Fundação de RS

(...)

Referindo-se ao Bonzão Esporte Clube-com aulas de futebol, música e artes -, no Irajá, onde fica a sede da empresa

(...)

A idéia a atuar na formação ética de jovens envolvidos, despertando-os para questões como espírito de equipe, solidariedade e cidadania.

13 Peça estratégica (IES)

(Faoze Chibli - revista Ensino Superior)

subtítulo: Escolas assumem papel de difundir ações de responsabilidade social sem fazer assistencialismo, e os resultados são ganhos institucionais e até mesmo didáticos.

Longe de serem apenas estratégia de marketing, as ações de responsabilidade social (RS) passaram por uma ampliação recente em vários setores, inclusive o acadêmico.

(...) 
"Existem alunos que, além de toda a formação acadêmica, serão empreendedores sociais". A idéia é que o desenvolvimento dessa cultura na universidade se transfira aos futuros gestores de empresas. o professor atenta ainda para o crescimento das oportunidades de emprego no terceiro setor.

professor do Ibmec

$(\ldots)$

$\mathrm{P}$ [diretora acadêmica de IES privada] considera que todos os envolvidos lucram com a RS. Ela acha possível a

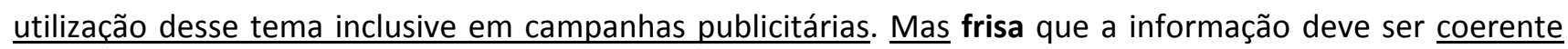

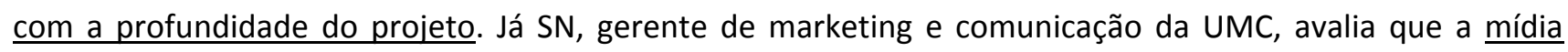
espontânea dá conta da divulgação de ações em RS. Ele considera que essa é uma forma mais legítima de veiculação nesse caso. E destaca: "Se o projeto dá certo, isso estimula outras empresas a fazerem o mesmo." (...)

Ela admite que a RS pode ser uma ferramenta de marketing, mas analisa que é preciso discernimento para se escolher o tom da divulgação. E acredita que esse não deve ser o carro-chefe de uma campanha publicitária. (diretora de pesquisa e extensão de IES privada)

Possível referência a Campanha Uniban/Pelé ?

(...)

"Esse tema ainda precisa ser tratado com mais profundidade. Acho que os benefícios do marketing são buscados em muitos casos" fustiga Silva.

(...)

"O que a empresa deveria buscar não é a imagem, mas a reputação, que é algo mais profundo" aponta Silva [gerente de certificação da Fundação Vanzolini entidade sem fins lucrativos ligada ao Depto. de Engenharia de Produção da Poli-USP].

Lógica de consumo - propaganda que vende um bom produto

14 Foco no econômico e no Social (CASO redigido pelo chefe do Fundo Pró-Infância e por assessora de marketing)

subtítulo: A Gerdau solidificou a sua atuação comunitária quando se apresentou não apenas como uma geradora de empregos e de recursos públicos pelo recolhimento de impostos, mas também por ser uma estimuladora de atitudes de cidadania nas regiões onde está presente. Esta é a reconstituição de um relato que reverencia valores e discorre sobre a participação de profissionais como cidadãos. $O$ caso, aqui detalhado, remete a conceitos e crenças que sempre existiram e que é tudo de mais importante que uma organização possa desejar.

O grupo Gerdau produz aço para transformar sonhos em realidade. Sonhos que hoje já são compartilhados com mais de 25 mil colaboradores, movidos pela certeza de que é possível superar limites, gerar 
desenvolvimento econômico sustentado e contribuir para a qualidade de vida, estimulando a habilidade transformadora presente nas pessoas, no processo siderúrgico e nas aplicações do aço. I have a dream

\section{(...)}

A sustentabilidade do grupo não se resume à gestão do negócio, à eficiência de seus colaboradores e à proteção do meio ambiente. É algo que transpassa os muros de suas unidades, confirmando que o sucesso empresarial caminha ao lado do desenvolvimento das comunidades.

\section{(...)}

A empresa, fundamentada numa cultura de solidariedade e crescimento dos indivíduos, fomenta uma atitude voluntária, portanto promulga ações que possam contribuir para o desenvolvimento sustentável das regiões onde está presente.

Cita Fundo Pró-Infância dos Profissionais da Gerdau "instrumento de sustentação de 150 instituições brasileiras"

\section{(...)}

O segredo do sucesso talvez esteja na procura dos potenciais das pessoas, dos lugares, das situações e na possibilidade de dedicar tempo a cultivá-los.

15 Ética e responsabilidade se aprende na escola

Entrevista com RF professora e escritora - Razão Social/ O Globo / Amélia Gonzalez

O Globo - Como a sra. está vendo o movimento de responsabilidade social no Brasil?

Eu gostaria de separar dois conceitos que são bem definidos e que à vezes vêm misturados. Uma coisa é a

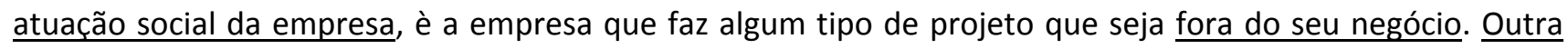
coisa, bem diferente, é a responsabilidade social corporativa. É preciso que fique bem claro o seguinte: nem sempre fazer projeto social significa que empresa tem uma atitude socialmente responsável. A responsabilidade social é uma atitude mais ampla, que implica em governança, que implica em relações trabalhistas justas. Investir no exercício de responsabilidade social não é só investir em projetos sociais.

\section{$(\ldots)$}

Referindo-se a empresas que agem de "forma incoerente".

Ou seja: a imagem é tudo para estas empresas, não?

Eu vejo que quando a empresa quer ter apenas uma imagem de boazinha, sem conteúdo real, aí realmente a coisa fica complicada. São campanhas marquetosas, associadas ao logotipo da empresa, mas onde não se consegue enxergar nenhum fio de continuidade. Não se consegue enxergar um valor de responsabilidade social na cultura destas empresas.

(...)

Qual o tipo de empresário que age desta forma? 
É aquele empresário mal informado, que continua achando que responsabilidade social é um penduricalho e não uma atitude estratégica. Na verdade, responsabilidade social deve ser uma estratégia empresarial tão importante quanto a estratégia financeira. Uma pessoa que vai dirigir uma empresa precisa pensar nisso em primeiro lugar.

\section{(...)}

Isto é um processo de aprendizado? De mudança de cultura?

Sim, sobretudo de aprendizado. (...)

As pessoas ligadas a universidades têm este desafio: introduzir o conceito de responsabilidade social em

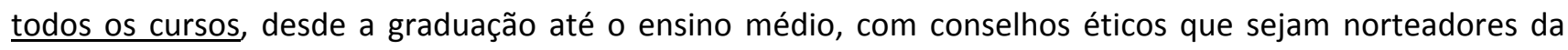
pessoa independente de sua nota no currículo.

\section{$16 \mathrm{Em}$ nome do futuro}

Revista Foco - retranca Finanças /Mercado de Capitais / Adriana Braz

Falas de consultores e executivos

subtítulo: Sustentabilidade é a palavra-chave dos relatórios anuais que as companhias de capital aberto apresentarão em breve ao mercado.

Os relatórios anuais acompanharam a globalização dos mercados. Estão mais completos e amplos. Neste ano, o tema central que muitas companhias tratam é a sustentabilidade. Segundo executivos, essa é a tendência mundial.

\section{(...)}

Economicamente, as empresas socialmente responsáveis ainda não conseguem mensurar isso, mas estão certas de que dá retorno na "precificação" de suas ações. Tanto que, em setembro do ano passado, a Bovespa lançou o índice de Sustentabilidade Empresarial da Bovespa (ISE), com mais de 20 companhias listadas. A empresa deve ter excelência na gestão da sustentabilidade sem deixar de criar valor a seus acionistas.

(Bovespa/ISE como prova)

\section{(...)}

Para demonstrar com profundidade a vivência da instituição, a publicação do relatório do ABN é realizada a cada dois anos. O banco inovou na forma de apresentação do relatório, que tem a forma de apresentação de uma revista para dar agilidade. A segunda edição, distribuída neste ano, traz uma reportagem sobre uma conversa entre FB, presidente do ABNAR, e outros presidentes de grandes companhias (RL da Petrobras Distribuidora, JP da Votorantim, CR da HP, e GL da Natura). O tema central da conversa era como mudar 0 jeito de ganhar dinheiro, respeitando as áreas social e ambiental, isto é, de forma sustentável. "O relatório anual passou a ser denominado Relatório de Sustentabilidade, que é mais amplo", afirma N [superintendente de Educação e Desenvolvimento Sustentável do ABNAR]. 


\section{$(\ldots)$}

\section{Referindo-se a relatório da Unilever}

No relatório deste ano, que será divulgado em maio, a empresa ousou: terá um documento conciso, mas acompanhado pelo DVD, desenvolvido pelos alunos do curso de responsabilidade social da escola Superior de Propaganda e Marketing (ESPM). "O diferencial dessa edição é que terá a visão externa, com os estudantes produzindo um curta-metragem" revela EM. [gerente da área de RS da Unilever] Linguagens diferentes (revista, documento conciso, DVD) para ampliar público. Incorporar "visão externa".

17 Responsabilidade Social: Moda ou consciência? (Revista @prender)

subtítulo: IES usam extensão universitária para projetos sociais, mas, para especialistas, as instituições ainda não incorporam seu verdadeiro compromisso perante a sociedade.

\section{$(\ldots)$}

“Agora o grande desafio à gestão universitária é a radicalização da extensão, principalmente na reestruturação da forma como ela é operacional”, acredita Calderón [ assessor para assuntos comunitários de IES privada]. "Radicalizar significa permitir a construção de uma IES socialmente responsável por meio de desenvolvimento de políticas viáveis de extensão no sentido financeiro, além de projetos sérios e consistentes enraizados nas atividades de ensino e pesquisa", conclui.

18 Responsabilidade Socioambiental valoriza as empresas (BOVESPA)

retranca Governança (sem assinatura?)

subtítulo: Conceitos de cidadania corporativa predominam nos países desenvolvidos

\section{(...)}

A muitos isso pode parecer idéias vazias, recheadas só de boas intenções, expostas para ser seguidas parcialmente (...). Para muitos outros - vale dizer, para os adeptos da cidadania corporativa - essa opção é estreita e ilusória. No mundo de hoje, argumentam, graves problemas como mudanças climáticas, crise e desperdício energéticos, pobreza absoluta, preconceitos raciais e sociais, exploração do trabalho infantil, corrupção têm de ser incorporados aos planos das organizações. Se não forem - se as organizações continuarem optando por lucros de curto prazo em prejuízo da sustentabilidade de longo prazo -, é sua própria sobrevivência, não apenas resultados daqui e dali, que estará posta em risco por essas ameaças modernas.

\section{(...)}

Cita várias iniciativas "de qualidade" do setor financeiro aderindo à sustentabilidade

Mas a iniciativa mais recente, $\underline{\text { mais ampla, mais ambiciosa e formulada para abarcar todas as personagens do }}$ mercado financeiro nasceu há um ano e meio e já começa a mostrar a que veio. Trata-se do programa que americanos e europeus batizaram de Who Gares Wins - mal traduzindo, "quem se preocupa com as coisas 
do mundo vai ganhar" (lá na frente). Ele pretende abrir o foco para as questões ESG [fatores ambientais, sociais e de governança corporativa], que vinham sendo tratadas de certa forma isoladamente, seja, por exemplo, pelos departamentos de TI ou pelas gerências de meio ambiente das empresas. Deseja levá-las à alçada das diretorias e dos Conselhos, tornado-as componente intrínseco da estratégia das companhias incrustando-as no núcleo central da tomada de decisões. Em outras palavras, deixariam de ser um apêndice, um anexo, um algo mais, nos documentos/relatórios das empresas, para transformar-se em sua própria razão de ser.

\section{$(\ldots)$}

"Uma revolução silenciosa está a caminho nos mercados financeiros globais" diz GP, chefe da Financial Markets Initiative, do Pacto Mundial. [ONU nasceu em 2000 e foi subscrito até final de 2005 por mais de 2.200 companhias e organizações globais / $9+1$ princípios (luta anti-corrupção acrescido em 2004)] O quarto princípio merece destaque: As empresas devem apoiar a liberdade de associação e o reconhecimento efetivo do direito à negociação coletiva. (A Gerdau subscreveu? Não)

\section{(...)}

Documento-chave, produzido com apoio de 20 instituições financeiras de nove países, mais IFC do Banco Mundia: Who Gares Wins - Integrando Mercados Financeiros a um Mundo em Transformação.

Seu objetivo: elencar recomendações para que todos os atores do sistema ( empresas, bancos, assets, corretoras, seguradoras, departamentos de análise e pesquisa, auditorias, consultorias, bolsas de valores, escolas, governos, agências reguladoras, ONGs, fundos de pensão e investidores em geral) integrassem efetivamente as questões ESG aos seus procedimentos e à sua missão. Patrocinadores: grandes instituições financeiras mundiais, incluindo BB e banco chinês.

\section{(...)}

Seu argumento central definia a proposta com clareza. "As instituições que apóiam este relatório estão convencidas de que, num mundo mais globalizado, interdependente e competitivo, o modo como são geridas as questões ambientais, sociais de governança corporativa é parte integrante da própria administração geral da companhia e isso é necessário para competir com sucesso", diz o documento.

19 Empresa têm dificuldades para promover diversidade (revista Administrador Profissional)

\section{(...)}

È o que revela o relatório social do fundo de previdência dos funcionários do Banco do Brasil (Previ). Em 2004, os negros em cargos de direção nas empresas nas quais o fundo tinha participação ganhavam $30 \%$ menos que seus colegas brancos. As mulheres em cargos gerenciais recebiam salários $10 \%$ a menos do que os dos homens na mesma posição.

Levantamento do Instituto Ethos, [...] e do Instituto Brasileiro de Geografia e Estatística (IBGE) feito com 247 das 500 maiores empresas do país, em 2003, mostra que a participação feminina nos cargos mais elevados 
das corporações era de $9 \%$ e o de negros $1,8 \%$. Um novo levantamento referente ao ano passado está prestes a sair, mas não deverá revelar avanços significativos.

(...)

Para ele, o mundo empresarial vem avançando muito no que diz respeito a processos e tecnologias, mas ainda é anacrônico do ponto de vista cultural.

Citação indireta de Hélio dos Santos presidente do Instituto Brasileiro da Diversidade

Diversidade associada à questão cultural e não política.

20 Capital em Prol do Social (Cláudia Manzzano / Distribuição, ano 14, n159, p2004-208, abr2006)

subtítulo: Responsabilidade social é mais que ações filantrópicas, e são os consumidores que começam a notar a diferença entre uma e outra.

Os "beneficiários" não notam diferença?

(...)

A forma de consumo ainda está atrelada a concentração e crescimento da renda, além da mentalidade do consumidor. "As coisas crescem muito lentamente. Se o consumidor demandar responsabilidade social, as empresas terão que mudar. $\underline{\mathrm{O} \text { consumidor é o estopim. }}$ A responsabilidade social da empresa depende da responsabilidade social do consumidor" lembra W (consultor da Integration)

"Ainda" repetidas vezes. A "evolução é uma questão de tempo. Associação com fenômeno natural, biológico $(\ldots)$

"Responsabilidade Social não é filantropia. É uma forma de gestão. Com ela a empresa gera impacto em funcionários, meio ambiente, sociedade, fornecedores e clientes", salienta OG, presidente do Conselho Deliberativo do Instituto Ethos.

\section{(...)}

Em pesquisa da InterScience, com seis mil entrevistados, $44 \%$ consideraram a responsabilidade social como um item muito importante na decisão de compra e um agregador de valor.

21 Responsabilidade Social é outra coisa (M\&M)

Entrevista com Reinaldo Bulgarelli, sócio da Txai Cidadania e Desenvolvimento Social consultoria

M\&M - Quando se fala em responsabilidade social corporativa é comum pensar em empresas que apóiam projetos de comunidades ou organizações não-governamentais. Mas uma outra vertente de raciocínio vai além, e entende que a questão perpassa toda a atuação da companhia, englobando o modo de relacionamento com seus públicos de interesse. Qual é a sua opinião?

O foco são as ações que a empresa estabelece com seus diferentes consumidores. Responsabilidade Social é cuidar da qualidade dessa relação, e aí não pode ser só a comunidade ou só com os colaboradores internos, e sim com todos os públicos estratégicos da organização. 
(...)

O vínculo maior da responsabilidade social é com a sustentabilidade e isso ajuda a compreender o conceito de que um negócio sustentável é aquele contribui para o planeta ser sustentável.

(...)

M\&M - No fundo, sua análise tenta desconstruir uma idéia ainda muito presente de que a RS é simplesmente apoiar um projeto social.

Felizmente isso já vem mudando. Entretanto, em um país como o Brasil, no qual as pessoas não têm recursos para as necessidades básicas, também não podemos desprezar esse tipo de apoio. Por uma questão de democracia - e não apenas pelo dinheiro - precisamos ser co-responsáveis pelo desenvolvimento. Então é interessante que as companhias participem das ações no campo social. É óbvio que não estou falando de assistencialismo e dessas bobagens que não raras vezes as empresas fazem com muito capricho.

A menção à democracia é tão fora de contexto que sua substituição por piedade, benevolência etc. não alteraria o sentido da fala. Experimento pode ser feito em outras menções, sobretudo à cidadania?

(...)

M\&M Em um mercado altamente competitivo, produtos e serviços estão cada vez mais parecidos (...) Nesse contexto a RS não está se transformando em mero discurso de apoio ao marketing?

Pode tornar-se só uma peça de marketing, mas depende muito da compreensão que a companhia tem da questão, se entendeu ou não os legítimos anseios da comunidade. (...)

Já vi organizações começarem com bobagens e depois fazer outras leituras da realidade, compreendendo os interesses legítimos, pois a sociedade está mudando.

\section{(...)}

As pessoas anseiam por outros atributos, e aí é necessário inserir no universo da marca a questão do respeito, cuidado com o meio ambiente, a valorização da diversidade. Para isso, não dá para escolher o tema $\underline{\text { somente como um diferencial competitivo, mas sim um diferencial significativo, que represente algo a mais }}$ para a sociedade.

22 Empresas confundem responsabilidade social com a corporativa

(Canal UOL executivo/ texto a partir de depoimento de consultora Cibele Salviatto)

Ainda há muita confusão no mundo empresarial a respeito do tema RS. $\underline{O}$ entendimento mais comum é o de que empresas têm exercido sua RS através de parcerias com ONGs ou apoio à projetos desenvolvidos pelas mesmas.

“No entanto, responsabilidade não significa doação ou terceirização de investimento social. Significa sim gestão, atitude. Estar atento ao consumo de insumos, buscar constantemente melhorar seus processos e seus produtos e adequá-los á realidade ambiental, cuidar do relacionamento para eles sejam frutíferos e construtivos para todos os partícipes, ser ético e transparente para garantir que a empresa poderá continuar 
a exercer o seu papel no futuro, trabalhar para garantir a sustentabilidade de seu negócio e ao mesmo tempo do ambiente e da sociedade em que está inserida", diz CS, sócia da consultoria Atitude.

De acordo com a consultora, essa confusão tira o foco do que realmente é importante e das ações que efetivamente levariam a sociedade, o planeta e as pessoas a uma transformação positiva. "Também impede que as empresas olhem para esse assunto com a devida importância, uma vez que passam a acreditar que já estão fazendo o seu dever e não percebem que estão incorrendo em riscos futuros irreversíveis e perdendo grandes oportunidades de negócio", explica.

\section{(...)}

A consultora adverte (...) “(...) Não se enganem: fundações, institutos e projetos sociais não eximem a empresa de sua responsabilidade. Responsabilidade Social não é Responsabilidade Corporativa", diz.

23 Cidadania Corporativa Estratégica: O início de uma nova Era

Miguel Fontes (site socialtec)

A literatura internacional apresenta três estágios históricos do envolvimento do setor corporativo em causas sociais ao redor do mundo. O primeiro estágio é conhecido como filantropia corporativa.

Até final dos 80 empresas "eram induzidas por conceituados pensadores econômicos" (Friedman, sobretudo - compromisso com acionistas, doações pessoais).

Logicamente, estes conceitos tiveram muita influência em todo século XX e está é a razão da existência de tantas fundações internacionais erguidas pelos donos ou acionistas de grandes empresas. É interessante ainda observar que este ainda é o pensamento de muitos empresários brasileiros, que começaram a entrar também no mundo corporativo internacional, recentemente.

\section{(...)}

No entanto, este primeiro estágio foi fortemente modificado durante a preparação e realização da ECO 92, sediada no Rio de Janeiro. Talvez, muitos brasileiros não saibam que este evento foi o grande precursor do conceito de responsabilidade social corporativa em todo o mundo.

\section{(...)}

Desde a Eco 92, a literatura internacional não trata mais o conceito de responsabilidade social corporativo como algo alheio a empresa ou sob domínio apenas de seus donos ou acionistas

\section{(...)}

Todo este processo vem levando donos de empresas internacionais a evitar a criação de uma entidade social para fins de filantropia e começado a investir fortemente para que causas e investimentos sociais façam parte da agenda executiva da própria empresa. 
Relata projetos Carrefour, CDB e Wal-Mart / pesquisa da Abras - mais da metade das empresas promovem atividades de inclusão social

“Hoje existe uma consciência maior sobre a importância desses projetos de responsabilidade social. Cada empresa pode ajudar preocupando-se com o que está no seu entorno. Precisamos dar exemplos" frisa [ presidente da AMIS]

(...) os empresários sabem da importância de suas empresas na geração de mais postos de trabalho e renda. citação indireta [ presidente da AMIS]

\section{(...)}

“Famílias que possuem uma pequena produção, mas que ás vezes não é suficiente para transformá-la em renda vão ter uma boa oportunidade agora. Nós estamos elaborando um convênio com o governo do Estado [Minas Gerais] que visa exatamente a promoção da agricultura familiar rentável. Além disso, vamos

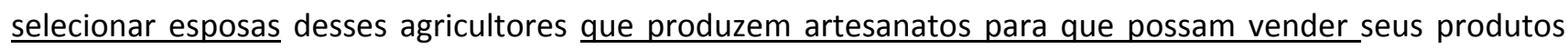
nos supermercados. Ou seja, vamos aproximar o supermercadista da comunidade. É uma tarefa realmente desafiadora porque teremos que criar talvez uma cooperativa", destaca [ presidente da AMIS]

25 Sustentabilidade: a nova fronteira da gestão corporativa

Revista do Anunciante / Tãnia Trajano e Mara Vegso / aborda 8a edição do Fórum Internacional de Estratégias de Comunicação Corporativa da ABA.

(...)

Referência ao "Mapeamento da Área de Comunicação Corporativa nas Empresas" estudo realizado por meio de questionários eletrônicos, com 56 associadas da $A B A$

De acordo com G [professor e consultor] as ações de Responsabilidade Social Empresarial despontam como grande novidade no setor, visto que no estudo realizado em 2002 elas sequer foram mencionadas. Hoje, algumas empresas já dispõem, inclusive, de áreas específicas para atividades de âmbito social, como diretoria de filantropia e ações sociais, superintendência de responsabilidade social ou gerência de sustentabilidade.

(...)

Mário Monzoni, coordenador do Centro de Estudos em Sustentabilidade da FGV-Eaesp

(...) iniciou sua apresentação lembrando que esta não é apenas mais uma palavra da moda, já que feito para ficar.

Porém, como ressaltou,quando se fala em sustentabilidade é preciso qualificá-la. A sustentabilidade do planeta, por exemplo, visa garantir um nível aceitável de relações sociais e ambientais. (...)

Já a sustentabilidade nas empresas visa mantê-las vivas no longo prazo, incorporando variáveis sociais, ambientais e econômicas. Citando uma frase de Milton Friedman, que recebeu o Prêmio Nobel de Economia 
em 1976 - "The business of business is business" - Monzoni salientou que a sustentabilidade nas empresas deve fazer sentido econômico, caso contrário será filantropia.

(...)

“As empresas que tomarem a iniciativa de serem sustentáveis e responsáveis - antes de serem obrigadas a isto - serão recompensadas por seus acionistas, satakeholders, agências reguladoras e, não menos importante no seu botton line. Por outro lado, as que falharem nesta tarefa, ignorando a governança corporativa e seus impactos no meio ambiente e na sociedade, semearão desastrosas conseqüências financeiras", alertou. [Monzoni, coordenador do Centro de Estudos em Sustentabilidade da FGV-Eaesp] (...)

Atenta a esta questão, em agosto de 2002 a PWCoopers realizou a pesquisa Sustainability Survey Report, para qual entrevistou 140 companhias norte americanas. Deste universo, 75\% afirmaram adotar alguma prática sustentável em seus negócios. Entretanto, a maioria (90\%) disse recorrer a estas práticas para proteger e fortalecer sua reputação, ou, como traduziu o palestrante, apenas para sair bem na foto. Mas $75 \%$ também esperam obter vantagens competitivas, o que é muito sensato. citação indireta

26 Aumenta ação social das empresas brasileiras (site empreendedor.com.br) Levantamento IPEA - participação empresarial na área social aumentou 10 pontos percentuais de 2000 a 2004 (59\% para 69\%)

(...)

A pesquisa procurou investigar, também, a percepção dos empresários sobre o seu papel na realização de ações voluntárias em benefício da comunidade. A grande maioria (78\%) acredita que é obrigação do Estado de cuidar do social e que as necessidades de atuar para as comunidades é maior hoje do que há alguns anos (65\%). Há, portanto, uma compreensão, no mundo empresarial, de que a atuação privada não deve $\underline{\text { substituir o poder público, }}$ tendo um caráter muito maior de complementaridade da ação estatal. Pesquisa realizada pelo IPEA - www.ipea.gov.br/asocial

\section{Compromisso com o Planeta}

Revista Update / Ricardo de Carvalho (jornalista e diretor de empresa de comunicação ambiental) Ao entrar no mundo da responsabilidade social, a empresa ganha um novo status de maior visibilidade, ao mesmo tempo em que fica sob a mira de instituições e consumidores que, de alguma maneira, fiscalizam e cobram os compromissos assumidos. Não basta às empresas realizar algumas açõezinhas de responsabilidade social. Elas precisam fazê-las direito e comunicá-las adequadamente, senão... Senão não adianta nada, é dinheiro jogado fora. Além "do risco de ver seus produtos e serviços vetados num futuro próximo", como fica claro na pesquisa RS das E - Percepção do Consumidor Brasileiro realizada pelo 
Instituto Akatu pelo Consumo Consciente e pelo I. Ethos de Empresas e Responsabilidade Social, divulgada em julho.

(...)

O I Ethos tem detectado uma tendência da maior importância: pequenas e médias empresas começam a despertar para consciência da RS. Se é de se esperar que grandes companhias com ações na Bolsa sejam indutoras de boas práticas, a adesão de pequenas e médias á causa deverá criar uma ampla rede de sustentabilidade (...)

(...)

Conclusão do texto:

Responsabilidade Social, boas práticas, índices de sustentabilidade empresarial são, na verdade, algumas de muitas iniciativas que fazem parte de um grande movimento global pela vida. É o que em economia se poderia chamar de ganha/ganha, em que todos saem ganhando: consumidores, empresários, funcionários, governo. Até o planeta, que ganha a chance de ter um futuro.

H. A. defesa da vida/laborans. Alternativa única: ou isso ou não há futuro

28 Até que ponto ser socialmente responsável?

(Revista Banas qualidade/ Geraldo Falcão)

subtítulo: Uma análise do ponto de vista estratégico

$(\ldots)$

Algumas normas como a AS 8000, param citar uma, com 96 empresas certificadas ou 9,9\% do total mundial, estruturam questões mínimas a serem atendidas pela estratégia do gerenciamento de recursos humanos, que envolvem: A conformidade das questões legais (que denomino de estruturais de risco), das questões das políticas de recursos humanos, do relacionamento com partes/stakeholders envolvidos com o negócio, da melhoria contínua e da gestão dos indicadores.

\section{(...)}

Nas linhas das normas ou dos capítulos sociais citados em documentos existentes, temos a grande oportunidade de implementar sólidas políticas de gerenciamento internas desta variável extremamente estratégica para sustentabilidade dos negócios. Já estaremos dando um grande passo ai tratar os riscos de negócio.

Neutralizados os riscos internos, interligados os diversos sistemas internos operacionais de gestão ao sistema de medição financeiro, apurados os resultados e estabelecido um sistema eficaz de realimentação de melhorias, acreditamos que, em uma segunda fase, as organizações em sua maioria podem voltar suas atenções às questões externas da RSE. Ou, no mínimo, implantá-los simultaneamente, pois são riscos independentes e não relacionados. 
29 Toyota Sustentável (Luciano Lopes/ de Campos do Jordão/SP)

Sucesso da primeira edição do Espaço Ecologia faz da montadora japonesa uma das pioneiras em educação ambiental no setor

[...] um projeto sustentável instalado em uma área de $6.000 \mathrm{~m}^{2}$ (...) "Este espaço tem objetivo de promover a educação ambiental e conscientizar todas as pessoas, sem exceção, quanto à preservação da natureza. Principalmente através das crianças, fazendo da ação um ciclo natural, vicioso e virtuoso coletivamente" afirmou GCS, gerente de Comunicação e Relações Públicas da empresa.

30 A responsabilidade Social em quatro tempos

Ricardo Voltolini jornalista, consultor de 3 Setor e RS (Idéia Social)

Uma análise da evolução do conceito de responsabilidade social nas empresas brasileiras indica a existência de quatro estágios. O Primeiro se baseia na negação da lógica de ser socialmente responsável. Os três seguintes, em sua afirmação. Mas diferem entre si no nível de intensidade com que a idéia passa do discurso a prática, incorporando-se as estratégias corporativas e alterando o modo de pensar e fazer negócios. Certamente, à medida que for apresentado a cada um deles, o leitor poderá fazer o exercício de encaixar as empresas que conheceu neste ou naquele estágio.

A exceção do primeiro os demais são complementares

O primeiro estágio é o da não responsabilidade social, uma espécie de fase zero ou pré-história do conceito. O nome pode nem ser o mais adequado, mas tem a sua força simbólica: nele, as empresas ainda não acordaram para a nova ordem, presas que estão a uma lógica egoísta que as transforma em organizações auto-centradas, preocupadas exclusivamente com seus processos e produtos, alheias aos eventuais impactos ambientais e sociais que possam causar ou mesmo às condições de vida de suas comunidades. (mesma crítica feita pelo marketing à administração)

\section{(...)}

A defesa deste ponto de vista se concentra no velho argumento de "já pago meus impostos, portanto, não tenho que assumir as responsabilidades do governo pela qualidade de vida das comunidades." [citação do outro - empresário arcaico] Por certo, o leitor já topou com uma empresa que pensa assim.

A boa notícia é que elas estão ficando cada dia mais raras. Isso significa na prática, um número crescentemente maior no estágio seguinte, o da cidadania corporativa. O nome nesse caso é bastante apropriado: uma empresa cidadã é aquela que se reconhece como parte de uma comunidade, entende ter um papel social e decide, de alguma forma, investir recursos em ações de saúde, educação, lazer e cultura.

Atitude pode surgir de dentro para fora ou de fora para dentro

[...] No primeiro caso, o retorno esperado atende a aspirações de natureza filantrópica. No segundo, adiciona valor a marca. 
Em comum, as empresas desse estágio agem de modo reativo, realizam, ações pontuais (doações ou eventuais projetos), não estruturadas, não mensuráveis e despregadas de qualquer estratégia corporativa. categoria da maioria das empresas

Ao fazerem algum investimento, ainda que pequeno e esporádico, sentem-se "cidadãs", sem ter que olhar para dentro, mudar estruturas, revisar formas de gestão.

Esta é a principal diferença para o terceiro estágio, o da responsabilidade social empresarial. Nele, as corporações aceitam o desafio - algumas mais, outras menos - de rever suas práticas sob a orientação de uma nova lógica: a de que o negócio além de gerar lucro para os proprietários ou acionistas, precisa considerar o bem-estar e a realização dos funcionários, a qualidade de vida das comunidades, o relacionamento ético com fornecedores e governos e o menor impacto possível ao meio ambiente.

(...)

O quarto estágio, o da sustentabilidade, é o mais avançado de todos. Enquanto no anterior, a responsabilidade social consiste em um conjunto de práticas internas, muitas vezes dispersas, não totalmente integradas e nem sempre intimamente ligada a estratégias central do negócio, o da sustentabilidade se caracteriza pela adoção de um modelo novo de pensar e fazer negócios. Representa, de fato, uma ruptura. Na busca do triple botton line, as empresas sustentáveis procuram conjugar resultados econômicos, sociais, ambientais, conferindo a cada um deles - e aí está seu grande diferencial - o mesmo nível de importância.

Para elas, boa oportunidade de negócio é aquela que vem acompanhada de inclusão social de indivíduos, desenvolvimento de comunidades e uso sustentável de recursos. Lucro bom é o que, de alguma forma, decorre de um processo no qual foi possível distribuir riqueza, prosperidade e justiça social, preservando a saúde do Planeta.

31 A Responsabilidade Social na Reestruturação (Aracruz Celulose - Case Studies)

Eloir Ambos da Silva/ Rosângela Gomes Schmachtenberg (RH Aracruz)

subtítulo No novo ambiente de negócios, somente terão lugar no mercado - e, por assim dizer, no futuro as empresas que conseguirem integrar adequadamente os fatores econômicos, sociais e ambientais, atingindo os patamares para serem consideradas sustentáveis. A Aracruz é uma empresa competitiva, por combinar vantagens de uma produtora de baixo custo com economias de escala, tecnologia florestal avançada e um curto ciclo de cultivo, proporcionado pelo clima brasileiro.

(...)

Trata-se da Responsabilidade Social, ou seja, da preocupação com o bem-estar coletivo, da comunidade, apoiado na cultura e nos preceitos das sociedades européias. 
Entrevista com Elcio Anibal de Lucca - presidente da SERASA

(Camila Stähelin/ Revista Empreendedor)

EAL é conhecido entre os empresários pela quantidade de prêmios que recebe como presidente da Serasa. A empresa, que possui o maior banco de dados econômico-financeiros da AL, foi a primeira a conquistar, por três vezes o Prêmio Nacional da Qualidade $(1995,2000,2005)$ (...)

Elcio é responsa'vel por um modelo de gestão baseado em valores cristãos e focado em seus funcionários (os chamados Ser Serasa - ser ético, ser gente, ser excelência, ser empreendedor).

\section{(...)}

Para o senhor, onde começa a responsabilidade social dentro da empresa?

Começa em cada indivíduo, na consciência de cada um. Todas as pessoas de caráter e ética têm vontade de fazer alguma coisa em benefício do próximo. Compete à empresa aproveitar esse desejo, do mesmo jeito que aproveita a vontade das pessoas de trabalharem em informática ou em marketing.

\section{(...)}

Então a responsabilidade social pode ser praticada não só pela grande empresa, mas pelas pequenas e médias?

A responsabilidade social parte do indivíduo. Se o sujeito sozinho tem atitude cidadã correta, ele pratica responsabilidade social.

(...)

Que projetos sociais da empresa são mais importantes para o senhor?

Nós atuamos em todos os setores, econômico, ambiental e social. O que faz isso funcionar, que é a mola propulsora, é o desejo de ser voluntário do Ser Serasa (como são chamados os profissionais da empresa).

33 Uma reflexão sobre o mundo dos negócios, a inclusão social e o desenvolvimento local

Adriana lelo Deróbio

Começa com citação de Kofi Annan

A WBCSD defende negócios sustentáveis com a inclusão social que beneficiam os mais pobres e as companhias, no modelo ganha-ganha.

(...)

O projeto Empório da Comunidade que o Instituto ABAD propõe traz a cena toda esta reflexão.

Tendo por cenário um escola seu bairro e os varejistas próximos desta comunidade consumidora, propõe-se uma transferência de renda aliada a freqüência escolar e ao consumo direcionado a produtos previamente selecionados. Como resultado desta inovadora proposta pretende-se obter uma comunidade mais estruturada e mobilizada, mais consciente das questões locais. 
(Revista Momento do Professor / texto de MCRA da IES Anhembi Morumbi)

\section{Referindo-se à confusão entre RS e marketing}

[...] ao contrário da responsabilidade social, o marketing social costuma restringir-se a projetos temporários, voltados, sim, à valorização da cultura, do esporte, da saúde e da educação, mas destinados, antes de tudo, a aumentar as vendas da empresa, ou melhorar a imagem da marca no mercado.

A responsabilidade social pode incorporar atividades assistencialistas e ações de marketing social, porém, por vincular-se ao processo de gestão, transcende a ambas. "Deve ser vista mais do que como uma simples prática: deve estar umbilicalmente associada a uma filosofia negocial que contemple aspectos que extrapolem a mera relação comercial/financeira das empresas (...)" ensina o jornalista e pesquisador Wilson da Costa Bueno.

35 A importância da responsabilidade social na busca e seleção de executivos

Luiz Felipe Calazans (Rh.com.br)

(..)

O conceito de RS também começa a gerar uma demanda de postos de trabalho em setores antes pouco valorizados, como organizações não-governamentais, consultorias ambientais, reciclagem de materiais e projetos sociais, os mais variados.

Nesse cenário, será questão de tempo o mercado exigir do profissional essa preocupação com a RS.

Fatalmente, ele terá de apresentar, além da sensibilidade e do interesse por questões sociais e ambientais, a capacidade de avaliar qual a estratégia de gestão mais adequada para se atingir os melhores resultados para a empresa, a sociedade e para a comunidade que a cerca, não importando qual seja seu porte.

36 Empresa cidadã conquista consumidores

Mariana Oliveira (mundo marketing)

Cita pesquisa Instituto QualiBest - 65\% associam RS com comportamento ético/41\% tem "extremo interesse pelo tema. (mais de 4 mil pessoas consultadas)

A Responsabilidade Social tornou-se mais que uma estratégia de marketing. Ela foi inserida nos valores empresariais e responde de forma positiva junto aos consumidores.

Embora algumas vezes ainda seja confundida com filantropia, segundo o Instituto Ethos, organização não governamental que é referência na área, a Responsabilidade Social é mais abrangente à medida em que foca na cadeia de negócios da empresa e engloba preocupações com acionistas, funcionários, prestadores de serviço, fornecedores, consumidores, comunidade, governo e meio ambiente a longo prazo.

O MKT faz o mesmo

GL, VP Executiva da ADVB DO Rio enfatiza que não se deve confundir estas duas vertentes. "Não podemos confundir estratégia de marketing com RS. As estratégias são criadas pelas organizações e uma de suas 
finalidades é a geração de lucros, o que não pode acontecer com as ações socialmente responsáveis", afirma. "O que acontece na prática é que os consumidores estão mais atentos a participação das organizações nas causas sociais, o que acaba gerando um maior número de adeptos a um determinado produto que tenha sua marca associada a projetos desse cunho. isto agrega força positiva e valoriza a marca, mas não pode ser visto como um instrumento visionário de lucro", avalia.

\section{(...)}

Algumas empresas têm seu nome diretamente associado às ações que realiza no âmbito social. Petrobras, Natura, Banco Bradesco, Rede Globo, Calçados Azaléa, Banco Real e O Boticário representam 45\% dos nomes mais lembrados segundo pesquisa QualiBest. As ações se concentram basicamente em educação e meio ambiente.

A Natura, reconhecida como uma empresa que pratica profundamente a Responsabilidade Social, foi contatada pelo Mundo Marketing para falar sobre este posicionamento. Porém, os diretores afirmaram que não se pronunciariam porque estas ações estão no DNA da empresa e não se caracterizam como estratégias de marketing. Negação do marketing

\section{Um mapa do Terceiro setor}

Update / HSM management / por Eduardo S.U. Pace, Leonardo C. Basso e Roseli da Silva

Pesquisa com 648 ONGs para detectar seus indicadores de desempenho traz panorama preocupante da gestão deste tipo de empresa.

Ainda que não sejam empresas de negócios, as organizações sem fins lucrativos têm "clientes" aos quais destinam seus serviços e devem financiar suas próprias atividades, fatos que as obrigam a pensar em gestão assim como o fazem as empresas que visam lucro. Um sistema de mensuração de desempenho na criação de valor que se baseie em indicadores de qualidade deve ser considerado, portanto, obrigatório para as ONG's.

38 Trabalho e qualidade de vida

Alberto Ogata (Gazeta Mercantil)

O artigo cita a professora Rosa Maria Fisher

Conceito inicialmente utilizado no Conselho Empresarial Mundial para o Desenvolvimento Sustentável, em 1998, estabelecendo que "trata do comprometimento permanente dos empresários de adotar um comportamento ético e contribuir para o desenvolvimento econômico, melhorando a qualidade de vida de seus empregados e familiares, da comunidade local e da sociedade como um todo".

(...)

Concluímos lembrando que os profissionais que atuam com RS e qualidade de vida devem, além do conhecimento das ferramentas de gestão, ter o que Dalai Lama chama de "valores humanos essenciais", ou seja, serem pessoas que se relacionem cordialmente. 
39 Maior Rigor para Balanço Social

Publicações serão avaliadas por várias organizações antes de terem o selo Ibase

Andrea Vialli / OESP/ Economia

Artigo trata do controle de qualidade (Selo IBASE) quanto às informações divulgadas pelos Balanços das Empresas. Faz um apontamento para setores que ainda não discutem a questão.

"O Setor sucroalcooleiro ainda é introspectivo em responsabilidade social, mas vamos avançar na proliferação desse comportamento" afirma JPQB, presidente de grupo usineiro.

\section{Lucro com o Social}

Paula Pacheco / Carta Capital /lances e apostas

Com menos recursos disponíveis, ONGs diversificam suas fontes e investem em produtos e serviços.

Cita grife do IBCC "O Câncer de mama no alvo da moda"

"Apesar de muitas empresas falarem de responsabilidade social, é difícil encontrar quem queira se associar a prostituição". GL presidente da DaVida ONG

41 Interações das redes sociais

Jorge Duarte / DCl / Carreiras e Gestão

Foco do artigo está em ações de estratégia de organizações em alcançar seus objetivos. Neste caso a idéia é a de REDE como um componente aglutinador das práticas comuns.

"As diversas aprendizagens que uma pessoa realiza se potencializam quando são socialmente compartilhadas na procura de solucionar um problema comum" afirma Dabas na obra Red de redes - lãs praticas de La intervención em redes sociales.

42 Empresas começam a investir em consumo responsável de álcool

Daniela D’Ambrosio / Valor Econômico

A indústria de bebidas alcoólicas resolveu abraçar o discurso do consumo responsável

O problema é cada vez mais sério - os dados que associam os acidentes a bebidas alcoólicas são alarmantes no mundo todo - e os investidores estão com o radar ligado.

43 Solidariedade Digital

Revista Foco / Ecoeconomia/ Dubes Sônego

Os dois endereços na rede talvez sejam os principais representantes de um novo modelo de assistencialismo social, ambiental e econômico. Em uma analogia simples, são "mercados" virtuais de projetos que reúnem 
iniciativas do gênero em diversas regiões do planeta. Em vez de entregarem dinheiro a grandes organizações, que decidem onde, como e quando alocar recursos, cidadãos e instituições doadoras têm a opção de escolher projetos que consideram relevantes dentro de uma ampla gama de opções. Com uma grande vantagem. Em ambos os sites estão disponíveis os contatos dos responsáveis pela execução dos projetos, que podem ser contatados diretamente por qualquer um dos doadores ou potenciais doadores.

Referência aos sites da kiva.org e globalgiving.com sites que aglomeram doadores e investidores em ações $e$ programas sociais e ambientais.

Semelhança com "cardápio" da Bolsa Social Bovespa

44 Responsabilidade Sócioambiental valoriza as empresas JÁ FICHADO

Revista Bovespa

Conceitos de cidadania corporativa predominam nos países desenvolvidos

45 Países Vêem de forma diferente a atuação social das empresas

Andrea Vialli

Estudo Instituto Market Analysis - 115 líderes de opinião em 10 segmentos (BR)/ 95 lideranças políticas empresa Mori Argentina(ARG)

No Brasil $51 \%$ dos entrevistados concordam que as empresas fazem bom trabalho para construir uma sociedade melhor. Já na Argentina este percentual cai para 8\%.

$(\ldots)$

Maturidade

O interesse pelo assunto entre os líderes de opinião brasileiros sugere a maior maturidade do movimento de RS no País, motivada pelo engajamento de entidades empresariais em torno do tema nos anos 90. "ONGs como o I. Ethos, a Fundação Abrinq e o Grupo de Institutos e Fundações de Empresas (GIFE tem auxiliado ad empresas a disseminar o conceito e colocá-lo em prática", explica E [diretor do Instituto que conduziu a pesquisa no Brasil]. Em ambos os países, no entanto, as empresas têm superado a mera filantropia e adotam programas mais consistentes de investimento social.

46 Utilização da Franquia em favor do Social

Artigo de autora - Coordenadora do Programa Formare da Fundação lochpe

Ser uma empresa cidadã não é mais uma mera questão de marketing. É uma necessidade que se torna filosofia de negócios a partir da pressão da sociedade em favor de empresas que cumpram o seu papel social. 


\section{A Ética no Consumo}

Revista O Globo / Marcia Cezimbra

Quem são os brasileiros que transformam em militância política pela ética a tendência de consumir produtos que protejam a natureza.

Cita consumidores que fazem escolhas a partir da conduta ética e ambiental das empresas

Dá dicas para ser "consumidor engajado".

Para estes militantes, consumir qualquer produto é um ato político. Eles estão obrigando as empresas a pensarem em responsabilidade social na hora de traçar estratégias de crescimento.

\section{Efeito Irradiado}

Silvia Torikachvili - Valor/ Empresa \& Comunidade

Responsabilidade Social garante segurança, gera prestígio, dobra os lucros. Que o diga lone Antunes, feliz proprietária da Help Express, empresa de motoboys, uma atividade conhecida no mercado como das mais perigosas para o trânsito, insegura para os trabalhadores e instável para os investidores.(...) O parceiro dessa mudança foi o Real ABN Amro. Em 2002, o banco decidiu que não bastavam fornecedores com um nome limpo na praça, eles deveriam ter também um produto ambientalmente correto e socialmente justo - itens que até então não entravam na relação de negócios.

(...)

Costa [coord.da área de gestão e relacionamento com fornecedores do ABNAmro] diz que o papel do banco não é obrigar as empresas a adotar esses critérios, nem excluir parceiros que não os pratiquem. "Queremos participar da inclusão de fornecedores convencidos de que não haverá futuro para eles fora da responsabilidade social".

50 Melhorar a compreensão do consumidor brasileiro sobre o papel das empresas é o primeiro passo para ampliar a RSE no Brasil

Ricardo Voltolini / ethos.org.br

O brasileiro confia mais nas empresas que têm ações de responsabilidade social do que os consumidores de outros 21 países. Esta foi a principal conclusão de estudo divulgada no final do ano passado, pelo Instituto Globescan em parceria com o Market Analysis Brasil.

Tratar os empregados de forma justa é a primeira atitude definidora do comportamento SR de uma empresa (aqui e nos outros países). Segundo lugar - "fazer doações" enquanto nos outros países é "proteger o meio ambiente".

De um certo modo, o dado confirma a persistência de uma falsa idéia de que a empresa socialmente responsável é a que coloca recursos em projetos sociais - algo compreensível no Brasil, a julgar a maior 
dimensão de nossos problemas e o fato de que, comparativamente, o Estado não funciona tão bem aqui na garantia do welfare state quanto em outros países do mundo. Mas subproduto de um raciocínio simplificador e paternalista contra o qual se deve lutar, na medida em que ele reforça, na percepção do

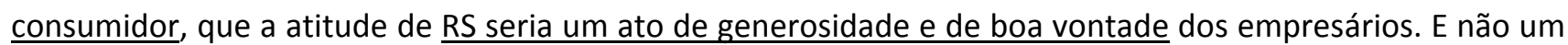
compromisso ético mais amplo da empresa contemporânea, que como consumidores, podemos e devemos influenciar.

Um outro dado importante do estudo confirma esta visão simplificadora do brasileiro: no mundo, $5 \%$ dos entrevistados disseram que a empresa socialmente responsável precisa ter lucro. No Brasil, ninguém considerou esse ponto.

\section{Ação Social não tira família da pobreza, diz economista}

Entrevistacom pesquisador do IPEA-coordenador de avaliação de políticas públicas

FORA DO FOCO DA PESQUISA

52 Desafio é incluir os mais pobres

Andrea Vialli / OESP/ Economia

"A verdadeira Responsabilidade Social será incluir as pessoas de baixa renda no mercado", disse Stuart Hart, professor de administração da Universidade de Cornell, nos Estados Unidos e autor do livro Capitalism at the Crossroads (Capitalismo na Encruzilhada, ainda sem tradução no Brasil). Segundo Hart, o futuro da empresa e o do próprio capitalismo depende de um novo modelo de negócios, baseado na criação de produtos e serviços que garantam acesso ao mercado para quatro bilhões de pessoas que vivem com menos de US\$ $1.500 /$ ano.

\section{(...)}

Segundo Mario Monzoni, coordenador do Centro de Estudos em Sustentabilidade da Fundação Getúlio Vargas, as estratégias de inclusão da população de baixa renda e as políticas de responsabilidade social empresarial podem andar juntas desde que não tenham um viés assistencialista. Exemplo disso é quando uma grande empresa passa a treinar seus fornecedores de pequeno porte para que incorporem práticas socioambientais ao seu dia-a-dia.

Mas há quem discorde. O professor Jean-Pierre Lehman, do Institute of Management Development (IMD), escola suiça de administração, entende que inclusão da população de baixa renda e políticas de responsabilidade social são coisas distintas. Para ele as empresas ainda engatinham quando o assunto é direcionar suas estratégias para essa parcela da população. "As empresas têm que se adaptar de modo a atingir a população mais pobre, especialmente nas áreas rurais e nas periferias de grandes cidades". 
Foi o que o ABN Amro Real decidiu fazer, ao criar a Real Microcrédito, braço do banco destinado a emprestar dinheiro, a taxas de juros reduzidas, para microempresários nas periferias de São Paulo e Rio de Janeiro. [ piloto na favela de Heliópolis em 2002]

A discordância é concordante.

53 Capital Humano

Revista Supervarejo

Consultora do Instituto Qualidade de Vida

“É preciso abandonar a mentalidade de que somente retorno financeiro é importante. Em qualquer empresa, funcionários desmotivados e infelizes geram mais custos porque ficam doentes e comprometem o lucro" afirma.

54 Poder e Responsabilidade - Revista Imprensa

Entrevista com Helio Mattar, presidente do Akatu

Aborda a passagem do paradigma de produto para o "relacional".

Ao grande poder das empresas, corresponde grande responsabilidade.

O senhor acredita que este poder tenha motivado a RS e o ISP nas empresas brasileiras?

Todos aqueles que têm poder, acabam sendo percebidos pelas pessoas - e como pessoas - e eles têm que retornar à sociedade na mesma proporção do poder que têm. Por isso que tanto é esperado dos governos. Sem referência à democracia/ poder como fonte de propriedade /link com WG dos Santos

(...)

(...) Poder somado à visibilidade leva às empresas a não serem mais entendidas apenas como o produto que elas fabricam, mas como sendo um conjunto de relações e há de se saber se ela faz a diferença para os públicos com os quais se relaciona.

Este impacto é mensurado de que forma? Pelos investimentos? Pelas ações sociais?

A sociedade é influenciada pelas empresas. De certa maneira, aquilo que as empresas fazem, definem o $\underline{\text { mundo em que a gente vive. Se as empresas contratam mão-de-obra infantil, a gente vai viver num mundo }}$ que tem mão-de-obra infantil. Se a empresa disser não, lugar de criança é na escola, apoiar o desenvolvimento da educação, as crianças ficariam na escola e melhoraria a educação. E assim por diante. Isso é apenas para dar um único exemplo do poder levado a seu aspecto relacional, levado ás relações que as empresas têm.

55 Mais magros mais produtivos

56 BID vai treinar 120 empresas em responsabilidade Social 
Andrea Vialli

Parceria BID e Ethos/Escolha de "empresas-âncora" em diferentes setores

Programa será realizado por grandes companhias em sua cadeia de fornecedores e clientes.

"Queremos provocar uma mudança no comportamento de gestão". [ diretor Ethos]

57 Empresas conhecem a teoria da atuação social. Falta a prática

Andrea Vialli/ OESP/ Economia

Os executivos brasileiros estão bem familiarizados com os conceitos de responsabilidade corporativa, mas a prática ainda deixa a desejar. Foi o que mostrou um estudo conduzido em três setores da economia brasileira - papel e celulose, alimentos e bebidas e energia elétrica. A pesquisa foi feita pela escola de negócios suíça Institute for Management Development (IMD) e pela Fundação Brasileira para o Desenvolvimento Sustentável (FBDS), entidade sem fins lucrativos voltada à pesquisa.

15 empresas / cinco em cada ramo/durante um ano/ 84 executivos ouvidos/ parte de estudo maior mundial do IMD para mapear práticas de sustentabilidade.

$(\ldots)$

“Em linhas gerais, podemos dizer que a questão ambiental preocupa as empresas, mas a atuação social ainda carrega ranço paternalista. Muitas empresas ainda direcionam recursos para projetos filantrópicos" diz $\mathrm{CL}$, coordenadora do estudo da FBDS.

Cita "exemplo positivo" Instituto Sadia e captação de gases em criações de suínos / créditos de carbono

58 Organizações fazem parcerias para valorizar produtos da Mata Atlântica

Valor / Empresa \& Comunidade

Ong's que se organizam para fortalecer seus produtos e ganharem projeção de venda e sustentabilizar as comunidades e por conseqüência o ecossistema de onde é extraída a matéria prima para a produção local. FORA DO FOCO

59 A imagem do Bem (CHECAR)

Daniele Madureira / Valor / Empresa \& Comunidade

Profissionalização do terceiro setor chega ao marketing e entidades procuram se fixar como marcas sociais.

(...)

“Enquanto as empresas brigam pelo 'share of mind' (lembrança de marca) do consumidor, as organizações sociais estão disputando o 'share of pocket', ou seja, o pedaço do bolso do cidadão comum disponível para fazer doações" diz CG, sócio de empresa voltada à criação e coordenação de projetos de RS.

(..) 
Incrementar a sua rede de 88 empresas também foi um dos objetivos da primeira campanha da história do Grupo de Institutos, Fundações e Empresas (Gife) lançada este ano. Criada pela DM9DDB, a ação tem a assinatura "Gife 10 anos, ações sociais de resultado". "Nos últimos 10 anos, o terceiro setor verificou uma rápida expansão no Brasil, mas ainda falta ampliar a conscientização sobre a diferença entre assistencialismo e modelos planejados de transformação social", diz FR, secretário-geral do Gife.

60 Bancos criam fundos com critérios sociais e ambientais (Andrea Vialli/ OESP/ Economia)

Produtos politicamente corretos ajudam a melhorar imagem institucional

Os bancos têm investido em produtos e serviços identificados com medidas de RS e ambiental. Cinco instituições financeiras já lançaram fundos de investimento do tipo SRI (sigla em inglês para investimentos socialmente responsáveis).

\section{(...)}

Banco Real ganha prêmio (Box)

Líder em Sustentabilidade em mercados emergentes / Financial Times

“O mercado tem percebido que rentabilidade e sustentabilidade não são excludentes. É ótimo que outros bancos lancem esses produtos, pois legitima nosso caminho" diz Barbosa [Presidente do Real ABN Amro]. $\underline{0}$ banco tem 10 milhões de clientes.

(...)

A publicidade dos bancos reflete essa preocupação. Bradesco e Banco do Brasil usam conceitos de responsabilidade socioambiental em suas propagandas.

\section{Os santos do Capitalismo}

Marcio Aith e Giuliano Guandalini / Veja/ Especial

A doação do investidor Warren Buffett à fundação de Bill Gates é o maior exemplo de como o capitalismo americano consegue não só gerar riquezas astronômicas como também devolvê-las de forma solidária e produtiva à sociedade.

\section{(...)}

As ações filantrópicas de Gates e de Buffet jogam mais uma pá de cal sobre a balela marxista segundo a qual o objetivo do capitalismo é a concentração de renda e a exclusão do proletariado. Ao construírem sua fortuna, os dois ajudaram a elevar a eficiência da economia americana, enriqueceram acionistas e criaram empregos - para não falar da democratização da informação promovida pelos computadores pessoais difundidos por Gates.

$(\ldots)$

$\underline{\text { O gesto filantrópico de ambos não só se insere na lógica do capitalismo moderno, como também coloca o }}$ regime num patamar moral superior. O filósofo alemão Karl Marx, arauto do comunismo, previa o fracasso 
do capitalismo porque o sistema dependia da exploração crescente e infinita do proletariado para gerar lucros e produtividade. Segundo ele, como existe um limite para a exploração do trabalho humano, os lucros parariam de crescer, assim como a produtividade. 0 socialismo triunfaria. Tudo errado. $\underline{O}$ capitalismo não precisa de pobres como imaginava Marx, uma mente de terceira categoria que conseguiu enorme legião de seguidores no século passado por sua_pregação de natureza religiosa. Exige, isso sim, consumidores com dinheiro, boa formação educacional e vontade de ascender socialmente. O próprio sistema cria um círculo virtuoso de riqueza, como mostram os indicadores sociais dos países que liberalizaram sua economia (veja quadro na pág. 64).

Tríade: consumo/ "educação"/ empreendedorismo

62 Consumo, logo existo

Carta Capital / Gestão / coluna Thomaz Wood Jr.

(...)

Consumir pode ser um passo para a construção da cidadania. Em um trabalho recente, o Instituto Fernand Braudel revela histórias da vida de moradores da inóspita periferia da Grande São Paulo. No centro das narrativas, a ampliação da capacidade de consumo e o acesso a bens e serviços.

M.Santos - acesso

(...)

Uma coletânea recente - The Ethical Consumer (Londres, editora Sage) - coordenada por Rob Harrison, Terry Newholm e Deirdre Shaw, procura iluminar as várias faces do consumo e consumismo. A pedra fundamental é o conceito de "consumidor ético". (...) o consumidor continuará a considerar custo e qualidade, porém somará outras preocupações à sua decisão de compra.

(...)

O que nos reserva o futuro? Por hora, consumo e consumismo crescem com vigor. Os ativistas da causa estão a avançar na batalha publicitária, porém a guerra pelos corações e mentes dos consumidores está longe de ser vencida. Transformar consumismo em cidadania não é tarefa trivial. No entanto, o preço por $\underline{\text { não fazê-lo }}$ para a biosfera e para a sociedade, é alto.

\section{Business ethics}

Artigo filosófico que tem sotaques acadêmicos, não apresentando em seu núcleo o discurso das empresas a respeito da responsabilidade social. Faz um esclarecimento da história sobre Ética e Negócio, concluindo como um campo aberto para futuras reflexões sobre a idéia do negócio estar ligado a ética da vida. 
Presidente do IAS faz diagnóstico assustador da educação e mostra como enfrentar o problema.

“Na escola pública há quantidade sem qualidade. No terceiro setor é o contrário. O desafio é ter as duas coisas". (destaque box)

(...)

(...) Há 12 anos, quando comecei, o instituto atendia 40 mil crianças. Mas o que adianta atender 40 mil num universo tão grande?

A senhora não estava satisfeita?

Não conseguia ficar satisfeita. Por isso, mudei o posicionamento estratégico do instituto para desenvolver soluções a serem aplicadas em larga escala. É como se tivéssemos transformado o instituto em laboratório que desenvolve "vacinas" para diversos "males sociais".

\section{(...)}

É a implantação de uma cultura gerencial?

Exatamente. A escola agora trabalha com metas. É possível colocar quantidade e qualidade na mesma equação e construir um país para todos.

Antes não trabalhava?

65 Responsabilidade Social em Movimento

Amélia Gonzalez / Razão Social

Resultados de pesquisas com objetivo de traçar perfil do movimento de RS

$(\ldots)$

Pesquisas feitas desde 2001 e apresentadas na Conf.Internac. do Ethos

Segundo FE, diretor da empresa [de pesquisa], na opinião de mais de $80 \%$ dos entrevistados, as corporações tentam ser socialmente responsáveis apenas para melhorar sua imagem, não porque querem dar uma contribuição positiva para a sociedade.

O desafio, portanto, está concentrado na área da comunicação das ações empresariais, acredita Echegaray. Isto aponta para uma decisão crucial que cai nas costas das empresas: é melhor investir mais para se posicionar no mercado de maneira socialmente responsável ou usar o dinheiro para mobilizar a opinião pública?"

\section{(...)}

Resultados indicam etiquetas nos produtos e certificações do governo

Já a produção de um relatório Anual (Balanço Social) recebe um apoio menor do público com a melhor forma de comunicação: apenas $20 \%$. 
67 A máquina Verde

\section{Dinheiro/traduzido de Fortune}

Lee Scott, CEO do Wal-Mart, não é um militante ecológico, mas promete fazer do maior varejista do mundo um exemplo ambiental. Ele fala sério?

\section{[Al Gore em convenção do Wal-Mart]}

(...) Gore deixou uma mensagem: ao abraçar um ambicioso plano para adotar práticas de negócios que sejam melhores para o meio ambiente, disse ele, o Wal-Mart ensinará ao mundo que "não precisa haver conflito entre o meio ambiente e a economia".

\section{(...)}

A reputação do maior varejista do mundo (BOX)

Os grupos ambientalistas estão em paz com o Wal-Mart. Todavia, a empresa permanece como um grande alvo para líderes sindicalistas e ativistas liberais. Aqui estão os pontos em que os críticos estão se batendo -e o que o Wal-Mart está fazendo a respeito. Por Jia lyn Yang

Tópicos: salários/saúde/discriminação/ economias locais

(...)

O exemplo que vem do Brasil

Filial do Wal-Mart entra na onda verde e vira peça-chave na nova filosofia do grupo

(Darcio Oliveira)

Até bem pouco tempo atrás seria improvável ver em um mesmo evento executivos do Wal-Mart e representantes das ONGs WWF e Greenpeace - a menos que esse evento fosse num ringue de boxe. É que organizações ambientalistas costumam estar, invariavelmente, em lados opostos aos das grandes corporações. Os interesses não convergem. Ou melhor, não convergiam. Na semana passada os "inimigos" se confraternizaram em São Paulo num seminário que durou dois dias e teve como palco o auditório do hotel Clarion, em Alphaville. $\mathrm{O}$ assunto era sustentabilidade ou, dito de outra forma, discutir como o Wal-Mart do Brasil poderia se inserir na meta mundial do grupo de se tornar uma potência verde, preocupada com a saúde do planeta.

\section{$(\ldots)$}

Além das mudanças estruturais, a rede está repetindo no Brasil a filosofia de Scott na negociação com fornecedores: quem abraçar a causa verde terá a "simpatia" do Wal-Mart. E a simpatia do Wal-Mart em qualquer transação comercial vale ouro.

68 Balanço Social, para render bem

Andrea Vialli

Um estudo internacional realizado pela consultoria KPMG com 1.6 mil grandes empresas mostrou que $74 \%$ delas publicam relatórios de sustentabilidade (ou balanços sociais, como são mais conhecidos no Brasil) com 
objetivos econômicos - ou seja, tentam garantir com as informações socioambientais um diferencial para suas ações no mercado.

"Falta transformar a responsabilidade social em números e mostrar seus impactos na produtividade, nos

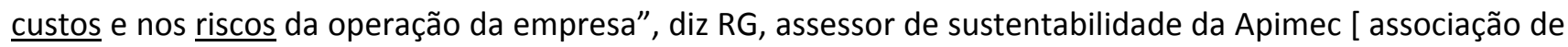
profissionais do mercado de capitais]

(...)

"Ainda há muito ceticismo quanto aos balanços sociais. Muitos analistas pensam que se trata de mais uma ação de marketing da empresa". [assessor Apimec]

69 Causa Social dá lucro a empresa

Andrea Vialli / Vera Dantas / Estratégia/ Economia \& Negócios / OESP

O Carrefour é a mais nova empresa a aderir ao chamado 'marketing relacionado a causas' (MRC). Nesse tipo de ação uma companhia apóia uma campanha, com o objetivo de melhorar sua imagem e vender produtos ligados à causa.

(...)

"O marketing relacionado à causa constrói uma imagem de simpatia para a empresa" afirma $\mathrm{CP}$, diretor de comunicação da Avon.

(...)

"Trata-se de uma parceria comercial, em busca do benefício mútuo. Se a empresa tem uma trajetória de credibilidade, só tem a ganhar com a ferramenta", diz. [sócio de consultoria especializada]

70 Mais empresas investem na área social (Revista Bovespa)

Entrevista com Anna Maria Peliano, socióloga/IPEA

Na entrevista a pesquisadora faz alguns apontamentos sobre investimentos sociais em projetos, valores $e$ motivos que levam as empresas a doarem ou investirem em projetos e como isso foi se modificando no Brasil. Cria uma relação com o quadro nacional e o internacional.

(...)

A grande concordância é que todas acham que é obrigação do Estado cuidar do social. Concordam com isso $81 \%$, mas a maioria acha que é papel delas também fazer alguma coisa pelo social.

\section{Ação Social ou puro Marketing?}

Andrea Vialli / Economia/ OESP

Levantamento Instituto QualiBest, especializado em pesquisa de mercado na internet

Segundo o estudo, o brasileiro está familiarizado com o tema responsabilidade social empresarial - $90 \%$ disseram conhecer o conceito - e acredita que as empresas que investem em projetos sociais devem divulgar 
isso em seus produtos ( $82 \%)$. Ao mesmo tempo, também tem uma postura crítica em relação aos objetivos da empresa: $33 \%$ acham que o interesse da empresa é vender mais, usando o projeto social como propaganda.

(...)

Para EKR, professor da FIA da USP, o cidadão comum está mais atento à atuação social das empresas porque percebeu que o governo não dá conta do recado.

[Ex-executivo que dá treinamento de gestão para ONGs] "Essa pressão é de fora para dentro. As empresas adotaram a responsabilidade social porque melhora a imagem e ajuda a construir uma marca forte", diz.

72 Responsabilidade Social na Sala de Aula

Marina Faleiros / Economia/ OESP

(...)

Para ela [profissional que fez MBA em Gestão de Empreendedorismo Social] as empresas estão muito interessadas em pessoas preparadas para a gestão social. As companhias que investem parte de seus lucros em um projeto querem ver o retorno disso, e exigem pessoas que entendam como devem ser geridos estes recursos.

(...)

"As empresas começaram a investir nisso e precisam de especialistas na área, que entendam como captar um recurso e dar resultado para quem doou o capital". [coord. curso FGV]

73 Negócios e Sociedade

Update

Segundo a mais recente pesquisa global do McKinsey Quarterly, a imensa maioria dos executivos ao redor do mundo concorda com a idéia de que o papel das corporações na sociedade vai muito além de simplesmente cumprir suas obrigações para com os acionistas. Contudo, esses executivos também afirmam que, para maior parte das empresas, as questões sócio-políticas - tais como meio ambiente e efeitos do offshoring apresentam riscos reais. Na verdade, eles afirmam que encontrar formas de controlar tais questões é tão importante que uma administração sociopolítica eficaz deve começar pelo CEO.

$(\ldots)$

Aceitando a RS

A grande maioria dos executivos no mundo todo acredita que as corporações deveriam equilibrar suas obrigações para com os acionistas e suas contribuiç̃oes explícitas "ao bem do grande público". No entanto, a maior parte deles vê seu envolvimento com o contrato social da empresa como um risco ao invés de uma oportunidade, e admite francamente que é ineficiente na administração de questões sociais e políticas mais amplas. 
74 Gestão para transformar

Empresa-modelo SERASA / Guia Exame Boa Cidadania

A Serasa procura adotar seu padrão interno de excelência no relacionamento com todos os públicos da empresa.

75 Estratégia para o Futuro

Empresa-modelo CPFL / Guia Exame Boa Cidadania

Qualidade e atenção aos públicos com os quais se relaciona são o caminho da CPFL para garantir a sustentabilidade.

76 Um banco e seus princípios

Empresa-modelo Banco Real / Guia Exame Boa Cidadania

Ao incorporar a preocupação com a sustentabilidade à sua gestão, o real tornou-se referência entre as instituições financeiras.

$(\ldots)$

O desenvolvimento sustentável deixou de ser um assunto reservado aos ambientalistas e chegou às empresas. FB - presidente do BR

77 Uma nova mentalidade

Empresa-modelo BASF / Guia Exame Boa Cidadania

A Basf que fazer com que funcionários em todas as áreas conheçam o impacto ambiental e social de seu trabalho.

(...)

Ainda há um longo caminho até que as ações sociais e ambientais da Basf estejam completamente integradas ao negócio. Mas o processo está evoluindo rapidamente.

78 Fazer o que? Contar Como? Caderno ESPM / EXPM? Artigo de LF

Falando em empresas: por um lado, temos hoje um conceito claro de que elas precisam atuar de forma transparente e cristalina na sociedade, e particularmente apontar a esta mesma sociedade suas formas de colaborar no desenvolvimento social; por outro lado ainda se vê - e muito!!! - uma forma de atuação parecida com que citei antes (a de investir mais na comunicação da ação do que na própria ação).

(...)

Síntese da conversa: na dúvida, contrate um especialista e analise com muito cuidado a questão, sob todos os aspectos. Pois atuar junto às áreas mais sensíveis da população exige cuidado ainda maior, uma 
preocupação ainda mais acentuada - pois estamos falando de vidas, de sustentabilidade, de futuro, e não só de negócios.

Minimiza a importância dos negócios/ defesa da vida/futuro

790 índice do Bem

administradores.com

As ações das companhias listadas no Índice de Sustentabilidade Empresarial (ISE) da Bolsa de Valores de São Paulo (Bovespa) estão ganhando a corrida da rentabilidade em relação às demais. De acordo com estudo da área técnica da Bovespa, os papéis das 28 empresas relacionadas na primeira edição do ISE subiram $28,8 \%$ nos últimos 12 meses, 3,54 pontos percentuais acima do acumulado no período do Ibovespa.

80 O negócio da Solidariedade

Maria Laura Neves/ Sociedade Filantropia/ Época

Caso da Fundação Monte Azul, que sofre com a "concorrência" de institutos empresariais.

Uma empresa socialmente responsável é aquela que tem condutas éticas, social e ambientalmente responsáveis com clientes, fornecedores, acionistas, funcionários, e comunidade onde atua. É uma condição que implica novas missões para as empresas, além de produzir e dar lucro. E que foi imposta a elas, sobretudo por pressão dos consumidores.

$(\ldots)$

“As empresas não estão preocupadas em resolver problemas sociais e ambientais. As ações de responsabilidade social ainda estão muito ligadas às questões de imagem no Brasil" diz presidente de Grupo O e Fundação $O$.

(...)

Mas a ação social de empresas também gera problemas. O primeiro é a competição por recursos. Os institutos empresariais recebem em primeira mão a verba que no passado ia direto para as associações filantrópicas tradicionais (...)

O segundo problema é a confusão de papéis entre o Estado e empresa. "À medida que o Estado deixa de cumprir suas funções de manutenção do bem-estar, as empresas começam a assumir esse papel" diz MAA, estudioso do terceiro setor da FGV-SP.

$(\ldots)$

"Ações de RS só aumentam os custos" diz o economista britânico David Henderson, autor do livro Misguided Virtue (algo como "virtude mal dirigida") com críticas contundentes à RS. De acordo com o economista Scheinkman [professor da Universidade de Princeton], também não cabe à empresa escolher as ações sociais em que deve ser investido o dinheiro do consumidor. "O ideal seria um sistema em que a ação filantrópica partisse do indivíduo", diz ele. 
810 Valor de uma cerificação socialmente responsável

Idéia Social

Para Débora Leipziger, responsável pela implantação da AS 8000 no Brasil, "as empresas começam a entender, mas ainda de forma muito lenta, que baixos salários, ambiente de trabalho ruim e o não cumprimento da legislação vigente são práticas que podem se transformar em lacunas na responsabilidade social se não forem cumpridas conforme determinados parâmetros.

82 A educação por todos e todos pela educação

Idéia Social

A co-relação entre educação e desenvolvimento talvez explique, em parte, a atenção mais recente de empresários e empresas socialmente responsáveis sobre o tema.

(...)

"A educação está se transformando em reivindicações de uma classe de empresários. E este é um cenário, sem dúvida, inédito no país. Ela vem ganhando status de prioridade nacional" afirma o ministro da Educação Fernando Haddad.

\section{Papel de empresas é criar modelos eficazes e replicáveis}

Sergio Mindlin, diretor-presidente da Fundação telefônica, compartilha do mesmo ponto de vista sobre o alcance da iniciativa empresarial. Em educação, nenhuma companhia tem porte para realizar uma ação generalizante. Este é definitivamente o papel do Estado.

(...)

O investimento social privado ajuda ou atrapalha a educação?

Cláudio de Moura e Castro

Economista, presidente de Conselho Consultivo de IES privada

Diante de sistemas educacionais pobres, mal geridos e pouco inspirados, os programas de RS das empresas sopram como uma brisa fresca. Afinal de contas, as grandes empresas são as vencedoras em mercados brutalmente competitivos. Quando decidem usar sua indisputável competência para ajudar a educação, isso só pode ser boa notícia. Mais ainda, a magnitude do seu esforço na área social é impressionante.

(...)

Um fator apontado pelos que estão próximos das escolas indica uma colisão de lógicas operacionais.

(...)

Portanto, a lição é clara. O investimento social privado é mais que bem-vindo, quando ajuda a educação. Mas quando desvia as atenções e os esforços ou está fora de sintonia com a escola, melhor seria se não existisse. Quando examinamos as fundações filantrópicas mais importantes, vemos muitos casos em que desenham seu programa para ajudar a escola nas suas tarefas mais nobres. Há programas lidando com os repetentes. 
Outros pescam os pobres talentosos, oferecendo a eles escolas de primeira grandeza. Há programas de gerenciamento de escolas municipais. (...) E muitos outros, dentro das organizações que compõe o Gife, por exemplo.

Mas infelizmente, nem tudo vai à direção certa. Há muito patrocínio para atividades que desviam a atenção da escola.

\section{(...)}

Já passamos a fase heróica e pioneira, quando a mera disposição de empresas para ajudar escolas era fato a ser automaticamente festejado. Justamente por vivermos em um momento onde tais atividades desabrocharam é que podemos ser um pouco mais críticos, notando que nem tudo o que está sendo feito ajuda tanto. Lembremo-nos, a causa é a da educação, não a de fazer alguma coisa na escola ou com os alunos.

83. When social issues become strategic (CHECAR)

84 América Latina: Cresce o interesse das empresas pela responsabilidade social empresarial Wharton/ Universia

(...)

As origens deste fenômeno cada vez mais comum remetem à necessidade dos empresários de melhorar seu vínculo com os diferentes setores da sociedade de alguma forma vinculados à vida da empresa; atenção pra com as demandas da comunidade, dos investidores, às vezes até por mera questão de moda ou desejo de maior exposição à mídia. $\mathrm{O}$ fato é que esse processo vem ocorrendo no mundo todo, e na América Latina há muito ainda o que aperfeiçoar nesse segmento.

“...a empresa que se preocupa com a RSE busca também satisfazer também a demanda de todos aqueles que, de alguma forma, participam da vida da empresa : acionistas, clientes, empregados, governo, sindicatos, fornecedores, etc".

85 Sustentabilidade em debate

Pierre Baldez / Jornal do Commercio RJ

4 a Conferência Negócios como Agentes para um Mundo Melhor (BAWB)

apresentação de casos de RS de mais de 40 empresas

O BAWB tem como objetivo disseminar ações bem-sucedidas de empresas lucrativas que beneficiam a sociedade. E, com isso, propiciar mundialmente negócios que geram a oportunidade de agir alinhado aos maiores interesses da humanidade e do mundo, enquanto, ao mesmo tempo, permite as companhias avançarem em crescimento e lucratividade. 


\section{FRAGMENTOS ARTIGOS 2007}

\section{Empresas Investem na História}

"Inspirada na responsabilidade Social - termo que definiu as práticas solidárias das companhias com as pessoas carentes e as comunidades -, a responsabilidade histórica é um conceito novo de benefício a sociedade" (jornalista)

\section{Hora da Civilização no Poder}

Valor (entrevista) Steve Rochlin - autoridade da área de RSC

"O que vemos hoje é que as grandes corporações entendem que para ter boa reputação e para serem vistas como bons negócios precisam começar a investir em atividades responsáveis e sustentáveis".

“Fornecedores em países menos desenvolvidos ou emergentes, que adotam princípios de sustentabilidade e responsabilidade social, são na verdade muito mais produtivos do que aqueles que não adotam essas práticas."

"O que vemos agora é um conjunto inteiramente novo de relacionamentos que na verdade modelam os princípios de responsabilidade social e sustentabilidade."

“Nos Estados Unidos um dos segmentos de consumo que crescem mais rápido é o que tem sido chamado de estilo de vida saudável e sustentável. Estima-se que há 40 milhões de consumidores engajados em comprar de companhias sociamente responsável e sustentável."

“...está emergindo uma consciência nova em termos de consumidores...

Os negócios sempre existiram para proporcionar soluções para grandes problemas e desafios da sociedade. Nós esquecemos isso.

"Existe um longo caminho a percorrer, mas agora o desafio para os negócios é estarem muito mais comprometidos em resolver os problemas da sociedade. E em fazer isso de um modo que os permita modelar as boas e sustentáveis práticas que o mundo precisa."

3 Atitude Responsável Influencia Estratégia de Comunicação

"Se as ações de responsabilidade social se tornaram parte efetiva da rotina das corporações, suas estratégias de comunicação e marketing também estão sendo modificadas por essa demanda."

"O motivo é claro: o outro lado, o consumidor mudou."

"Ninguém quer comprar um problema ambiental, um acidente de trabalho, a exploração da mão-de-obra infantil." (jornalista) 
“E eles já nos procuram para compartilhar dos nossos valores de transparência e clareza de informações, de comunhão com uma causa, uma vontade de melhorar o mundo e gerar negócios bons para todo o planeta." (diz Diretor de Marca B Real)

“...mostrando que as ações estão totalmente vinculadas aos negócios da companhia." (explica Dutra VP Unilever)

4 (3B) Natura é referência em relacionamento e preservação

"O olho no olho é o nosso melhor veículo e a estratégia sempre foi deixar que os outros dissessem que somos uma referência em responsabilidade socioambiental." ( diz executivo Natura)

“...trabalha em parceria com uma cooperativa de catadores de resíduos que beneficia mil pessoas, proporcionando aumento da renda mensal, capacitação, retirada de crianças de lixões, envolvimento em programas sociais de governo e assistência sanitária. (...) Todas as atividades estão sendo contabilizadas para que, em cerca de cinco anos, a empresa esteja com a conta de emissão de CO2 zerada." (jornalista)

\section{Escola Fundamental agora ensino empreendedorismo}

“Crianças a partir de seis anos já começam a aprender, em sala de aula, como avaliar oportunidade, ter próatividade e elaborar um plano de negócios." (jornalista M. Aragão)

\section{A era marquetique}

\section{Ricardo Voltolini}

Giles Lepovetski cunhou a expressão "Marketique" para designar o marketing ético, que reforça as marcas a partir de valores cultuados pela sociedade.

Segundo o especialista francês, uma empresa não pode mais apenas vender produtos. Precisa criar uma relação profunda com o público reforçando sua marca com base em valores cultuados pela sociedade. Neste sentido qualquer comunicação empresarial deve funcionar como reforço a um sistema de valores, integrando e utilizando a ética como vetor de legitimidade institucional."

Assim, daqui por diante, não bastará ao consumidor apenas saber o benefício entregue por um produto, nem só o tipo de imagem da empresa associada a ele. Importará cada vez mais captar a alma da marca. (jornalista)

7 Correndo na Pista da Educação (entrevista V. Senna IAS)

"Para chegar até aqui, adotei um gerenciamento que é o mesmo utilizado nas empresas: atuação em grande escala com foco em resultados."

"Há grande mudanças no desempenho do mundo empresarial diante do cenário social brasileiro. Acredito que o investimento social privado deve ser cada vez mais um investimento estratégico, comprometido com as ações em grande escala, capaz de dar conta deste enorme desafio de diminuir as desigualdades sociais. 
Vejo que em muitas empresas, a chamada responsabilidade social corporativa está cada vez mais saindo do marketing, da área de recursos humanos ou do campo de relações institucionais para ocupar um lugar mais digno: o coração e a mente dos líderes empresariais."

\section{Relação com Ethos}

\section{Corporações Verdes}

“Plante uma semente, regue com dedicação de deixe que ela crie raízes. Se fizer disso uma ação prioritária de sua empresa, pode ter certeza: seus negócios florescerão."

(jornalista - citação livre de "orientação objetiva e valiosa" de "gurus dos negócios" / dica)

E aquele que restringe o impacto de seu negócio aos resultados financeiros de cada fim de mês está fadado ao desaparecimento. Pelo menos é o que sentenciam os analistas. (jornalista/ seguido de citações diretas de consultores).

“Não é conveniência nem oportunismo. É visão estratégica. Os executivos compreenderam que existe uma relação de interdependência entre todos os atos de produção, o consumo, e o que ocorre na sociedade e na natureza". ( resumo do jornalista) seguida de citações de R Young e executivos

"Os consumidores vêem as corporações como agentes sociais e não apenas agentes de produção, e as punem por ato de irresponsabilidade ambiental, seja deixando de comprar os produtos, seja falando mal das empresas aos familiares e amigos". (Helio Mattar Akatu)

\section{Na era do Dinheiro Sustentável / JAMESON (link?)}

Se não por conviç̧ão, mas por puro pragmatismo e senso de sobrevivência. O motor dessa tendência (...): dinheiro.

"A falta de monitoramento do impacto das companhias no meio ambiente é vista como uma bomba em potencial para seus negócios - e pode vir a comprometer o pagamento de empréstimos no futuro" (A.L. Herzog - jornalista)

"Cada vez mais as instituições financeiras levam em considerações aspectos ligados a sustentabilidade antes de liberar financiamento para as empresas".

(entrevistas Suzano, Bertin, Real executivos)

"A sustentabilidade surge como tendência, mas a alma do capitalismo continua a mesma".(jorn.)

10 Educação: Pacto pela Qualidade

Artigo assinado por J.Gerdau.J.

Compromisso Todos pela Educação, lançado em 2006, é a consolidação dessa angústia da sociedade, resultado da atuação histórica pouco eficaz do Estado. 
Nós, lideranças empresariais, sindicais, acadêmicas e políticas, precisamos nos mobilizar e priorizar os investimentos na educação. Não podemos permitir que as iniciativas lançadas fiquem no papel, sob o risco de condenarmos o futuro de crianças e jovens pela baixa qualidade do ensino. Isso significaria também consentir em uma situação inaceitável - condenar o Brasil ao baixo crescimento e ao aumento da desigualdade social nas próximas décadas, o que atinge a todos.

O mesmo executivo FDP no Painel empresarial - "Atitudes positivas para enfrentar a crise" ABAP (Nov/2008)

O problema empresarial de geração e manutenção de emprego está na legislação trabalhista brasileira tremendamente inflexível. As lideranças sindicais têm um discurso uniforme: precisamos evoluir, mas não se mexe nos direitos adquiridos.

Tenho uma visão extremamente radical desse processo: ter o mínimo de obrigações estabelecidas e ter o máximo de flexibilidade de negociação.

A visão corporativa que existe na área trabalhista é proteger o coitado do operário, mas a capacidade política de organização do setor leva a estabelecer o máximo de flexibilidade em horários, em regime de trabalho em casa, fora de casa etc.

É impensável que uma legislação estabelecida na década de 30 regulamente as condições atuais do trabalho.

O contrato deveria ter meia dúzia de cláusulas básicas a se respeitar e o resto seria negociado, quase individualmente, porque os contratos coletivos estão fora da realidade. Sem flexibilidade não se constrói. Num pacto precisa-se de flexibilidade e remuneração variável em função da produtividade.

11 Os novos rumos da comunicação corporativa novo modelo de integração da comunicação para as empresas (afirma consultor estratégico de comunicação)

12 A Responsabilidade Socioambiental (Kleber Kuwabara)

Isto é, na hora de investir, cada vez mais irá fazer a diferença se a empresa respeita o meio ambiente e participa de políticas de inclusão social. Com o aquecimento do planeta as preocupações neste sentido tornaram-se mais urgentes que nunca, sendo até um despropósito deixar de lado essa abordagem.

O resultado é que para estar engajada no seu circuito mundial, a empresa deve cumprir essa lição de casa, para ter verdadeiro "grau de investimento (jornalista especializado em investimentos).

13 Além do Bem (Karina Padial)

Painel Ethos - Rede Ethos de Jornalistas

(referência a pesquisa Ethos/ ANDI - avaliou 54 jornais - "conteúdo existente na mídia sobre o tema é majoritariamente factual") 
Os dados revelam que os veículos de comunicação não tendem a uma contextualização mais consistente ou uma postura mais explicativa e opinativa; avaliação que também foi compartilhada por Nelson Niero - Valor Econômico: “Nós precisamos cobrir sustentabilidade de maneira mais crítica, investigativa, porque o jornalista não quer apenas vender o peixe da empresa, o leitor precisa de informações consistentes", ressalta.".

R.Young Ethos: Eu sinto que, como profissionais, individualmente, os jornalistas estão cada vez mais abertos. Mas até que ponto essas pessoas têm poder de influenciar e transformar os veículos em que trabalham?

14 Empresas ficam só no discurso da Sustentabilidade (Andrea Vialli)

Dados de estudo da FDC

Na prática, as empresas não estão conseguindo adequar seus modelos de negócios aos desafios do mundo contemporâneo (...) por isso, muitos programas de responsabilidade social continuam resvalando no assistencialismo e não aproveitam as novas oportunidades de negócios geradas pela crise.

“Aplicar a sustentabilidade à estratégia de negócio ainda é um tabu para muitas empresas. (...) As empresas ainda têm dificuldades de 'casar' as duas coisas" diz Cláudio Boechat coord. Núcleo de pesquisas FDC.

Para Paulo Itacarambi, diretor executivo do Instituto Ethos - a entidade que reúne mais de 1.000 empresas que se declaram engajadas com a responsabilidade social -, falta coerência as ações das empresas. (DI)

"Vemos grandes empresas de produtos de consumo com estratégias de inclusão dos mais pobres, mas que não tem, ao mesmo tempo, uma política para reduzir o impacto ambiental causado pelas embalagens", exemplifica.

15 Filantropicapitalismo, a nova ordem mundial (Cláudia Piche)

A análise é da russa Olga Alexeeva, uma das principais especialistas mundiais em investimento social privado. Cunhado por Mathew Bishop, editor do jornal The Economist, em Nova lorque, o termo filantropicapitalismo procura designar o que seria uma nova forma de fazer a filantropia.

Olga adota o conceito como uma espécie de definição guarda-chuva, que incorpora o investimento social e a responsabilidade social empresarial.

“Antes, no modelo tradicional, a intervenção social ocorria por meio de um testamento (...). um filantropo, um investidor social jovem, que quer fazer em vida, engajando-se na atividade e colocando todo o seu conhecimento de negócio na intervenção social". diz

Referindo-se a países como Brasil e Índia

“(...) Toda esta experiência reforça o seguinte quadro: as pessoas não têm a ilusão de que as empresas irão suprir o papel do Estado, mas ao mesmo tempo o Estado não atinge as expectativas da demanda social. Fica uma lacuna que nem a empresas e nem o Estado consegue suprir." acrescenta Olga. 
16 A Nova obsessão da Natura (Melina Costa)

Em seus quase 40 anos de história, a Natura tem sido guiada por duas obsessões. A primeira é sua notável capacidade de inovar. (...) A segunda é a sustentabilidade. Seus funcionários são treinados para pensar dia e noite em maneiras de preservar o meio ambiente ou de beneficiar comunidades de alguma forma afetada pelas atividades da empresa. Nos últimos meses, porém, as obsessões tradicionais deram espaço a outra, mais urgente - a agressividade. A palavra de ordem agora é aumentar a produtividade da companhia.

Num primeiro momento a Natura - afirma - não fará demissões. Mas, na prática, congelará as contratações. As mudanças num momento particularmente delicado para a empresa, (...)

(...)

Quem passava boa parte do tempo pensando no bem-estar das populações ribeirinhas e na conservação das matas ciliares esta sendo pressionado a entregar mais resultados. "Isso está mudando o clima na empresa", diz um alto executivo do setor de cosméticos.

(...)

Segundo EXAME apurou, uma consultoria especializada em coaching foi contratada para executar uma espécie de lavagem cerebral nos executivos. As sessões que são individuais e duram quase 2 horas, têm como objetivo incutir agressividade no comportamento da direção da Natura (a empresa nega que a contratação da consultoria seja uma reação aos maus resultados).

17 A Corrida por uma imagem Sustentável (bancos)

Cristiane Mano

“(...) o banco tem se esforçado para aproximar cada vez mais a sustentabilidade do centro de sua estratégia.

"Nunca tentamos usar o envolvimento do banco com assuntos ligados a sustentabilidade para promover nossa imagem e nem vamos fazer isso de maneira ostensiva." (VP MKT)

A movimentação do Itaú faz parte de uma ampla e acelerada transformação pela qual o mercado financeiro vem passando em todo o mundo. Poucos setores são tão organizados quanto o de bancos em relação à discussão sobre a sustentabilidade nos negócios.

Movimento geral do setor bancário, que no Brasil tem o destaque do Real ABN Amro, que desde 2000 iniciou movimento para colocar sustentabilidade no centro de seus negócios.

Cita o FT Sustanaible Banking Awards, do jornal ingles Financial Times. Prêmio que contou com mais de 100 instituições participantes de 51 países. HSBC premiado em 2006 por neutralizar 100\% das emissões de carbono de escritórios e agências em 2005.

(...)

Critérios como esse hoje são tão disseminados que se tornaram uma espécie de nova esfera da competição entre bancos em todo o mundo." 
(...)

O financiamento a pequenos empreendedores não tem apenas objetivos assistencialistas, segundo os executivos do Itaú. "Estamos desenvolvendo nossa estratégia de modo a não perder de vista o retorno financeiro da operação" diz Diretor

18 Projetos devem mudar e influenciar vidas (Caio Neumann / Idéia Socioambiental)

Especialista de Harvard diz que é o líder que dá o tom das ações sociais das empresas.

Elaborou caso sobre Fundação Bradesco

\section{Entrevista:}

Antes de a responsabilidade Social integrar as corporações, as empresas, assim como os indivíduos, doavam recursos para fins comunitários por espírito de caridade. Não se comprometiam com mudanças internas. Nem se preocupavam com os impactos dos fundos doados para a melhoria da qualidade de vida dos beneficiados. Nada era estratégico, tudo era pontual.

Que critérios devem ser utilizados para avaliar os impactos?

Um bom critério é o quanto o projeto está relacionado com as políticas públicas que tangenciam o problema.

(...) Outro critério é a capacidade de gerar solidariedade voluntária.

19 Prêmio vê' boas idéia e boas práticas' (Jacira Werle)

"Não há dimensão para a responsabilidade social".

“(...) várias ações podem ser práticas de responsabilidade social."

"As empresas perceberam na premiação uma oportunidade de divulgar as boas ações que estão fazendo para a sociedade". (Pres. júri MKT Best empresário)

\section{Os mais conscientes}

Cada vez mais aumenta o grupo de empresas brasileiras interessadas em contribuir para ações voltadas à preservação do meio ambiente e á redução das desigualdades de distribuição de renda no país. Conceitos como sustentabilidade e inclusão social já passam a integrar o vocabulário diário dos executivos nas grandes corporações. Os consumidores, por sua vez, começam a identificar essas iniciativas socialmente responsáveis.

Estes casos apontam para uma atuação entre empresas e resultados sociais, existe uma aproximação entre estas empresas, o papel do Estado (omisso), e atuação da empresa na qualidade de vida das pessoas... o campo da responsabilidade social é imenso do ponto de vista estratégico, estes cases são um bom exemplo desta idéia... O que a cidadania tem a ver com: a ação da empresa, as pessoas atendidas, os resultados alcançados (do ponto de vista mercadológico). 
21 Responsabilidade Social Ganha papel central a estratégia da empresa (Andrea Vialli)

Para presidente do Instituto Ethos, porém, isso não significa que os grupos já sejam socialmente responsáveis.

O movimento global de sustentabilidade nas empresas deverá seguir quatro grandes tendências nos próximos anos, de acordo com estudo realizado pela consultoria britânica SustainAbility. (...) divulgado na Conferência Internacional do Instituto Ethos.

O estudo (...) modo como as empresas estão incluindo as questões sociais e ambientais nas suas estratégias de negócios, (...) e mostra que há quatro principais cenários. Em um contexto, a sociedade consegue entender às demandas sociais sem degradar o meio ambiente. Em outro cenário, há ganhos ambientais, mas a população mais pobre não se beneficia, pois há retração da economia. Em outra projeção, as demandas sociais são atendidas, mas aspectos ambientais são deixados de lado. No quarto cenário, nem as demandas sociais nem o meio ambiente conseguem avanços significativos.

"Responsabilidade Social empresarial não é um fim em si, e sim um meio de se chegar à equidade social, preservação ambiental e geração e distribuição de riqueza." (Aron Cramer Business Social Responsibility BSR)

\section{Pressões Sócio Ambientais}

"Coitados de vocês"

É isso que John Elkington, fundador da consultoria Sustainability, tem a dizer a CEOs que ainda não acordaram para os desafios da sustentabilidade no século 21 .

(Cynthia Rosenburg)

No cenário otimista, as pressões são contornadas - mas não sem que, antes, o mundo se confronte com uma espécie de choque global. No que diz respeito a atuação das empresas, uma das principais conclusões é que a responsabilidade social tradicional era ineficaz diante das novas forças.

Terão chances as que conseguirem inovar em seus modelos de negócios e encontrar soluções de mercado reais para os grandes problemas que o mundo enfrenta. DI especialista

Na última década, as empresas criaram departamentos de RS, publicaram relatórios socioambientais e passaram a conversar com os stakeholders. O problema é que muitos dos temas que perceberam como sendo questões 'de cidadania' eram, na verdade, profundamente estratégicos - e foram parar nas mãos de pessoas que não tinham relação alguma com os conselhos de administração. Isso é muito perigoso.

\section{Z3Açãoestimula oexercício da cidadania}

Este artigo possui uma relação mais voltada para uma idéia de publicidade de uma classe que sente prejudicada e quer se valer deste direito de se indignar (núcleo restrito de indignados) 
Artigo relaciona as questão ao negócio, obedecendo a critérios e princípios, dentro da cadeia "estratégia". Ele discute alguns desafios de área. Relaciona as políticas públicas com os desafios ... Cidadania $e$ responsabilidade de quem?

Pesquisa comandada por Cláudio Boechat

Núcleo Andrade Gutierrez de Sustentabilidade na Fundação Dom Cabral/ AccountAbility

(...) os pesquisadores desenvolveram o conceito de "competitividade responsável".

Índice de Responsabilidade Corporativa Nacional.

Índice de Competitividade Responsável (ICR)

Os principais resultados comprovam uma relação forte entre o grau de RS das empresas de um país e a competitividade nacional.

No mapa de desafios da sustentabilidade, aparece, no tópico "Cidadania" (último de 31), o desafio do "baixo engajamento das pessoas na garantia do cumprimento dos seus direitos e deveres como cidadãos".

No momento em que os temas sustentabilidade e responsabilidade corporativa são tão citados no meio empresarial, muitas vezes associados à excelência gerencial, pode-se indagar sobre até que ponto convergem as duas agendas - do desenvolvimento sustentável e da estratégia empresarial.

25 Responsabilidade Socioempresarial: vantagem competitiva

(artigo assinado por consultor)

Falar de Responsabilidade social não é algo tão novo assim. Muitos empresários já estão engajados nesse novo modelo de gestão em função do peso que esse assunto tem assumido em seus negócios. Antes de tudo, responsabilidade socioempresarial se refere a uma postura, uma forma de conduzir as atividades empresariais. É, portanto, muito mais do que simplesmente realizar ações sociais pontuais ou de cunho assistencial.

A responsabilidade socioempresarial nasceu com o intuito de garantir à sociedade condições favoráveis de sobrevivência, muito pela incapacidade do Estado em prover isso de maneira equilibrada e adequada,

(...)

O lucro empresarial é imperativo e deve ser exigido das empresas, porém, deve ser entendido como meio, energia, combustível que permitem à empresa atingir seus objetivos, sua missão.

\section{(...)}

A capacidade de gerar riqueza de uma empresa, como agente econômico, passa a ser cada vez mais, fundamentalmente dependente de sua aprovação social, (...) Isso quer dizer que, sem aprovação social, a capacidade comercial tende a ser comprometida".

(...)

Podemos concluir que o grande objetivo de uma empresa não é garantir o lucro aos seus acionistas, mas, sim, existir e persistir. 


\section{0 social como estratégia}

Desenvolvimento sustentável e pacto social fazem parte da estratégia da empresa para os próximos anos. “Acreditamos que é preciso mexer na base da pirâmide. Já estamos na maioria dos lares, principalmente nos das classes A, B, C. Para viabilizar o crescimento da empresa, também precisamos garantir nossa presença nos lares das classes D, E". (Elaine Molina Gerente RS Unilever)

27 Código de Ética e Responsabilidade Social (Lúcia Rebouças jorn)

Dados da I Pesquisa sobre Códigos de Ética no Brasil

500 empresas. 63,4\% afirmaram adotar práticas de RS. Apenas 22,4\% disseram ter Código de Ética e 24,4\% balanço social.

(...) questionamento sobre o que é verdade e o que é mero marketing entre as práticas alardeadas na mídia pelas empresas. Uma visão unicamente "marketeira" nessa seara precisa ser revista ou vai acabar saindo caro.

A imagem da empresa que não entrega o que promete ficará no mínimo chamuscada no mercado financeiro e no consumidor.

Adotar código de condutas éticas ajuda a empresa a criar um espírito de equipe que aumenta sua rentabilidade, a fidelidade dos colaboradores, enfim, intensifica o vínculo entre ela e seus participantes.

\section{Futuro Responsável}

Dados do levantamento pesquisa Ibope "Sustentabilidade: Hoje ou Amanhã?" levantamento em julho 2007 com homens e mulheres (+16) ABC e entrevistas com 537 executivos de 381 grandes empresas nacionais. 79\% dos executivos e 55\% dos cidadãos já ouviram falar de sustentabilidade empresarial.

somente as marcas que fazem um trabalho baseado nesse pilar é que vão sobreviver no futuro".

“As marcas recebem influências de vários fatores diretos e externos. Elas devem se preocupar com idéias de sua época, com o momento histórico. E a responsabilidade social faz parte do atual momento histórico pelo qual o mundo passa". afirma (profissional de comunicação/ eco discurso FHC)

Joyce acredita que investir em ações socialmente responsáveis é mais do que simplesmente uma boa ação. Pode gerar negócios para a empresa.

29 Ação Social é só relações Públicas (entrevista com especialista Robert Reich - credenciado pelo mercado e pela academia)

A responsabilidade Social é uma questão de relações públicas. As empresas não foram criadas para ser instituições de caridade. $E$, hoje, elas têm menos condições ainda de desempenhar esse papel. Vivem numa competição tão acirrada que não podem sacrificar os ganhos de seus acionistas ou deixar de oferecer bons 
negócios para os consumidores em nome de algum benefício social. É ilógico fazer isso. Cria a falsa impressão de que as empresas são pessoas, com uma preocupação moral. As empresas não são pessoas. Nem instituições morais da sociedade. São pedaços de papel, acordos contratuais. O objetivo das empresas é jogar o jogo econômico da forma mais agressiva possível.

\section{(...)}

Se ajudarem, de fato, as empresas a aumentar seus lucros, então elas são práticas de boa gestão. Neste caso as empresas já deveriam fazer isso de um jeito ou de outro."

(...)

As empresas não devem satisfação aos çidadãos, mas sim a seus acionistas. (funcionários, consumidores categorias da cadeia produtiva)

30 Uma campanha com Gol de placa

(case redigido por executivos de empresa)

Era preciso estreitar os laços com o consumidor de forma impactante e abrangente, considerando que a companhia está presente em todo o Brasil, comercializando cerca de 1.400 tipos de produtos, de leite em pó a sorvetes, de barras de cereais e chocolates a ração para animais de estimação.

3110 mandamentos \& 7 pecados capitais da comunicação corporativa

Matéria elaborada a partir da consulta a "dez maiores nomes da área". ( executivos e consultores da área de comunicação corporativa, citados ao longo do texto)

LEAD

Em tempos de competição feroz, uma boa imagem é questão de sobrevivência. (Darwin link)

Diante de uma lista crescente de produtos e serviços (...) o consumidor terá de usar algum critério para fazer sua escolha. Hoje é consenso que os valores intangíveis da marca, como boa imagem, responsabilidade social e ambiental, pesam cada vez mais nessa decisão.

(...)

A responsabilidade social é tida não como uma ferramenta de marketing, mas como uma necessidade. As empresas que querem se manter onde estão têm de oferecer à sociedade mais que seus produtos. No entanto não dá para ficar só no discurso. Gastar mais com publicidade que na ação social é em si inadmissível.

“A responsabilidade social precisa ser verificada não só no âmbito da comunicação, mas sim pelos impactos reais" alerta P. Itacarambi I. Ethos. (reais = econômicos = cadeia produtiva)

$(\ldots)$ 
A distância entre o que se diz e o que se faz está cada vez menor, observam os comunicadores. É um grande risco vender uma imagem que não corresponde a realidade. Por exemplo, uma organização que patrocina projetos sociais, mas usa mão-de-obra irregular em suas unidades.

\section{CORTADO}

33 A expansão do mercado Brasileiro (Daniela de Fiori e Paulo Mindlin)

Estrutura de caso (descrição de objetivos, metodologia e resultados de ações sociais/ambientais do W-Mart) Ao mesmo tempo em que os grupos beneficiados melhoram a qualidade de vida da sua família, eles influenciam todo entorno. Impactam positivamente também para a unidade Wal-Mart, com redução no índice de criminalidade e aumento da segurança para seus clientes.

\section{(...)}

Para que os projetos tornem-se sustentáveis e respeitem as diferenças regionais, o Instituto Wal-Mart associa-se ou contrata entidades locais que já estejam envolvidas com as comunidades e tenham experiência na capacitação de grupos. A gestão e acompanhamento dos projetos recebem a expertise dessas parcerias e os resultados tornam-se mais efetivos.

(por antonímia, os grupos são, originalmente, tidos como incapazes - de consumir, gerir sua vida econômica) Depois de treinados/ capacitados/ "empoderados"/ podem andar com as próprias pernas (dentro da trilha pré-definida).

Ensina-se um caminho das pedras. Mas as pedras e os caminhos possíveis são muitos.

\section{(...)}

A missão da rede Wal-mart é melhorar a qualidade de vida das comunidades em que atua. Para isso, além da política comercial de "Preço Baixo Todo Dia" (Every day low price), que tem em si o conceito de "vender por menos para as pessoas viverem melhor", a rede tem a preocupação de investir na área social, canalizando recursos financeiros e humanos para o aprimoramento do relacionamento e o desenvolvimento das comunidades onde atua.

34 A força das marcas éticas (Ricardo Voltolini)

Dados de Pesquisa Ipsos encomenda CIESP "Indústria e Empresários na Opinião da Sociedade" mil pessoas/ 70 municípios

Troca dos primeiros lugares "Investir no Brasil" (de 40 para 33\%) e "RSE" (de 37 para 40\%)

Texto associado a casos de empresas.

A conclusão, inequívoca, reforça resultados de outros recentes estudos e também a impressão de quem trabalha com o tema: especialmente nos dois últimos anos (2006/2007), RSE começou a sair do círculo de especialistas, como se fosse uma seita de iniciados, deixou de ser assunto aleatório na percepção do 
brasileiro e se transformou, de fato, em uma preocupação - aqui, claro, caberia relativizar o nível de entendimento do entrevistado sobre a matéria; mas ainda que seja superficial, reagir positivamente a ela em uma pesquisa de opinião pública demonstra, no mínimo, familiaridade com o termo e com as idéias que comporta.

\section{(...)}

(...) afinal, constitui, em si, ato de responsabilidade social empresarial investir em um país no qual o desemprego impõe-se como grave problema social e um entrave ao bem-estar e desenvolvimento. Mas para

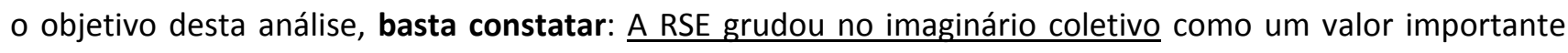
associado à melhoria da qualidade de vida das pessoas, do país e do planeta.

35 A mãe de todas as responsabilidades (autor não explícito / coluna site)

A empresa que tem a intenção de se perpetuar no mundo de hoje, com vistas para o futuro, deve inescapavelmente legitimar suas atitudes, ações, posturas e, especialmente, ter consciência de dar conhecimentos dos impactos de suas atividades no passado, no presente e no futuro em diferentes níveis, do comercial ao social. Aquela historinha mal-contada ou a varrida do lixo para debaixo do tapete já não são aceitas e colocam qualquer organização em risco.

Em risco de, peremptoriamente, sumir do mapa.

(...)

Mas para que haja sustentabilidade e para que a organização obtenha êxito na sua legitimação perante a sociedade, é preciso recorrer à mãe de todas as responsabilidades, aquela que pariu a RSE e a própria sustentabilidade, ambas citadas por 10 entre 10 empresários. A convergência das responsabilidades empresariais se dá sob o guarda-chuva da Responsabilidade Histórica Empresarial, que reúne responsabilidades comercial, legal, ambiental, cultural, social etc.

(...) é um conceito sistêmico (...) nos provoca a olhar para trás e para frente (...)

Para conhecer uma empresa (...) é preciso olhar sua trajetória no tempo, na perspectiva histórica, que contém todas as suas responsabilidades cumpridas ou não.

36 Avançar ou perder a dianteira (Aline Ribeiro e Ricardo Corrêa fotos)

Referência à linha Ekos, lançada em 2000

Além da mensagem de originalidade e sofisticação, os sabonetes, óleos e xampus carregavam outra, talvez ainda mais importante: a de que a Natura sabia fazer negócios de mãos dadas com a natureza. As vendas cresceram rapidamente e a linha ajudou a consolidar, na mente dos consumidores, a imagem ecológica e socialmente responsável da Natura

(...) 
Agora com a onda do marketing verde provocada pelo aquecimento global, empresas de todos os setores de bancos a fabricantes de produtos de limpeza até roupas íntimas - tentam se apropriar da causa. Isso coloca a Natura numa posição de prisioneira do próprio pioneirismo. Ou ela prova que consegue levar seu compromisso socioambiental a novos patamares ou corre o risco de ter suas ações vistas como insuficientes.

(...)

Crescimento + Sustentabilidade é uma equação que nem a Natura nem nenhuma outra empresa consegue hoje elucidar. "Quando a meta é crescer e crescer, em algum momento a expansão provoca um impacto ambiental maior", diz Giovanni Barontini (consultor de sustentabilidade)

(...)

“A discussão dos impactos ao meio ambiente está cada vez mais presente na área de inovação. Foi pensando nisso que a Natura uniu as duas coisas" diz Bronès (francês, gerente de impactos ambientais)

"Com suas embalagens, a empresa espalha milhões de toneladas de resíduos pelo Brasil todos os anos, sem nenhum programa consistente de reciclagem". (afirma consultor especializado - não identificado).

(...)

No passado a Natura estudou a criação de um projeto de logística reversa (...). Desistiu do sistema porque seria caro demais. Agora decidiu tentar novamente. (parceria com ONG de catadores de rua no Recife)

37 Cio da terra (Paula Grinover) referência a C. Buarque LEAD

A degradação acelerada do meio ambiente saiu do círculo de discussões acadêmicas, disparando o alerta vermelho de governos e da sociedade organizada. O mercado corporativo, sensível ao tema, começa também a erguer a bandeira da sustentabilidade.

(texto permeado de citações de acadêmicos e casos de empresas)

A responsabilidade socioambiental deixou de ser uma boa ação de grandes companhias ou atitudes de

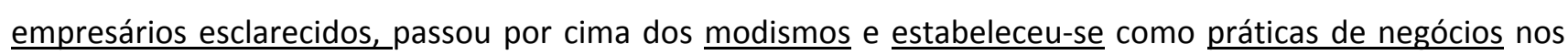
últimos anos. Hoje é questão básica de sobrevivência no mundo corporativo e se mostra fundamental para a continuidade do homem na Terra, diante de previsões cada vez mais terríveis sobre mudanças climáticas e degradação ambiental. Darwin / laborans

(...)

"Sustentabilidade não é apenas um mote para comunicação. Mais do que falar, queremos fazer. Expressamos o que de fato é imagem com correspondente na identidade" pontua FM diretor de estratégia de marca do BReal

“É nosso jeito de ser e fazer negócios, é como queremos ser vistos, temos centenas de ações ecoeficientes, usamos esses critérios em decisões de crédito e, nos últimos anos, estamos dando densidade a essa visão, que é estratégica e não simplesmente marketing.(...)" 
38 Como anda a emergência do capitalismo ético no Brasil? (Samyra Crespo/AKATU)

Em artigo recente (...) exploramos a idéia de que o socioambientalismo (...) não podia ser considerado anticapitalista.

Ao contrário, argumentamos, o movimento predominantemente no campo da sustentabilidade, isto é, o mainstrean, mostra um vigoroso fascínio pela idéia de que o mercado - portanto os mecanismos econômicos- podem contribuir com maior rapidez, escala e eficiência para que as sociedades de um modo geral, e brasileira dentro deste conjunto, possam dar as respostas que exigem os atuais desafios de ordem global, Estamos falando da pobreza e estamos falando dos problemas ambientais.

\section{(...)}

[...] a tradução dos negócios em uma economia que se conecta cada vez mais com condicionalidades sociais e ambientais é fisiologia da economia/negócios sustentáveis. E a existência dessas condicionalidades é a alma do capitalismo ético.

(...)

Evidentemente, não estamos falando que todas as empresas limparam sua produção ou aderiram a tecnologias mais brandas. Mas no mundo dos negócios, sabe-se que essa é uma tendência inexorável, e quem não proceder, estará morto em poucos anos.

Naturalmente, a modernização ecológica da economia se deu a partir do efeito catalisador - e civilizatório de um movimento social combativo, antecipador, como foi o ambientalismo com as respostas das políticas públicas e dos estados nacionais.

Mas o capitalismo ético é mais do que boa política ou boa prática de "comando e controle" (Discurso citado), ele é auto-consciência, ele é transformação de relações sociais, ele é possibilidade de novas configurações econômicas, de uma nova economia. É a possibilidade concreta de fazer desenvolvimento sustentável. REPETIÇÃO / CIDADÃO GIDENS

\section{(...)}

Há um otimismo no ar, só atenuado pela preocupação alarmista, mas real, de que o aquecimento global, talvez nos exija mais do que respostas capitalistas. Mas essa é uma outra história. (abertura abstrata para outros caminhos/ameaça velada?)

39 Consciência Ambiental ganha espaço nas corporações

Muitas delas já perceberam que além, de ser responsáveis com o ambiente em que estão inseridas, diante da percepção de que podem economizar gastos e garantir a existência dessas fontes de recursos minerais no futuro, precisam também conscientizar seus empregados e envolvê-los nessas ações para que a iniciativa gere frutos. As ações contribuem, inclusive, para tornar a empresa mais atraente aos olhos dos seus colaboradores. 
40 Consolidando a empresa cidadã (CASE SABESP)

Pode-se dizer que isso faz parte do seu DNA, de empresa de serviço público com atuação num setor diretamente ligado à saúde, à qualidade de vida, e à preservação do meio ambiente

(...)

O objetivo é consolidar a responsabilidade social como parte da estratégia da empresa, ressaltá-la como uma finalidade integrada ao negócio e torná-la um vantagem comparativa no mercado, reconhecida por clientes, acionistas, governo, investidores e pela sociedade em geral.

41 Consumo consciente: o que muda nos negócios (Supermercado Moderno)

Ela não compra por impulso, só leva o que vai consumir. Quer saber a origem do produto e recusa artigos sob suspeita de produção com mão-de-obra escrava.

Esse horizonte não é fruto da imaginação de militantes sonhadores, mas de evidências reveladas por pesquisas.

42 Consumo Responsável (retranca "Rumo ao Primeiro Mundo") Natalie C. Consani

Cita pesquisas inSearch e Akatu 2006 sobre consumo e ações de supermercados

Esse horizonte não é fruto da imaginação de militantes sonhadores, mas de evidências reveladas por pesquisas.

Referindo-se a hábitos de consumidores (de diferentes faixas de renda) que passam a incorporar preocupações com impactos ambientais e sociais

\section{Democracia Moderna}

FHC citado por Merval Pereira

A centralidade da pessoa, o deslocamento do coletivo ao individual, são características de nossa época que se refletem no funcionamento da Justiça e que tem conseqüências no funcionamento da democracia moderna, destacou. "Mas não estamos voltando ao liberalismo clássico, e sim ao individualismo com responsabilidade social"

O conceito de "RS" que hoje é inerente ao capitalismo moderno, "é a aceitação de que as ações não dependem apenas do governo, de que todos nós, como seres humanos, temos responsabilidade pelo estado do planeta".

44 Firme compromisso com o Social (CASO de empresa) 
[...] a White Martins, como empresa socialmente responsável, confirma suas expectativas em relação a essa nova estrutura de investimento social, que certamente, tornar-se-á uma prática adotada por outras empresas.

45 Marketing e Meio Ambiente - Gestão Integrada

É tendência a citação do meio ambiente e da responsabilidade social como a mais moderna forma de transmitir correção e dignidade humana.

Muitas empresas utilizam-se dos termos para tentar buscar nova identidade de marca para competir em melhores condições que seus concorrentes e abrir uma frente geradora de opinião favorável, que é a atenção e o cuidado no desenvolvimento social.

(...)

Cidadania e conservação de meio ambiente não é só uma questão de moda. É um esforço duro, focado nos consumidores e nos produtores de bens e serviços que orienta o consumo, que reconhece o ciclo completo dos produtos que fornecem oportunidades de crescimento sustentável.

(...)

Cabe aos profissionais de marketing, os quais protegem os sistemas produtivos dentro de suas mais variadas especialidades, educar seus consumidores, alertando-os, envolvendo-os e convocando-os para que, cada vez mais, exijam a garantia de produtos e serviços mais aperfeiçoados e mais condizentes com a modernidade de consumo.

46 Lucro! Que mal há nisso? (Francisco Riga - BANAS)

É o efeito "bola-de-neve": a vantagem do lucro "empresarial" é revertida na contribuição para que outras pessoas possam ter acesso ao "lucro individual", caracterizado pelo emprego ou benefícios sociais. Os programas de RS desenvolvidos pelas empresas são exemplos vivos. A prática não contribui apenas para a própria corporação que tem redução na carga de impostos ou para proporcionar um melhor relacionamento com os clientes ou os seus acionistas, mas também para elevar a qualidade de vida na comunidade a qual está inserida.

A promoção de trabalhos e atividades para minimizar a desigualdade social e a proteção ao meio ambiente também é um bom exemplo de compartilhar os lucros e trazer benefícios para a sociedade, além de desenvolver a sustentabilidade do próprio negócio.

(...)

Todos devem comemorar a geração de lucros de uma empresa. Afinal, basta refletir: todos perdem com o prejuízo! (quanto e como não é explicitado)

47 Inserir ou não a responsabilidade social na propaganda de marca? Eis a questão. (Idéia Social) 
matéria com depoimento de publicitários/ e executivos de empresas

Baseadas na idéia de que cada dia mais os clientes desejarão fazer negócios com empresas humanas, solidárias e éticas, que pensam e agem como eles próprios, agências de propaganda começam a criar campanhas nas quais não se vende produto nem serviços, mas os valores de responsabilidade social de uma empresa.

Mas existe hoje - ressalta - uma espécie de "modismo do poder do bem" que se caracteriza por um uso inadequado da responsabilidade social na propaganda corporativa sem o respaldo de uma prática efetiva no cotidiano das operaç̃os de negócio. Luiz Lara (publicitário)

Se as empresas praticarem efetivamente, o que dizem, acho muito natural que queiram comunicar. $O$ que não pode é comunicar sem a prática. Luiz Lara (publicitário)

Os entrevistados de IdéiaSocial foram unânimes no repúdio à idéia de se apropriar dos valores da responsabilidade social empresarial como mero suporte ao discurso de marketing da empresa.

48 Menos Marketing mais ações (JB Ecológico Sergio Amoroso)

Subtítulo: Como o empresariado brasileiro começou a entender o seu papel social e ambiental.

O estudioso norte-americano Lester Salamon, da Universidade de Hopkins, já vem apontando há algum tempo que a responsabilidade social não surgiu por simples benevolência empresarial, mas, antes de tudo, pela necessidade crucial de estratégias de melhoria das condições de vida das pessoas que trabalham nas empresas e, também, de soluções para problemas da comunidade em que elas estão inseridas. É importante ressaltar que isso não pode se confundir com marketing, mas com o papel do empresário como transformador social e da empresa como seu instrumento.

A linha mestra das ações sociais deve nascer de uma visão profunda da relação de interdependência "governo-empresa-homem-natureza". Pode-se entender essa ligação como um ciclo natural, uma cadeia de ligação: este é, sim, o princípio verde que deve ser cultivado.

49 Mídia e a consciência dos consumidores (Rodrigo Lóssio)

Dados de pesquisa Akatu 2005 sobre consumidor.

(...)

“A mídia tem um papel crucial não só na transparência no que ocorre em relação às empresas e ao governo, mas também pelo conteúdo e pela mensagem que veicula, ajudando a educar ou a deseducar os consumidores", destaca o gerente de projetos especiais do Instituto Akatu, AB.

(...)

Conseguir que os consumidores percebam as ações de responsabilidade socioambiental que são feitas é um grande desafio para as empresas brasileiras. 
50 Não é fácil ser verde: o ambientalismo pode ajudar na imagem de sua empresa, mas será capaz de mantêla no azul? (Wharton Universia)

Cita relatório IPCC (painel intergovernamental sobre mudança climática com referência a provas "inequívocas" do aquecimento global.

Depoimentos de professores e pesquisadores da Wharton

As pesquisas mostram que, em um mercado competitivo, a percepção de que uma empresa é socialmente responsável pode ser um ponto de diferenciação para o consumidor, porém deve ser um elemento sincero, profundamente arraigado na cultura corporativa, diz Kahn (professora de MKT da Wharton)

(...)

Subtítulo Estratégia proativa (cita empresas como W-Mart)

Além disso, muitas companhias estão privilegiando as soluções ambientais em face de regulamentações mais severas.

51 Não cometa os mesmos erros. Insucessos na implantação de programas de responsabilidade social empresarial (Fabio Rocha) IETEC

Texto prescritivo com erros destacados por especialistas

A busca desesperada das empresas pelo "selo" de empresa cidadã tem levado-as a equívocos tão significativos que a própria não adoção de práticas de responsabilidade social empresarial.

Quando estas empresas fazem parte de setores de altíssima competitividade, isto se agrava, pois, seus concorrentes já realizam ações sociais e assim elas não podem esperar muito tempo para atingirem o título de uma empresa socialmente responsável.

52 O Futuro é Verde (19 set. 2007)

Entrevista presidente da Costa Rica (concedida a Duda Teixeira PA VEJA)

LEAD

O presidente da Costa Rica diz que só a educação tira a América Latina da pobreza e que é possível, sim, conciliar preservação com desenvolvimento.

(tom de exemplo a ser seguido / resposta aos que não acham possível)

Veja- Historicamente, o crescimento aconômico foi sempre acompanhado de devastação ambiental. Como um país em desenvolvimento como a Costa Rica consegue proteger tão bem a sua floresta tropical? enquanto o Brasil não consegue

Não temos opção. O desenvolvimento futuro será verde ou não se realizará. Precisamos cuidar de nosso principal tesouro, que é a natureza para continuar habitando este planeta. 
Entrevista com Fabio Barbosa (concedida a Giuliano Guandalini PA VEJA)

Há oito anos, o banqueiro FCB tomou uma decisão aparentemente contrária aos interesses dos acionistas do Banco $R$, instituição que preside. B decidiu criar linhas de créditos em condições especiais para clientes com boas práticas ambientais, e recusar empréstimos a empresas que, embora tivessem capacidade de pagamento, desrespeitassem o meio ambiente ou fossem tolerantes com práticas trabalhistas inaceitáveis. A decisão que se mostrou acertada, transformou B, que acaba de ser empossado na presidência da Febraban em uma das maiores referências em sustentabilidade no mundo dos negócios. Não apenas pelos critérios éticos de sua orientação, mas por conciliá-los com perfeição na busca por lucros.

Veja - O senhor não teme que a sustentabilidade se transforme num modismo vazio ao qual empresas aderem mais por conveniência do que por convicção?

Por convicção ou por conveniência, o fato é que as melhores empresas e alguns países estão repensando sua maneira de fazer negócios. Por crença ou pressão da sociedade, não importa. $\mathrm{O}$ assunto sustentabilidade está na pauta de todos os executivos. Sem falar que as empresas que não respeitam as leis ambientais estão sujeitas a multas milionárias, o que compromete a própria existência delas. $\mathrm{O}$ assunto passou a fazer parte da estratégia de negócios de qualquer companhia. Isso é bom e veio para ficar. Virou negócio. (...) Obviamente há um certo exagero de algumas ONGs, mas isso é normal. Um dia chegaremos a um equilíbrio. (FBarbosa)

\section{JÁ FICHADO (20)}

55 Responsabilidade Social em todos os portes

Lana de Paula (Supervarejo) entrevista Ricardo Young

A gestão de negócio de forma socialmente responsável é uma tendência?

Sim, além de uma tendência também é uma necessidade. De um lado, as empresas vêm sendo pressionadas pela sociedade civil há pelo menos 40 anos para agir de maneira diferente [...]. De outro lado, há os impactos das mudanças climáticas (...)

(...)

Como saber a diferença entre RS e filantropia?

A filantropia é basicamente uma ação social externa da empresa, que tem como beneficiária principal a comunidade (...)

A responsabilidade social é focada na cadeia de negócios da empresa e engloba preocupações com um público maior (acionistas, funcionários, prestadores de serviços, fornecedores, consumidores, comunidade, governo e meio ambiente), cuja demanda e necessidade a empresa deve buscar entender e incorporar aos negócios. 
Em entrevistas o senhor já afirmou que "a globalização é um modelo de desenvolvimento econômico insustentável, que vem acelerando a destruição ambiental, a exclusão social e a concentração de renda". Que alternativas existem a esse processo?

A alternativa é o desenvolvimento sustentável, que concilia crescimento econômico com inclusão social e preservação ambiental.(...)

Não é preciso abrir mão dos lucros, mas é imprescindível adotar os princípios da responsabilidade social empresarial, baseados na ética, na transparência dos negócios e no diálogo constante com as partes interessadas.

56 Responsabilidade Social tem nome, profissão e endereço.

Entrevista com executiva Márcia Tedesco, gerente de comunicação e e RS do Aché Labs.

Houve evolução nessa área/

Muita. Antes o que havia eram as doações para causas que a empresa simpatizava. Depois, foi a vez do investimento social - em que organização escolhia o projeto, destinava os recursos e monitorava a utilização. Na seqüência, surgiu a responsabilidade social atrelada ao negócio, com as empresas conduzindo seus investimentos para o seu segmento de atuação. Seguindo essa tendência também o conceito de marketing tradicional ganhou divisões como social e institucional.

(...)

É uma área estratégica?

Se considerarmos o aspecto puramente econômico ou financeiro, não, pois ainda faltam indicadores tangíveis do resultado do investimento social para o negócio da empresa - a questão do impacto no faturamento. Acredito que estão se tornando cada vez mais estratégicas e o espaço e ampliação que vêm conquistando são sinais que apontam isso. Se olharmos pelo fortalecimento da imagem, pelo posicionamento que a empresa toma frente ao mercado, internacionalização e estabelecimento de parcerias, a atuação responsável tem um valor imensurável e é, sim, estratégica.

\section{(...)}

Há diferenças na atuação dos profissionais brasileiros e de outros países?

Aqui o desafio é maior por uma questão cultural. Em países da Europa e Estados Unidos as pessoas aprendem desde cedo que têm um papel social a desempenhar. (...) Já no Brasil há lacunas educacionais muito grandes e vai se construindo uma cultura de pessoas que não conhecem seus direitos e deveres. Aqui há uma oportunidade imensa de interferir no processo de transformação social e acho que devemos encarar isso como oportunidade e não como obrigação.

57 Transformar e sobreviver

(Cristiano Eloi, Denise Turco e Tânia Longaresi - Revista Distribuição) 
(...) depoimentos de executivos do setor supermercadista e da indústria e especialistas legitimados por instituições/organizações

Não é possível pensar em desenvolver um projeto de responsabilidade social e ambiental se o empresário não cumprir com a lição básica de casa. "A primeira regra é simples: trate o seu funcionário como gostaria que ele tratasse o seu melhor cliente. Caso contrário, qualquer ação parecerá uma jogada de marketing e, mais cedo ou mais tarde, o mercado vai perceber que todo o discurso sobre a responsabilidade social não é sincero". (coord. de programa de RS no varejo FGV)

\section{(...)}

Mas, atualmente, filantropia não é sinônimo de responsabilidade social. [...] o investimento social aprovado consiste no repasse sistemático de recursos privados para fins públicos por meio de projetos culturais, socais e ambientais.

(...)

O objetivo é a continuidade dos negócios. O desenvolvimento sustentável é a capacidade para continuar os negócios indefinidamente no futuro. (consultor)

O mundo capitalista é movido pelo bolso e os consumidores privilegiam os produtos que têm um valor social. (consultor)

(...)

O empresário explica que desde 2003, quando começou a desenvolver ações de mobilização em benefício da comunidade em que atua, seja na coleta seletiva de lixo ou fazendo com que os funcionários e consumidores exerçam a cidadania de forma plena, a empresa aumentou a fidelização de clientes. "Além disso, essa fidelização também aumentou internamente, pois, quando trabalhamos com pessoas felizes, a produtividade aumenta". (empresário do setor supermercadista)

(...)

O social como estratégia

Responsabilidade social pressupõe o desenvolvimento de ações integradas ao modelo de negócio. Unilever mostra como integrar a prática à gestão da empresa. (exemplo/ modelo a ser seguido)

\section{CORTADO}

59 A era do consumidor politicamente correto e ecologicamente engajado

(Beatriz Camargo - revista Recall)

Referências ao Ethos, Akatu e empresas modelo, institutos de pesquisa

$(\ldots)$ 
O comprometimento em relação à redução do consumo de água e de energia no processo produtivo passou a ser uma preocupação em todos os aspectos da operação. Trata-se de eliminar impactos ambientais no conjunto da cadeia de negócios, desenvolver produtos e serviços que ajudem os consumidores a reduzir o próprio dano ecológico e melhorar a qualidade de vida, além de incentivar padrões responsáveis de consumo.

No interior de São Paulo, uma das empresas que podem ser apontadas como modelo de ecoeficiência é a Invista, multinacional líder na produção de fibras e polímeros e dona de marcas como...

\section{(...)}

O comportamento do mercado consumidor brasileiro não difere muito do que é notado no restante do mundo. O diagnóstico Walk the Talk, elaborado pelo Pacto Global (uma iniciativa da ONU em prol da responsabilidade social), programa de meio ambiente das N.U., e a consultoria francesa Utopies, prevê que o grupo de consumidores responsáveis, que é hoje inferior a 10\% do total de compradores, tende a crescer nos próximos anos (...)

O estudo define o marketing verde como alternativa economicamente viável - em particular para empresas que não dispõem de grandes somas para publicidade - porque as ações social e ambientalmente responsáveis são cada vez mais discutidas na sociedade, o que agrega valor ao produto e à empresa. (conceito de administração de rumor)

60 Bancos saíram na frente/ Andrea Vialli (Razão Contábil)

Itaú e Bradesco - primeiro e terceiro no ranking de melhor website brasileiro de Sustentabilidade 2006/2007. Foram pioneiros em assumir as boas práticas, especialmente as de RSC graças ao histórico comum de investimento social.

Considerados, na mesma ordem, os mais sustentáveis e éticos da AL em pesquisa da Management\&Excellence (julho 2006).

Bradesco mantém há 51 anos a Fundação Bradesco.

(...)

Além do Investimento social direto, o banco oferece aos clientes produtos financeiros focados em responsabilidade social.

(...)

O Investimento em sustentabilidade tem gerado bons dividendos ao banco. (Itaú)

(...)

Apesar da experiência acumulada no meio século de existência da Fundação Bradesco, o banco até bem pouco tempo tinha uma postura bastante discreta na comunicação de suas ações no campo da responsabilidade social. Com o engajamento cada vez maior do setor bancário no tema com uma postura não tão discreta assim - resolveu reestruturar sua estratégia de comunicação da sustentabilidade. 
“Percebemos que havia uma necessidade de informar sobre as ações, já que, como líder de mercado, somos uma vitrine. O que a gente faz pode servir de referência para outras empresas, outros setores". ( PL diretor superintendente do Bradesco)

(...)

2006 - fusão área RSA e Rel com Investidores = Relações com o mercado. "RSA e RI são faces diferentes de uma mesma moeda, e interagimos com a diretoria executiva do banco".

“A percepção do banco melhorou muito, pudemos demonstrar que responsabilidade social é uma postura estratégica do banco e não apenas um modismo" J.P. Leroy Bradesco

61 Contribuição na Infra-estrutura e no Social (CASO Alston)

(...)

A missão da empresa é, portanto, a de contribuir com o desenvolvimento do país, nas áreas de geração de energia, controle ambiental e transporte ferroviário propondo e ofertando soluções completas nessas áreas que reúnam o sucesso do desenvolvimento econômico, o progresso social e o respeito ao meio ambiente.(...)

62 O Fortalecimento de um Braço Social (CASO Nova América Alimentos)

[...] a Fundação destaca-se por contemplar a modernização das relações de trabalho e a atuação social como um todo, atendendo as empresas nos serviços de recursos humanos e desenvolvimento, recrutamento e seleção administração de pessoal, remuneração - e também comunicação interna e responsabilidade social.

63 Responsabilidade Social eleva prestígio

Entrevista com publicitário Angelo Franzão (M\&M)

LEAD

Um conceito que pode ser o fiel da balança para impulsionar o prestígio é o comprometimento com ações de responsabilidade social, o que contribui para elevar o grau de respeitabilidade da marca no segmento de atuação.

64 Tudo pelo Social (Ana G. Araujo entrevista Viviane Senna / Revista MKT)

Como são feitas as parcerias? Quais são os critérios do instituto para desenvolver seus projetos com outras entidades e empresas?

O que sempre defendo é que mudanças que o país tem de enfrentar são mais que estruturais. Elas são éticas, sociais e políticas, o que pressupõe o compromisso dos três setores da sociedade. (...) Nesse sentido nossa relação com os demais setores é a mais ampla e transparente possível. Para implementarmos um programa educacional como política pública contamos com o compromisso e a vontade política dos governantes daquele município ou estado e com o investimento de recursos de uma empresa aliada. 
(...)

O que é marketing social para a senhora?

É utilizar ferramentas de marketing para impactar comportamentos e atitudes. Já o "marketing relacionado à causas" é o posicionamento que liga uma marca a uma causa, trazendo benefícios mútuos. Mas acredito que mais importante do que dar nomes é saber que existe realmente o engajamento por uma causa. E o que se espera das empresas é um comprometimento com o presente e o futuro do país. Se isso pode ser aliado à projeção da marca, ao aumento dos lucros ótimo. Mas que esses dois motivos não se sobreponham ao cumprimento de um dever ético e cidadão de descruzar os braços e dar a sua contribuição à construção de um país mais digno e justo para todos.

FAZER/ FAÇA SUA PARTE/ outros estão de braços cruzados

\section{JÁFICHADO}

66 Voluntariado se moderniza e vira estratégia empresarial

Andrea Vialli

Empresas têm ganho de imagem e maior motivação dos funcionários

Levantamento recente feito pela ONG Riovoluntário com 103 empresas de todo o País mostrou que 45\% das companhias mantêm programas estruturados de voluntariado e $73 \%$ delas estimulam o voluntariado em programas sociais da própria empresa.

Para Anísia Sukadolnik, diretora do Centro de Voluntariado de São Paulo: "Se a empresa não pensar estrategicamente e não tiver valores sociais, o programa não tem eficácia.."'

Fonte: O Estado de S. Paulo, São Paulo, 01 Ago. 2007, Economia, p. B18.

67 Conceito de sustentabilidade ainda é desafio pra profissionais da comunicação. (Cláudia Piche - Idéia Social)

Artigo trata de aspectos relacionados a comunicação das empresas a respeito da sustentabilidade.

Pesquisa ABERJE "Mulher na Comunicação e Sustentabilidade"

A pesquisa foi realizada só com mulheres que ocupam cargos no setor de comunicação das empresas.

Busca entender como o conceito de sustentabilidade é tratado em cada grupo empresarial, como funciona a partir de sua matriz, "economicamente viável, socialmente justo e ecológicamente correto".

Como pensa cada profissional a respeito do tema...

"Posso garantir que igualmente eles desconhecem o tema em toda sua profundidade" avalia (diretora do instituto de pesquisa).

Hierarquia tem peso maior que gênero. O conhecimento é significativamente maior quando são avaliados os profissionais em cargo de diretoria. 
68 Prêmio ECO aprofunda critérios, diz presidente do Grupo Full Jazz

(site Amcham)

Entrevista com Cristina Carvalho Pinto (colunista Mercado Ético)

Amcham: No portal Mercado Ético, a senhora afirma que Sustentabilidade não é apenas um conceito, mas sim um sentimento. Como isso ocorre?

Existem dois níveis em que o assunto Sustentabilidade tem sido tratado: um em que a verbalização é intensa, mas a consciência é precária. Outro em que se fala menos e se faz mais. Fazer não envolve apenas a prática, mas um trabalho interno que certamente se refletirá na vida pessoal e na vida profissional. Esse é um esforço $\underline{\text { sentimental, quase espiritual, no sentido em que se aprende que a própria vida não pode ser melhor que a }}$ vida do planeta.

69 Ética e gestão cidadã (Sálvio Di Girólamo - Banas) colunista? jornalista

Cidadania corporativa é, antes de tudo o mais, um estado de espírito, um estado de consciência, são princípios e valores que começam e são praticados individualmente, estendem-se à família e desta se irradiam por toda a sociedade

Muitas são as interpretações dos termos responsabilidade social empresaria e cidadania corporativa; porém, seria um grande equívoco pensá-las como filantropia ou programas assistencialistas.

(...)

Cidadania corporativa ou Responsabilidade Social Empresarial funcionam como GPS, da sigla em inglês de Global Positions System, de uma empresa, mostrando sua posição nas coordenadas de resultados e práticas de gestão.

70 Sem transformação não há marca social

Rodrigo Laro

Cita empresas que trabalham com a noção de "Ciclos Sociais Estratégicos"

SSL International (Durex) preservativos. Projeto Hora $H$ no Brasil sobre sexo seguro, premiado pelo GBC (Global Business Council); Pesquisa sobre Sexo Seguro no Parlamento Europeu, se tornou referência em mesas empresariais e científicas internacionais quando o assunto são indicadores comportamentais que possam fomentar políticas públicas mais eficazes de sexo seguro.

Realizar doações pontuais ou simplesmente realizar estratégias institucionais com valor social agregado não são os melhores caminhos quando o assunto é a construção e o fortalecimento da marca social e uma organização empresarial. Para que a atuação social gere frutos institucionais e negociais, é necessário seguir 
critérios estratégicos similares aos empreendimentos no trato do core business da empresa. Entre eles: Conceito, Prazo e Metodologia.

(...)

Portanto, o desenvolvimento e o fortalecimento da marca social da empresa é absolutamente possível, mas

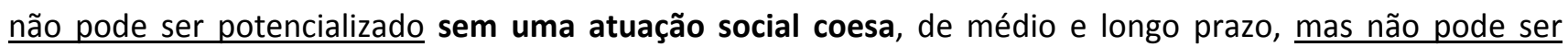
potencializado sem uma estrutura de gestão. (início da conclusão do artigo)

71 Empresas investem em responsabilidade-social

Pesquisa revela que $91 \%$ das empresas incluem a responsabilidade socialem-sua estratégia.

72 Os elos da sustentabilidade (Mauro Ambrósio - site executivos financeiros)

cita setor de cosméticos e pesquisa $2^{\circ}$ estudo BDO Trevisan de RSC

Apesar de ser um tema muito explorado pela mídia em geral, responsabilidade social corporativa ainda é muito confundida com filantropia, que é apenas um dos elos - ou stakeholders - que compõem uma grande corrente.

(...)

Antes, porém, deve-se ter em mente que Responsabilidade Social Corporativa define-se pelo estabelecimento de atividade empresarial associada ao desenvolvimento da sociedade de maneira sustentável, respeitando e valorizando seus recursos humanos e naturais. A sua meta central está relacionada à melhoria da qualidade de vida, ao bem estar dos cidadãos, e a diminuição da desigualdade social.

73 Responsabilidade Social e Varejo (artigo de doutora em MKT)

Responsabilidade social é uma forma de gestão em que o empresário busca um resultado mais amplo: Além do lucro, as atividades da empresa devem gerar resultados positivos nos aspectos ambientais e sociais".

“...a Responsabilidade Social tem como objetivo a construção de um mundo melhor, onde os negócios possam ser realizados sem comprometer os recursos naturais e humanos hoje existentes".

74 A responsabilidade Civil na relação de consumo

Aborda a responsabilidade da população em relação ao consumos e suas ramificaçés conceituais sobre $\theta$ consumo, oconsumidore oproduto.

75 SETIN - Responsabilidade Social (CASO)

A Setin procura, através de seus projetos, promover a qualidade de vida e a consciência de se prevenir danos ao meio ambiente, proporcionar a emoção artística não apenas na construção efetiva de seus 
$\underline{\text { empreendimentos imobiliários, mas também, em ações em que seus operários possam exercer seus talentos }}$ artísticos".

“Cria-se, por meio de tais ações, a integração cada vez maior dos operários com a empresa, isto é, apesar do cotidiano duro das atividades braçais da construção civil, a momentos em que os funcionários sentem que eles criam algo para eles mesmos e não apenas belas edificações de luxo para outras pessoas".

760 que move a tendência dos "produtos éticos"

(Michael Skapinker - Valor Econômico)

Dados de empresas que comercializam produtos com selo "Fairtrade" no varejo

Finalmente, embora os supermercados reconheçam que apenas uma minoria está realmente preocupada com essas questões, a proporção está aumentando. Os varejistas precisam estar alertas à mudança. Um executivo do setor disse" "Um comerciante esperto está a meio passo à frente do Consumidor. Dez passos à frente e você está fora do negócio".

77 Brasil pode ter selo de boas práticas (Neila Baldi - Gazeta Mercantil)

A moda pegou e veio para ficar. Cada vez mais produtores têm buscado certificações para vender seus produtos, sobretudo aquelas voltadas à exportação.

(...)

Hoje no Brasil atuam 19 certificadoras - nacionais e internacionais.

78 Brasileiro vê ação social como uma ferramenta de marketing (Cynara Escobar)

Dados de pesquisa Ibope Inteligência (público $A B C$ e empresários)

Os brasileiros estão vendo com ressalvas os investimentos em sustentabilidade anunciados pelas empresas e acreditam que ações não passam de estratégias de marketing. Para mudar essa imagem, grandes corporaç̃̃es tentam ampliar suas ações nesse sentido, como as do mercado imobiliário, financeiro e varejo.

79 Um evento para atrair 1 milhão de empreendedores (Marianna Aragãoo

Semana Globalde Empreendedorismo

80 Consumo Responsável (revista E não assinado)

Subtítulo: Cada vez mais cientes do poder de suas escolhas, consumidores cidadãos passam a decidir o que levam para casa de olho na responsabilidade ambiental dos fabricantes.

"É possível reduzir muitíssimo o impacto de cada indivíduo/consumidor sobre a natureza pelo simples ato de reduzir e repensar o consumo de bens" (representante do IDEC)

81 Consciência ambiental ganha espaço nas corporações

Ruth Harada

Exemplos de empresas em RSC. Economia de papel, energia etc.

(...) Na divulgação do Informe Anual de Responsabilidade Corporativa, no início de julho, o presidente do grupo Telefônica no Brasil, ACV, afirmou que a intenção da companhia com a publicação - feita este ano pela terceira vez no Brasil - “é estimular outras empresas a copiar a idéia”. 


\section{A empresa flexivel}

83 Socialização do Poder e Propriedade

Wanderley Guilherme dos Santos (Valor Econômico - Eu\&Fim de semana)

Dificuldade ética universal derivada do fato da promessa capitalista de obtenção de todos os bens disponíveis ter-se revelado duplamente falsa.

Falsa porque não foram comportamentos orientados por uma ética radicalmente utilitarista que asseguraram a vitória e consolidação do capitalismo em seus primórdios.

Falsa ao se descobrir a essencial heterogeneidade entre os bens disponíveis, categórica diferença entre bens "democráticos" (multiplicação - e possibilidade de aquisição - dependo da produtividade do trabalho humano) e bens "oligárquicos" (absolutamente escassos e não passíveis de multiplicação pelo trabalho ou tecnologia). Glória, poder e riqueza não podem ser adquiridos mesmo se houver dinheiro.

$(\ldots)$

A generalização da ética utilitária capitalista pôs a nu os limites estruturais da nova ordem.

A explosão da demanda é resultado do exercício pleno da racionalidade capitalista.

Na ordem capitalista contemporânea o fundamento da propriedade é o poder (invertendo Marx).

\section{(...)}

A possibilidade de igual acesso aos bens democráticos é tecnicamente imaginável, mas a estrutura da distribuição da propriedade faz com que seja impossível na prática.

(...)

Escapar à ética competitiva utilitária e a privatização do poder político exige uma espécie de socialização do poder, isto é, sua distribuição igualitária virtual, atualizável sempre que um direito for maculado, a fim de que os seres humanos tenham soberania sobre perfis distintos de distribuição da propriedade, sobre o que deve ser produzido e apropriado e, muito especialmente, que retenham o poder causativo de reformular decisões anteriores.

Muito difícil no curto prazo.

Tese: A socialização do poder em conseqüência da simplificação tecnológica e progresso do conhecimento irá adquirir visada de concreto possível, fazendo a questão da propriedade sua subsidiária.

Conclusões:

1) a ordem capitalista é, no curto prazo, incompatível com uma ética não utilitária

2) no longo prazo, uma ética utilitarista inviabiliza a ordem capitalista

3) ocorrendo a socialização do poder, ética e política podem se solidarizar na resposta à questão da sobrevivência da espécie: o que produzir com o poder e como distribuir a propriedade. 


\section{TRANSCRIÇÕES}

\section{DAS ENTREVISTAS}




\section{ENTREVISTADO A}

\section{Conte sobre seu trabalho na empresa.}

Estou na empresa há 5 anos e sou Coordenador de RP. Trabalho numa área onde uma parte cuida de comunicação corporativa, assessoria de imprensa, relação com stake holders, outra parte cuida de sustentabilidade, responsabilidade social, muito com foco na formação dos projetos e na comunicação.

\section{Qual o conceito de responsabilidade social que orienta a empresa?}

Não tem como eu não ter o discurso da empresa, como profissional, afinal de contas sou eu que toco a área. Para a empresa RS é a maneira como para fazer negócio, abrangendo todos os aspectos, todos os temas e públicos, de modo a garantir a perenidade nos negócios, com menor impacto possível em meio ambiente, com melhor aproveitamento dos recursos humanos, financeiros, obediência às leis. E um retorno para...para a melhoria da sociedade. Até porque nossa missão como empresa é levar melhores condições de higiene e saúde a todas as pessoas, todos os dias. Tem uma missão. Então RS ou Sustentabilidade está muito ligada a garantir melhores condições de higiene, saúde e bem-estar.

\section{Estes conceitos mudaram? Como a empresa atualiza nos seus programas?}

Sim, constantemente. Até por conta dos relatórios. Que começaram como relatório social, depois virou balanço social, e agora é um relatório de sustentabilidade. Quer dizer, você vai incorporando cada evolução desses indicadores até chegar na questão do sustentável, que é o guarda-chuva, quando você diz sustentabilidade, que eu daria o nome de perenidade, pela continuidade em todos os aspectos, ... perenidade dos negócios. Desde o manejo sustentável da fazenda que nos abastece com as árvores para o processo de obtenção de celulose, para produção de papéis, até a obediência às leis trabalhistas, o trato que a gente tem com toda a cadeia produtiva, de banir, de ser totalmente contra a exploração infantil, o trabalho forçado, condições desumanas de empregabilidade. Que isso pode ser muito mascarado no discurso. A gente, por exemplo, construiu em 2006, acho que foi inaugurado em 2007 um centro de distribuição. Nós temos duas fábricas e todos os produtos são concentrados nesse centro de distribuição e lá é expedido para todo país. Um dos cuidados que a gente teve foi desde o momento da escolha do local, que embora fosse uma região de floresta de mata atlântica, era uma região que era um campo, uma fazenda, e a gente podia remanejar aquilo. $A$ 
gente recuperou, a gente plantou 13 mil mudas de árvores nativas, construiu a obra e teve esse replantio. Criamos além de tudo um espaço para o caminhoneiro ficar. Até expedir, abastecer, recarregar, ele fica horas ali. E não são todas empresas que tem um espaço com chuveiro, televisão, lanchonete, para que possa ficar ele e família. Então não é o cuidado só com o produto e com a questão do meio-ambiente. É ter um espaço onde ele possa descansar. Ele e a família. Às vezes viaja ele a esposa e filhos. Onde ele possa tomar banho, se alimentar, ter acesso à mesma refeição que nossos funcionários da fábrica e depois de lá ele parte para a continuidade do trabalho dele. Ele não fica mal alojado. Um tratamento humano mesmo. A gente nessa inauguração e temos mantido como um programa, de fazer uma semana de capacitação para empresas de transporte, desde o manuseio da carga, porque o nosso produto quando chega no ponto-de-venda onde a escolha é feita, o produto tem que estar em perfeitas condições. Se você vê um pacote de papel higiênico amassado você não compra. Embalagem de fralda rota, aberta, você também não compra. Da maneira como ele lida com nossos produtos, até a prevenção de DST/Aids, até uma parceria com uma ONG chamada WCF contra a exploração sexual nas estradas, para conscientizar esse caminhoneiro do risco e da indústria que ele está gerando uma vez que ele se vale da questão da exploração sexual. Então a sustentabilidade para mim está como global. Não dá para pensar só na cadeia produtiva ou no insumo, mas tudo aquilo que permeia os negócios.

\section{Sustentabilidade deve ser um nome de 2006 para cá?}

Na verdade o que existe é o seguinte: o relatório social serve para reportar as ações. É o cachorro que balança o rabo e não o rabo que balança o cachorro. Quer dizer, eu não uso o relatório social para desenvolver ações, talvez uma ou outra ação corretiva, muito mais com foco na comunicação. Às vezes a gente faz muito bem feito mas não divulga adequadamente para o público de interesse. Mas o controle ambiental ético existe na corporação desde antes de eu entrar na companhia. É o que garante que uma empresa como a empresa tenha 136 anos de história no mundo. Ela foi fundada em 1872 nos Estados Unidos e no Brasil está desde 1996. Ela comprou parte da K, Kj, foi fazendo jointventures com várias empresas até construir um portfólio. O relatório se associa à comunicação. Os procedimentos de gestão de recursos hídricos, de energia elétrica e envio de material para aterro isso segue uma política global que tanto na minha fábrica em Mogi das Cruzes, quanto na minha fábrica na Coréia, seguem, tem os mesmos indicadores e os mesmos desafios. E o que a gente tem feito a medida dos anos é um monitoramento e evolução desses resultados. Cada vez a gente produz mais, usando um menor volume de água, menor quantidade de energia e menor envio de aterros. A gente tem uma fábrica em Porto Alegre que ela manda $0 \%$ de resíduos. Tudo é reaproveitado. Uma fábrica de absorventes. Todo resíduo da produção é reaproveitado. Em algumas operações, como a de papel, a gente não consegue ainda, mas a gente tem buscado soluções. 


\section{Como é feita a divulgação demandada pelo mercado?}

Criou-se uma necessidade. 0 mercado passou, nos últimos 10 anos, a se preocupar muito mais com as formas de produção, a questão da responsabilidade social, em obediência às leis, mitigação, minimização de impactos no meio ambiente. Uma vez que a gente já tinha esse processo, é uma oportunidade de comunicar mesmo. Agora, outras empresas passaram a ver isso como um negócio positivo. Empresas como a $\mathrm{Nt}$ e o Bt que se valem da extração de recursos naturais para produção de produtos. Cremes, cosméticos. O Body Shop começou esse movimento na Inglaterra. Agora o nosso processo, o nosso produto que é papel ele sempre dependeu da atividade florestal. Tanto é que toda a produção de papel no Brasil é feita de florestas certificadas. E uma questão que a gente discute bastante é a questão do papel reciclado ou papel de celulose virgem para a gente muito bem resolvida. O que acontece é o seguinte: uma vez que você tem uma empresa que faz papel a partir de fibras virgens - celulose, tirada da árvore - você favorece a questão do reflorestamento. É uma atividade florestal. Você planta, abate, e isso contribui com a recuperação, seqüestro de carbono. A empresa não produz, não tem fazenda, a gente compra de fornecedores a celulose. Mas nossos fornecedores têm excesso de créditos de carbono, porque nossa operação favorece o crédito de carbono. Então você planta, abate, planta, abate, cumprindo toda a legislação, com período de replantio, condições, fertilização, processos que causam menos dano ao meio ambiente, enfim. Porque você tem mata nativa, não é o nosso caso. É floresta. Estamos processando isso há muito tempo. Além da questão de captação do $\mathrm{CO} 2$, o papel você consegue reciclar uma certa quantidade de vezes. O papel reciclado não existe se não houver o papel branco. Outra questão é que você tem um impacto com o reprocessamento, a questão da tinta, do plástico, uma produção que não é tão limpa para reciclar aquele papel. Uma vez que você tem os dois concomitantemente você tem a opção de retirar o papel branco que seria descartado no meio-ambiente e dar uma destinação nobre. E por outro lado você tem uma opção que é a celulose virgem. É interessante que os dois existam e não que um sobreponha ao outro.

\section{Trabalhar com todo material em papel reciclado é um equívoco?}

É precipitado, porque depois você começa a ter o triple botow line, que é o tripé. Economicamente não é viável porque começa a faltar matéria-prima para o mercado. Se todo mundo usar papel reciclado vai faltar o papel branco. É a mesma coisa, por exemplo, a história da garrafa PET, você consegue o reaproveitamento, faz alguma coisa que seja fixa, aquela coisa fiz, você transformou a garrafa PET numa mesa, mas é aquela mesa? Quer dizer, não vai ter mesa pra sempre, então eu acredito que sustentabilidade não é uma revolução, mas é uma evolução dos processos, é uma evolução do processo, é minha concepção, você não esta quebrando o status quo, e da maneira 
como você avalia sua relação com sociedade, comunidade, público interno, governos e autoridades, até a maneira como você produz, mas você nunca vai ter o impacto zero no meio ambiente, qualquer atividade econômica ela é passível de o que agente tem buscando paulatinamente, cadê vez mais é a gente esse efeito que é plenamente possível.

Pula um pouco para estrutura, uma coisa liga para outra, como que isto entrou na pauta da empresa, se tem a ver com a sua chegada aqui, esta questão sobre tudo ainda tanto da responsabilidade social, através da comunicação disso através dos relatórios, (a imprensa também), e como é que isso foi sendo estruturado e onde se encaixa hoje na empresa a questão da responsabilidade social, se isto esta relacionado a um departamento, como que isto foi crescendo se estruturando?

$\mathrm{Na}$ verdade isto esta (dentro), em todas áreas da empresa, inclusive a gente começou a publicar o Balanço Social, relatórios, e detectou, como agente entrevista todos os públicos estratégicos, isso sobre para o gerente de vendas, que é o maior relacionamento do cliente, suply, porque compra a matéria prima, insumo, e tem a relação com os transportadores, o financeiro, porque reporta os resultados, e tem auditoria e controles internos, e a comunicação porque comunica, quer dizer, toda ponta do processo, se a empresa inteira não adota parâmetros de responsabilidade social nas suas operações, eu não tenho como me ( ) eu me torna a ponta do processo. O que eu faço ali na comunicação é desenvolver projetos com comunidades, seja com foco em educação ambiental, seja na doação de produtos para algum orfanato onde agente tem fábrica, aconselha e desenvolver alguns projetos junto com fornecedor, junto com clientes, ver a s necessidades dos clientes como a KB consegue atender esta necessidade, mas eu não sou uma ilha.

Na NN tem um processo, de pensar como é que a escola vai encarar esta questão, que seria a RS para uma escola, no nosso caso a concepção vai ao âmbito da formação, formar pessoas que tenham mais até que outras ações esporádicas do que a escola já faz. Sensibilização e tomador de decisão. $O$ nosso desafio lá, não imagino, que seja o de vocês aqui, como é que agente faz para chegar nesses lugares, todos, montaram comitê, existe uma diretriz, que vem enfim, né? Só nas reuniões, como é que a idéia, faz para aparece para ser RS se disseminada na corporação?

A decisão do B., da diretoria, porque em 2002 com a vinda do presidente que agente tem até hoje o João, o que aconteceu foi que agente reviu os valores da empresa, tinha outro corpo diretivo, que a partir de 2001 e 2002 mudou. J. veio da Editora Abril eis milagre, para assumir uma diretoria, então ele construiu todo o B., em fez todo um plano de ação, uma missão e meta todo um planejamento chamado visão 2008, o que a empresa desejava ser em 2008, chegar no 2012 agora, enfim, então ele trouxe um corpo diretivo todo novo, os valores da empresa, responsabilidade social está na 
pirâmide de valores, cada área é responsável por todas as ações tomadas pela empresa ela leva em consideração de responsabilidade social, tenho um exemplo para te dar agora, é festa de final de ano, olha como a coisa desce no nível mais tático da história, agente tem desde de julho deste ano a lei seca, não tá nem aí festa de final de ano, por que as pessoas vem e bebe e vão embora, isso nunca foi uma questão supermercado de, então agente decidiu este que ano que não teria na festa de final de ano com bebida alcoólica, mas a festa é um momento esperado pelo funcionários, é uma questão que todo mundo espera aguarda, é o evento mais comemorado no ano, agente mudou o foco da festa, não mais uma festa a noite com DJ e balada, vai passar um dia inteiro com família num outro espaço aqui em SP mesmo, o dia inteiro, tem churrasco, agente colocou um conceito de responsabilidade Social, que passar o dia inteiro com família, é um educandário, como se fosse um orfanato, uma espécie de fazenda... ações, dia do voluntariado, pintar, reformar, lavar cortina, fachada chega aqui, chega o engenheiro, (o cara trabalhar na festa) é para preparar o que precisa ser feito, os funcionários vão se organizar em grupo sob a regência de um arquiteto, REFORMAR (é vão trabalhando... a festa é um) na parte da manhã, depois tem um almoço, tem cerimônia de entrega de prêmio, quem fez o projeto mais criativo, tem todo um aparato de uma comunicação, agente fez uma sinergia de projeto, a questão da festa, a questão de responsabilidade social, um programa de voluntariado que a empresa já tem, e tem este educandário, que agente apóia, um grupo de crianças que tocam música, tem instrumentalização, tocam piano, violino, guitarra, eles tem uma banda, super boa, e agente consegui melhorar o conceito, agente não mascara, não está no discurso, (...) para uma festa de fim de ano, obediência as leis é preciso para se ter responsabilidade social, não posso permitir fazer uma festa onde, ah não vai ter bebida, ou vai ter bebida meio período, aquela coisa, não pode mais agente dá um jeito, o cara pode atravessar a rua e beber, (tiveram que conceber a festa sem isso) sim!, outra coisa é a certificação do fornecedor, agente exige uma certificação do cara para ele prestar serviço para empresa, e ele é auditado, com alguma frequência (isto inclui terceirizado), terceirizado, (que é uma questão importante), agente coloca numa questão de contrato de RS, agente assina pacto, como este contra a prostituição infantil, o projeto em associação da indústria com relação a certificação de fornecedores comuns de produtos de higiene, projetos de resposta de projetos lei com relação a política de resíduos sólidos, então isto faz parte do negócio da empresa, é a dinâmica.

\section{Vocês têm um documento, alguma coisa que vocês circulam uma lauda de responsabilidade social ou não?}

Não, as questões elas, elas são discutidas, embora, dizem questões surgem se não consegue gerar um documento prático. 
Embora não tenha vindo de cima para baixo, vamos trabalhar esta questão é: como isto vai ser feito?

O que tem que ficar claro: Isto não tem o nome de sustentabilidade, não, isto está incorporado de uma maneira que faz parte da tomada de decisão, é parte do negócio, não é indissociável, uma coisa, nos temos uma política, e precisa consultar a política,

\section{É dissociável?}

Não, não é dissociável, é incorporado totalmente, em tudo que se faz.

\section{Não gira uma questão: preciso consultar um manual?}

Isto já é considerado - se bem que as questões surgem, é porque na festa do ano passado, ninguém cogitou que pudesse ser um problema esta questão, agente procura estar em conformidade, a EMPRESA ela num lança tendência, não é inovadora neste sentido, o ano passado agente nem pensava em lançar, olha, se beber não dirija, suas campanhas, se tornou uma melhor maneira de atender.

Você falou como tem entrado na pauta, como é que tem sido estruturado. Quando a estrutura afeta...

Foi feito um café ... que incorporou toda a empresa em relação a tomada de decisão. Como eu já te falei da responsabilidade social, são os projetos com comunidade, ai é minha área que toca que tem relação com a comunidade, tem os projetos de responsabilidade social, que apóia o orfanato, educação ambiental, são projetos feitos com parcerias com órgãos públicos onde agente tem fábrica, isto é coordenado por mim, e tem um trabalho desenvolvido localmente pelos recursos humanos nas unidades

Então seria no teu caso mais voltados como assuntos corporativos, relações públicas, e também um pouco $\mathrm{RH}$, assim, o lócus...

A gerência da fábrica representa a empresa CIESP no FA, órgão de meio ambiente no sul, enfim, estas questões.

Falou um pouco da evolução como é que isso... não muito tempo que acontece, neste pouco tempo, você percebe, na sua percepção quais são as mudanças mais significativas, como era percebido na empresa e hoje? 
Isto esta incorporado no discurso, acho que é um discurso de empresa a dez, quinze anos, era muito mais pautado na performance do produto, no mercado, ação de marketing, depois teve uma evolução das empresas procurarem.

\section{No discurso interno das empresas?}

Discurso como empresa, sempre pautado por conquista de mercado, segmentação de público, nem segmentação, um conceito novo, era muito mais dentro do marketing, da publicidade do produto um foco empresa e produto, eu acho que a coisa tem mais bem elaborada digamos que agente passa a elaborar outros ingredientes, que ninguém questionava. Começou com filantropia, vem uma empresa adota um asilo, está totalmente dissociada das atividades de uma empresa, eu tenho uma empresa e adota um projeto de informática que eu apoio, isto num primeiro momento, não EMPRESA, isto estou falando de mercado. Depois o segundo tem a responsabilidade social, que aquela coisa que você tem obediência a leis, a preocupação econômico, eu apoio a comunidade, ai uma coisa mais ligado ao seu negócio, se tema é higiene, vou promover workshop de higiene, assinar algum acordo municipal ou estadual com alguma ONG, para melhores, para favorecer suas higiene em comunidades carente. E Agora com o conceito de sustentabilidade, evolve todo, inclusive com você. Porque que você teria um projeto deste e desmatar a floresta... Você pode ter este projeto com a comunidade, mas o seu funcionário você burla a lei ali, você dá um gato. Esta tudo se sofisticando.

\section{Embora você não veja como revolução, mas percebe uma evolução?}

Isto acontece como as empresas americanas, controles contábeis, isto também é responsabilidade social, você ter uma empresa que maquia resultados.

Agente falou do conceito, da estrutura, da comunicação um pouquinho também, das ações, do que você fazem, primeiro, você gostaria de destacar alguma ação, você já falou, um pouco de duas ai na conversa, mas tem algumas que chama atenção, você acha que tem um resultado mais interessante e como ela consegue, como é que é decidido como é que vai ser feito aquela ação como é que ela é desenvolvida e o que se espera e como é que ela é controlada. Seriam três momento que me interessaria.

De determinado projeto!

Pode ser, acho que isso foi uma coisa que você pensou como padrão, você pode até falar no geral, às vezes é mais fácil falar do projeto. 
Vou tratar de uma questão pública, além deixar só direitos sólidos para a industria, você tem uma questão que está tramitando no congresso, que é uma lei que quer tributar a empresa encima das embalagens, se você produz x milhões de pacotes de fraldas, você será tributado por esta conta, então não só a EMPRESA mas toda o setor da higiene tem trabalhado na questão de oferecer condições para não ser tributado, que desenvolver cooperativas de catadores, captadores de papel, material reciclado, desenvolver cooperativa, condição piloto do estado de SC, em cindo cidades, uma parceira da XXX, junto a Fundação BB, na qual XXX cuida só da comunidade, incentivando o desenvolvimento da coleta seletiva, e a capacitação destas cooperativas escolhidas, a prefeitura de alguns deste município escolhidos, passou por uma triagem, se comprometia a ceder o galpão e não privatizar a questão do lixo no município, a partir do momento que você privatiza, você não possibilita geração de emprego e renda para a comunidade carente, aquele catadores desarticulado, e a fundação BB comprava os equipamentos para estas cooperativas, então nos verificamos onze municípios, fechamos em seis e chegamos ao final com quatro cidades.

\section{Vocês conseguiram articular todas as cidades?}

Foi Joinvile, Blumenau, São Bento do Sul e Florianópolis, então agente propiciou um treinamento para os catadores associados a estas cooperativas, dezoito meses questões sobre empreendedorismo, marketing, beneficiamento do material reciclado, aumentar em grande escala, porque você, a medida que você trata e trabalha com insumo de material reciclado, você consegue ter ganho por beneficiamento, o cara arrecada no papel vendo por preço muito baixo para outro, que tem dois papéis, que melhora um pouquinho e separa e vai... até para estreitar as associações da indústria e aumentar arrecadação de diversas condições de negociação para pode abastecer diretamente a indústria, no caso do papel aconteceu porque é um indústria muito específica, o volume é muito grande e a questão da triagem e preparo envolve muitos preceitos técnicos, que talvez as cooperativas num primeiro momento não estejam preparados. Mas plástico deu certo no sul tem a CONDOR, pela cor, né? Pelo tipo de plástico, porque o plástico é bem mais fácil, Tem papel, apara branca, o volume acaba sendo muito pequeno, mas pro plástico se consegue trabalhar melhor tem até uma das cooperativas que esta negociando diretamente com a Condor, em São Bento do Sul sem intermediários, isso promoveu a geração de emprego, renda, aumentou o número de cooperados, se articulou com as cooperativas, elevou sua representatividade dos municípios, e agente conseguiu ai ter um piloto, que agora vai ser passado, esta sendo repassado para o Estado do RJ, são cinco municípios 
Esses processos todos, como é que a coisa começa, tem uma demanda, vamos pensar em uma demanda, na concepção do projeto ele é produzido na empresa, surge na empresa, já vai pra fora, ela já é compartilhada?

Uma vez que a EMPRESA dentro de uma relação, enfrentar esta questão e também a ser taxada, tributada, o setor conjuntamente decidiu, gostaria de ter um projeto como resposta para o Governo Federal, então foi uma ação tomada com EMPRESA e os concorrentes, e todo setor de higiene e cosmético, então precisamos ter uns participantes deste grupo de trabalho que eu trabalho meio ambiente, meio ambiente não é valor agregado, é commodities, isto é uma preocupação de todos e todas, eu faço este projeto junto com a $X, Y, Z \ldots$

\section{Os integrantes deste grupo de trabalho são profissionais como você?}

Não, eles são profissionais melhores do que eu.

\section{Não tão humildes como você.}

É um comitê de meio ambiente, eles são todos técnicos de segurança, saúde e meio ambiente, eu ou o único cara de comunicação, junto com a diretoria de meio ambiente, eu sou o cara de comunicação porque eu cuido da responsabilidade social, eu vou muito mais pelo aspecto humano do que pelo aspecto técnico.

\section{Como é que isto chega na comunidade? Quem faz a ponte?}

Uma vez que agente colocou também o poder público como parceiro o governo, as prefeituras, a prefeitura tem um órgão de meio ambiente que é a empresa que faz a coleta seletiva, ou tem as cooperativas, então se ela vai mapeando, vai chegando, com a apoio neste caso de Santa Catarina com Fundação BB. Tinha na agência, chegava às comunidades mapeava, fazia triagem, mas a condição era, a prefeitura tem que ceder o galpão, a prefeitura não pode privatizar a questão do lixo e tem que assinar um convênio, para garantir a perenidade deste projeto, se garante que sim, e depois aluga o galpão, enfim, não cede ou pões ma empresa privada...

\section{Vocês saem de cena?}

Este em Santa Catarina agente ficou por 18 meses, depois um período adicional de seis meses, depois agente saiu, agente investiu, e agora acompanhando os resultados, monitoramento, aumento de pessoas envolvidas, quantidade de material, enfim, agente desenvolveu as cooperativa com apoio do Sesi, para que ela se auto gerisse e desenvolvesse. 
É um investimento por meio do material humano, através dos profissionais, ou a empresa compra alguma coisa?

A empresa pagou o SS, o galpão é cedido pela prefeitura, os equipamentos pagos pelo $\mathrm{FBB}$, e a capacitação técnica e a comunicação que as pessoas façam coleta seletiva e o SN pago pela XXX para desenvolver - Associação das Indústrias.

\section{Entra a parte da KB também...}

Pra você perceber é uma alternativa ao projeto de lei, quando agente mostra que esse modelo dá certo, não tem porque ter uma tributação. Ali tem grande Responsabilidade Social.

\section{O projeto de lei - A tributação seria feita se o projeto não tivesse o aproveitamento?}

O projeto está tramitando, agente não conseguiu mudar esta lei por enquanto, estas reuniões em Brasília, é um projeto sobre tributação de resíduos sólidos, no Rio de janeiro já existe este projeto, é a questão da embalagem - me desculpe, tributação por embalagem gerada, tem que ter um controle porque agente paga impostos, a união sabe, no Rio de Janeiro agente desenvolveu um projeto agora, para compensar foi muito bem aceito pelo Carlos Minc, que era secretário municipal de meio ambiente e agora é ministro do Meio Ambiente, ele deixou uma outra pessoa que esta dando continuidade nesta questão, porque no rio existe uma tributação, existe um pagamento, então depois vingou este projeto agente não precisa pagar este tributo, precisa prestar contas, sobre impacto social e ampliação de seus dados é um bem para gente que envolve para uma questão nacional, tem um projeto de educação ambiental, tem escola do lado da fábrica e a diretora manda visitar agente...

\section{É uma demanda do entorno?}

Não, não tem nenhuma demanda, deixo te contar como funciona. Este foi um projeto da questão da coleta seletiva, o outro sobre educação ambiental, as pessoas querem visitar a fábrica querem saber. Como é que faz papel higiênico, querem vem, vão lá visita, o papel que sobre, feito em jumbo, como é picotado, empacotado, criança adora ver como é feita, depois passa o dia na fábrica, almoça e tem uma palestra sobre segurança na fábrica e vão embora. Ai numa dessas visitas elas não sabiam por agente tinha cada lixo para uma cor, verde - vidro, vermelho, plástico, amarelo - metal e azul - papel, se não está escrito ela não sabem para que funciona, elas tem uma carência muito grande sobre informação e conteúdo do meio ambiente

\section{É uma escola específica?}

Sim, uma escola específica, uma situação que eu deflagrei isto, tinha esta questão que eles vão lá e visitam, e agente está dentro de uma comunidade que num futuro próximo alguns caras serão 
nossos funcionários, como acontece, em comunidades menores até, o que aconteceu? e agente pensou um projeto educacional para desenvolver com os professores, para que ele possa abordar as questões, instrumentalizar os professores para que ele trabalhe com este tema em sala de aula, agente conversou com algumas escolas, eles toparam, a gente desenvolveu cartilha e material junto com os professores, o que você idealiza? Agente podia tratar assuntos sobre biodiversidade, coleta seletiva, protocolo de Kioto, num primeiro momento agente pagou a escola pela coleta seletiva que fizeram só que agente viu que era muito complicado a questão logística de recolher lixo, pagar a escola, situação da escola questão do conteúdo programático desenvolvido em sala de aula, tem que aprender relatório agente dá uma remuneração para escola, seja em espécie, seja em dinheiro espécie que eu falo

\section{Material...}

Uma mesa de ping-pong, bebedouro, agora agente está num dilema, que é perceber que assim, agente não tem como gerir escolas, porque nosso negócio não é a gestão, aqui que entra responsabilidade social e entra sustentabilidade, por que eu fico desenvolvendo, fomentando, para aquela questão do meio ambiente, porque depois nos nossos produtos, o cuidado com o meio ambiente é o nosso cartão de visita, segundo ponto mais forte da EMPRESA, só que eu não tenho como acompanhar isso no dia-a-dia, eu posso ter problema como estas comunidades, que não sabem como, se a premiação não chega no dia eu posso ter problema, se der qualquer coisa errado com o projeto eles passam a criar uma dependência. Agente está em estudo outro modelo agora de desenvolver e instrumentalizar a delegacias de ensino fomentar os multiplicadores para que eles passem isso às escolas, para que de uma difusão, estas células de educação ambiental nas delegacias de ensino e na secretaria de educação do município onde se esta buscando agora é uma maneira de chegar lá e poder passar.

Qual o papel da empresa na sociedade - você acredita que o melhor caminho seria passar para uma instância estatal de alguma forma, governamental?

Sim, sim, ter aumento em difusão e amplitude, tirando a responsabilidade pela gestão da escola, isto não é uma responsabilidade da indústria isto é papel do estado, mas o que agente pode enriquecer esta estrutura por tudo que agente tem de bom e de boas práticas, você faz..., você faz...

\section{Tentativa e erro!}

Agente esta cheio de erros, mas é a maximização dos resultados. 
Nesta questão da educação que você esta tratando - a empresa está passando por uma discussão de políticas públicas ou você acha que não?

Não, não, simplesmente foi uma necessidade do projeto para agente se tornar conhecido nas comunidades. Como a empresa menos de 10 anos no Brasil, a comunidade não sabe nem que empresa é aquela, se era EMPRESA ou K, e já tinha se tornando KC, é uma ação de relacionamento com a comunidade mesmo, nossa papel como membro daquela comunidade...

Mas esse movimento de sair de uma relação com a escola e passar a uma relação com a diretoria de ensino. Cuidado de não assumir uma responsabilidade que não é de vocês...

Melhorar expertise da delegacia de ensino da secretaria de ensino, não eu reinventar a roda, mudar processo, contratar consultoria para desenvolver um projeto em uma ou duas escolas, em outras escolas geram uma demanda infinita, acaba nos tornando uma anti-propaganda, contra propaganda.

Dentro destas situações, ou seja, a questão dos efeitos, resultados, de alguma forma você tenta mensurar isto, a questão dos desempregos, impacto na educação das crianças, e neste âmbito se você tem contato direto com as pessoas, ou se tem algum resultado, tanto do ponto de vista mais amplo, qualitativo, tantas crianças, ou se você percebeu, depoimento, coisas que chamaram a atenção, como impacto das ações da empresa, seja na comunidade, da escola, nos catadores.

No caso das escolas que eu acompanho mais de perto, dos catadores tiveram um aumento da receita, aumento de beneficiamento de produtos, indústria... objetivo ali, no caso das escolas, a questão do meio ambiente entrou na pauta da escola, a escola comenta isto, faz mesa redonda, promove discussão com alunos, os professores desenvolvem brinquedo técnico com material reciclado, puff com garrafa PET, eles plantam mudas de plantas frutíferas no jardim da escola, o jardim estava abandonado no primeiro momento, diminui-se a questão do jogar lixo no chão da escola, e eles passam a jogar lixo no latão, se trabalha a questão da cidadania, não só a preocupação ambiental mas a cidadania, momento que você começa com o meio ambiente de jogar o lixo no cesto de lixo, se começa a buscar o cesto de lixo, que a escola não tinha, se coloca o lixo atrás da porta, entrar com o projeto de educação ambiental, um latão de óleo, personaliza e torna uma lata de lixo, uma coisa gera a outra, agente tem isso, não tem lata, na sala de aula tem que ter para resíduo seco e resíduo orgânico, e de preferência que os alunos não comam na sala de aula, se tem o horário de intervalo, uma cantina e um pátio, não comam na sala de aula, sala de aula é sala de aula, começa a trabalhar a conscientização, isto impede as pessoas de comer na sala de aula.

O que você falou é uma questão que volta e maio isto aparece no relatório ou pelo menos nas intenções empresas, de alguma forma impactar no grande chão, guarda chuva de cidadania, isto 
entra sob este rótulo, diretamente nas preocupações da KBC ou você prefere isto como desdobramento, e qual é a sua percepção deste tipo de impacto, e até saber não um questionário, ou uma prova, como é que você percebe dentro do seria de cidadania... Você falou um pouco acho já, né?

Não se sobre Cidadania para EMPRESA

Se isto se existe como uma percepção para empresa, você deu uma percepção de que você entende de impacto, do que agente pode chamar de cidadania, você falou de educação, do lixo, dos hábitos e ai vai.

A questão do consumo consciente, e muito mais no que tange a tocar os negócios a questão ética, então a questão de respeitar contratos, respeito as normas, regulamentações, agente uma fralda na argentina que o tempo de duração dela é de três anos, e no Brasil dois, é o mesmo produto, eu tenho um produto que depois de dois anos, eu tenho que refugar, dar nova destinação, que esteja dentro do período de vida útil, estou respeitando a legislação, agente tem na EMPRESA uma linha chamada linha ética, "programa chamado fazer o que é certo", e está muito bem sinalizada na empresa você vai no café na recepção tem o folheto explicando o que é, e tem números para você ligar na EMPRESA no mundo inteiro, Qualquer assunto de natureza ética, que você se sinta confortável a reclamar com eu gestor direto, ou com o departamento jurídico da empresa, você liga neste número, uma atendente em português...

\section{Uma espécie de uma ouvidoria...}

Neste caso chega para uma comissão, e diretores aqui do Brasil, tem que mandar um caso para ter um report para a corporação, e isto funciona e já teve caso de assédio moral, nos tivemos palestras de assédio moral, pra todos os líderes da empresa, o que configure tudo, vê se pode, tratar o funcionário de alguma maneira e não saber que aquilo caracteriza assédio moral, tratar o veio uma advogada e fez uma palestra, todos a... a questão do código de ética, ele é discutido entre os funcionários, o manual, agente faz agora uma campanha, está até acontecendo, montar em fascículos a questão, ... estou cinco anos na empresa, existem clássicas questões, por exemplo, recebimento de brindes, propina e corrupção de órgãos públicos, agente tem uma área de importação e exportação, agente precisa de um produto, tem uma carreta parada no porto de santos, e aí...

\section{O que fazer?}

E qual é a implicação disto, como proceder neste caso, e até a postura do funcionário para inibir qualquer tentativa de corrupção ativa ou passiva por um órgão público, isto é abordado 
internamente, faz parte do treinamento para os funcionários, sobre esta questão, ... está na maneira como se conduz os negócios esta comunicação da linha ética, tem o número da matriz para casos muitos sérios, ou de repente uma estância local, para tirar qualquer dúvida tem o ramal que é o diretor jurídico, se liga lá, 4467, cai na mesa do diretor, ninguém sabe que ele tem o ramal, mas se ligar no diretor.

Quando eu falei sobre Cidadania, puxou para os efeitos da cidadania na conduta da empresa e do lado de fora você percebeu a pouco tempo, questão da educação, da escola, tem alguma coisa que chama atenção?

Você fala como resultados da floresta urbana?

Pode ser, agente esta falando meio misturado. Você fica mais fácil falar do projeto específico do que falar no geral.

Empresa Cidadã.

Acho que sim, sim, é uma coisa legal, é um tema, um conceito que eu gostaria até de ouvir o que você pensa deste rótulo. Mas, de efeitos da cidadania na população, da comunidade como é que você percebe.

Os projetos são de resultados individuais, não tenho como porque eu não faço um projeto, tirando oeste de Santa Catarina, que é um apoio a um projeto de maior escala que envolve município que eu tenho como mensurar, o quanto de lixo passou a ser separado nos município, tenho resultado grande, agora sobre discussão ambiental em escola, eu sei que os alunos são sensibilizados pela questão, aquele cara vai ser o cara que não vai jogar lixo no chão, não vai poluir os rios, vai se muito mais bem informado, mesmo que ele faça isso, ele não vai poder dizer eu não sabia, eu não tenho um impacto social, porque a atuação deste projeto especificamente é baixa...

\section{Não tem como medir isto!}

Não é o interesse.

Já que você falou, vou incorporar na próxima pergunta questão da empresa cidadã, que é um, está bastante disseminado o termo, como é para vocês, vocês usam, não usam o que significa para vocês o termo?

Agente não usa, a agora a diretoria desenvolveu um slogan para KB como Higiene, Saúde e Modo Sustentável, Higiene e saúde modo sustentável em sustentabilidade. Eu gosto deste nome, porque sustentabilidade é outra coisa ... de qualquer maneira isto quer dizer que a empresa incorporou isto 
e tem que comunicar, não basta fazer bem feito, tem que mostrar que faz. A mulher de Cezar, não basta ser honesta, tem que provar que é honesta...

\section{A verdade!}

É uma maneira do mercado, não do consumidor, do mercado em Geral, até para se posicionar como empresa. A questão da empresa cidadã, eu acho que é chavão, ele pode funcionar, mas, a partir do momento que a empresa está preocupado com todas as questões, que agente falou aqui, aí tem selo ABRINQ de empresa cidadã, de repente a empresa faz uma doação para ABRINQ...

Tem autores que questiona até a incompatibilidade, tem empresa e tem cidadão...

Conceito original ao meu ver, é como a empresa se relaciona com outros atores da sociedade, é uma empresa cidadã que faz parte da sociedade porque ela cumpre todos os preceitos que o cidadão cumpre, pagamento de imposto, geração de emprego, favorecimento da geração de riqueza, renda, empresa cidadã eu posso considerar uma empresa simplesmente atende legislação, paga os tributos e gera riqueza, como tem cidadão, não está vinculado a ter um projeto na escola,

\section{Entendi!}

Aí tem a empresa amiga da criança, e amiga da escola.

Fico pensando na questão da empresa cidadã e do cidadão, o cidadão no Brasil tem mais deveres que direitos, nem a empresa tem os direitos, tem o direito, mas não tem acesso às coisas, queriam saber se dá para fazer o paralelo.

Dá, totalmente. Empresa obedece a lei, paga tributos, tem muito pouco retorno sobre isto. Como indústria. Dá uma olhada na rua, contribui com imposto, IPTU, e tudo mais, agente fica parado no trânsito, 400 funcionários indo para casa de uma maneira.. Uma hora, ou duas parada, sujeito a enchente, assalto no farol, não ter transporte de qualidade, a empresa cidadã ela congrega uma parcela da sociedade a empresa é uma .... da sociedade.

Critérios: $\mathrm{O}$ que acontece em critérios de como a verba será investida. Uma parceira com a UNCEF para pensar como investir a empresa como um todo. Qual a melhor forma para destinar a verba tal, isto é feito caso a caso.

Cada projeto é uma sentença, o do Unicef por exemplo. É uma demanda o Unicef tem investido nisso, em analisar e estudar o perfil da criança e do adolescente jovem, dos paises onde tem UNICEF, vários países do mundo, e ai detectou-se que embora o índice dos Brasil seja médio, agente não está entre os piores, e nem entre os melhores, agente está médio de desenvolvimento infantil, agente 
tem bolsões de pobreza e temos necessidades pontuais, a questão do índio e da população de negros, chamam de populações de quilombolas, na região do semi-árido, estas crianças são os quem o menores índices de desenvolvimento humano, desculpa, índice infantil IDI - Índice de desenvolvimento infantil, as médias mais baixas do país, e nas periferias dos centros urbanos, SP, RJ e outras cidades. Por exemplo: Se minha média de SP 0-10, é oito, ou sete. Vou ver que a criança de pinheiros, tem desenvolvimento infantil muito superior àquele que está no Grajaú, São Miguel, em Guaianazes. Você tem que desenvolver projeto para contemplar, porque o UNICEF trabalha com o bem estar como cada crianças individualmente, então desenvolver este projeto com a população de índio que tem muito pouco acesso a este recurso, com quilombolas, e aqui as plataformas urbanas, que agente já tem um piloto SP e RJ.

Na verdade vocês vão buscar apoio a órgãos e instituições que possam de alguma forma nortear ai...

O trabalho da UNICEF impacto de políticas públicas, coordenando ONG e atores de governo prefeituras, fazendo articulação política, para que se impacte políticas públicas, e trabalhando o desenvolvimento de projetos com atores locais, você não contrata uma empresa para ir para o Nordeste, você busca um parceiro local, uma ONG lá, que conhece a cultura e vai desenvolver o projeto de acordo, dentro das possibilidades, por isso que as vezes o trabalho do UNCEF é um pouco abstrato. A medida ...

Me chamou a atenção desde que eu vi o logo da UNICEF primeiro na camisa do Barcelona, e depois da camisa do Boca Jr. O Boca Jr, agora é pago para colocar o logo, quem foi até quem. Se foi o Barcelona que foi bate na porta do Unicef ou vice-versa. No caso de vocês quem que procurou?

É uma parceria mundial que já acontece a seis anos da corporação EMPRESA Fundação EUA, com o UNICEF americano, não só a UNICEF, agente tem parceria com YMCA, Cruz Vermelha, outros órgãos. O conceito de filantropia no EUA é diferente, você doa uma parte de seus recursos para estes órgãos. A empresa não desenvolve projetos como aqui no Brasil, você tem um órgão que faz isso. A EMPRESA americana, que .. demanda.. a empresa pode indicar, quero que este dinheiro que doou, na sua cartela de projetos vá para projetos na África como foi a questão da AIDS, nos países da Africanos que era uma questão muito séria. É uma questão muito séria. Depois se percebeu que pode ser investido na África, não se tem operações na África, mas agente tem operações em muitos paises emergentes, que tem indicadores muito ruins, tão baixo, como os da África. Então deixar para investir na África empresas que tem operação geradora lá, diamante, ou algum fundo, eu vou investir na China, se chegou na China, dinheiro da EMPRESA, para crianças na China, ai você não tinha um 
articulador local, EMPRESA não está no momento de poder gerir estes projetos do Unicef na china, então monta o projeto e vamos atuar no Brif.... Envolve a Indonésia e a Turquia -

\section{Brif Sun, África do Sul, Sol da África...}

Brasil. Rússia, Índia, China, Indonésia e Turquia. São paises chaves para EMPRESA. E aí, Brasil, BRift, começa com B, e o Brasil destes países emergentes é o que tem entregue melhores resultados, a Rússia foi inaugurada no ano passado, a China ainda esta muito recente, Indonésia é incipiente ainda, agente tem uma demanda, e agente tem um cara que cuida de comunicação, e pode comunicar a parceira, inclusive de responsabilidade social e estar interessado e disponível que sou eu. Então eu passei uma semana visitando projetos, com pessoal, ... UNICEF montaram uma caravana, doadores pessoa física, uma mulher de um milionário americano, esta junto com a gente, numa VAN no interior da Bahia, na periferia do RJ, para conhecer estes projetos como poderia ajudar, e agora já vou conhecer o projeto.

Você fala de oferecer os melhores resultados, você reporta a eles para garantir o reinvestimento? Sim, na verdade você tem um certo local, entre eu EMPRESA e os coordenadores destas plataformas, tem estes reports constantes tem material de comunicação interna, de resultados.

\section{Os operadores da UNICEF são os articuladores, na Bahia vai tem uma ONG, que associa.}

Não, quem associa é o UNICEF, ele faz o repasse do fundo.

\section{Você não atua diretamente no projeto.}

Não, eu faço a mensuração dos resultados, e a comunicação interna de todos os meus funcionários aqui, e ajudo na construção destes projetos, plataformas urbanas, eu participo das reuniões para saber como investidor, como pode ser feito, investido, como capital intelectual mesmo.

\section{E o engajamento dos funcionários.}

Agente ainda não tem desenvolvido isto.

\section{Os funcionários do local.}

Não, poderia, por exemplo, plataforma urbanas pelo, agente esta desenvolvendo um projeto piloto, Heliópolis aqui em SP, e em uma comunidade chamada Cantinho do Céu, em interlagos, lá é continho do Céu, porque se tem um bolsão de pobreza e tem o Céu, e agora eles se juntaram para ver as necessidades, na comunidade, como vão se articular localmente, desenvolver os interesses comunitários, a partir do momento que se tiver um modelo de gestão, e ver como você consegue 
incorporar voluntários, ai se trabalha a comunicação, para incentivar, mas agente esta no momento ainda de articulação local, quem da comunidade pode desenvolver este projeto?

\section{Quais as perspectivas? Como se vê daqui pra frente esse movimento da empresa?}

Um momento otimista, do ponto de vista da responsabilidade social, onde se toca os projetos, teve uma evolução, floresta urbana, educação ambiental em escola, o conceito da floresta urbana qual é? Usar material do meio urbano para fazer novos produtos, não precisa ir até a floresta, usa a floresta como meio urbano, ai tem essa cara de projeto. Você tem as escolas, na questão empresa escola, você tem a empresa, e secretaria de meio ambiente, educação, maior... isso é Mogi das Cruzes, Suzano, ... Pinto e Eldorado do Sul, onde agente tem operação

\section{Mogi eu Moro lá...}

Que legal, em Mogi agente tem Centauro Takaoka, nas escolas, as outras escolas não sei o nome de cor, são 17 escolas, esta articulação para que você realmente o resultado impacto, Unicef é muito positivo, eu quero ver, minha expectativa para o futuro é começar a colher frutos nos projetos, ao longo dos anos, no intervalo social evoluir de categoria de $\mathrm{C}$ para B de B para A.

Como você acha que a empresa reconhece isto, vê isso na visão da empresa, para que serve isto. As ações de responsabilidade Social?

Ela está para respaldar tudo aquilo que desenvolvido sobre o discurso da empresa, além do que isso, favorece na relação com a comunidade, é relações públicas. Como a empresa se relaciona dentro.

\section{A empresa pensa desta forma também não só você.}

Não, por exemplo. Quando vou falar de Balanço Social aplicar os resultados nas fábricas, tem funcionários novos, quando sair de uma empresa e vim para EMPRESA, coloquei em consideração o balanço Social de vocês. Eu e o Balanço Social eu achei que esta empresa mercê meu trabalho. O cara que é coordenador meio ambiente, não vai sair de uma empresa e entrar numa empresa que não esta preocupada com isso...

\section{O Balanço Social é uma coisa consultada para quem procura emprego.}

Principalmente, você esta fim de um empresa, você pesquisa sobre uma empresa, você entre no site, tem o relatório social para dowload, com relação de sustentabilidade, o cara lê aquilo e já forma sua opinião sobre o tipo de empresa que ele quer. 
Não é necessariamente um profissional de meio ambiente qualquer profissional. Este foi da área de meio ambiente, mas tenho uma profissional de finanças que se identifica com um projeto de voluntariado. Empresas são todas muito parecidas. Se tem o computador, tem a mesa, o escritório, a Vila Olímpia e o trânsito. Agora a possibilidade de uma empresa qual é? O seu interesse pessoal, a sua filosofia de vida, esta incorporado dentro da empresa, e estou falando de escritórios onde as pessoas são qualificados são capacitadas, tem nível universitário é pós graduação, então a pessoa pode escolher, o mercado está aquecido, vem trabalhar aqui por identificação com a empresa, porque se não identificarem para trabalhar, procura outra, então isso vai muito mais na identificação da pessoa, da pessoa física com a missão da empresa, questão do salário, o mercado, tem uma certa faixa, consegue. Com relação ao governo e autoridade, uma vez que agente bate na porta do BNDES, para pedir apoio, crédito, com relação a máquina, maquinário, gera de riqueza nos município, nos favorece e trazem novos em novas regiões, inclusive com abatimento de imposto sobre produto. Do ponto de vista da comunidade, faz um relacionamento muito melhor e com imprensa, uma vez que isto é muito bem divulgado, se agente tiver qualquer problema, a fábrica pegar fogo, mesmo que agente tenha todo trabalho de prevenção a gente não tem uma imprensa evasiva, ele vai tentar nos ouvir, ele vai dar o fato, mas ele vai nos ouvir, e considerado, e não contrapor, o que agente espera que ela contraponha na matéria e que tenha esta blindagem na imagem da empresa.

\section{Na parte de comunicação. Por que Balanço Social x Relatório Anual são separados?}

Por ser uma empresa com capital fechado, ela é limitada no Brasil. A gente só publica o relatório social e não o financeiro, porque ele é aberto por região pela corporação. Na matriz você tem os dois compilados. Você tem o relatório com os dados, demonstrações financeiras e as ações de responsabilidade social. Os programas corporativos em âmbito global. Por país é relatório de atividades sociais. Alguns dados financeiros são abertos, mas não todos. Por conta de ações, de interesses de investidores, questão alheia à política da empresa.

\section{No Brasil, a publicação ocorre desde 2004.}

Eu entrei na empresa em 2003, até então não tinha a prática de publicação de relatórios. Em 2003 eu comecei a compilar todas as ações que as unidades da empresa desenvolviam. Que eram ações muito mais de filantropia, de (dna) corporativo, em torno da fábrica. A gente publicou o primeiro ano com alguns dados de Ibase, depois migrou pra Ethos, agora a gente tá indo para o segundo ano de GRI.

O primeiro ano foi o ano passado, que a gente está na categoria $C, 1.0$ dos balanços. A gente começou com IBASE, evoluímos para Ethos, agora entramos no GRI, na categoria C, meu objetivo para o relatório 2008 - a publicar em 2009 é entrar na categoria B ou A. Como certificação. 


\section{Certificação...}

Cada um desses indicadores vai evoluindo. O Ibase está muito mais ligado ao que a empresa desenvolve com funcionários. Tem lá questões como lucro da empresa e investimento em educação de funcionários, meio ambiente, cultura e higiene para públicos internos e externos. O Ethos envolve públicos de interesse. Também em relação com fornecedor, governo, meio ambiente, relação com público interno. O GRI desdobra esses indicadores... é uma etapa evolutiva do Ethos. E é um padrão mundial. Posso ter tanto aqui, quanto na Coréia, no mesmo indicador. E tanto a EMPRESA quanto o concorrente vai seguir os mesmos preceitos de indicadores.

\section{Diferentes públicos - como comunica? Ênfase maior nos corporativos?}

Na verdade é uma estratégia de negócio por conta dos nossos produtos são de higiene - fralda, absorvente, papéis higiênicos ou a mão - o que representa a maioria dos nossos produtos. A gente tem uma ação muito mais pautada para a informação e representatividade dentro das associações de classe, seja a Associação Brasileira das Indústrias de Higiene e Perfumaria ABIPET? e lá tá NT, AV, $\mathrm{BT}, \mathrm{PT}, \mathrm{JH}$... Nos outros fóruns que a empresa faz parte, no relacionamento com governo e imprensa, tanto é que a gente tá entre as 50 empresas mais sustentáveis segundo a mídia. Publicado pela revista Imprensa. Edição de março. No setor de higiene e cosméticos a gente está em 2o lugar, só atrás da NT, em divulgação para a imprensa.

A gente não desce até o consumidor final, isso é resultado de pesquisa, é um amadurecimento, de estar na área de interesse do consumidor. A gente tem uma pressão muito mais do cliente de ele querer produtos sustentáveis. Nosso cliente é WM, o CBD, CF. Isso na divisão consumo. Na divisão EMPRESAP, que é dispenser de banheiro, sabonete. A empresa é o tomador de decisão. Para ele é importante. Tanto é que publicar balanço social, abrir esses resultados e as práticas de consumo, quanto a gente investe em programas ambientais, se aquele material é reciclado, é processado, a destinação daqueles que é hidrossolúvel, isso faz parte até para poder participar de uma concorrência. Então eu tenho uma ação com cliente para produtos institucionais e corporativos com públicos estratégicos, e não consumidor porque não está na árvore de tomada de decisão dele. Isso é resultado de pesquisas.

\section{Na hora que escolhe o produto...}

Ele não tem interesse. Ele tem interesse na performance, no rendimento, ele não quer saber se o produto é biodegradável, se não é. Isso para produtos de higiene e descartáveis. O consumidor dos nossos produtos não apontam isso (opção por produtos "conscientes"). Embora a gente tenha visto que em alguns outros segmentos é importante isso até como fator de decisão de compra. E eu já 
ouvi pesquisas onde ele estaria até disposto a pagar mais. No momento como nós estamos, não está disposta a pagar mais e também não tem muito interesse pela questão da fralda. Não está na pauta. A empresa tem tomado ações preventivas, mas com foco em melhorar processos, num padrão global, novas tecnologias, porque eu acho que quem sai na frente nisso lidera o mercado. E a gente fez estudos ambientais vendo a equivalência entre um produto descartável (fralda) e o impacto do pano também, desde a plantação do algodão, do processamento, do uso de detergente para lavar isso, do consumo de água. Um estudo feito pela Agência Nacional Britânica atesta que é um empate. Os dois têm o mesmo dano ambiental.

\section{Caneca e copo descartável?}

O copo é todo reaproveitado, circuito fechado, gera um copo novo. O BR implantou o projeto (das canecas) em 2003, quando começou esse assunto. E eles viram que o consumo de água para lavar essa caneca, e de detergente era muito maior. Além da questão do lixo do escritório. Você tem mil pessoas no ambiente de trabalho. E tem a questão de higiene. A gente tem a questão também dos papéis e das toalhas de mão. Que é a retro-contaminação. Você usa, você espirra e lava a mão, não lava direito, não usa sabonete, tem gente que só molha a mão e seca na toalha. Daqui a pouco o outro vai usar. $\mathrm{O}$ uso de pano favorece a retro-contaminação. Em caso de crianças, maior quantidade de assadura, problema de pele, alergias. 


\section{ENTREVISTADO B}

(Gravação perdeu o começo)

É impossível não falar de relações até porque o que a gente está vivendo hoje. A empresa teve uma mudança no seu controle acionário em 2007 , julho de 2007 , a SRS passou a ter $70 \%$ das suas ações nas mãos de um grupo europeu...

\section{(som inaudível)}

$30 \%$ ainda estão com um Banco no Brasileiro, mas 70\% estão com esta organização irlandesa, que tem sede na Irlanda, em Dublin, mas também, uma parte importante tem na Califórnia. Então é impossível não falar deste histórico desta mudança de controle acionário e da sua influência na publicação de nosso relatório. Por quê? Primeiro, a SRS um empresa fechada, que tinha um histórico de publicação de relatório com maior nível de transparência desde 2004 publicando relatório GRI, acompanhando. (2004 já era GRI) primeiro ano quando começou o GRI agente fez, quando não era GT..., hoje já é GT...

\section{Você já estava aqui na empresa?}

Não. Eu entrei no relatório G2, faz dois anos, 2006, engraçado agente comparar a entrada na empresa a partir dos modelos de relatório. Mas foi o que aconteceu comigo. Que coisa Boa...

\section{A empresa melhorou...}

Mas, com a mudança do controle acionário, agente passou a reportar a área de responsabilidade corporativa nossa, até um pouco recentemente, muito recentemente chamava-se cidadania empresarial, olha, meu cartão ainda está cidadania empresarial meu cartão ainda não acabou, eu gosto de usar e.

Muito interessante, que eu tenho visto no SRS, um dos motivos de ter escolhidos a empresa de vocês, de forma qualitativa, foi observar se a empresa tem seu trabalho reconhecido pelo Mercado, como você são habituais no guia exame, boas práticas corporativas. Acho que a NT foi que mais apareceu, e vocês em segundo, ta lá, 2007, vocês tem muito ligada na qualidade de vida, é a cidadania empresarial não é tão clara, e claro que você entende qualidade de vida como parte da responsabilidade ai depois eu queria que você falasse destas duas ...

Nosso conceito, muito recentemente da cidadania empresarial como conceito de responsabilidade social corporativa, como guarda-chuva macro de ações internos e externos. Interno agente chama de 
qualidade de vida. E investimento social externo estaria dentro deste mesmo guarda-chuva de cidadania empresarial. Tanto é que agente na estrutura da empresa, hoje agente tem uma área chamada desenvolvimento sustentável, super recente este nome, uma atualização segundo os padrões. Nós estamos tentando acompanhar o mercado, da mesma forma que o guia exame começou chamando responsabilidade social, cidadania, corporativa, esta querendo acompanhar agente acredita que o discurso influencia a prática.

\section{Se eu não acreditasse...}

Fiz questão de fazer este link, pois foi o que me lembram, os limites da minha linguagem é o limite de meu mundo...

\section{Falar com alguém da sua área, a mesma bibliografia.}

Desenvolvimento sustentável hoje na SRS, responde para um organismo internacional, um departamento internacional da SPS de responsabilidade corporativa então é nós tivemos um processo grande durante o ano de 2007, posso dizer, de convencimento dos novos acionistas, da importância de publicação de um relatório de GRI. A X é uma empresa, não tenho nada a esconder, é um fato, eles não tem um histórico de publicação, relatório de responsabilidade corporativa, tanto é que o relatório anual deles é separado, (Ainda bem que você fez esta pergunta) isto é sinal de estarem em um nível menos evoluído. O relatório anual separado de responsabilidade social e responsabilidade corporativa demonstra um desmembramento das ações, e o nosso concentrar em um único relatório, é para fazer com que as ações sejam realmente permeadas na gestão, é uma demonstração que nós conseguimos fazer com que a gestão revele e materialize as iniciativas de desenvolvimento sustentável. Só o fato de você ter dois relatórios numa mesma empresa, um de responsabilidade anual e outro de responsabilidade corporativa já mostra que é um pouquinho.

\section{Normalmente é um balanço mais financeiro...}

Exatamente, voltado..., quando você está preocupado com o engajamento com a parte interessada, parte interessa qual? Todas. Publico interno, universidades, ong's, clientes, fornecedores e acionistas, você publica um único relatório. Que mostra a parte ...

\section{Em relação às empresas, é uma tendência...}

É uma tendência das empresas que estão preocupadas, não chego nem a dizer que são as empresas que fazem um trabalho sério, não isso. E sim, empresas que estão preocupadas em atingir um nível de excelência. É como, quase como mandatória, compulsória, se você tiver separado as duas formas 
de report, isso demonstra como isto está separado dentro da empresa, na verdade relatório corporativo nada mais é do que demonstração de gestão, não é peça publicitária, nada contra.

\section{É um grande folder...}

tanto que é que relatório de GRI mostra ... eu publico as multas que a gente levou... te digo com toda a clareza do mundo, que não tenho nada a esconder, que nós tivemos no ano de 2007, muita dificuldade para... O relatório esta pronto, eu não consegui publicar o relatório.

\section{Procurei no site, ou não estou procurando direito ou não tem ainda.}

Não tem, então o que eu posso te dizer. Sendo muito clara. Mudanças no controle acionário da empresa influenciam toda a estratégia de responsabilidade corporativa, de sustentabilidade, de desenvolvimento sustentável qualquer que seja o nome que você quer dar, para esta relação dos aspectos sociais, ambientais e econômicos.

Aproveitando a deixa. A respeito do nome. Quando comecei a fazer meu Doutorado, o discurso, da responsabilidade social das empresas.... e agente tem pelo 3 denominadores... Como você vê os conceitos?

Até muito recentemente agente optou por cidadania empresarial porque agente, até muito recentemente mesmo, cidadania empresarial dentro da SRS, a SRS se enquadra numa empresa que acredita que ela tem um papel além da sociedade do que é o papel econômico. Então ele tem que ter um papel de cidadã, empresa cidadã. Daquela que se preocupa com os aspectos sociais, ambientais, que não se coloca com o centro, mas como parte, da sociedade. Então aquelas coisas de modelo. Fazer um modelo sistêmico. Então a SRS nunca vai estar no meio, ela vai estar na ponta, relacionada com outros agentes, de indústria, de varejo, com consumidor final, com universidade, se enquadra neste papel. Da mesma forma que nós temos o papel cidadão como pessoa física, a SRS se enquadra como pessoa jurídica da empresa cidadã. Mas, aliada as estas coisas de tentar trazer estes aspectos de modelos mais modernos de gestão, aliada ao padrão internacional, agente viu, por mais que nós tivéssemos, o conceito não mudou, não vou te falar que a gente mudou de dois meses pra cá, agente acredita que o desenvolvimento sustentável, ...o que agente quer demonstrar, então cidadania empresarial tinha um ranso, muito voltada para filantropia, e agente não queria isto, agente quer também, trazer como estratégia de negócio, e eu vou contar um pouco mais pra você. Porque que a SRS se enquadra com a questão de desenvolvimento sustentável na a própria estratégia de negócio? Primeiro o que é a SRS? 
Existem na sociedade pra, trazer informações de crédito e informações segura de negócio. Informação segura de negócio. Como fazer com que as empresas e a as pessoas físicas tenham um grau de certeza maior nas suas decisões de negócio. Como a questão da responsabilidade social entra, a responsabilidade socioambiental entre neste viés. Agente tem o nosso rating, como score das empresas... Quando uma empresa preenche seu balanço financeiro e manda para SRS, os nosso analistas econômicos fazem uma análise do grau de risco daquela determinada organização, e aquela determinada organização se enquadra (notas) risca baixo, risco, alto...

\section{E a mudança...}

Então a idéia da mudança de nome, tanto, por um alinhamento a nomenclatura mais atual que tem sido utilizada pelas corporações, que fala desta temática e também para abarcar melhor, aspectos sociais, ambientais e econômicos. E não ficar com cunho muito assim...

\section{Tem a cidadania e a idéia de filantropia...}

Depois eu queria voltar a falar sobre rating... E o nosso... responsabilidade corporativa...

\section{Porque cidadania? Porque você fez esta associação?}

Na verdade nós tínhamos, um pequeno, um pouco de "ranso", esta coisa de empresa americana, que acha que filantropia é a partir de doações. Queria um pouco se desvincular, enfim, agente não queria falar responsabilidade social, porque agente sabia que nossa responsabilidade era muito maior do que só o aspecto social. Então agente quis falar cidadania, olha, eu como cidadã tenho responsabilidade muito maior do que apenas as sociais, sociais, meu lugar no mundo, as ambientais, impactos econômicos, por isso cidadania, que é trazer características da pessoa física para dentro da organização, que tem que, que sabe que conhece seu papel como responsável pela disseminação mundial muito maior do que a apropria operação dela.

Tinha entendido errado. Mudado de cidadania corporativa para Sustentabilidade, porque cidadania tinha uma relação com a filantropia.

Não tem isso..., porque desenvolvimento sustentável consegue trazer a parte negocial para o tema, então este olhar de como com o nosso próprio corpo... nos temos um impacto, sociedade, como agente faz uma análise econômica de uma determinada empresa ela não pode ser analisada única e exclusivamente pelo seu viés econômico. Então as análises do SRS tem os indicadores sociais, e ambientais de uma única organização, nos coube, o que é? Analisar informações...

\section{Negócio seguro...}


Do ponto de vista sócio ambiental e não só econômico. A empresa tinha um rating maravilhoso independente dela ser mineradora, que não está preocupada com a relações ambientais, isto tem um impacto na co-relação muito grande, a sustentabilidade nos primeiros setores, então agente começou a fazer uma análise setoriais.

Vocês levam estes fatores em conta - não é uma coisa que aconteceu sempre. Exatamente, é muito recente, então quando um grande banco compra de uma determinada empresa $X$, uma empresa média no sul do país, vamos analisar o rating desta empresa, então o rating dela não analisada exclusivamente pelo seu viés econômico. A empresa pode naquele dado momento estanque, estar com um rating ótimo econômico mas ela tem um passivo ambiental, e social tão grande que ao longo prazo pode ser péssimo para a organização que está cedendo crédito.

Isto vocês fazem desde quando, esta análise vocês fazem desde quando...

É muito recente, de 2000 para cá. Isto é muito recente, esta preocupação sócio-ambiental, isto é fazer a sustentabilidade do negócio, aí que eu faço a diferenciação, com uma empresa cidadã do ponto de vista do seus funcionários, públicos interno, mas nem sempre o desenvolvimento sustentável (core-bussines) no seu negocio principal.

\section{A questão dos funcionários já vem fundação empresa?}

Então é iniciativa tanto de público interno, como com parcerias com organizações sociais, organizações assistencialistas, creche, ong's de maneira geral sempre teve este cunho.

\section{De onde veio?}

Presidente, nós tivemos durante 17 anos o mesmo presidente...

\section{Uma pessoa que prezava isto...}

Com caráter pessoal. ele tinha isto como um jeito de ser. Esta coisa que responsabilidade social muda o jeito de ser. Ele tinha isto dentro dele. De ajudar a comunidade, e sabe que a SRS tem um papel maior do ele próprio.

\section{Cuidados com o funcionário...}

Público interno, sempre, qualidade de vida, nos temos aqui os projetos internos, uma escola de música, escola de teatro, academia, a própria escola... não é escola para os funcionários, para terceiros, escola de 1, 2 e 3 grau, parceira com a Fundação Bradesco, pessoal da limpeza pode fazer o curso aqui, nos temos esta preocupação, aqui no prédio, 4 andar. Tem uma escola... 


\section{Escolhe um horário compatível}

De manhã, (...) estão, esta parte educacional ta entrando muito forte parte de qualidade de vida do funcionário, por exemplo: uma escola de circo aqui.

Deixa eu fazer uma pergunta: você falou do pessoal da empresa: terceirização como é que esta relação porque volta e meia algumas empresas, como você falou, vocês oferecem uma série de beneficio para o terceirizado. Tem algum controle? Cobrança sobre a postura da empresa conforme a empresa terceiriza? Exemplo da EP acontecia assim, agente percebia um procedimento com um funcionário, mas a conduta em relação aos terceirizados escapavam um pouco do controle da empresa- eu não sei como é que vocês lidam com isso?

Diariamente agente, nos temos uma estrutura preocupada com isso, tem 12 pessoas na área de desenvolvimento sustentável, empresa de 2500 funcionários, tem 12 pessoas que estão full time, alocadas para isso, estão contratadas para isso, então nós temos um olhar muito atento para isso. Todos estes cursos extras, que não fazem parte, que não é curso técnico da empresa, são todos abertos para a comunidade, curso de teatro, escola de música, nós temos ...o nosso segurança ... ele faz escola de música, ele faz escola de teatro, agente está sempre preocupado a dar esta oportunidade, obviamente, internamente, nos temos o embate com a área jurídica, que vira e meche se preocupa em não configurar uma relação de empregabilidade, porque eles não são nosso funcionários, então tem que ser sempre estes cursos que se configuram como atividade extra carreira, tudo que é qualidade de vida.

Relação aos benefícios o responsável é a empresa "deles", ai se tem alguma cobrança, algum questionamento?

Cesta de natal, exemplo, isto é benefício de funcionário, então agente não pode dar.

Fica a critério da empresa, vocês fazem exigências com os fornecedores, WM por exemplo faz um série de exigências com seus fornecedores. Com relação ao terceirizado vocês tem...

Temos uma iniciativa, que a área de educação que coordena que se chama integração. Integração 3 dias de evento, que quando o novo funcionário entra na empresa para ele conhecer a lógica da empresa, parte negocial que ele vai trabalhar exatamente a técnica, e os produtos e iniciativas que institucionais, este institucional é a área de desenvolvimento sustentável, voluntariado, é a qualidade de vida, educação, este treinamento que o terceirizado faz com a gente, independente dele ser terceirizado para entender a lógica da empresa com a integração junto. 


\section{Direitos, relação trabalhista...}

Estamos sempre com a preocupação, o jurídico esta sempre preocupado com isto para não se configurar, eu já briguei lá trás por isso.

É uma das críticas - agiria ou atuaria em uma coisa extra direito - extra relação de trabalho, no caso dos funcionários tem todos os direitos garantidos, os benefícios...

Legalidade... isto é uma responsabilidade social.

\section{Fazem a obrigação é um pouco mais...}

Fazemos a obrigação e este um pouco mais, um muito mais. Qualidade de vida. Semana que vem nós termos um grande evento na SRS, que é o recital escola de música, no teatro gazeta, 1000 pessoas, todo mundo pode levar dois convidados, segunda e terça. Agente está preocupado que o funcionário tenha um desenvolvimento pessoal também, extra profissional, sabe aquela coisa de sair da caixinha, só ficar analisando balanço, ótimo maravilha que você tenha sua técnica, você é um profissional para fazer, mas além disse agente saber que tem um papel no mundo, e seu papel no mundo, é ter relacionamento pessoal, é saber viver em sociedade, é ter uma preocupação com a cultura, e o nosso diretor de RH, ele é teatrólogo, ele escreve, o roteiro do recital, esta preocupado com aquele dia, o recital, quem são as pessoas, são os alunos da escola de música, da escola de teatro, ter esta preocupação, A SRS é uma empresa que está....

Para o ano que vem, a idéias para os projetos, o jeito de cuidar dos funcionários veio lá traz de uma pessoa que é o presidente, deu este tom para a empresa.

Ele também deu um tom muito forte para o nosso trabalho de voluntariado, SRS tem um histórico de voluntariado muito grande, mas porque, o presidente incentivava demais isto, você tem que fazer alguma coisa para sociedade além do seu trabalho no dia-a-dia, se doar para a sociedade, a sociedade é melhor quando todo mundo está bem, não existe empresa rica e sociedade pobre. (...) ano que vem

\section{Presidente para as pessoas responderem}

Exatamente! Então poucas pessoas na sociedade, ... querer fazer alguma coisa... de repente com o incentivo da própria empresa, ficou mais fácil, meu telefone, para fazer uma ligação para o patrocínio de uma determinada organização. Semana passada foi o dia do voluntário SRS, que é este dia voluntário SRS, é um dia, ...além voluntariado que a empresa incentiva. Eu sou voluntário em uma determinada organização, eu posso usar o telefone da SRS, e-mail do SRS, eu posso usar meu o recurso como profissional para ajudar uma outra organização, eu tenho autorização, minha liderança 
para isso, eu posso usar o nome da SRS, ale disso tem um único dia que é o dia $D$, que agente fala, que dia internacional do voluntário, a empresa inteira, atua em uma única organização, grande o suficiente para saber ... as 600 das pessoas que se doam este dia para a organização, jardinagem, pintura, mutirão, sabe aquele trabalho de mutirão, que á uma cara nova para empresa...

\section{Como é que vocês definem?}

Nas agências, que a SRS trabalha com agência, como é agência de banco. Nós temos no Brasil inteiro as agências. Aqui é a sede, nós temos 144 pontos estratégicos.

\section{No Brasil inteiro?}

As agências escolhem suas próprias organizações parceiras, sempre tem uma organização, uma creche, um asilo, uma organização assistencialista que o funcionário atuam como voluntário, eles fazem nesta mesma organização. Aqui na sede como agente tem várias organizações sempre se escolhe uma que seja grande o suficiente que consiga receber 500 a 600 pessoas, que tenha obviamente a necessidade, é claro que agente não vai escolher um grande hospital, por mais que o hospital seja terceiro setor, ele já tem os recursos necessários, agente escolhe uma organização que esteja realmente precisando desta...

Tem algum critério, uma questão que sempre fica. Um funcionário que conheceu alguém, você tem um procedimento, um critério mais padrão.

Caso a caso. Recentemente nós temos uma política. Que tipo de organização que pode participar? Primeiro que esta organização tem que estar com todos os seus... Sem pendências financeiras. Nosso negócio, o que é o nosso negócio? Nós temos que analisar o Balanço desta organização. Nós não vamos atuar em uma organização que tenha desvio de dinheiro, que o dirigente com o nome com algum problema financeiro. Queremos uma organização idônea.

\section{Este é o primeiro crivo. Crivo estratégico.}

Ela tem que estar cadastrado em nossa base de dados, porque a nosso base de dados não é só para pessoa... (ONG e OSCIP) nem ong e nem oscip, nenhuma organização do terceiro setor, é obrigada legalmente a publicar balanço, no então, a SRS valoriza isto, e usa isto como processo de seleção, então ela não é obrigada a publicar mas aquela que publica, estar com os documentos em ordem tem uma certa preferência em comparação com as outras organizações. Outra coisa, como você ... capacita-los para ajudar a organização. Para você ser voluntário em uma organização você não vai poder..., ah! vou ser voluntário em uma organização que está tudo certinho, não. Você pode ajudar 
inclusive... exemplo: você pode doar seu trabalho voluntário como contador fazendo a análise do balanço.

Foi uma das matérias da exame, falando justamente isso - tinha o voluntariado e uma espécie de consultoria de gestão.

Exatamente, os advogados podem doar o seu trabalho voluntário com assessoria jurídica, temos esta linha de voluntariado forte.

Você falou no 10 critério do balanço, desta responsabilidade fiscal.

Pro voluntariado nós temos organizações que lidam com assistência social, pro voluntariado, o que são estas organizações, são creches, são asilos, são organizações, de abrigos, que você pode fazer um trabalho. Pro voluntariado é. Por que? Porque isto já é histórico do nosso trabalho voluntário, então agente não vai mudar. Olha o funcionário já faz este trabalho, não é porque a empresa tem uma característica $\mathrm{X}$ que, vai mudar... ong ambientalista por que nós estamos no tempo de aquecimento global, nada disso. Se hoje nos temos uma postura para ação social...

Você acha que a questão da sustentabilidade de alguma forma responde a uma demanda de mercado, uma demanda de global, em que medida isto de alguma forma interferiu nas ações, mudou um pouco o jeito de fazer?

Porque agente está mais preocupado com as questões ambientais, incluir critérios ambientais nas análises econômicas, ...de repente a Petrobras saiu do ISE (saiu do ISE brigou com o ethos - está tenso). De que forma isso balançou o rating da Petrobras aqui na SRS. Esta preocupação de satisfação ambientais, ... diferença no nosso jeito de fazer... Questão da reciclagem, esta preocupação com a reciclagem, o prédio inteiro, o que agente faz com a reciclagem, agente vende isso, compra... o Dinheiro arrecadado para comprar cesta básica para a comunidade... tem esta preocupação com as coisas que estão acontecendo, você olhar para o meio ambiente, de você olhar área essa realidade, para atualidade...

\section{É uma resposta a um movimento.}

Estamos preocupados com isso, acabei de fechar uma parceria hoje com a ong report Brasil, a partir de hoje é uma novidade, até operacionaliza tudo, no rating da empresa e no CPF das pessoas físicas que tiverem no trabalho, envolvidas com trabalho escravo vai ter uma marcação... isto é muito bom para o setor. A empresa que tem o proprietário $X$, que tem ... com trabalho escravo .... os bancos tem que prestar atenção nisto... agente nunca teve... especificamente A ONG report Brasil, isto é bom para o setor, é mercado, agente assinou um pacto contra o trabalho escravo, tá bom, SRS 
assinou um pacto contra o trabalho escravo, em 2002, mas, além disso, o que é que agente faz, além de nosso como operação, nosso impacto, cadeia de valor, é mais ... do que é o impacto dos negócios.

Na conduta das empresas que ela está avaliando, radical - o trabalho escravo seria assim impensável...

Nosso rating...

A questão de direitos, trabalhistas, sindicatos, este tipo de coisa, isto entra também nas avaliações ou não?

Isto entra nos aspectos sociais, no GRI, nosso rating é baseado no GRI e no ISE e no (outro).

\section{Tem a questão do Ibase.}

No ibase, agente publica o ibase, mas como operação...

\section{Como parâmetro?}

Exatamente, as perguntas específicas do ibase não encarou em nosso ratig, agente achou que o GRI está mais amplo, agente então, o ibase, foi muito legal, agente foi... no ibase também, porque ai agente tem uma comparação funcional, porque muitas empresas brasileiras publicam um relatório seguindo o modelo do lbase.

Você acha que tem uma imigração, as pessoas estão migrando para um modelo GRI ou não?

Não é diferente, é legal por que você tem o lbase, alto investimento em educação, e o GRI não é.

O SRS..., O ibase você consegue ver porcentagem de investimento em educação, cultura e esporte, então dá para você comparar...

\section{Isto é integra com o público interno?}

Isto é externo e este é interno.

\section{E o GRI não tem esta divisão?}

Esta divisão não é tão claro, tem um indicador de investimento social, mas não tem separado, quanto que vai para a educação, quanto vai para cultura, então este para comparação nacional é melhor, agente vê aqui, o que vem escrito em investimento... aplicado. 
O Ibase não, ele é nosso modelo de operação, até algumas perguntas aqui, de trabalho voluntário, reclamação, tipo PROCON estas coisas isto entra, então agente até pegou algum, infelizmente ainda não tem...

(sem áudio)

Eles estão negociando a questão do discurso, então eles querem a alinhamento de discurso...

\section{Com as outras unidades?}

Com a global, porque eles não fazem o GRI, O nível de .... é maior do GRI, porque...

\section{É menor que o lbase, e maior que outros - detalhes e certos aspectos...}

Não é que é maior, o GRI é muito maior que o lbase, o lbase é social só, não tem quase nada de ambiental o Ibase, pouquíssimo coisa ambiental e o GRi, tem...não este que é melhor e maior.

\section{A impressão que eu tenho é: que as coisas, questão social, se fundiu, se misturou, com a ambiental ou não.}

No discurso sim, mas um pouco menos na prática, e uma coisa que eu vejo muito claro, é a grande, lado positivo do GRI, tal da moda do... teste de materialidade, ouvir o que as partes interessadas está preocupada, o Ibase não, preenche sozinha, sem ninguém dá pitaco, agente vai, busca os dados, pega os dados, preenche o relatório, pronto e auto declarado. O GRI, você tem que ouvir o cara, o que cliente esta interessado, o que fornecedor está interessado, tem que fazer consulta pública, o que é consulta pública. Chama todo mundo, aqui.

\section{Como é que é - comunidade?}

Agente convida, parte estratégica da comunidade, ong's parceiras, os vizinhos o entorno

\section{Na compreensão de comunidade seria - ong, vizinho...}

Agente chama poder público, secretaria, imprensa, público interno, representantes do público interna com diferentes níveis salariais...

\section{Como é que feito? É uma reunião?}

Reunião com apresentação de relatório, com discussão, apresentação de temas que são relevantes para cada um dos atores, ai se tira o que são os temas ... O questionário, faz discussão na hora... Já faz um 5 anos, de 2004 para cá, do GRI, então, o que eu posso te dizer, é um modelo estruturado de 
iniciativa, e que é uma alteração do controle acionário muda completamente, porque você tem um processo meio que

(sem áudio)

pra depois voltar, então, se eu não tenho ainda pra te apresentar é que ainda estamos em negociação.

Mudança acionária questão financeira da empresa tem poder para acabar com a questão da responsabilidade social, talvez não acabe porque tem resistência interna ou não.

Não é porque tem interna, não é nem tão interna, assim, seria um tiro no pé, sabe aquela coisa de, os três pilares da sustentabilidade, Econômico, social e ambiental, você já viu tripé de uma perna só, a longo prazo não existe, é um tiro no pé, é não pensar estrategicamente, responsabilidade social corporativa e desenvolvimento sustentável é garantir que a empresa seja na futura... garantir a perenidade da empresa, garantir o lucro também.

\section{O que garante não é a resistência interna...}

Não é só a interna, tem um... não quero que pense só no interno, porque pó, interno é que, nós estamos aqui, como funcionário, é garantir a resistência da empresa no longo prazo, mais longo do que nossa vida como funcionário de uma empresa, em termos de perenidade mesmo, para os outros que virão, que virão, que virão, acho que: é sim para o público interno, não só, é a sociedade, todo mundo que está... pensando em cadeia, claro que o público interno é o responsável por tudo esse negócio se não ... viram máquina,

\section{São as pessoas que fazem acontecer}

Exatamente, são as pessoas que fazem as coisas acontecer, não diria que assim, única e exclusivamente, tem um grande, referência, uma grande influência, não é somente o público interno que faz garantir, por que senão, no curto prazo, a agente consegue, é, a organização consegue segurar a bola, a fúria, não sei o que do público interno...

\section{Entendi...}

Não consegue, mas no longo prazo não sei se tem, algo como relacionamento no começo e no longo prazo, se dá um jeito no namoro, mas depois. Esse caminho, eu acho que a lógica é esta,

Então o convencimento foi por aí, tentar convencer a empresa de que... 
Estamos no convencimento diário com a nossa gestão atual, ... da empresa, então muito legal a gente poder trazer .... que não tem uma história de responsabilidade social, que vem de uma empresa que não tem história, acaba se apaixonando pelo tema,

[sem áudio]

enfim, papel de convencimento com ele, ele enxergar, ver tanta coisa boa, é a responsabilidade social, e ele não tinha a noção, sabe, responsabilidade corporativa, direitos humanos, programa de empregabilidade de pessoas com deficiência da SRS, reconhecido pela ONU, desde 2001,

\section{O prédio também, acessibilidade...}

Todo accessível, além de ter esta questão... porque prédio é prédio,

\section{Acessibilidade física...}

Além disso, nós temos capacitação destas pessoas, ... reunião de capacitação destas pessoas, pra muito antes de ter este negócio da Lei, ...cota...

Que a maioria das empresas não seguem, até porque dizem que não conseguem...

Aquela coisa, claro não consegue porque não deixa...

\section{[sem áudio]}

Tanta coisa discriminatória, aqui na SRS, quando eu entrei na SRS, mas gente o que que isso, o cara que vai te receber quando se faz um processo de seleção é assim, ele falando do prédio inteiro,

[sem áudio]

é o que vai te levar então, o advogado,

[sem áudio]

aqui não tem... o síndrome de down, então tem essa coisa, ambiente de trabalho como um fator de diferenciação para a própria realidade para empresa, não é que, agente sabe que isto é bom para empresa, porque a empresa é reflexo do que é lá fora, porque lá fora nem todo mundo é igualzinho, porque é que a empresa vai ser, então nós somos espelhos da realidade lá fora, ... capacitar, dar oportunidade, e depois de capacitar dar oportunidade como ...

A inclusão feita de qualquer jeito, acaba aceite por inverso, Na época, na ECA, vamos incluir as pessoas, colocaram um rapaz com tremendas dificuldades de se expressar, com tabuleiro, quer dizer, isto é um desastre, por que na verdade ele esta na sala, o professor não esta preparado para receber, a sala não tinha lugar, o alunos ficavam putos com ele porque ele atrapalhava, e ele ficava, ... todo mundo com muita pena, o cara taí, vamos tentar ajudar, enfim... 0 efeito da 
inclusão foi potencializar os preconceitos, porque não tinha, não tem nenhum preparo porque o professor, cara taí nós vamos botar ele aí, você se vira e dá um jeito, e não é tão fácil assim.

Não é, tem que ter muito, primeiro de tudo, apoio da alta direção para isso, se você não tiver apoio da alta direção, nós queremos ter capacitação e depois dar oportunidade de crescimento para a pessoa, nada vai acontecer, então hoje, nós estamos capacitando além da nossa cota ideal, segundo legalidade, nós temos 37 pessoas com deficiência numa capacitação de seis meses em parceira com mais 15 empresas, porque a SRS, não é somente para nossa sede, é muito mais do que empregabilidade, é capacitação para o mercado de trabalho, não é só cumprir, não é para cumpri uma questão de legislação não. Depois de terminar a capacitação estas pessoas podem ser contratadas por estas empresas que financiaram o treinamento. Então colocar a questão da deficiência como um projeto, um processo de inclusão social e também como um projeto de gestão, de uma empresa que tem um ambiente mais diverso, empresa mais produtiva que encara as questões do mundo no mercado lá fora de maneira diferente, então, se eu tivesse que escolher dois grande projetos da SRS para falar: O projeto de Empregabilidade de pessoas com deficiência e o nosso programa de Qualidade de Vida, a maneira como aqui nós não chamamos de funcionários, maneira um pouco pop, cultura organizacional, Ser SRS, calma deixa eu explicar até recentemente, (Não é colaboradores) vai ver isto no relatório, até recentemente nós éramos Ser SRS, ser SRS, só ser SRS, (Ser cidadão, ser SRS ser...) Ser de que porque também é o começinho da palavra SRS, um jogo de palavras que identificava a pessoa que tinha valores comuns com os dá organização,

Mas se refere as pessoas assim, porque o ser SRS, já conversou com ser SRS...

Cultural total, e agora...

\section{Ser o que?}

Não tem sobrenome, foi feito toda uma estratégia de marketing, comunicação interna, como você vai tratar com um estrangeiro,

\section{[sem áudio]}

\section{Mas não difícil: vou te passar para o ser SRS.}

Agente acostuma, ser SRS não é, vira e meche eu escrevo ser SRS \{Ela está rindo: ser SRS não é nada difícil agente acostuma, totalmente, eu trabalhei em uma empresa 3 anos, ... estranho! Mas depois você se habitua\} \{terceiro: Ele está perguntando se as pessoas falam ser SRS..., sim ser SRS...sim\} isto é muito comum, se esta cultura organizacional é muito forte, agora a gente tem que se acostumar a falar ser SRS 
O que é, colaborador, é muito, é funcionário, é trabalhador, e agora o ser SRS foi mais elaborado, fizeram um brincadeira.

No dia-dia, você se refere a você mesmo, como funcionário, comunicado sim, prezado Ser SRS, NO diálogo nem pode, você não fala funcionário, é difícil falar, quando vocês se referem alguém, aquele ser SRS lá, você não sabe o nome dele, o segurança sabe muito, porque eles acompanham agente, por favor acompanha o ser SRS, ser SRS tal até metrô tal (Divertido) Você acostuma viu, Até em palestra eu falei, ... é difícil você falar funcionário em outra empresa,

\section{Já não soa natural}

Não soa natural, aí tem que por colaborar, dá uma ... você sabe que esta palavra não se fala, é engraçado é cultural mesmo.

Mero detalhe, meus amigos que não são ser SRS...

\section{Ser de casa, ser SRS.}

Eu poderia caracteriza que é uma empresa com muita cultura organizacional fortíssima, então agente tem isso assim realmente atrelado valores e tudo mais, esta coisa da mudança do controle acionário, intactas, intactas e muito, como isso, e assim, agente tem

\section{(sem áudio)}

muito bons como...

Me fala uma coisa dura assim, teve mudanças, temores, cortes...

Não, neste momento não,

\section{Nem com a crise agora, não assombrou...}

(...) último, é assim há pessoas, agente pode sim ter que dar uma olhada mais atenta as linhas orçamentárias, então sabe, coisa que nós tivemos mais flexibilidade para orçamento, joga daqui, põe ali, tínhamos um caixas melhores, agora ta mais, a parte financeira ta pegando mais no pé, mais em momento nenhum a crise

(sem áudio)

empresa ta crescendo, muito.

(sem áudio)

Agora novembro, fechamos com 249 5, empresa está crescendo,

(sem áudio)

da MF, então está contratando muito...

(sem áudio) 
jornalístico. Estava em torno de 100, 120 pessoas, (sem áudio) nós tivemos que comprar outro prédio, não é só aqui, Agora tem na Paulista, na Antônio Carlos, então,

Não prever este tipo de impacto, que nem a história recente dos brancos, você percebe no discurso, até algumas sobreposições, isto quer dizer que algumas pessoas vão ser mandado embora.

Agente acha que, algumas pessoas mandada embora não, agente está querendo... algumas pessoas até foram mandadas embora, mas porque, é tipo de gestão, ... agora internacional, agora a empresa ficou um pouco mais ágil, então a pessoa está mal acostumada, num modelo mais... a empresa que tinha mais, mais "mãezona", levava um susto, ... esporádico,...

\section{Sem querer, não é uma coisa que virou...}

Área comercial está contratando muita gente, quer crescer, a empresa quer crescer na América Latina, então ela foi comprada para crescer na América Latina, não é, então este aspecto agente tem que toma um pouco...

\section{Por contratação mesmo, funcionário CLT?}

Tudo CLT, nossos funcionários são todos $C L T$, nós temos um único mecanismo de, que eles chamam de representantes, são pessoas que vendem os produtos SRS mas eles são, por exemplo, você tem uma empresa, ... Brasil, não precisa ser funcionários da SRS para vender o produto massapê. ... Focos ou agentes da SRS, por exemplo em Manaus, ... em comum, existem os representantes locais, quem tem, precisa estabelece uma agencia mesmo que pequenininha...

\section{É uma questão de vendas, tem as comissões, a negociação...tá}

\section{[sem áudio]}

... aqui é interno ...

Sempre há uma terceirização plástica, é o novo proletariado, como sempre...

Então. Nosso .. interno.

Só a parte de segurança você falou.

Segurança, limpeza, sem áudio, é terceirizado... Agente falou bastante coisa...

\section{Tem uma estrutura, do departamento?}

Desenvolvimento Sustentável. 


\section{Como é que é esta estrutura, a quem ele se reporta, como isto está dentro da empresa?}

Nós temos aqui - DS - Desenvolvimento Sustentável, nós temos aqui, processo SRS social, que é o nosso voluntariado, investimento social privado, empregabilidade de pessoas com deficiência, Qualidade de Vida, que cuida (Do Ser SRS) de tudo que é cuida do que é extra benefício, carteira, extra a carteira, teatro, aula de música, coral, academia, tudo que é, não tem a ver, não esta na folha de pagamento que ele vai ter todos aqueles..., promoção da saúde, nutricionista, médico, psicólogo.

\section{Isso Público Interno?}

Tudo interno?

\section{Externo é aqui?}

É, mas isto aqui é tudo para nosso Público Interno, sem áudio, aqui é um gerente, e aqui sou eu, sustentabilidade, que é assim, seria, dar um apoio, sem áudio, então aqui 2, 6, 2, 4, certinho doze pessoas...

Se eu entendi, é você que cuida da comunicação de tudo isso?

É, na verdade eu tenho este papel de ter um olhar para as questões de sustentabilidade, então, eu faço o relatório corporativo,

Que acaba abarcando, tudo isso aqui...

Isso tudo, mas que estas pessoas cuidam dos projetos específico, eu cuido da questão da comunicação destes projetos, mas faço o relatório corporativo, e tenho relações com os institutos parceiros, Instituto Empresarial, GRI, GIFE, (relações públicas também). Eu sou relações públicas de formação, eu fiz RP na ECA.

\section{Achei que você fez jornalismo?}

Não, mas não, eu perguntei?

Você era do mesmo departamento nosso lá, as moças do RP, a mulherada do RP, preconceito, agente enchia o saco delas?

Vocês adoram, vocês adoram, não vem que não tem (você com aquele ar, garotos, agente abarca vocês, com aquele olhar) é verdade, agora eles entendem... 
Então, eu tenho um papel de parcerias estratégicas, sem áudio, projetos e produtos que tenham relação com a sustentabilidade, parceria com o Repórter Brasil, projetos como o rating social e ambiental, este olhar para a sustentabilidade que não de projetos específicos, mas um olhar mais macro de trazer para estratégia do negócio...

Esse nome não era este então, há um tempo atrás, ou se já era sustentabilidade, você entrou em 2006 você falou...

Eu entrei na cidadania empresarial na linha da cidadania empresarial.

\section{Esta titulação é de quando?}

É recente, este ano também, setembro, é setembro se não me engano, setembro...

Sem tomar muito seu tempo, antes disso como que era? Lembra mais ou menos...

Antes disso, Qualidade de Vida era uma gerência, era separado, era uma gerência separado, esta parte aqui, era isso aqui, antes disso, Qualidade de vida

\section{Estes dois eram uma gerência, estes 3 era aonde?}

Estes 3 eram assim, eram a cidadania,

\section{Entendi.}

Então de setembro pra cá, ... muito recente.

\section{Muito Bom!}

Então estamos neste processo de nos entendermos ainda né, o nosso papel. OK? Vou te deixar isto com você, aqui nossa apresentação mais recente, que tem este viés, da questão da sustentabilidade, olha que a SRS, práticas e processo de políticas, levando em consideração os aspectos sociais, ambientais e econômicos, materializam com relacionamento com cada uma das partes interessadas, numa gestão sustentável, ai conta um pouquinho dos processos dividido com cada um dos pilares.

\section{Muito bom.}

Tá bom. Este é seu.

\section{Muito obrigado.}

Mande uma cópia? 


\section{ENTREVISTADO C}

Como é que a questão da responsabilidade social é tratado, ou melhor dizendo, se situa dentro do desenho organizacional da empresa, isto tem a ver na verdade com a tua posição, o papel que você ocupa aqui, e a quanto tempo você faz isto, e como é que foi, claro que em pinceladas, sua trajetória, para chegar nesta posição que você está hoje.

A área de responsabilidade social está hoje dentro de um departamento que agente chama de departamento de relação com o mercado, ... ele tem duas áreas que é a relação com investidos e responsabilidade socioambiental, no mesmo guarda-chuva. Acima de mim eu tenho um diretor departamental que cuida destas duas áreas, diretamente, e temos um diretor executivo gerente, que tem outros departamentos no seu guarda-chuva, e um vice presidente que é o seu MV, acima deste diretor gerente. $O$ regimento da área...

Isto com relações com o mercado...

Relação com o mercado

\section{E dentro tem esta subdivisão...}

Exatamente... O regimento do nosso trabalho, principalmente da organização, esta muito ligado a um comitê de responsabilidade socioambiental, este comitê ele tem 4 vice presidente do Empresa, são nove, 4 fazem parte deste comitê, 5 diretores gerentes, são diretores executivos, e outros 11 diretores departamentais de vários departamentos, ale do nosso, Marketing, Organizações e ..., patrimônio, etc... Deliberações mais importantes de responsabilidade socioambiental são levados para este comitê, tem reuniões periódicas e extraordinárias quando necessária. A área foi criada em outubro de 2005, eu fui para área somente em outubro de 2006, eu estava em outro departamento na Empresa, fazia por conta própria um curso na USP, ... Gestão de tecnologia Ambiental, eu já tinha interesse em atuar na área, e quando eu soube que a área foi criada eu prontamente me candidatei, para vir trabalhar na área, entre conversas com antiga gerente da área e o nosso diretor, somente em outubro que vim trabalhar nesta área.

\section{Outubro que você fala...}

Em 2006. Na ocasião a área tinha quatro pessoas. Eu e mais três pessoas. Em fevereiro de 2007 eu assumi a gerência da área, e daí em diante a gente foi só crescendo, em termos de pessoas, em termos de responsabilidade, e hoje agente tem 9 pessoas.

\section{Debaixo do guarda chuva socioambiental...}


Como gerente destra área de responsabilidade sócio ambiental. Ainda tenho, três principais direcionamentos da área, muito mais, agente chama até pilares da atuação. Um mais focado em finanças sustentáveis, e aí também coloco risco socioambiental, um muito mais em governança e gestão da sustentabilidade, e aí eu tenho as ferramentas como os índices de sustentabilidade, o GRI mesmo, o relatório GRI, sendo uma ferramenta que agente usa para gestão, entre noutras, e o outro pilar que agente entende que o investimento social ambiental, que tem o ISP no meio que é Investimento Social Privado, tem a nossa relação com a Fundação, com o voluntariado, programa de voluntariado empresarial, parcerias de patrocínio que tem uma ligação sustentável, fica tudo neste pilar. Agente separa nessas três formas de atuação, para cada uma delas, destes três pilares, eu tenho uma pessoa que centraliza, que encabeça as ações, e eu estou diretamente ligado ao Jean que é o diretor departamental.

\section{Por isso que você não tem um tempo nenhum?}

Não que, por exemplo, é porque hoje, ele está muito a frente do relatório o GRI, ele tem muito menos tempo que eu...

\section{Porque está fechando?}

Agente está em plena construção do relatório, e é uma loucura mesmo. Ontem ele teve que sair...

\section{Coleta informações do Brasil inteiro?}

Na verdade, está centralizado ali na sede, que é a matriz administrativa, mas são 39 departamentos, são no mínimo 30 interlocutores, então, não é nada fácil.

Uma pergunta em relação a questão do Comitê: este comitê de alguma forma define as diretrizes, a pauta da questão: seria a primeira questão da periodicidade, e a segunda questão e a da definição da pauta, ela vem de repente de alguma forma de consulta, ela parte da direção?

É fácil de responder, eu tenho seis comitês anuais, ou seja, um a cada dois meses

\section{Esta turma toda que você fala...}

Esta turma toda, eventualmente agente faz reuniões extraordinárias. Em geral quando, agente já tem, eu tenho, por exemplo, já a data fechada para o próximo semestre, senão a diretoria executiva não... está absolutamente programado, no próximo semestre agente até o final do ano, então isto já é com bastante antecedência, já estipulado. Quanto à pauta, eu tenho algumas pautas que são eu diria assim, as clássicas para cada período do ano, então no início do ano é comum agente falar de voluntariado, é muito comum agente falar do próprio relatório mesmo, até para dar um report, 
sobre o relatório de sustentabilidade, mas, esta pauta ela é construída de acordo com os projetos que vão surgindo. O último comitê, por exemplo, que nos fizemos em dezembro, tinha como pauta, uma das pautas o programa de eco eficiência, que agente iniciou no meio do ano, mas que agora tem uma configuração muito maior, de uma configuração, que agente busca disseminação para todos os colaboradores. Então é um projeto maior, então tinha que levar para um comitê para decidir como seria seu cronograma, como seria sua comunicação, como seria seu escopo para o ano de 2009. Ele havia surgido antes, né, na verdade ele é uma evolução do que agente tinha um projeto que agente chamou de neutralização de carbono, ... estufa ... passando por uma metodologia de controle e monitoramento, certificação da ISO 14064 normas para mudanças climáticas, e agora vem a fase mais madura, que é você não só entender de onde vem suas ambições, e também ver o processo de ... é diminuir seu impacto nos recursos naturais, então a eco eficiência casou com este projeto que começou em 2006. Então já é o prazo mesmo. Em 2009 o que agente quer? Agente quer disseminar isto mais fortemente para todos colaboradores, fazendo com que eles entendam as medidas de eco eficiência que o Empresa tem adotado, e que eles interajam com as sugestões, com as idéias, com as propostas, que agente tem de eco eficiência pela economia de água, energia papel, etc e pra que também proponham sugestões e idéias. Então vai ser uma via de duas mãos, então agente educa mas também pretende que eles no dêem um bom retorno. Isto foi só uma das pautas, pra porque, porque que é um projeto que vai ser iniciado muito forte agora em 2009. Quando um projeto vai ser iniciado próximo de um período do comitê ele é pauta do comitê. E algumas pautas já são fixas, o relatório de sustentabilidade ele é um report, que é fixo, o índice Dow Jones, e leasing que também têm, estes índices eles tem períodos específicos no ano para você tanto iniciar o questionário tanto para você ter o resultado, isto também faz parte da pauta, você tem também além do relatório, tem a pauta do voluntariado que também é anual, agente inicia o ano com esta pauta e depois termina com o report dela, mas eventualmente agente também passa para todos os membros do comitê uma solicitação, porque muitas vezes agente tem uma pauta que não venha da nossa demanda, o departamento de marketing, quero propor uma nova comunicação, que propor uma nova linha de comunicação interna ou externa, o RH, por exemplo, com um posicionamento sobre S.A. 8000 então vira e mecha agente tem esta proposição.

Você falou da eco-eficiência? Às vezes é difícil em uma corporação identificar... Este projeto ele veio da onde, foi da inteligência de mercado, de algum diretor, foi enfim...

Ele veio muito, pelo que nós tivemos acompanhamento ele nasceu mesmo a nossa necessidade de responder os índices, e ao CDP - que é aquela iniciativa de investidores londrinos, de você fazer um report, 


\section{Isto em 2005...}

É 2005, no ano seguinte, em 2006 agente começou a verificar o que seria realmente ideal para você responder ao CDP, isto também já olhando para o índice Dow Jones, que cada vez mais tem forçada a barra no quesito sistemáticas. Para agente responder ao CDP com boa propriedade, agente teria que fazer um inventário. Assim surgiu, assim nasceu, e a idéia de revolução deste inventário passava pela neutralização ou compensação do que agente tinha emitido com o plantio de árvores, com o processo contínuo de você realmente realizar isto a cada ano, não só um ano estanque, você teria que fazer continuamente este processo de averiguação, claro, cada ano agente apura mais, cada ano agente descobre uma emissão ou um fator de emissão que não foi bem revisto, ou bem apurado no ano anterior, e por aí vai, principalmente das fontes indiretas de emissão, aí é transportadora de malotes, taxistas que prestam serviços para o Empresa, então tudo isso tem que ser controlado e cada vez mais agente vai buscar estas informações. Agente foi muito transparente em colocar tanto na primeira e na segunda edição do nosso inventário, que existiam realmente alguns índices que agente não consegui averiguar. Alguma coisa agente consegue inferir, mas não é tudo, e aquilo que não é possível inferir com a metodologia do GHG, protocol, e usando a ISO 14064 como base, simplesmente fomos transparente, isso não é possível ser, não deu conta agora, e temos metas de $\mathrm{X}$ avanço para o ano que vem ou pro outro. E aí para este avanço e também com a ISO agente sentiu necessidade de você formar e centralizar os controles internos sobre todas estas fontes emissoras, porque quando eu falo de fazer um inventário não estou falando só Empresa deste prédio, eu estou falando de todas as agências, eu to falando dos Seguros, mais de 5.000 agências. Eu estou falando do Empresa Seguros, que tem N sucursais também do Empresa Seguro. É o grupo todo. Então, eu tinha descentralização de informação. Agente formou grupo de trabalho, por exemplo, eu tenho cento e cinqüenta pessoas em todo Empresa, aproximadamente 150 pessoas em todo Branco, são 11 grupos, com 150 pessoas no total, são aproximadamente nove a doze pessoas por grupo, Porque? Vou dar um exemplo da energia elétrica, eu tenho uma centralização no departamento que chama de patrimônio, que centralize todo gasto, o custo do consumo de energia elétrica no Brasil, mas os seguros, o Empresa Seguros, ele tinha outra centralização, ele pagava a conta por fora, era outra fatura, então o que é que aconteceu, todo mundo que tinha alguma ligação de controle com um fator de emissão, por exemplo, energia elétrica, foi colocado no grupo de trabalho, o principal controlador, no caso, o este departamento, é o gestor principal deste grupo, então, este GT se reúne, este pessoal padronizou uma forma de apurar e transferir esta informação para este único gestor, que depois, nos reporta a informação para agente poder fazer o monitoramento, o acompanhamento de acordo com uma nova ... para isso, para que desse tudo isso certo, nos tivemos que formar nove grupo de trabalho, mais um grupo gestor macro, que reúne todos os cabeças de 
chave destes outros GTs, e um grupo que é só para comunicação, comunicação interna e externa quando for a hora.

Você percebe uma relação disto Econômica já, você está fazendo uma coisa ... tem um controle que você não teria? Uma relação ecológica?

Já, já. Já teve algum... Eu já tive alguns reports, e agente começou a pegar mais firme agora no final do ano, a nossa intenção é, fazer duas reuniões semestrais no ano que vem e no final do ano que vem apresentar um Balanço, um Balanço mesmo, de... o que nos conseguimos avançar com o projetos, por fonte de emissão, ou seja, cada um destes grupos de trabalho ele vai apresentar o que ele conseguir avançar, onde ele conseguir chegar em termos de redução de gás de efeito estufa e emissão, e de valor também. Monetário. E o que é que foi que ele conseguir auferir para o Empresa. Já existem algumas boas experiências. Não era a motivação original, mas aí, agente pega carona numa crise, e também num posicionamento do Empresa de você diminuir suas despesas, para que se adeque a crise que está aí, sem equívoco. Agente, nada mais é do que, agente pegou uma onda boa, já tinha o projeto em andamento, desde meio deste ano, e até para certificação da Isso a gente teria que ter estes grupos formados.

A respeito de uma matéria que saiu a respeito do que você falou a te agora, só que mais a respeito ambiental, naquela última matéria da revista exame, empresas modelos de sustentabilidade, visando que agora é sustentabilidade, não é mais cidadania corporativa, ela falava da questão da educação para o crédito, 0 tom da matéria era que a partir da campanha o Empresa do $P$, no começo de 2007, isso ganhou força, do meio ambiente e da concessão de crédito, e aí assim, minha pergunta seria, eu conhecia o Empresa assim, na minha idéia, o Empresa é a Fundação Empresa, este balanço Sócio Ambiental, isto mudou de algum tempo, o que mudou é a infra de comunicação, o que é a prioridade, vocês continuam trabalhando as várias frentes?

O pilar social, que, acho que, o maior expoente da ação do Empresa em termos social realmente e a Fundação, se bem que a Fundação ela é separada, ela tem uma gestão, ela é acionista do Empresa, ela é a maior acionista individual do Empresa, esta é a, este é o fator diferencial da Fundação, o Empresa ele num, a porta de cursos, são dividendos...

Ela tem ações no Empresa...

Exato, ela tem ações no..

\section{Quem foi a idéia?}

...Nome da pessoa A., teve a brilhante idéia, e foi brilhante... 


\section{Ele comprou ações de si mesmo...}

Exato, ele doou né, passou ações que seriam do grupo, seriam da família, pra uma fundação. Ela é hoje, fora o que está no mercado, é a maior acionista do Empresa. Então os dividendos, os recursos que são hoje da Fundação elas provém do retorno financeiro do Empresa, é uma idéia de sustentabilidade, e pouco divulgada.

\section{Porque é pouco divulgada?}

Não sei, até pouco tempo atrás a fundação também era pouco divulgada, a própria Fundação, pouca gente falava do Empresa ou mesmo das ações do Empresa de sustentabilidade.

Ela inclusive, no relatório de Socioambiental ela não é contabilizada, como ... para educação, ela vem caracterizada com um asterisco.

Justamente por isso, ela não é um investimento direto do Empresa, para um projeto Social ela é fruto dos dividendos da operação. Quanto mais o Empresa ganha, quanto mais o Empresa lucra, mais a Fundação também terá recursos para poder investir em seus projetos sociais, é auto sustentável. E foi uma idéia realmente inovadora, se agente pensar que fi assim em mais de cinqüenta anos. $E$ resultou realmente num sucesso.

\section{IT, não tem isso...}

Acredito que não é esta formula, eu realmente não estudei a funda para saber quais são os ..... neste sentido, o que sei que na Fundação $O$ tem também, parte, o compromisso do Grupo 0 com a Fundação é um percentual da sua rentabilidade.

\section{Mas a Fundação 0 não é acionista?}

Não é acionista do grupo, é diferente, né... Ser acionista é um outro patamar.

\section{Stakeholder do grupo...}

É bem diferente, outro chapeuzinho o stakeholder, que você coloca. O Empresa ele tem, alem da fundação, ele tem uma iniciativa, Finasa Esporte, que tem um pilar social muito grande, que pouca gente sabe, o pessoal foca muito no time de Vôlei, que é o mais visível, na verdade o projeto foca, meninas carentes da região de OC, trabalha bastante com o entorno, além de Vôlei, trabalha também com o Basquete e tem todo o processo de educação, educação ambiental, educação comportamental (Não é associado a Fundação Empresa) Não, é a FS esportes, que dá noções de 
higiene pra as meninas, que insere as meninas novamente na sociedade numa outra vertente que é o esporte.

\section{Complementação escolar, é uma ação...elas vão para times...}

Sim, se existe a possibilidade daquelas que conseguem maior performance, e perfil, seria depois levadas para algum time. Se inscreve e da mesma forma que a Fundação, a Fundação tem um processo de escolha, aí cai outra lenda. O pessoal pensa: São filhos de funcionários que estudam na Fundação. Não chega a 6 \%. A maioria não é. Por quê? Como é feito a seleção? Por proximidade da escola, seja ela onde estiver no Brasil todo, e por pobreza. Por pobreza. Eles tem uma equipe que visita cada um dos candidatos na casa, um por um, para verificar se as informações do estado da família são coerentes. Existe uma metodologia para averiguar qual a carência que a família tem para poder realmente privilegiar aqueles que têm a maior carência pelo estudo. Agora o pilar social...do Empresa

Só uma curiosidade avaliação da condição econômica: a Fundação ela da algum apoio econômico para família, ela oferece, enfim, a educação - diz respeito a formação

Exatamente, existe algumas escolas por exemplos mais afastadas que são alternadas, a criança fica lá, 40 escolas, a criança fica lá o tempo inteiro, são escolas bem nos "fundões" do Brasil. O Colega estava comentando, que os pais chegam a viajar de barco para ir para escola e vão com mala, porque quando vão visitar o filho, tem uma reunião, etc. eles ficam lá, Ficam na... escola e depois retornam, ou quando vão buscar em período de férias, acabam ficando até um dia na escola e depois retornam. São coisas de nosso Brasil.

\section{A escolha dos locais, também é por critério de índices de IDH?}

Isso não sei te responder.

\section{Não é por proximidade de agência.}

Não, não é mesmo. A única que foi assim mais por proximidade é aquela que foi a primeira é Osasco, por que tem sua origem e administração ali. Agora quanto aos outros pilares sociais, você falou de educação. Educação interna também.

Da educação para o crédito - como se fosse uma trajetória, da Fundação e agora esta na concessão de crédito.

Agente tem um processo de educação interna, para a sustentabilidade. O lançamento... 


\section{Educação destes funcionários}

... é, os nossos colaboradores. O processo também tem uma lógica, da mesma forma como foi este projeto da eco-eficiência. Quando agente lançou o Empresa do $\mathrm{P}$, isto foi em novembro do ano passado, surgiu também, existiu àquela expectativa, vai ser uma grande vitrine, porém vidraça, obviamente. Da mesma forma como, a exposição ficou muito maior, uma exposição que era muito, antes... totalmente ..., bem discreta, ficou escancarada. As nossas ações também. Então a margem, para as críticas aumentou também. Qual é o principal canal de comunicação com a maioria, ou com boa parte dos stakeholders, são os funcionários. As pessoas de linha de frente, o cara que está agência, o corpo a corpo, que está conversando com o cliente, principalmente estas pessoas. Não é segredo para ninguém, que pouca gente conhece sustentabilidade, pouca gente conhece responsabilidade socioambiental, a não ser, por mais que a mídia hoje tem martelado, a comunicação esta muito forte. Mas também não é muito, não tem muito conteúdo, todo mundo fala de sustentabilidade mas ninguém explica de sustentabilidade. É uma diferença muito grande. E agente sabia que esta deficiência ia ser latente e teria que ser trabalhado. Então, um dos primeiros, uma das primeiras ações que começo já em dezembro do ano passado, logo que depois do Empresa do $P$ ser lançado, foi uma série de cartilhas mensais. Estas cartilhas elas explicavam. $O$ que é desenvolvimento sustentável, o que é consumo consciente, poluição, energia, lixo, que isto tem a ver com seu dia-a-dia no Empresa e fora dele, principalmente. Então estas cartilhas foram feitas com conteúdo em parceria com a KT. Passou muito conteúdo, e elas foram aí, martelando mês a mês na cabeça de nossos colaboradores.

\section{Tinha reuniões palestra...}

Não só o envio de material. Esta foi a primeira ação. Uma outra ação...

\section{Isto em conjunto com o lançamento da campanha?}

A campanha lançou em novembro, em dezembro já lançou a primeira cartilha.

\section{Já dentro do guarda chuva de comunicação do Empresa do $P$.}

Exatamente, já previsto para o ano todo, também agente já tinha avançado bastante, agente chama de treinet, um treinamento pela internet, e-learning. Porque, agente em 87 mil colaboradores. Você pensar em palestra, curso, ou qualquer coisa presencial, com esta turma toda. - Resolvemos isso, fechar o Morumbi e levar todo mundo para lá. - Isso é muito espalhado, dá uma capilaridade imensa. E a forma que a gente encontra para fazer essa disseminação de conhecimento realmente é esta ferramenta de e-learning. Que alias tem um sucesso tremendo. Agente montou então o curso, 
e-learning, com a parceria com a parceira da FGV do Rio de Janeiro que nos deu o conteúdo, houve uma série de amortizações e também inserimos muita coisa da linguagem financeira.

$\mathrm{Na}$ verdade agente teve mais dois, duas propostas, aquela que estava mais pronta, e mais próxima, do que agente queria. E também, tem a haver com o momento, o momento que agente tinha que dar uma base. ... Sobre Sustentabilidade, sobre finanças sustentáveis, para que o pessoal ter um início de um diálogo com os stakeholders, de forma que seja possível responder pelo menos a um questionário simples. Porque este Empresa do P existe?

\section{O quer dizer isto daí? Exatamente. Todos os colaboradores em todos os níveis, todas as instâncias, vocês fizeram a mesma cartilha ou vocês fizeram cartilhas diferentes}

A mesma cartilha, o diretor recebeu a mesma cartilha que eu, o funcionário da agência, A mesma cartilha, o mesmo treinamento, foi feito um processo muito forte de divulgação deste treinamento, por meios das comunicações internas, meio marketing Agente tem um jornal que se chama Sempre em Dia, ele sai sempre todo dia, como o próprio nome diz, todo dia sai, as inserções da comunicação, este sempre em dia é lido mesmo nas agências, ele vai impresso uma via só, e disseminado pela internet principalmente, e agente forçou bastante o interesse pelo curso, agente também teve uma outra ação de endomarketing forte. Agente lançou, ... não sei se você já viu o desafio da razão que foi no ano passado, com a campanha das 120 razões do Empresa, um livrinho, o pessoal do endomarketing, lançou da mesma forma, um e-learning, um treinet, que era um Quiz, onde a pessoa estudava 120 razões, e respondia o Quiz, aquele que ia acertando, era aberto para todo público interno. Tinham três fases, a primeira fase, passava pela segunda fase, um pouco mais difícil, da segunda fase para um fase presencial, não importa de onde vinha a pessoa, auditório. Inclusive foi a PG e... Acho que era o BJ. Isso. Que conduziram o Quiz presencial lá na CD. Finalíssima. Com o Sr. ..., 20 pessoas foram para a finalíssima, e ganhava, prêmios. Este ano agente fez para o desafio do Planeta, que era a pessoa estudar, aquele e-learning, aquele o treinet, de sustentabilidade, as seis primeiras cartilhas que ele tinha recebei, mas o nosso relatório de sustentabilidade, que agente lançou uma versão exclusiva e específica para o funcionário. Ou seja, aquele relatório nosso de sustentabilidade, tem um filhote que é só para o público interno, todo o funcionário recebeu. Os 87 mil. Para que? Para estudar para poder responder o Quiz. Este Quis teve a primeira fase, da mesma forma, a segunda fase e a terceira foi agora no final de novembro, 20 pessoas, Brasil, departamentos e agências, se reuniram, responderam as perguntas, fizeram uns joguinhos, todos ligados a sustentabilidade, ações do Empresa de sustentabilidade, perguntas até bem complexas em termos de sustentabilidade e de ações do Empresa, e as cinco primeiras vão para Amazônia. $\mathrm{O}$ ano que vem naquele Hotel ..., aquele hotel nas árvores. Cinco deles com um acompanhante para este hotel. 0 interessante é que dos funcionários ativos, tirando aqueles que estão de licença férias, $87 \%$ 
responderam, detalhe, ele só poderia participar do Quis, se ele tivesse feito a matrícula, no Treinet, e-learning de sustentabilidade.

Você acha que, assim, de funcionário, é percebido como uma obrigação pelo funcionário, ou se ficar fora disso, de alguma forma pega mal, na sua percepção, ou eles já engajaram nesta questão? Eu acho, que a segunda opção é mais ..., pelo discurso que agente recebeu, pelo feed-back, pelo feed-back deles, óbvio que não existe um mundo perfeito no ambiente corporativo, mas existe uma coisa que esta competição interna, ela não é vista assim como um fator muito negativo, é muito comum, é visto, como meu departamento tem que participar, uma coisa interdepartamental, como a gente não vai participar, assim a mesma coisa com o voluntariado, a cultura já impele para isso, não é uma questão de um fato isolado. Embora, o tema, se agente comparar o tema deste ano com o do ano passado, o tema deste ano gerou mais interesse, não sei se a viagem é um prêmio mais cobiçado, ou se o tema era mais agradável. Do que 120 razões. $O$ tema ele é muito atual. Ele tem um índice de rejeição baixo, eu acredito. Você fala de sustentabilidade, de desenvolvimento sustentável, de responsabilidade socioambiental, soa bem. Isso, também é um tema que está muito em foco, gera mais interesse, gera curiosidade, acho que tudo isso colaborou para o sucesso, $87 \%$ das pessoas ativas, nós achamos alto pra "caramba"'.

\section{Tem cara de índice de obrigatoriedade...}

Se houve, foi muito natural, dentro da cultura, o que aconteceu é dentro da cultura do Empresa mesmo, o que agente não pode, o que tem que dar o braço a torcer e que o endomarketing foi muito bem feito, para justamente provocar isso tudo, foi muito bem feito, e o evento final foi fantástico. Isso não para por aí, isso foi o primeiro passo, ótimo a semente lançado, onde eu quero chegar. $\mathrm{Na}$ educação. Educação não se faz de um dia para o outro. Ela vai ó... levar um bom tempo. Temas diferentes para o ano que vem, para chegar puramente, o que agente chamaria de apurar a visão de Sustentabilidade dentro do Core Bussines, é o cara que é o nosso gerente, que esta lá na linha de frente, entender que ele tem que inserir no dia-a-dia dele, na oferta de um produto, ou na gestão com o cliente, a sustentabilidade, inserir isto no Core Bussines, como se isso, aliás, tem que ser assim, como se isto nunca estivesse separado, a sustentabilidade ali, e meu trabalho aqui. A intenção é justamente esta, chagar nesta evolução, e não dá para fazer isto do dia, isto não se faz por decreto.

\section{Começou o processo mais organizado no final de 2007?}

Exato. Porque inicialmente você desperta o interesse, depois você vai trazendo, já despertamos o interesse, traz então ele para conhecer cada vez mais, e aí vai apurando toda esta comunicação e este processo de educação. Não chamo nem de treinamento, é educação mesmo. 
Conceitualmente conheço pessoas que ficariam incomodas, você chamar de educação, pelo fato de ter o objetivo mais focado, por ser uma coisa não tão aberta, mais universalista, mas aí seria legal até te ouvir, você distingue, treinamento que é uma coisa mais empresa, e uma coisa que você esta chamando de educação

Eu chamo de educação porque a visão que agente quer passar, elege, o curso, o e-learning ele tem isso, ele tem que conhecer o tema, não para utilizar só dentro de seu ambiente de trabalho, pelo contrário, assim como ética, assim como, e o curso também envolve isso, ele tem que utilizar para a vida dele. Ele tem que passar isso, ele tem que deixar de usar o carro um dia. E porque que ele tem que deixar de usar o carro um dia, não é só o fator econômico, sim você vai economizar trezentos e tanto reais por ano, mas você vai economizar $X \mathrm{CO}^{2}$, e $\mathrm{X}$ gás de efeito estufa que será liberado no ambiente também. É algo mais integrado, não é só. E para o Empresa também é interessante. Por quê? Você também pode, ter maior consciência, e com esta maior consciência você está interagindo de uma forma mais próxima da sociedade, que o nosso principal stakeholder, é o Cliente. É processo de aprendizado também. A maior parte das cartilhas, por exemplo, alias, todas as cartilhas, elas trazem muito mais informação para o dia-a-dia da pessoa do que apara o seu trabalho em si. É lógico que se ele sai da sala e apagar a luz quando sair, ele vai economizar energia elétrica e conta para o Empresa, mas é lógico se ele fizer na casa dele ele vai economizar para ele e vai economizar para a natureza, é recurso natural. Algo muito amais integrado, vai ale do que um treinamento que é focado só no dia-a- dia de trabalho da pessoa.

Então - para fechar esta parte: este balanço, vamos dizer assim, se é que é possível fazer, colocar esta questão, do socioambiental... Liga com uma pergunta que eu ia te fazer, dessa migração de nomes, vamos dizer de rótulos, que agente sabe que por traz de um rótulo tem um conceito, como você bem colocou, eles estão bem embaralhado na mídia. As pessoas falam de socioambiental, responsabilidade social, fala de sustentabilidade, fala de desenvolvimento sustentável, fala de investimento social, tudo meio que, ao mesmo tempo, tem visões diversas, tem pessoas que vêem isso como evolução, tem gente que vêem como conceito totalmente diferente e articulado, e observando nos relatórios do Empresa, acho que o que está disponível na internet, é 2004 por acaso, se não me engano, ou 2005... tem vários relatórios PDF’s lá... Aí o primeiro deles, 2003, ele era Relatório Social,

Isso, até 2005 ele foi...

Depois ele virou relatório socioambiental.

2006 em diante 
E agora ele é Sustentabilidade, acho que agora os dois últimos, se não me engano, 2006, 2007, aí eu queria te ouvir assim, como é que você vê estas mudanças do conceito de nomes, como é que o conceito se articula com outro ou não se articula, porque acho que isto tem a ver com este balanço socioambiental...

Ele se articula porque realmente é uma evolução. O que antes era muito foco no social mesmo, e aí a Fundação Empresa e o FN Esporte, e até mesmo a histórica proximidade que o Empresa tinha com patrocínios e incentivos culturais, para festas locais, ou eventos locais, ou até mesmo atrelado ao incentivo fiscal, rouanet, era muito mais forte, era visto como maior clima de interesse da sociedade, ou seja, o retorno que

\section{Financiava Festas Junina?}

A festa Junina, não sei, ou festa local. Tinha muito mais esta percepção, de que realmente você tem, o retorno da sociedade tem que estar mais atrelado a sociedade, e o ambiental ele fica um pouco a revelia, mas muito mais por relato, a parceira com a SOS Mata Atlântica já existe a 19 anos, não que dizer que a preocupação com o meio ambiente não existia, (Empresa um parceiro Investidos) Ele começou com a doação e depois foi desenvolvendo produtos, que é o caso do Título de Capitalização e Cartão de Crédito, parte do que seria receita pro Empresa seria revertida para a SOS, isso já acontece a longa data, mas o despertar mesmo, para uma visão, uma estratégica de sustentabilidade, se deu mais recentemente, principalmente quando foi criada a área de responsabilidade socioambiental - 2005, principalmente para relatos, existiam ações, existiam preocupações, mas não existia uma centralização disso tudo, até mesmo uma forma de você relatar o que você estava fazendo, até mesmo planejando, ou seja, a visão de longo prazo, estratégica, não era muito clara nos relatórios, o relatório de Sustentabilidade , 2006, que saiu em 2007, ele já era uma tendência para isso, e adotar o padrão GRI também já foi um avanço, 2007 também, agora que saiu agora em 2008, ele melhorou bastante, e agora eu acho que agente vai ter um salto de qualidade muito grande, porque agente tem um diálogo maior com os stakeholders, de forma que agente vai poder entender exatamente o que tem que passar para estes públicos, anteriormente agente não tinha um engajamento tão forte, foi o primeiro ano por exemplo que agente fez um painel com os Stakeholders, para poder discutir o que é relevante num relatório, o que pode ser tirado de um relatório, e o que não foi abordado no relatório.

\section{Como é que a composição deste painel?}


Agente teve 103 participantes, foram 6 painéis, a cada dia agente fazia um período com um público, na parte manhã com um público, na parte da tarde, agente convidou Colaboradores, Fornecedores, ONG's, Academia, Governo e Sociedade e Fornecedores do Empresa. (Sociedade você fala sociedade, tem a ong's, a sociedade) Sociedade eu digo mais os Sindicatos, Associações, e governo são representante de Secretaria de Prefeitura, etc. Agente colheu deste seis públicos, realmente foi muito rico, tanto para o relatório, quanto para a gestão, porque, apesar de que o foco tenha sido para o relatório em si, a peça de comunicação que agente pode falar, agente realmente colocar a prova se agente estava no caminho certo ou não,

\section{Painel é para avaliar o balanço}

O balanço, o relatório...

\section{Faz parte dos critérios da GRI?}

Justamente, e também agente está no processo de AA 1000, que é o processo de engajamento com o Stakeholders, também, basicamente você mapear o Stakeholders, entender quais são os temas chaves para eles e trabalhar no sentido de ouvir e dialogar para poder construir uma comunicação para eles, tudo isso dentro de uma série de requisitos, é quase uma norma, mas não é certificada.

\section{Isto está dentro do global Compact?}

Isso é outra coisa, ele pode e muito, se utiliza do GRI, não, não é, o GRI tem aquelas outras qualificações de acordo com que você atende dos requisitos. Este processo ela vai ter um engajamento com os Stakeholders muito mais sério agora, e apurar um pouco daquela comunicação, lá de 2005, 2005, que era uma visão muito nossa, muito mais nossa do que do público, para uma visão mais próxima daquilo que agente espera ou o que eles esperam ouvir, além daquilo que agente espera passar.

Consulta para o que eles esperam ouvir, esta consulta interfere na pauta do que vocês vão fazer, ou tem coisas que vocês podem fazer e vocês já fariam, ou coisas que vocês não podem.

Aí existe aquela matriz de materialidade onde você coloca, poxa, a percepção dele, e a percepção nossa, que é importante para o Empresa também, passar para a Sociedade. O que pode, e se sabe que teve umas coisas engraçados, teve um grupo lá, fornecedor, não foi governo e sociedade, cliente também, Os dois observaram: - Vocês estão abrindo demais aqui, dados como reclamações, não 
têm necessidade de ser tão detalhado. Agente achou engraçado, foi um ponto positivo, Estava lembrando isto esses dias, agente estava revendo isso. Mas claro, levam bastante críticas também, muitas críticas, principalmente das metas que agente espera para o Futuro, e claro quanto mais agente puder estar a vontade para falar estas metas, acho que mais fácil também agente ter um processo de feedback deste público, afinal de contas, muitos deles estarão acompanhado se agente esta ou não realizando aquilo que se propõe. Acho que é uma transparência importante para este público.

Mas eles não demandam coisas que o Empresa não pode fazer, por exemplo. Acho que o Empresa deveria investir mais em educação, mais escolas, focar questões de cidadania, de limpeza, não sei. Como é que vocês lidam com isso, na verdade você falou na consulta, e que a consulta de alguma forma interfere na pauta, nas decisões da onde vocês vão aplicar ou vão investir, e aí é o ponto que gostaria de entender melhor.

Estes pontos são levados na discussão, mas é claro que estrategicamente pode não ser o momento de, por exemplo, de investir em tecnologia limpa, estou dando um exemplo, isto não foi levantado, se algum grupo, vocês tem que investir forte em tecnologia eólica, e energia eólica, a ta, isto pode ser levada em pauta, ... para nosso departamentos de empréstimos e financiamentos, para ver se tem uma linha atrelado a isto, se há possibilidade, ou simplesmente agente pode fazer um estudo e dizer, ou não, isso não é factível agora para o Empresa. É lógico, o que eu tenho que fazer no mínimo é um feedback, aliás, é prevista se dar um feedback para este tipo de interlocutor, mas não obrigatoriamente e acho que esta é uma premissa do Empresa, de escolher os temas que são estratégicos e importantes para agente avançar, em termos de gestão e termos de report, são duas coisas bem separadas, porque, é fato, eles não se, estes interlocutores não ficam retidos só no conteúdo do relatório, eles também nos dão outros feedback's, principalmente em relação a gestão, o Empresa... praticar tais, juros, ou deveria ter uma ação específica para micro-crédito, exato, uma questão mais social, isso independe do relatório. O relatório pode até ter uma informação lá, mas o incremento o Plus da gestão do Empresa em relação isso é diferente, mas sempre são levados a discussão, para você ter idéia, o resultado deste painel foi levado para aquele comitê que eu estava te falando, com os principais pontos, inclusive alguns foram objetos de curiosidade, porque é que agente não esta fazendo isso, porque agente não avanço em cima disso, alguns nem tanto, daí agente constrói materialidade uma matriz boa.

\section{Quero entender melhor Matriz Materialidade?}

Não, não só pode não pode, existe, claro, vai sempre existir esta censura, 


\section{Capacidade operacional...}

Sim, exista uma coisa que está muito desalinhada, o Core Bussines do próprio Empresa, isto seria uma parte da matriz, mas não é só isso, a matriz ela também vai levar em consideração aquilo que agente acha importante falar, por exemplo, para nós é importante falar deste projeto de eco eficiência, afinal de contas ele tem, ele é sustentabilidade pura na veia, ele tem o pilar ambiental, social, econômico ali, latentes né, é importante para gente reportar que está fazendo isso, por que é um exemplo, algo que pode até ser replicado na sociedade, pode ser utilizo por outra empresa. Mas é importante para o Stakeholders ouvir? Será? Eu digo que sim, porque os painéis me indicaram isso. É importante estrategicamente para nós, porque demonstra a nossa preocupação frente às mudanças climáticas, demonstra o posicionamento do Empresa compromisso a Sustentabilidade e o Stakeholders quer ouvir. Ele mesmo nos painéis deu este indício. Então numa matriz materialidade, estaria, em troco, é o que eu quero falar e o que ele quer ouvir. Guardada nas devidas proporções. É uma matriz mesmo. Ai eu defino aquilo que eu quero colocar no relatório escrito, que é a principal peça de comunicação, aquilo, que talvez não vá com detalhes, mas possa ser referência lá, e colocar no material on-line, que também uma outra forma de comunicação importante, e aquilo que no momento não interessa e não é factível comunicar. É assim que é montado. De acordo com a intensidade.

\section{Ou fazer se for o caso?}

Ou fazer se o for caso, ou fazer separado, fazer separado, agente não fez uma matriz.

\section{O painel foi construído pro report a princípio?}

Exato, é, foi pro report, e serviu muito para os dois casos, para gestão, tanto que agente na avaliação agente separou um item só para gestão.

\section{Mas não existe um painel para gestão?}

Ainda não, a AA 1000 prevê isto. Por isso que ela é mais profunda.

Por que isto tem a ver um pouco com aquela história que eu te falei com origem do projeto, não sei se isso é viável ou não? Que projetos eu vou investir o ano que vem? Ai isto é uma cisão ao princípio. Hoje na maior parte das organizações é do Empresa, dá organização. Ela pode até consultar. Mas é parte daqui pra fora. Não sei se é exatamente assim, ou se está previsto um painel, uma matriz deste tipo pra decisão de investimento, de projetos sociais, projetos ambientais, e por ai vai...

Acho que eu não entendi bem, quanto a esta matriz, de projetos. 
Seria maiS ou menos a mesma coisa, só que na origem da gestão. Não no report?

Isso já não existe. Na gestão não tão forte. É a AA 1000 que vai nos dar muito subsídio, existem sim algumas manifestações pontuais, dos painéis, dos encontros de fornecedores. (AA 1000) Mas o que é que ela prevê? Ela prevê um engajamento mais íntimo mesmo. Que aí você contempla mais a gestão, não só a comunicação, mas também a gestão, as expectativas de, estratégicas mesma que a instituição tem com relação ao Stakeholders, até um pouco do impacto que agente causa na vida deles. O que agente previu é de fazer este painel, como quase, como um piloto, né, do que seria pra gente uma AA 1000. Por que um projeto de AA 1000 ele começa agora e vai terminar daqui a uns 2 ou 3 anos. Ele é bem complexo. A previsão sempre de um projeto de implementação desta norma da AA 1000, ela leva de dois anos para cima.

Das decisões estratégicas: Em que nível isto é percebido, como interferências nas estratégias do Empresa, ou do Empresa e da Empresa, da Corporação. Esta questão da consulta é uma coisa que tem aparecido em várias instâncias, tem um certo nível de decisão estratégia imagino que não seja, que não basta uma consulta pública, não sei, ou se isso passa por esta AA 1000 que você esta falando. De alguma forma as ações sociais, ambientais, tem que estar relacionadas com o negócio, ou o que a empresa faz, o seu principal, operação. Então de alguma forma se você, dependendo do tamanho da abertura que você der para questões sociais e ambientais talvez isso interfira no que a empresa faz, não se isto é possível de acontecer?

Não, é possível que existam realmente alguns inputs que vão te, que vão te direcionar para um caminho que não aquele que realmente faz parte da operação de um Empresa. Vocês têm que abrir uma escola. Espera aí. Agente não tem nada a ver com isso, agente não é, nós não somos não é uma universidade. Ou uma. Agente não é uma instituição de ensino, agente é uma instituição financeira. Mas acho que vocês poderiam investir no ensino. Espera aí. Então eu posso investir, num grupo, é de ensino que possa, aí é outra, o que agente pode é transportar isso para nossa realidade. Vocês têm que ajudar no combate as mudanças climáticas. Esta bom. Como? O que o consumo de energia elétrica, por exemplo, se for comparar com uma grande indústria, é pires, certo, mas se eu financiar novas tecnologias, financiar novas tecnologias para aquela indústria consumir menos energia elétrica, eu estou fazendo uma ação mais efetiva, ..., em relação as mudanças climáticas e estou no meu negócio. Estes inputs podem ser transportados para nossa realidade. É ai que agente ganha. Não necessariamente eu preciso atender a demanda pura, como ela foi concebida, mas ela pode sim, servir de inspiração digamos assim, ou direcionamento para algumas expectativas, ou até mesmo para algumas oportunidades, ou riscos, nada mais é também do que você identificar entre riscos e oportunidades, aquilo que pode ser atrelado para o negócio, dentro de uma concepção de 
sustentabilidade. Não vou esquecer o lado financeiro, afinal de contas, isso é um Empresa, e eu posso também agregar...

Mas é um Empresa que parece Empresa mesmo...

Agente não faz a menor questão de não ser Empresa, quem diz que Empresa é ruim, cultura ...americana, que você não pode ter lucro, que o dinheiro é algo impuro, ou coisa assim, mas, ele tem que ser utilizado de alguma forma, e agente que utilizar com responsabilidade, e dentro de uma filosofia de Sustentabilidade. Se eu tenho um input de uma escola, que é social, vou abrir uma escola, mas eu posso ter instrumentos financeiros que viabilizam... eu não vou emitir menos $\mathrm{CO}^{2}$, talvez minha missão é mínima em relação a várias indústrias, mas eu posso ter instrumentos financeiros que ajudem a uma inovação tecnológica para aquela indústria emitir menos, ou seja, os instrumentos financeiros podem ser atrelados aos pilares. Não sei se, esta é a nossa lógica, esta é a lógica do trabalho, esta é nossa lógica para trabalhar com estes três pilares. Não sei se respondeu a sua pergunta.

Respondeu - empresa esbarra num limite - vou citar. Uma empresa que começou a prestigiar ou favorecer o trabalho de uma escola, numa proximidade, e um belo dia a diretora da escola ligou reclamando porque eles não tinha mandado tal coisa...

Isto é comum...

Mas ai a reação dele foi, acho que agente está fazendo coisa errada...

Isto é comum, principalmente com aquelas empresas pioneiras e acabam adotando a cidade

Mas aconteceu, A Unilever fez um trabalho de adoção da cidade, de você investir na cidade Ai o prefeito liga, vem cá preciso de uma Ambulância...

\section{Exatamente!}

Estão tomando até o lugar do poder público

Ou das políticas públicas...

Ou das políticas públicas, justamente, você acaba até se misturando com estas políticas públicas.

Como é que é esta relação no Empresa com Políticas Públicas, se ele tem, diálogo, se isto está na pauta? 
Isto está muito mais distante, as políticas públicas em si, elas estão bem mais distantes, ela não está na pauta agora, vigente.

Então vai trabalhar apoiar uma instituição, ou financiar uma escola, isso necessariamente não tem, uma conversa, com a delegacia de ensino, Diretrizes.

Depende muito do caso, por exemplo, Cetesb, a Cetesb tinha um problema com postos de gasolinas, com passivos ambientais terríveis, vazamentos, etc. etc. Estava na iminência de autuar estes postos impedindo o funcionamento em si. Agente conversou com a Cetesb, de modo que agente, nós criamos uma linha, específica para os postos de gasolina, uma linha de crédito, que será destinada, logo, logo vai estar na prateleira, eles chamam, mas ela já está, já foi desenhada para os Postos de gasolina para eles se adequarem, se adequarem, exatamente, as normas Cetesb, sanar o passivo ambiental, mas agente não conseguiria passar esse. Estas linhas são travadas, porque eles não tem uma licença de funcionamento, a Cetesb fez um acordo, que daria uma licença prévia, desde de que ela tivesse, o posto tivesse uma TAC, Termo de Ajustamento de Conduta, que direcionaria, e aí o Empresa automaticamente liberava um financiamento via BNDES, para que o cara se adequasse. Então existe sim um arranjo, existem possibilidades, mas são muito pontuais, não é uma prática constante, são bem pontuais, agente traz sim o órgão ou o público, seja lá qual a instância, para conversar, quando tem realmente uma ligação forte, entre o que agente quer oferecer de produto e o destinatário final e se existe um meandro por exemplo, uma secretaria, ou qualquer tipo de órgão. Esta foi uma demanda que surgiu meio que por acaso, mas que foi muito...

Acho que é o Robert Reich. A empresa perceber seu limite de ação.

Ela tem que perceber duas coisas, seu limite de ação e suas responsabilidade em cima disso tudo também, e ela tem muita responsabilidade, é crescente, cada vez mais. Acho também quanto mais as empresas se inserem nos diálogos, em ações efetivas, acho que aí a máquina começa a funcionar melhor.

Máquina, Políticas Públicas...

Isso.

Porque essa é uma questão? Você tem instância de deliberação que estão relativamente esvaziadas para decisões de ordem pública? Quando você fala, dos painéis, é uma espécie de deliberação privada que vocês abrem para decidir o que vocês vão fazer. Com a participação dos stakeholders, e públicos aí. As instâncias públicas se você se perguntar quais são? Tem as ouvidorias, a audições, elas, ou as pessoas não acreditam nelas, ou elas desistem, enfim, é uma 
coisa que, como todo processo político, está bastante desgastado. E de repente fica aquela questão, a empresa em relação a tudo isso. De vez em quando dependendo do depoimento me parece que a empresa tem que tomar um cuidado para não entrar num lugar onde ela não vai dar conta. Neste caso a escola. Qual é a decisão da empresa que eu achei inteligente, não, agente tem que falar com a Diretoria de Ensino. Não com a escola diretamente. As vezes me parece que a Diretoria de Ensino é uma instância mais aparelhada para lidar com estas questões. Vocês passam por estas situações? O que é que você acha destas relações com estas instâncias deliberativas, e decisões públicas. $O$ que agente tem lá. Conselho Tutelar, que é uma instância, tem suas limitações públicas com a participação de um monte de gente lá... Como é que você vê, as ações do Empresa, talvez no âmbito da responsabilidade?

Agente aqui tem pouca, pouco contato, principalmente com órgãos governamentais, e tem pouca demanda deles, bem pouca. Eu tenho pouquíssima experiência para te dizer o teor deste relacionamento. Mas o que eu entendo, que pelo menos, a impressão que eu tenho quanto tinha um pouco contato, agente é muito procurado, principalmente pelas prefeituras, são ações muito pouco complicadas, alguns patrocínios específicos, ou doações, pouco complicadas, em geral não é algo complexo ou muito duradouro, um grande projetos que o Empresa se envolva em si, existem aqueles patrocínios locais, bem, pontuais, que em geral elas são geridas pelas diretorias ou gerências regionais, que fazem as combinações já com órgãos locais, sejam eles, tribunal de contas, uma delegacia, uma prefeitura, ou coisa assim, eles são muito procurados nas agências, ou os pólos regionais e acabam tratando nessas instâncias mesmo. Quando nos procuram com projetos maiores isto é deliberado para diretoria executiva. Uma outra estância de decisões. Mais uma vez. Os casos que eu acompanhei foram sempre para patrocínio, ou para ações bem pontuais, nada de projeto em longo prazo ou de compromisso muito mais elaborado, mais, com uma construção muito mais elaborado. Nem tem fórum para isso) Não, não tem.

A empresa Cidadã, que é outro rótulo também e da cidadania. Da minha percepção dos projetos, no balanço Socioambiental, parece que tem ...ambiental e como é que entra cidadania nesta história na sua concepção. Tanto a empresa cidadã e o cidadão, pessoa física, e pra onde vai, quais são as perspectiva de trabalho, como é que você vê isso e como é que você acha que as coisas vão andar na tua instituição daqui pra frente?

Não dá para desvincular mesmo, estava até conversando com uma pessoas da SOS Mata Atlântica, o fato de você preservar a Mata Atlântica, não é só pela Biodiversidade da própria Mata Atlântica, mas também pelo serviço que ela presta para gente, para o cidadão, água, clima, ou até mesmo, a beleza que ela possa te oferecer. Então, os benefício sociais, estão muito ligados aos ambientais, não temo se desvincular, realmente. Eu acho que também esta postura de cidadania, por exemplo, o Empresa, 
pessoas física, agente tem algumas parcerias, e algumas, como A SOS Mata Atlântica, AACD, Instituto Airton Senna, que só vem crescendo, ou seja, agente está cada vez mais intricado com iniciativas privadas e principalmente de ONG's. Como apoiador, principalmente agente está tentando focar principalmente como parte, como eu diria, como parceria mesma, ou seja, o ano passado agente teve a Fundação Amazônia Sustentável, que foi aquele Lei, entra uma parceria governamental que foi tratada numa instância ... nossa, que agente é co-fundador da fundação Amazônia Sustentável, junto com o governo do Amazonas, os recursos que são provenientes de produtos como cartão de crédito, e títulos de capitalização de novo, são destinados para a Fundação para honrar o compromisso de 10 milhões ao ano, ao longo de cinco ano, e uma doação de 20 milhões inicial. Mas sempre é o foco de atrelar isso, de alguma maneira a um negócio, a um produto, a simples gestão, os 20 milhões que foram doados pelo Empresa, eles estão sobre a Gestão do Empresa ...Manneger, então você atrela também a doação de recursos, algo em benefício, algum propósito financeiro, seria ingenuidade pensar que existe somente uma doação, acho que hoje você conseguir interligar as suas ações ao seu negócio, acho que é o mais correto a ser feito, e acho que estas parcerias vão acabar crescendo, existe um foco maior agora, por exemplo, na Amazônia. Nada impede que eu tenha uma Fundação Cerrado, uma Fundação Pantanal Sustentável, por exemplo, e outras empresas sigam este exemplo. É uma postura que o empresariado esta tomando. Cada vez fica mais próxima das ações sociais.

Quando eu falo social, tentando separar, aquilo que você esta exemplificando que não dá para separar, talvez, o que eu estava querendo dizer é assim. Que as relações, de alguma forma, onde está mais evidenciando a questão ambiental, e talvez seja menos presente, pelo menos no discurso, as questões relacionadas com a educação com saúde, que, por exemplo, seja o caso da fundação, me chama a atenção aquele título. Da educação para o... do crédito para o ambiente. É claro que uma educação pressupõe um cuidado ambiental, tem me chamado a atenção é o seguinte, parece que no discurso está mais presente.

Acho que o ambiental começou a equilibrar mais, porque você tinha um forte pilar social com a Fundação, a Fundação ela sempre foi, embora houvesse na disciplina de educação ambiental para as crianças, o grande benefício da Fundação é o Social, Finasa Esporte é a mesma coisa, entre outras ações o ambiental, ele parecia, até se você realmente retroagir nos outros relatórios, nos outros relatos, ele parecia meu a margem, das ações do Empresa. Agente teve agora por exemplo algumas manifestações de, até premiação, com nosso case com a fundação Amazônia Sustentável, ele parece ser a primeira vista, muito ambiental afinal de contas o principal propósito é a preservação da Floresta em pé. Mas o recurso é destinado para as famílias, exatamente. Ou seja, são $R \$ 50,00$ de bolsa floresta por mês para cada família, para cada mulher de família, dá família, para que ela permaneça com aquela região que está ocupando preservada. Ou seja, o social também está muito 
ligado, o social também é foco. É difícil agente dizer que uma organização, como é o caso da SOS Mata Atlântica, dizer que está desassociada demais com o social, é que agente foca muito mais, talvez no discurso, talvez a forma, talvez do Empresa do Planeta para cá, a forma de comunicação, ou até a percepção pela força que hoje a comunicação tem feito frente a mudanças climáticas, aquecimento global, a percepção em cima do ambiental seja maior, mas não é bem esta, acho que o equilíbrio esta muito bem pautado, quando eu falo da Fundação Amazônia sustentável, por exemplo, é um caso, você tem um benefício social imenso para aquelas famílias que estão lá, você tem o benefício ambiental também, mas aquelas famílias te um benefício social muito grande, e muitas vezes você deixa até de ser reportado, em detrimento a forte imagem ambiental que hoje o meio de comunicação esta evidenciando, e muita vezes não é nem o Empresa que faz isso, a mídia mesma acaba percebendo e focando muito mais o ambiental. Talvez agente tenha falhado em algumas comunicações e até o relatório ser revisto.

No caso como você falou, teve uma demanda que veio. Num momento teve uma preocupação...de que isso seria importante para o negócio

Tem uma febre muito grande de saber o que agente está fazendo, a febre dos investidores em saber o que as empresas estão fazendo quanto a questão ambiental, que é mais latente, talvez seja a bola da vez, isto acabou priorizando algumas informações, mas eu não vejo muito desequilíbrio.

Em termo de investimento, isso você não acha houve, que não é uma coisa que teve uma transformação tão grande - eu acho que não - acha que é mais report do que gestão no caso...

Acho que houve, acho que cresceu, cresceu investimento, equilibrou mais o investimento em meio ambiente, mas de fato, Stakeholders.

Agente pensa realmente em focar também crédito e educação, acho que crédito responsável e educação talvez acho que é fundamental, e está na pauta.

Investimento na área educacional...

Crédito responsável, uma escola de crédito responsável, crédito consciente e educar para isso.

\section{Uso do dinheiro.}

A final de contas a Sustentabilidade do cliente também é interessante para gente. Faz sentido. Isto também está ligado, mas não adianta nada eu falar disso para um público interno que mal sabia o que era sustentabilidade, concorda. É o que eu digo que é um processo de educação, um processo de preparo do corpo interno para poder atender esta demanda enorme que é a sustentabilidade, e não podia partir para, eu não poderia dar um sistema de choque, tinha que ser paulatino, 
paulatinamente agente estava trabalhando em cima disso. Primeiro ter paciência para gente chagar lá.

Distinguir responsabilidade Social para sustentabilidade Hoje, você falou que era uma evolução, enfim mas...

Vou tentar achar uma coisa bem emblemática, porque, eu acho que, uma coisa não suplanta outra, eu não integro a questão de responsabilidade social, com o tema sustentabilidade, eu acho que ela se complementa, na verdade ela complementa, ela dá um corpo maior, ela é nome de escopo, ela aumenta a responsabilidade de nossa ação, ou seja, agrega outros elementos além daquele que era mais puramente social, sustentabilidade ela evolui, mas não enterra a nossa responsabilidade social ..., mas em termos de responsabilidade social eu falo duas coisas quando converso com formadores de opinião, primeiro: que é primeiramente é um compromisso ético, com as futuras gerações, ponto. definição em uma frase de sustentabilidade, seria isto; segundo: isso vale mais para vida pragmática. Não se constrói sozinho. Tem que ser construído em conjunto. Entra o Empresa com seus Stakeholders, seus shareholders, seja lá...

\section{Shareholders são os acionistas...}

Isso, seja lá qual for o nome que se dê em todo esse grupo, mas tem que se construir sozinho, com, chamar os competidores, ou outros Empresas, não importa, não dá para construir sozinho não, não pode ser, tem que se construir em conjunto sempre, para encerrar. 
ENTREVISTADO - D

Primeira pergunta é um pouco do que você começou a falar antes. Na verdade é situar você enquanto profissional, trajetória, como é que você chegou na questão Responsabilidade Social. Priorizando sua trajetória aqui dentro da empresa.

A minha carreira sempre foi em Recursos Humanos, estou no Empresa já há dez anos, também vim pro, na época do BCM, e logo depois, entrei no BCM, o BCM já comprou o Vero, em 2001 eu estava gerenciando a área de recrutamento e seleção da organização, 2000, 2001, foi quando o Empresa começou a discutir a questão de desenvolvimento sustentável, sustentabilidade, mas na época agente falava de responsabilidade social, era o termo que agente utilizava, e naquela época houve uma, quem puxou este movimento foi o presidente da empresa, SB, ele fazia um comitê, na verdade ele queria provocar a organização em relação a este tema, ele chamou algumas pessoas do nível de diretoria para começar a conversar sobre o tema, então teve um grupinho bem pequeno, 5, 6 pessoas, um embrião para começar esta temática, então ele padronizou toda quarta feira da $12 \mathrm{~h}$ à 13h, ele fazia uma reunião com este grupo, para discutir, depois fazer a questão da avaliação dos indicadores INSTITUTO EMPRESARIAL, por que é que eu estou contanto isso? Por que foi a partir daí, que começou a surgirem as iniciativas que o Empresa desenvolver nesta temática, que veio a originar uma área que é a área que eu faço parte hoje. Então nesta época este grupo se reunia e discutia, e toda oportunidade eles desenvolviam uma proposta que era montar um grupo de trabalho, definindo um dos diretores para que ele fossem padrinho daquele grupo, para que o grupo pudesse estudar para fazer proposta para a organização. Então nesta época eu gerenciava a área de recrutamento e seleção, e o diretor de RH, F..., na época, compunha este grupo pequeno com o F, aí eles viram que na avaliação do Instituto Empresarial, os indicadores, a questão de meio ambiente, a questão de diversidade eram questões críticas na organização, pela avaliação que tinha sido feita, uma avaliação entre eles, não foi uma avaliação profunda, envolvendo muita gente da empresa, percepção deles. Aí nasceu o tema de diversidade como necessário ser estudado como grupo de trabalho, F. ficou responsável como possível padrinho, e aí ele foi me convidou para facilitar este tema dentro da organização, aí você fala assim, mas, por que você? Acho porque também que diversidade tinha um recorte forte de recursos humanos, tinha uma questão que eu gerenciava uma área que podia potencializar esta temática dentro da empresa, mas eu acho também que tinha a ver com meu perfil. Então ele me chamou, falou assim, você esta recebendo está missão, vai facilitar este tema, você monta grupo e faça uma proposta de como sensibilizar a organização em relação a este tema. E agente fala que na época, quanto este movimento começou, agente falava que era voluntário estimulado, aquilo não era minha função mas eu recebe, assim como eu, outras pessoas receberam esta demanda, em outros temas, mas agente fala assim, que era fora da função, ai eu 
brinco quando eu faço apresentação sobre isso, que de forma alguma eu podia dizer não, imagina o meu diretor que vinha, .. o presidente, aí recebi um tema que eu não sabe o que é que era exatamente porque era super novo, enfim, aí eu comecei, montei um grupo, fui ver pessoas que tanto eu conhecia por entrevista de carreira, que poderia também ter afinidade com este tema, formei um grupo aqui dentro, e aí, montei o grupo e falei qual era a missão que ele tinham recebido, que era sensibilizar nada mais do que isto, que agente tinha que fazer uma proposta para sensibilizar a organização, aí fui ia trazer um consultor, trouxe um consultor para dar uma base conceitual para o grupo, para as pessoas que queriam participar.

\section{Perfil - Tinha um envolvimento com algum tipo de questão deste tipo ou não?}

Não, mas era mais a questão da postura e das defesas que normalmente eu faço daquilo do que eu acho que é correto, daquilo que é justo, eu acho muito mais, eu acredito que tenha sido esta, ... , para o F. ter me convidado. O grupo começou isto foi metade de 2001, eu vou parar aqui depois se você quiser aprofundar um pouquinho como fica neste trabalho eu posso contar, mas, estou querendo dar origem a área. Quando foi em outubro de 2001, FB, presidente, trouxe de volta a ML, estava na Europa trabalhando na matriz, com uma visão mundial da parte de recursos humanos, ele convidou a ML para voltar para o Brasil, para criar esta área, diretoria de Desenvolvimento Sustentável, a ML volta em outubro, ela também é uma profissional de RH.

\section{Do que você conhece você diria que é a... dá pra dizer que tem que ser profissional de RH?}

Não, não, também vou te falar um pouquinho não. A ML então volta em outubro, aí ela vai entender, porque ela estava afastada do Brasil já faz algum tempo, ela vai entender este movimento, que este movimento começa em 2000, já tinha vários grupos de trabalho fazendo proposta em relação a alguns temas, que o comitê, este comitê de diretores tinha definido, então já rinha um grupo estudando micro crédito, um grupo estudando questão meio ambiente, que vai surgir aí o programa de eco eficiência, eu estava com Diversidade, e aí a ML vem, faz um mapeamento para entender, mas também tinha uma pessoa em RH que tinha sido, antes da ML chegar, designada para apoiar este grupo, também ela é um profissional de RH da área de desenvolvimento organizacional, então ela é meio Responsabilidade Social, meio Recursos Humanos, então a ML chega, se aproxima desta pessoa para entender, essa pessoa acaba vinda para trabalhar na área da ML, ela vai conversar com os diretores para entender um pouco da situação e fazer uma proposta de estrutura da área, então ela fez uma proposta para tem uma caixinha, que era trabalhar a questão de gestão, a questão de negócio e uma questão de ação social. Ela me chama para conversar e me fez a proposta par vir para a diretoria dela. Então ela nasce com uma diretoria com report a presidência, ela cria uma estrutura com este três temas e aí ela me convida para vir para área para ficar para a ação social só que 
começo agente trabalha, eu tinha que desenvolver o tema de ação social, mas trabalhar em projetos de forma transversal dentro da equipe foi uma tentativa que agente fez no início.

\section{O nome já era diretoria de desenvolvimento sustentável?}

Não, era diretoria de responsabilidade social. Bom, ela nasceu assim, e aí, inicio de 2002 eu chego na área e a ML praticamente já tem as três, então, eu em ação social, a B que era essa pessoa que tinha ficado $50 \%$ e 50\%, em gestão, e aí ela traz, a B também é de recursos Humanos, mas o CN, que vem pra área de negócio, então ele já é um profissional com a formação diferenciada, pra negócio, e também já atuava dentro da área do segmento, dentro da empresa, com uma visão mais, da operação de Empresa mesmo.

\section{Quando você fala gestão, teria a ver com a gestão interna, funcionário?}

Tinha que olhar assim, tudo que era questão, a relação, como é agente se relacionava com os fornecedores, a relação com os funcionários, tinha uma diversidade de temas, por exemplo, o tema de diversidade, (gestão) gestão, a ML faz a proposta da estrutura então ela cria, como ela teve a entrevista com os diretores, como ela percebeu que aí os diretores que não participavam deste grupo pequeno, começava, já estava começando a se sentir incomodado de não fazer parte, porque o tema já estava encaminhando, a ML propõe para o $\mathrm{FB}$, que abram três comitês, um focado em negócio, um focado em mercado, e um focado em ação social, para poder aprofundar a discussão e ter todos os diretores participando, então, ele aceita a proposta e cada diretor então escolhe de qual comitê ele quer fazer parte, para poder acolher os interesses. Então você tem no comitê de ação social, por exemplo, o diretor da área de varejo que gerenciava toda a rede de agências quis fazer parte do comitê de Ação Social, para discutir a questão...

\section{Não era predeterminado?}

Não, não, era uma escolha, é lógico que de alguma forma ele acabava tendo alguma representação e o tema transitava de um para outro.

\section{A divisão eu entendi mais ou menos - ela permanece até hoje?}

Não, ela foi evoluindo com o passar do tempo. Então só para você entender. O que é que ele discutia no comitê de gestão, confunde um pouquinho. Se fosse uma proposta da operação de micro crédito, estaria discutido no comitê de mercado. A mobilização dos nossos fornecedores para o tema responsabilidade social, que tinha um grupo que faria isso foi no de gestão, o tema diversidade era discutido no comitê de gestão, porque tinha um viés de relacionamento com o funcionário, mas quando o grupo estudou o tema, propôs para a organização que visse o tema além da relação dos 
funcionários, e a ação social era discutir o quanto que o recurso financeiro que a Empresa colocava para investir em projetos sociais na comunidade

\section{Fora da empresa?}

Aí é a relação com a comunidade. Então a evolução foi com o passar do tempo, aí foi em 2002, 2003, 2004, depois eu posso, se você achar que a data é importante, aí tem um calendário que muda, o comitê de gestão e o comitê de mercado passa a ser integrado, então agente manteve o foco no comitê de ação social, um comitê específico, que esta sendo construído, se integra então os dois comitês, e aí nasce o comitê, Conselho de sustentabilidade, aí também, mantêm as representações da diretoria neste conselho, que aí é o local onde se discute as oportunidades, os temas, as idéias que são desenvolvidas,

\section{Isto é 2005, 2006, ou antes?}

$2005,2006 \ldots$

\section{Onde começa a aparecer o termo?}

É. O que aconteceu também neste meio do cominho acho que é legal de você saber. Que a ML monta a área finalzinho de 2001, 2002, 2003. O que é que acontece. Tem uma mudança na estrutura, a área de Educação da empresa que normalmente está dentro da área de Recursos Humanos, vem para baixo da diretoria da ML. Houve uma mudança, ... que era diretora de RH vai para Europa, então surgiu a oportunidade de pegar a área de educação e trazer para baixo da diretoria responsabilidade social. Por quê? Porque essa nossa experiência neste já período mostra que nos estamos falando de mudança de cultura, e a melhor ferramenta para suportar uma mudança de cultura, é tudo o que agente faz em termos de educação, treinamento, então a área vem para baixo da área da ML, para que ela pudesse fazer um alinhamento e fazer com que o tema fosse sendo inserido em todas as ações educativas da empresa. Então ela fica com a gestão área de educação e rebatiza o nome da diretoria, que fica Diretoria de Desenvolvimento Sustentabilidade e Educação. 2003, 04 e 05, acho que em 2006 ela devolve a área de treinamento para o $\mathrm{RH}$, que ela já tinha feito o trabalho de inserção do tema.

Levantar esta questão de responsabilidade social...

Para potencializar.

Esta questão da área de treinamento em educação, professoras e pessoas da área de educação fazem uma distinção bastante grande, conceito de educação e conceito de treinamento, vocês 
fazem alguma distinção aqui, você percebe, coisas que se pode chamar isto, isto é treinamento, isto educação, ou não?

Agente, eu não presencio nenhuma discussão para diferenciar isto, mas agente tem, o que agente desenvolveu nesta trajetória foi um modelo educativo, se agente quer educar o adulto, é educar para que? Por quê? E como? Então para área de educação, esta sendo gerida pela $\mathrm{ML}$, desenvolve um projeto que é desenvolver um modelo educativo, para ter esta visão definida, agente está aqui falando de educação de adulto, nesta perspectiva de uma Empresa está trabalhando o tema sustentabilidade, então para trabalhar esta questão da visão sistêmica, o indivíduo como pessoa não só como profissional, então tem um modelo conceitual que foi desenvolvido para suportar toda construção das iniciativas

\section{Modelo educativo da empresa...}

Da empresa...

\section{Todas as ações caem e treinamento...}

Que vai além da sala de aula...

\section{Chegamos a diretoria atual de desenvolvimento sustentável...}

Isso, que depois também a estrutura vai mudando conforme o tema vai se inserindo no Empresa. Então esta foi a estrutura inicial, hoje a diretoria se chama desenvolvimento sustentável, ela continua, o que é que ela tem hoje, ela tem um a pessoa focada questão da visão de mercado, inserção de sustentabilidade na relação da empresa com o mercado, olhando tanto nossos clientes como outras áreas, tem uma pessoa que trabalha com todas as diretorias da empresa, para ajudar, estas áreas a entenderem o que elas fazem, como que por meio de seus processos e suas políticas podem ser de sustentabilidade, então esta área faz isso, e alem de fazer isso, faz, também como é que agente mobiliza os nossos clientes, nossos fornecedores para o tema sustentabilidade. Ela em uma outra caixinha que...

Isto tem a ver com aquele espaço Vero de práticas sustentáveis...

Já nasceu no momento que agente, nasceu o que agente chama de Vero Práticas de Sustentabilidade. Tem uma caixinha que esta desenvolvendo que chama de ações educativas para sustentabilidade, que na verdade é uma área que faz muita relação com recursos Humano, com a área de educação, mas ainda agente gera muito conteúdo, trabalha junto com RH mas gera muito conteúdo aqui dentro, depois tem uma caixinha que olha a questão dos canais alternativos, então agente tem o portal de sustentabilidade, que nasceu, a nova configuração nasceu... 


\section{Mais focado em comunicação ou não...}

Também comunicação, e também, é, que utiliza canais, mais usado a parte de tecnologia, também muito, nasceu desta discussão das práticas, porque agente que atingir maior número de pessoas, então tem que utilizar a tecnologia para favorecer este movimento, e continua a área de ação social. Então ficamos em quatro caixinhas agora.

\section{Nesta configuração tem muitas as pessoas trabalhando?}

Acho que atente está com 60, 65 pessoas...

\section{Aí tem...}

O diretor executivo ligado ao presidente da empresa...

Toda esta questão de como é que a empresa se insere como que foi estruturada... Então, deixo eu te contar, ainda falando da estrutura para te dar uma avaliação, que é assim, a nossa área nasceu para ser uma facilitadora da empresa para inserir sustentabilidade no dia-a-dia da organização, ela não nasce como uma área e projetos, teoricamente não é uma área que desenvolve projetos, a única área que desenvolve e gerencia processo é a minha área, imagina que eu na tenho isso inserido, quer dizer, eu trabalho na organização, mas eu não delego responsabilidade, porque eu tenho uma área e uma equipe para fazer projetos sociais, diferente do, por exemplo, o C que tem ajudar as áreas a entender sustentabilidade no dia-a-dia das áreas, então nós somos facilitadores e provocadores de iniciativas, agente suporta, mas agente não é responsável por desenvolvimento de iniciativas, tirando a minha área, a minha área e mais..., faz rodar estes projetos, dentro e fora da empresa, por que é construção de cultura, então eu trabalho a parte de dentro. O que é que acontece? Com esta trajetória algumas áreas vão sendo criadas, quando agente definiu a política de risco socioambiental, nasce então uma de risco socioambiental dentro da área de crédito, aquele grupinho que nasceu lá em 2001, para estudar meio ambiente, que gera uma iniciativa de eco eficiência, então também nasce uma área para suportar o processo de eco eficiência da empresa dentro da parte de administração predial, a operação de micro-crédito que era um grupo, nasce uma empresa de microcrédito, que nasceu, inicialmente a $\mathrm{ML}$ assumiu a gestão, porque agente precisava fazer com que entrasse no ar, a hora que nasceu, estruturou agente transfere para área e negócio, para o especialista, a iniciativa de mobilização de fornecedores também nasce assim, tinha um grupo, de alguma forma a ML ficou com algum tipo de gestão, mas na hora que formatou transfere para área de suprimentos para que fique lá, a nossa área já nasce com a proposta de desaparecer ao longo do tempo. 
Isso que eu ia falar...

Qualidade, área de qualidade...

Pensei a questão de ética, a disciplina ética na escola, a tendência é que você trabalhe a ética em todas a disciplinas, pelo que você está falando, se eu entendi corretamente este núcleo de 60 pessoas, ainda cumpri esta função de ficar fazendo com que o tema permeie toda organização, quando permear...

Missão cumprida ela desaparece, então, ela nasceu assim, o acordo feito do F com a ML foi esse, a ML conforme foi trazendo os profissionais fez este acordo, todo mundo sabe que depois no mercado seria uma área Biodegradável, quando agente começou a falar no mercado, nossa área era Biodegradável, aí ficou, saiu na mídia. O que é que aconteceu, primeiro agente, tinha uma ganância, agente falava para 2004, começou em 2001, agente subestimou o desafio, porque é mudança e cultura, então agente começou a não mais falar na data, então agente passou a ter um entendimento diferente, não é que a área desaparece, a área ... muda o patamar e o foco dela, por exemplo, o práticas nasce nesta perspectivas, o que é que agente vinha trabalhando, agente vinha trabalhando internamente, com todas as áreas para inserir a sustentabilidade, o que é que é o práticas, é uma iniciativa que vai alem, agente começa a compartilhar com a empresas a experiência que o Empresa tem nesta trajetória, então já é um avanço na nossa área, então muda um pouco o papel, agente continua trabalhando internamente para inserção mas também começa a trabalhar com o mercado no sentido de compartilhar esta experiência. Em termos de estrutura acho que eu te dei um panorama bem geral, porque você vê que as áreas vão criando a estrutura...

Nesta trilha, aproveitando o que você fala das transformações, agente pode falar da questão do conceito. Mudança de nomes. Como é que você vê esta mudança, Responsabilidade Social, depois surgindo Responsabilidade Socioambiental e mais recentemente Sustentabilidade, e qual a sua percepção destes conceitos da relação entre eles...

Acho que o mercado foi entendendo melhor do que estava se falando, apesar de que eu acho, que ainda tem gente que acha, hoje menos do que ouvia no passado, era muito engraçado quando agente começou a sair no mercado para fazer a apresentação agente ficava 1 hora, 1 hora, falando do que o Empresa fazia em relação ao tema, ainda usando o tema Responsabilidade Social e depois que você terminava a apresentação vinha sempre alguém falando de projetos sociais, então agente tomava muito cuidado em toda nossa comunicação, sempre tomou muito cuidado para colocar a luz e um tema maior e não ficar falando de projetos sociais, então acho que assim, lá atrás se confundia muito, acho que hoje o mercado já se posicionou de uma forma mais adequado em relação ao tema, 
mas ainda tem, tem gente que ainda tem dificuldade de entender. Acho que foi uma evolução natural de construção de conhecimento e entendimento sobre a proposta, aqui agente fala desenvolvimento sustentável, mas tem gente que ainda, agente pode dizer assim, agora se tratando de 32 mil funcionários do Vero, e mais 20 e tantos mil do TDR, então eu só vou falar de quem já viveu mais esta trajetória que é a equipe do Vero, mesmo dentro destes $32 \mathrm{mil}$, tem gente que ainda não tem o conceito incorporado, não tem o entendimento perfeito do conceito, mas agente sempre trabalhou na questão de que isto precisaria estar no Core da organização, inserir no Core, nós como Empresa como é que agente conseguia construir lucro, o fator econômico, associado ao desenvolvimento social e a preservação do meio ambiente. Aí, a parte de enriquecimento social, que é quanto que agente ainda tem de projeto social, compõe esta estratégia, mas era um pedacinho de uma estratégia maior.

A minha impressão é que a tua área, de ação social talvez tenha sido a que mais se transformou, ou, deixo recolocar a pergunta. Quando se tem a idéia de responsabilidade social talvez a idéia de ação social não fosse uma idéia muito imediato... A impressão é que, cresce uma questão de se falar da gestão, você falou de negócio, de se aproximar das ações, das operações da empresa, cresce na minha percepção também assim, a questão do ambiente, do meio ambiente e o social não sei exatamente o que é que acontece, se ele muda se ele diminui, se ele permanece, como você esta na área de ação social, seria legal ouvir a sua percepção?

O movimento da empresa ela já nasce na perspectiva maior, o Empresa se posicionou desde o começo trabalhando na inserção de sustentabilidade, entre aspas, na época, mesmo que não fosse este o nome, porque agente faz uma avaliação, já nasceu na perspectiva da integração do econômico, social e ambiental, foi assim que nasceu. A área de ação social, se você olhar hoje, agente discutiu muito internamente aqui, a minha área pode ser uma área que não precisa estar dentro desta estrutura de desenvolvimento sustentável, ela pode ser uma área que poder estar dentro de qualquer local da organização, entre aspas, ela pode estar dentro da área de marketing, que é muito comum estar dentro desta estrutura no mercado, ou até pode pelo viés que nós trabalhamos muito o engajamento de funcionários, pode estar dentro da área de recursos humanos, mas não necessariamente, ela esta dentro, por que agente fechou o guarda-chuva, ai se fala assim, como é que fica, se transformou, eu diria que esta área se orientou pelos mesmos conceitos que Sustentabilidade trabalha, então toda estratégia que desenvolvimento social privado ela trabalha na perspectiva de social, do econômico, e ambiental, lógico que tem um projeto que pode puxar mais o ambiental e agente sempre olha o social e ver como que isto pode impactar no econômico, eu posso ter um projeto de geração de renda que necessariamente tem que estar associada ao ambiental e 
consequentemente também estar no social. Então todo investimento em projetos eu também integro os três eixos.

Na verdade de largada eu já tinha esta concepção...

Pensa assim, este pedacinho, historicamente, todas as empresas no Brasil de alguma forma, todas não, a maioria, já tem uma longa trajetória, porque é um tema mais antigo, de colocar, ou apoiar uma creche, um orfanato, então isso é uma coisa, já esta na nossa cultura empresarial já a mais tempo, quando a ML estrutura esta área, esta função era desenvolvida pela área de marketing, que era solicitado diariamente por apoiar projetos de instituições sociais, ou porque alguém algum político vem pedir, instituições de relacionamento vinha, e o Empresa apoiava, assim como todas as empresas, então já tinha um histórico, quando a ML monta a estrutura dela, este tema é transferido para área dela, e aí é transferido com duas iniciativas que a área de marketing já historicamente apoiava, que era a alfabetização, Alfabetização Solidária, Alfasol e também a Universidade Solidária que era da $D$. Rute, então a $M L$, herda estas duas parcerias, o que é que agente faz? Agente vai estudar o tema, porque para nós era como se agente estivesse partindo do zero, só que a empresa não estava partindo do zero. Então toda a conceituação, a discussão o debate e a decisão ela já é tomada nesta perspectiva do desenvolvimento sustentável, porque agente foi também construir um conhecimento sobre isso para poder posicionar o Empresa como que ele queria investir nesta área. Então eu diria assim, ela cresceu, não se ela, você falou assim, transformou. Pode até ser, porque acho que é uma área super, agente costuma dizer, ela compõe uma estratégia maior, mas ela se alimenta muito dos conceitos de sustentabilidade. E de novo, ela pode ser a qualquer momento separada desta área porque... Não sei se eu te respondi.

Respondeu... Como você lida, vocês que desenvolvem os projetos? Terceiro pedaço, um é o conceito, a estrutura e agora um pouco ações? 0 que me interesse mais é o como as coisas acontecem, porque assim? Quais são as ações, agente até já tem colocado nos relatórios sociais, na mídia e tudo mais... Ai, você pode falar em geral, se é que existe em geral, ou falar de algum projeto que te chama a atenção, e esse como, na seguinte, como é que surge a idéia, quem vai atrás quem, vocês recebem uma demanda de fora, como é que isso acontece, se é que existe um jeito de acontecer?

Agente fala assim, agente vive a melhor situação que hoje agente perdeu o controle de como as coisas nascem e como que elas acontecem que esta é a melhor da situação. Que quando se está começando, você sabe por onde começa, onde vai dar, você sabe tudo que está no espaço. Hoje agente já não sabe, é isto que agente fala assim, a organização tem que viver isto, então pode numa determinada área pequena que agente nem tem a visibilidade na estrutura ter desenvolvido uma 
iniciativa que estes funcionários já entenderam qual o seu papel e qual, como é a sua área na função que ela tem dentro da organização ela pode levar esta temática.

\section{Comunidade, demanda vem da comunidade vai para lá, as duas coisas...Vamos fazer um projeto.}

Acho que se agente for discutir a área da comunidade talvez não seja o melhor pedaço, deixa eu te falar, vou falar maior, depois agente pode especificar um pouquinho aí. Eu diria assim, que hoje as iniciativas da empresa, em relação a este tema, esta assim, ou porque esta sendo demandado pelo mercado. Por exemplo, Boto, agente fez uma operação com eles, que eu não consigo te dar detalhes que eu não vivi, que era uma operação mais de negócio, que a Boto estava investindo na questão da, numa determinada região, queria trabalhar com a comunidade do assentamento onde as famílias foram apoiadas pela Empresa para financiamento para ter outro tipo de produção alem dos eucaliptos, para intercalar a época de produção, então isto é uma operação que nasce nesta perspectiva. Muito provavelmente a Boto tinha um projeto de investimento que veio e ai agente levou a iniciativa como esta olhando o ambiental, social e econômico. Então, isto nasce vindo do mercado

\section{Demanda da empresa e seu público...}

Você tem a iniciativa que nasce de um funcionário. Vou te identificar agora como. Programa de eco eficiência, a Empresa quando estuda este tema então decide por várias ações, de dar uma caneca de cerâmica para cada funcionária, colocar os coletores de papeis nas mesas, tal, e aí faz o processo de sensibilização, e aí agente vai aprender que, algumas decisões, ah, põe a caneca e tira os copos, para que ninguém possa usar. Aí nossa postura sempre foi o processo educativo, a Empresa nunca quis assim, não, forço, a pessoa tem que entender qual o papel dela naquela demanda, então, só em relação, manteve o copo, é uma questão de escolha das pessoas. Então agente viu, que isto daí, o tempo todo precisa de um suporte de comunicação e educação, porque é uma mudança de hábito. Então o que é que agente viu. Que nem sempre o resultado da eco-eficiência estava legal. O que é que aconteceu em uma determinada área? Um funcionário começou a perceber que o descarte dos materiais não estava adequado em relação. O que é que ele fez? Ele com outro montou um sisteminha, um processinho, fez um cartão vermelho e cartão verdinho e os dois no final do dia percorriam todas as mesas de trabalho da área e começou a colocar um cartão vermelho quando a pessoa descartava errado, e aí ele criou uma metodologia, um processo, e aí o que é que aconteceu, a pessoa foi entender, porque que eu estou com este cartão vermelho, ah, você colocou o copo no lugar errado, o papel.... Aí esta idéia foi copiada. Isto se criou um processo de avaliação dentro das áreas periodicamente, onde todas as áreas são monitoradas pelo mesmo sistema, ai duas pessoas da área são convidadas para fazer este processo, leva esta metodologia e as páreas são avaliadas e aí sai 
um ranking de como as áreas estão em relação as este assunto. Como que nasce? De uma postura de um funcionário.

Tem a haver com a cultura de empresa também, quando você fala de ranking das áreas...

Éh, você tem que usar isto, por que assim que as pessoas, é cultural mesmo. Então, outra forma. Você pode estar no conselho e alguém traz uma informação de mercado, ou porque sei lá, de um concorrente que esta fazendo alguma coisa, e ai traz a idéias pode-se provocar, provocar também o desenvolvimento de um grupo, ou alguma área liderar o desenvolvimento de alguma idéia e voltar para o conselho para discutir.

Na verdade não tem um procedimento, padrão...

Ele não é único, ele é orgânico, ele é orgânico, ai o que é que tem. Quando agente tem a inserção de sustentabilidade nas áreas, todas as áreas elas são estimuladas e apoiadas, para que a cada ano ela defina um planejamento e neste planejamento ela possa identificar as oportunidades que ela tem de inserção de sustentabilidade, então ali neste momento ela também identificar a oportunidade de desenvolver iniciativas, então ali pode surgir um novo projeto.

Este negócio de cartão - verde - vermelho, ele não percebido como uma ação social, ele é de sustentabilidade ou de inserção de sustentabilidade nas áreas, e o que tem me chamado a atenção sobre os projetos fora das empresas. Instâncias deliberativas, empresa vai, isto parece que tem acontecido mais ou menos, depende da trajetória, você tem uma demanda de fora, uma comunidade próxima pede alguma coisa, ai pode surgir um projeto, ou o inverso, de repente a empresa tem algumas prioridades ou as duas coisas misturadas, não sei?

É a minha área, eu vou falar dela, é que você viu que eu procuro ficar no maior, eu já te dei assim, nossa estrutura é esta e nosso propósito...

\section{Esta ação social ela está relacionada e não tem como separar?}

Isto, agora eu vou te falar como é que nascem as iniciativas sociais. É assim, nos temos um posicionamento, nós temos um foco, quais são as causas que a Empresa quer trabalhar. Que nasce onde, nasce nesta conceituação e neste debate que tem com o comitê de ação social de 2002 cá, naquela época as reuniões eram quinzenais, e foi quinzenal por mais de ano, 8 ou 9 diretores e o FB. O FB participa.

Isto que você vai falar eu já tinha lido, mas esta ficando mais forte ainda, tem uma questão do comprometimento pessoal, se não fosse o FB, não tinha. 
Agente sempre diz, tem uma pessoa que foi, ele puxou, ele puxou, só que o F, o estilo dele não de imposição, ele é de convencimento, agente poderia, ou tem empresa que sai, define uma política escreve a política, divulga e todo mundo tem que cumprir. A política aqui, é a última coisa que vai acontecer, depois de tudo debatido, o processo educativo feito, todo mundo já ter incorporado e aí vem uma política. O caminho é mais longo, mas este é o jeito que a organização escolheu para fazer. Então nasceu. Lá agente definiu lá trás qual era o foco. Agente definiu que seria a educação, depois agente foi encaminhado, definiu que era a educação na relação com a escola pública, que era onde o grupo queria investi, depois agente investe em educação, sim, a maior parte de nosso investimento, mas agente investe em projetos sociais também com temas de meio ambiente, geração de renda e diversidade que são temas que agente trabalha na perspectiva de sustentabilidade. Então tinha o porque a ação social ser dirigida por este olhar. Então agente começa a trabalhar, são estes os temas, agora agente trabalha muito por programa, este tema, todo mundo tem uma ótima iniciativa social, todo mundo tem demandas, o Brasil, muita necessidade, então se você não define, um posicionamento e uma estratégico, você fica muito vulnerável a tudo que tem, então agente constrói as nossas propostas, então é assim, na medida que, agente tem o foco definido, o valor que a gente define, como agente faz este investimento, com que premissas, então as premissas são, o Empresa quer construir cultura, se eu quero construir cultura, eu sempre que preciso mobilizo meus funcionários para participarem das iniciativas sociais, este é um critério, se eu mobilizo o funcionário, eu sou um Empresa e me relaciono com tanto, dentre pessoa jurídica e pessoa física, é uma oportunidade de engajamento desta população, também é, então eu também procuro fazer engajamento com meus clientes e fornecedores também por meio de iniciativas sociais, o Empresa não investe, o critério não é investir somente onde o Empresa está presente, não é só onde o Empresa esta presente, tem empresas que é assim, principalmente indústria, estou aqui e no entorno, a nossa proposta eu invisto, onde estou presente e onde eu não estou presente, onde sei que existe a necessidade, de acordo com minha definição de critérios eu vou investir, então tem algumas premissas, citei alguma delas, aí eu trabalho por programas, nós não atuamos com balcão de pedidos, eu diariamente, a minha equipe diariamente recebe solicitação de doações e patrocínios, todas elas são recebidas, são avaliadas, são registradas e tem retorno, mas a grande maioria recebe um não, porque agente já tem programas definidos, então, eu tenho o Projeto EB, que se propõe trabalhar no relacionamento com a escola que é voluntariado coorporativo, eu tenho o trabalho com os Direitos da Criança e do Adolescente, por meio de um programa que tem um processo estruturado ao longo do ano, de como identificar os projetos, de como apoiar, porque aí eu trabalho com um programa e debaixo do programa tem varias iniciativas, eu tenho um processo, se não, não dá, não dá para ficar apoiando tudo que vem do entorno, mas você estimula a agência e o gerente geral de uma agência, hoje não, porque eu trabalho institucionalmente, não por localidade, ou então 
pode até ter uma participação da agência em alguma coisa lá, mas é com a verba deles, e não com a verba que a nossa área gerencia.

Você fala também da questão da educação pública, que é uma questão polêmica, na verdade, tem, pensadores e estudiosos que acham que as empresas não devem se envolver com as políticas públicas, a empresa é empresa, e as políticas públicas tem instâncias de deliberação das quais as empresas participariam, quando você fala de política pública, o Empresa Vero de alguma forma tem que se envolver com as políticas públicas. Como é que se dá esta relação?

Agente tem, um dos nossos orientadores, e assim, agente trabalha sempre para fortalecer as políticas públicas, se eu vou trabalhar no espaço que existe política, no mínimo eu tenho que saber da política, e trabalhar em favor dela e não para dificultar, acho que esta é uma questão, porque assim, é muito comum as empresas nos fóruns que está se discutindo o social. Todo mundo fala assim, Ah, eu quero influenciar a política. Agente aprende também que é muito legal, perguntava para todo mundo lá, mas como é que agente consegue fazer isto? Ninguém tem uma resposta muito convincente, então nossa postura, eu tenho orientadores, quando eu fala, uso os orientadores fortalece, se conseguir influenciar melhor é, mas agente no mínimo fortalece.

\section{Como é que vocês fazem esta relação, vocês vão até o governo?}

Pena assim, o principal projeto hoje na relação com as escolas é o projeto EB, que é o voluntariado corporativo, então eu convido, agente tem um projeto que estimula nosso funcionário a se organizar em grupo e estabelecer um relacionamento com uma escola, e aí ela vai estabelecer um relacionamento, apresentando qual que é o foco do projeto, como que o voluntário atua, e se a escola quer ser parceira, se ela quer ser parceira ela tem responsabilidade, e aí eles vão montar, combinar um jeito de trabalhar, a escola é representante do sistema, eu não vou na secretaria, eu até posso ir na secretaria se eu tenho um programa maior, por exemplo, em São Paulo agente lançou a dois anos atrás, um programa de capacitação de professores, no município de são Paulo, capacitação em arte e leitura, porque agente sabe que a questão leitura é deficitária, então para agente montar este programa que era a primeira turma, agente foi até a secretaria municipal e estadual, porque, aqui no município de São Paulo, eu tenho vários grupos de funcionários que tem relacionamento com algumas escolas tanto municipais quanto estaduais, aí agente montou o projeto e foi na secretaria e fez a parceria até publicaram deram pontuação para os professores, mas foi a primeira experiência, eu não necessariamente eu interajo na secretaria, eu entendo que a escola é o interlocutor também para cima no sistema deles. 
O que aconteceu ... uma situação se você já passou algo semelhante e como é que você percebe. Eles começaram, a colaborar com a escola, nesta política do entorno, uma escola próxima a uma das unidades industrial, tudo indo muito bem, até que um dia a diretora, a escola ligou, vocês esqueceram de mandar "não sei o que", naquele momento, mas este não é nosso papel, e meio que eles deram um passo atrás, a escola começou a ter demanda como se eles fossem a delegacia de ensino, então eles pegaram e começaram a falar para a delegacia de ensino, enfim, perceberam que este contato direto com a escola, no caso daquela empresa, começou a gerar uma relação que eles não davam conta, enquanto empresa, ai, pelo que você esta falando aqui, a história é um pouco diferente, não sei se já aconteceu...

Não porque o Projeto EB, define qual é o âmbito que ele propaga, e quais são os temas, agente tanto pode contribuir com a escola em melhorias que podem influenciar positivamente na gestão, na infraestrutura, e na parte pedagógica, e agente trabalha com que tema: esporte, recreação e cultura, diversidade, empreendedorismo e meio ambiente, é por aqui que agente trabalha, e aí o voluntário tem uma responsabilidade e a escola com a comunidade escolar tem outra, e aí a composição destas responsabilidades fazem o projeto acontecer. Dá para, agente tem hoje 455 escolas parceiras, porque o voluntariado não individual é em grupo, no Brasil inteiro, então, eu não posso te dizer se teve situações assim, porque quem viveu a relação são os grupos de funcionários, tem uma equipe técnica que desenvolve a suas cotas, define os limites e suporta o voluntário para que ele faça, mas eu não vivo a relação com a escola, direto.

A questão do Balanço Social e o relatório Anual, é uma coisa que algumas empresas tem documentos juntos, documentos separados, como é o caso da Fartura, ela já nasceu tudo numa coisa só. As Empresas normalmente têm dois relatórios, não sei como é o caso da empresa Vero trabalha, o relatório de sustentabilidade é o relatório da empresa, ou ele tem o relatório financeiro, relatório, isso é junto ou misturado, ou não é uma questão que surgiu aqui, as questões vão se fundi...

Vou te falar um pouco, mas que você entenda que isso é algo..., agente está num momento de mudança. O que aconteceu, primeiro relatório que o Empresa, desenvolveu o relatório Social, como é conhecido no mercado, ale nasceu, já foi integrado, isto 2002, acho que foi em 2003 que nasce o primeiro relatório. Hoje, por exemplo, sei que o TDR ele tem separado. Acho que tem olhando a BCM, pegando gestão anterior, acho que o BCM tinha também um relatório de resultado específico.

\section{Uma questão de como é comunicado?}

Agora eles estão trabalhando no relatório, e eu estou esperando para ver como vai ser. 
A mídia, matérias: Grande questão era essa: 0 que vai acontecer, o fato do FB ser mantido como presidente já, do grupo, já tem um indicador, que as coisas não vai ser, não vão acabar com tudo, não é assim, não vai ser uma devastação, mas é claro que tem culturas diferentes, e nessa, você falou que tem essa transição, e algumas empresas isso tem maiores e menores impacto, e aqui dentro, é tudo uma mudança de cultura, o trabalho todo é um trabalho de cultura, e como é que você vê isso daqui pra frente como é que você esta sentido?

Então, acho que agente tem algum sinalizador, porque, primeiro o Empresa Vero ele tem um reconhecimento no mercado, em relação a esta prática de inserção de sustentabilidade bem forte, foi muito interessante nós que vivemos esta trajetória esta construção ver a reação do mercado, foi muito legal agente ver a reação do mercado, foi muito legal, por onde agente caminhava as pessoas estavam preocupadas, como é que o TDR ia tratar disso, e assim, era gente de relacionamento da empresa, era gente de relacionamento pessoal, profissional, e assim, concorrentes, foi muito legal assim, ver o nível de sensibilidade que o mercado tinha em relação, como é que o TDR, a mídia, como é que o TDR ia tratar, e também foi muito legal, agente ouvir, não ouvir diretamente, ouvir pessoas comentando de empresas que trabalhavam com o Empresas, disse assim, se o TDR não for cuidadoso eu vou tirar minha conta, então teve uma pressão do mercado muito, se vocês pudessem registrar isso, acho que, foi um momento marcante no mercado saB. Bom. O que é que acontece, acho que TDR comprou, imagino que ele soubesse na época o que ele estava comprando. Então acho que o valor da ação que ele pagou já mostrava o que tinha de construção, então acho que quando eles começam a entender um pouco mais da unidade Brasil, porque, foi mundial, ai vem entender Brasil, aí eles entendem, acho que o Empresa Vero, olhando o BCM como um todo, tinha um posicionamento forte nesta questão, mas agente tem que marcar que o Empresa Vero no Brasil foi quem mais impulsionou a BCM nesta temática, então o Brasil foi referência, porque quando você olhava o BCM, o BCM tinha valores, o BCM já tinha uma questão de valores que trazia eco, fazia eco para esta temática, mas agente tem que entender que o $\mathrm{F}$ Barbosa presidente da empresa aqui no Brasil ele foi quem impulsionou...

\section{Ele entrou com a BCM?}

Ele era BCM, ele era BCM, ele que fez a interação com o Vero, então o Empresa Vero, então o Vero, o Empresa Vero, o Empresa BCM aqui no Brasil ele foi referência para o mundo BCM, e inspirou o BCM, tanto é que a área de Desenvolvimento Sustentável lá na Europa foi criado depois de agente já ter 3 a 4 anos inspirado em nosso modelo. Então muito da experiência Brasil foi compartilhada, ganhou força e repercussão mesmo. Bom, isso só para te dar uma noção. Então ai o TDR chega, ele vai se aproximar aqui. Vem conhecer, o F é definido como presidente, eu acho que esta é uma informação importante, relevante, esta certo, porque é a primeira vez, e aí no histórico que agente tem do TDR, 
que o TDR deixa o presidente de uma empresa que foi comprada, é raro, e ainda no perfil do TDR, que é um perfil de, que o principal executivo, o B, ele precisa ter uma relação de muita confiança em quem ele vai colocar, então tem uma mensagem relevante. O F então fica, quando o $\mathrm{F}$ assume quando ele assume de fato, porque teve um longo período de negociação com Empresa central $\mathrm{S}$, da empresa Central Brasileiro, para o $\mathrm{F}$ poder assumir a cadeira, o $\mathrm{F}$ começa a conversar com o nível executivo, fazer a apresentação, a ML foi convidada logo de início para fazer uma apresentação sobre o que é que o branco fazia para o $B$, para o $P$ que é um executivo que olha o Brasil está lá, mas ele vem para cá para acompanhar o processo de integração junto com o F, o P conheceu, e o P leva este tema para pauta de uma reunião com o $B$, foi coisa de um mês e meio, aí a ML vai e faz a apresentação para o B, para o dono do TDR, diz que ele ficou super atento, anotou um monte de coisa, e deu sinalo verde. Então a ML, já fez, para seguir, depois tinham alguns executivos que não estavam presentes na reunião ... ele pediu para que a $M L$ apresentasse de novo para alguns que não estavam presente, ela vai depois para Madri de novo para fazer a segunda apresentação, então eu entendo, entendo não, a sinalização é, vamos continuar com a prática. Ai tem outra coisa, o F diz, não sabe fazer de uma forma diferente, isto está na gestão do F.

Imagine que todos os argumentos tenham passado pela questão dos negócios, sobretudo isto, isto não é uma coisa nova para vocês, justificativa pelos negócios...

Não porque já nasceu assim. Agora tem uma questão, que é. O mundo empresarial fala assim: Qual é o resultado que o tema sustentabilidade trás para organização. Foi a pergunta que está na pauta. E a questão é como é que agente consegue mensurar isto. Agente consegue mensurar com vários indicadores, o quanto que a marca da empresa está associada a Sustentabilidade, mas ele não indicador de números, de núcleo, ele não é direto, ele é indireto, então agente tem a sensação por meio de vários indicadores e que contribui sim para o resultado da organização. O que nós estamos fazendo agora é desenvolvendo um modelo, estamos em piloto, para tentar mensurar financeiramente esse...

Impacto da Sustentabilidade nos números. Uma das leituras é que se o Empresa vai bem nos números, se ele vai bem financeiramente, enfim, já é um indicador por si, que dizer um Empresa sólido, enfim, que tem uma, enfim, a parte financeira bastante sólida vamos dizer assim, e trabalha com sustentabilidade quer dizer, isto já é um indicador per si, mas não é isto que você esta falando. Você está falando de indicadores de relação mais direta, de ações? Porque hoje agente está assim, isto dá resultado para fidelizar, dá resultado para atrair. 
Esse momento que vocês viveram de reação de mercado, você falou que não foi cientificamente registrado, das manifestações, não deixa de ser um indicador?

Lógico, isso para mim é um indicador de resultado, mais aí o principal executivo quer saber. Quanto que isto gera de lucro, então você tem que responder esta pergunta. Então agora agente esta experimentando, agente ... nossa cota, desenvolvendo este projeto a quase dois anos, agente vem tratando dele, e agora agente esta pilotando este modelo.

Da relação, porque às vezes, uma das coisas difíceis de fazer, nestas áreas de humanidades, são as relações diretas que volta e meia são demandadas mais qual a co-relação entre a ação social e o lucro. Quer dizer. Tem caminhos aí...

Tem caminhos, uns são objetivos e outros são mais subjetivos. É um grande desafio.

Então Ricardo, deixa eu falar, acho que é legal falar um pouco do práticas que acho também que pode te. O que agente viu, aquela coisa da área desaparece, agente foi avançando, foi avançando internamente e viu que tinha, tinha uma demanda muito forte de empresas que queriam vir aqui no Empresa para entender a nossa experiência, atende, e aí disse assim. De repente a nossa agenda estava totalmente tomada por estas visitas, então agente falou assim. Espera, tem alguma coisa acontecendo. De todos os tipos, grande média, muitas de relacionamento da empresa, algumas até com menos relacionamento, mas muitos clientes da empresa, ou então, o gerente de relacionamento com a empresa, e a empresa pedia, e agente ia até a empresa apresentar, então agente viu que agente tinha um papel que era. Se agente esta inserindo no nosso negócio, ajudando as empresas a inserir por meio da relação da empresa com os fornecedores, tem todos os critérios, é difícil um trabalho para que os fornecedores também seguissem este movimento, como que agente levava para que as empresas pudessem também inserir e acelerar este processo, que quando o Empresa começou os modelos eram quase que inexistentes, agente foi pelo aprendizado, então é legal quando você como que a empresa trata a questão de governança, trata a questão de educação, de engajamento, então agente deu uma parada, vamos estruturar, organizar nossa experiência para poder compartilhar, é aí que nasce então o Espaço Vero de Sustentabilidade, que é nesta perspectiva de compartilhar com estas empresas, e assumir um compromisso de contribuir para quês estas empresas acelerem o processo de inserção.

\section{Tem na internet ou não?}

Pela Internet tem cursos que qualquer pessoa pode acessar, tem curso, agente esta colocando cada vez mais, Direitos Humanos, construção sustentável, então ali a internet oferece várias oportunidades, mais agente faz um programa que é presencial de dois dias, onde agente convida por meio dos gerentes de relacionamento com as empresas, para que eles convidem as empresas e as 
pessoas, agente pede que venha no mínimo duas pessoas por empresa, porque dá mais força para equipe voltar depois, porque agente sabem que nem sempre, então uma pessoa fica muito solitário, então que no mínimo duas, tem empresa que manda cinco participantes, então agente monta grupos nas capitais, e fica dois dias com eles contando qual foi a experiência da empresa em relação a inserção de sustentabilidade, então qual que é a nossa proposta. Não é discutir conceito. Mas é discutir prática. Porque conceito tem várias outras instituições que fazem. Agente fala assim, como é que na nossa prática agente fez. Então agente passa dois dias falando, como é que nasceu, como que agente montou os processos de governança, como que foi a questão de engajamento, passa pelo engajamento dos funcionários, como que agente engajou os fornecedores, como que tratou a questão do ambiental por meio do Core da empresa, para que as pessoas entendam que é por meio do Core, que é maior que investimento social. Aí no finalzinho da agenda aí eu vou lá e falo do desenvolvimento social privado, ai já formou, aí são dois dias com as empresas, e agente vai apresentando e fazendo o exercício com as empresas, que ela tem uma cota para que ela possa pensar como que ele voltando para empresa, ele poderia levar o tema para inserir dentro da missão e inserir em produtos, inserir em educação, então, apresenta e eles fazem o exercício para eles verem como que seria a cota deles, e a nossa proposta e que a nossa experiência é a nossa experiência, serviu para esta organização que tem um perfil, para que ela inspire outros, mas cada um pode começar de seu jeito por onde entender que tem mais chance de sucesso, então, o tempo todo agente trabalhou nessa associação, referência, e tem sido muito, muito legal, agente começou em 4 de dezembro de 2007, botamos 14 turmas durante 2008, toda equipe gerencial, a ML, o C, eu e o S, agente o tempo todo agente está orquestrando, e é muito legal, aí depois agente faz uma pesquisa com eles, no evento mesmo que, aí já tem a ver com a avaliação de resultados, agente faz uma pesquisa como é que eles avaliam que a empresa esta indo em relação a vários itens, governança, inserção em produtos, agente tira o marco zero, o marco zero que é a participação do programa, depois de oito meses agente faz uma pesquisa de como é que eles vem a evolução da empresa naqueles temas, então agente está agora rodando para ver, agente já rodou a primeira avaliação duas, três turmas, então agora agente vai voltar com as demais até que, tem que esperar os oitos meses, e em oito meses agente faz a pesquisa, manda pela internet eles responde, então agente está avaliando o quanto que esta avançando, porque nosso... é que eles avancem.

Neste questão, do tempo, vamos dizer assim, nos projetos também tem esta questão, você esta avaliando o que aconteceu depois, você tem uma duração, por exemplo a educação me parece que é mais de longo prazo, EB, ou ele tem uma duração enfim, determinada, ele tem uma duração de um ano e depois a escola é acompanhada ou não é acompanhada? 
Então, cada projeto tem um jeito, um desenho, no caso da relação com a escola, agente não define prazo, a hora que a, (...) entre o voluntário e a escola, e a hora que eles entenderem que a relação já avançou até aonde poderia e agente trabalha na certeza de não, de fortalecer a escola, de modo que ela não crie uma relação de dependência,

\section{Até onde vai?}

Eles tem que avaliar, eles avaliam se é o caso, tem escola que é parceira do grupo a 5 anos, agora agente esta fazendo uma mudança também porque este projeto eu recebi para gerenciar em 2005, e ele era uma projeto que já existia desde 98, então eu recebe em 2005 e fiz toda uma análise dele para inserir a questão de sustentabilidade, trabalhando os conceitos para que a agente possa, você perder uma relação de 10 anos com a escola tem alguma coisa errada

\section{A duração é uma questão importante aqui...}

Então é uma mudança de cultura porque o que você esta apontando o exemplo da outra empresa, os voluntários anteriormente, falavam assim, Ah! Escola, nós somos o projeto EB o que é que vocês precisam? Aí a escola fazia uma relação de coisas que ela precisava, caiu na pergunta errada né, a escola fazia uma relação e o voluntário ficava se desdobrando para arrumar recursos a para dar tudo que a escola queria, depois de 2005 agente fez um redesenho eu falei, é outra coisa, ele é parceiro e aí escola tem sua responsabilidade, neste caso não tem prazo. Você estava querendo saber assim, se você apoiar um projeto de uma instituição, quanto tempo você apóia, por quanto tempo você apóia? Via de regra eu apoio um ano, dentro dos programas os projetos são avaliados ao longo de um ano e se apresentam um resultado podem ser financiado por mais uma anos, então trabalha na média de 2 a 3 anos de apoio.

\section{Não é balcão né?}

Não é balcão, e que eu não estou detalhando com você como que é, eu não, nós não apoiamos projeto isoladamente, eu apoio programas, que é que é o programa? O programa é uma proposta estruturada e eu apoio projetos debaixo de programas, vou dar um exemplo para você. Nós vimos em 2002, que a questão do Estatuto da Criança e do Adolescente, o que é uma política, tinha muita fragilidade no nosso país, uma política bárbara na nossa sociedade, é bárbaro, mas que a nossa sociedade não conhece, e aí você fala assim, eu vou trabalhar para influenciar a política que, fortalecer a política que está ai, então agente trabalha em favor do estatuto, do ECA, então nasce aí em 2002 o Amigo Vero, o que é que é o Amigo Vero, então é um, tem base no estatuto para fortalecer os conselhos e melhorar a questão do atendimento da questão da criança e adolescente, o que é que a gente faz, escolhemos $M G$, pegamos uma região que todo mundo sabe que era uma 
região carente que é o VJ, olhamos os município existentes, dos 54 municípios, 11, convidamos os conselhos dos município a mandarem seus projetos com foco em educação, 11 mandaram

\section{Conselhos Tutelares no caso...}

Não, conselho de direitos, porque a violação é com o Conselho de Direitos, 11 projetos vieram, projetos assim, numa folhinha, aí agente vai estuda estes projetos, aí monta um grupo de trabalho com funcionários lá em Minas, leva os projetos que tem, faz a avaliação com eles, qual o projetos que vocês apoiariam, é como agente faz a questão do engajamento, e aí eles tiram dos 11 projetos, 5 projetos, ai disse assim, mas eu não me sinto confortável em decidi por este ou por este por que papel, aí nasce ali uma oportunidade e os próprios funcionários falam assim porque agente não vai visitar estes município. Que a minha equipe, agente não tinha pensado nisso foi lá na experiência que veio, e aí agente organiza a visita nos 5 municípios que eles já selecionaram, com eles mesmos, quem é que vai visitar eles, eu ponho uma equipe para acompanhar para agente aprender também, aí eles voltam e dos cinco eles indicam 1 colocando 1 como reserva, agente pega este 1 projeto e capta recurso no Estado de Minas, entre os funcionários, com informática né, agente divulga e vai falar o que é o ECA, o que é o mecanismo legal, destinação para Imposto de Renda, faz a equipe lá conhecer e disponibiliza por meio de sistema, para ver se ela vai aderir ou não, e apresenta o projeto, foi um sucesso, o projeto precisa de 54 mil, e conseguiu 112 mil

\section{Com doação dos funcionários?}

Dos funcionários, sucesso, agente mostra o resultado...

\section{Sempre a relação com um conselho?}

Um conselho, e aí agente apoio dois, o reserva acabou sendo apoiado, era piloto para agente aprender, para agente aprender, o que é que aconteceu? De uma no para outro, 2002 era piloto, 2003 passou a ser Brasil. Nasce de fato Amigo Vero para toda comunidade. As mesmas premissas que agente sou no piloto, agente foi acolhendo, agente caracterizou, então, 2003 agente fala para todos os funcionários sobre o Estatuto, sobre o mecanismo legal...

\section{Aí, foi uma comunicação Nacional...}

Nacional, aí agente vai até as regiões falar com as lideranças da empresa, porque, pensa que, agente tem o Brasil recortado por diretorias e rede, então a diretoria do norte e nordeste ele tem lá os estados norte e nordeste, e lá quantas agências e funcionários, e aí agente vai, foi muito legal este reinício, agente mapeou, agente fez uma mapa do Brasil com base em dois indicadores sociais, índice de desenvolvimento infantil, e índice de exclusão social, mapeou os piores município, e 
pintava-os, o mapinha ia até lá, eu gosto de contar do Sul, quando eu fui discutir com a liderança lá do Sul, estava toda liderança, diretor de rede, diretores, os regionais, eu te apresente o que é que é como que funcionava o Amigo Vero e mostro um mapa para ele e decidir quais os estados que ele queria convidar para participar, convidar os municípios em situação crítica, (você mostra mapa do Brasil para a região Sul) é, mas aí olhando a região dele, porque, a premissa do VJ para nós foi validada no piloto, o fato de voe ir numa região carente que precisa, fera uma coisa que tinha um efeito, então agente não tem, eram 5.500 município na época, não tem como convidar todos, por isso que agente aplicou dois indicadores sociais, fez o recorte, e pintava onde era o mais crítico com base nestes indicadores, então no Sul, o Diretor ... Rio Grande do Sul, Paraná, Santa Catarina, é Acre, e também é Acre, umas coisas... ele entra aqui assim, aí você mostrava como estava pintada, a Região do Sul era nítida de que o Acre era pior, e aí você põe a liderança para discutir qual estado que eles queriam convidar, o que é que você acha que? Maior debate, não, porque, Paraná, rio grande do sul, e aí agente vai provocando, até que eles tirarem um posicionamento que é o Acre que eles querem convidar. Na época, para lá dentro pegar, convidar só os conselhos dos direitos dos municípios em situação crítica em relação a estes indicadores.

Talvez seja mais difícil convencer os funcionários em investir no Acre e não aqui? Por isso que agente queria compartilhar com eles, que por vezes nosso olhar, é lógico que agente olhar aqui em São Paulo, você vê muita carência, tem criança pedindo, mas tem município não tem recurso, agente queria trabalhar esta coisa, que as vezes nosso olhar não atinge, e o recurso também não chega, por isso que agente fala assim, não é só onde o Empresa está presente, agente quer contribuir com o país, então por isso agente tem que ir onde o Empresa não está presente. Eu estou te contando isso, mas para você ver como é que é, hoje eu não vou mais às regiões, discutir, eu fiz isso por dois anos, porque ai agente vai aumentando o número de estados, mas eu fazia, a liderança vem discutir esse posicionar, hoje agente faz uma automática, agente mapeia os município

\section{Tem uma quantidade certa?}

Hoje todos os estados são envolvidos, só que agente convida 2.000 mil municípios para que eles inscrevam os projetos, aí eles inscrevem os projetos...

\section{Com base nesse critério?}

IDI e Exclusão Social para educação para garantia de direitos, pode ser infantil, complementar ou profissionalizante, agente faz uma pra seleção, agente pega os melhores projetos da região Norte e Nordeste e vai discutir com um grupo de funcionários..., tem quase 500 funcionários que participam deste grupos pelo Brasil, e aí agente vai todos os anos discutir, e aí eles vão visitar, a visita é parte do 
processo, eles pegam uma semana inteira e vão visitar os municípios muito distantes para ver se de fato aquilo que está no papel tem chance de dar resultado, voltam da visita eles validam os projetos em ordem de prioridade e agente divulga para todos os funcionários em ordem de prioridade, então vai um projeto da região, até que vai enchendo a caixinha daquele projeto vai entrando outro.

\section{Fica listinha de funcionário vai doando?}

Vai doando, então eu estou aqui eu posso escolher um projeto lá do norte, então, eu sempre tenho no mínimo 7 projetos na tela...

O que limita é a resposta, vamos supor que vocês tenham uma super respostas, você vão apoiando mais projetos, você não tem um número pré-determinado?

Não, agente selecione o mínimo de 4 projetos por região, aí que agente trabalha a mobilização dos funcionários, para que agente mobilize todos os funcionários para participar, até hoje agente conseguir preencher todos, então o ano passado agente apoiou 40 projetos, agente conseguiu, aí ela é pessoa física, $1 \%$ pessoa jurídica Empresa e agente convida nossos clientes para participarem também. $\mathrm{O}$ ano passado agente conseguiu quase 8 milhões para apoiar os 40 projetos .

\section{$200 \mathrm{mil}$}

É...

\section{Valor razoável!}

Razoável!

\section{Isso tem a duração de um ano?}

Aí agente faz uma parceira com o Conselho, agente apóia, mas apóia assim, manda o dinheiro, no ano seguinte que é o ano que ele vai executar o projeto ele tem 3 encontros agendados ao longo do ano, no início, no meio e final do ano, onde o município manda 4 representante, que é, o conselho, a entidade executora e conselho tutelar e alguém da prefeitura.

\section{Entidade executora normalmente é uma ONG?}

É ONG, e tem município que a própria prefeitura, às vezes o município é tão pequeno que nem tem ONG, então eles vêm para passar por uma oficina de dois dias, passa pelo projeto, agente capacita discutindo o próprio projeto, então agente reúne um grupo de município que este grupo vai se encontrar três vezes ao longo do ano, aqui, São Paulo, agente faz um recorte para deixar mais próximo, então são algumas oficinas, então isso, agente tem uma posição que agente fala, agente 
não manda só o dinheiro, agente manda o dinheiro, mas agente quer participar, então estas oficinas é uma oportunidade que agente tem, para capacitar a equipe do município por meio da discussão do projeto, com todas estas questões, planejamento, acompanhamento, e avaliação de resultados, então agente vai vendo o quanto que o projeto esta dando resultados, e ao longo do caminho entre um encontro e outro ele tem uma assessoria on-line para poder discutir, que agente paga uma assessoria para fazer isso.

Já aconteceu de vocês ficarem Insatisfeitos com o projeto? Cancelamento...

Insatisfeito, suspender não porque o recurso vai antes. Mas insatisfeito sim.

\title{
0 que é que vocês fazem?
}

Ele não é renovado. O que é que acontece, no final do primeiro ano eles mandam de novo a proposta, além de agente estar avaliando na oficina o funcionário volta lá para avaliar em loco. Aí ele volta dizendo, realmente o resultado apareceu, não apareceu, confirma o que está aparecendo e reapresenta no ano seguinte para os funcionários

\section{Estes resultados, ele na verdade já estão estabelecidos lá no começo?}

Quando projeta os indicadores, na primeira oficina agente consciência os indicadores de resultados.

\author{
Eles são estabelecidos já com a participação da empresa? \\ Participação da empresa e deles.
}

\section{No projeto deles esta lá, eu quero fazer tal coisa por objetivos tais...}

Na primeira oficina, e define os indicadores, e o acompanhamento de resultado é com base nos indicadores. E no final do ano agente faz a avaliação dos indicadores, quem participa da avaliação, tem um sisteminha, a pessoa da minha equipe que é responsável pelo projeto, a consultoria e a equipe local do projeto, eles também entram no sistema fazem a avaliação e depois isso é discutido. Então, aconteceu já, de projeto que não atingiu, mascarou mais o resultado que deveria.

\section{Não atingir não é uma falha em si mesmo, aconteceu, mas não deu conta, ou subestimou...}

É que acontece, às vezes, a prefeitura ela participa tão, se apropria tanto que ela acaba metendo os pés pelas mãos, mas a maioria dos projetos até hoje tem apresentado resultado, porque, porque eles aproveitam muito bem estas oficinas, é uma oportunidade impar, aí quando eles sabem que eles podem tem apoio renovado com base no resultado, eles trabalham muito forte para isso, aí renova, é o segundo ano a mesma coisa, aí ele pode ter o terceiro ano de apoio, aí é o limite. 
É uma faca de dois gumes você tem uma coisa muito legal, as pessoas ficam estimuladas, mas muitas vezes o cara não dá conta. Dois caminhos, aumentava comunicação, inflava a qualidade das pesquisas... maturação são limitadas e tendem a melhorar...

Agente começou apoiando só um ano, os primeiros projetos foram apoiados por um ano, aí agente viu com a experiência que era pouco tempo para maturar, então agente extendeu para dois e três anos. É aprendizado mesmo, acho que é isso, você vai começando, vai aprendendo, vai vendo onde pega, e vai se reposicionando.

Talvez o estímulo para reportar resultado possa, enfim, você acha que não é nenhum problema então, se o cara não conseguir, o projeto pretende diminuir...

Não, não é, é que é assim, o resultado não é, você precisa ver como o que é que é que agente avalia, em termos de indicadores sociais, objetivo mesmo, que são negociáveis, nós temos um modelo. Neste do Amigo Vero, participação, envolvimento e participação da família, porque agente sabe que não adianta você trabalhar somente com a criança, o projeto tem que dar conta de fazer com que a família participe do processo de desenvolvimento, então muitas vezes, tem indicadores que avaliar questão do engajamento da família e como que o projeto faz isso.

\section{Ai no final do ano, quantas vezes o pai foi na escola?}

Aí tem projeto que agente fala, o projeto do Amigo Vero, tinha, o Amigo Vero é menos, a questão de geração de renda, mas se você esta trabalhando direto com o profissionalizante, se esta capacitando jovens para algum tipo de competência e habilidade profissional, que gere de alguma forma renda, agente também tem indicadores que avaliam isso. Então para cada projeto agente tem que olhar para a natureza e daquele rol de indicadores quais são os que ele vai, porque agente padronizou os indicadores para avaliar o investimento social privado e realizado pelo Empresa, então eu tenho, são os indicadores econômicos, sociais e ambientais. Aí eu olho o Amigo Vero, qual o objetivo, defino, quais os indicadores do Amigo Vero, e para cada projeto que apoiado pelo Amigo Vero ele pega uma, então ele é uma árvore, ele é uma árvore que vai amarrando para eu poder olhar o investimento social privado da empresa, mais eu to te falando, comecei falar isso, para dar o efeito de, então é assim, ao longo do ano, então, as vezes o resultado pode ser parcial, mas agente vê que a equipe se empenhou muito pouco, ou pouco profissional para trabalhar, aí a agente não vai apoiar mais, agente já tem uma equipe compromissada com o resultado, porque o relacionamento fica muito próximo, são três vezes por ano, eles são apoiados on-line, nosso funcionário vai na oficina, o cara que foi visitar vai muitas vezes na oficina para ver como é que esta, aí ele vai visitar de novo no final do ano, então é muito próximo, segundo ano,fica mais próximo, terceiro ano, mais próximo ainda, é 
uma relação bem forte que agente tem com o município. Eu estou te contando isso para você entender, eu estava falando a questão do Balcão, ao longo do ano eu recebo muita solicitação de patrocínio e doação para projetos que trabalham com público infanto-juvenil, aí eu digo para eles, não apóio. Por quê? Porque eu apoio por meio do investimento do Amigo Vero. Ah, mais o Amigo Vero é destinação do Imposto de Renda. Ele é. Só que, tem um dinheiro que a Empresa bota para operação do Amigo Vero, na verdade ele é um dinheiro público, é meu, é da Receita Federal, é meu imposto que eu digo para a receita que eu quero. Então você não pode tratar isso como investimento social privado.

\section{É assim que o funcionário...}

É pelo imposto de renda. Ricardo você sabe que você pode por isto pelo imposto de renda? O Estatuto traz um mecanismo, empresa pode destinar até $1 \%$ de seu imposto de renda devido para os conselhos e a pessoa física pode destinar até $6 \%$ de seu imposto de renda devido desde que ela utiliza o formulário completo do imposto de renda e a empresa tem que ter a apuração pelo lucro Vero, não pode ser estimado, então, tem este critério. Para poder usar. Tem uma parte da população que faz e utiliza e tem gente que faz a doação sem necessariamente usar o imposto de renda, aí é doação. É muito legal porque que a cada ano cresce o número de funcionários, só para você ter uma idéia de percentual do quadro, $54 \%$ do quadro de funcionários que aderem, para você ter uma idéia, no Brasil, então, é muita gente.

\section{Este não é o caso daquele voluntariado estimulado...}

Este eu não trato como voluntário...

\section{Que você falou no começo da entrevista...}

Aí agente esta trabalhando com outro conceito, é que o voluntário para nós, é o voluntário que se envolve diretamente na ação com o tempo dele, aqui eu estou falando do cara que pega o imposto de renda e destina isto para mim não é voluntário. Aí eu tenho as pessoas que trabalham no processo, os funcionários que vem que acabariam os projetos, que vão visitar então eu não trato isso como voluntário, não porque, porque ele é indicado pelo gestor para participar do grupo. O Amigo Vero, para ele ser executado eu preciso de funcionários para executar,

\section{É uma atividade profissional...}

É profissional, então eu peço para o gestor da região indicar um funcionário da equipe para participar do grupo, ele vai avaliar, ele tanto vai ajudar nos processos de avaliação dos projetos como ele vai representar e falar sobre o projeto para equipe daquela área, então ele também é um disseminador 
do projeto para equipe, assim como ele também define com a equipe a estratégia de abordagem com o cliente, porque o cliente também é convidado a participar e mandar recursos do Imposto de renda. Eu estou te contando isso, porque acho que dá para você vê, como que agente trabalha a questão do engajamento, que o Empresa poderia ter feito um programa que pegava seu $1 \%$ do IPJ, que é fácil, vou na controladoria, qual que é um 1\% que o Empresa, não é isso que agente quer, mudança de cultura, o Empresa cria um processo, este processo custa, e é este que é o Investimento Social Privado da empresa, eu tenho um orçamento, não, mas, eu nem ponho isto, eu não entro, eu tenho orçamento anual para fazer o Amigo Vero operar. Viagens, pagar consultoria que me apóia, isto tem um custo, além, isto aqui eu ponho no meu relatório como investimento social privado. 0 que é imposto de renda, que eu digo quanto que agente captou, dos funcionários, IPJ dos clientes, isto é só uma informação, mas isto não investimento social privado, porque isto é dinheiro público.

\section{Imposto de renda da empresa?}

Ele entra nos projetos. Estou te contanto que dá para você ver o engajamento, como que agente tem uma postura de não só mandar dinheiro mas construir resultado juntos, por meio deste acompanhamento, e dar um tempo para maturar o resultado, é que, foi este aprendizado que agente teve, agora eu trago para outra questão, eu não estou aberta para apoiar qualquer projeto, porque eu tenho um canal para apoiar, projeto que tenham a ver com os direitos da criança e do adolescente, assim como o Amigo Vero eu tenho outros.

Tem este mesmo princípio, talvez deixe mais tranqüilo esta questão da demanda...

É lógico, ah, mas meu município não foi convidado. Não foi por quê? Porque é pelo indicador tal e tal. Que bom que seu município não e convidado porque esta numa condição melhor em relação a estes indicadores. Então, eu tenho que ter uma, eu tenho uma forma, eu tenho que ter uma forma transparente de justificar porque agente é muito questionado.

Aliás, vocês são questionados por uma monte de coisa. Como é que é hora da separação? Acabou o terceiro ano, acabou? Como é que você tem percebido?

O que agente tem percebido, que ao longo deste três anos, o município que fica os três anos, ele fica mais, a equipe fica mais encorpada do município, ele recebe muita, é que é uma capacitação bem intensa, o que é que agente quer, que o Conselho de Direitos da Criança e do Adolescente ele se fortaleça, ele tem que desempenhar o papel dele, no Brasil ainda esta, apesar do Estatuto ter 18 anos, a estrutura do Conselho vem junto com o estatuto, ele ainda é uma estrutura muito frágil, então, estes 3 anos agente pensa que estar com o projeto, mas agente esta capacitando o conselho, porque agente quer que o Conselho se fortaleça, e ao longo destes três anos ele aprende que ele tem que se estruturar, tem um papel...

Desculpe te tomar tanto tempo assim, quando você fala em capacitar, você acha que a principal é capacitação, é uma capacitação em Gestão? 
É, é gestão, só que agente capacita em gestão discutindo o projeto, é muito diferente de ir lá levar alguém para falar de planejamento. Eu pego um tema e discuto os temas, porque são dois dias intenso de atividades, cada mesa é um município, imagina que eu tenho no mínimo oito municípios na sala, e o nível de troca entre eles é muito legal, então têm ganhos bárbaros. Então eu diria assim, Amigo Vero é uma referência hoje para trabalhar esta questão dos Direitos da Criança e do Adolescente, colocados na prática. E aí no final do terceiro ano, muitas vezes eles já estão com a estratégia para captar mais recurso, pois são poucas as empresas que sabem disso, que fazem isso, que sabem como fazer, então eles vão aprendendo a ter este tipo de postura de abordagem no município, depois, no meio do caminho deste período todo, agente fez uma pesquisa com os municípios que deixaram de ser apoiados pelo Amigo Vero, que tinha acabado o vínculo, $70 \%$ dos projetos tiveram continuidade. Ou porque a prefeitura se apropriou como política pública, ela passou a ter a gestão, não era e passou a ter, ou porque o conselho conseguiu viabilizar recurso, captação de outras fontes, foi a única pesquisa que agente fez, só para ter um pouco do termômetro.

\section{Você falou que começou em 2005?}

Piloto foi 2002, 2003 foi expandido para o Brasil, agente fez esta pesquisa acho que em 2005. Então foi um sinalizador bom, porque, ... ele se fortalece mesmo. É fortalecer o Conselho, não a prefeitura o conselho.

\section{Escola vai como voluntário?}

É outro programa. Então, em via de regra, eu trabalho programa, eu não fico aberta para apoiar projetinho. E não, não dá. Agente costuma dizer assim. Agente tem que ter uma estratégia como pessoa jurídica, eu não posso me dar ao luxo de ficar pulverizando nosso investimento, eu tenho que ter um investimento para de fato ter resultado. E quando você tem uma estratégia e sabe como fazer, aí você consegue .. , você fica quieto pulverizando, você não consegue.

\section{Empresa Cidadã: Vocês usam não usam, como é que você vê isso? A questão da cidadania...}

Agente usa pouco, não. Me vi hoje, até hoje discutindo aqui dentro. Pode até ter uma peça de comunicação que fale. Agente fala muito de cidadania, mas não fala empresa cidadã.

\section{Não é pessoa jurídica?}

É, O que agente quer com esta cultura que agente possa ter as pessoas exercitando sua cidadania. Este Amigo Vero é uma caso. Eu tenho um mecanismo legal, que eu tenho uma lei que me disponibiliza eu preciso saber ela, e eu preciso decidir se eu quero usá-la. Então agente trabalha muito esta questão e cidadania, mas não usa muito este termo de empresa cidadã. 


\section{ENTREVISTADO E}

Eu tinha dividido aqui a conversa em três grupos. Conceito - falar desta mutação dos nomes, responsabilidade social, sustentabilidade, e por aí vai, como é que a empresa vê este conceito, mais institucional, como você percebe aqui dentro, como é que as coisas acontecem. 0 segundo, a estrutura, como é que a empresa se estrutura, a questão da sustentabilidade é tratada dentro da empresa, e o terceiro são ações, você pode falar de coisas mais gerais e coisas específicas que te chamam a atenção e você acha importante, e tem um pouquinho de comunicação mas acaba entrando nos outros, a questão de Balanço, tem empresas que tem dois balanços...

Normalmente tenho começado, você fala um pouco de qual é seu papel aqui dentro, de como é que a empresa está montada para tratar da questão, em termos de departamento, para tratar da questão de sustentabilidade.

Eu trabalho no departamento de sustentabilidade e tem um histórico. E que depois eu também posso te dar este material, e talvez te ajude também. Deixa eu contar então. Aqui a área de sustentabilidade no Brasil, ela nasceu mais ou menos em 99 e 2000, com departamento chamado Responsabilidade social, onde a ex-gerente que cuidava do relacionamento de RPs, de Rp, ela foi transferida para esta de responsabilidade social, onde principalmente atuava nesta área de projetos sociais, relacionamento com a comunidade, doação e assim por diante. Este conceito foi evoluindo e aonde começou toda parte de responsabilidade social com voluntariado, e acompanhando todo movimento principalmente com o instituto Instituto Empresarial, com os indicadores, os trabalhos e assim por diante, em 2005 agente mudou do departamento de responsabilidade social, para sustentabilidade. Isto mundialmente foi criado em 2002, 2003, este departamento global, já era sustentabilidade, aonde tinha todo movimento anterior e um histórico de sustentabilidade principalmente focado em meio ambiente na Empresa global, por meio das políticas, ecovision 1, ecovision 2, ecovision 3, e aonde este departamento mundial, global de sustentabilidade foi criado, são mais antigas, desde da década de 80 , tem coisa dos anos 70 também, então já foi uma evolução ao longo do tempo, focado em meio ambiente, e toda parte de filantropia ia meio que em paralelo. $\mathrm{Na}$ verdade eles agruparam estes dois temas, e começaram globalmente a trabalhar este tema. Aqui no país também já seguia as normas mundiais de meio ambiente e já faziam o relacionamento com a comunidade por meio de doações. Em 2005, mudou-se para este departamento de sustentabilidade onde tinha na época uma diretora de sustentabilidade, eu que acabo cuidando toda, alguns projetos e a coordenadora de projetos sociais. No meio deste ano, para o final deste ano a diretora saiu, e agora atualmente eu estou respondendo pela área de sustentabilidade e coordenadora de projetos esta cuidado de projetos sociais, voluntariado, diversidade e inclusão, este é o escopo mais ou menos do que agente tem trabalhado atualmente. Dentro de sustentabilidade agente está falando de todos 
os relacionamentos com todas as unidades de negócios internamente, e também a criação de produtos ou de serviços internos para que estas áreas tenham suporte para tais que eu vou especificar em cada projeto que agente vai desenvolver. Então, este é o escopo geral.

Quando você falou desta questão da diversidade, na parte voltada para os funcionários. Isto também tem um histórico para a empresa organizado?

Tem um histórico por estar na política, no código de conduta, PGN, Política Gerais de Negócio, está contido lá, mas mundialmente começou um movimento sobre diversidade e inclusão, onde agente, foram criados alguns ... mundiais, e aqui tem uma pessoa que é responsável pela diversidade e inclusão na América Latina. Então isto também foi um movimento mundial. O movimento nosso de responsabilidade social, o departamento foi criado antes de qualquer outro departamento global de sustentabilidade. Então aqui foi um dos pioneiros neste tema, no Brasil eu estou falando, 1999, 2000. O que mais, mundialmente tem um comitê global, com várias pessoas globais, diretores e vicepresidentes globais e que atualmente, o ... deste comitê é o vice-presidente da área de iluminação global. Então na Empresa é divido em três segmentos (Consumer Lifestyle, Healthcare, Ligthing) Consumer Lifestyle - toda aparelhagem eletrônico, Healthcare é Raio X, Ultra-som, e Ligthing toda parte de iluminação. Então este $\mathrm{CIO}$ mundial de Ligthing é $\mathrm{O}$... deste grupo global de sustentabilidade. Aonde entram vários personalidades...

\section{Isto é um rodízio ou é uma escolha?}

Na verdade a pessoa acabou de sair, a pessoa que é BC, que era esta daqui, esta daqui acabou de sair deste Board, e ele que assumiu. Então tem este cara que é o secretario deste Board, aonde entram várias pessoas de várias áreas e esquemas diferentes, vários assuntos diferentes e tem os membros Extern Board Members, que são os CEOs das várias regiões ou país.

\section{Esta BC era de que?}

Ela era da área de purchase, que era de fornecedores, então, e ela foi trabalhar na $\mathrm{S}$, ela era do Board mundial da Empresa, uma das únicas mulheres, $S$ é concorrente da Empresa, ela é a primeira mulher do Board dentro centenários de anos que $S$ tem. Então ela que vai estar mudando tudo isso lá. Então ainda é uma configuração antiga para você ter uma idéia.

\section{Só fiz esta pergunte para ver se tinha uma relação desta área light com a política de responsabilidade social da empresa?}

Talvez tenha, talvez ele tenha sido escolhido especificamente agora, porque o tema eficiência energética é um dos grandes temas de sustentabilidade nosso. Então, talvez tenham agrupado e 
feito isto daí. Mas agente politicamente nunca sabe o que esta por traz de tudo isso, então é uma, dizem até que ele é o futuro $\mathrm{CIO}$ da Empresa das três áreas, que é uma preparação, enfim. Aí rola tudo quanto é tipo, rádio peão. Então este é o Board Global, estas áreas, Consumer Lifestyle, Healthcare, Ligthing, as três unidade de negócio, tem uma pessoa que é Sustentability Ligthing, Sustentability Healthcare, que eles ficam pensando dentro negócio deles, o que é que da para fazer de sustentabilidade desde os produtos verdes até dentro dos próprios processos, tem uma pessoa de research que a Empresa é uma das maiores, uma das três maiores criadoras de patentes do mundo, então tem uma área lá, na sede, que tipo uma cidade universitária só da Empresa, para criação de desenvolvimento de produtos, idéias e patentes,

\section{Eles não fazem muito alarde disso?}

Não fazem muito alarde disso, é uma coisa super você sabe mais do google lá, que bem menorzinho, bem menos de produção, e aqui agente é a terceira maior, a quarta maior empresa de produtos e patentes, de patentes do mundo, então o próprio CD, DVD, Blue-ray, é holandesa. E nos países, tem ou tinha as pessoas responsáveis e sustentabilidade e o (nome) é o responsável, secretario global e é o Head do Sustentability Oficce global. Aí você tem as pessoas de report, analista, o pessoal só de desenvolvimento de produtos e pessoal só de comunicação em sustentabilidade. Então, isto aqui é só para você ter uma idéia de como funciona esta estrutura.

\section{A parte de comunicação, tem pessoas de comunicação no departamento?}

Não tem, não tem, tem uma pessoa que é a Tiara que por acaso esta aí, que é uma pessoa eu é de comunicação externo, principalmente de relacionamento com a imprensa, que ela acumula as funções corporativas, então entra RH, IT e Sustentabilidade que é uma das coisas que mais dá pano para manga. E tem a EL e o RC que fazem comunicação interna também, que também é assim, agente subsidia eles de muitas informações para que eles possam fazer toda esta comunicação interna.

De certa forma você fornecem conteúdos para comunicação. As pessoas de comunicação é outro departamento? É outro departamento.

\section{Chamam de departamento corporativo?}

Isso, departamento corporativo, eles na verdade respondem para uma diretora de comunicação e esta diretora responde direto para o presidente. Mas agente subsidia e faz muita parceria, as vezes até nós mesmos criamos algumas comunicações internas e eles são meio que consultores pra gente, as vezes até o contrário, as vezes agente cria conteúdo dá para eles, eles acabam. 


\section{Departamento próximo?}

Muito próximo, muito necessário inclusive. Aqui no Brasil como ficou. Nosso departamento de sustentabilidade sou eu e a RT, que é coordenadora de projetos, nós respondemos direto ao vice presidente da área de Healthcare, que é o vice presidente da América Latina de cuidados com a saúde, e ele reporta para o presidente. Então ele acumula a função da operação de Healthcare mais Sustentabilidade, e aqui agente tem três VPs, o VP e, tem mais VPs, mas dentro das operações agente tem VP Consumer Lifestyle, VP Healthcare, VP Ligthing para América Latina. O ideal seria que fosse o VP de ligthing que cuidasse da gente já que o CO de Ligthing é.

\section{Este acumulado, são por conta de re-arranjos?}

São, neste caso, foi uma acumulação mesmo, porque a nossa diretora que cuidava de sustentabilidade respondia direto para o presidente...

\section{Presidente Brasil?}

América Latina.

\section{Tá, porque tem os diretores?}

Isso, aqui é um Headquarter América Latina,

\section{Entendi, aqui é uma sede Latino Americana?}

Isso, Latino Americana. Aí eles respondem tanto a América Latina quanto a, esta diretora era América Latina, ela respondia direto ao presidente, depois que trocou o presidente, respondia para o vice-presidente, e com a saída dela, nós dois estamos respondendo direto para o vice-presidente. Só para você ter uma idéia.

\section{Esta Diretora é daqui?}

Não, é uma diretora do Brasil, é uma outra pessoa que saiu,

\section{Quando?}

Setembro. O presidente da América Latina saiu em outubro. Foi uma troca de presidente, e agora está um interino que é da sede. Nós estamos numa. Você está no meio de uma mudança estrutural poderosíssima. Porque não é só lá na sede enquanto aqui no Brasil também. Então esta tendo uma mudança estrutural e talvez até regional. Principalmente depois desta crise, que foi em novembro por aí... 


\section{Já tem relação direta com a crise?}

A saída dos, do presidente e da diretora não, mas estas mudanças que estão tendo a partir de agora provavelmente, acumulo de funções, mudanças de regionalização, enfim, e assim por diante.

\section{E a saída da Diretora, ela era diretora de sustentabilidade?}

De sustentabilidade, ela que fundou o departamento. Foi uma questão particular dela e de mudanças do presidente também. Aí teve a mudança de gestão e aí ela particularmente achou que era a hora de sair, ela virou consultora agora, então foi momento ideal.

\section{Ela saiu da Empresa?}

Da Empresa também. Mas não full time, mas só.

\section{A diretoria de sustentabilidade isolada deixou de existir?}

Deixou de existir.

\section{Esta acumulada por uma pessoa de ...}

De HealthCare, de cuidados com a saúde. Quem é nosso departamento agora agente reporta. Então esse é um panorama que está agora, pode ser que janeiro mude. Pode ser que janeiro apareça algum diretor, algum gerente, ou que agente responda a uma outra pessoa, enfim, agente está bem neste momento de transição, antes era muito claro, departamento, diretor, presidente, que agora agente foi jogado pra cá, pra lá...

\section{Mas isto não implicou na demissão de ninguém?}

Não.

\section{A estrutura enxuta continua?}

Continua enxuta. Só tinha uma pessoa a mais que era diretora, que era quem faria provavelmente este seu atendimento, porque agente estava lendo a alteração, e agora agente tem que fazer a parte de representação, que era a maior parte do tempo que ela fazia, representação...

\section{Você não ... que isso seja um enfraquecimento da área aqui dentro?}

Não, eu acho que não é um enfraquecimento, na verdade é uma adaptação as mudanças que estão acontecendo, e tem uma coisa bacana também, que agora agente está mais próxima da operação, agente está falando diretamente com uma pessoa que cuida de uma operação. Então você consegue 
entender. Se você for ver do ponto de vista de Sustentabilidade agente consegue entrar mais dentro das operações. Que eu estou falando, dos negócios mesmo. Ah. Então agente está em contato com o cara do Marketing de HealthCare que viu uma grande possibilidade de agente fazer um trabalho com os hospitais que estão também demandando este de sustentabilidade, estão iniciando, então vamos utilizar isto como uma forma de aproximação do cliente, e assim por diante, e assim vai.

\section{Isto pode acontecer com outras, algumas áreas.}

Com algumas áreas estão acontecendo também. De Consumer Lifestyle o WM está fortemente cobrando seus fornecedores sobre sustentabilidade, no caso você está estudando bastante, então, eles são muito bacanas e eles estão forçando todos fornecedores. Agente está mais tranqüilo, porque agente já tem política, tem global, blablabla, tem departamentos, tem metas, tem isso, para agente é mais tranqüilo de mostrar resultados para eles.

\section{Uma matéria que a Empresa estava cobrando alguém?}

Nossos fornecedores, é uma reação em cadeia, exatamente. E aí agente está mais próximo ao negócio agora, porque antes era mais corporativo, era mais reputação, era mais os projetos internos, voluntariado, e agora agente começa a entrar no negócio mesmo, relação cliente empresa, então, é um inicio aí, estamos aprendendo também esta todo mundo aprendendo na verdade. Deu para ter uma idéia do panorama geral...

\section{Deu e deu para perceber que estava num momento de transição...}

De transição, exatamente, e não foi por causa da crise, foi em função da saída da diretora com questões pessoas, a questão da saída do presidente também da América Latina, então ainda estamos num momento de transição.

Já aproveitando, você falou dos Conceitos. Não sei qual foi o uso aqui. $O$ que agente tem visto é Responsabilidade Social, A Socioambiental, e depois a Sustentabilidade.

Agente entende a linha do tempo das empresas, você já deve ter visto isso várias vezes.

\section{Eu vi uma coisa semelhante com a Professora Rosa Fischer.}

Rosa Maria Fischer, isso, que ela faz umas separação, o pessoal do IDIS, do Marcos Kisil, que eles usam também isto daqui, agente também adaptou isto daqui, da Filantropia, do investimento social, da responsabilidade social, isto foi que um meio passo a passo nosso, do departamento de entender a diferença de filantropia de responsabilidade social, isto para gente mostrar os nosso companheiros de trabalho aqui internamente, olha, quando estou falando de sustentabilidade, estou falando de 
negócio, estou falando de fornecedores, estou falando de algo entre as partes, não estou falando de doação para uma ONG, não estou falando de voluntariado, também é isto, mas não é só isto, o que é que você como compras, você como contador, você de comunicação, você como Marketing pode fazer para contribuir não só no meio ambiente, mas no social, também no econômico, enfim, e aí agente mostra a linha do tempo que é um pouco do conceitual que agente tem...

Estas atividades que de alguma forma não estão relacionado diretamente a operação você acha tende a perder força. Ou ela permanece inalterada?

Acho que elas permanece, até pela vontade de próprios funcionários, então, agente tem cerca de $8 \%$ a 10 \% de funcionários voluntários, que você está falando e um pouquinho de filantropia, um pouquinho de investimento social privado, isto meio que emana do funcionário. Foi muito engraçado o case. Que agente teve o pessoal. Do Momento lá do sul, Rio Grande do Sul, de santa Catarina, deu problema, E agente falou. Não, agente não vai se posicionar como Empresa doando alguma coisa, porque agente cada mais quer fugir deste conceito de filantropo de doação. Aí, começou a pipocar várias pessoas internas fazendo uma mobilização pessoal, e agente falou, não, então vamos dar o suporte total, então, o que é que você precisa? Um caminhão, Ah,. Vamos achar um caminhão, mas é os funcionários da Empresa agente está dando total suporte a movimentação, mas não é mais a política da empresa, por que senão. É aquele negócio, agente dá o peixe, de pesca, e tem a questão. (Na sua percepção a doação seria uma coisa) Na verdade, Na percepção da Empresa, da Empresa mesmo, que a doação tem um caráter muito caritativo, não de desenvolvimento, agente prefere pegar este dinheiro e desenvolver por meio de treinamento, por meio de educação, por meio de captação, enfim, por estes outros caminhos. Agente, ao invés, por uma ONG, chega, agente já fez alguns projetos igual deste tipo. Olha eu quero dinheiro por um projeto, ou por uma doação, invés disto agente pega e paga, o Instituto Fonte, que é uma ONG super bacana de capacitação, organizacional de ONG's, de mobilização de recurso e tudo mais, olha então você não quer aprende com ele, como é que faz este trabalho? Ah então que dizer que vocês não fazem Filantropia, não fazem doação. Sim agente faz não tem jeito, você acaba fazendo em um momento ou outro por equipamentos, por excesso de material que sobra, por dinheiro mesmo, por relacionamento da alta direção. Enfim.

\section{Começou a pegar mal...}

Exatamente!

Até entendo, você está usando uma lógica da empresa optar por fazer um outro tipo de investimento... 
Isso, isso, isso. Mas acaba acontecendo ainda. Agente sabe que tem. Acabam fazendo este tipo de doação, as vezes sem controle, e as vezes por relacionamento da comunidade local, das fábricas eu estou, mais ou mesmo estou te falando. É uma coisa que acontece porque sabe que no país precisa, mas por política agente não faz mais este tipo de cação, a não ser emergencial, como já foi feito lá globalmente. É uma questão que agente ainda tem a desenvolver bastante. Aqui como agente ao tem uma fundação, tudo agente faz por este departamento, então agente não tem os benefícios financeiros, fiscais, que muitas outras fazem isso em função disto também que acaba abrindo concorrência, edital, e aí todo mundo concorre assim por diante. Aí então isso é um pouquinho do que agente entende de filantropia, doação, investimento social privado agente entende a prestação de contas, quando esta ONG, retorna pelo menos o que foi feito com o Dinheiro. Responsabilidade Social agente entende o diálogo entre as partes interessadas, Sustentabilidade é trazer o conceito para o negócio da empresa. Isto é um pouquinho da evolução do que agente passou aqui. Então, Sustentabilidade agente pega da comissão..., isto que é legal da missão e visão, você deve ter lido também, que faz parte a melhoria da qualidade de vida das pessoas. A Empresa nasceu para ter sustentabilidade, estar querendo melhorar a qualidade de vida das pessoas, já esta missão mesmo, não precisa escrever sustentabilidade, igual o CEO mundial veio aqui, e ele falou que não precisa escrever no pilar de nada, não precisa colocar no Brand de nada, porque para ele já esta, tem que estar enraizado nas ações do dia-a-dia de cada pessoa. Isto é um pouco do conceitual de Sustentabilidade. Deu para ter um panorama?

\section{Você falou agora como é que a responsabilidade Social significa para empresa, e aí ela está dentro.}

E aí o que agente separa que é legal. Mostrar também. Isto aqui é um pouco do histórico que eu te falei, desde de 1970, isto aqui depois eu posso, eu te mando, aqui agente tem quatro responsabilidades dentro do conceito. Ambiental, Social, Econômico, é o tripé. E agente coloca aqui o individual. Que aquela coisa do indivíduo ser Empresa, ser responsável. Agente entende, agente fez esta matriz, tudo começa com este indivíduo que tem o conceito ético e para isso agente tem treinamentos em ética, tem a política de ética, tem os nossos compromissos, você assina quando você recebe esta política, código de conduta, princípios gerais de negócios, os princípios geais de negócio, você assina que você esta ciente que você sabe, tem a linha ética, aonde você pode denunciar qualquer pessoa de qualquer escalão, muitas pessoas de alto escalão, de vice presidente e presidente já caíram em função desta linha ética, esta linha ética começou no Brasil e se espalhou pelo mundo como uma ferramenta, tudo começa por aí, ai tem o econômico, social e ambiental e aí todos os nossos outros stakeholders, onde você vai falar de oportunidade e inovação, onde você vai falar de diálogo e impacto, então isto é pouco que resume a sustentabilidade aqui dentro. Além do diálogo e impacto, oportunidade e inovação, com todos estes outros stakeholders. 


\section{Você acha que tem pesado algum lado aí, ou não?}

Com certeza tem pesado mais para o meio ambiente, do momento, as ONG's, estou falando isso o Brasil, os fornecedores que agente tem todo este trabalho mundial de auditoria dos fornecedores, comunidade e funcionários sempre, e agora agente esta querendo chegar nos consumidores e clientes, consumidores são consumidores finais e clientes na verdade são os nosso, [inaudível] no caso de iluminação, ou os nossos distribuidores, na verdade a Empresa acaba não vendendo quase nada direto para o consumidor, é tudo pelo submarino.com, pelo Americanas, o WM já é o terceiro mundial, tem muito pouco, quase nada direto, tem aqui só na loja vip nossa é só, agente está aos poucos querendo chegar nos conceito de sustentabilidade para estes outros stakeholders.

\section{Já tem alguma coisa de respostas, tem algum segmento que a resposta é baixíssima?}

Está bem baixo, com o consumidor final, agora se for com os clientes você já tem.

\section{As empresas você chama de cliente?}

Nossos clientes empresariais. Então o WM é um exemplo, agente acabou de fazer uma ação super bacana com eles, de ponto de venda para falar dos produtos verdes, como também algumas dicas do instituto AT, agente está fazendo com alguns clientes da área médica, os hospitais para desenvolver projetos em conjunto, da área de iluminação tudo que é eficiência energética e tudo o mais, tudo está em pauta também, então agente tem um nicho de clientes bem bacana para trabalhar e desenvolver que agente está já ai com alguns cases bacanas e outros a iniciar e assim por diante. Fornecedores tem trabalho bem bacana que são auditorias, são mundiais com vários critérios baseados na ISO 14000 e AS 8000 e outros critérios que a Empresa desenvolveu, estes fornecedores são auditados pela SGS uma terceira parte, onde eles vão estes fornecedores e avaliam as condições deles, trabalho infantil, de ética de meio ambiente, de social, de saúde e segurança, enfim,. Alguns macro pontos para poder avaliar, isso não só no Brasil como no Mundo inteiro. Isso que estava no Guia exame de sustentabilidade. Isso, estava citando que você acaba indo pela cadeia, e eles começaram a melhorar, gostaram da coisa e começaram até a ampliar mais.

\section{A divisão de fornecedores é local, você falou que a política é global mas os fornecedores...} São contatados localmente.

\section{Imagino que tenha alguns globais?}

Isso, alguns são globais, por exemplo tem muitos, a maioria são globais, ou seja, agente esta tentando regionalizar. Em recife por exemplo, tem um projeto chamado Projeto Vínculos, onde 
agente está pegando pequenas e médias empresas, do setor, de fornecedores da Empresa, da Alcoa e da Guerdau, são, destas três ancores, mas 28 fornecedores, agente está capacitando eles, em qualidade, meio ambiente, saúde segurança e sustentabilidade, para que eles possam atender a demanda destes grandes três âncoras. Desenvolver localmente, é uma das coisas que agente tem desenvolvido este projeto em conjunto com a V, X, Z, F e H. Cinco, está no relatório também se precisa de mais informações você me fala. Isto é toda parte de conceito ainda né, que agente está falando. Aí entra os projetos específicos, os quatro pontos específicos. Então aí entram todos os projetos que é que está tudo no relatório que eu acho que aí entra nas ações.

Você falou na questão dos funcionários, que aí agente acabou comentando do voluntariado, e agora você falou que tem toda esta mudança de concepção, mas voltado para a própria ação e como é que isto chega até eles?

Isso, agente tem um trabalho bem forte em todo nosso material de comunicação, as [inaudível] atitudes, acho que você chegou a ver lá no site, temos a revista que é bimestral, além desta tem uma revista, interna, além desta revista tem uma revista chamada Expression que é mais corporativa, mais genéricas da Empresa e este específico de sustentabilidade, começou como responsabilidade social e ela é bimestral ela vai para todos os funcionários da América Latina, então eu estou falando de chão de fábrica, dos vários públicos aqui.

\section{0 conteúdo vocês?}

Nós que fornecemos o conteúdo e comunicação é nosso prestador de serviços para esta atividade...

\section{Vocês são os clientes?}

Isto, nós somos os clientes deles, é lógico que tem ....que corre... buscando todas informações, faz toda diagramação, e este é o modo de agente cada vez mais inserir, agente sempre coloca, acaba tendo um cunho educativo, sempre tem aquela parte de o que é bom, o que é que não, o que é que da para reciclar, toda parte de ética, que agente tem uma referência de ética, tem uma parte, isto aqui por exemplo, do voto consciente, que agente teve bastante, sempre tem um artigo de algum especialista, este aqui foi o VC que é o da ONG, enfim, sempre tem este cunho bem educativo também, depois se vai pode examinar um pouquinho mais..., chega na mão de todos os funcionários, jornalista e alguns formadores de opinião,

\section{Todos, as camadas...}

Todos os níveis, camadas e acessos, e assim por diante. Funciona muito bem nas fábricas. Por $2 / 3$ da população dos funcionários não terem acesso a computador, porque, nos somos uma fábrica de 
montagem, não é fábrica de serviços de software, então, 2/3 acabam recebendo isto, fora isso tem a TV corporativa, fora isto tem a Internet, a Intranet, que agente sempre está comunicando, os e-mails SPAM...

\section{E-mail, infantilzinho. Isto vai para a filha de funcionário também?}

Vai para a filha de funcionário, este daqui, esta daqui, é o ... para colecionar agente coloca, contando um pouquinho o conceito de Sustentabilidade, e no fim, agente sempre tem uma placa do funcionários cidadão, e pequenas atitudes, que é para os filhos de funcionários, aonde no final eles podem desenhar, e mandar para agente e ganhar um brindizinho então é aquele conceito mesmo de atender todos estes públicos, desde que as novidades de sustentabilidade, da TV mais ecológica, do novo selo verde, do Mundo Empresa, um pouco do mundo externo, tem um conceito um pouco de colecione, o conteúdo, sempre agente coloca alguma coisa de ética, sempre, todos, e aí as novidades conforme vai acontecendo e uma parte para levar os voluntários, para reconhecer os voluntários, e uma parte para as crianças para desenhar. Esta estrutura basicamente que permeia todo o conteúdo dela. E aí tem tudo né. Isto aqui é um pouco de comunicação que agente entende também como uma forma de educação pro funcionário também, Qual que é o retorno disto? Que me perguntaram hoje de manhã, agente ainda não tem como mensurar, mas sempre que agente encontra gente tanto interna como externamente sempre comenta da atitude, talvez algum dia tenha que fazer uma pesquisa e tudo mais, mas aí você prefere gastar um dinheiro fazendo material do que efetivamente a pesquisa.

Outros entrevistados, o banco estão sofrendo uma pressão mais intensa. Qual é o retorno deste investimento todo, imagino que aqui também tem, não sei que tamanho qual a resposta que vocês estão dando?

O retorno deste movimento

\section{A empresa investe nisso, imagino que tenha!}

Ah! Investimento em Sustentabilidade

\section{A revista...}

Os projetos e tudo mais (como é que isto é percebido, isto é um gasto, e retorno é difícil de mensurar, e como é que esta questão aparece e não aprece) Então Ricardo, eu acho que, tem um movimento que é muito consolidado pela própria estrutura organizacional Global, então, o CEO global veio aqui, de uma hora de palestra que ele fez, quinze minutos, uma pessoa pegou, levantou, perguntou sobre sustentabilidade, ele deu uma aula de sustentabilidade, em 20 minutos da uma 
hora que ele falou para o público. Então você já começa a entender que faz parte mesmo da cultura é meio Top Daw. O retorno de imagem e de reputação é medida principalmente pelo pessoal da área de comunicação e eu tenho feito ultimamente pesquisas com o público externo para mensurar efetivamente comparando as marcas. Então é um modo de mensuração e de reputação, uma das coisas que eu até coloquei no nosso planejamento deste ano, de mensurar o quanto de reputação isto gera, dentro da sustentabilidade, responsabilidade social, enfim, sempre comparativa as outras marcas, tem algumas outras pesquisas de impacto de consumidor da área de Marketing que também mensura isto. Este é um outro indicador. Tem um outro indicador que é do Engaging Employer Service. Que é para o engajamento dos funcionários aqui. Tem uma pergunta de Sustentabilidade de diversidade, e o quanto você está satisfeito com isso, e de orgulho você tem de trabalhar nesta empresa. Então agente, você começa a juntar todos este indicadores, eu tenho como mostrar o quanto sustentabilidade tem agregado a este valor,

\section{É mais imagem e simpatia da marca?}

Isso, ainda eu não consigo mostrar financeiramente, estou buscando este indicador, tanto é que tem este projeto com o WM, que agente fez direto com ponto de vendo, e eu estou vendo de agente faturou a mais, sendo sustentabilidade ou não, comparar esta loja com outras lojas, agente tem um ponto de venda se valeu o investimento, para falar que a Empresa é mais verde e blábláblá...

\section{Investimento de comunicação neste ponto de venda.}

Isso, com o tema Green, com o tema verde, que eu recebi hoje estas fotos desta ação, junto com o AT e tudo o mais.

\section{Negócio complicado, esta medição financeira ela é...}

Ela não pode ser só financeira, por isso que eu tirei aqui, os outros indicadores antes para você chegar, Ah! É dinheiro, quanto teve de retorno?

Quando você falou que é uma coisa top daw, que vem, não seja tão questionado, uma empresa, enfim...

Não, mas é questionado, é questionado o tempo todo, tempo todo, investimento, será que vale a pena, tudo isso, vai investir nestes projetos, que retorno este projeto traz, ou quantas crianças estão sendo ajudadas, ou fazer um curso de educação para sustentabilidade o que é que o gerente vai ganhar com isto, aonde ele vai estar na tendência, e ai eu começo a contar toda esta história que eu contei, tem a questão da reputação, tem a questão do engajamento dos fun...dos, dos, dos empregados, tem a questão das vendas, tem a questão da reputação com os clientes, tem a questão 
de Benchmark dos vários stakeholders, e você não esta aqui a toa, há um relacionamento com academia, queira ou não, aonde eu estou mostrando tudo o que agente faz, a academia vai mostrar e tem uma matéria específica de doutorado, sobre isto, falando de uma empresa, da Empresa, então toda uma questão de ganho que.

Algumas empresas até consideram isto, não sei se vocês, uma das entrevistas que não aconteceram, Ah! agente tem muitas entrevistas para apoiar, então agente não vai trabalhar para apóia a sua, ... conceder uma entrevista é um apoio, sim, consideramos um apoio, no sentido de apoio de visibilidade, ....não ser um estudo de caso, mas vai aparecer, eu falei, não, ah! tá. mas é um parecer muito controlado, depois que estiver pronto, tem que passar para o departamento de comunicação, para eles aprovarem a publicação, estudo de caso é assim mesmo. 0 que acaba podando muito os estudos de caso de coisas que não deram certo, que seriam legais também, então assim, como você acabou de falar, é evidente, faz parte das ferramentas de comunicação, a comunicação via um diálogo, com a academia, com a ciência e tudo mais)

Esta página que agente criou lá a pedido de alguns estudantes, também é uma forma de atrair, agente até colocou nesta home nova que agente esta preparando um boxzinho, um botão, especialista: trabalhos universitários. A pessoa já clica já vai lá, espero que o seu trabalho esteja lá também, três ou quatro trabalhos, lá já, até internacional, é já estão lá. Este fluxo também, queira ou não, é imagem que está aparecendo lá em cima, é a Empresa, está ajudando, é o trabalho, blábláblábláblá. Então são estes vários indicadores de resultados, que não são tão fáceis para mensurar o quanto o pessoal de comunicação espera, por exemplo, que é clipping, não sei que lá, também, já não funciona mais mas é mais difícil mensurar do que o pessoal de vendas, é difícil, ou de contabilidade, é difícil.

Primeira experiência vocês vão fazer nesta loja que teve o investimento e depois vocês vão avaliar Isto, exatamente, agente está fazendo um projeto também da área de iluminação, onde agente talvez tenha um approach, em empresas que tenham este tom de sustentabilidade, ou seja, você tem um nicho de mercado agora específico para este tema, e agente possui as iluminações mais sustentáveis e que economiza mais energia do mercado, então como fazer este approach específico para isto.

Porque é um negócio complicado lâmpada. Quando eu era moleque época eu usava para fazer "cerol". Hoje o descarte é feito na, vocês tem ...

O descarte é o nosso grande problema mundial, é o nosso grande um problema mundial. 


\section{Meu problema como descartador, o que é que eu vou fazer com esta lâmpada.}

Exatamente, exatamente.

Pessoal, se eu quiser me desfazer de lâmpadas da Empresa ou de até outra, eu tenho que ir até aonde.

Na verdade você pode descartar no lixo comum que ele não vai fazer tanta, problema ambiental. Se você tombar, falam que tem mercúrio, principalmente estas daqui, se você tomba um caminhão cheio delas, você vai ter $10 \mathrm{ml}$ de mercúrio, porque a quantidade é muito pouco, então se pode descartar no meio comum, o ideal seria que o governo junto com as várias empresas, recolhessem isto, enfim, como é feito na Europa, na Europa agente tem um preço mais alto, onde neste preço esta o descarte das lâmpadas de uma maneira correta. Recolhimento e descarte. Aí não, igual, tendo óleo agora no PA, WM, pilhas como no BR, tem também, então é uma, mas tem uma questão política envolvida aí que é muito forte, porque? Porque, o governo não consegue controlar as falsificadas, as lâmpadas piratas, que também tem, que é $1 / 3$ do mercado Brasileiro. Se agente tiver que também descartar, vai ficar inviável você, e vai sofrer, quem vai sofrer vai ser o consumidor.

\section{O valor dela é mais...}

O valor vai aumentar. Para você fazer uma lâmpada incandescente, que é aquela de buldo, custa R\$ 1,20 , $R \$ 1,00$, você teria que fazer, cobrar o dobro, $R \$ 2,00, R \$ 3,00$, para poder compensar o descarte depois, fora que você vai ter que descartar ainda a sua pirata, que você paga os impostos direitinho,

\section{Ela ofereceria condições para as pessoas captar as lâmpadas...}

Sim, sim, tem um programa prontinho, tem um programa prontinho, só não tem uma lei...

\section{Com caminhão logística este tipo de coisa?}

Normal, igual fazem com pilha, igual fazem com bateria de carro, igual fazem com óleo usado em posto de gasolina, tem várias empresas que já fazem isto, só que para pessoa jurídica, então cada pessoa jurídica, tipo a Empresa neste prédio é responsável por jogar lixo, para aquele prédio lá, aquele prédio lá, e aquele prédio lá, todo mundo, cada um é responsável pelo seu lixo, dentro dos lixos estão as lâmpadas, para descartar as lâmpadas de um modo correto ele tem que contratar uma empresa.

\section{Você reaproveitam isto na fábrica depois?}


Não dá para reaproveitar, ela vai ser reciclada de outra forma, porque estas lâmpadas tem o mercúrio, o pó branco e as coisas de alumínio, que é muito pouco, precisa juntar muito, muito, muito...

\section{Insignificante para dar o peso?}

Exatamente, diferente de uma lata de alumínio, você já amassa cem, já da um kilo, ou plástico, ou $\mathrm{PET}$, e também porque não existe o mercado, a hora criarem este mercado, como estão criando de várias outras coisas aí vai funcionar, ou quando baixar aquela lei, da política de resíduos sólidos, está para sair já a dez anos e não sai. E a Empresa, junto com as outras fabricantes, junto com o governo está tentando estudar uma forma de fazer isto, esta lei acabar vingando. Então não é uma coisa, a Empresa ta, não, está tentando.

Umas coisas difíceis têm várias coisas difíceis, mas a Lâmpada talvez na minha cabeça seja a mais difícil, tem aquele negócio, em casa uma hora alguém joga fora, as vezes eu faço isso, vai guardando, vai guardando...

Se for lâmpada incandescente dá para levar ainda naqueles postos recolhedores de vidro, metal, agora estas daqui é um pouco mais complicado. E os equipamentos agente está começando um projeto piloto em Manaus, nas revendas autorizadas da Empresa, revendas não, aquelas que concertam, autorizadas Empresa, tem duas, você leva aparelhos Empresa e recolhem, que tem uma fábrica que é da Empresa lá em Manaus, e agora agente vai desenvolver isto no resto do Brasil para poder recolher os produtos.

Dois universos: Ações internas voltadas para os funcionários, você falou algumas coisas também e em termos de cuidados com os funcionários, cuidados trabalhistas, tem uma política específica ou não.

Isso, agente segue estes PGN, Princípios gerais de Negócio, e dentro destes PGN agente tem toda parte trabalhista, tem que seguir as leis locais e tem auditorias internas em cima deste PGN e se agente ver que tem algum problema agente pode ligar para esta linha ética e falar, não está seguindo os PGN's, isto eu estou falando desde as questões trabalhistas, até assédio, fornecedores, propina, tudo, toda esta gama de assuntos que são de ética, que também são de sustentabilidade, por isso que agente tem colocar ética como centro de tudo, nas comunicações agente sempre esta colocando porque ela é a base conceitual para trabalhar o todo.

E das ações, tem as questões ambientais, e você falou do voluntariado. Tem alguma que você gostaria de chamar atenção? 
$\mathrm{O}$ que tem do investimento social privado. O que tem bacana do investimento social privado e que todos os nossos projetos, eles estão muito alinhados com os dois temas de sustentabilidade que é o cuidados com a saúde e eficiência energética. Então por exemplo, agente tem um projeto que aprendendo com a natureza, que ele leva para as escolas públicas o conceito de eficiência energética, por meio de formação de professores e por meio do voluntariado ativamente uma vez por mês nestas escolas fazendo atividade lúdicas com as crianças. A então isto é um evento. Ah! O que é que tem? Tem a ver com o negócio, te a ver com os nossos conceitos. Cuidados com a saúde, outro exemplo, é falando de coração, que é um projeto que não tem voluntariado, mas é de formação de professores, um concurso, aonde os alunos tem que desenvolver uma vinheta com o conteúdo sobre saúde cardiovascular. E o que tem? Tem tudo a ver, Porque agente tem muitos equipamentos desde desfibrilador, monitor cardíaco, enfim, então você começa a trabalhar estes conceitos nas escolas públicas, sempre nas escolas públicas

\section{Como é que você chegam nas escolas?}

Agente tem ou parceiros ONG's, que fazem toda parte operacional do projeto, ou seja, planejam, desenvolvem, implementam e controlam, e agente sempre acompanhando tudo isso, seja por meio, com sustentabilidade, no caso mais a RT, que cuida destes projeto, ou diretamente, ou uma empresa, uma consultoria, uma agência de projetos, que desenvolve este projeto e agente vai acompanhando controlando, estes pontos.

\section{Sempre escolas públicas?}

Sempre escolas públicas...

\section{Como é que você escolhem estas escolas?}

Sempre em parceria com a Secretaria Municipal de Educação, seja municipal ou estadual. Por exemplo, no FC, agente falou com o assessor do secretário e ele falou, vamos abrir para todas as escolas, agente readaptou o projeto ano que vem, no estado de São Paulo. Por exemplo, em V. o projeto AN, já esta lá desde de 2001, eles gostaram tanto da metodologia que me virou política pública. Então todas as escolas municipais da cidade de V. têm a atuação, tem na grade curricular deles, o aprendendo com a natureza, que é transversal a várias matérias.

\section{No caso você fornecem conteúdo, material?}

Conteúdo, material, treinamento, depende de cada projeto em relação a isto. O V. e deixe viver que é o projeto de $\mathrm{CHH}$, os funcionários voluntários são treinados, dentro de um treinamento super pesado, de 24 horas, e eles vão depois atuar nos hospitais contando histórias para as crianças, isto 
tudo com o apoio desta ONG que chama VV. Então há um outro tipo de projeto, com outro público, mas também dentro do nosso assunto cuidados com a saúde, você está levando a marca Empresa dentro do Hospital, enfim, sempre tem que estar alinhado também com o negócio da empresa.

Você falou que virou política pública. A Empresa, ela continua financiando isto.

Ela continua apoiando os conteúdos programáticos, os treinamentos de professores, mas o gerenciamento de acompanhamento das atividades, acaba entrando já no que é de prache na secretaria Municipal, isso, como eles controlam os assuntos de matemática, português, eles também agora controlam este tipo assunto.

A questão do tempo, levar o conteúdo para a Secretaria. Imagino que isto tem um custo, para vocês. Quanto tempo isto acontece. Você já tem uma duração predeterminada?

É uma duração anual.

\section{Vocês fazem um projeto ano a ano?}

Isso, ano a ano, tem o início né, de janeiro, a março...

\section{0 programa é um ano?}

isso, vamos implantar em um ano e em quais escolas. Esta, esta, esta e esta. Aí no outro ano, vamos implantar em quais escolas, Ah! Vamos implantar nas mesmas, vamos implantar em novas. Ah, mas o conteúdo programático do aprendendo com a natureza são dois anos, ah, então tem que manter os dois projetos, ah não. FC pode ser em qualquer escola, porque a cada ano vai mudando o tem, a então pode ser em qualquer escola e nas mesmas que quiserem, e assim por diante. Estou te dando dois exemplos bem específicos, $F C$, que é o genérico ou o $V V$, que depende basicamente do funcionário voluntário. Que vai no hospital se ele desistir por razões outras, que, não esta dando mais tempo, sei lá, a mãe ficou doente, como já houve caso, ah, não tenho mais tempo, preciso cuidar da minha mãe, aí acaba o número de visitas deste voluntário. Então é isto, que acho que bem bacana como diferencial aqui dentro da empresa, pode escolher, qual o tipo de atuação, qual o tema, e qual o tempo e sempre subsidiado com muita capacitação, em relação aos funcionários, Doe Vida, que o de DST, Doença Sexualmente Transmissíveis, e Gravidez Precoce, que também são palestras que são feitas pelos funcionários voluntários em escolas públicas de Ensino Médio, então eles vão uma vez por mês, aí pode ser escolas diferentes, pode ser em ONG.

Mas ele tem $\mathrm{m}$ compromisso, o tanto de tempo que ele tem que se comprometer. Ele, tem. Agente libera 4 horas por mês para o funcionário voluntário atuar no durante o horário de trabalho. Se ele 
quiser ele pode parar. Mas agente sempre tem muitas ferramentas para a manutenção do voluntário. Começou já em 2001, já tem 7 anos de experiência de acompanhamento, inclusive agente ganhou prêmio do Rio-Voluntário, que é aquela OnG lá do Rio, por ser uma de Voluntariado mais estruturado, agente só falta, levar ele, não agente leva ele lá, porque Táxi também é pago mas tem que, ... tem o conhecimento, agente sempre está colocando aqui no material, tem toda uma ferramental.... Estes são alguns exemplos, de projetos de investimento social privado, acho que este de fornecedores foi este que eu contei anteriormente, das auditorias e desenvolvimento local... E aí tem o fornecedores que é um projeto bacana, tem estes projetos que agente está iniciando com os clientes e consumidores, tem um projeto de Ética que muito bacana, e você vai ver nos relatos, que este de treinamento, e tem o projeto que agente vai começar no ano que vem, que é educação para sustentabilidade, para os grande gerentes que vão estar passando por estes conceitos para eles entenderem um pouco mais de como podem ajudar isto no negócio eles também.

\section{Números. Tem a verba. Como é decidida a distribuição da verba. Isto vai sendo deliberado ano a} ano.

Agente tem uma deliberação anual, que é feita, e ao longo do ano agente vai tentando conquistar novas verbas ou conforme o projeto for aparecendo.

\section{Isto internamente.}

Isto internamente, isso, isso, principalmente agora com esta demanda externa, por exemplo, o Projeto do WM, não é uma verba que saiu do nosso orçamento do departamento, agente foi consultor para este projeto, ah, o projeto da área de iluminação, ah, agente também não, ah, projeto de sustentabilidade, mas é um projeto de iluminação, então a sustentabilidade vai só dar os conteúdos técnicos, então nós somos meio que consultores internos, a cada dia mais agente está virando consultor interno, outro exemplo também é bacana, o projeto VV é totalmente área de HealthCare, então agente já vendeu o projeto para a HealthCare pagar, é um projeto deles...

\section{Este orçamento é do setor?}

É do setor deles. Então isto é o conceito que cada vez mais agente quer, ah, o Doe Vida é um projeto antigo, então já é corporativo então agente que paga, o AN também já é um projeto antigo, então agente que paga, então é um pouquinho deste conceito que agente usa. Agente tem um projeto com os DA também, agente acabou vendendo esta idéia para o pessoal de HealthCare, e aí eles também gostaram da idéia e tudo, isso, é um patrocinador interno para um projeto externo. Então, a área de iluminação também, agente tem um projeto ou outro, agente vai lá e vende para eles, seja de investimento social privado, ou mesmo na área de negócio. 
Na verdade a pergunta é se tinha que fazer divisão de bolo, mas pelo que você está falando não exatamente, um projeto mais educacional, social, tem um projeto mais de maio ambiente, cada um vocês vão alocando no setor, quer dizer, pela operação esta relacionada...

Com a efetividade. Agente é farto de idéias, mas, as vezes o dinheiro não é suficiente. $E$ muitos dos negócios, principalmente na área Sustentabilidade não na área de Investimento Social Privado, acabam sendo feitos pelos próprios, pela própria demanda dos funcionários. Então uma das coisas que eu fiquei sabendo a pouco, lá em Manaus finalmente estão substituindo isopor por aquele composto, como é que chama, esquecei o nome, que parece casca de ovo, que vem no papelão na verdade, polpa, chama polpa, que é o papelão já reciclado algumas vezes e aí finalmente estão colocando a primeira vez na Empresa no mundo inteiro, embalagens de DVD, de, a maioria ainda vem de isopor, porque o marketing acha que é mais bonito quando você abre o produto, marketing Global eu acho, que é mais bonito olhar aquele branco em volta e o produto em destaque do que o cinza e marronzinho, parece aspecto de sujo, de terra, então, para isso agente fez uma cartinha para o consumidor, é uma coisa que os nossos concorrentes já fazem a.

Isopor que foi de alguma forma absolvido de uns tempos para cá, de impacto ambiental... Eles estão reciclando, as fábricas de isopores, tem reaproveitamento, só que, como a sua lâmpada, como o DVD, ainda falta, no Brasil ainda uma cultura para chegar lá. Então é mais fácil você jogar no lixo, ... aqui, do que você levar lá no PA, você levar pra, ou você, porque é faz parte do consumidor, se o consumidor foi lá comprar, porque que ele não pode ir lá devolver. Ou senão o sistema público, porque o sistema Público não coleta.

Sistema faz falta - no pique de fazer uma coleta seletiva, você separa, a coisa junta na porta de casa e vai pro lixão, que é o que estão fazendo.

Exatamente, exatamente, então, tem a coleta seletiva de algumas ruas de São Paulo também que é feito, então, porque que não ampliar isto, enfim, aí é, questões que não é só da Empresa, nas lâmpadas é a mesma coisa. Igual o... CEO Mundial veio aqui, e eu perguntei para ele porque o Green Peace mundialmente fez uma ação contra a Empresa com o lixo eletrônico, e esta ação que agente está fazendo em Manaus é meio resposta a isto, para evolver lá na Fábrica. E quando, antes disto tudo acontecer eu perguntei par ao CEO, mas este negócio do Green Peace, agente não tem que responder a eles, não é a sociedade demandando, ele falou olha, na verdade é uma questão que não é só da Empresa, e dos outros fabricantes é do governo, e disto é daquilo, aquilo e aquilo. Então, a maioria dos temas quando se fala do descarte, está envolvida com isto, a um envolvimento de muitos outros stakeholders e não somente a empresa fabricadora, fabricante. 
Então, quando você fala, uma das últimas perguntas. A empresa tem todo um trabalho, e aí depende de outras instancias, sejam governamentais. $O$ conceito, a forma que vocês trabalham a sustentabilidade ela prevê algum tipo diálogo na Empresa neste tipo de instância.

Então um exemplo da lâmpada é o que está acontecendo, entre a ABILUX - Associação Brasileira de Iluminação e o governo Federal, então juntou a Osram, a GE e a Empresa, tem mais uma que eu não lembro o nome, estão conversando, as grandes, mais algumas distribuidoras com o governo, oh, vamos lá, vamos limpar lá o mercado das piratas, (Governo é uma Secretaria) a secretaria do Meio ambiente junto com uma secretaria

Isto estadual...

Federal, uma instancia bem maior, e vamos juntar e vamos tentar combater tudo isto dai, para poder dar conta disto também, e já estão se pensando em várias possibilidades como a criação de uma ONG só que trabalha com isso, ou fazer uma instancia da ABILUX que trabalha com isso, ou contratar uma empresa para cuidar disso tudo e as empresas só pagam, enfim, e o governo também vai baixar a taxa de iluminação para que seja mais barato que as piratas, enfim, precisa tem uma ganha, ganha, ganha, ganha, porque senão só o governo acaba ganhando com os impostos, que também não é justo, e quem acaba pagando tudo é o consumidor final, Somos nós. Que é o mais difícil de tudo. Então é isto que está se articulando dentro daquela faixa do diálogo.

Esta questão do diálogo, entra, imagino que entre, por causa daquela teoria dos stakeholders lá, a questão de comunidade, de consumidor, já aproveita agora para emendar uma coisa que você não falou e que algumas empresas falam, que é a história da empresa cidadã, então ela entra em conceito de cidadania, e prevê algum tipo de diálogo de deliberação. Primeiro se vocês trabalham com este tipo de conceito, ou não, se é usado e se não é usado, e depois, pensando nesta instancia de deliberarão que você falou que era em um nível mais institucional entre associações, e tem outro tipo de instancias voltadas para consumidor, ou algum outro tipo de diálogo, com comunidade...

O conceito de cidadão, agente, já usou acho que no passado, mais internamente, mas externamente agente já não utiliza mais, e na questão destas outras instancias agente faz parte de vários grupos, como CEBEDS, O IE, o AT, O GF, todas estas associações de classes ou de temas, agente faz parte, temáticas, agente faz parte e sempre esta discutindo todos estes temas também.

\section{Turma, sua turma?}


Não, não, aqui tem uma pessoa que cuida de assuntos governamentais, então ele que apresenta a Empresa nestas instancias, ...LETROS, ABILUX, no próprio Governo, lá em Brasília, enfim, tem uma pessoa que cuida só destes contato externos relacionados a estes temas.

É uma pessoa que precisa estar bem relacionado com a idéia de Sustentabilidade...

Sim, é uma pessoa que esta sempre acompanhado agente...

Muitas vezes em outras empresa esta relação, há sempre uma relação com este tipo de impostos, ou deste tipo de coisa, a sustentabilidade entra médio na pauta...

Acho que não estaria no $100 \%$, mas, não estaria no $0 \%$ também. Estaria, em certos assuntos 30 , em certos assuntos 70, depende muito de cada assunto e de cada pauta. Então, o importante, além de estar presente na pauta, é que ele já sabe aonde recorrer, isso que eu acho que é o mais importante, se é meio ambiente, tem uma pessoa de meio ambiente, se é um tema sustentabilidade, vem já nos procurar, enfim sempre tem esta parte que acaba acontecendo.

A última pergunta. A idéia de Balanço Social e Relatório anual. Em algumas empresas já nasceram juntos, e outras são dois documentos, que se fundiram, e na Empresa como é que você trabalham isto?

Então. Na América Latina agente não publica o balanço financeiro, porque nós somos uma empresa de capital fechado. No Brasil eu estou falando, desculpa, não é América Latina. Agente só publica o América. Não publica o Brasil, só publica a América Latina como um todo para a Empresa Europa, e quem publica o Balanço Financeiro é só a Empresa Global, mas nenhuma publica o financeiro.

\section{Distribuição para os acionistas é feito pela Global...}

Global, isto, é fechado e não tem, só vai ver Nova York, Amsterdã, tudo controlado pela Empresa, tralalala... Lá eles também fazem separadamente o relatório Global de Sustentabilidade que é este daqui, que já fazem uns três, quatro anos que eles fazem, seguindo o GRI, tudo direitinho, e aqui agente fez o primeiro nosso em 2005 ou 2004, 2005 que é referente a 2004, que não era um relatório, era um portfólio de atividades, resultados de atividades, e a partir de 2005, 2006, 2007, nós fizemos um relatório, primeiro não era tanto GRI, em 2006 era GRI, que era mais adaptado, agente escreveu primeiro depois mostrou que tinha do GRI, e este aqui agente foi atrás das informações segundo o GRI, é este daqui, provavelmente você já deve ter visto, 2007, 2008 e este daqui é o 2006, e este relatório ele é da América latina, nós somos a única região que realiza ele, fora da Empresa Global, além da Empresa Global e parece que o ano que vem vai ser o relatório financeiro e o de 
Sustentabilidade junto Global. Provavelmente agente vá colocar uma publicação bem menor, talvez só pela internet ainda. Agente está ainda estudando para ver o resultado disto.

\section{E aqui o 2007 e 08 ?}

Ele foi na verdade, deu uma atrasada no lançamento e agente já conseguiu colocar os dados de julho, até julho de 2008.

\section{E o próximo que vai sair vai ser o 2009?}

2009.

\section{Relativo?}

2008, 2009. Tem que pegar os dados totais de 2008 mais os de 2009. Então também é uma decisão que agente ainda está tomando, porque eu não sei se tem uma demanda tão grande para agente ficar fazendo a cada ano um relatório, principalmente quando você vai imprimir usar papel.

Não sei se eu entendi, no relatório global, deve passar a ser uma coisa só.

Isso, porque tem o Sustentabilidade e tem o Financeiro,

\section{Que é aberto?}

Que é aberto que você pode entrar na Internet e baixar e tudo mais.

\section{Quando for uma coisa só ele vai ficar aberto também?}

Vai ficar aberto também porque este aqui é o que reponde para os acionistas, tanto este quanto outro..

\section{Embora seja capital fechado vai ser transparente neste sentido?}

Ele é capital fechado no Brasil, fora ele é capital aberto.

\section{Mas este vai para acionista também?}

Este vai para o acionista, este é aberto a qualquer um.

\section{Este pega na internet?}

$\mathrm{Na}$ internet. Este aqui também pega pela Internet.

\section{$\mathrm{O}$ ano que quem vou pegar financeiro e este junto na internet?}

Tem o Financeiro na Internet também, se você for investidor. Não é complicado porque, agente as vezes se perde também, tem o internacional, tem o regional, é aberto aqui, não é aberto ali é complicado. Vou deixar também para você o guia de diversidade e inclusão, da Empresa da América Latina este aqui é o nosso folheto de diversidade, este aqui é o gerenciamento de energia que o nosso, o discurso que o nosso presidente fez, (são materiais internos) são materiais internos, esse aqui são todos externos, este aqui é interno mais o público formador de opinião, que é o seu caso. 